\title{
DXNDES
}

\section{Biblioteca Digital}

Desenvolvimento em debate, v. 1

Organizadora: Ana Célia Castro 
DESENVOLVIMENTO EM DEBATE Novos Rumos do

Desenvolvimento no Mundo 
Organizadora

Ana Célia Castro

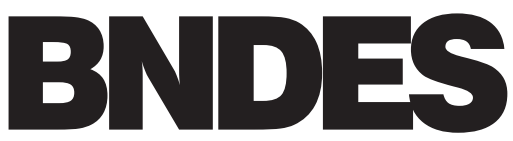

DESENVOLVIMENTO

EM DEBATE

Novos Rumos do

Desenvolvimento

no Mundo 
Direitos desta edição:

BNDES - Banco Nacional de Desenvolvimento Econômico e Social

Av. República do Chile, 100 - Centro

CEP 20031-917 - Rio de Janeiro - RJ

www.bndes.gov.br

Produção:

MAUAD Editora Ltda.

Av. Treze de Maio, 13, Grupo 507 a 509 - Centro

CEP 20031-000 - Rio de Janeiro - RJ

Tel.: (21) 2533.7422 - Fax: (21) 2220.4451

www.mauad.com.br

Capa:

Victor Burton

Foto da capa:

Romulo Fialdini

Tradução e revisão dos artigos internacionais:

Vera Ribeiro

Segunda orelha:

O termo "Consenso do Rio" foi proposto por Giovanni Dosi

no Seminário Novos Rumos do Desenvolvimento no Mundo

CATALOGAÇÃO NA FONTE

Departamento Nacional do Livro

D451

Desenvolvimento em debate: novos rumos do desenvolvimento no mundo / Organizadora Ana Célia Castro.

- Rio de Janeiro : Mauad : BNDES, 2002.

v. 1

$452 \mathrm{p} . ; 14 \mathrm{~cm} \times 21 \mathrm{~cm}$

ISBN 85-7478-093-6

1.Brasil - Desenvolvimento econômico.

2. Desenvolvimento econômico - Aspectos sociais. 3. Bem-estar social. I. Castro, Ana Célia. II. Banco Nacional de Desenvolvimento Econômico e Social.

CDD 338 


\section{SUMÁRIO}

$\begin{array}{ll}\text { Apresentação - Eleazar de Carvalho Filho } & 7\end{array}$

Prefácio - Paulo Sérgio Moreira da Fonseca 9

Introdução - Ana Célia Castro 13

\section{A NOVA AGENDA MUNDIAL:}

revolução tecnológica e integração global

A globalização e o Brasil: uma história em três atos

Albert Fishlow

Padrões locais e divergentes de aprendizagem tecnológica em mercados (parcialmente) globalizados

Giovanni Dosi e Carolina Castaldi

Globalização e desenvolvimento:

perspectivas para as nações emergentes

105

Sanjaya Lall

Debatedores:

Helio Jaguaribe

133

Rubens Ricupero

AGENDA SOCIAL E COMBATE À POBREZA: sociedade, cultura, democracia e liberdades individuais

Por uma nova visão da política social na América Latina:

desfazendo mitos

Bernardo Kliksberg

Rumo a uma guerra social planetária?

185

Ignacio Ramonet

Da política social para um contrato social

de economia aberta na Amércia Latina

Nancy Birdsall

Debatedores:

Carlos Francisco Lessa

Sônia M. Draibe 


\section{DESENVOLVIMENTO E GLOBALIZAÇÃO: perspectivas para as nações}

Depois do neoliberalismo, o quê?

Dani Rodrik

Globalização e desenvolvimento

José Antonio Ocampo

Políticas de desenvolvimento no mundo da globalização

Joseph E. Stiglitz

Debatedores:

Edmar Bacha

Luciano Martins

\section{DESAFIOS DO CRESCIMENTO:}

instituições, investimento, competitividade e tecnologia

O novo regime global de propriedade intelectual e sua dimensão imperialista: implicações para as relações "Norte/Sul" Benjamin Coriat

O novo paradigma do desenvolvimento e suas instituições: conhecimento, tecnologia da informação e recursos humanos. Perspectiva comparada com referência à América Latina Manuel Castells

Crescimento econômico na América Latina:

desafios para uma nova era

Sebastian Edwards

Debatedores:

Antonio Barros de Castro

Winston Fritsch 


\section{APRESENTAÇÃO}

É com grande satisfação que, no encerramento das comemorações do cinqüentenário do BNDES, lançamos os livros resultantes dos Seminários Novos Rumos do Desenvolvimento no Mundo e dos Painéis do Desenvolvimento Brasileiro. No âmbito destes eventos, que se realizaram ao longo de quatro meses, refletimos sobre os processos de desenvolvimento no mundo e, em particular, no Brasil.

O propósito dos Seminários foi discutir os novos padrões de desenvolvimento, face à realidade da globalização e dos anseios de estabilidade monetária, o que, entendemos, demandava fortemente o aprofundamento do debate sobre o papel do Estado, especialmente frente aos objetivos de: (i) manutenção da estabilidade macroeconômica; (ii) melhoria das condições de competitividade; e (iii) redução das desigualdades sociais e regionais.

Sob os títulos "Revolução Tecnológica e a Integração Global", "Agenda Social e o Combate à Pobreza", "Desenvolvimento e Globalização", "Os Desafios do Crescimento: O Papel das Instituições" e "Investimento, Competitividade e Tecnologia", questões cruciais do desenvolvimento mundial foram abordadas por eminentes intelectuais da academia e por pensadores e formuladores de políticas de organismos internacionais, em mesas presididas por Ministros de Estado, e outras autoridades governamentais.

Nas doze sessões dos Painéis do Desenvolvimento Brasileiro, foram tratados, de forma mais detalhada, os grandes temas abordados no seminário internacional. No mesmo formato da etapa internacional, colaboraram renomados especialistas filiados a linhas distintas de pensamento. 
O BNDES procurou, com a realização deste ciclo de debates, reafirmar seu compromisso com o futuro da sociedade brasileira, e com a atribuição de permanecer à vanguarda do desenvolvimento, patrocinando não só os projetos de investimento que impulsionam o crescimento da economia, como também as grandes reflexões a respeito dos rumos do desenvolvimento nacional.

No contexto de um cenário mundial crivado de incertezas econômicas e de agudas indefinições geopolíticas, avançamos em discussões sobre temas da mais alta relevância, com o propósito de apresentar à sociedade, e à nova administração, que assume em janeiro próximo, um conjunto organizado de reflexões e propostas de ação voltadas para o desenvolvimento do Brasil.

Eleazar de Carvalho Filho

Presidente do BNDES 


\section{PREFÁCIO}

No âmbito das comemorações de seus 50 anos e também visando destacar a importância do tema, o BNDES promoveu, durante os meses de agosto, setembro, outubro e novembro de 2002, sob coordenação de sua Área de Planejamento, um amplo debate sobre as questões do desenvolvimento face à realidade da globalização. As dificuldades enfrentadas pelos países, em especial os emergentes, em alcançar níveis aceitáveis de desenvolvimento fizeram com que os temas relativos a: desigualdades sociais, equilíbrio inter-regional; elevação das taxas de crescimento da economia, ampliação das oportunidades de ocupação e emprego, enfrentamento das restrições externas e desenvolvimento tecnológico, permeassem todos os trabalhos.

Este livro reúne as opiniões surgidas ao longo dos debates, oriundas de diferentes linhas de pensamento, tendo incorporado, no âmbito dos textos dos sistematizadores, visões do corpo técnico do Banco. Apresenta, portanto, diversas propostas alternativas que foram discutidas por Executivos e técnicos de todas as Áreas do Banco, incluindo a Alta Administração.

Esse debate teve como resultado uma agenda sobre o desenvolvimento e o delineamento da seguinte função objetivo para o BNDES: "Promover o crescimento com ampla inclusão social (incorporando a dimensão da cidadania), com redução das desigualdades espaciais (visando o equilíbrio inter-regional), com intenso desenvolvimento tecnológico, elevada competitividade e uso sustentável dos recursos naturais (buscando a viabilização do futuro) e com expressivo incremento das exportações (objetivando a inserção soberana do país no mundo globalizado)." 
As atividades desenvolvidas consistiram em:

- Seminário internacional, realizado nos dias 12 e 13 de setembro de 2002, sobre os Novos Rumos do Desenvolvimento no Mundo, com quatro painéis, em cada um dos quais participaram três palestrantes e dois debatedores. Foram convidados, como palestrantes, personalidades internacionais e, como debatedores, dois intelectuais brasileiros de escolas distintas de pensamento. Autoridades governamentais presidiram as mesas e Ministros de Estado e os Presidentes do BNDES e do Banco Central realizaram palestras. O Excelentíssimo Senhor Presidente da República proferiu conferência que encerrou o evento.

- Doze Painéis sobre o Desenvolvimento Brasileiro, realizados entre os meses de agosto e outubro, trataram de forma mais detalhada os grandes temas abordados no seminário internacional. Esta etapa, voltada para o corpo técnico do Banco, sem a presença de imprensa, contou com a colaboração de convidados externos ligados a diversos segmentos da sociedade, governo, trabalhadores, empresariado e academia. Para cada tema foram contratados dois pensadores de linhas distintas, encarregados da elaboração de textos e sua apresentação nos painéis, que contaram, também, com a participação de três debatedores. Esta etapa dos trabalhos teve intensa participação do corpo técnico do Banco, que organizado em grupos de trabalho escolheu Palestrantes e Debatedores, preparou os termos de referência para elaboração dos textos dos Palestrantes, e acompanhou sua elaboração.

A condução dos trabalhos ficou a cargo de um Comitê Coordenador formado pelas Áreas de Planejamento, Comunicação e Cultura, Administrativa e Gerência Executiva de Desenvolvimento de Competências. O Banco contou, ainda, com o apoio da Professora Ana Célia Castro do Curso de Pós-graduação em Desenvolvimento, Agricultura e Sociedade, da Universidade Federal Rural do Rio de Janeiro, tanto nas atividades de planejamento e organização dos eventos, quanto na coordenação de especialistas contratados para realizar o acompanhamento, sistematização e consolidação dos debates. 
No total foram envolvidas diretamente cerca de 200 pessoas, considerando corpo técnico do Banco, equipe de consultores, palestrantes e debatedores.

Finalizando, considero oportuno registrar que, ainda que tenhamos recebido importantes recomendações e propostas por parte de palestrantes e debatedores, grande parte destas se constituíam em ações já desenvolvidas pelo Banco, mas que independente disso foram registradas. Importa também destacar que os textos são de inteira responsabilidade dos autores, não se constituindo em opinião do BNDES.

\section{Paulo Sérgio Moreira da Fonseca}

Superintendente da Área de Planejamento 


\title{
INTRODUÇÃO
}

Seminários "50 anos do BNDES"

\author{
DESENVOLVIMENTO EM DEBATE
}

\section{SEMINÁRIO INTERNACIONAL: NOVOS RUMOS DO DESENVOLVIMENTO NO MUNDO}

\author{
Ana Célia Castro*
}

Buscamos, neste texto, desenhar o mapa atual do desenvolvimento, conforme foi percebido no seminário internacional do BNDES. Este mapa é tão mais importante quando se quer situar o debate brasileiro no movimento de renovação das idéias observado ao longo das sessões do Seminário Novos Rumos do Desenvolvimento no Mundo. Seria impossível fazer justiça à riqueza das posições apresentadas por palestrantes e debatedores. Assim sendo, optamos por privilegiar: o estado das artes do debate; a emergência de novas idéias; os consensos e desacordos em torno dos quais se alinharam muitos dos participantes e, finalmente, as implicações políticas e sugestões de políticas que resultaram deste seminário.

Muitas das idéias que vieram a ser discutidas nos "Painéis do Desenvolvimento Brasileiro", realizados no BNDES, foram previamente debatidas no Seminário Internacional. Mediante esta sistematização, busca-se também ressaltar os temas que apareceram de forma recorrente, pretendendo, assim, aproximar-se do objetivo que orientou todo o processo de discussão: repensar estratégias e políticas para o BNDES num contexto de mudança.

* Curso de Pós-graduação em Desenvolvimento, Agricultura e Sociedade - CPDA/ Universidade Federal Rural do Rio de Janeiro. 


\section{O estado das artes do debate sobre os Novos Rumos do Desenvolvimento no Mundo. $O$ desenvolvimento sem adjetivos.}

1.1. A noção de desenvolvimento ganhou complexidade, integrando suas múltiplas dimensões: "crescimento com estabilidade"1, "desenvolvimento como liberdade", "desenvolvimento com eqüidade"3, "desenvolvimento tecnológico e conquista de novos espaços internacionais", "acesso à informação e ao conhecimento" " "desenvolvimento institucional próprio" . Esta visão de conjunto foi compartilhada por muitos e talvez seja o maior consenso que emerge do seminário internacional.

A seguinte citação de Manuel Castells expressa essa proposição: (...) "se a estabilidade é uma condição necessária para o desenvolvimento, ela não é uma condição suficiente para o desenvolvimento, nem econômico nem social. Como afirmaram analistas, críticos e líderes políticos em debates a respeito da região, o crescimento econômico, na nova economia aberta, deve ser complementado por uma política de redistribuição. Contudo, para poder redistribuir, primeiro os países precisam gerar riqueza. Isso significa que a ênfase precisa voltar, como nos bons tempos da economia desenvolvimentista, para o crescimento econômico fundamentado na produtividade e para a geração das condições dessa produtividade: o desenvolvimento das forças produtivas. O problema é que, hoje em dia, as forças produtivas não se medem em toneladas de aço nem em quilowatts, como diriam Henry Ford ou Lênin, mas

\footnotetext{
${ }^{1}$ Vejam-se, principalmente, os textos de Stiglitz, J.; Fishlow A., Edwards, S; Rodrik, D., todos os artigos foram apresentados no seminário internacional e estão sendo publicados neste volume.

${ }^{2}$ Vejam-se, principalmente, Birdsall, N.; Ramonet, N.; Kliksberg, B.; Ocampo, J.A. O conceito de "desenvolvimento como liberdade" foi concebido por Amartya Sen em seu livro: "Desenvolvimento como Liberdade", Companhia das Letras, Rio de Janeiro, 2000.

${ }^{3}$ Concentram-se nessa temática os textos de Birdsall, N., Kliksberg, B. e Ramonet. N., mas também os de Ocampo, J.A; Stiglitz, J. e Rodrik, D.

${ }^{4}$ Lall, S.; Dosi, G.; Coriat, B.; Rodrik, D., Castells, M.mas também Fishlow, A., Ocampo, J.A. e Ramonet, I., este como contraponto.

${ }^{5}$ Castells, M.; Coriat, B.; Dosi, G.; mas também Ocampo, J.A. e Rodrik, D.

${ }^{6}$ Birsall, N., Castells, M.; Coriat, B.; Dosi, G.; mas também Ocampo, J.A, Rodrik, D. e Stiglitz, J..
} 
na capacidade inovadora de gerar valor agregado através do conhecimento e da informação. Esse modelo de crescimento econômico baseado no conhecimento é o mesmo em toda parte, como foi a industrialização no paradigma de desenvolvimento anterior. Ele requer o uso de tecnologias de informação e comunicação baseadas na eletrônica, mas não é resultado da tecnologia: é produto de um conjunto de condições inter-relacionadas..."

1.2. Crescimento com estabilidade: uma dimensão necessária, não garantida, e não suficiente.

Vários autores - com destaque para Stiglitz, Rodrik, Edwards, Fishlow e Ocampo ${ }^{7}$ - insistiram na idéia de que a estabilidade é um ingrediente fundamental do desenvolvimento - a instabilidade e a inflação produzem severas perdas nas camadas pobres da população. $\mathrm{O}$ receituário ortodoxo, hegemônico nos anos 1990, porém, não garantiu a estabilidade. Mais do que isto, nem mesmo garantiu a retomada do crescimento econômico, em uma década caracterizada pelo medíocre desempenho latino-americano.

Ouçamos Joe Stiglitz: “As medidas de estabilização não garantem o crescimento econômico. Países que seguiram as receitas do FMI, desde a Bolívia até a Mongólia, têm indagado: sentimos a dor, fizemos tudo o que vocês nos recomendaram; quando começaremos a colher os frutos? Enquanto isso, países que seguiram um curso independente, como a China, ou que foram seletivos, como o Chile, saíram-se muito melhor. As medidas de estabilização - definidas como rigor tributário e uma política monetária "sensata" - nem sequer garantem a estabilidade, uma vez que as mudanças repentinas nos sentimentos dos investidores, com mercados abertos de capitais, levam a evasões maciças, que deixam em sua esteira o caos econômico, mesmo em países com instituições moderadamente sólidas, mas especialmente naqueles em que a regulamentação do setor financeiro é fraca e não existem redes de segurança. As repetidas crises financeiras dos últimos seis anos dão amplas provas

\footnotetext{
${ }^{7}$ É importante assinalar que outros autores, como Birdsall, Kliksberg, Lall, Coriat e Dosi, compartilham essa idéia de que o crescimento com estabilidade é uma dimensão fundadora do desenvolvimento econômico. É nesse sentido que afirmamos que, independentemente da ênfase de sua análise, os autores compartilharam da idéia da complexidade do desenvolvimento.
} 
disso. A liberalização do mercado de capitais - feita na seqüência equivocada, ou prematuramente - não leva a um crescimento econômico mais rápido, porém expõe efetivamente os países a níveis de risco mais altos: trata-se de um risco sem recompensa. Os benefícios da liberalização do comércio são mais questionáveis do que sugeriria o mantra do livre comércio, particularmente quando a agenda do livre comércio é do tipo assimétrico, que tem caracterizado o mundo nos últimos anos (...) Desconhecer as dimensões sociais e políticas - como fizeram o FMI e o Consenso de Washington - é não apenas má política social, mas também má política econômica."

Nesta mesma linha, acrescenta Dani Rodrik: “A alternativa não deve ir contra o crescimento econômico. Na verdade, deve ser inflexivelmente favorável a ele. $\mathrm{O}$ crescimento nem sempre precisa gerar uma redução satisfatória da pobreza e pode ter efeitos adversos sobre a preservação ambiental. Mas os problemas da pobreza e do meio ambiente são muito mais fáceis de enfrentar no contexto de uma atividade econômica robusta do que em meio à estagnação. (...) A principal crítica ao neoliberalismo não é a de que ele tenha gerado crescimento à custa de uma pobreza maior, do aumento da desigualdade e da degradação ambiental, mas que, na verdade, ele não conseguiu gerar o desenvolvimento econômico de que o mundo necessita, a fim de estar mais preparado para lidar com esses outros desafios."

A propósito do mesmo tema, Sebastian Edwards adverte quanto à excessiva dependência em relação à poupança externa: "Evitar a crise macroeconômica é um componente fundamental de qualquer estratégia sensata de promoção do crescimento; há uma ampla comprovação de que as crises cambiais tiveram efeitos devastadores no bem-estar econômico e atrasaram enormemente o crescimento. (....) a dependência excessiva da poupança externa - cuja contrapartida são os grandes déficits em Conta Corrente - é sumamente arriscada, uma vez que os fluxos de capital podem cessar abruptamente, obrigando o país a enfrentar uma grande e custosa inversão da Conta Corrente".

Em síntese, e como nos diz José Antonio Ocampo: “Até o momento, não se confirmou a idéia de que a combinação de economias abertas e macroeconomia estável - no sentido restrito em que essa expressão passou a ser usada, isto é, designando equilíbrio fiscal e inflação baixa seria suficiente para promover o rápido crescimento econômico. Isso desencadeou um debate (...). A interpretação ortodoxa é que os mercados não foram suficientemente liberalizados. Tal visão é desmentida 
pelos episódios mais prolongados de crescimento rápido no mundo em desenvolvimento (...) todos os quais envolveram uma mistura de "heresias locais" com prescrições políticas mais ortodoxas. As interpretações alternativas enfatizam o papel das falhas do mercado, particularmente no funcionamento dos mercados de capital e de tecnologia, como explicação do crescimento lento. Também essa linha de raciocínio precisa explicar por que, no passado, foi possível um crescimento rápido em muitos países em desenvolvimento que enfrentavam limitações dessa natureza."

Observe-se que a posição de Rodrik vai mais além da idéia de que o crescimento com estabilidade é apenas uma dimensão necessária do desenvolvimento. Segundo o autor, existem princípios universais, que fazem parte de qualquer programa de desenvolvimento, mas as adaptações dos países a esses princípios seguem suas características e vocações próprias. Esta é uma idéia matriz que vai reaparecer como uma das idéias força do debate. Mais precisamente, e nas palavras de Rodrik: "A análise econômica expõe muitos princípios sólidos e que são universais, no sentido de que qualquer programa de desenvolvimento sensato tem que levá-los em conta. O que tenho em mente são coisas como: assegurar os direitos de propriedade e a vigência da lei (para que os investidores, atuais e potenciais, possam ter a expectativa de conservar a renda de seus investimentos); reconhecer a importância dos incentivos privados e alinhá-los com os custos e benefícios sociais (para que se possa chegar à eficiência produtiva); administrar a política financeira e macroeconômica com a devida consideração para com a sustentabilidade da dívida, os princípios de prudência e a moeda sólida (para que a inflação, a volatilidade macroeconômica, as crises financeiras e outras patologias possam ser evitadas). Esses são princípios universais da boa gestão econômica, mas - e este é o ponto fundamental - não constituem um mapa de arranjos institucionais ou receitas políticas únicos.”

1.3. Desenvolvimento como liberdade, desenvolvimento com eqüidade, desenvolvimento sustentável: indissociáveis das outras dimensões do desenvolvimento.

As idéias foram relacionadas com inclusão social; cidadania; justiça; necessária redução da desigualdade e da pobreza; criação de oportunidades de emprego, trabalho e renda; redução da informalidade no mercado de trabalho; capital social e redes de segurança; capacitação; apoio 
a pequenas e médias empresas; em resumo, a dimensão social do desenvolvimento é compartilhada por todos os autores e debatedores do Seminário Novos Rumos, independente da ênfase que cada autor tenha dado a esta ou a outras dimensões integradas do desenvolvimento. Esta é, aliás, a principal razão por que o desenvolvimento prescinde hoje de adjetivos.

Se todos concordaram e mesmo acentuaram sua importância, como o objetivo maior do desenvolvimento, ou como a sua missão civilizatória, essa foi, sem dúvida, a pauta preferencial de discussão dos trabalhos de Birdsall, Kliksberg e Ramonet. ${ }^{8}$ As suas posições, entretanto, foram muito variadas, com diferentes implicações políticas (e de políticas), que serão mais adiante apontadas.

Neste conjunto de idéias, cumpre destacar as que, de forma similar, vieram a ter espaço privilegiado nos debates brasileiros sobre a agenda social:

- o crescimento econômico não necessariamente reduz a desigualdade social;

- a desigualdade social é um entrave fundamental ao desenvolvimento;

- as políticas sociais variaram de enfoque ao longo do tempo na América Latina, ora adotando a perspectiva de um contrato social amplo - que caracterizou o período áureo de crescimento na região - ora como políticas compensatórias e direcionadas a grupos sociais específicos, competindo com outros gastos num orçamento fiscal limitado;

- as redes de segurança e o chamado capital social, ao lado de políticas ativas de emprego, capacitação e de defesa dos direitos dos trabalhadores, são ativos que ajudam no combate à desigualdade e à pobreza.

Comecemos por Kliksberg: "Uma pergunta de fundo é como recuperar uma reflexão que vincule a ética à economia, iluminando com valores éticos o caminho a seguir e resgatando a ética como um motor do projeto de desenvolvimento. (...) Um país deve ter todo o empenho em crescer e dispor de estabilidade, progresso tecnológico e competitividade, mas os

\footnotetext{
${ }^{8}$ A agenda social constituiu também parte importante dos textos de Ocampo e de Castells, neste caso enfatizando a dimensão da exclusão dos pobres de uma economia intensiva em conhecimento e informação.
} 
fatos indicam que, por si só, o crescimento não resolve o problema da pobreza.(...) Os dados comparativos mundiais demonstram que a desigualdade é um entrave portentoso ao desenvolvimento sustentado. (...) Nos órgãos internacionais, há uma unanimidade quanto ao fato de que a América Latina é a região mais desigual do planeta. (...) A desigualdade da América Latina não se apresenta apenas no plano da distribuição de renda. Afeta outras áreas chaves da vida, como o acesso a ativos produtivos, o acesso ao crédito, as possibilidades de educação, a saúde e, atualmente, a integração no mundo da informática. A crescente desigualdade no acesso à informática vem criando o risco de uma nova forma de analfabetismo, o analfabetismo cibernético, que exclui vastos setores da população do circuito fundamental da informação e das comunicações avançadas."

Ignacio Ramonet acentua a crítica contundente à desigualdade social: “Outra constatação: a supremacia geopolítica e o exercício da hiperpotência, na era do neoliberalismo, de modo algum garantem a todos os cidadãos um nível de desenvolvimento humano satisfatório.” E conclui: “...o patrimônio das 15 pessoas mais ricas do planeta ultrapassa o produto interno bruto total do conjunto dos países da África subsaariana..."

No que diz respeito às implicações de posições diferenciadas sobre a desigualdade e a pobreza para a política social, Nancy Birdsall diferencia as políticas direcionadas para grupos específicos (o que tem a ver com o diagnóstico de que o crescimento, apenas, não garante a redução da desigualdade), por um lado, e políticas mais amplas, que estabelecem um pacto social duradouro: "Diante das pressões fiscais contínuas, passou-se a usar a abordagem de direcionar os recursos para os pobres, ou seja, de alocar os recursos orçamentários limitados de modo a obter a maior redução possível da pobreza por cada centavo gasto. Levantaram-se mapas e perfis da pobreza, a fim de identificar a população com os mais altos índices de pobreza. Os programas resultantes foram concebidos como programas pequenos, específicos e rigorosamente direcionados. Nesse sentido, a política social abandonou por completo a idéia de um contrato social maior entre o Estado e a sociedade como um todo. A política social e as estratégias globais de desenvolvimento e crescimento dos países da região ficaram inteiramente desvinculadas. Tal como no segundo período, a ênfase continuou a recair no equilíbrio fiscal entre as políticas macroeconômicas e os programas sociais, sendo estes vistos como uma ameaça potencial ao déficit público e à estabilidade macroeconômica." 
Para concluir, os autores chamaram a atenção para as diferentes formas que as sociedades têm de lidar com a desigualdade e pobreza através do incentivo ao capital social. Assim, destaca Kliksberg: "O capital social implica instalar no foco do desenvolvimento fatores pouco considerados, como a confiança interpessoal, a capacidade de associação, a consciência cívica e os valores éticos. As medições indicam que esses fatores têm um peso direto nos desempenhos macroeconômicos, produtivos, políticos e sociais dos países. A capacidade de associação vincula-se sobretudo à capacidade de a sociedade gerar toda sorte de formas de cooperação. Quando ela é vigorosa, constrói-se um tecido social rico, que dá margem a múltiplas formas de contribuição para o projeto global de desenvolvimento. (...) Entre outras expressões do capital social encontramse o voluntariado e a responsabilidade social das empresas privadas."

Prossegue Jose Antonio Ocampo a este propósito: “Os sistemas de seguridade social e as redes de segurança social da região tiveram que se haver com os problemas criados pela cobertura segmentada e insuficiente dos sistemas desenvolvidos no passado (...). Assim, os níveis aumentados de riscos macro e microeconômicos traduziram-se em riscos sociais maiores e em mais demandas de proteção por parte de sistemas subdesenvolvidos de proteção social. Em diversos casos, além disso, os princípios de universalidade e solidariedade que devem caracterizar os sistemas de proteção social foram postos de lado nas reformas da seguridade social. Aliado às tendências adversas do mercado de trabalho, isso se refletiu na frustração do avanço no custeio desses sistemas."

1.4 - O desenvolvimento, num mundo globalizado e numa economia intensiva em conhecimento, não pode prescindir do amplo acesso à informação e ao conhecimento e de políticas voltadas para a conquista de novos espaços na competição internacional.

A dimensão do desenvolvimento tecnológico e da competitividade significa o firme ingresso numa economia intensiva em conhecimento e informação e em suas redes globais de comunicação. Esta dimensão do desenvolvimento esteve igualmente presente na grande maioria dos textos apresentados nos Novos Rumos do Desenvolvimento, merecendo particular destaque nos textos de Sanjaya Lall, Manuel Castells, Giovanni Dosi, Benjamin Coriat, mas também em Joe Stiglitz, Dani Rodrik, Sebastian Edwards e Ignacio Ramonet (no caso deste autor, com conteúdo altamente crítico). 
As questões aqui discutidas apontam para a necessidade da redução da brecha tecnológica e de conhecimento dos países menos desenvolvidos para com as economias mais dinâmicas, como condição do progresso social. Neste contexto, são tradicionalmente destacados os fluxos internacionais de capital e de conhecimento. A busca do emparelhamento tecnológico, ainda que seletiva (para não ficar na dependência da dotação de recursos), depende da construção de instituições sólidas de apoio, que serão a seguir discutidas. Mas depende igualmente da existência/construção de uma competitividade sistêmica, que melhore as condições de acesso das empresas aos mercados internacionais de bens e serviços.

O novo paradigma tecnológico, bem como o crescimento econômico, não assegura a convergência tecnológica, ou o emparelhamento. As evidências apontadas por autores, em especial por Sanjaya Lall e Giovanni Dosi, são contrárias à tese da convergência. Neste sentido, reabre-se o espaço antes ocupado por políticas industriais e tecnológicas, condenadas ou sujeitas a duras críticas na década precedente.

Se o emparelhamento, ou convergência, não está assegurado, a sua possibilidade de ocorrência conta com mais uma força contrária: o atual sistema de direitos de propriedade expresso no TRIPS. Mais do que isto, ao privatizar, antecipadamente, resultados potenciais de pesquisas tecnológicas e de seus processos de obtenção de resultados, o atual sistema internacional de direitos de propriedade "chuta a escada por onde subiram"9 os países que se encontram hoje na liderança do desenvolvimento tecnológico. Citando Coriat: "Quando ficou claro que não mais poderiam dominar as firmas japonesas unicamente com base na tecnologia de produção, as empresas norte-americanas tentaram consolidar sua vantagem comparativa na pesquisa e desenvolvimento. Para tanto, precisariam encontrar meios de reduzir a capacidade dos competidores de praticar a engenharia reversa com seus produtos. (...) Com vistas a esse objetivo, as firmas norte-americanas começaram a pressionar o Congresso para que ele ampliasse a proteção da propriedade intelectual de seus projetos de semicondutores" (...) “...não surpreende descobrirmos que a aplicação do TRIPS tem causado grandes conflitos, em especial nas questões de saúde pública. Uma vez que seus efeitos no comércio Norte/Sul, tais como podemos começar a avaliá-los e medilos, parecem totalmente incapazes de eliminar as desigualdades ligadas ${ }^{9}$ Este é o tema e o título do livro de Ha-Joon Chang recentemente publicado: "Kicking
away the ladder". 
ao comércio (ao contrário do que afirmam os proponentes dessa política), o que temos testemunhado, em muitas áreas, é um espetáculo de grandes conflitos. (...) Numa época em que a maioria das pessoas concorda que as economias mundiais vêm-se tornando mais e mais "calcadas no conhecimento", a produção e a circulação mundial do saber transformou-se, mais do que nunca, numa questão estratégica. Além disso, o acesso ao conhecimento passou a ser um fator cada vez mais importante, sobretudo para os países em desenvolvimento que, por enquanto, só podem dar uma contribuição limitada para a geração do saber. (...) Se as economias mundiais de fato passaram a fazer um uso mais intensivo do conhecimento, barrar o acesso a ele (através da extensão de patentes, que não passam de puras barreiras institucionais) não é, com certeza, o modo mais adequado de ajudar os países em desenvolvimento a crescer, a fim de que possam firmar-se sobre os próprios pés e dar sua contribuição para o crescimento e o bem-estar que devemos estar contemplando."

Em resumo, esta dimensão do desenvolvimento não pode ser considerada isoladamente, na medida em que está profundamente conectada com as duas dimensões anteriores - desenvolvimento com estabilidade e inclusão social. Mas, como as demais, não pode ser assumida como resultado espontâneo das forças de mercado e deverá ser objeto de políticas específicas, da reconstrução institucional e da busca da inserção soberana nos arranjos regionais e internacionais. Vejamos as citações mais importantes dos autores.

Para Manuel Castells, a nova economia é uma economia global. "A economia global é um novo tipo de economia. É a economia cujas atividades nucleares têm a capacidade de funcionar como uma unidade em determinado momento, em escala planetária. Essa capacidade precisa ser entendida em termos tecnológicos, institucionais e organizacionais. No plano tecnológico, ela se baseia em telecomunicações, no transporte veloz e nos sistemas informatizados. Institucionalmente, baseia-se na desregulamentação, na liberalização, e na privatização. Em termos organizacionais, baseia-se na ligação das empresas em redes e em formas flexíveis de gestão e trabalho. A dimensão-chave da globalização é a globalização financeira - os mercados financeiros são hoje globalmente interdependentes e funcionam eletronicamente em tempo real, contornando os controles governamentais e determinando o destino da economias (...) O comércio internacional também é uma dimensão importante da globalização, mas sua expansão é sobretudo uma função da internacionalização da produção. (...) A ciência e a tecnologia, assim 
como o trabalho altamente qualificado, também se organizam em escala global. E a migração de trabalho não qualificado vem aumentando em toda parte. A economia global é sumamente segmentada: nem todos são incluídos, mas todos são afetados. (...) O aumento do valor das ações é determinado pelas expectativas e pela confiança, bem como por sua combinação certa: nos mercados emergentes, há grandes expectativas mas pouca confiança, de modo que o capital está sempre pronto para entrar e sair. (...) Neste bravo novo mundo financeiro, as ações converteram-se em moeda (...). A economia imaterial é uma economia real. $\mathrm{O}$ desempenho das empresas nessa economia baseada na informação, movida pela informação e valorizada pela informação determina o destino das pessoas e dos países."

A relação entre o novo paradigma tecnológico e as oportunidades de conquista de novos mercados por empresas de países em desenvolvimento é destacada por Sanjaya Lall: "A competitividade é a chave do crescimento industrial e do desenvolvimento num mundo globalizado. A "via mestra" para a competitividade - que combina parcelas crescentes dos mercados abertos com o aumento da renda e do emprego envolve a construção de um forte setor fabril, voltado para as exportações. Por sua vez, isso requer a capacidade de criar empresas que se liguem a cadeias de valor global dinâmicas e a aprimorar constantemente a eficiência e as capacitações para enfrentar os salários crescentes e as mudanças tecnológicas. A estrutura do comércio e das cadeias de valor global vem-se modificando, sendo seus componentes mais dinâmicos os produtos de tecnologia intensiva e os sistemas de produção integrados. As diferentes regiões têm enfrentado esse panorama com graus variáveis de sucesso: algumas saem-se espetacularmente bem, outras mal conseguem acompanhá-lo e muitas estão sendo marginalizadas. As explicações dessas diferenças não estão em quanto as economias se "abriram" para os fluxos de comércio, investimento e tecnologia, mas em quão bem se vincularam aos sistemas globais e desenvolveram suas potencialidades tecnológicas e outras para usar as novas tecnologias.'

Acrescenta ainda Sanjaya Lall: “A principal causa dos grandes saltos para cima entre 1985 e 1998 foi a participação crescente em redes globais de produção, que elevou acentuadamente a parcela de produtos complexos nas exportações (...). Os países em desenvolvimento são um grupo que vem-se saindo bastante bem nesse quadro dinâmico das exportações. (...) Nos outros produtos manufaturados, sua vantagem em 
relação aos países industrializados aumentou conforme os níveis tecnológicos. À primeira vista, esse é um resultado contrário à intuição: a teoria nos levaria a esperar que os países em desenvolvimento crescessem mais depressa que os países desenvolvidos nos produtos de baixa tecnologia, menos nos de média tecnologia e menos ainda nos de alta tecnologia. Os dados mostram exatamente o inverso."

A relação entre padrões de mudança tecnológica e desenvolvimento é o ponto central do artigo de Giovanni Dosi: "Os dados relativos aos países da OCDE parecem sugerir que a relação entre as atividades inovadoras e os níveis do PIB estreitou-se mais ao longo do tempo e é sumamente significativa desde a Segunda Guerra Mundial. Além disso, o dinamismo inovador, medido pelo aumento do registro de patentes de diferentes países nos EUA, sempre parece ter uma correlação positiva com o crescimento do PIB per capita. Esse vínculo é particularmente sólido entre 1913 e 1970. Inversamente, um sinal de que o regime de crescimento internacional pode ter-se modificado na década de 1970 é que, durante esse período, essa relação se enfraqueceu e perdeu importância estatística. (...) Uma questão delicada, mas crucial, concerne à relação entre os padrões de mudança tecnológica e os padrões de crescimento econômico. Naturalmene, a aprendizagem tecnológica envolve muito mais elementos do que a simples descoberta inventiva e o registro de patentes. De igual importância são as atividades de imitação, engenharia reversa, adoção de inovações incorporadas no capital e a aprendizagem (...). Além disso, a mudança tecnológica nem sempre se conjuga com a inovação organizacional."

$\mathrm{Na}$ mesma direção de Manuel Castells, Joe Stiglitz enfatiza a mudança de paradigma tecnológico: "Pode-se pensar no conhecimento como uma forma particular de informação, e, como tal, os resultados da economia da informação seriam aplicáveis ao campo da economia da inovação. As teorias padronizadas presumiam uma tecnologia fixa, mas é claro que no centro do crescimento e do desenvolvimento encontra-se a mudança tecnológica, a criação e adoção de novos modos de produção e novos produtos. Portanto, as teorias padronizadas sobre a eficiência dos mercados não têm nada a dizer sobre esse campo. Ao contrário, há boas razões para crer que, em geral, os mercados não produzem resultados eficientes por si mesmos. O conhecimento tem os atributos de um bem público e a inovação gera enormes externalidades. Além disso, grandes incertezas associam-se à inovação, de modo que as conseqüências da falta de mercados seguros tendem a ser particularmente graves. 
(...) Assim, a teoria econômica moderna criou um sólida presunção para o papel do governo."

Concordando com a avaliação de Sanjaya Lall sobre os países do Leste Asiático, afirma Stiglitz: "Um ingrediente central das políticas de sucesso dos países do Leste Asiático foi a tentativa deliberada de reduzir a "defasagem do conhecimento". Esse países perceberam que o que os separava dos países mais desenvolvidos não era uma simples defasagem de capital, mas uma defasagem de conhecimento, e trabalharam com afinco e com êxito para levar a tecnologia moderna para suas sociedades."

Stiglitz, a este propósito, aponta recomendações de política industrial e tecnológica: "Existem nichos que um país como o Brasil pode descobrir, e alguns deles serão de alta tecnologia, como aviões que atendam a um mercado regional. (...) Cada vez mais, as economias modernas são economias do setor de serviços e do conhecimento. (...) Não há respostas fáceis para perguntas sobre quais são as vantagens comparativas dinâmicas de um país. Mas ao menos isto deve ficar claro: na Nova Economia, é provável que essas vantagens sejam acentuadamente diferentes do que foram no passado. Isso exigirá que se repensem as estratégias de governo em cada uma das áreas em que ele se envolver."

Nesta mesma linha, da importância da economia do conhecimento para diretrizes de política, Dani Rodrik observa: "Saber na produção de quê um país é (ou pode ser) bom constitui um grande desafio do desenvolvimento econômico. Nem a teoria econômica nem a ciência administrativa são muito úteis para ajudar os empresários (ou o Estado) a escolher os investimentos apropriados no amplo leque das atividades de setores modernos, dentre as quais podem haver dezenas de milhares, quando se vai além de categorias genéricas como "produtos intensivos em mão-de-obra" ou "produtos baseados em recursos naturais". No entanto, tomar as decisões certas de investimento é a chave do crescimento futuro, uma vez que determina o padrão de especialização.”

Ocampo chama também a atenção para tecnologias que respeitem o meio ambiente: "A transformação das estruturas produtivas, portanto, deve ser uma prioridade explícita de qualquer estratégia de desenvolvimento. Seu objetivo central, num meio aberto como o que caracteriza as economias latino-americanas de hoje, deve ser a criação de uma competitividade sistêmica, baseada em três pilares fundamentais: a criação de sistemas de inovação para acelerar a acumulação de capacidade tecnológica; o respaldo a novas atividades produtivas e à formação de vínculos na produção; e a oferta de serviços infra-estruturais de alta 
qualidade. O papel dos mercados financeiros fortes já foi enfatizado como um complemento essencial a um ambiente macroeconômico apropriado. (...) A criação de mercados para os serviços ligados ao meio ambiente é a idéia mais promissora nesse campo, uma vez que gera, simultaneamente, os incentivos econômicos e o financiamento necessários à adoção das novas tecnologias."

Albert Fishlow, no seu artigo de recuperação da trajetória do desenvolvimento brasileiro, nos diz: "Nas últimas décadas, quando o comércio internacional expandiu-se duas vezes mais do que a taxa do produto interno bruto, foram os produtos manufaturados e os serviços que exibiram um dinamismo muito maior, e não as vendas de produtos primários. (...) É nessas áreas que a vantagem comparativa do Brasil terá que se destacar. A Embraer é um exemplo clássico de uma antiga empresa estatal que evoluiu com sucesso para a condição de fornecedor internacional de aviões comerciais. É também um caso em que o recurso brasileiro à Organização Mundial do Comércio levou à vitória na disputa com o Canadá e a Bombardier. Alguns hão de argumentar que esse exemplo revela a importância dos subsídios e do apoio estatais. Mas essa história de evolução de fornecedor nacional para competidor internacional também envolveu uma compreensão implícita dos ganhos obteníveis com o comércio e da vantagem comparativa: a empresa é não apenas o maior fornecedor isolado de divisas para o Brasil, como é também um dos principais importadores. Esses insumos menos dispendiosos permitem que a produção da empresa fique na vanguarda tecnológica."

Para concluir, Nancy Birdsall integra as múltiplas dimensões do desenvolvimento: "Por último, o acesso aos mercados dos países ricos deve ser visto como central para o contrato social da economia aberta. O contrato social baseado no emprego e no crescimento, numa economia aberta, não depende apenas da abertura das economias da América Latina, mas de seus mercados externos. Pelo menos parte da instabilidade que tanto tem custado à camada intermediária e aos pobres se reduziria na região, se houvesse uma melhora em seu acesso ao mercado norte-americano e aos europeus; o maior crescimento das exportações e a diminuição da necessidade de empréstimos externos afastariam mais as economias da instabilidade financeira. Além disso, é provável que os empregos criados em setores como a agricultura (no Brasil, a soja), a indústria de calçados e a indústria têxtil ampliassem a demanda de mãode-obra menos qualificada. Nesse caso, os benefícios da ligação com a economia global aumentariam para a vasta maioria de famílias em que 
os adultos ainda têm níveis relativamente baixos de instrução. Sem esse acesso, pode não ser impossível, mas com certeza será difícil imaginar que a região possa implantar o tipo de contrato social que esbocei."

1.5. O Desenvolvimento possui uma inegável dimensão institucional, ou seja, pode ser promovido por instituições reguladoras, protetoras, estimuladoras, capazes de alavancar mudanças e reorientar o processo histórico. Mas pode ser, contrariamente, retardado ou barrado, em certas circunstâncias, por instituições que restrinjam excessivamente a autodeterminação dos países, colocando barreiras à busca dos seus caminhos próprios e singulares de desenvolvimento.

Dani Rodrik foi o palestrante que mais destacou, no Seminário Novos Rumos, a importância das instituições no processo de desenvolvimento. As instituições, a despeito da inegável universalidade de certos pilares institucionais como os direitos de propriedade e as instituições políticas da democracia, são também o elemento de originalidade de cada país, na medida em que assumem, em cada caso, formatos próprios e diferenciados, muitas vezes único. Desta forma, a despeito de as instituições funcionarem como âncoras, que atribuem regularidade aos processos e reduzem sua incerteza estrutural, é possível introduzir mudanças institucionais, criar novas instituições, disseminar novas crenças que serão, possivelmente, amplamente compartilhadas. Assim, o formato que assume o desenvolvimento nacional é, em grande medida, único, dependente do passado ("path dependent”, ou seja, é dependente da trajetória anterior), e capaz de alterar a direção dos processos históricos futuros. No que diz respeito ao processo de desenvolvimento - principalmente quando se trata do desenvolvimento "substantivo" - as instituições são, portanto, cruciais.

Vejamos as citações mais importantes de Dani Rodrik a este propósito:

1. “As transições para o alto crescimento econômico são desencadeadas, tipicamente, por uma gama relativamente estreita de mudanças políticas e reformas institucionais. (...) Em nenhum desses casos vemos as reformas ambiciosas recomendadas pelo Consenso Ampliado de Washington desempenharem um papel importante logo no começo, ou como pré-requisito.

2. As mudanças políticas que dão início a essas transições para o crescimento combinam, tipicamente, componentes ortodoxos e inovações institucionais pouco convencionais. (...) 
3. As inovações institucionais não se transferem com facilidade de um lugar para outro. $\mathrm{O}$ que funciona num contexto amiúde não funciona bem em outro.(...)

4. Sustentar o crescimento econômico é um desafio em si, e não se pode presumi-lo como um resultado certeiro. Historicamente, poucos países mantêm o crescimento elevado ao embarcarem nele.(...) Isso aponta para a importância crucial de fortalecer e renovar as instituições durante as fases de crescimento acelerado da economia, a fim de poder lidar com choques e outras fontes de adversidade. (...)

Esta breve resenha do histórico empírico sugere um programa de crescimento com dois componentes: (1) uma estratégia de investimento a curto prazo para deslanchar o crescimento, e (2) uma estratégia de criação de instituições a médio e longo prazos, para dar resistência à economia frente à volatilidade e aos choques adversos."

Ainda Rodrick: "Um regime econômico internacional favorecedor do desenvolvimento é aquele que faz muito mais do que promover o acesso dos países pobres aos mercados dos países industrializados avançados e promulgar códigos, padrões e "práticas ótimas". É aquele que permite aos países pobres experimentarem arranjos institucionais e lhes dá espaço para conceberem suas próprias soluções, possivelmente divergentes, para os gargalos de desenvolvimento que têm de enfrentar. É aquele que avalia as demandas de reforma institucional não pela perspectiva da integração (“de que precisam os países para se integrar?”), mas pela perspectiva do desenvolvimento ("de que precisam os países para chegar a um crescimento econômico amplo e eqüitativo?”). Segundo esta visão, os arranjos econômicos internacionais não mais serviriam de instrumentos de harmonização de políticas e práticas econômicas entre os vários países, visando à maximização do comércio e dos fluxos de investimento, mas de arranjos capazes de intermediar as diferentes práticas e instituições nacionais. (...) Como já foi sugerido, as "funções" exercidas por instituições de alta qualidade (conceder direitos de propriedade, regular os incentivos e assim por diante) configuram múltiplas formas institucionais, como mostram esquematicamente as Figuras 2 a 4. A primeira coluna de cada figura refere-se aos objetivos a serem alcançados: eficiência produtiva, estabilidade macroeconômica e financeira, justiça distributiva e alívio da pobreza. A coluna seguinte lista os conceitos relevantes, a partir da análise econômica. Por exemplo, os 
direitos de propriedade e a estrita observância da ordem jurídica são necessários para se chegar à eficiência produtiva; a sustentabilidade da dívida e a solidez da moeda são necessárias à estabilidade macroeconômica, e assim por diante. A terceira coluna ilustra algumas das escolhas institucionais que precisam ser feitas. Essas escolhas não são fixadas pela análise econômica (embora a análise econômica possa ser de enorme utilidade para esclarecer as contrapartidas a obter). Que tipo de sistema jurídico deve o país adotar: o direito consuetudinário, o direito romano, ou um híbrido dos dois? Qual é o equilíbrio exato entre a competição descentralizada no mercado e a intervenção pública? Quais os tipos de instituições financeiras/de gestão empresarial mais apropriados para mobilizar a poupança interna? Deve a política tributária ser pautada por normas legais e, nesse caso, quais são as normas apropriadas? Qual é o tamanho apropriado da economia pública? Qual é o aparelho regulador apropriado para o sistema financeiro? Quão progressivo deve ser o sistema tributário? Como devem organizar-se os mercados de trabalho? (...) Os arranjos institucionais têm um grande componente de especificidade. Descobrir o que "funciona" no plano local requer experimentação. As reformas que têm sucesso num contexto podem exibir um rendimento precário ou fracassar por completo em outros. Como afirmei antes, essa especificidade ajuda a explicar por que os países bem-sucedidos (...) quase sempre combinaram elementos heterodoxos com medidas ortodoxas. Explicaria também por que persistem importantes diferenças institucionais entre os países avançados da América do Norte e da Europa Ocidental e o Japão, em áreas como o papel do setor público, a natureza dos sistemas jurídicos, a gestão empresarial, os mercados financeiros, os mercados de trabalho e os mecanismos de seguridade social."

Destaque-se ainda, neste mapeamento, a importância das instituições relacionadas com a pesquisa, desenvolvimento e a difusão de informações, que poderiam atuar positivamente no sentido da convergência tecnológica, não assegurada pela globalização. A ênfase, no caso, é especialmente de Giovanni Dosi (e a advertência quanto a possíveis retrocessos foi de Coriat): "Dito de outra maneira, é fácil mostrar que um mundo que, em certo nível, torna-se cada vez mais integrado - mas não (aproximadamente) idêntico nas condições iniciais, nas instituições, capacidades tecnológicas, mecanismos de interação econômica, etc. pode ficar sujeito a várias formas de círculos virtuosos ou viciosos "locais”. (...) Como há sinais de que a orgia do fanatismo pelo mercado 
vem-se esgotando, é mais do que hora de começar a concentrar a atenção também em normas políticas e instituições que fomentem a aprendizagem tecnológica e sua difusão dentro e através dos países. Em outras palavras, é chegada a hora de construir um "novo consenso", que ponha em destaque a exploração de formas de gestão institucional que tornem a acumulação de conhecimentos e sua exploração econômica eficiente (ao menos em parte) compatíveis com os interesses dos agentes movidos pelo lucro. Em tudo isso, muitas vezes, embora nem sempre, a existência de mercados que funcionem bem tende a desempenhar um papel central. Mas, como tem enfatizado repetidamente Joe Stiglitz, o mundo está cheio de "falhas de mercado" (sobretudo a falha intrínseca associada a qualquer geração de conhecimento puramente dirigida pelo mercado)."

O papel das instituições internacionais foi ainda destacado por muitos palestrantes, tanto na construção de barreiras ao desenvolvimento como no caso dos TRIPS (destacado por Benjamin Coriat) - quanto à possibilidade de criar inegáveis oportunidades para os processos de desenvolvimento. O caráter hegemônico de instituições como o FMI, Banco Mundial, OMC, e as características oposicionistas e de contratendência das instituições do tipo ONGs, que exercem uma declarada função de oposição aos Fóruns internacionais econômicos, caso do Fórum Social de Porto Alegre, foram temas abordados principalmente por Ramonet. Ainda no plano das instituições internacionais, Ocampo destacou a importância das redes de organizações, nas quais as instituições regionais e sub-regionais exercem papel não desprezível.

A este propósito afirmou Ignacio Ramonet: “A globalização financeira, aliás, criou seu próprio Estado. Um Estado supranacional, que dispõe de seus próprios aparelhos, redes de influência e modos de ação. Trata-se da constelação formada pelo Fundo Monetário Internacional (FMI), pelo Banco Mundial, pela Organização para a Cooperação e Desenvolvimento Econômicos (OCDE) e pela Organização Mundial do Comércio (OMC). Essas quatro instituições falam a uma só voz que ressoa na quase totalidade dos grandes meios de comunicação para exaltar as "virtudes do mercado.(...) Por outro lado, criam-se instituições contrárias ou para contrabalançar o poder exagerado das instituições internacionais. (...) Essa espécie de Internacional rebelde reuniu-se em Porto Alegre no exato momento em que se realizou, em Davos (Suíça), em 2001, e em Nova York, em 2002, o Fórum Econômico Mundial, que há décadas reúne os "novos donos do mundo", em particular 
todos os que pilotam concretamente a globalização. E que já não escondem sua inquietação. Eles levam muito a sério os protestos da cidadania que, de Seattle a Kananaskis, passaram a ocorrer sistematicamente a cada conferência de cúpula das grandes instituições que de fato governam o mundo: OMC, FMI, Banco Mundial, OCDE, G7, ALCA e até a União Européia."

Ressaltando o papel das instituições regionais, afirma Jose Antonio Ocampo: "Isso implica que o esforço de construir instituições fortes para uma ordem global melhor deve basear-se numa rede de instituições mundiais, regionais e nacionais, em vez de se limitar a uma ou algumas instituições internacionais. A ação nos níveis regional e sub-regional desempenha um papel de peso como intermediária entre as ordens global e nacional, por quatro grandes razões: a complementaridade entre as instituições globais e regionais numa comunidade internacional heterogênea; o tamanho desigual dos atores envolvidos nos processos globais, que significa que a voz dos países se fará ouvir melhor se for expressa como uma voz regional; o maior sentimento de posse das instituições regionais e sub-regionais; e o fato de que, em algumas áreas (como na política macroeconômica e regulatória), o alcance da autonomia eficaz da política econômica deslocou-se da arena nacional para os níveis subregional ou regional. Portanto, um sistema que se baseie em redes de instituições globais e regionais será não apenas mais eficiente, como também mais equilibrado em termos das relações de poder. (...) Em última instância, todavia, as instituições internacionais continuariam a depender das responsabilidades e políticas nacionais, o que é uma característica essencial de um sistema internacional em que os processos políticos continuam a se alicerçar em Estados nacionais. Um corolário fundamental disso é que as instituições globais devem ser firmemente respeitadoras da diversidade. Ademais, esse é o único sistema compatível com a promoção da democracia no nível mundial. Aliás, promover a democracia como valor universal implica assegurar que os processos nacionais que proporcionam representação e participação possam influir na definição das estratégias de desenvolvimento econômico e social, bem como intermediar as tensões inerentes ao processo de globalização. (...) A construção das instituições, nesse sentido, reconhece que o desenvolvimento abarca objetivos amplos, idéia esta que está implícita no conceito de desenvolvimento humano sustentável ou no conceito mais recente do "desenvolvimento como liberdade" (Sen, 1999). É óbvio que tais conceitos expressam elementos permanentes e 
profundamente arraigados da reflexão sobre o desenvolvimento. Sua principal implicação é que o sistema econômico deve estar subordinado aos objetivos sociais mais amplos (Polanyi, 1957). Essa é a única maneira de enfrentar as violentas forças centrífugas que caracterizam os negócios privados de hoje. De fato, em muitas partes do mundo desenvolvido (e industrializado), as pessoas vêm perdendo o sentimento de pertencerem à sociedade, bem como sua identificação com as metas coletivas e sua consciência da necessidade de desenvolver laços de solidariedade. Esse fato deixa clara a importância de fomentar esses liames, a fim de "criar a sociedade". Significa, em outras palavras, que todos os setores da sociedade precisam participar mais ativamente de instituições políticas democráticas e que é necessário criar, na própria sociedade civil, uma vasta gama de mecanismos que fortaleçam as relações de solidariedade e responsabilidade sociais e, acima de tudo, consolidem uma cultura alicerçada no sentimento de identidade coletiva e de tolerância pela diversidade."

Nesta mesma linha, Edwards apontou o papel da cultura e das crenças compartidas como elemento institucional fundamental do desenvolvimento: "A idéia de que a cultura afeta o desempenho econômico não é nova, obviamente. Max Weber deixou isso claro em sua análise das origens do capitalismo. Em época mais recente, a idéia de que a cultura e as instituições, em particular, desempenham um papel fundamental no desenvolvimento foi enfatizada por estudiosos como Douglas North, Francis Fukuyama e Robert Putnam. Douglas North, agraciado com o Prêmio Nobel, afirmou que os países capazes de desenvolver instituições fortes, que protejam os direitos de propriedade e ajudem a solucionar as disputas, têm "custos de transação" baixos e podem dedicar-se plenamente às atividades produtivas. Robert Putnam concentrou-se no papel do capital "social" e afirmou que as diversas culturas tratam essa importante forma de capital de maneiras diferentes. Francis Fukuyama enfatizou o papel da confiança. Baseando-se nessa noção, Ronald Inglehart (2000) apresentou, recentemente, dados sugestivos de que algumas culturas têm um grau maior de confiança do que outras. As culturas "de alta confiança", por sua vez, têm-se saído melhor em termos do desempenho econômico. Os países da América Latina saem-se particularmente mal nessa dimensão da confiança, com a Argentina, o Brasil, o Chile e o México exibindo uma "confiabilidade" significativamente menor que a das nações européias e asiáticas. (...) Essa ênfase na cultura ajuda a situar a tecnologia numa perspectiva adequada. Em particular, 
frisa um aspecto recentemente salientado por alguns autores, no contexto da "nova" economia e do desempenho empresarial: a menos que seja acompanhada por mudanças "culturais" - com o que me refiro a mudanças institucionais, mudanças de valores e profundas mudanças econômicas -, a tecnologia da informação terá pouco efeito no crescimento e no desempenho gerais. Em termos de clichês, poderíamos dizer que "a revolução da tecnologia da informação exige uma revolução cultural”!

\section{Consensos e dissensos: o Consenso de Washington e os aspectos complexos e contraditórios da globalização.}

Em relação à globalização em geral, e ao Consenso de Washington em particular, os palestrantes colocaram-se em diferentes posições, revelando uma avaliação complexa desses temas e de sua relação com o desenvolvimento.

Cumpre destacar, no tocante à globalização, as posições quase opostas defendidas por Ignacio Ramonet, de um lado - a globalização é a pilhagem planetária - e Sanjaya Lall, de outro - através de uma análise baseada fundamentalmente na experiência benigna dos países do Leste Asiático. A este propósito, Lall destaca os benefícios da integração no mercado mundial. Adverte, no entanto, para a importância de os países ocuparem espaços privilegiados nos fluxos de comércio, e de se precaverem contra os riscos envolvidos. Ressalta, a este propósito, a necessidade de instituições protetoras.

A posição de Ignacio Ramonet poderia ser sintetizada com as seguintes citações: “A globalização é também a pilhagem planetária, como mais uma vez acaba de denunciar a Conferência de Joanesburgo sobre desenvolvimento sustentável. Os grandes conglomerados devastam o meio ambiente através de expedientes absurdos; tiram proveito de riquezas naturais que são patrimônio comum da humanidade, e o fazem sem escrúpulos e de maneira irrefreada. Isso é igualmente acompanhado pela criminalidade financeira ligada ao mundo dos negócios e aos grandes bancos, que reciclam somas superiores a um trilhão de euros por ano, ou seja, mais do que o produto interno bruto de um terço da humanidade. (...) Assim, a Terra passa por uma nova era de conquistas, como durante as colonizações. Mas, enquanto os atores principais da expansão conquistadora anterior eram os Estados, desta vez são as em- 
presas e conglomerados, os grupos industriais e financeiros privados que pretendem dominar o mundo.(...) Assistimos, assim, a um espetáculo insólito: a ascensão poderosa de firmas planetárias, diante das quais os contrapoderes tradicionais (Estados, partidos, sindicatos, meios de comunicação) parecem cada vez mais impotentes. O fenômeno principal de nossa época, a globalização liberal, não é pilotado pelos Estados. Frente às empresas gigantescas, estes perdem mais e mais suas prerrogativas. Os cidadãos assistem, impotentes, a uma espécie de golpe de Estado planetário de um novo tipo. E constatam simultaneamente que, tanto no norte quanto no sul, flagelos sociais que se acreditava haverem desaparecido, como a exploração de crianças, encontram-se em pleno recrudescimento. (...) Indústrias inteiras são brutalmente arruinadas em todas as regiões. E com o sofrimento social daí resultante: desemprego maciço, subemprego, precariedade, exclusão. Há 50 milhões de desempregados no seio da União Européia, um bilhão de desempregados e subempregados no mundo."

Segundo ainda Ramonet, "essa concentração do capital e do poder acelerou-se de maneira espantosa nos últimos vinte anos, sob o efeito das revoluções na tecnologia da informática." Entretanto, há um movimento de oposição que se organiza também no plano internacional: "Por isso é que os cidadãos vêm multiplicando as ações e mobilizações contra os novos poderes, como temos visto desde dezembro de 1999, por ocasião da conferência de cúpula da Organização Mundial do Comércio em Seattle, depois em Praga, em Davos, em Nice, em Quebec e em Gênova. Eles estão convencidos de que, no fundo, o objetivo da globalização liberal, neste começo de milênio, é a destruição do coletivo, a apropriação das esferas pública e social pelo mercado e pelo setor privado. E estão decididos a se opor a isso. (...) O século XXI começou em Porto Alegre. Com efeito, todos aqueles que, de um modo ou de outro, contestam ou criticam a globalização neoliberal reuniram-se, de 25 a 30 de janeiro de 2001 e de 31 de janeiro a 5 de fevereiro de 2002, nessa cidade do sul do Brasil, onde se realizaram os dois primeiros encontros do Fórum Social Mundial e onde se realizará, em janeiro e fevereiro de 2003, o terceiro FSM. Nessa cidade singular, onde floresce uma democracia que não é como as outras, o Fórum Social Mundial tentou, em 2001 e 2002, montar uma outra globalização que não mais exclua os povos. (...) Em Porto Alegre, neste século XXI que começa, alguns novos sonhadores que almejam o absoluto lembraram que não é apenas a economia que é mundial: a proteção do meio ambiente, a crise 
das desigualdades sociais e a preocupação com os direitos humanos também são questões internacionais. E cabe aos cidadãos do planeta enfim as tomarem em suas mãos."

Uma interessante nota de Nancy Birsall acerca dos impactos da globalização no que diz respeito ao agravamento da pobreza e da desigualdade agrega o seguinte: "As reformas econômicas da década de 1990 (as chamadas reformas do Consenso de Washington) não prejudicaram os pobres. Mas também não os ajudaram, nem foram benéficas para a camada intermediária. Seus benefícios foram basicamente colhidos pelos ricos. Para começar, o copo está pela metade. A análise econométrica, usando dados de levantamentos domiciliares sobre a maioria dos países da região em vários anos das três últimas décadas, combinados com índices de reformas econômicas nos diferentes países, sugere que a liberalização do comércio e, como grupo, outras reformas econômicas estruturais, como a privatização, as reformas trabalhistas e as reformas fiscais, não prejudicaram os pobres (e a redução drástica da inflação os ajudou). A única exceção foi a liberalização do setor financeiro, que prejudicou os pobres em termos absolutos. (...) Em nenhum país houve uma melhora evidente no que constitui, de modo geral, taxas altíssimas de desigualdade de renda... Os ingredientes da boa política social - ênfase contínua nos investimentos no ensino fundamental e concentração dos programas de saúde, nutrição e treinamento nas famílias pobres - têm melhorado a vida das pessoas e podem vir a aumentar a renda. Mas, sem crescimento, parece improvável que eles possam causar uma redução de fato dos altos índices de pobreza. (...) Além disso, não é fácil manter investimentos sociais adequados quando o crescimento é pequeno, a dívida pública é grande e não há expansão dos orçamentos governamentais."

Voltemos a Sanjay Lall: “Ao mesmo tempo, as próprias tendências políticas refletem as realidades tecnológicas - o reconhecimento de que a única maneira de os países pobres se beneficiarem dos novos conhecimentos produtivos, atingirem grandes mercados e participarem da "mudança global" da atividade produtiva é serem mais abertos. A meu ver, não há outra maneira de chegar ao desenvolvimento industrial senão participar da dinâmica da globalização. (...) Ser "mais aberto", entretanto, não significa confiar inteiramente no livre mercado. O sucesso competitivo, numa economia global norteada pela inovação, requer fortes potencialidades locais, e o desenvolvimento das potencialidades enfrenta numerosas falhas institucionais e de mercado. As forças do livre merca- 
do não conseguem promovê-lo. Não conseguem fazer uma alocação ótima de recursos, facilitar as mudanças estruturais e dinamizar a competitividade em economias com mercados e instituições ausentes ou sumamente deficientes e com problemas maciços de coordenação. Resta um marcante papel estratégico para os governos dotados de iniciativa. Esse papel é ainda mais intenso com a abertura dos mercados e a mobilidade crescente dos fatores produtivos. (...) Há muitas maneiras de fazê-lo de modo eficiente, como mostra a experiência do Leste Asiático (...) Esse panorama tem um lado otimista e um lado pessimista. $\mathrm{O}$ otimista consiste em que se mostra ser possível os países em desenvolvimento crescerem e competirem com eficiência no contexto emergente, entrando em mercados competitivos de produtos manufaturados e subindo rapidamente na escala tecnológica. O pessimista é que há uma tendência para uma divergência cada vez maior, e não para uma convergência. O processo de globalização tem distanciado os que estão "dentro" e os que estão "fora" do dinamismo tecnológico. Alguns países "de dentro" têm participado de sistemas internacionais e integrados de produção. Dentre estes, os realmente dinâmicos são os que desenvolveram uma sólida capacitação tecnológica local; os demais países "de dentro" precisam seguir seu exemplo, investindo em capital humano e tecnológico. Os demais países em desenvolvimento encontram-se "do lado de fora" em graus variáveis, desde os que estão prestes a se juntar aos que já entraram, num dos extremos, até os que correm o risco de marginalização a longo prazo, no outro.(...) A globalização movimenta os recursos produtivos e o conhecimento pelo mundo afora, em ritmo acelerado. Todavia, não reduz a necessidade de capacitação e instituições locais; muito pelo contrário, a força do sistema local de aprendizagem torna-se cada vez mais importante para atrair e "enraizar" os recursos móveis que se acham disponíveis no exterior. Pelo simples fato de o capital e as tecnologias estarem mais acessíveis (e mais livres para se movimentar), os países têm que oferecer qualificações, potencialidades, redes de abastecimento, instituições e infra-estrutura melhores para atrair recursos de alta qualidade. A simples abertura das economias para as forças do mercado global, sem aprimorar as qualificações e as potencialidades, pode servir para explorar a capacidade já existente, mas, a prazo mais longo, pode ser a receita da estagnação na base da escala tecnológica e de renda. (...) Que é preciso para que os países em desenvolvimento logrem êxito num contexto globalizado? Numa palavra, competitividade. Faz muito tempo que a competitividade internacional é considerada vital para as economias industrializadas; com a 
globalização, também vem-se tornando crucial para os países em desenvolvimento, que ficaram longamente isolados dos mercados mundiais. Chegar à competitividade é difícil e requer muito mais do que a simples "abertura" passiva para os mercados livres."

Dani Rodrick situa-se no grupo dos palestrantes do Seminário Internacional que vê mais oportunidades do que riscos nos processos de globalização em curso, e isto porque é otimista em relação ao papel que podem desempenhar as instituições, por um lado, e à possibilidade de se corrigirem os rumos da globalização, por outro. Segundo as suas palavras: "Por último, acho que não nos devemos opor à globalização em si. Os países pobres precisam de mercados e de tecnologia, aos quais só podem ter acesso através do contato estreito com a economia mundial. O problema não está na globalização, mas na agenda distorcida que a dirige atualmente. (...) Quando falo em "agenda distorcida", penso em coisas que vão além da reclamação tradicional a respeito das assimetrias no acesso ao mercado. O que temos hoje em dia é uma orientação que privilegia em excesso a liberalização do comércio e dos mercados financeiros, enquanto desconsidera por completo os benefícios muito maiores que se podem extrair da liberalização do comércio da mão-deobra. É uma orientação que desconhece a necessidade legítima dos países em desenvolvimento de dispor de "espaço" e autonomia políticos em que possam elaborar suas próprias estratégias. (...) Não devemos rejeitar a globalização; devemos corrigir seu protocolo. (...) Na verdade, precisamos voltar a um modelo "leve" de globalização - com menos concentração na disciplina e na harmonização internacionais - e desistir de adotar uma versão "pesada" que sufoca os países em desenvolvimento. A abordagem de "integração superficial" do GATT mostrou-se muito mais acolhedora para os projetos de desenvolvimento do que o modelo de "integração profunda" da OMC. (...) E, num modelo "leve" de globalização, é preciso deslocar a atenção para o relaxamento das restrições à mobilidade da mão-de-obra. Essa é uma área em que os benefícios são maiores para a eficiência global e os países pobres do que todas as outras coisas constantes da agenda atual de negociações."

Uma visão que ressalta a complexidade e as assimetrias da globalização seria, sobretudo, a de Joseph Stiglitz: "Atualmente, uma questão é debatida em toda a América Latina: falhou a globalização ou falhou a reforma? O que fica claro é que há uma decepção com as medidas políticas impostas nas duas últimas décadas - aquelas que se concentraram na liberalização, na privatização e na estabilização, e que passaram a 
ser coletivamente conhecidas como normas do Consenso de Washington. (...) Um exame mais atento do exemplo de sucesso freqüentemente repetido, o Chile, mostra que, nos anos de seu desempenho fenomenal, com um crescimento de $7 \%$, o país não fez simplesmente sucumbir, querendo ou não, aos ditames do Consenso de Washington. Como nos exemplos de sucesso do Leste Asiático, ele foi seletivo, fazendo acréscimos e subtrações nas receitas padronizadas, de um modo que lhe permitiu moldar a globalização de acordo com seus objetivos. (...) Voltando-nos mais estritamente para a economia, a globalização tem três vantagens claras: a demanda dos produtos de um dado país já não fica restrita a seu próprio mercado; os investimentos de um país não mais ficam restritos ao que ele próprio pode poupar; e os países podem ter acesso (mediante um preço) à mais avançada tecnologia. Mas, correspondendo a essas oportunidades, há alguns desafios de porte: os países desenvolvidos aprenderam a usar uma multiplicidade de barreiras não-tarifárias para manter do lado de fora os produtos do mundo em desenvolvimento; embora o investimento externo direto traga não só o acesso ao capital, mas também à tecnologia e aos mercados, isso não se aplica ao capital financeiro de curto prazo, que expõe os países a uma enorme instabilidade."

Sua posição mais otimista em relação às possibilidades de mudar o quadro internacional reflete a esperança de que países como o Brasil adotem uma postura agressiva em defesa de um regime mais equilibrado, não só para o seu próprio bem, como para o benefício do mundo inteiro. "Mesmo dentro dessas regras, creio que países como o Brasil podem contribuir para moldar a globalização, para fazê-la funcionar não apenas para os ricos dentro do país, como para todos. Para fazê-lo, porém, tais países precisam escolher seu próprio rumo, livres dos mantras simplistas que desempenharam um papel tão central no direcionamento da política econômica da América Latina na última década. Não será fácil, mas não existe alternativa."

O debatedor Luciano Martins, Embaixador do Brasil em Cuba, sintetiza com grande elegância as posições dos palestrantes a este respeito: "Acrescente-se que o estado-nação também está em crise pelas ameaças "por cima". E essas vêm da globalização, ou seja, da vulnerabilidade por ela gerada no contexto da interdependência assimétrica por ela criada e agora agravada pela atual geometria mundial de poder. Essa vulnerabilidade talvez possa ser resumida em quatro fenômenos principais: 
a) a "lógica" do sistema financeiro internacional (cujos movimentos estão gerando aquilo que o Prof. Stiglitz qualificou como "automatic destabilizers"), assim como a dos estranhos critérios adotados pelas agências de "rating", que oscilam, como escreveu em artigo recente Ocampo, da "exuberância irracional" ao "pânico irracional"- mas que influenciam movimentos de capital;

b) as posições arbitrárias do FMI e, às vezes, do Banco Mundial. Vejam o caso interessante da crise energética de um país conhecido. Uma empresa estatal tinha US\$ 4 bilhões para investir para prevenir uma (previsível) crise energética. Mas foi impossibilitada de fazê-lo porque o FMI decreta que investimentos de empresas estatais devem ser contabilizados como gastos públicos. Curioso. Nos Estados Unidos, os novos "robber barons" da Enron e similares, graças a essa pérola semântica chamada "creative accountability" (leia-se fraudes contábeis), praticaram à vontade justamente o oposto: contabilizaram como sendo investimentos o que na realidade eram gastos. E parece que os famosos mecanismos "auto-reguladores" do mercado foram incapazes de detectar tais procedimentos. Se é assim, pergunto que eficácia possuem;

c) Alberto Fishlow argumenta, a meu ver com razão (e creio que há duas décadas que insiste nisso), que a forma de diminuir a vulnerabilidade decorrente da "ciclotimia" (para repetir a expressão do Presidente do Banco Central) dos fluxos de capital externo é aumentar a poupança doméstica. Mas isso supõe justamente a adoção de políticas públicas voltadas para criar condições de investimento e para restringir o deslocamento de capitais domésticos para o exterior. (...)

d) o Prof. Lall chamou a atenção em seu paper para o fato inegável de que a melhor inserção internacional dos países em desenvolvimento depende em grande parte do aumento da competitividade de suas exportações. Nada mais sensato. Mas como, atingido esse objetivo, lutar contra os subsídios e as barreiras de todo tipo através das quais os países desenvolvidos defendem seus mercados ao mesmo tempo que exigem a abertura dos nossos..."

Haveria ainda que registrar as posições relativamente convergentes de Albert Fishlow e Sebastian Edwards, de crítica operacional ou pontual a alguns aspectos da globalização ou conceitos do consenso de Washington. A abertura excessiva da conta de capitais, a velocidade 
das mudanças e o grau de dependência dos fluxos externos de capital estariam entre os aspectos preocupantes.

Segundo Fishlow: "A dissolução dos controles monetários, das cotas e de outros empecilhos ocorreu no fim da década de 1950 ...(...) e sua dimensão conduziu, como seria inevitável, a um amplo debate sobre as virtudes da globalização. (...) A globalização e a maior dependência dos sinais do mercado tornaram-se o inimigo óbvio. A conversão ao capitalismo e a privatização generalizada trouxeram apenas ganhos ilusórios. A freqüência das crises internacionais nos últimos anos é uma prova incontestável disso. (...) A globalização é uma realidade. Por sua natureza, a exposição ao mundo externo acarreta riscos e oferece oportunidades. $\mathrm{O}$ velho mecanismo da acumulação de reservas já não serve de garantia da independência nacional. Num mundo de movimentações de capital imensamente rápidas e substanciais, é assim que acontece. Nesse mundo, cabe comercializar mais produtos e serviços e depender menos dos fluxos provenientes do exterior. É esta a minha mensagem de hoje."

De acordo com Sebastian Edwards: "Muitos críticos da globalização, entre eles Joe Stiglitz e Paul Krugman, afirmaram que, para que a liberalização econômica tenha sucesso, é essencial que as reformas sejam implementadas na velocidade certa e na seqüência certa. Esse é um princípio muito importante, que esses dois autores têm razão de enfatizar. Eles acertam particularmente o alvo ao afirmarem que a abertura demasiadamente precoce da Conta de Capitais tende a gerar graves perturbações e acaba contribuindo para a deflagração de grandes crises."

Por fim, cumpre registrar a posição de Giovanni Dosi acerca das relações entre globalização e convergência tecnológica. O ponto central da sua contribuição aos debates é que a globalização - basicamente de caráter financeiro - não assegura a convergência tecnológica e, ao que parece, a tendência aponta na direção oposta. Desta forma, algumas das razões para o otimismo em relação aos processos de abertura deveriam ter em conta a necessidade de apoio institucional deliberado à inovação e à aprendizagem tecnológica, que ocorre necessariamente no interior das economias nacionais: "Em suma, se nossa interpretação está certa, a chamada "globalização" tem a ver, acima de tudo, com (a) a liberalização internacional dos movimentos de capital e (b) a liberalização (bastante assimétrica) dos fluxos de comércio, ao mesmo tempo que surte efeitos bastante controvertidos sobre os padrões internacionais de aprendizagem tecnológica e a distribuição correlata das possibilidades de crescimento entre os países. (...) Primeiro, há que desfazer o mito de 
que a "globalização" - no sentido de maior integração internacional acompanha naturalmente a "convergência" ou a maior uniformidade das potencialidades tecnológicas. (...) Como foi mais extensamente discutido, o conhecimento, distinguindo-se da simples informação, tende a ser de transmissão muito lenta, uma vez que costuma incorporar-se em pessoas, organizações e redes locais específicas. (...) Segundo, num mundo caracterizado por múltiplas formas de lucros localizados crescentes, a maior integração pode levar a fenômenos de diferenciação crescente, com o auto-reforço e o confinamento de determinadas atividades produtivas, padrões de especialização e capacidades tecnológicas (ou falta delas). (...) Dito de outra maneira, é fácil mostrar que um mundo que, em certo nível, torna-se cada vez mais integrado - mas não (aproximadamente) idêntico nas condições iniciais, nas instituições, capacidades tecnológicas, mecanismos de interação econômica, etc. - pode ficar sujeito a várias formas de círculos virtuosos ou viciosos "locais". (...) Terceiro, o impacto da maior integração tende a depender das formas pelas quais ela é implementada.(...) Quando os choques macro ("globalizantes") induzem repentinamente a uma seleção maior das empresas nacionais (especialmente na América Latina), é freqüente a mortalidade maciça das firmas acarretar uma aparente redução da defasagem de produtividade em relação à fronteira internacional. Mas isso parece ser acompanhado - ao menos na América Latina - por aumentos notáveis das taxas de desemprego (isto é, transições de partes da força de trabalho, como diz Joe Stiglitz, de estados de baixa produtividade para situações de produtividade zero) e por uma acentuação das restrições da balança comercial ao crescimento, o que constitui, por sua vez, o efeito conjunto de uma elasticidade relativamente baixa das exportações para o crescimento mundial e de uma elasticidade alta das importações para o crescimento interno. Mas, se não é a "globalização", quais são os ingredientes e processos relativos e invariantes, se é que existem, que impulsionam a equiparação tecnológica?"

Grande parte dos debatedores do Seminário Novos Rumos compartilhou, aliás, essa avaliação complexa sobre os benefícios e riscos da globalização. Apenas para ilustrar, tomemos as posições de Helio Jaguaribe e Edmar Bacha.

Segundo Helio Jaguaribe: "O Brasil nesses últimos vinte anos, a despeito de que diversos governos não tinham ideologia neoliberal, na verdade adotou, de uma maneira bastante sistemática, o consenso de Washington. Tanto no sentido de tentar melhorar as linhas de governabilidade 
e de responsabilidade da situação financeira do país, como também no sentido da abertura do mercado, da privatização, da abertura indiscriminada ao capital estrangeiro, etc. (...) $\mathrm{Na}$ verdade, foram vinte anos de estagnação. (...) O Brasil está condenado, como tantos outros países, a se converter no segmento anônimo do mercado internacional? (...) É necessário um consenso a respeito das grandes metas nacionais".

Já Edmar Bacha propõe uma agenda positiva em relação à dependência externa: "Da forma que eu vejo, há três opções, aparentemente e não necessariamente excludentes, para superar esta restrição financeira de divisas. A primeira opção é o estabelecimento de um emprestador de última instância para as economias emergentes no contexto de uma nova arquitetura financeira mundial. Isso significaria substituir o FMI por um FME, ou seja, por um fundo de mercados emergentes. (...) Uma segunda opção, restrita agora à nossa região, seria estabelecimento de uma área de livre comércio das Américas, acompanhada de uma dolarização completa. O problema com essa opção, obviamente, seria a perda de soberania nacional na América Latina, dado o desproporcional poderio econômico e militar dos Estados Unidos. (...) Resta-nos pois a terceira opção, que é ampliar e aprofundar os mercados financeiros domésticos, tornando assim o processo de investimento menos dependente do financiamento externo. (...) Concluo esperando que a análise dos dissidentes de Cambridge, sobre as diferentes alternativas para o desenvolvimento financeiro local, nos permita avançar ao longo dessa terceira opção."

Uma outra agenda positiva foi proposta nesse caso pelo debatedor da sessão Agenda Social e Combate à Pobreza, o Reitor da UFRJ, Carlos Francisco Lessa: "Isso repõe a necessidade de reconstruir, sim, um discurso sobre a nação. A nação não pertence ao jurássico. O discurso da globalização supôs cancelá-la, mas, na hora da aflição, a última instância, a última barreira, está exatamente na idéia da nação. Esta idéia é que tem de ser reconstruída, como barreira, como linha de defesa, como a possibilidade de construir as respostas, quando se está isolado e levado à situação de passar a ser uma peça não mais desejada pelo processo de globalização. Penso que se a África subsaariana pudesse construir um movimento desse tipo, escaparia das maldições trágicas a que ela está submetida. Acho que a Argentina vai dar para a América Latina o exemplo histórico da reconstrução por esse caminho. Vou prognosticar, ou pelo menos eu vou fazer uma espécie de aposta na reconstrução de um discurso nacional argentino. Espero que ele seja nacional, democrático, e preocupado com o social. E acho que necessariamente assistiremos a uma retomada da idéia de nação." 


\section{Diretrizes e políticas para os Novos Rumos do Desenvolvimento no Mundo}

Uma leitura dos textos apresentados no Seminário Internacional Novos Rumos do Desenvolvimento no Mundo apontaria o seguinte conjunto de diretrizes e políticas para o desenvolvimento "sem adjetivos".

4.1. Políticas macroeconômicas: redução da vulnerabilidade externa; política tributária "brilhante", estabilidade interna.

\subsection{Política social}

4.2.1. No plano internacional

- Fundo global de coesão social.

- Bens públicos globais.

- Superação das assimetrias internacionais - cidadania global.

\subsubsection{No plano nacional}

- Independentemente das políticas sociais compensatórias e focalizadas, reconstituir o "contrato social amplo na economia aberta", através das políticas de geração de emprego, trabalho e renda; apoio a MPME; desenvolvimento desde dentro.

4.3. Política industrial e tecnológica

- Ênfase na competitividade sistêmica e na promoção de exportações.

- Acesso a mercados e às redes globais. Conectividade.

- Convergência tecnológica, pesquisa, educação e infra-estrutura.

- Promoção da flexibilidade na economia; redefinição de setores e do padrão de investimento.

- Desenvolvimento institucional próprio.

Vejamos mais detidamente os conteúdos e a defesa desse conjunto amplo, diversificado e integrado de estratégicas e de políticas.

4.1. Políticas macroeconômicas: redução da vulnerabilidade externa; política tributária "brilhante" e estabilidade interna.

As estratégias adotadas por países em desenvolvimento deveriam incorporar pelo menos quatro componentes, segundo Ocampo: políti- 
cas macroeconômicas para reduzir a vulnerabilidade externa e facilitar o investimento produtivo; estratégias de desenvolvimento produtivo para criar competitividade sistêmica; política social atuante - educação, emprego e proteção social; e instituições específicas que gerem um equilíbrio apropriado entre os interesses públicos e privados. Em suas próprias palavras: “(...) não existe um modelo único de gestão econômica que garanta a estabilidade macroeconômica, nem tampouco existe uma forma única de integração na economia internacional ou de concepção das instituições econômicas e sociais. Na terminologia de Albert (1991) e Rodrik (1999) ${ }^{10}$, existem diferentes "variedades de capitalismo", como indica a experiência dos países desenvolvidos e em desenvolvimento. É bom que seja assim, pois isso implica que a democracia tem um papel a desempenhar e que a "posse" das políticas de desenvolvimento tem um sentido positivo, não constituindo uma simples concordância "voluntária" com o paradigma dominante (ou, o que dá no mesmo, uma aceitação cega das "restrições" impostas pela globalização)."

Como vários autores apontaram, especialmente Edwards e Fishlow, a variável de ajuste mais vulnerável na América Latina é a baixa taxa de poupança, em torno de $20 \%$ do PIB durante a década de 1990, e a elevada poupança externa, que tendeu a ultrapassar 5\% do PIB no período de 1970-1999: “Os déficits historicamente grandes no balanço de pagamentos não são sustentáveis ao longo do tempo (...) costumam ser acompanhados por "inversões", amiúde geradas pela "cessação repentina" da entrada de capitais (...) e os efeitos mais graves das inversões da Conta Corrente no desempenho econômico ocorrem indiretamente, através de seu impacto nos investimentos." (Sebastian Edwards).

O receituário - amplo e consensual - de políticas macroeconômicas proposto por Edwards, Fishlow, Ocampo, Stiglitz e Rodrick ${ }^{11}$ seria: estabelecer medidas macroeconômicas coerentes e flexíveis; reduzir os níveis excessivos de endividamento público e privado; prevenir desequilíbrios nos preços macroeconômicos essenciais; manter um sistema de regulamentação e supervisão rigorosos, principalmente nos períodos de euforia financeira; implementar políticas concernentes ao passivo, que visem assegurar a manutenção de perfis adequados de vencimento com respeito às obrigações públicas e privadas nos âmbitos interno e ex-

\footnotetext{
${ }^{10}$ Ver citações no texto dos autores.

${ }^{11}$ A referência é sempre o artigo dos palestrantes no seminário internacional.
} 
terno; estabelecer sistemas tributários sólidos, taxa de câmbio competitiva, taxas de juros reais moderadas e mercados financeiros fortes.

O elo de ligação entre as políticas de estabilidade macroeconômica e a implementação de políticas sociais de amplo alcance, sendo aquelas precondições destas, parece ser a política tributária. A esse propósito Nancy Birdsall observa que: “ 'uma política tributária brilhante' é o ingrediente central do contrato social numa economia aberta. Emprego a palavra 'brilhante' porque, ironicamente, o padrão das economias dos mercados emergentes na América Latina é mais alto que o dos Estados Unidos e das economias européias. É que essas economias latino-americanas emergentes têm dois problemas: mercados financeiros internos menos sólidos e menos resistentes aos revezes econômicos, e um histórico ruim. Os mercados financeiros de pouco lastro dificultam a administração da instabilidade por parte do governo. O histórico ruim (de tomada de empréstimos mal administrada, com as crises resultadas de inflação e monetárias) significa que os credores internos e externos continuam céticos quanto à capacidade política de os governos administrarem seus orçamentos, sem recorrerem, nas situações de crise, à emissão de moeda ou a novas rodadas de empréstimos excessivos e dispendiosos."

\subsection{Política social}

\subsubsection{No plano internacional}

A urgência das políticas de inclusão social se refere tanto à esfera nacional quanto ao plano internacional. As instituições de governança global, portanto, terão um papel a desempenhar assim como os governos e as organizações da sociedade civil, no âmbito dos países. A este propósito, algumas sugestões foram encaminhadas pelos palestrantes do Seminário Novos Rumos do Desenvolvimento no Mundo. Entre elas, destacam-se as sugestões de Ocampo, a seguir indicadas.

- Fundo global de coesão social e bens públicos globais para a superação das assimetrias internacionais e o estabelecimento de uma cidadania global.

Como disse Ocampo: "Dadas as gritantes desigualdades que caracterizam a ordem global, um componente central da expressão material desses direitos é o cumprimento dos compromissos de assistência oficial ao desenvolvimento (AOD) assumidos no contexto da ONU. A longo prazo, isso deverá levar à criação de um verdadeiro "fundo global de coesão social" que facilite o exercício dos direitos econômicos e sociais 
dos membros mais pobres da comunidade internacional. (...) a ação redistributiva do Estado é indispensável no nível nacional, para assegurar a igualdade de oportunidades, os esforços nacionais só podem ter pleno sucesso no nível global se forem complementados por uma cooperação internacional projetada para superar, gradativamente, as assimetrias básicas da ordem global, que estão na raiz das profundas desigualdades internacionais na distribuição de renda."

Ainda a este propósito Ocampo chama a atenção: "As deficiências exibidas pelo atual processo de globalização demonstram a necessidade de trabalharmos em direção a três objetivos fundamentais:

- garantir uma oferta satisfatória de bens públicos globais;

- construir um sistema mundial baseado nos direitos humanos, isto é, uma cidadania global; e

- superar gradualmente as assimetrias que caracterizam o sistema econômico mundial.

(...) Construir a cidadania global numa comunidade internacional heterogênea implica o respeito por direitos humanos básicos e pela diversidade cultural, assim conciliando o princípio da igualdade com o "direito de ser diferente". (...)"

A garantia de oferta de bens públicos globais complementa suas recomendações para uma política social global. Trata-se de assegurar os chamados "bens públicos puros" - "bens e serviços com grandes externalidades, mas cujos benefícios podem ser apropriados em caráter privado, e bens comuns globais (que são rivais no consumo). Nesse sentido lato, o conceito inclui, entre outras coisas, a paz e a justiça internacionais, a diversidade cultural, a luta contra as pandemias internacionais, a sustentabilidade do meio ambiente, a regulamentação do uso dos bens comuns globais, normas para regular as transações econômicas internacionais e a estabilidade macroeconômica e financeira mundial."

- Política Social no plano nacional

O consenso entre vários palestrantes de que o crescimento não garante a redução das desigualdades sociais leva à recomendação de políticas sociais compensatórias e focalizadas. Entretanto, e na medida em que estas políticas competem com outros gastos num orçamento limitado, elas passam a ser vistas como alternativas a políticas estruturais 
direcionadas: geração de emprego, trabalho e renda; apoio a MPME (micro, pequenas e médias empresas) e desenvolvimento "desde dentro". Com isto, tende-se a abandonar o "contrato social amplo" da política econômica, com claro prejuízo para as camadas de rendas médias, que se situam no limiar da pobreza e que são as principais vítimas da instabilidade econômica. São elas, por outro lado, que garantem a estabilidade política e institucional. A síntese que emerge do seminário Novos Rumos aponta para a necessidade de retomar o contrato social amplo numa economia aberta como direção predominante das políticas sociais, sem no entanto descartar os programas de seguro social focalizado, buscando integrá-los na concepção do contrato amplo.

A seguir, apontamos os consensos sobre as políticas sociais nacionais que emergem do debate, utilizando os textos dos participantes.

- Uma política social eficaz é a que ataca efetivamente as causas, e não apenas os sintomas da pobreza. Como tais causas são múltiplas, requer-se necessariamente a ação integrada de diversas organizações em diferentes campos. É preciso somar o governo federal, as regiões, os municípios, a sociedade civil e as organizações dos próprios pobres, e integrar as ações nos campos do trabalho, da educação, da saúde, da família e outros. Impõem-se alianças estratégicas entre as diferentes organizações.

- É urgente a necessidade de políticas sociais coesas, integradas, descentralizadas, implementadas em co-gestão com a sociedade civil, participativas, transparentes, com alto padrão de gerenciamento social, com meios efetivos de mobilização produtiva, resgate da dignidade e integração social.

- A educação é o meio primário de sustar a reprodução intergeracional da pobreza e da desigualdade. A garantia do acesso à educação tornou-se ainda mais importante, na medida em que se ampliou a necessidade de recursos humanos capazes de se engajarem em novos modos de produção e na maior competição internacional.

- O desenvolvimento dos sistemas de proteção social por princípios da universalidade, solidariedade, eficiência e integridade é a chave para corrigir desigualdades marcantes no acesso a esses serviços. A solidariedade deveria ser garantida por uma combinação de contribuições compulsórias, transferências públicas e subsídios cruzados entre as diferentes camadas de renda e grupos de risco. 
- O voluntariado, a sétima economia do mundo em produto bruto, deveria ser incentivado. O trabalho voluntário presta uma gama vastíssima de serviços aos setores mais fragilizados da população, como os sem-teto, as crianças, a família, os imigrantes, os deficientes e os idosos. $\mathrm{O}$ incentivo à responsabilidade social empresarial poderia dar-se de várias formas - através, por exemplo, da constituição de fundos de investimento que pedem aos investidores que só comprem ações das empresas com melhores índices de responsabilidade com a cidadania.

- É necessário contar com as organizações dos próprios pobres. Um dos elementos fundantes disso é que, nestas, os pobres realmente participam, recuperando a confiança em si mesmos e em sua comunidade; investir no fortalecimento da capacidade de organização dos pobres, mediante uma capacitação de seus líderes, a oferta de infra-estruturas para atividades societárias, a desregulamentação jurídica e outros meios.

A Profa. Sônia Maria Draibe, da UNICAMP, debatedora da sessão Agenda Social e Combate à Pobreza, sintetiza essas questões. Em suas palavras: "De fato, o que parece estar em jogo, dadas as novas condições socioeconômicas, é o conceito de "segurança socioeconômica" - ou seja, a proteção econômica do social. Ou, ainda, o enraizamento da economia na sociedade através de estruturas, de sistemas de regulação, de proteção e de distribuição que limitam a insegurança social e econômica, reduzem as desigualdades e produzem padrões mais amplos de oportunidade. (...) Por sua capacidade de criar solidariedades e ao mesmo tempo de desenvolver capital humano - pilares do novo contrato social - o novo sistema de proteção social tem na educação e na política de saúde suas áreas estratégicas de intervenção. (...) Finalmente, um efetivo sistema de proteção social deve e pode abrigar desde formas de renda mínima até a forte afirmação do direito ao trabalho, não substituível pelos programas anteriormente referidos. Em outros termos, por novo que seja, há uma dimensão de conservação no sistema de proteção social aqui delineado, dado que se insiste também e sempre no papel fundamental de trabalho, do direito ao trabalho e da proteção ao emprego como suas formas centrais."

Para concluir as recomendações do Seminário Novos Rumos relacionadas com a política social brasileira, citemos a síntese proposta pelo debatedor Carlos Francisco Lessa, reitor da UFRJ: "Quando uma sociedade gasta, educando sua nova geração, ela está se repondo no futuro. 
Quanto é que isso vale? Eu acho que o exercício de custo/beneficio para avaliar isso é um exercício de mediocridade, de aprisionamento dos direitos."

\subsection{Política industrial e tecnológica}

A política industrial e tecnológica, que esteve praticamente banida do receituário de políticas nos anos 1990, foi apontada por vários palestrantes do Seminário Internacional Novos Rumos do Desenvolvimento no Mundo como um componente fundamental das políticas de desenvolvimento no mundo globalizado e numa economia intensiva em tecnologia e conhecimento.

A esse respeito, os principais argumentos vêm de Joseph Stiglitz e serão, a seguir, sumariados “.... os Estados Unidos e o Leste Asiático fornecem provas convincentes da importância da política industrial. (...) Um ingrediente central das políticas de sucesso dos países do Leste Asiático foi a tentativa deliberada de reduzir a 'defasagem do conhecimento'."

E conclui Stiglitz com uma assertiva sobre a moderna política industrial: "Seja como for, aprendemos com os erros, e creio que estamos em condições de criar uma política industrial ainda mais eficaz. A política industrial moderna concentra-se em tentar identificar áreas em que as falhas de mercado tenham a máxima probabilidade de serem melhor sucedidas. Por exemplo, ela busca áreas em que avultem as falhas de coordenação, ou em que haja grandes desperdícios ou problemas significativos de apropriação. As pesquisas sobre a Internet ilustram todos esses problemas. Seria difícil uma empresa privada apropriar-se de toda a gama de benefícios da Internet; o valor desta aumentou com o uso, mas, se um construtor potencial da rede tivesse que esperar que as empresas de aplicativos da Internet lhe pedissem para criá-la, ela nunca teria sido desenvolvida. A Internet teve enormes conseqüências para todas as empresas, e não apenas para as que estão diretamente envolvidas com o marketing em rede. A economia da informação também nos ajuda a entender por que os mercados de capitais são amiúde imperfeitos e, por conseguinte, por que o governo pode ter que desempenhar um papel importante nesse campo. (...) A infra-estrutura é outra área em que o governo é dominante: que áreas de pesquisa apoiar, onde construir estradas e aeroportos, moldam a economia e a competitividade."

Nesta mesma direção Sanjaya Lall insiste sobre o papel catalisador da política industrial no Leste Asiático. Na América Latina, diz o autor, 
tanto o setor público quanto o privado precisarão perguntar-se "quais serão as vantagens comparativas no futuro, e de que modo eles podem e devem alterar essas vantagens comparativas através dos investimentos. Cada vez mais, as economias modernas são economias do setor de serviços e do conhecimento."

Entretanto, o debatedor Winston Frisch, da sessão Desafios do Crescimento: Instituições, Investimentos, Competividade e Tecnologia, adverte acerca dos principais entraves à implementação de uma política industrial consistente: (...) "dado um conjunto de oportunidades de investimento é o custo de capital que vai determinar o nível de investimento. É claro que há fatores macroeconômicos e institucionais que influenciam o custo de capital. Há também um vastíssimo conjunto de fatores culturais, históricos, etc.(...) Mas eu gostaria agora de me concentrar, por considerar extremamente relevante, no custo de capital como determinante de investimento. Vamos considerar que os outros determinantes das possibilidades de investimento são dados e olhar somente o custo de capital, pois estou convencido de que o maior problema, o maior desafio da política industrial no Brasil é o alto custo de capital, e não como normalmente se discute, a calibragem de incentivos tradicionais de política industrial que afetam preços relativos, como tarifas, subsídios, etc."

- Ênfase na competitividade sistêmica e na promoção de exportações

O foco na competitividade sistêmica e na promoção de exportações remete a Lall, que mencionou a importância dos impulsionadores estruturais da competitividade (UNIDO), sendo os principais o investimento estrangeiro direto, as qualificações, a pesquisa e o desenvolvimento nacionais, o sistema de licenciamento e infra-estrutura física. Mesmo não tendo em conta o papel das instituições e da gestão governamental, os "impulsionadores" correlacionam-se muito bem com o desempenho da competitividade.

- Acesso a mercados e às redes globais. Conectividade.

Manuel Castells chamou a atenção para as características da economia global em rede, baseada no conhecimento. Segundo Castells, fazse necessário, na América Latina, "um agente do interesse público capaz de promover o novo paradigma do desenvolvimento nas condições específicas de inserção de cada país na economia global, um agente que possa servir de interface entre o Estado e a sociedade civil, entre os fluxos globais de capital e as empresas nacionais, e entre as instituições 
existentes de produção do conhecimento e de recursos humanos (educação, pesquisa) e as novas necessidades desses fatores de produção, com isso estimulando o desenvolvimento dos recursos humanos e a geração de conhecimentos em projetos estabelecidos como metas. (...) Trata-se de uma estratégia de desenvolvimento concentrada num desenvolvimento econômico que seja sustentável, globalmente competitivo e alicerçado numa base endógena de recursos humanos, formada por pessoas sadias, instruídas e seguras. Talvez os Bancos de desenvolvimento tradicionais da América Latina, como o BNDES, que foram atores cruciais no período de industrialização e da modernização inicial da América Latina, possam ser regenerados para desempenhar esse papel. (...) E somente se isso acontecer é que a América Latina poderá aceitar o desafio do novo modelo de desenvolvimento - um desafio que as políticas liberais de livre mercado que dominaram a última década não conseguiram enfrentar, com isso levando a América Latina a mergulhar numa situação dramática e, quem sabe, tornando a globalização socialmente insustentável na região."

- Convergência tecnológica, pesquisa, educação e infra-estrutura. Pesquisa, desenvolvimento, informação (PDI).

Um dos maiores consensos revelados no seminário internacional Novos Rumos do Desenvolvimento no Mundo foi o do papel crucial do conhecimento como condição do desenvolvimento. Diria Ocampo: "Qualquer dessas estratégias deve basear-se num maior investimento público e privado na educação, na formação profissionalizante e administrativa e na ciência e tecnologia. Essa estratégia deve ser implementada através de muitas formas diferentes de colaboração entre o Estado e o setor privado, todas as quais devem concentrar-se na criação de sistemas dinâmicos de inovação. (...) Na área da educação, os esforços devem concentrar-se na conquista de uma abrangência universal, de preferência até a conclusão do curso secundário, e na redução das diferenças na qualidade do ensino oferecido aos diferentes grupos socioeconômicos. Também se fazem necessárias novas abordagens da aprendizagem, envolvendo o acesso ao conhecimento, o emprego de redes de computadores e o uso das tecnologias de informática e comunicações. A modernização das ferramentas de ensino não é suficiente, entretanto. Ainda mais importante, em conjunto com essas novas ferramentas, é desenvolver as funções cognitivas superiores, orientando o processo de aprendizagem para a identificação e resolução de proble- 
mas, uma capacidade maior de reflexão, a criatividade, a capacidade de distinguir entre o que é o que não é importante, e as aptidões de planejamento e pesquisa, já que essas funções são vitais num mundo saturado de informações."

Essa variável estratégica da política do desenvolvimento - a busca da convergência tecnológica através dos investimentos na economia do conhecimento - esteve, em diversos momentos do seminário, indissoluvelmente ligada a outras dimensões do desenvolvimento e de suas políticas, mais concretamente à política social e à política industrial.

Como bem assinalou Kliksberg: “ 'O conhecimento é a única fonte de vantagens relativas’ (Thurow, 1996) ${ }^{12}$. A educação é a via mestra para que se possa gerar e utilizar o conhecimento. $\mathrm{O}$ índice de retorno sobre o investimento, nas indústrias que investem em conhecimento e capacitação, é o dobro do obtido pelas indústrias que concentram seus investimentos no ativo imobilizado e em equipamentos. $\mathrm{O}$ mesmo ocorre noutros campos. Segundo os cálculos do UNICEF, um ano a mais de escolaridade entre as meninas da América Latina poderia reduzir as taxas de mortalidade infantil em 9 a cada 1.000. O incremento do capital educativo reduziria a gravidez na adolescência, melhoraria a capacidade de acompanhamento da mulher na gestação e no período pós-parto e ampliaria sua cultura para um desempenho nutricional adequado."

O debatedor Antonio Barros de Castro, do Instituto de Economia da UFRJ, por outro lado, chamou a atenção para a evidente correlação entre a política tecnológica e a política industrial. Concordando com o palestrante Benjamin Coriat, nesta mesma sessão, ambos enfatizaram a importância de uma política de soberania nacional para contra-arrestar a tendência à redução das oportunidades de desenvolvimento imposta por países tecnologicamente mais avançados. Nas palavras de Castro: "A terceira etapa da lei de Prebish qual seria? Os desenvolvidos agora tratam de impedir que os avanços da economia do conhecimento tenham o seu valor aviltado. Criar, prototipar, inovar, está se tornando mais barato - e o conhecimento está se difundindo mais rapidamente. Aí vêm, a galope, pelo menos Coréia e China. Insisto, mais uma vez se recoloca a questão dos preços relativos. Trata-se, no instigante paper de Coriat, de impedir que os preços relativos dos produtos de fronteira caiam. E isto se tenta, criando uma série de dificuldades para a difusão

\footnotetext{
${ }^{12}$ Ver a citação da fonte no artigo de Kliksberg (2002).
} 
do conhecimento. Diluem-se assim, mais uma vez, as possíveis "vantagens do atraso", na expressão de Gerschenkron. De fato, a grande possível vantagem do atraso é poder tomar o conhecimento a grande goles. Mas desde List pelo menos se sabe que aqueles que sobem tendem a "chutar a escada pela qual subiram" (título do mais recente livro de HaJoon Chang). Nada há de surpreendente nisto. Nem sequer a renúncia à autodefesa, por parte de muitos, deve surpreender."

- Promoção da flexibilidade na economia - redefinição de setores e do padrão de investimento

Este ponto da agenda das políticas de desenvolvimento, num certo sentido corolário do item anterior, não pode deixar de ser mencionado. O ponto esteve presente tanto no artigo de Joseph Stiglitz quanto no de Dani Rodrik: na nova economia, é provável que as vantagens sejam acentuadamente diferentes do que foram no passado e isso exigirá que se repensem as estratégias de governo em cada uma das áreas em que ele se envolver.

Segundo Stiglitz: "Uma parte fundamental dessa política industrial de bitola larga consiste em trabalhar pela promoção da flexibilidade da economia, isto é, através de políticas ativas no mercado de trabalho, ensino permanente e educação voltada para o aprender a aprender. Haverá necessidade de mudanças nos currículos, e de vínculos mais estreitos entre as universidades e a indústria. (...) No século XXI, a educação precisa direcionar-se para desenvolver a capacidade de iniciativa e a de lidar com um mundo em processo acelerado de mudança."

- Desenvolvimento institucional próprio

Finalmente, e tendo obtido um sólido "de acordo" do conjunto de palestrantes e debatedores do Seminário, a necessidade de um desenvolvimento institucional específico a cada país fecha o conjunto de recomendações de política. Este é o ponto central da contribuição de Dani Rodrik, que é aqui sumariamente apresentada:

"Qualquer estratégia nacional de desenvolvimento, na era global, deve alicerçar-se em sólidos pactos sociais que assegurem a estabilidade política, em sistemas e práticas legais não arbitrários, que garantam a segurança dos contratos, e numa burocracia de Estado imparcial e relativamente eficiente. Esses requisitos institucionais genéricos, que têm sido corretamente enfatizados na bibliografia recente, são componentes 
essenciais de um ambiente adequado de investimento e, como tais, podem ser vistos como condições necessárias do crescimento. Em (...) "uma estratégia de construção institucional: os mercados não são autocriadores, auto-reguladores, auto-estabilizadores nem autolegitimadores. O crescimento econômico requer mais do que um aumento temporário dos investimentos e da iniciativa empresarial. Exige o esforço de construir quatro tipos de instituição, necessários para manter o ímpeto de crescimento e criar resistência aos choques:

- instituições criadoras de mercados (direitos de propriedade e cumprimento de contratos);

- instituições reguladoras do mercado (para lidar com externalidades, economias de escala e informações incompletas);

- instituições estabilizadoras do mercado (para a gestão monetária e fiscal);

- instituições legitimadoras do mercado (proteção e seguridade sociais; política redistributiva; instituições de administração de conflitos; parcerias sociais)." 
PALESTRAS

\section{A Nova Agenda Mundial: REVOLUÇÃO TECNOLÓGICA E INTEGRAÇÃO GLOBAL}





\title{
A GLOBALIZAÇÃO E O BRASIL: UMA HISTÓRIA EM TRÊS ATOS
}

\author{
Albert Fishlow*
}

\section{Introdução}

Este qüinquagésimo aniversário do BNDES proporciona uma boa oportunidade de olharmos para trás, neste começo do século XXI. E, no ponto em que estamos, podemos também olhar adiante para as próximas décadas. O que vemos é um drama marcado por três atos decisivos na experiência brasileira.

A primeira parte é de relativo sucesso: o período de substituição de importações do pós-guerra, no qual um papel estatal crescente pareceu dar a orientação para o crescimento acelerado. Essa época, no entanto, também foi marcada pela rejeição firme de um mercado de comércio mundial em expansão, aumentando, ao contrário, a dependência de um crescente mercado global de capitais no início dos anos setenta. A dívida tornou-se uma parte central da história: primeiro, o crescimento promovido pela dívida, até a primeira crise do petróleo no fim de 1973, depois, a dívida impulsionada pela própria dívida, no restante daquela década. Infelizmente, essa parte da história acabou mal, com a crise do petróleo de 1979, o aumento subseqüente das taxas de juros e as dificuldades generalizadas da dívida durante a década de 1980 .

O segundo período destaca-se por duas fases inter-relacionadas: a econômica e a política. Por um lado, houve a frustração pela contínua falta de crescimento econômico, e por outro, os primórdios da compreensão de que o modelo que antes servira tão bem, calcado na iniciativa e nos subsídios estatais e concentrado no mercado interno, exigia mudanças. Os índices elevados de inflação eram um sintoma de grandes déficits governamentais e de uma política macroeconômica que era mais reativa

* Columbia University. 
do que independente. O Plano Cruzado, em 1986, não apenas fracassou, como também desencadeou o calote brasileiro um ano depois coisa que os mercados internacionais estão sempre relembrando, com prejuízo para as taxas de juros. Os Planos Collor não conseguiram solucionar o problema e veio a deterioração.

Em termos políticos, os resultados foram muito mais positivos: houve o restabelecimento do governo civil e o desabrochar da sociedade civil. Aprovou-se uma nova Constituição e as eleições livres e a escolha popular foram substituindo mais e mais a participação limitada. O Brasil sobreviveu a um impeachment presidencial e aos problemas de governabilidade que antes pareciam haver bloqueado o progresso.

O terceiro período começou com o Plano Real, em 1994. Em meio às angústias atuais em torno da taxa de câmbio, da atual taxa de crescimento, do índice de inflação, do superávit fiscal etc., é importante enfatizar o grau de mudança positiva por que passou o Brasil. Antes de mais nada, a fonte da inflação foi identificada com precisão e enfrentada: os déficits fiscais estão na raiz do problema. Uma segunda mudança foi o amplo grau de privatização ocorrido nos setores de energia, telecomunicações, indústria petroquímica, mineração, siderurgia e outros. A privatização também significou a necessidade de novos tipos e formas de regulação estatal que se foram tornando disponíveis. E uma terceira alteração decisiva ocorreu na importância do intercâmbio internacional de bens e serviços. A partir do início da década de 1990, houve uma grande redução das tarifas; o Brasil buscou ativamente a integração regional no MERCOSUL e emergiu como uma voz de destaque na OMC.

Esperava-se que esse período assistisse a uma recondução do Brasil aos altos índices de expansão econômica de anos anteriores. Mas isso não aconteceu. A combinação de múltiplas crises financeiras internacionais - México, Ásia e Rússia - com a manutenção excessivamente prolongada da âncora cambial e a redução do ritmo global de crescimento impediu o Brasil de atingir esse estágio final do processo de reforma. Esse panorama global mais perturbador ainda persiste e exige mudanças. Mas há também três modificações internas importantes que ainda restam, para que o Brasil transforme esse terceiro ato num período de expansão sustentada. 


\section{Ato I: O passado}

O Brasil logrou êxito em sua transição para um crescimento industrial acelerado depois da Segunda Guerra Mundial. A estratégia foi direta: substituir as importações através da produção interna. As taxas de expansão da década de 1950 foram elevadas e o índice aumentado de investimento externo direto conseguiu contrabalançar os déficits crescentes da Conta Corrente. Mas a falta de exportações, em parte devida à supervalorização da taxa de câmbio, e a queda nos preços do café começaram a trazer maus presságios no final da década. Também nessa ocasião, os problemas fiscais internos, que tinham sido enfrentados mediante a transferência da taxação implícita de um setor agrícola beneficiado pelos altos preços externos, começaram a vir à tona. No fím dos anos cinqüenta, essas dificuldades tornaram-se óbvias, mas produziram uma resposta posterior insuficiente por parte dos governos Quadros e Goulart.

A resposta foi a intervenção militar, em 1964. Vieram então os anos do "Milagre", 1968-1973. Não só houve um espetacular crescimento econômico interno, como o Brasil entrou no cenário mundial. Alterou drasticamente a composição de suas exportações e reduziu de modo decisivo sua dependência anterior das exportações de café. Começou a entrar no recém-criado mercado de eurodólares para contrair empréstimos externos. E buscou um papel diplomático especial. Fizeram-se projeções da nova importância brasileira no ano 2000 - facilmente demonstrada pela projeção de altas taxas de crescimento no futuro.

A crise do petróleo, no fim de 1973, levou esse período a um fim prematuro. Em certo sentido, a expansão contínua no restante da década de 1970 foi ilusória. Embora o crescimento continuasse, ele se tornou cada vez mais dependente de fluxos de endividamento. A dívida afigurava-se uma estratégia atraente num mundo em que as taxas reais de juros eram baixas, como permaneceram até o fim dos anos setenta. Mas houve uma mudança sutil. $\mathrm{O}$ que tinha sido um crescimento conduzido pela dívida, no começo da década, converteu-se num endividamento conduzido pela dívida, à medida que déficits recordes nas importações foram sendo financiados. Era uma estratégia precária. Embora o crescimento continuasse, em índices mais baixos, a inflação interna aumentou, e um mecanismo de pára-e-anda ( stop and go) lidou de maneira ineficaz com esse caráter cumulativo da economia brasileira indexada da época.

Faltaram ao Brasil a necessidade ou as pressões internas para reagir de outra maneira, como fizeram muitos países asiáticos na ocasião. $\mathrm{O}$ 
financiamento externo era fácil de obter e, a princípio, tinha taxas reais de juros negativas. A precariedade da situação só veio a se revelar depois de uma nova alta dos preços do petróleo, durante a guerra Irã-Iraque, de um aumento abrupto das taxas reais de juros e de uma recessão nos países da OCDE. E, àquela altura, praticamente todos os países latino-americanos haviam sucumbido.

Não é que a substituição de importações tenha reinado, inalterada, desde a década de 1950. O problema primário - que persiste no Brasil de hoje - foi a abertura assimétrica para a economia mundial na década de 1970. Obtiveram-se vastos fluxos financeiros, mas o compromisso com a penetração comercial ficou substancialmente para trás. As distorções fiscais persistiram e contribuíram para esse resultado. Esse foi o período de nacionalização substancial das empresas, para facilitar seu acesso ao mercado externo de capitais. Ocorreram déficits internos crescentes, agravados pelo compromisso generalizado com os subsídios governamentais. A taxa de câmbio ficou supervalorizada.

Sob a liderança do então recém-nomeado ministro da Fazenda, Delfim Netto, em agosto de 1979, fez-se um último esforço para salvar a situação. Mas ele não deu em nada. A princípio, recebeu-se um financiamento externo adicional, mas este desapareceu em 1981, à medida que a economia brasileira teve de lidar com a relutância dos bancos credores. E, em 1982, a questão havia-se deslocado da continuidade da expansão para uma redução significativa das importações e do crescimento.

Foi durante os anos setenta que começou a ocorrer a verdadeira demarcação entre os países asiáticos e os latino-americanos. Uma medida decisiva dessa diferença foi a importância do comércio nas duas regiões. Na Coréia, por exemplo, a parcela das exportações no produto interno bruto subiu de 9\% em 1965 para 37\% em 1983; no Brasil, essa proporção se manteve em $8 \%$ nos dois anos.

No conjunto, o comércio internacional vinha crescendo com o dobro do índice do produto interno no período pós-guerra, apesar das dificuldades da década de 1970. Contrariando a pressuposição de Raúl Prebisch de que a demanda externa não se mostraria uma base para o crescimento rápido, com isso justificando a substituição das importações, a redução do protecionismo tornou-se uma tendência contínua nos mercados mundiais. Em contraste, havia no Brasil um consenso favorável a garantir a viabilidade dos novos esforços de produção nacional de bens intermediários e bens de capital. 
Ainda era cedo demais para aplicar a esse processo a terminologia posterior da globalização. Mas ele consistiu na recuperação rápida das economias européias, facilitada pelos arranjos do mercado comum entre elas, e também no crescimento acelerado do Japão, integrado ao mercado norte-americano. A dissolução dos controles monetários, das cotas e de outros empecilhos ocorreu no fim da década de 1950. A Rodada Kennedy deu um forte impulso a esse processo no início da década de 1960.

Nos anos setenta, começou-se a falar dos NICs: os países recémindustrializados. Havia dois tipos deles. Por um lado, os países emergentes da Ásia, como Coréia, Taiwan, Hong Kong e Cingapura; por outro, os países bem-sucedidos na substituição de importações na América Latina: o México e o Brasil. Estes haviam começado a modificar sua política a partir dos anos cinqüenta, dando um papel mais preponderante aos tecnocratas nacionais. $\mathrm{O}$ que não se percebeu, na época, foram as diferenças significativas de desempenho no crescimento posterior que viriam a emergir. Ainda era uma disputa. Infelizmente, a década seguinte, de 1980, resolveu a questão de maneira decisiva, e deixou a América Latina - e o Brasil - decididamente para trás.

\section{Ato II: Os anos oitenta}

Para o Brasil, essa década foi uma tragédia econômica. Após um século de expansão contínua, mesmo durante a Grande Depressão da década de 1930, o crescimento fez uma parada desnorteante. Ao mesmo tempo, para o resto do mundo, foi um período de revivescência do comércio e do intercâmbio financeiro. Essa fase assistiu à ascensão temporária do Japão ao status de país de vanguarda e, em caráter mais permanente, viu os Estados Unidos se converterem na maior nação devedora do mundo.

O impacto dos choques externos no Brasil, no período de 1981-1983, quando cessou o fluxo de capitais, subiram as taxas de juros e a OCDE entrou em recessão, teve o valor substancial de 9,3\% da renda. Esse valor, apesar de grande, ainda foi menor do que o efeito nos países asiáticos, afetados principalmente pela menor demanda de seus produtos pelos países industrializados. A grande diferença apareceu na magnitude do choque negativo em relação às exportações. Nesse aspecto, o Brasil ficou à frente de todos, com uma proporção de 1:37. Isso se deu como resultado do baixo índice de participação do País no comércio de bens e serviços. 
O Brasil fez uma redução drástica de suas importações naqueles anos. A maneira de fazê-la foi manter baixo o crescimento agregado. Como conseqüência, surgiram os superávits comerciais. Aliás, eles ocorreram com tamanha rapidez, que houve quem se enganasse, acreditando que a crise seria de curta duração. Mas, à medida que os preços internacionais se deterioraram e as exportações não conseguiram sustentar uma expansão significativa, os bancos manifestaram não só uma relutância contínua em fazer novos empréstimos, como também o desejo de reduzir seus riscos. Essa falha do mercado levou ao Plano Baker, que procurou tirar proveito da expansão internacional multilateral dos empréstimos como um incentivo à participação dos bancos comerciais. Também isso surtiu pouco efeito. Os bancos queriam um papel menor, não um papel contínuo.

A bomba da dívida acabou sendo finalmente desativada por uma redução de seu valor nominal nos termos do Plano Brady, iniciada no México em 1989. Mas o Brasil só conseguiu resolver sua situação em termos equivalentes tempos depois, na década de 1990. Antes disso, porém, veio a necessidade de lidar com a inflação interna. Quando Delfim Netto tornou-se ministro da Fazenda, em 1979, a elevação anual dos preços no atacado era da ordem de aproximadamente 50\%. Quando ele deixou o cargo, no fim de 1984, esse número fora praticamente quintuplicado. Embora tivesse havido uma recuperação do crescimento, após seu agudo declínio anterior, havia necessidade de mudanças mais fundamentais e estruturais.

Uma primeira tentativa foi o Plano Cruzado, em fevereiro de 1986, que se assemelhou, em linhas gerais, ao Plano Austral argentino do ano anterior. Depois de um certo sucesso inicial, o esforço sofreu uma derrocada fragorosa. Constatou-se que o Brasil não era a Suíça, afinal. Os planos Austral e Cruzado tiveram um destino comum. Seu fracasso pode ser atribuído a uma política salarial, monetária e fiscal excessivamente expansionista. Houve um excesso de sinais verdes. Os salários aumentaram depressa demais, graças aos bônus previstos no Plano, que foram de $15 \%$ para os que ganhavam apenas o salário mínimo e $8 \%$ para todos os demais. O aumento explosivo do consumo em 1986, logo depois do Plano, provocou uma escassez inicial de mão-de-obra e novos aumentos salariais. Do lado monetário, o governo tirou pleno proveito do aumento da demanda de saldos monetários e os aumentou suficientemente, até as taxas de juros se tornarem negativas. E, acima de tudo, o equilíbrio fiscal operacional, ajustado pela inflação, em vez de ficar em zero, como fora inicialmente projetado, registrou um déficit de 3,6\% do PIB. 
Era preciso travar uma batalha mais longa e mais árdua contra a inflação. Poucas tentativas iniciais conseguiram sucesso, e o Brasil não foi a exceção. O Plano Bresser não funcionou por muito tempo em 1987, dada a recusa a impor os aumentos de impostos necessários. A frustração foi acompanhada pela redução das taxas de crescimento e pelo aumento dos índices de inflação. Depois disso, os grandes esforços do novo presidente, Fernando Collor, também fracassaram. Embora a oferta monetária tenha uma clara relação com o nível dos preços, sua redução drástica, como foi tentado, juntamente com o controle de preços e salários, não resolveu o problema. Ao contrário, a atividade econômica tornou a reagir de maneira adversa, não ocorreram reformas adicionais e a inflação acabou voltando, num índice muito mais alto, à medida que a oferta monetária tornou a se expandir.

E assim continuou o Brasil, frustrando os interesses internos e uma comunidade internacional que, no início dos anos noventa, evidenciava um interesse renovado pelos investimentos externos na América Latina. Nessa ocasião, a força dominante viria a ser o compromisso direto de recursos por parte de empresas internacionais, retornando ao padrão vigente cerca de quarenta anos antes. E, no início da década de 1990, como praticamente todos os outros países haviam conseguido fazer uma transição bem-sucedida para déficits públicos e taxas de inflação muito menores, o Brasil ficou praticamente isolado na região, incapaz de gerir essa transformação.

Em conseqüência disso, o mundo externo passou a prestar menos atenção. Embora Collor tivesse feito alguns esforços para reduzir o protecionismo brasileiro, isso surtiu pouco efeito num Brasil em desordem macroeconômica. As importações caíram para seu nível mais baixo, levando o Brasil a ultrapassar em muito pouco a menor percentagem global.

No nível internacional mais amplo, a década de 1980 distinguiu-se por três fatores. Primeiro, houve um crescimento muito menor do comércio em relação ao produto interno bruto mundial. Durante essa década, tal relação resvalou quase para o nível da unidade. Pareceu haver uma parada decisiva no caminho de avanço que havia caracterizado o período pós-guerra. Em parte, o problema foi de crescimento mais lento e dos primórdios da resistência ao processo de globalização no mundo industrializado.

Uma segunda característica foi a expansão dos fluxos de capital. E nisso, houve um novo fenômeno: os Estados Unidos tornaram-se seu maior destinatário no mundo. Em vez do equilíbrio no comércio, numa era de 
expansão relativamente lenta das exportações de mercadorias, os Estados Unidos converteram-se decisivamente aos superávits sistemáticos nas importações - e ao dólar forte -, garantindo sua confiança nos gastos maiores com a defesa. Esse foi um resultado singular. A regra anterior tinha consistido em os países ricos exportarem capital para o resto do mundo; nesse momento, os Estados Unidos passaram a adotar uma estratégia diferente.

E, em terceiro lugar, houve o fim da Guerra Fria. Isso teve um impacto decisivo. Para começar, significou que o capitalismo, numa ou noutra forma, era o único modelo a ser seguido pelos Estados. Antes disso, o thatcherismo dera algumas indícios das grandes mudanças que viriam a ocorrer na Europa em termos mais gerais. Nessa ocasião, o processo foi impulsionado. Na América Latina e na Ásia - a China e a Índia vêm-nos rapidamente à lembrança -, a direção da economia pelo Estado, ou até sua orientação substancial, não tardaram a diminuir. Essa alteração foi decisiva. Foi o novo elemento que levou ao ressurgimento da economia internacional nos anos noventa. E sua dimensão conduziu, como seria inevitável, a um amplo debate sobre as virtudes da globalização.

\section{Ato III: a década de 1990 e o depois}

Também o Brasil se converteu nos anos noventa. Um mecanismo decisivo foi o Plano Real. Ele foi concebido por muitos dos mesmos criadores do fracassado Plano Cruzado, mas, desta vez, não houve controle de salários e preços, nem qualquer regra de indexação que depois viesse a surgir e anular a estabilização. E um novo dado foi o aumento imediato das importações. A competição do mercado, em vez das instruções do governo, seria usada para garantir a continuidade da estabilização. E, é claro - e de peso crucial -, haveria um grande superávit inicial do governo para estabelecer a credibilidade do projeto.

O Plano Real foi um sucesso. Já existe há oito anos, e as mudanças realizadas - como a eliminação da âncora cambial para a estabilização e a introdução de uma política fiscal e monetária séria - foram para melhor, não para pior. Desde 1994, o Brasil tem conseguido levar sistematicamente adiante sua conversão a uma política macroeconômica séria. Mas esta não surtiu os efeitos mágicos esperados na taxa real de crescimento. Por que não? 
Antes de mais nada, há duas ótimas razões externas. Ao longo da vida do real, houve uma sucessão de crises internacionais, que necessariamente tiveram repercussões. Logo no fim de 1994 veio a "Crise Tequila”, no México, cujos principais efeitos imediatos foram sentidos noutros pontos da região, mas também tiveram conseqüências menores no Brasil. Mais grave foi a crise asiática de julho de 1997, que levou a aumentos acentuados das taxas reais de juros, penalizando a expansão interna. Aos poucos, as taxas tornaram a cair, mas voltaram a ser empurradas para cima pela crise russa de agosto de 1998. Depois disso veio o primeiro empréstimo do FMI, insuficiente para evitar a desvalorização brasileira imediatamente posterior, em janeiro de 1999.

Seguiu-se toda uma onda de interesse renovado na economia internacional. Comissões especiais, em grande número, fizeram relatórios a respeito das inadequações, sob a forma de fluxos financeiros globais que tiveram um aumento exponencial. O papel do sistema bancário ficou no cerne da questão na época, e assim ficaria ainda mais, posteriormente. Mas a recuperação veio mais depressa do que muitos esperavam.

As dificuldades provenientes do exterior foram substanciais. Somente o crescimento rápido dos Estados Unidos impediu distúrbios mais significativos. Foi um período em que seu crescimento mais acelerado da produtividade, associado ao avanço tecnológico cada vez mais localizado na América, preservou a demanda global. Na verdade, a expansão do comércio ocorreu em índices impressionantes nos anos noventa, e foi esse grande mercado aberto que garantiu o avanço noutros lugares. Obviamente, foi isso que se deu na recuperação do México, realizada no contexto de um novo acordo comercial que deu um impulso preferencial não apenas às exportações mexicanas, como também, o que é mais significativo, aos investimentos externos norte-americanos e à reestruturação do setor industrial do México.

Mas esse não foi o fim da história. Após um ajuste brasileiro surpreendentemente rápido e bem-sucedido à desvalorização, que não provocou a volta da inflação, como muitos haviam previsto, novos superávits fiscais primários levaram à recuperação no fim de 1999 e em 2000. O futuro finalmente parecia mais positivo.

Surgiram então as circunstâncias especiais de 2001. Primeiro, houve uma recessão nos Estados Unidos e uma diminuição da demanda externa, em termos mais gerais, à medida que o crescimento do comércio global foi cessando; e isso foi antes da intercorrência de 11 de setembro. Segundo, surgiram problemas crescentes na Argentina ao lon- 
go do ano, os quais, como seria inevitável, levaram a uma hesitação com respeito ao Brasil e reduziram o fluxo de investimentos diretos, ao mesmo tempo que pressionaram a taxa de juros e a taxa de câmbio brasileiras. $\mathrm{O}$ desfecho eventual foi a desvalorização argentina, com uma crise de grandes proporções, o que tem surtido efeitos continuados. E por último, surgiu um problema interno com o abastecimento de energia, decorrente da insuficiência das chuvas, cuja gravidade, por sorte, foi menor do que se havia imaginado.

Tudo isso inibiu a continuidade da expansão e impôs pressões adicionais à política fiscal e monetária interna. E o fato de o crescimento global não ter exibido a recuperação prevista em 2002 levou, já agora, a dúvidas crescentes sobre as virtudes da via orientada pelo mercado. Isso se aplica especialmente à América Latina, onde as taxas de crescimento projetadas têm sido sistematicamente reduzidas e só tornam a se elevar em anos posteriores. Em meio a tudo isso e aguçando o sentimento da opção, existe a realidade da frustração popular crescente e a pressão das eleições.

A globalização e a maior dependência dos sinais do mercado tornaram-se o inimigo óbvio. A conversão ao capitalismo e a privatização generalizada trouxeram apenas ganhos ilusórios. A freqüência das crises internacionais nos últimos anos é uma prova incontestável disso. Constata-se esse fato não apenas com respeito às reações observadas no Brasil - onde o Fórum de Desenvolvimento Social de Porto Alegre surgiu como um contraponto ao Fórum Mundial de Desenvolvimento de Davos -, mas até às observadas na Europa e nos Estados Unidos. Basta lembrar a reação à reunião da Organização Mundial do Comércio em Seattle, alguns anos atrás, e a necessidade sistemática de uma segurança muito maior nas reuniões regulares do Banco Mundial e do FMI.

É claro que a globalização não teve o efeito de solucionar universalmente os problemas da pobreza, das doenças e da educação limitada, que continuam abundantes. É igualmente óbvio que alguns países em desenvolvimento, particularmente na Ásia, mas também noutros lugares, alteraram sua posição relativa em conseqüência dos efeitos positivos do acesso aos mercados mundiais.

Quero abordar aqui duas questões centrais: a real e a financeira, ou as questões do comércio internacional e do fluxo de capitais. Começo pela primeira, com ênfase no MERCOSUL.

Recentemente, o presidente Fox, do México, fez uma visita ao Brasil e, juntamente com o presidente Cardoso, aprovou tarifas mais baixas, numa redução média de $8 \%$ para $1,1 \%$, para uma extensa lista de 
800 produtos. Esse primeiro acordo entre os dois países destinava-se a ampliar o comércio bilateral entre eles, até então bastante modesto. No entanto, curiosamente, o produto de maior importância potencial - os automóveis - ficou para ser discutido numa viagem a Buenos Aires, no dia seguinte, onde haveria uma reunião do MERCOSUL. E a ironia é que essa questão controvertida continuou sem solução, à espera de maiores discussões entre o Brasil e a Argentina.

Essa situação ilustra bem o problema brasileiro. Em contraste com a rápida expansão comercial de que o México desfrutou depois da aprovação do Acordo Norte-americano de Livre Comércio, duplicando a participação percentual das exportações no PIB de $15 \%$ para mais de 30\%, o MERCOSUL tornou-se uma fonte de declínio. Em vez dos 100 bilhões de dólares em exportações projetados para o Brasil há cinco anos, o total de 2002 ficará bem abaixo de 60 bilhões. Ao se concentrar na expansão do MERCOSUL e enfatizar as virtudes potenciais de um mercado sulamericano crescente, como fez ao realizar a primeira reunião dos líderes dessa região em Brasília, o Brasil tendeu a minimizar a alternativa de uma associação mais estreita com os Estados Unidos. Antes mesmo de virem para o primeiro plano a recente Lei Agrícola [Farm Bill] e o aumento do protecionismo norte-americano no setor da siderurgia - os quais, justificadamente, provocaram uma condenação generalizada -, o Brasil havia reagido com frieza à possibilidade de negociação de uma Área de Livre Comércio das Américas. Em Quebec, o presidente Cardoso deixou claras as suas dúvidas, mesmo depois de o Brasil haver conseguido garantir um período de cinco anos de negociações adicionais, em vez dos três anos defendidos por vários outros países.

Essa relutância não é uma simples resposta irracional. No período de 1950 a 1980, o Brasil conseguiu uma das mais altas taxas de crescimento do mundo em desenvolvimento, ao mesmo tempo que preservava um alto nível de protecionismo. Utilizou como motores a substituição de importações e o mercado interno, em vez das exportações para o mercado mundial em rápida expansão, como fizeram os países asiáticos emergentes. Depois disso, em meio à estagnação dos anos oitenta e às reformas dos anos noventa, embora as exportações tenham conseguido avançar mais depressa do que nas décadas anteriores, a parcela do comércio foi pequena demais para funcionar como uma força dinâmica.

É muito fácil ficar apenas fazendo críticas aos Estados Unidos, assim como à Europa e ao Japão, a respeito das exportações agrícolas. Não há dúvida de que existem restrições severas. Também não há dúvi- 
da de que a Rodada de Doha acabará assistindo a uma abertura mais convincente e contínua do que a que caracterizou os resultados da Rodada do Uruguai. O Brasil e seus aliados fronteiriços tenderão a conseguir ganhos reais. Não há dúvida de que há grandes somas envolvidas, o que se revelará vantajoso.

Mas, a prazo mais longo, não foi nesse mercado que ocorreram os grandes avanços do comércio internacional. A demanda de produtos agrícolas, até no plano internacional, cresceu mais devagar do que a renda. Outros países também entraram no mercado - basta observar a ascensão do Vietnã na produção de café. Nas últimas décadas, quando o comércio internacional expandiu-se duas vezes mais do que a taxa do produto interno bruto, foram os produtos manufaturados e os serviços que exibiram um dinamismo muito maior, e não as vendas de produtos primários.

É nessas áreas que a vantagem comparativa do Brasil terá que se destacar. A Embraer é um exemplo clássico de uma antiga empresa estatal que evoluiu com sucesso para a condição de fornecedor internacional de aviões comerciais. É também um caso em que o recurso brasileiro à Organização Mundial do Comércio levou à vitória na disputa com o Canadá e a Bombardier. Alguns hão de argumentar que esse exemplo revela a importância dos subsídios e do apoio estatais. Mas essa história de evolução de fornecedor nacional para competidor internacional também envolveu uma compreensão implícita dos ganhos obteníveis com o comércio e da vantagem comparativa: a empresa é não apenas o maior fornecedor isolado de divisas para o Brasil, como é também um dos principais importadores. Esses insumos menos dispendiosos permitem que a produção da empresa fique na vanguarda tecnológica.

Mas a política industrial, tal como empregada com êxito no caso da Embraer, pode ter sua eficácia exagerada. Há também muitos fracassos complexos, tanto nos países já desenvolvidos quanto nos que estão em desenvolvimento. A incapacidade de desenvolver um setor nacional de computadores no Brasil, ao longo de muitos anos, apesar dos subsídios e da ampla proteção, certamente é um deles. Boa parte da experiência européia é igualmente negativa.

Todavia, o Brasil tem uma vantagem significativa. Ele é um retardatário nessa área e, portanto, não precisa nem deve enfatizar a pesquisa e desenvolvimento de ponta, mas, antes, a maior capacidade de seguir e imitar. $\mathrm{O}$ incentivo privado à inovação está no cerne do sucesso. Sem dúvida, algumas verbas públicas iniciais podem justificar-se, para garantir a transmissão plena das informações. Mas melhor será dirigir o 
grosso dos gastos brasileiros para o aprimoramento maciço do sistema educacional, garantindo que os ganhos quantitativos dos últimos anos se mantenham e concentrando a atenção nas deficiências qualitativas. Já se escreveu muito sobre esse assunto. Não há necessidade de reiterar aqui a importância de haver menores gastos públicos no ensino superior, no qual o desembolso per capita ultrapassa o do Reino Unido, e de aumentá-los no ensino primário e secundário, no qual o desembolso per capita é da ordem de 1/10 do daquela região.

Há muito espaço para a política econômica externa brasileira, à medida que se dedicar uma atenção séria à ALCA, à União Européia e à OMC. Mas a orientação única que tem sido especialmente favorecida pelo Itamaraty nos últimos anos - ampliar o MERCOSUL para transformá-lo numa área geral de livre comércio na América do Sul - é menos atraente hoje do que no passado. Nos primeiros anos do MERCOSUL, o crescimento do comércio entre os quatro países comprometidos com um mercado comum em 1994 foi muito intenso. Esse intercâmbio não tardou a chegar ao auge, mas, nos últimos cinco anos, a expansão declinou. O crescimento negativo na Argentina e no Uruguai e o avanço mais lento no Brasil não ajudaram. Em termos mais fundamentais, a grande indústria que deu impulso inicial ao MERCOSUL, a indústria automobilística, ficou praticamente inoperante através das fronteiras nacionais, em decorrência da desvalorização brasileira de 1999. A atual crise argentina piorou ainda mais a situação.

Foram enfatizadas duas direções para modificar o MERCOSUL. Uma delas consiste em procurar avançar para políticas e normas macroeconômicas comuns o mais depressa possível, a fim de estabelecer a segurança. Com um conhecimento seguro, seria possível fazer investimentos para explorar as vantagens comparativas nacionais. Essa parece ser a linha que vem sendo seguida. Não logrou um grande sucesso, pois nem na Argentina nem no Brasil, e em menor grau no Uruguai, os objetivos nacionais cedem minimamente aos interesses econômicos dos vizinhos. Se a Europa levou cerca de cinqüenta anos para chegar a sua união econômica, com ajuda externa norte-americana e a ameaça constante da União Soviética - e com uma interrelação comercial muito maior -, a perspectiva de progresso a curto prazo entre os países do MERCOSUL parece limitada.

A segunda abordagem consiste em transformá-lo numa união de livre comércio, em vez de um mercado comum. Isso permitiria aos países imporem níveis individuais de proteção a terceiros, ao mesmo tempo aderindo ao livre comércio internamente. Haveria, portanto, uma ne- 
cessidade muito menos intensa de cooperação. Essa vem-se tornando cada vez mais a alternativa preferida pela Argentina, particularmente uma vez que Cavallo envidou esforços para restabelecer a substituição de importações em seus últimos meses no poder. Também no Brasil, entretanto, quase todo o leque atual de candidatos à presidência parece favorecer essa postura. A união de livre comércio simplesmente ratificaria o que se observa ser a política efetiva dos membros. O comércio externo fora da união, nos próximos anos, tem muito mais probabilidade de ser uma fonte dinâmica de demanda.

Isso ainda deixa um conjunto complexo de palcos em que o Brasil pode e deve buscar ativamente um comércio mais livre. Num mundo ideal, essa negociação ocorreria exclusivamente na Organização Mundial do Comércio. É claro que um foro único proporciona uma base não discriminatória para as concessões. Mas a realidade é diferente. Somente sob a pressão de avanços potenciais que ocorram em diversos níveis regionais é que parece possível chegar a uma solução multilateral aceitável. A Rodada de Doha, por sua vez, já conseguiu alguns avanços importantes.

Três deles, de especial interesse para o Brasil, podem ser resumidamente assinalados. Primeiro, houve um reconhecimento do problema generalizado do comércio de produtos agrícolas, no qual, ironicamente, os Estados Unidos foram um elemento de destaque entre os três grandes países industrializados. Segundo, os direitos de propriedade intelectual - uma das grandes mudanças da Rodada do Uruguai - foram reconhecidos como tendo limites claros, quando entram em conflito com a política nacional em áreas como a saúde. A AIDS foi um exemplo específico: por que deveriam os países pagar preços tão altos pelos medicamentos, quando havia alternativas equivalentes, porém mais baratas? Os preços já começaram a refletir esse novo padrão. Terceiro, medidas de salvaguarda nacional como as dos Estados Unidos, geradas há muito tempo, sob a vigência de acordos internacionais de comércio anteriores, ficariam abertas à discussão. As limitações impostas à importação de aço pelos Estados Unidos, de fato, podem acelerar o exame da legitimidade dessas exceções.

É provável que uma conclusão bem-sucedida da Rodada de Doha dependa da concorrência dos múltiplos acordos regionais que vêm sendo simultaneamente buscados. Essa foi, com certeza, a experiência da Rodada do Uruguai. Isso significa que os debates em torno da ALCA, bem como a busca de laços mais estreitos entre o MERCOSUL e a União Européia, continuarão a ter importância. Aliás, do ponto de vista brasileiro, essas discussões regionais alternativas proporcionam um com- 
ponente de rivalidade direta que não tem como ser prejudicial. Observe-se a recente decisão do Chile de assinar um acordo com a União Européia, apesar do atraso nas negociações com os Estados Unidos. Pode-se esperar que essa situação estimule os esforços norte-americanos de entrar na concorrência.

O Brasil e os Estados Unidos presidirão juntos a rodada final de negociações da ALCA. É claro que, até para que isso seja possível, o Congresso norte-americano terá que aprovar a Lei de Promoção do Comércio, que mal tem continuado a avançar. Sua formulação inicial, que sofreu emendas na Câmara e no Senado, foi insatisfatória. Essa condição de aprovação "a toque de caixa" havia falhado nos dois mandatos do presidente Clinton. Agora, mesmo em meio ao sucesso potencial, a forma da legislação conseguiu persuadir boa parte do mundo de que os Estados Unidos não valorizam o comércio internacional. O Brasil tem estado entre os observadores próximos e inquietos. Surgiu um anteprojeto final, majoritariamente aprovado por uma pequena margem. Apesar de suas reconhecidas limitações, ele proporcionará o âmbito necessário para que os Estados Unidos se concentrem apropriadamente não só nas negociações regionais, mas também na Rodada de Doha.

Quem está à espera nos bastidores é a União Européia, cujas discussões com o MERCOSUL avançaram na área industrial, mas continuam muito atrasadas na área fundamental da agricultura. Os recentes tratados da U.E. com o México e o Chile ilustram a importância crescente da Espanha como um ator de peso nas discussões sobre a América Latina dentro da União Européia. Nos últimos anos, a Espanha suplantou os Estados Unidos como fornecedora de capital à América do Sul, incluindo-se aí os fluxos enviados ao Brasil. Seus interesses estendem-se pelos setores intensivos em capital, como energia, telecomunicações e especialmente finanças. Os grandes prejuízos espanhóis na Argentina, que atualmente se refletem no Brasil, não farão esse interesse desaparecer. E isso é vantajoso para o Brasil.

Mas todas essas negociações, por mais complexas, absorventes e até fecundas que sejam, não são o bastante. O Brasil precisa voltar sua atenção, definitivamente, para o comércio internacional. Se os Estados Unidos puderam separar do Departamento de Estado os seus interesses no comércio internacional, o Brasil certamente poderá fazer o mesmo. $\mathrm{O}$ Itamaraty, apesar dos avanços contínuos dos últimos anos, não dispõe de pessoal nem estrutura que lhe permitam abarcar a multiplicidade de negociações que constituem uma necessidade prática para qualquer país gran- 
de. O Brasil, nos termos da antiga estrutura, foi um participante menor do que deveria ter sido no comércio mundial. Desde 1950, enquanto outros países exploraram um comércio mais livre, a participação brasileira no comércio internacional diminuiu. Se revertido, esse processo poderá introduzir um componente importante de dinamismo no futuro imediato.

O Brasil precisa de nada menos do que duplicar sua participação no comércio internacional nas próximas décadas. Precisa realizar o que foi obviamente incapaz de fazer no período de 1998-2002, quando a meta buscada era de 100 bilhões de dólares no fim do período. Conseguir isso não só trará um importante estímulo para o crescimento futuro, como garantirá ao Brasil um papel internacional destacado.

Há também avanços que se fazem necessários na frente financeira. Existe a responsabilidade conjunta. E a resposta apropriada à grande volatilidade dos fluxos internacionais de capital que se observou na última década, com seus custos internos substanciais, também começa no nível nacional. O Brasil precisa de uma taxa de poupança interna mais alta. Seu nível atual, em relação ao produto interno bruto, não é muito diferente do que era em 1959. Situa-se em bem menos de $20 \%$.

Essa dependência maior das fontes internas reduz, necessariamente, o grau de exposição aos riscos globais. O investimento externo direto é desejável por sua contribuição positiva para a produtividade. Uma das realidades marcantes dos últimos anos foi a maior velocidade da transferência internacional de tecnologia. Mas esses efeitos benéficos não se aplicam a outras formas de financiamento externo necessárias para compensar a poupança interna insuficiente, e aumentam a exposição aos caprichos e venetas da comunidade financeira global. Todos estamos familiarizados com a realidade do risco moral e com o conseqüente comprometimento excessivo dos recursos externos que dele pode resultar. Nas ocasiões em que essa segurança se mostra sem valor, como aconteceu na Argentina, e em que há prejuízos substanciais para credores e investidores privados, isso pode levar a conseqüências adversas. O que tem atrapalhado enormemente a reforma internacional nessa área é a impossibilidade de criar, para o mercado financeiro, regras que tanto os credores quanto os devedores julguem satisfatórias.

É possível que esses ajustes acabem acontecendo, mas, até lá, as ações internas terão que substituí-los. E a ação importante, nesse caso, é uma oferta suficiente de poupança interna, que permita uma dependência menor dos financiamentos externos. Essa oferta de poupança, além disso, pode vir com relativa rapidez dos superávits fiscais do setor pú- 
blico. O que se faz necessário é uma inversão da prática do passado. Durante alguns períodos do crescimento brasileiro no pós-guerra, foi a poupança privada que financiou a expansão do setor público. Agora, é o setor privado que pode conseguir a vantagem de uma oferta regular de recursos provenientes dos superávits públicos. Estes devem ser vistos positivamente como fontes de investimento, e o serão, se houver uma queda nas taxas reais de juros internas.

Esperar pela reforma financeira internacional pode vir a ser como ficar esperando Godot. Pode-se trabalhar por ela, mas, entrementes, não é preciso que se fique parado.

\section{Conclusão}

Concluo com uma nota positiva. O otimismo, ao que parece, tornou-se a bênção redentora daqueles dentre nós que há muito se preocupam com a América Latina. Mas o mercado mundial de hoje vai melhorar e, quando isso acontecer, o Brasil colherá benefícios importantes de seu novo compromisso com o comércio, desde que mantenha seu curso. Do mesmo modo, embora persista a vulnerabilidade aos choques de capital, um grau maior de poupança interna proporcionará um remédio parcial, que poderá contribuir muito para contrabalançar suas conseqüências negativas.

A globalização é uma realidade. Por sua natureza, a exposição ao mundo externo acarreta riscos e oferece oportunidades. $\mathrm{O}$ velho mecanismo da acumulação de reservas já não serve de garantia da independência nacional. Num mundo de movimentações de capital imensamente rápidas e substanciais, é assim que acontece. Nesse mundo, cabe comercializar mais produtos e serviços e depender menos dos fluxos provenientes do exterior. É esta a minha mensagem de hoje. 
Desenvolvimento em Debate - 74 


\title{
PADRÕES LOCAIS E DIVERGENTES DE APRENDIZAGEM TECNOLÓGICA EM MERCADOS (PARCIALMENTE) GLOBALIZADOS
}

\author{
Haverá algo de novo? \\ E que podem fazer as medidas políticas a esse respeito? \\ Um manual conciso.
}

\section{Giovanni Dosi* e Carolina Castaldi*1}

\section{Introdução}

O objetivo da nota que se segue é oferecer um arcabouço interpretativo dos processos internacionais de inovação e difusão tecnológica, bem como de suas relações com o crescimento geral da renda, mas com ênfase especial no possível papel desempenhado pelo chamado fenômeno da "globalização" nas duas últimas décadas.

O campo a ser abordado é vasto e nossa única ambição, aqui, só pode ser a de oferecer um conjunto bastante telegráfico de propostas e alguns dados sugestivos (há muito mais a ser encontrado na bibliografia por que nos pautaremos). ${ }^{2}$

Convém começar pelo panorama geral e relembrar alguns aspectos básicos de longo prazo na acumulação tecnológica e no crescimento da renda, em particular em sua dimensão internacional (Seção 2). Dadas

\footnotetext{
* LEM, Escola Sant'Anna de Estudos Avançados, Pisa, Itália.

${ }^{1}$ Os autores são muito gratos pelos comentários de diversos participantes e, em particular, dos debatedores, Hélio Jaguaribe e Rubens Ricupero. O título do artigo imita deliberadamente, em parte, o do artigo de Patel e Pavitt (1998), de cuja visão partilhamos em larga medida.

2 Discussões mais detalhadas de um dos autores encontram-se em Dosi, Pavitt e Soete (1990), Cimoli e Dosi (1995), Dosi, Freeman e Fabiani (1994), e Dosi, Orsenigo e Sylos Labini (2002).
} 
essas propensões seculares, que, como veremos, tendem a exibir a divergência como característica dominante, até que ponto e em que direções são elas influenciadas pelos processos contemporâneos incluídos na categoria elegante e bastante vaga de "globalização"? Para abordar essa questão, faz-se necessária uma digressão esclarecedora, que explicite os fenômenos - reais ou imaginários - subjacentes à própria "globalização" (Seção 3). Em seguida, na Seção 4, afirmaremos que nem os indícios contemporâneos nem a teoria respaldam a idéia de que a "globalização" caminhe naturalmente de mãos dadas com a convergência internacional: num bom número de casos, verifica-se o contrário. Inversamente, podemos identificar alguns ingredientes e processos robustos, subjacentes ao avanço nas tecnologias e na renda, que não se correlacionam com as chamadas tendências da "globalização". Discutiremos conjuntamente essas dimensões políticas subjacentes.

\section{Divergências tecnológicas e de renda como padrões seculares}

O fenômeno básico pelo qual começar é, com efeito, a distribuição internacional das atividades inovadoras, sumamente desigual, surgida desde a Revolução Industrial (Dosi, Pavitt e Soete, 1990), partindo de condições antes bastante homogêneas, pelo menos entre a Europa, a China e o mundo árabe (Cipolla, 1965). É fato, sem dúvida, que a "inventividade" tecnológica é difícil de medir, mas, independentemente do substituto escolhido, o quadro que emerge é de uma alta concentração das inovações num pequeno número de países. Uma ilustração disso, usando patentes registradas nos Estados Unidos, é apresentada na Tabela 1. 
Tabela 1: Patentes norte-americanas concedidas, por país solicitante e por ano (\% de beneficiados não norte-americanos)

Table 1: US patents granted, by country of applicant and year (\% of non-US recipients)

\begin{tabular}{|c|c|c|c|c|c|c|c|c|c|c|}
\hline & & 1883 & 1900 & 1929 & 1958 & 1973 & 1986 & 1990 & 1995 & 1999 \\
\hline \multirow[t]{14}{*}{ OECD } & Australia & 1.11 & 2.33 & 1.96 & 0.60 & 0.92 & 1.14 & 1.01 & 1.00 & 1.02 \\
\hline & Austria & 2.62 & 3.36 & 2.47 & 1.12 & 1.02 & 1.090 & 0.915 & 0.738 & 0.688 \\
\hline & Belgium & 1.590 & 1.35 & 1.30 & 1.14 & 1.23 & 0.74 & 0.73 & 0.87 & 0.93 \\
\hline & Canada & 19.94 & 10.54 & 10.25 & 7.99 & 6.20 & 4.01 & 4.33 & 4.61 & 4.64 \\
\hline & Denmark & 0.56 & 0.46 & 0.71 & 0.74 & 0.70 & 0.56 & 0.37 & 0.44 & 0.70 \\
\hline & France & 14.22 & 9.79 & 9.76 & 10.36 & 9.38 & 7.22 & 6.67 & 6.17 & 5.49 \\
\hline & Germany & 18.67 & 30.72 & 32.36 & 25.60 & 24.25 & 20.80 & 17.72 & 14.49 & 13.42 \\
\hline & Italy & 0.24 & 0.92 & 1.19 & 3.02 & 3.39 & 3.05 & 2.93 & 2.36 & 2.14 \\
\hline & Japan & 0.16 & 0.03 & 1.40 & 1.93 & 22.10 & 40.35 & 45.43 & 47.64 & 44.70 \\
\hline & Netherlands & 0.24 & 0.75 & 1.57 & 5.71 & 3.03 & 2.20 & 2.23 & 1.75 & 1.79 \\
\hline & Norway & 0.32 & 0.49 & 0.71 & 0.61 & 0.42 & 0.25 & 0.26 & 0.28 & 0.32 \\
\hline & Sweden & 0.95 & 1.32 & 3.19 & 4.64 & 3.40 & 2.70 & 1.79 & 1.76 & 2.01 \\
\hline & Switzerland & 1.75 & 2.27 & 4.46 & 8.80 & 5.79 & 3.70 & 2.99 & 2.31 & 1.84 \\
\hline & UK & 34.55 & 30.52 & 22.23 & 23.45 & 12.56 & 7.37 & 6.49 & 5.42 & 5.13 \\
\hline \multicolumn{2}{|c|}{$\begin{array}{l}\text { Eastern Europe } \\
\text { (including Russia) }\end{array}$} & 0.40 & 1.49 & 1.62 & 0.55 & 2.53 & 1.13 & 0.35 & 0.27 & 0.29 \\
\hline \multirow[t]{6}{*}{ NICs } & & 0.40 & 1.12 & 1.03 & 1.31 & 1.36 & 1.50 & 3.19 & 7.33 & 12.09 \\
\hline & Israel & & & & & & 0.58 & 0.70 & 0.84 & 1.07 \\
\hline & Singapore & & & & & & 0.01 & 0.03 & 0.12 & 0.21 \\
\hline & Taiwan & & & & & & 0.63 & 1.70 & 3.55 & 5.31 \\
\hline & Korea & & & & & & 0.14 & 0.52 & 2.54 & 5.12 \\
\hline & Hong Kong & & & & & & 0.09 & 0.12 & 0.19 & 0.22 \\
\hline Others & & 3.28 & 2.54 & 3.07 & 2.43 & 1.72 & 2.19 & 2.61 & 2.59 & 2.79 \\
\hline \multicolumn{11}{|l|}{ Of which: } \\
\hline \multirow[t]{4}{*}{ Latin America } & Argentina & & & & & & 0.05 & 0.04 & 0.07 & 0.06 \\
\hline & Brazil & & & & & & 0.08 & 0.09 & 0.14 & 0.13 \\
\hline & Mexico & & & & & & 0.11 & 0.07 & 0.09 & 0.11 \\
\hline & Venezuela & & & & & & 0.06 & 0.05 & 0.06 & 0.06 \\
\hline
\end{tabular}

Source: US Patents office 
O clube dos grandes inovadores tem sido bem pequeno, ao longo de todo esse período de aproximadamente dois séculos e meio, e tanto o ingresso nele é restrito (o Japão foi o único novo sócio de peso a ingressar no século XX, enquanto a Coréia e Formosa foram acréscimos recentes) quanto é lento o ritmo de mudança das posições relativas.

Ao mesmo tempo, desde a Revolução Industrial, observa-se uma explosão de padrões de renda divergentes, partindo de um nível per capita pré-industrial bastante parecido. Bairoch (1981) apresenta estimativas que mostram que, antes da Revolução Industrial, a defasagem de renda entre os países mais pobres e os mais ricos era certamente menor do que a proporção de 1 para 2, sendo, provavelmente, da ordem de apenas 1 para 1,5. Inversamente, a tendência dominante, depois da Revolução Industrial, é de uma diferenciação rápida e crescente entre os países e de uma divergência global. Mesmo no período que se seguiu à Segunda Guerra Mundial, comumente considerado uma era de uniformidade crescente, a hipótese da convergência global, isto é, de uma convergência da população geral dos países para níveis de renda cada vez mais similares, não é corroborada pelos fatos (De Long, 1988; Easterly et al., 1992; Verspagen, 1991; Soete e Verspagen, 1993; Durlauf e Johnson, 1992; Quah, 1996). Ao contrário, observam-se alguns indícios, ainda que não fartos, de convergência local, ou seja, de subconjuntos de países agrupados de acordo com alguma característica inicial, como o nível de renda (Durlauf e Johnson, 1992) ou a localização geográfica. Os padrões típicos são graficamente ilustrados na Figura 1, extraída de Durlauf e Quah (1998), que mostra o aparecimento de uma distribuição em dois picos dos países com probabilidades baixas (embora positivas) de transição entre os clubes dos "pobres" e dos "ricos" (e também vice-versa).

Ao mesmo tempo, as diferenças intergrupais no tocante ao crescimento do desempenho parecem significativas. Observam-se também defasagens persistentemente amplas - e, em alguns casos, alargando-se (a exemplo de alguns países da América Latina) - de produtividade em relação à fronteira internacional (cf. Tabela 2, sobre a produtividade da mão-de-obra; ver também van Ark e McGuckin, 1999). 

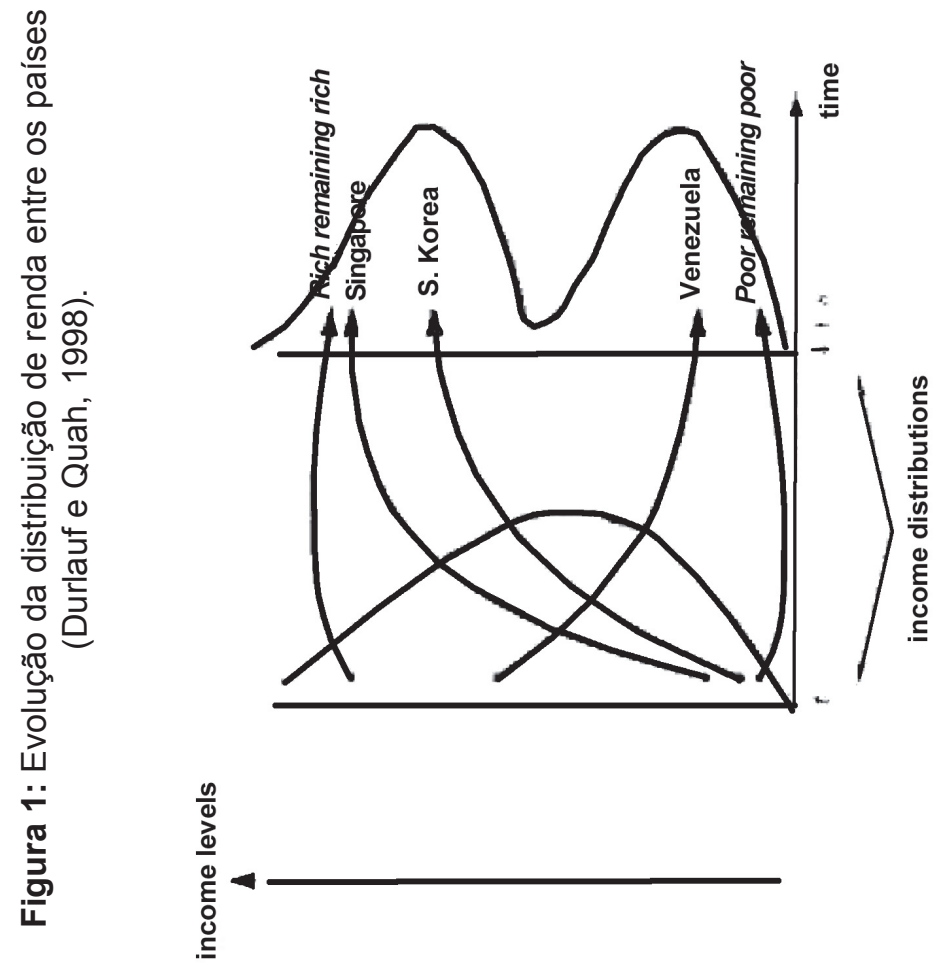

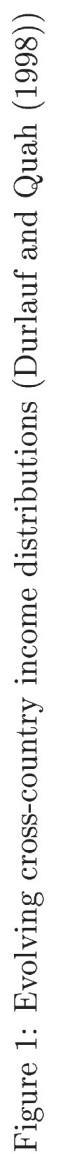


Tabela 2: Produtividade da mão-de-obra em relação aos EUA (PIB real por hora trabalhada)

Table 2: Labor productivity relative to US (Real GDP per hour worked)

\begin{tabular}{llcccccc}
\hline & 1870 & 1913 & 1950 & 1973 & 1990 & 1998 \\
\hline OECD & Austria & 61.3 & 56.8 & 32.0 & 64.0 & 79.9 & 78.4 \\
& Belgium & 96.4 & 71.9 & 48.9 & 71.2 & 91.2 & 97.2 \\
Denmark & 69.8 & 69.9 & 51.9 & 69.9 & 72.0 & 75.8 \\
& Finland & 38.2 & 36.5 & 33.8 & 58.2 & 67.3 & 74.4 \\
France & 61.3 & 56.2 & 46.0 & 76.0 & 97.9 & 97.6 \\
Germany & 68.9 & 59.2 & 31.5 & 62.2 & 72.9 & 76.9 \\
& Ireland & & & 29.5 & 41.5 & 72.0 & 78.3 \\
Italy & 46.7 & 41.6 & 34.6 & 67.1 & 80.0 & 80.8 \\
Netherlands & 108.0 & 80.3 & 52.7 & 82.2 & 100.2 & 88.6 \\
Norway & 53.3 & 46.9 & 47.0 & 65.1 & 87.8 & 94.8 \\
Spain & & & 20.6 & 45.8 & 63.0 & 63.5 \\
Sweden & 54.2 & 50.4 & 56.0 & 76.0 & 74.7 & 76.0 \\
Switzerland & 68.0 & 64.5 & 70.1 & 78.2 & 83.3 & 71.8 \\
UK & 113.3 & 84.2 & 62.7 & 67.3 & 71.2 & 79.5 \\
& & & & & & \\
& Australia & 154.7 & 107.0 & 76.2 & 72.8 & 74.1 & 77.9 \\
Canada & 76.0 & 86.9 & 81.7 & 83.2 & 78.2 & 75.4 \\
Japan & 20.4 & 21.1 & 16.4 & 48.8 & 63.3 & 65.2 \\
US & 100.0 & 100.0 & 100.0 & 100.0 & 100.0 & 100.0
\end{tabular}

\begin{tabular}{llllll} 
Latin America & Argentina & 48.7 & 45.1 & 32.0 & 38.9 \\
& Brazil & 19.6 & 24.4 & 23.4 & 22.8 \\
& Chile & 36.8 & 37.6 & 31.8 & 38.2 \\
& Colomib & 22.1 & 24.0 & 25.0 & 24.0 \\
& Mexico & 28.2 & 37.6 & 33.5 & 29.1 \\
& Peru & 22.3 & 26.2 & 15.0 & 15.2 \\
& Venezuela & 86.3 & 81.2 & 48.2 & 39.7 \\
Asian NICs & & & & \\
& Hong Kong & 59.4 & 31.6 & 53.2 & 54.3 \\
& Singapore & & 28.7 & 41.8 & 52.6 \\
& Korea & & 15.3 & 27.1 & 33.7 \\
& Taiwan & & 18.4 & 32.9 & 44.0 \\
\hline
\end{tabular}

Source: Maddison (2001), Total Economy Database at Groningen Growth and Development Centre GGDC (2002a) 
Uma questão delicada, mas crucial, concerne à relação entre os padrões de mudança tecnológica e os padrões de crescimento econômico. Naturalmente, a aprendizagem tecnológica envolve muito mais elementos do que a simples descoberta inventiva e o registro de patentes. De igual importância são as atividades de imitação, engenharia reversa, adoção de inovações incorporadas no capital e aprendizagem através do "fazer" e do "usar" (Freeman, 1982; Dosi, 1988; Patel e Pavitt, 1998). Além disso, a mudança tecnológica nem sempre se conjuga com a inovação organizacional. Ainda assim, é importante assinalar a existência de vínculos significativos entre as atividades inovadoras (avaliadas em sentido bastante estrito, ou seja, em termos de patenteamento e atividades de P\&D) e o PIB per capita (por ora, evitaremos qualquer discussão detalhada a respeito da causalidade).

Como foi discutido em Dosi, Freeman e Fabiani (1994), os dados relativos aos países da OCDE parecem sugerir que a relação entre as atividades inovadoras e os níveis do PIB estreitou-se mais ao longo do tempo e é sumamente significativa desde a Segunda Guerra Mundial. Além disso, o dinamismo inovador, medido pelo aumento do registro de patentes de diferentes países nos EUA, sempre parece ter uma correlação positiva com o crescimento do PIB per capita. Esse vínculo é particularmente sólido entre 1913 e 1970. Inversamente, um sinal de que o regime de crescimento internacional pode ter-se modificado na década de 1970 é que, durante esse período, essa relação se enfraqueceu e perdeu importância estatística.

Em geral, pelo menos desde a Segunda Guerra Mundial, as taxas de crescimento do PIB parecem depender: (i) das atividades inovadoras internas, (ii) dos índices de investimento em bens de capital, e (iii) da difusão tecnológica internacional (Fagerberg, 1988; De Long, 1988; Soete e Verspagen, 1993; Meliciani, 2001; e Laursen, 2000, entre outros).

Por sua vez, a capacidade de inovação e de adoção rápida das novas tecnologias tem uma forte correlação com o bom desempenho no comércio (Dosi, Pavitt e Soete, 1990).

Além disso, embora a disseminação tecnológica se dê em velocidade muito alta, pelo menos entre os países da OCDE, persistem algumas especificidades importantes nos "sistemas nacionais de inovação", relacionadas com as características da infra-estrutura científica e técnica, com os usuários e produtores locais e com outras características institucionais e políticas de cada país (Lundvall, 1992; Nelson, 1993; Archibugi, Howells e Michie, 2001). 
Repetindo, a tendência dominante em todo esse quadro sugere uma divergência permanente na capacidade tecnológica relativa, na eficiência da produção e na renda. Ao lado disso, porém, há duas mensagens mais esperançosas.

Primeiro, a despeito dos padrões marcantemente divergentes, também assistimos a um nível médio secularmente crescente de conhecimento tecnológico na maioria dos países (acompanhado ainda por um crescimento dos níveis de renda per capita). Segundo, embora seja fato que o "clube dos inovadores" tem tido um número singularmente pequeno e fixo de sócios, convém assinalar a possibilidade de ingresso de alguns novos membros de sucesso (dentre os quais, em diferentes épocas, os exemplos mais notáveis foram os Estados Unidos, a Alemanha e o Japão) e a possibilidade de retrocesso de alguns candidatos promissores (cf. as vicissitudes da Argentina nos últimos cem anos).

Em vista disso, de que modo esse cenário de longo prazo é afetado pelas recentes mudanças das relações econômicas e políticas, no campo internacional, reunidas sob o rótulo de "globalização"?

Para dar uma resposta provisória, é preciso começar explicitando exatamente o que se pretende dizer, e se os supostos fenômenos têm substância empírica.

\section{Uma digressão necessária: "globalização" de quê?}

Percorramos rapidamente alguns campos em que uma literatura freqüentemente anedótica identifica as forças da "globalização". (Para análises muito mais detalhadas, com as quais concordamos em larga medida, ver Eatwell, 1996; Stiglitz, 2002; Meier, Stiglitz e Stern, 2000; Kleinknecht e ter Wengel, 1998; ver também Bowles, 2001, e a discussão apresentada em Berger e Dore, 1996, e em Hollingsworth e Boyer, 1997.)

\section{- Comércio internacional}

Houve, de fato, um processo de "globalização" do comércio internacional depois da Segunda Guerra Mundial, em velocidade muito acelerada. Entretanto, para situar as coisas em perspectiva, convém lembrar que a proporção do comércio internacional (exportações e importações) em relação ao PIB de muitos países só veio a suplantar a de 1913 por volta do fim da década de 1970, início da de 1980 (ver 
na Tabela 3 os dados referentes a alguns dos grandes países desenvolvidos).

Além disso, cabe notar que os obstáculos institucionais e tarifários à "globalização" continuaram a ser dos mais altos nas atividades em que os países em desenvolvimento costumam ser mais competitivos, como produtos agrícolas, indústria têxtil etc.

Por último, há que assinalar a persistência de notáveis diferenças de preço internacionais, mesmo em produtos comercializáveis e com baixas barreiras tarifárias (cf. as discussões em Rodrik, 2002a, e Bradford, 2002).

- Produção das empresas multinacionais

Há indicações de que as empresas multinacionais aumentaram um pouco suas atividades de produção fora dos países em que têm suas sedes. Entretanto, observe-se que:

1. a multinacionalização da produção tem sido sobretudo um fenômeno intra-OCDE, com pouco ou nenhum impacto nos países em desenvolvimento e nos países ex-comunistas (cf. Kleinknecht e ter Wengel, 1998);

2. pelo menos com respeito à $\mathrm{OCDE}$, os padrões de especialização específicos de cada país continuam a ser muito persistentes e dependentes da via adotada (cf. Meliciani, 2001; Scarpetta, Bassanini, Pilat e Schreyer, 2000);

3. quando não o são, como em alguns países em desenvolvimento, isso parece resultar sobretudo de grandes choques macroeconônicos e institucionais (cf. muitos países da América Latina), de impacto altamente controvertido na capacidade tecnológica e de produção (cf. Cimoli e Correa, 2002; ver também adiante). 
Tabela 3: Exportações e importações de mercadorias como percentagem do PIB (preços atuais)

Table 3: Exports and imports of goods as a percentage of GNP (current prices)

\begin{tabular}{lrrrr}
\hline & 1913 & 1950 & 1973 & 1994 \\
\hline France & 30.0 & 21.4 & 29.2 & 34.2 \\
Germany & 36.1 & 20.1 & 35.3 & 39.3 \\
UK & 47.2 & 37.1 & 37.6 & 41.8 \\
Netherlands & 60.0 & 70.9 & 74.8 & 89.2 \\
US & 11.2 & 6.9 & 10.8 & 17.8 \\
Japan & 30.1 & 16.4 & 18.2 & 14.6 \\
\hline
\end{tabular}

Source: Kleinknecht and ter Wengel (1998)

- Mercados de trabalho

Nem de longe se "globalizaram" os mercados de trabalho, com a exceção parcial da ponta superior da distribuição das qualificações (isto é, engenheiros, cientistas, administradores etc.) e de alguns "novos gurus econômicos" de vários tipos, como atores e jogadores de futebol... ${ }^{3}$ Ao mesmo tempo, mercados de trabalho sistematicamente nacionais aliaram-se a assimetrias acentuadas e persistentes nas qualificações da população (ver na Tabela 4 dados sobre as diferenças das realizações educacionais entre vários países).

\footnotetext{
${ }^{3}$ Para uma discussão da falta de globalização dos mercados de trabalho e suas implicações, ver Rodrik (2002a).
} 
Tabela 4: Média de anos de escolarização

Table 4: Mean years of schooling

\begin{tabular}{|c|c|c|c|c|c|}
\hline & & 1970 & 1980 & 1990 & 2000 \\
\hline \multirow[t]{20}{*}{ OECD } & Australia & 10,2 & 10,3 & 10,4 & 10,9 \\
\hline & Austria & 7,4 & 7,3 & 7,8 & 8,4 \\
\hline & Belgium & 8,8 & 8,2 & 8,9 & 9,3 \\
\hline & Canada & 9,1 & 10,3 & 11,0 & 11,6 \\
\hline & Denmark & 8,8 & 9,0 & 9,6 & 9,7 \\
\hline & Finland & 6,1 & 7,2 & 9,4 & 10,0 \\
\hline & France & 5,7 & 6,7 & 7,0 & 7,9 \\
\hline & Germany & - & - & 9,9 & 10,2 \\
\hline & Ireland & 6,8 & 7,5 & 8,8 & 9,4 \\
\hline & Italy & 5,5 & 5,9 & 6,5 & 7,2 \\
\hline & Japan & 7,5 & 8,5 & 9,0 & 9,5 \\
\hline & Netherlands & 7,8 & 8,2 & 8,8 & 9,4 \\
\hline & New Zealand & 9,7 & 11,5 & 11,3 & 11,7 \\
\hline & Norway & 7,2 & 8,2 & 11,6 & 11,9 \\
\hline & Portugal & 2,6 & 3,8 & 4,9 & 5,9 \\
\hline & Spain & 4,8 & 6,0 & 6,4 & 7,3 \\
\hline & Sweden & 8,0 & 9,7 & 9,5 & 11,4 \\
\hline & Switzerland & 8,5 & 10,4 & 10,1 & 10,5 \\
\hline & UK & 7,7 & 8,3 & 8,8 & 9,4 \\
\hline & US & 9,5 & 11,9 & 11,7 & 12,0 \\
\hline \multirow[t]{4}{*}{ NICs } & Israel & 8,1 & 9,4 & 9,4 & 9,6 \\
\hline & Singapore & 5,1 & 5,5 & 6,0 & 7,1 \\
\hline & South Korea & 4,9 & 7,9 & 9,9 & 10,8 \\
\hline & Hong Kong & 6,3 & 8,0 & 9,2 & 9,4 \\
\hline \multirow[t]{5}{*}{ Latin America } & Argentina & 6,2 & 7,0 & 8,1 & 8,8 \\
\hline & Brazil & 3,3 & 3,1 & 4,0 & 4,9 \\
\hline & Chile & 5,7 & 6,4 & 7,0 & 7,6 \\
\hline & Mexico & 3,7 & 4,8 & 6,7 & 7,2 \\
\hline & Venezuela & 3,2 & 5,5 & 5,0 & 6,6 \\
\hline \multirow[t]{3}{*}{ World } & Mean & 4,2 & 4,9 & 5,8 & 6,4 \\
\hline & Standard deviation & 2,6 & 2,8 & 2,9 & 2,8 \\
\hline & Coefficient of variation & 1,6 & 1,8 & 2,0 & 2,3 \\
\hline
\end{tabular}

Source: Human Development Report 2001। 


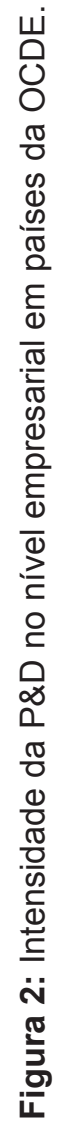

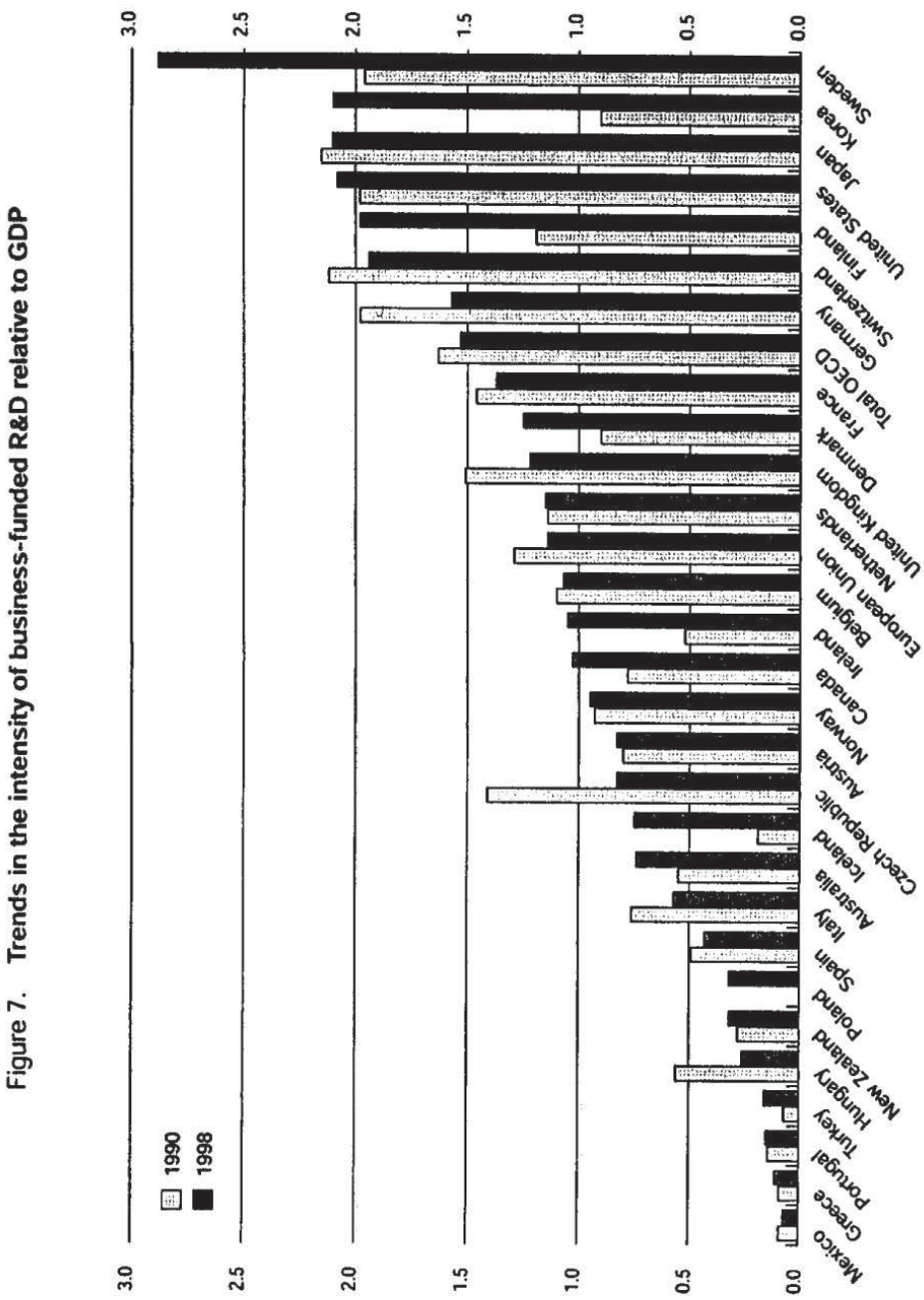

Desenvolvimento em Debate - 86 
- Padrões de geração e disseminação de novas tecnologias

Já mencionamos a concentração permanente das atividades inovadoras - a despeito de algumas exceções notáveis a esse padrão, como a Finlândia, a Coréia, Formosa e, em menor grau, o Brasil e a Índia.

Como não é de admirar, esses padrões de produção inovadora encontram correspondência nas diferenças internacionais persistentes na parcela de recursos dedicados à aprendizagem tecnológica formal (também reveladas pela $\mathrm{P} \& \mathrm{D}$ financiada com recursos privados). Assim, embora a Coréia tenha suplantado há algum tempo alguns países "desenvolvidos", como a Itália, a maioria dos países de baixo desenvolvimento continua a exibir níveis desprezíveis de investimentos privados na P\&D (cf. Figura 2).

Ao mesmo tempo, a internacionalização das atividades inovadoras pelas empresas multinacionais, fora de seus países de origem, teve um certo aumento, mas ainda estamos falando de proporções bem reduzidas. A maioria dos estudos indica que o registro de patentes das multinacionais no exterior é da ordem de $10-15 \%$ do total de suas patentes, o que é mais ou menos comparável a sua parcela do patenteamento total dos países anfitriões. Além disso, a maior parte dessas atividades de pesquisa no exterior ocorre dentro dos países da OCDE (para uma discussão dos dados, ver Patel e Pavitt, 1997 e 1999, e Cantwell, 1992).

As tecnologias de informática e comunicações [TIC] certamente determinaram uma difusão mais fácil da informação. Todavia, são poucos os indícios de uma aceleração generalizada dos índices de adoção das tecnologias "novas" (por exemplo, relacionadas com a TIC) e "antigas" (de telefones a tratores). A Tabela 5 e as Figuras 3, 4 e 5 mostram dados sobre a disseminação desigual das TIC. ${ }^{4}$ Observem-se também as diferenças internacionais impressionantes na difusão das TIC: por exemplo, comparem-se a Finlândia com a Polônia, ou o Leste Asiático com a América Latina.

\footnotetext{
${ }^{4}$ As distribuições Figura 5 foram obtidas a partir da estimativa da densidade nuclear de todos os países cobertos pelos Indicadores do Milênio da ONU (cerca de 100 nações). Note-se o surgimento da bimodalidade na distribuição, que aponta para uma diferença acentuada entre os países em desenvolvimento e os desenvolvidos.
} 
Figura 3: Intensidade de uso da Internet em diferentes países e regiões (Relatório sobre Desenvolvimento Humano, 2001).

The large circle represents world population.

Pie slices show regional shares of world population.

Dark wedges show internet users.

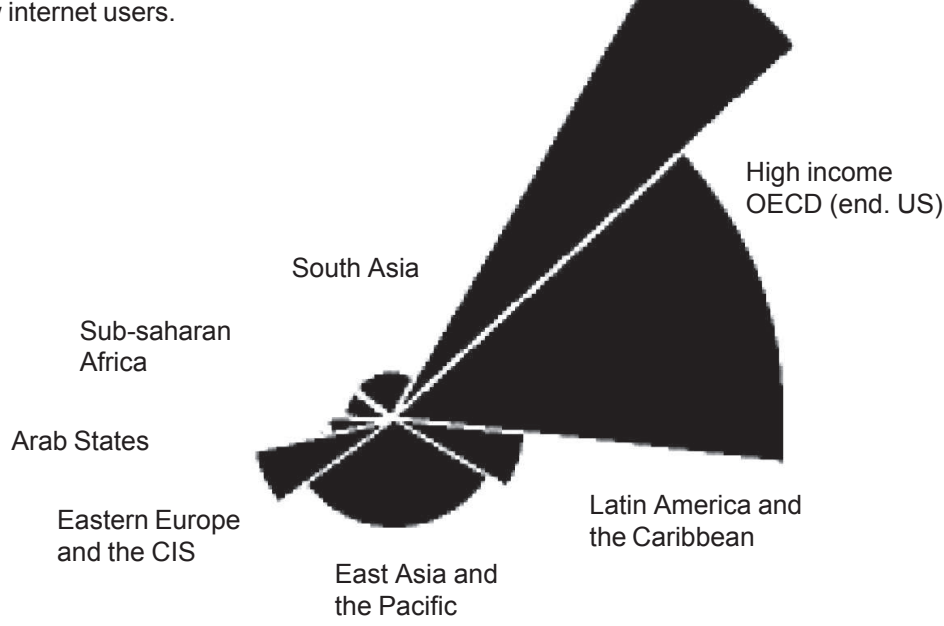

Internet users

(as percentage of population)

$1988 \quad 2000$

United States

26.3

54.3

High income OECD (excl. US)

28.2

Latin America and the Caribbean

6.9

3.2

East Asia and the Pacific

0.5

2.3

Eastern Europe and CIS

0.8

3.9

Arab States

0.2

0.6

Sub-saharan - Africa

0.1

0.4

South Asia

0.04

World

2.4

0.4

4.7 

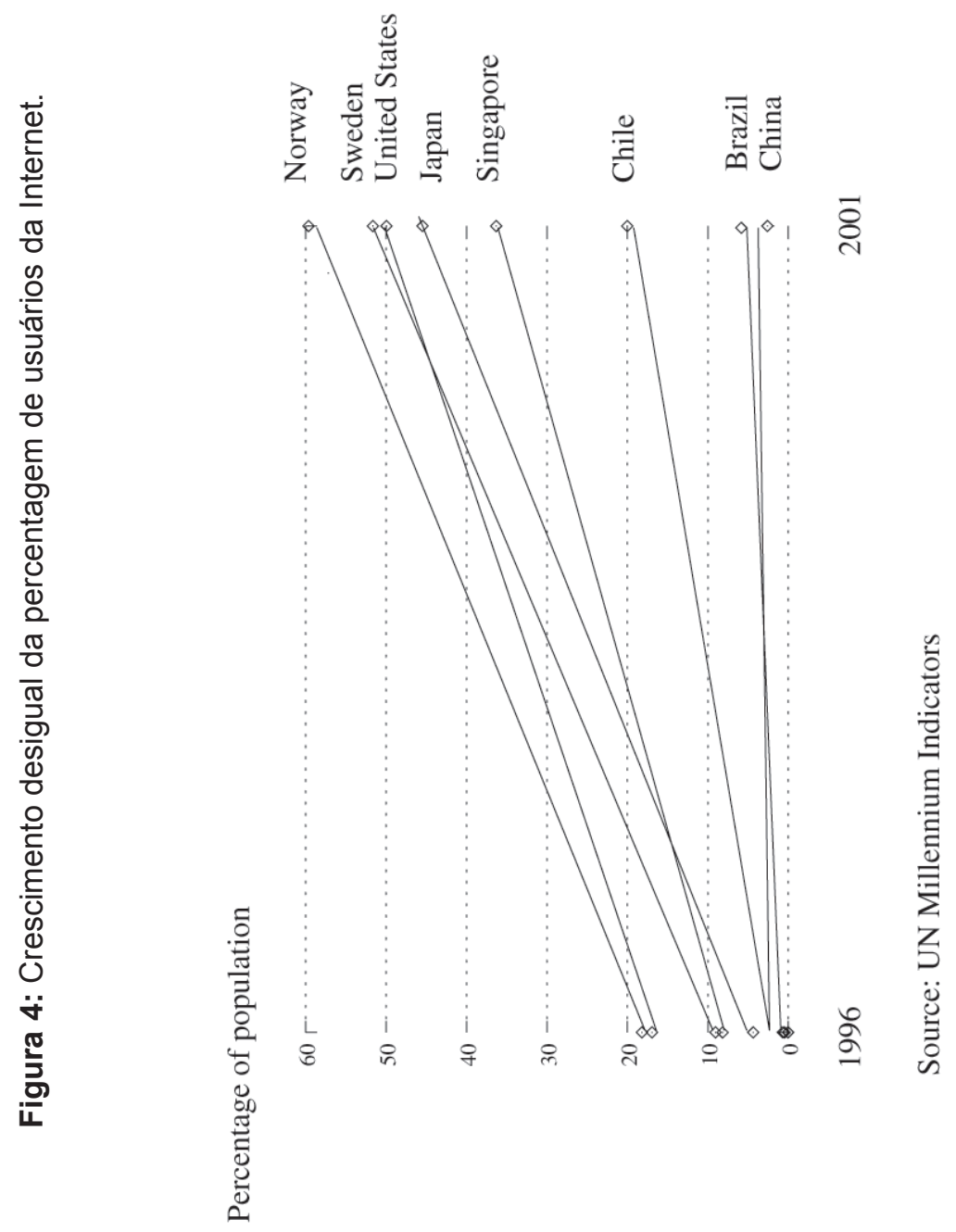

A Nova Agenda Mundial -89 
Figura 5: Distribuição dos índices disseminação da TIC
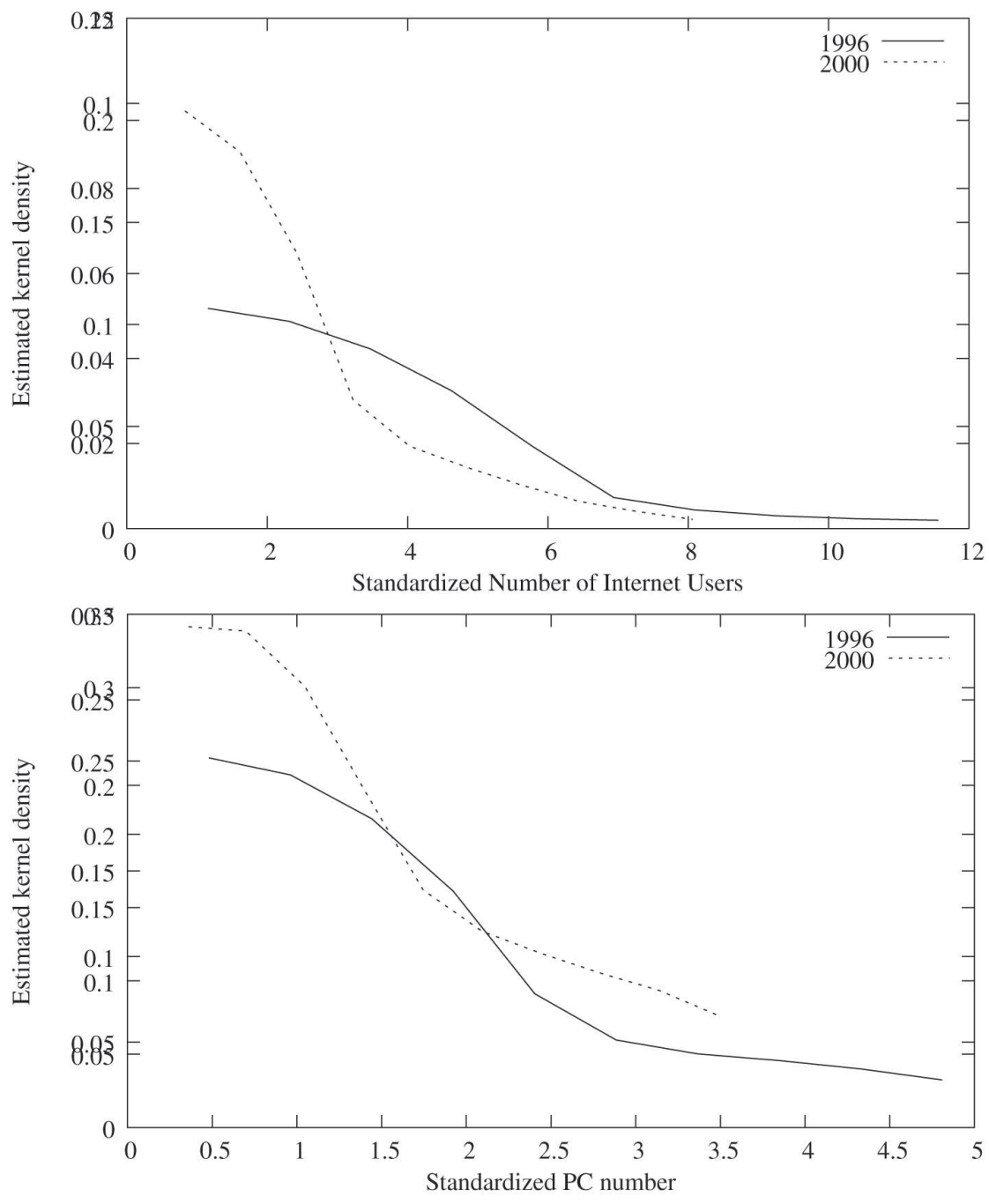
Tabela 5: Índices de disseminação da TIC

Table 5: Indexes of ICT diffusion

\begin{tabular}{|c|c|c|c|c|c|c|c|}
\hline & & $\begin{array}{l}\text { Intern } \\
\text { (\% of }\end{array}$ & $\begin{array}{l}\text { et use } \\
\text { popul }\end{array}$ & tion) & $\begin{array}{l}\text { Perso } \\
\text { per } 1 \\
\end{array}$ & $\begin{array}{l}\text { al com } \\
0 \text { popı }\end{array}$ & $\begin{array}{l}\text { puters } \\
\text { ation }\end{array}$ \\
\hline & Country & 1991 & 1996 & 2001 & 1991 & 1996 & 2000 \\
\hline OECD & Australia & 1,1 & 3,3 & 37,2 & 16 & 29 & 47 \\
\hline & Austria & 0,3 & 3,1 & 31,9 & 8 & 17 & 28 \\
\hline & Belgium & 0,0 & 3,0 & 28,0 & 10 & 22 & 34 \\
\hline & Canada & 0,6 & 6,7 & 43,5 & 13 & 25 & 39 \\
\hline & Denmark & 0,2 & 5,7 & 44,7 & 13 & 30 & 43 \\
\hline & Finland & 1,4 & 16,8 & 43,0 & 11 & 27 & 40 \\
\hline & France & 0,1 & 2,6 & 26,4 & 7 & 16 & 30 \\
\hline & Germany & 0,3 & 3,1 & 36,4 & 10 & 21 & 34 \\
\hline & Italy & 0,0 & 1,0 & 27,6 & 5 & 9 & 18 \\
\hline & Japan & 0,0 & 4,4 & 45,5 & 7 & 16 & 32 \\
\hline & Netherlands & 0,5 & 5,8 & 32,9 & 11 & 23 & 39 \\
\hline & Norway & 1,4 & 18,2 & 59,6 & 15 & 32 & 49 \\
\hline & Sweden & 1,2 & 9,1 & 51,6 & 13 & 29 & 51 \\
\hline & Switzerland & 1,2 & 4,6 & 40,4 & 11 & 34 & 50 \\
\hline & UK & 0,2 & 4,1 & 40,0 & 12 & 22 & 34 \\
\hline & US & 1,2 & 17,0 & 50,0 & 23 & 36 & 59 \\
\hline NICs & Hong Kong & 0,1 & 4,8 & 45,9 & 6 & 19 & 35 \\
\hline & Korea & 0,1 & 1,6 & 51,1 & 5 & 13 & 24 \\
\hline & Taiwan & 0,1 & 2,8 & 33,7 & 7 & 26 & 48 \\
\hline & Singapore & 0,2 & 8,2 & 36,3 & 4 & 10 & 22 \\
\hline & Israel & 0,2 & 2,1 & 23,1 & 7 & 16 & 25 \\
\hline Latin America & Argentina & & 0,1 & 8,0 & 1 & 3 & 5 \\
\hline & Brazil & 0,0 & 0,5 & 4,6 & 0 & 2 & 5 \\
\hline & Chile & & 0,7 & 20,0 & 2 & 4 & 8 \\
\hline & Colombia & & 0,3 & 2,7 & & 2 & 4 \\
\hline & Mexico & 0,0 & 0,2 & 3,5 & 1 & 3 & 6 \\
\hline & Peru & & 0,3 & 11,5 & & 2 & 4 \\
\hline & Venezuela & & 0,3 & 5,3 & 1 & 3 & 5 \\
\hline Average & World & 0,3 & 1,4 & 11,0 & 5 & 7 & 10 \\
\hline & OECD & 0,6 & 6,8 & 39,9 & 12 & 24 & 39 \\
\hline & NICs & 0,1 & 3,9 & 38,0 & 6 & 17 & 31 \\
\hline & Latin America & 0,0 & 0,3 & 7,9 & 1 & 3 & 5 \\
\hline Standard devia & ion (World) & 0.4 & 3.1 & 16.1 & 5 & 10 & 14 \\
\hline
\end{tabular}

Source: Elaborations on UN Millennium indicators 


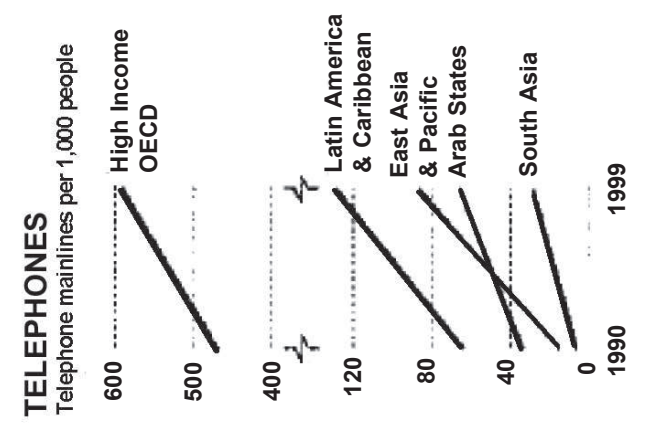

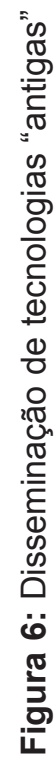
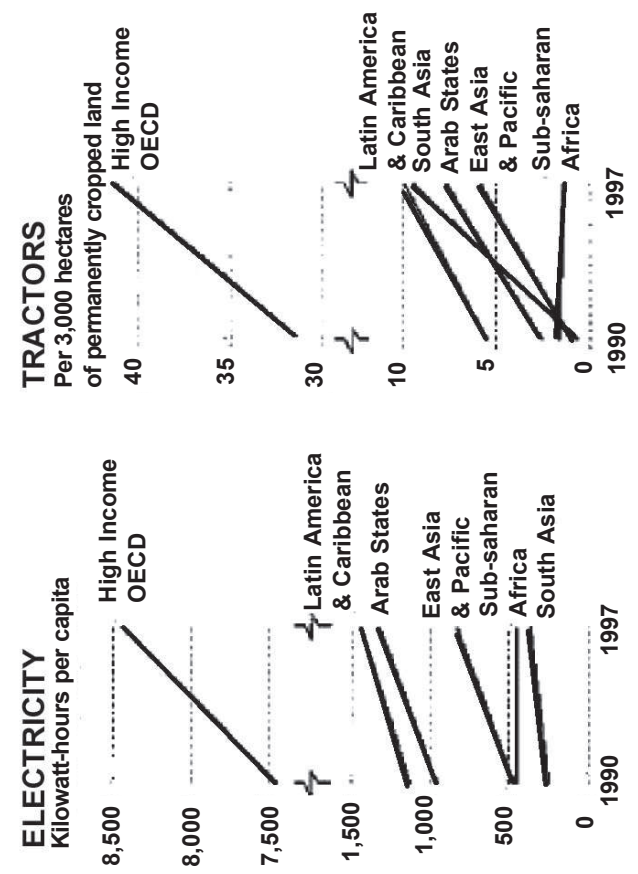

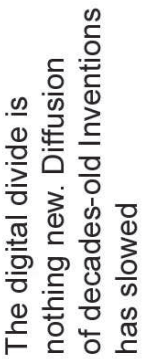


- Mercados financeiros

A liberalização dos mercados financeiros foi, de fato, o fenômeno mais marcante a deslanchar com ímpeto no último quarto de século (cf. Blundell-Wignall e Browne, 1991). Apenas para dar uma indicação da ordem de grandeza, um dia de negociação com divisas estrangeiras na década de 1990 era, tipicamente, mais de cem vezes maior do que o comércio mundial por ano (ver Eatwell, 1996). Em geral, as barreiras à movimentação do capital ruíram precipitadamente, com isso aumentando também a volatilidade dos fluxos financeiros. Mesmo nesse caso, porém, é de se notar que a "globalização" ocorreu muito mais depressa com respeito ao capital especulativo "quente", de curto prazo, tendo um impacto muito menor - se é que exerce algum - nas atividades de investimento e produção a longo prazo (como foi discutido em Ocampo, 2002, a propósito da América Latina). Na verdade, uma conjectura plausível é que, em alguns países, estas últimas atividades tornaram-se mais marginais e "nacionais". Paralelamente, a poupança e o investimento mantiveram-se obstinadamente nacionais (com respeito ao chamado "enigma de Feldstein-Horioka" e sua persistência, ver Feldstein e Horioka, 1980, Obstfeld e Rogoff, 1996, e Eatwell, 1996).

\section{- Arranjos institucionais}

Com toda certeza, o atual regime "globalizado" de relações internacionais e políticas está ligado à difusão - ou, em muitas situações, à imposição violenta - de determinados arranjos institucionais, extraídos de uma forma particular de capitalismo ocidental - o laissez-faire anglosaxão - e que vão desde as bolsas de valores até os sistemas de direitos de propriedade intelectual. ${ }^{5}$ Todavia, a disseminação desordenada de alguns componentes do "modelo anglo-saxão" está longe de haver produzido uma convergência internacional para um arquétipo institucional único, a despeito da violência com que ele é comumente imposto à comunidade internacional pelas organizações que implementam o chamado "consenso de Washington" (para discussões minuciosas, ver Berger e Dore, 1996; Stiglitz, 2002; Krugman, 1999; Rodrik, 2002b).

\footnotetext{
${ }^{5}$ Ver, entre outros, Coriat (2002) e Stiglitz (2002).
} 


\section{Para além do "alarde da globalização": sobre alguns ingredientes da equiparação tecnológica}

Em suma, se nossa interpretação está certa, a chamada "globalização" tem a ver, acima de tudo, com (a) a liberalização internacional dos movimentos de capital e (b) a liberalização (bastante assimétrica) dos fluxos de comércio, ao mesmo tempo que surte efeitos bastante controvertidos sobre os padrões internacionais de aprendizagem tecnológica e a distribuição correlata das possibilidades de crescimento entre os países.

Primeiro, há que desfazer o mito de que a "globalização" - no sentido de maior integração internacional - acompanha naturalmente a "convergência" ou a maior uniformidade das potencialidades tecnológicas. Como foi mais extensamente discutido em Pavitt (1999 e 2002) e em Dosi, Orsenigo e Sylos Labini (2002), o conhecimento, distinguindo-se da simples informação, tende a ser de transmissão muito lenta, uma vez que costuma incorporar-se em pessoas, organizações e redes locais específicas.

Segundo, num mundo caracterizado por múltiplas formas de lucros localizados crescentes, a maior integração pode levar a fenômenos de diferenciação crescente, com o auto-reforço e o confinamento de determinadas atividades produtivas, padrões de especialização e capacidades tecnológicas (ou falta delas). ${ }^{6}$

Dito de outra maneira, é fácil mostrar que um mundo que, em certo nível, torna-se cada vez mais integrado - mas não (aproximadamente) idêntico nas condições iniciais, nas instituições, capacidades tecnológicas, mecanismos de interação econômica etc. - pode ficar sujeito a várias formas de círculos virtuosos ou viciosos "locais".

Terceiro, o impacto da maior integração tende a depender das formas pelas quais ela é implementada. A experiência de muitos países latino-americanos é um bom exemplo disso. Quando os choques macro ("globalizantes") induzem repentinamente a uma seleção maior das empresas nacionais (especialmente na América Latina), é freqüente a mortalidade maciça das firmas acarretar uma aparente redução da defasagem de produtividade em relação à fronteira internacional. Mas isso parece ser acompanhado - ao menos na América Latina - por aumentos notáveis das taxas de desemprego (isto é, transições de partes da força

\footnotetext{
${ }^{6}$ Sobre essa questão, numa bibliografia crescente, ver os argumentos complementares de Arthur(1994), Dosi, Pavitt e Soete (1990), Krugman (1996), Antonelli (1995) e Cimoli (1988).
} 
de trabalho, como diz Joe Stiglitz, de estados de baixa produtividade para situações de produtividade zero) e por uma acentuação das restrições do saldo da balança comercial ao crescimento, o que constitui, por sua vez, o efeito conjunto de uma elasticidade relativamente baixa das exportações para o crescimento mundial e de uma elasticidade alta das importações para o crescimento interno (cf. Cimoli e Correa, 2002).

Mas, se não é a "globalização", quais são os ingredientes e processos relativos e invariantes, se é que eles existem, que impulsionam a equiparação tecnológica? Essa não é uma pergunta que se possa responder minuciosamente num artigo curto. Basta mencionar que diversos estudos apontaram determinadas combinações entre formas de organização empresarial e arranjos institucionais como particularmente favorecedoras ou nocivas para a acumulação tecnológica. De fato, a comparação entre a experiência dos países do Extremo Oriente e da América Latina é particularmente reveladora (cf. Amsden, 1989 e 2002; Wade, 1990; Kim e Nelson, 2000; Dosi, Freeman e Fabiani, 1994, entre outros). A Tabela 6 dramatiza algumas das diferenças mais notáveis entre essas várias dinâmicas comparativas. Em última instância, o sucesso ou o fracasso parecem depender das combinações de diferentes arranjos e políticas institucionais, na medida em que elas afetam os processos de aprendizagem de indivíduos e organizações, por um lado, e os processos de seleção (incluindo, é claro, a competição no mercado), por outro.

Em linhas mais gerais, seria útil dispor de uma taxonomia sobre os níveis (ou seja, as variáveis de "controle" e "situacionais") em que operam as medidas políticas. Certamente, a experiência histórica mostra uma grande variedade de combinações específicas de países e setores entre os tipos de política ilustrados acima. Mas, ainda assim, emergem algumas regularidades e trade offs sutis.

Primeiro, uma regularidade que tem prevalecido, desde a Europa e os Estados Unidos do século XIX até os tempos contemporâneos, é a centralidade dos órgãos públicos, tais como as universidades, e da política pública na geração e no estabelecimento de novos paradigmas tecnológicos (Dosi, 1982).

Segundo, e em termos correlatos, "muitas vezes, os incentivos não bastam”. Um papel crucial das políticas adotadas é afetar a capacidade dos agentes, em especial no caso precedente dos novos paradigmas tecnológicos, mas também em todos os casos de equiparação em que nenhuma estrutura razoável de incentivos seria suficiente para motivar os agentes privados a superar grandes atrasos tecnológicos. 
Terceiro, a disciplina do mercado é útil, na medida em que extirpa as empresas de baixo desempenho e recompensa as de alto desempenho em populações particulares de firmas. Entretanto, nada garante que choques extremamente seletivos não venham a eliminar as próprias populações, em sua totalidade, com isso eliminando também qualquer possibilidade futura de aprendizagem.

\section{Tabela 6: Divergência dos Sistemas Nacionais de Inovação e Produção nas décadas de 1980 e 1990}

\begin{tabular}{|c|c|}
\hline Leste Asiático & América Latina \\
\hline $\begin{array}{l}\text { Sistema de ensino em expansão, com alta } \\
\text { proporção de estudos de engenharia. }\end{array}$ & $\begin{array}{l}\text { Deterioração do sistema de ensino, com uma } \\
\text { produção proporcionalmente mais baixa de } \\
\text { engenheiros. }\end{array}$ \\
\hline $\begin{array}{l}\text { Rápido aumento das atividades científicas e } \\
\text { técnicas no nível empresarial, especialmente } \\
\text { em P\&D. }\end{array}$ & $\begin{array}{l}\text { Crescimento lento, estagnação ou declínio da } \\
\text { P\&D em nível empresarial e de outras } \\
\text { atividades de aprendizagem. }\end{array}$ \\
\hline $\begin{array}{l}\text { Integração progressiva das atividades de } \\
\text { desenho industrial, marketing e pesquisa } \\
\text { dentro das empresas. }\end{array}$ & $\begin{array}{l}\text { Redução da P\&D ou declínio do marketing } \\
\text { empresarial diversificado (especialmente em } \\
\text { mercados estrangeiros). }\end{array}$ \\
\hline $\begin{array}{l}\text { Desenvolvimento de infra-estrutura sólida de } \\
\text { ciência e tecnologia. }\end{array}$ & $\begin{array}{l}\text { Enfraquecimento da infra-estrutura de } \\
\text { ciência e tecnologia. }\end{array}$ \\
\hline $\begin{array}{l}\text { Forte influência dos modelos japoneses de } \\
\text { administração e organização em redes. }\end{array}$ & $\begin{array}{l}\text { Influência contínua de modelos de } \\
\text { administração ultrapassados. }\end{array}$ \\
\hline & \\
\hline $\begin{array}{l}\text { Investimento pesado nas telecomunicações } \\
\text { avançadas. }\end{array}$ & $\begin{array}{l}\text { Lento desenvolvimento de telecomunicações } \\
\text { modernas. }\end{array}$ \\
\hline $\begin{array}{l}\text { Indústria eletrônica forte, com crescimento } \\
\text { acelerado e grandes exportações. }\end{array}$ & $\begin{array}{l}\text { Indústria eletrônica fraca, com baixas } \\
\text { exportações. }\end{array}$ \\
\hline $\begin{array}{l}\text { Em linhas gerais, padrões de especialização } \\
\text { favorecedores de produtos com alta } \\
\text { elasticidade de renda. }\end{array}$ & $\begin{array}{l}\text { Especialização em produtos com baixa } \\
\text { elasticidade de renda. }\end{array}$ \\
\hline $\begin{array}{l}\text { Participação crescente em redes e acordos } \\
\text { internacionais sobre tecnologia. }\end{array}$ & $\begin{array}{l}\text { Baixo nível de participação em redes } \\
\text { internacionais de tecnologia. }\end{array}$ \\
\hline $\begin{array}{l}\text { Esforços políticos sofisticados para fomentar } \\
\text { a aprendizagem tecnológica e generalizar a } \\
\text { busca de renda, mesmo em regimes de } \\
\text { proteção do mercado interno (até os anos } \\
\text { oitenta). }\end{array}$ & $\begin{array}{l}\text { Da proteção generalizada, com poucas } \\
\text { salvaguardas contra a falta de busca de } \\
\text { renda, para "regimes selvagens de } \\
\text { mercado", com pouco incentivo à } \\
\text { aprendizagem. }\end{array}$ \\
\hline $\begin{array}{l}\text { Distribuição relativamente igualitária da } \\
\text { renda. }\end{array}$ & $\begin{array}{l}\text { Distribuição de renda muito desigual — e } \\
\text { cada vez mais desigual. }\end{array}$ \\
\hline
\end{tabular}


Quarto, as medidas políticas - especialmente as voltadas para a equiparação tecnológica - costumam enfrentar a necessidade de equilibrar as medidas que visam a construção da capacidade (e também a proteção do "aprendiz nascente") com mecanismos que reprimam a inércia e promovam a busca de renda. Por exemplo, estes últimos são um dos principais elementos ausentes na antiga experiência latino-americana de substituição de importações, ao passo que as primeiras são o que falta em muitas políticas mais recentes de "liberalização".

\begin{tabular}{|c|c|}
\hline CAMPOS DE INTERVENÇÃO POLÍTICA & MEDIDAS POLÍTICAS \\
\hline (i) Oportunidades tecnológicas. & $\begin{array}{l}\text { Medidas voltadas para a ciência, ensino de } \\
\text { pós-graduação, projetos tecnológicos "de } \\
\text { ponta". }\end{array}$ \\
\hline (ii) Potencialidades tecnológicas. & $\begin{array}{l}\text { Política mais abrangente de ensino e } \\
\text { formação, medidas que afetem o } \\
\text { conhecimento incorporado nas organizações, } \\
\text { política de difusão. }\end{array}$ \\
\hline (iii) Incentivos e mecanismos de seleção. & $\begin{array}{l}\text { Medidas que afetem, por exemplo, os } \\
\text { subsídios à P\&D; a concorrência e a } \\
\text { oposição aos cartéis; a penetração no } \\
\text { mercado e a falência; a alocação de recursos } \\
\text { financeiros; os mercados de propriedade } \\
\text { empresarial, os direitos de propriedade } \\
\text { intelectual e, em linhas mais gerais, os } \\
\text { regimes de apropriação. }\end{array}$ \\
\hline $\begin{array}{l}\text { (iv) Arranjos institucionais para gerir a } \\
\text { distribuição da informação e os padrões de } \\
\text { interação entre diferentes tipos de agentes } \\
\text { (bancos, acionistas, dirigentes de empresas, } \\
\text { trabalhadores etc.). }\end{array}$ & $\begin{array}{l}\text { Medidas correspondentes às indicadas acima, } \\
\text { abrangendo também, por exemplo, as regras } \\
\text { do mercado de trabalho, arranjos intra- } \\
\text { empresariais para o compartilhamento de } \\
\text { informações, mobilidade e controle etc. }\end{array}$ \\
\hline $\begin{array}{l}\text { (v) A identidade dos agentes, so bretudo a } \\
\text { natureza, estrutura, propriedade etc. das } \\
\text { empresas. }\end{array}$ & $\begin{array}{l}\text { Da criação de empresas estatais para sua } \\
\text { privatização; de políticas de "defesa } \\
\text { nacional" para políticas que afetem os } \\
\text { investimentos das empresas multinacionais. }\end{array}$ \\
\hline
\end{tabular}




\section{Conclusões}

Entre os muitos inconvenientes dos padrões atuais de "globalização", um dos mais graves, a longo prazo, é a perda de poder dos governos nacionais e até de instituições supranacionais (como a União Européia) sobre muitos dos instrumentos políticos que "fizeram o Ocidente enriquecer”, parafraseando Rosenberg e Birdzell (1987), e que, no passado, também permitiram que alguns países em desenvolvimento saíssem da armadilha da pobreza e entrassem no clube dos exploradores relativamente ricos da rápida aprendizagem tecnológica. É desnecessário dizer que também os mecanismos e graus de perda de poder são diferentes nos vários lugares do mundo: em alguns casos, repetindo, trata-se de um exemplo de pacotes impostos; noutros (ainda menos justificáveis!), trata-se de dificuldades auto-infligidas, impulsionadas pelos talibãs do mercado. Todavia, essa faceta diruptiva da moda atual da "globalização" ainda não foi longe demais, felizmente. A formulação política ainda tem muitos graus de liberdade inexplorados (o que se aplica, de maneiras diferentes, desde Brasília até Bruxelas ou Washington). Como há sinais de que a orgia do fanatismo pelo mercado vem-se esgotando, é mais do que hora de começarmos a concentrar a atenção também em normas políticas e instituições que fomentem a aprendizagem tecnológica e sua disseminação dentro e através dos países. Em outras palavras, é chegada a hora de se construir um "novo consenso", que ponha em destaque a exploração de formas de gestão institucional que compatibilizem a acumulação de conhecimentos e sua exploração econômica eficiente (ao menos em parte) com os interesses dos agentes movidos pelo lucro. Em tudo isso, muitas vezes, embora nem sempre, a existência de mercados que funcionem bem tende a desempenhar um papel central. Mas, como tem enfatizado repetidamente Joe Stiglitz, ${ }^{7}$ o mundo está cheio de "falhas de mercado" (sobretudo a falha intrínseca associada a qualquer geração de conhecimento puramente dirigida pelo mercado). Portanto, eis uma idéia sensata: aprimoremos uma visão pragmática dos mercados internos e internacionais, vendo-os como úteis para a consecução de objetivos mais fundamentais - por exemplo, relativos à produtividade, ao crescimento da renda, ao bem-estar social etc. -, e não como objetivos em si mesmos.

${ }^{7}$ Por exemplo, Stiglitz (1994). 


\section{Referências bibliográficas}

AMSDEN, A. H., Asia's Next Giant: South Korea and Late Industrialization, Oxford, Oxford University Press, 1989.

AMSDEN, A. H., The Rise of "The Rest", 1850-2000: Late Industrialization Outside the North Atlantic Economies, em revisão, 2002.

ANTONELLI, C., The Economics of Localized Technological Change and Industrial Dynamics, Kluwer Publishers, 1995.

ARCHIBUGI, D., HOWELLS, J. e MICHIE, J., Innovation Policy in a Global Economy, Cambridge, Cambridge University Press, 2001.

ARTHUR, W. B., Increasing Returns and Path-Dependence in the Economy, Ann Arbor, University of Michigan Press, 1994.

BAIROCH, P., "The Main Trends in National Economic Disparities since the Industrial Revolution", in BAIROCH, P. e LEVYLEBOYER, M. (orgs.), Disparities in Economic Development since the Industrial Revolution, Macmillan, 1981.

BERGER, S. e DORE, R., National Diversity and Global Capitalism, Ithaca, N.Y., Cornell University Press, 1996.

BLUNDELL-WIGNALL, A. e BROWNE, F., Macroeconomic consequences of financial liberalisation: a summary report, Working Paper 98, OECD Department of Economics and Statistics, 1991.

BOWLES, S., "Globalization and Redistribution: Feasible Egalitarianism in a Competitive World”, in FREEMAN, R. (org.), Inequality, Oxford, Macmillan, 2001.

BRADFORD, S., "Paying the Price: Final Goods Protection in OECD Countries", Review of Economics and Statistics, a ser publicado, 2002.

CANTWELL, J., "The Internationalization of Technological Activity and its Implications for Competitiveness", in D. GRANSTRAND, L. HÅKANSON e S. SJÓLANDER (orgs.), Technology, Management and International Business, Chichester e Nova York, Wiley, 1992.

CIMOLI, M., "Technological Gaps and Institutional Asymmetries in a North-South Model with a Continuum of Goods", Metroeconomica, Cappelli Ed., 39, 3, 1988, p. 245-274.

CIMOLI, M. e CORREA, N. Trade Openness and Technological Gaps in Latin America: A "Low Growth" Trap, LEM, Escola Sant'Anna de Estudos Avançados, Working Paper 2002/14, 2002. 
CIMOLI, M. e DOSI, G., "Technological Paradigms, Patterns of Learning and Development: An Introductory Roadmap", Journal of Evolutionary Economics, 5, 3, 1995, p. 243-268.

CIPOLlA, C. M., Guns and Sails in the Early Phase of European Expansion, 1400-1700, Londres, Collins, 1965.

CORIAT, B., "O novo regime global de propriedade intelectual e sua dimensão imperialista. Implicações para as relações 'Norte-Sul'”, artigo apresentado no Seminário "Novos Rumos do Desenvolvimento no Mundo", organizado pelo BNDES, Rio de Janeiro, 12-13 de setembro de 2002.

DE LONG, B. J., "Productivity Growth, Convergence and Welfare", American Economic Review, 78, 1988, p. 1138-1154.

DOSI, G., "Technological Paradigms and Technological Trajectories: A Suggested Interpretation", Research Policy, 11, 1982, p. 147-162.

DOSI, G., "Sources, Procedures and Microeconomic Effects of Innovation", Journal of Economic Literature, 26, 1988, p. 1120-1171.

DOSI, G., FREEMAN, C. e FABIANI, S., "The Process of Economic Development: Introducing Some Stylized Facts and Theories on Technologies, Firms and Institutions", Industrial and Corporate Change, 3, 1, 1994, p. 1-45.

DOSI, G., ORSENIGO, L. e SYLOS LABINI, M., "Technology and the Economy", LEM, Escola Sant'Anna de Estudos Avançados, Working Paper 2002/19, 2002, a ser publicado in SMELSER, N. J. e SWEDBERG, R. (orgs.), Handbook of Economic Sociology.

DOSI, G., PAVITT, K. e SOETE, L., The Economics of Technical Change and International Trade, Harvester Wheatsheaf, 1990.

DURLAUF, S. N. e JOHNSON, P. A., Local Versus Global Convergence Across National Economies, NBER Working Paper 3996, 1992.

DURLAUF, S. N. e QUAH, D., The New Empirics of Economic Growth, Center for Economic Performance, 1998, artigo de debate 384, 1998.

EASTERLY, W., LEVINE R. e REBELO, S., How Do National Policies Affect Long-run Growth? A Research Agenda, Banco Mundial, artigo de debate, 1992.

EATWELL, J., International Financial Liberalisation: The Impact on World Development, ODS UNDP, 1996, artigo de debate 12, 1996.

FAGERBERG, J., "Why Growth Rates Differ", in DOSI, G., FREEMAN, C., NELSON, R., SILVERBERG, S. e SOETE, L., 
Technical Change and Economic Theory, Londres e Nova York, Pinter Publisher, 1988.

FAGERBERG, J., HANSSON, P. G., LUNDBERG, L. e MELCHIOR, A., Technology and International Trade, Cheltenham (RU) e Brookfield (EUA), Edward Elgar, 1997.

FELDSTEIN, M. e HORIOKA, C., "Domestic Saving and International Capital Flows", Economic Journal, 90, 358, Royal Economic Society, 1980, p. 314-329.

FREEMAN, C., The Economics of Industrial Innovation, Londres, Francis Pinter, 1982.

GGDC, Total Economy Database, http://www.eco.rug.nl/ggdc, Groningen Growth and Development Center, Universidade de Groningen, 2002.

GGDC, ICOP Industry Database, http://www.eco.rug.nl/ggdc,

Groningen Growth and Development Center, Universidade de Groningen, 2002b.

HOLLINGSWORTH, R. e BOYER, R., Contemporary Capitalism: The Embeddedness of Institutions, Cambridge University Press, .....

LAURSEN, K., Trade Specialisation, Technology and Economic Growth: Theory and Evidence from Advanced Countries, Cheltenham (RU) e Lyme (EUA), Edward Elgar, 2000.

LUNDVALL, B. A., National Systems of Innovation: Towards a Theory of Innovation and Interactive Learning, Londres, Pinter Pub., 1992. KIM, L. e NELSON, R. R., Technology, Learning and Innovation: Experiences of Newly Industrialising Economies, Cambridge University Press, 2000.

KLEINKNECHT, A. e WENGEL, J. ter, "The Myth of Economic Globalisation”, Cambridge Journal of Economics, 22, 1998, p. 637-647. KRUGMAN, P. R., The Self-Organizing Economy, Cambridge, Mass. e Oxford, Blackwell Publishers, 1996.

KRUGMAN, P. R., The Return of Depression Economics, Nova York, W. W. Norton, 1999.

MADDISON, A., The World Economy: A Millennial Perspective, OECD, Paris, 2001.

MEIER, G. M., STIGLITZ, J. E. e STERN, N., Frontiers of Development Economics: The Future in Perspective?, Oxford University Press, 2000. 
MILICIANI, V., Technology, Trade and Growth in OECD Countries, Londres e Nova York, Routledge, 2001.

NELSON, R. R., National Systems of Innovation, Oxford, Oxford University Press, 1993.

OBSTFELD, M. e ROGOFF, K., Foundations of International Macroeconomics, MIT Press, 1996.

OCAMPO, J. A., "Globalização e desenvolvimento", artigo apresentado no Seminário "Novos Rumos do Desenvolvimento no Mundo", organizado pelo BNDES, Rio de Janeiro, 12-13 de setembro de 2002.

OECD, A New Economy? The Changing Role of Innovation and Information Technology in Growth, OECD, Paris, 2000.

PATEL, P. e PAVITT, K., "The Technological Competencies of World's Largest Firms: Complex and Path-dependent, but Not Much Variety", Research Policy, 26, 2, 1997, p. 141-156.

PATEL, P. e PAVITT, K. "Uneven (and Divergent) Technological Accumulation Among Advanced Countries: Evidence and a Framework of Explanation", in G. DOSI, TEECE, D. J. e CHYTRY, J. (orgs.), Technology, Organization and Competitiveness: Perspectives on Industrial and Corporate Change, Oxford, Oxford University Press, 1998; reproduzido em PAVITT, K. (org.), Technology Management and Systems of Innovation, Cheltenham, Edward Elgar, 1999.

PAVITT, K., Technology Management and Systems of Innovation, Cheltenham, Edward Elgar, 1999.

PAVITT, K., Knowledge About Knowledge since Nelson and Winter: A Mixed Record, SPRU Electronic Working Paper 83, 2002.

QUAH, D., "Twin Peaks: Growth and Convergence in Models of Distribution Dynamics", Economic Journal, 106, 1996, p. 1045-1055.

RODRIK, D., Feasible Globalisations, texto mimeografado, Universidade de Harvard, 2002.

RODRIK, D., “Depois do neoliberalismo, o quê?”, artigo apresentado no Seminário "Novos Rumos do Desenvolvimento no Mundo", organizado pelo BNDES, Rio de Janeiro, 12-13 de setembro de 2002a. ROSENBERG, N. e BIRDZELL Jr., L. E., How the West Grew Rich, Nova York, Basic Books, 1987. 
SCARPETTA, S., BASSANINI, A., PILAT, D. e SCHREYER, P., Economic Growth in the OECD Area: Recent Trends at the Aggregate and Sectoral Level, Departamento de Economia da OCDE, texto de trabalho 248, 2000.

SOETE, L. e VERSPAGEN, B., "Technology and Growth: The Complex Dynamics of Catching Up, Falling Behind and Taking Over", in A. Szirmai, B. Van Ark e D. Pila (orgs.), Explaining Economic Growth, Amsterdã, Elsevier Science Publishers, 1993.

STIGLITZ, J. E., Wither Socialism?, Cambridge, Mass., MIT Press, 1994.

STIGLITZ, J. E., Globalization and Its Discontents, Nova York, W. W. Norton, 2002.

VAN ARK, B. e MCGUCKIN, R. H., "International Comparisons of Labor Productivity and Per Capita Income", Monthly Labor Review, julho de 1999, p. 33-41.

VERSPAGEN, B., "A New Empirical Approach to Catching Up or Falling Behind", Structural Change and Economic Dynamics, 2, 2, 1991, p. 359-380.

VERSPAGEN, B., Uneven Growth between Interdependent Economies: An Evolutionary View on Technology Gaps, Trade, and Growth, Aldershot (Inglaterra), Avebury, e Brookfield, Ashgate Pub. Co., 1993.

WADE, R., Governing the Market: Economic Theory and the Role of Government in East Asian Industrialization, Princeton, Princeton University Press, 1990. 


\title{
GLOBALIZAÇÃO E DESENVOLVIMENTO PERSPECTIVAS PARA AS NAÇÕES EMERGENTES
}

\author{
Sanjaya Lall*
}

A competitividade é a chave do crescimento industrial e do desenvolvimento num mundo globalizado. A "via mestra" para a competitividade - que combina parcelas crescentes dos mercados abertos com o aumento da renda e do emprego - envolve a construção de um forte setor fabril, voltado para as exportações. Por sua vez, isso requer a capacidade de criar empresas que se liguem a cadeias de valor global dinâmicas e a aprimorar constantemente a eficiência e as capacitações para enfrentar os salários crescentes e as mudanças tecnológicas. A estrutura do comércio e das cadeias de valor globais vem-se modificando, sendo seus componentes mais dinâmicos os produtos de tecnologia intensiva e os sistemas de produção integrados. As diferentes regiões têm enfrentado esse panorama com graus variáveis de sucesso: algumas saem-se espetacularmente bem, outras mal conseguem acompanhá-lo e muitas estão sendo marginalizadas. As explicações dessas diferenças não estão em quanto as economias se "abriram" para os fluxos de comércio, investimento e tecnologia, mas em quão bem se vincularam aos sistemas globais e desenvolveram suas potencialidades tecnológicas e outras para usar as novas tecnologias.

\section{O contexto}

A globalização vem mudando radicalmente o contexto do desenvolvimento econômico, trazendo em seu bojo uma enorme promessa e também graves riscos. Neste artigo, concentro-me no desenvolvimento econômico e entendo a globalização no sentido de uma integração crescente das economias nacionais.

\footnotetext{
* Professor de Economia do Desenvolvimento, Universidade de Oxford.
} 
Que é preciso para que os países em desenvolvimento logrem êxito num contexto globalizado? Numa palavra, competitividade. Faz muito tempo que a competitividade internacional é considerada vital para as economias industrializadas; com a globalização, também vem-se tornando crucial para os países em desenvolvimento, que ficaram longamente isolados dos mercados mundiais. Chegar à competitividade é difícil e requer muito mais do que a simples "abertura" passiva para os mercados livres. É algo que tem de ser construído, e esse é um processo complexo, exigente e dispendioso (Organização de Desenvolvimento Industrial das Nações Unidas [UNIDO], 2002). Os países industrializados também têm grande preocupação com ele, com a manutenção de sua vantagem competitiva sobre os novos concorrentes, e sua preocupação se revela no fluxo contínuo de análises da produtividade e da competitividade.

Para os países em desenvolvimento, o processo é mais difícil e as pressões são correspondentemente maiores, embora um grande campo do pensamento sugira que, com suas vantagens no custo da mão-deobra, tudo o que eles precisam fazer é abrir-se para o comércio global e os fluxos de investimento. Os dados mostram que essa é uma visão demasiadamente simplista e mais tem levado a uma divergência crescente do que a uma convergência. Neste artigo, ao lado dessa variação, descrevo suas manifestações e suas causas.

As principais razões da importância crescente da competitividade internacional são tecnológicas. O ritmo acelerado da inovação - com a conseqüente promessa de um vasto aumento da produtividade - torna mais dispendioso isolar as economias do comércio e do investimento internacionais. Como as novas tecnologias beneficiam todas as atividades, comercializadas e não comercializadas, o acesso rápido a elas, sob a forma de novos produtos, equipamentos e conhecimento, torna-se vital para o bem-estar das nações. $\mathrm{O}$ isolamento dos mercados e tecnologias globais já não é uma opção viável para nenhum país em desenvolvimento. Além disso, há um encurtamento da "distância econômica" - conseqüência da mudança tecnológica nas comunicações e nos transportes que reduz os custos de transação e informação e, com isso, força as economias a se aproximarem. A crescente capacidade empresarial de integrar atividades muito dispersas, que também é conseqüência do encurtamento da distância econômica, permite que as cadeias produtivas se espalhem por distâncias maiores e, desse modo, levem a uma integração maior de atividades, processos ou até funções específicas. 
A interação desses fatores tem causado mudanças significativas na localização da atividade produtiva nos vários países e, portanto, levado a novos padrões de comércio global e vantagens comparativas nacionais. Há um aumento contínuo de atividades e funções que buscam locais mais eficientes em todo o globo, liderado sobretudo pelas empresas multinacionais, mas também, em alguns casos, pelos revendedores varejistas (Dicken, 1998). Assim, as cadeias globais de valor têm-se tornado mais articuladas e recebido uma coordenação rigorosa, em especial nas atividades tecnologicamente sofisticadas. Uma vez que essas atividades sofisticadas são os segmentos de comércio de crescimento mais acelerado, a entrada nas atividades mais dinâmicas, baseadas na tecnologia, implica conectar-se com as cadeias dominadas pelas corporações multinacionais.

A mobilidade crescente dos fatores produtivos, entretanto, não significa que eles se estejam disseminando uniformemente pelos países de custo baixo. Ao contrário, há uma tendência cada vez maior - sobretudo nas atividades de tecnologia intensiva - para que os recursos móveis se concentrem num punhado de locais. Em outras palavras, são poucos os "lugares aderentes" nas "encostas escorregadias" da atividade globalizada. ${ }^{1} \mathrm{E}$, o que é mais importante, essa "aderência" tende a aumentar com o tempo, em decorrência de forças cumulativas como a capacitação (dependente da trajetória), o desenvolvimento institucional e da infra-estrutura, as economias de escala e de aglomeração e as externalidades de rede. Além disso, à medida que os primeiros a se deslocar aumentam suas vantagens de localização e a renda cresce, os atrativos de seus mercados internos aumentam e reforçam sua tendência para os fatores móveis. É por isso que, uma vez iniciado, o processo de divergência industrial aumenta cumulativamente; é claro que, em algum momento, ele pode ser revertido, se os custos aumentarem antes da produtividade ou se houver um congestionamento indevido, mas esse estágio ainda está meio longe de ser atingido no mundo em desenvolvimento.

A globalização da atividade econômica, portanto, não reduz a necessidade de que as economias de baixos salários se tornem competitivas (em termos não salariais), muito pelo contrário. À medida que mais locais com salários baixos competem pelos recursos móveis e que a mudança técnica desgasta a vantagem competitiva da mão-de-obra não

1 Nota da tradução: sticky places in the 'slippery slopes'. 
especializada e barata per se, a qualidade das potencialidades e das instituições locais torna-se o determinante primordial da possibilidade de atrair recursos externos. O mais importante é que as cadeias de valor, globais e emergentes, não são fechadas. Em virtude da especialização crescente, os atores principais de cada cadeia de valor dependem cada vez mais de fornecedores independentes de insumos, serviços e até inovações, inclusive nas indústrias de tecnologia intensiva altamente concentradas. Em conseqüência disso, há um espaço considerável para que as empresas nacionais entrem nas cadeias globais de valor como fornecedores e, em alguns casos, como atores independentes. Pela mesma razão, os fornecedores para clusters locais tornam-se mais importantes como chamarizes para as corporações multinacionais. Assim, há pressões competitivas cada vez maiores no sentido de fomentar aglomerados locais eficientes.

Até aqui, enfatizei os fatores tecnológicos externos e outros no aumento da importância da competitividade internacional para os países em desenvolvimento. Mas as pressões competitivas crescentes são também conseqüência de uma liberalização política deliberada. Ao mesmo tempo, as próprias tendências políticas refletem as realidades tecnológicas - o reconhecimento de que a única maneira de os países pobres se beneficiarem dos novos conhecimentos produtivos, atingirem grandes mercados e participarem da "mudança global" da atividade produtiva é serem mais abertos. A meu ver, não há outra maneira de chegar ao desenvolvimento industrial senão participar da dinâmica da globalização.

Ser "mais aberto", entretanto, não significa confiar inteiramente no livre mercado. O sucesso competitivo, numa economia global norteada pela inovação, requer fortes potencialidades locais, e o desenvolvimento das potencialidades enfrenta numerosas falhas institucionais e de mercado. As forças do livre mercado não conseguem promovê-lo. Não conseguem fazer uma alocação ótima de recursos, facilitar as mudanças estruturais e dinamizar a competitividade em economias com mercados e instituições ausentes ou sumamente deficientes e com problemas maciços de coordenação. Resta um marcante papel estratégico para os governos dotados de iniciativa. Esse papel é ainda mais intenso com a abertura dos mercados e a mobilidade crescente dos fatores produtivos. Mas é muito diferente do papel tradicional assumido pelos governos durante a época da substituição de importações, quando as intervenções políticas não eram guiadas para superar as falhas institucionais e de mercado para construir capacitações internacio- 
nalmente competitivas. Agora, elas têm que abordar especificamente essas falhas e tentar ganhar acesso a mercados e tecnologias globais. Há muitas maneiras de fazê-lo de modo eficiente, como mostra a experiência do Leste Asiático (Lall, 1996, 2001), porém falaremos disso mais adiante.

\section{Mudanças estruturais na economia global}

O rápido progresso tecnológico tem causado mudanças significativas a longo prazo na estrutura da atividade industrial. As atividades com maior "intensidade tecnológica" - as que têm gastos superiores à média com a P\&D - tendem a crescer mais depressa do que outras. Embora toda atividade se sirva das novas tecnologias, as diferenças no potencial inovador, na velocidade de aplicação das novas inovações e os diferentes índices de expansão da demanda afetam as taxas de crescimento relativo.(V)C relativas de crescimento Os dados da Tabela 1, extraídos da Fundação Nacional de Ciências (NSF, 1999), mostram que, no mundo inteiro, as atividades de "alta tecnologia" estão-se expandindo muito mais depressa na produção e no comércio do que noutras atividades manufatureiras. Observe-se também que o comércio tem crescido com muito mais rapidez que a produção, o que aponta para a globalização de todas as economias. Os 68 países da amostra da NSF respondem, em conjunto, por mais de $95 \%$ da produção industrial mundial.

As atividades industriais de tecnologia intensiva não apenas lideram em termos de dinamismo, como, em geral, também oferecem um potencial maior de aprendizagem e um maior transbordamento (spillover) de benefícios para outras atividades. Isso tem implicações importantes para os países em desenvolvimento. Primeiro vem o argumento da "posição no mercado". O país que quiser situar sua produção e suas exportações nos mercados que crescem mais depressa terá que passar para atividades com uso intensivo da tecnologia e atualizar sua estrutura tecnológica. Segundo, os países que quiserem aprofundar o desenvolvimento tecnológico e lucrar com os efeitos de transbordamento da aprendizagem em setores tecnologicamente de ponta também terão que se concentrar nas atividades intensivas em tecnologia. Terceiro, os que quiserem participar dos segmentos mais dinâmicos do comércio mundial os sistemas internacionais de produção das companhias transnacionais - terão que desenvolver suas capacitações para atividades intensivas em tecnologia. Poderão ingressar no estágio de montagem, porém, mais tarde, precisarão aprimorar sua posição dentro do sistema, passando para 
Tabela 1: Taxas de crescimento da indústria de alta tecnologia e outras, 1985-1997 (percentagens)

\begin{tabular}{lcccc}
\hline & Produção total & $\begin{array}{c}\text { Todas as } \\
\text { exportações }\end{array}$ & $\begin{array}{c}\text { Produção de } \\
\text { alta tecn. }\end{array}$ & $\begin{array}{c}\text { Exportações } \\
\text { de alta tecn. }\end{array}$ \\
\hline 68 países & 7,30 & 5,90 & 10,80 & 12,70 \\
China & 11,70 & 20,50 & 14,90 & 30,20 \\
Coréia & 10,20 & 10,60 & 15,40 & 18,70 \\
Cingapura & 8,00 & 15,00 & 13,10 & 21,70 \\
Taiwan & 4,70 & 12,00 & 11,60 & 18,90 \\
Hong Kong & $-0,20$ & 13,50 & 3,50 & 18,10 \\
& & & & 10,10 \\
EUA & 2,90 & 8,80 & 4,70 & 5.80 \\
Alemanha & 2,20 & 4,10 & 3,80 & 8,00 \\
Reino Unido & 1,70 & 6,30 & 3,30 & 4.40 \\
Japão & 1,70 & 2,40 & 5,20 & 10,80 \\
França & 1,20 & 5,80 & 3,60 & \\
\hline Fonte: NSF (1999). & & & & \\
\hline
\end{tabular}

as atividades de fabricação, concepção de projetos, desenvolvimento e serviços regionais.

Agora, consideremos os padrões tecnológicos detalhados das exportações, divididas entre produtos primários e manufaturados, subdividindo-se estes últimos em quatro categorias, a saber: produtos baseados em recursos naturais [RN]; de baixa tecnologia [BT] (como produtos têxteis, artigos de vestuário, calçados, produtos com engenharia simples); de média tecnologia [MT] (máquinas industriais, automóveis, produtos químicos etc.); e de alta tecnologia [AT] (onde a ICT aparece como uma subcategoria). O grupo de tecnologia média é o maior - o coração da indústria pesada -, mas o de alta tecnologia, com apenas 18 produtos no nível SITC de três dígitos, vem liderando o comércio mundial e, dentro de pouco tempo, poderá ser a maior categoria isolada. 
Tabela 2: Estrutura das exportações mundiais, 1985-2000 (em milhões de dólares e percentagens)

\begin{tabular}{lrrrrc}
\hline & & \multicolumn{5}{c}{ Taxa } \\
Pnual de & Distrib. & Distrib. \\
Produtos & $\mathbf{1 9 8 5}$ & $\mathbf{2 0 0 0}$ & cresc. & $\mathbf{1 9 8 5}$ & $\mathbf{2 0 0 0}$ \\
\hline Todos os setores & 1.703 .582 .494 & $5,534,008,649$ & $8.17 \%$ & $100 \%$ & $100 \%$ \\
Produtos Primários & 394.190 .554 & $684,751,141$ & $3.75 \%$ & $23.1 \%$ & $12.4 \%$ \\
Produtos Manufaturados & 1.252 .573 .675 & 4.620 .266 .770 & $9,09 \%$ & $73,5 \%$ & $83,5 \%$ \\
\hline Baseados em recursos naturais & 330.863 .869 & 863.503 .545 & $6,60 \%$ & $19,4 \%$ & $15,6 \%$ \\
De Baixa Tecnologia & 241.796 .065 & $862,998.972$ & $8,85 \%$ & $14,2 \%$ & $15,6 \%$ \\
De Média Tecnologia & 485.784 .011 & 1.639 .871 .870 & $8,45 \%$ & $28,5 \%$ & $29,6 \%$ \\
De Alta Tecnologia & 198.029 .682 & 1.269 .587 .194 & $13,19 \%$ & $11,6 \%$ & $22,9 \%$ \\
$\quad$ (dentre eles, ICT) & 90.151 .843 & 773.119 .244 & $15,40 \%$ & $5,3 \%$ & $14,0 \%$ \\
\hline
\end{tabular}

Fonte: Cálculos do UNCTAD, baseados no banco de dados Comtrade da ONU, usando a classificação elaborada por Lall (2001).

A Tabela 2 mostra os índices de crescimento do período 1985-2000. Os produtos primários foram os de crescimento mais lento e cortaram quase pela metade sua parcela do total de exportações. Em seguida vieram os produtos manufaturados baseados em recursos naturais. Os produtos de tecnologia baixa e média cresceram mais ou menos no mesmo ritmo e ambos aumentaram ligeiramente sua parcela do mercado (num cálculo mais detalhado, que não é exibido aqui, os produtos de média tecnologia cresceram mais depressa que os de baixa tecnologia depois de 1995). O grupo de crescimento mais rápido foi o dos produtos de alta tecnologia. No início do período, em 1985, os 18 produtos de alta tecnologia abrangiam cerca de $10 \%$ do total do comércio mundial; em 1998 , respondiam por quase $1 / 4$. No ritmo atual, esse pequeno número de produtos (no nível de 3 dígitos do SITC, rev. 2 - a classificação aqui empregada -, há 45 produtos primários, 65 baseados em recursos naturais, 44 de baixa tecnologia e 58 de média tecnologia) logo responderá pela maior parte das exportações. Dentre os 20 produtos que cresceram mais depressa no comércio mundial (com valor de exportação igual ou superior a 5 bilhões de dólares) no período de 1990-2000, os cinco líderes foram todos de alta tecnologia. Deles, quatro são produtos eletroeletrônicos e um é farmacêutico. 
Em termos de fração do mercado, os produtos primários vêm perdendo terreno sistematicamente desde 1976. Dentre os produtos manufaturados, os baseados em recursos naturais perderam terreno a partir do início dos anos oitenta, os de baixa tecnologia, desde 1993, e os de média tecnologia, desde 1998 (Figura 1). O único grupo a aumentar sistematicamente sua fração do mercado foi o dos produtos de alta tecnologia. Embora esses dados possam não captar as tendências reais a longo prazo, eles sugerem que a conclusão anteriormente extraída sobre o dinamismo dos produtos de tecnologia intensiva é bem fundada.

Figura 1: Parcelas dos produtos manufaturados nas exportações mundiais, conforme o nível de tecnologia (\%)

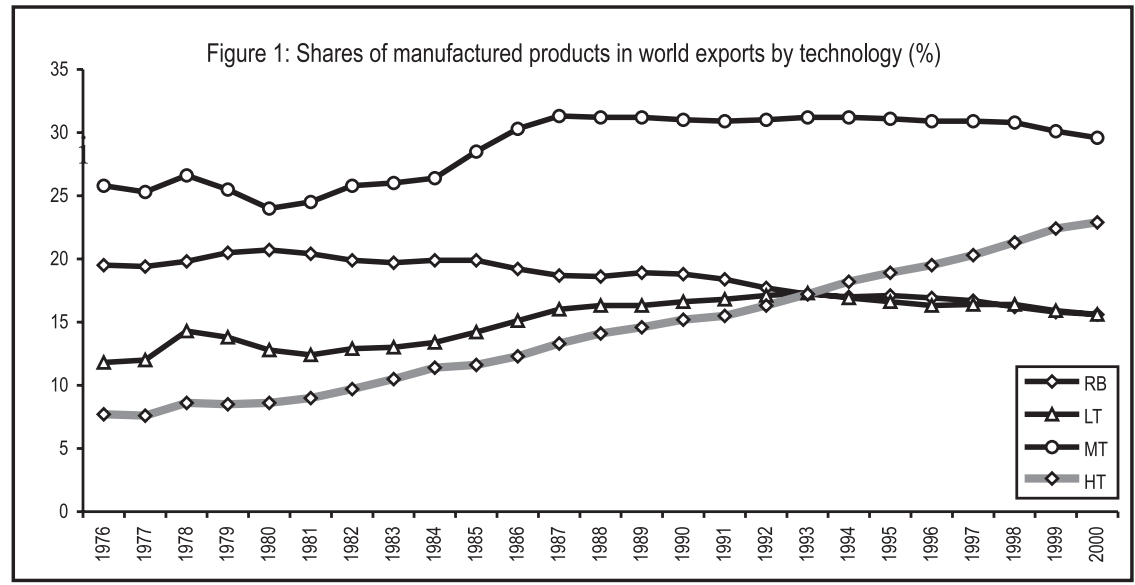

\section{A competitividade nos países em desenvolvimento}

Os países em desenvolvimento são um grupo que vem-se saindo bastante bem nesse quadro dinâmico das exportações. Para começar, o total de suas exportações de produtos manufaturados tem crescido mais depressa que o dos países desenvolvidos. Isso é esperável, uma vez que eles partiram de uma base inferior. Entretanto, os padrões tecnológicos de seu crescimento são interessantes e um tanto inesperados. Os países em desenvolvimento cresceram mais devagar do que os desenvolvidos nos produtos primários e nos manufaturados com base em recursos naturais (Figura 2), presumivelmente em virtude da aplicação mais rápida da nova tecnologia ou por causa das barreiras e subsídios comerciais do 
mundo industrializado. Nos outros produtos manufaturados, sua vantagem em relação aos países industrializados aumentou conforme os níveis tecnológicos. À primeira vista, esse é um resultado contrário à intuição: a teoria nos levaria a esperar que os países em desenvolvimento crescessem mais depressa que os países desenvolvidos nos produtos de baixa tecnologia, menos nos de média tecnologia e menos ainda nos de alta tecnologia. Os dados mostram exatamente o inverso. Além disso, não são apenas as taxas de crescimento que exibem essa tendência (causada, digamos, pela pequena base de produtos de alta tecnologia); os valores implicados também são enormes. As exportações de alta tecnologia são hoje o maior componente isolado das exportações de produtos manufaturados dos países em desenvolvimento. Em 2000, com um valor de 445 bilhões de dólares, elas superaram em US\$ 60 bilhões as exportações primárias dos países em desenvolvimento, em US\$ 210 bilhões as exportações de manufaturados baseados em recursos naturais, em US\$ 39 bilhões as de produtos de baixa tecnologia e em US\$ 140 bilhões as de produtos de média tecnologia.

Figura 2: Taxas de aumento anual das exportações dos países desenvolvidos e em desenvolvimento, 1985-2000 (\%)

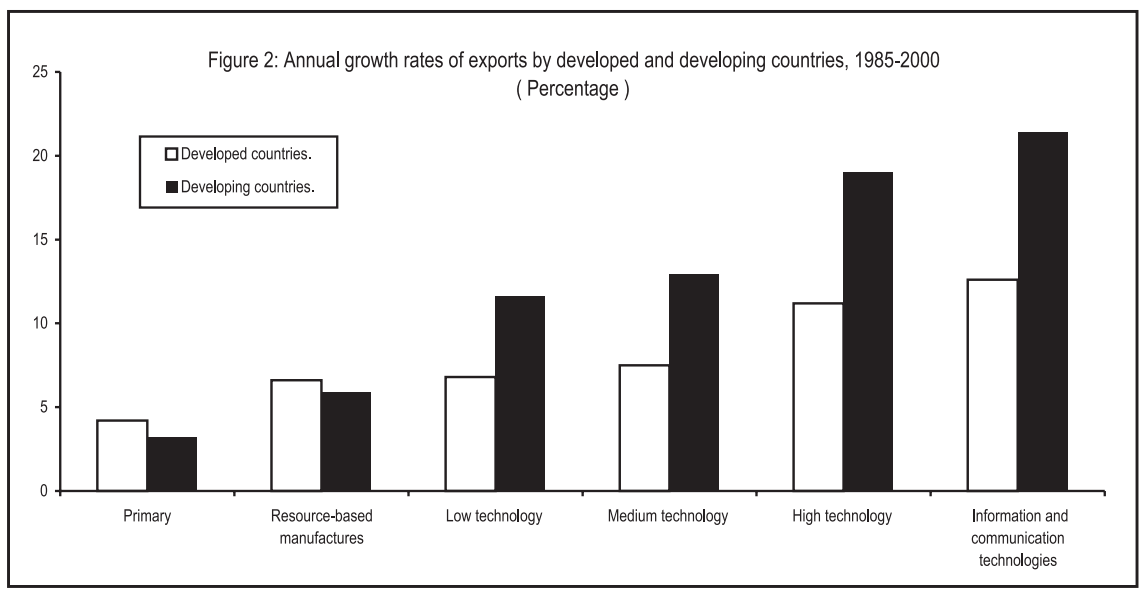


Esse padrão sugere que os países em desenvolvimento vêm-se saindo muito bem com a globalização, aumentando sua competitividade geral e também passando rapidamente para as exportações dinâmicas, baseadas na tecnologia. Infelizmente, essa é uma verdade apenas parcial. O dinamismo e o sucesso nas exportações de tecnologia intensiva são $a l$ tamente concentrados, tanto por região quanto por país. Além disso, a profundidade e o "enraizamento" locais das atividades de alta tecnologia variam enormemente entre os exportadores de sucesso; os que têm raízes pouco profundas poderão ter dificuldade de sustentar seu recente aumento da produção competitiva. Consideremos, em primeiro lugar, a concentração no nível regional (Figura 3).

Figura 3: Parcelas regionais das exportações de produtos manufaturados dos países em desenvolvimento, 1998

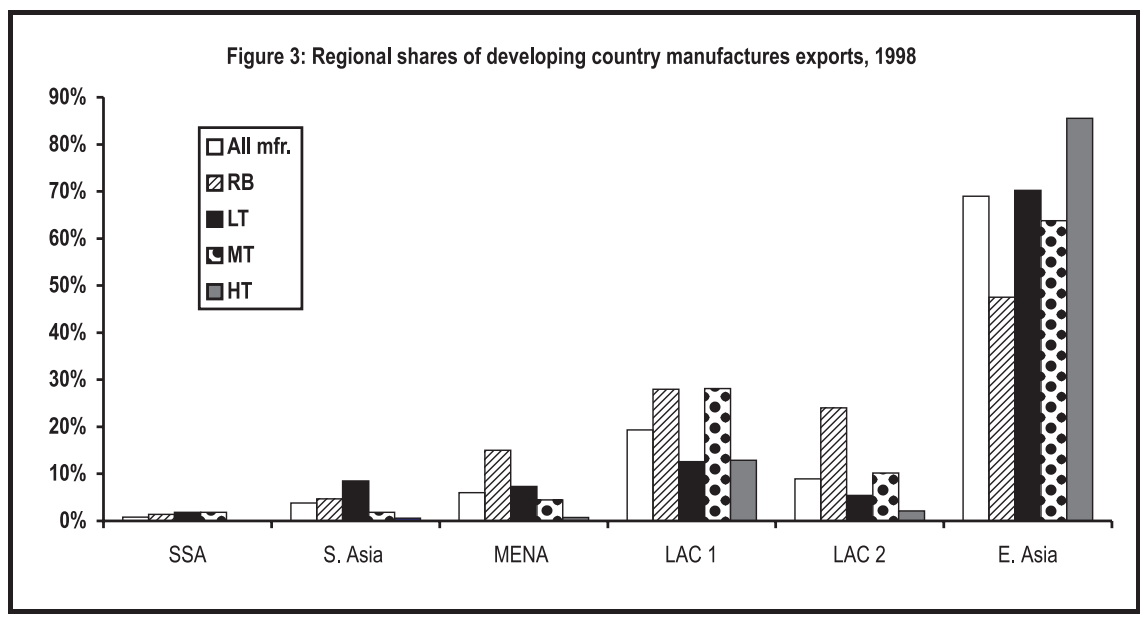

O Leste Asiático responde agora por cerca de $75 \%$ do total de exportações de produtos manufaturados e cerca de $90 \%$ das exportações de produtos de alta tecnologia. E mais, seu predomínio aumentou em praticamente todas as categorias desde 1985. No extremo oposto, a África sub-saariana (mesmo incluindo a África do Sul, que responde por mais de $40 \%$ de sua produção industrial e mais ainda de suas exportações de manufaturados) é fraquíssima e vem perdendo suas pequenas parcelas ao longo do tempo. Sua quase completa falta de exportações de produtos de alta tecnologia é um sinal de sua marginalização na dinâmica do comércio mundial. A Ásia Meridional se sai bem nos produtos de baixa tecnologia, basicamente artigos de vestuário, mas tem um desempenho extremamente fraco nas outras 
categorias (note-se que esses dados excluem as exportações indianas de programas de computador, que não são captadas por eles).

A América Latina e o Caribe (ALC) aparecem duas vezes: ALC 1 inclui o México, enquanto ALC 2 o exclui. A razão dessa distinção é o efeito maciço do NAFTA sobre as exportações, já que ele deu ao México um acesso privilegiado aos mercados norte-americano e canadense. Sem essa grande "distorção" comercial, a ALC 2 tem um desempenho bem fraco em termos dos produtos dinâmicos do comércio mundial - surpreendente, em vista do tamanho e da tradição industrial do Brasil, da Argentina e do Chile. No México, em contraste, a atividade de montagem das maquiladoras e noutras áreas, voltada para o mercado norte-americano, tem impulsionado as exportações de produtos de média tecnologia, como os automóveis, e de alta tecnologia, como os produtos eletrônicos.

Agora, consideremos a concentração no nível dos países. A Figura 4 mostra os dez maiores exportadores de manufaturados do mundo em desenvolvimento nos anos de 1985, 1998 e 2000. Essas nações respondem agora por mais de $80 \%$ das exportações dos países em desenvolvimento e sua dominação tem aumentado no correr do tempo. Os níveis de concentração sobem conforme os níveis de tecnologia, atingindo seu pico nos produtos de tecnologia intensiva. Portanto, a liberalização e a globalização estão levando a um aumento, e não a uma redução, das barreiras ao ingresso de novos competidores nas atividades avançadas.

Figura 4: Exportações de produtos manufaturados dos dez principais países em desenvolvimento, 1985, 1998 e 2000 (em milhões de dólares)

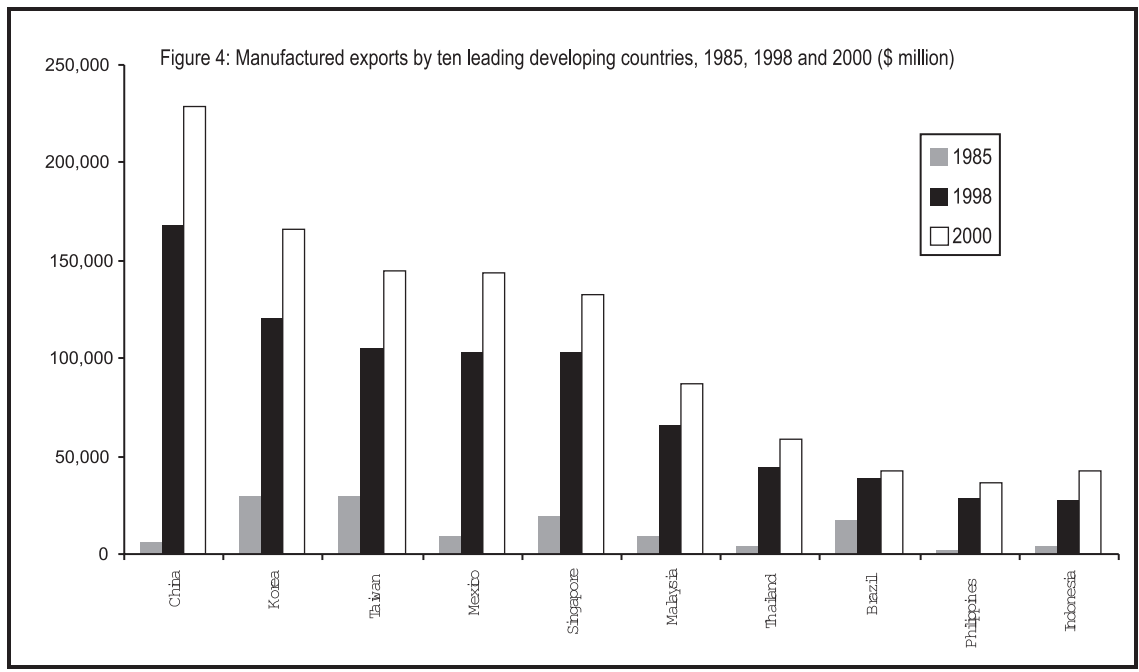




\section{Índice de "desempenho industrial competitivo" (DIC) da Unido}

Agora, examinemos o desempenho industrial competitivo no nível regional. ${ }^{1}$ Esta seção baseia-se no novo índice DIC da UNIDO, que se concentra na capacidade nacional de produzir competitivamente artigos manufaturados. Uma vez que nenhum indicador isolado é capaz de captar todas as dimensões relevantes da produção competitiva, o índice de desempenho é construído a partir de quatro componentes sobre os quais se dispõe de dados:

- VAM: O indicador básico do desempenho industrial é o valor (em dólares) do valor agregado de manufaturados (VAM) per capita em cada país. O VAM é deflacionado pela população para levar em conta o tamanho do país.

- Exportações de produtos manufaturados: As exportações de manufaturados per capita levam em conta a competitividade da atividade industrial. Se toda a produção industrial ficasse plena e igualmente exposta à concorrência internacional, o VAM captaria automaticamente o elemento competitivo. Mas isso não acontece. A política comercial e outras limitam a exposição da indústria nacional à competição internacional. O mesmo é feito por certas barreiras "naturais" ao comércio, como o custo elevado do transporte, o acesso aos recursos naturais, as diferenças de gosto, as variações jurídicas e institucionais e as defasagens na informação. A produção para o mercado interno (particularmente nos países com grandes mercados, ou com uma política vigorosa de substituição de importações) enfrenta uma concorrência menos intensa do que a voltada para a exportação. A medida referente à exportação ajuda a superar parte dessa lacuna, indicando quão competitiva é a atividade industrial num conjunto de mercados. Essa variável também capta outro aspecto importante do desempenho industrial. Ela mostra a capacidade da indústria nacional de se manter atualizada em termos das mudanças técnicas, pelo menos no tocante aos produtos exportados: as exportações podem ser usadas para demonstrar se os produtores estão usando tecnologias competitivas (isto é, modernas). Isso é importante porque as medidas de tecnologia abaixo não captam o aprimoramento tecnológico dentro de grandes grupos de produtos; o indicador das exportações compensa parcialmente essa incapacidade.

${ }^{1}$ Esse índice foi preparado pelo autor para a UNIDO (2002), com a colaboração de Manuel Albaladejo. 
- Estrutura tecnológica do VAM: A fração das atividades de média e alta tecnologia no VAM (MAT) é o terceiro componente do índice DIC. Quanto mais alta a parcela do MAT - quando mais complexa a estrutura industrial em termos tecnológicos -, melhor se considera ser o desempenho industrial competitivo, e não apenas porque o desenvolvimento industrial geralmente acarreta uma melhora em relação às atividades de baixa tecnologia e baseadas em recursos naturais, mas também porque as estruturas intensivas em tecnologia são estruturalmente melhores para o crescimento, o desenvolvimento ou a competitividade. ${ }^{2}$ Em virtude da natureza da aprendizagem, que é lenta, incremental e dependente da trajetória, a mudança estrutural não é automática nem fácil; por isso, as estruturas com atividades mais complexas são consideradas "melhores". Isso constitui uma simplificação, é claro. Muitas indústrias de baixa tecnologia e calcadas em recursos naturais podem ter surtos de crescimento rápido. Algumas atividades isoladas dentro delas podem ter segmentos de alta tecnologia. Mesmo admitindo tudo isso, a medida referente à complexidade tecnológica oferece informações proveitosas sobre a capacidade de sustentação do crescimento nos vários países.

- Estrutura tecnológica das exportações de manufaturados: argumentos semelhantes aos relativos à complexidade tecnológica aplicamse às estruturas de exportação, levando ao componente final do DIC: a parcela dos produtos de média e alta tecnologia (MAT) nos produtos de exportação manufaturados. É útil examinar separadamente as estruturas de exportação e as estruturas de VAM, porque, em algumas situações, as duas diferem significativamente. No mundo em desenvolvimento, por exemplo, as grandes economias de substituição de importações tendem a ter estruturas mais complexas de VAM que de exportação.

Os valores de cada variável foram padronizados na amostra, indo de zero (pior desempenho) a um (melhor desempenho). O índice final é a

\footnotetext{
${ }^{2}$ As estruturas tecnologicamente complexas oferecem um potencial maior de aprendizagem e se prestam melhor ao aumento sustentado da produtividade no correr do tempo (graças ao maior potencial de aplicação de novos conhecimentos científicos). Muitas têm maiores benefícios de transbordamento (spillover), especialmente as que se encontram em atividades do tipo ' $h u b$ ', que disseminam a tecnologia por atividades diferentes. As atividades de alta tecnologia têm melhores perspectivas de crescimento na produção e na comercialização e são as áreas freqüentadas pelos sistemas de produção internacionais dinâmicos.
} 
média dos quatro valores padronizados. Não se atribuiu peso a nenhum dos componentes, já que não há razão a priori para atribuir pesos diferentes. Todavia, os resultados são mostrados passo a passo, para que fique claro o efeito de cada componente na classificação.

$\mathrm{O}$ valor médio do índice DIC de cada região é mostrado na Figura 5 (note-se que, como o DIC não é uma participação relativa, pode elevarse em todas as regiões). Os países industrializados melhoram seu desempenho e, como não é de admirar, conservam uma dianteira significativa em relação ao resto do mundo. No mundo em desenvolvimento, o Leste Asiático, com ou sem a China (L. Asiático 1 e 2, respectivamente), tem, de longe, os países com melhores desempenhos, tanto em termos de seus níveis absolutos do índice quanto em termos de melhoria ao longo do tempo. Com o México, a América Latina mostra uma certa melhora no desempenho, mas permanece quase estagnada sem ele.

Figura 5: Índice DIC da UNIDO, por região

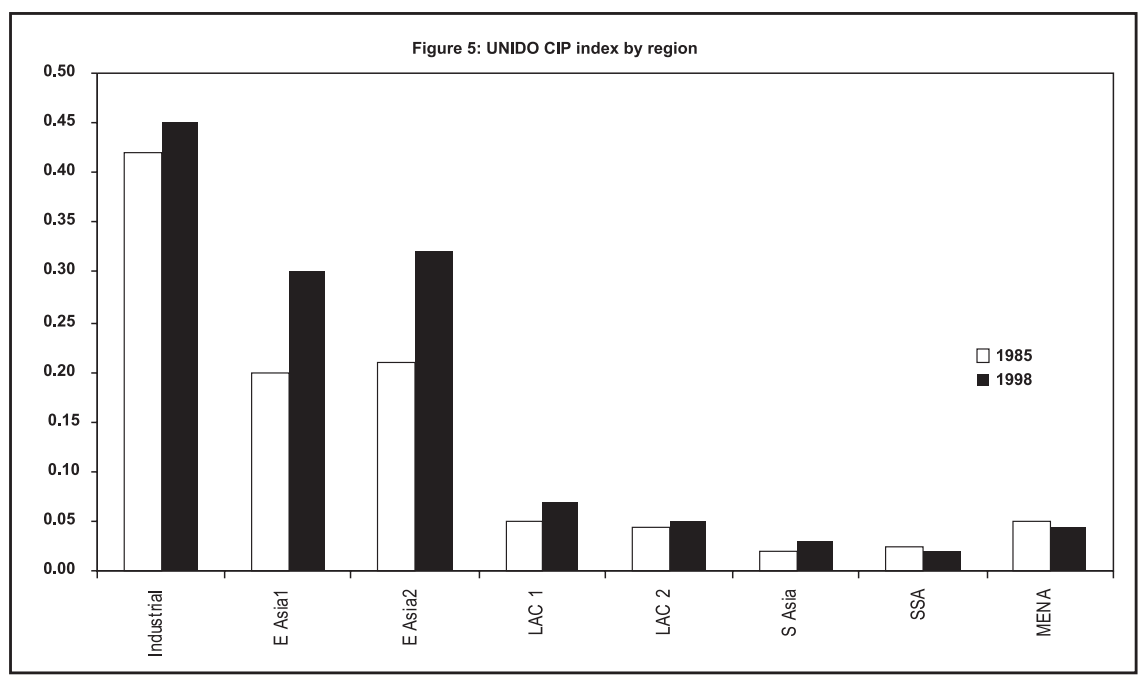

O Brasil sai perdendo nesse índice, ao longo do tempo: em 185, ficou em $27^{\circ}$ lugar entre 80 países e liderou a região da América Latina e Caribe, logo à frente do México, situado em $28^{\circ}$ lugar. Em 1998, havia caído para o $33^{\circ}$, enquanto o México subiu para o $23^{\circ}$. No mundo em desenvolvimento, o Brasil também fica atrás de tigres asiáticos como Cingapura (que é líder mundial), Taiwan, Coréia, Malásia, Filipinas, Hong Kong e Tailândia. 
Observem-se dois aspectos do índice DIC. primeiro, há uma estabilidade considerável nas posições do DIC nos anos de 1985 e 1998. O coeficiente de correlação entre os dois valores do índice nesses anos é 0,94, o que sugere que o desempenho reflete processos lentos e incrementais. Segundo, mesmo assim é possivel haver saltos nas posições. Ao longo do período, 22 países trocaram de posição por dez ou mais colocações. Os países próximos do topo e da base tendem a ser relativamente estáveis, enquanto os da faixa intermediária são mais móveis.

A principal causa dos grandes saltos para cima entre 1985 e 1998 foi a participação crescente em redes globais de produção, que elevou acentuadamente a parcela de produtos complexos nas exportações (e no VAM, num prazo mais longo). Nos 40 países da faixa superior, as melhoras mais notáveis ocorreram na Irlanda, Filipinas, China, Tailândia, Malásia, Costa Rica e Hungria, com o México, a Coréia, Formosa e Cingapura vindo logo atrás.

Todavia, existem modos diferentes de participação nas redes globais. Dois países, a Coréia e Formosa, participaram não por aumentos significativos da presença de corporações multinacionais na atividade de exportação, mas por acordos não eqüitativos como a FEO (fabricação de equipamentos originais), a subcontratação para os compradores e, é claro, a criação de canais diretos de exportação. Isso acarretou um desenvolvimento maciço das potencialidades tecnológicas e outras por parte das empresas locais, sustentado por uma ampla intervenção governamental em todos os mercados, inclusive a promoção seletiva da indústria nascente.

Os outros países bem-sucedidos basearam-se mais intensamente no IED (ver adiante), mas com subestratégias diferentes. Cingapura, por exemplo, apoiou-se maciçamente na política industrial de visar e atrair as empresas multinacionais de alta tecnologia, criar qualificações e instituições locais e desenvolver a infra-estrutura especializada. Como resultado, moveu-se para o topo da escada tecnológica e agora vem tomando como alvo a P\&D e as atividades de serviços de alto valor das corporações multinacionais.

A Malásia, a Tailândia, a Indonésia e as Filipinas tomaram menos medidas proativas quanto ao IED e ao desenvolvimento de qualificações e instituições locais (embora tenham usado de outras maneiras a política industrial). Como resultado, estão muito abaixo de Cingapura no espectro tecnológico. Todavia, têm hoje uma aguda consciência da 
necessidade de aprimorar as potencialidades e as redes de fornecedores para preservar a vantagem competitiva, à medida que os salários sobem e surgem competidores mais baratos. Como veremos mais adiante, suas potencialidades ficaram bem atrás das da Coréia e Formosa.

A China é um caso à parte, em virtude de suas dimensões, sua tradição industrial, seu contexto político e suas ligações étnicas. Ela pode combinar componentes de todas as outras estratégias bem-sucedidas com seu próprio conjunto de políticas, a fim de reestruturar e desenvolver as empresas nacionais, grandes e pequenas (Nolan, 2001). Embora sua base de qualificações e esforço tecnológico seja pequena, segundo os padrões internacionais, ela teve base suficiente para causar um aumento espetacular das exportações em todo o espectro tecnológico. E vem construindo rapidamente sua base de capacitação, ao mesmo tempo que introduz sua capacidade humana "excedente" em atividades industriais modernas, o que sugere que esse impulso ainda terá um caminho considerável pela frente.

Nenhum desses países dinâmicos conforma-se ao modelo "ideal" propagado pelo Consenso de Washington. Os que aprimoraram mais depressa suas capacitações transgrediram praticamente todas as regras do manual neoclássico, usando a intervenção seletiva na maioria dos mercados, a fim de orientar a alocação de recursos, desenvolver as potencialidades nacionais e dinamizar a vantagem comparativa. São suas estratégias que compõem o molde em que outros países subdesenvolvidos terão de basear suas estratégias industriais para desenvolver a competitividade no mundo de hoje.

\section{Principais exportadores conforme as categorias tecnológicas}

Os quatro gráficos a seguir mostram alguns dados que talvez sejam de interesse: os países de melhor desempenho, no mundo desenvolvido, em cada categoria tecnológica de produtos manufaturados exportados durante 1985-2000. O aspecto mais notável dos gráficos é a explosão de exportações da China em todas as categorias, o que desmente a impressão inicial de que ela é sobretudo um exportador de produtos simples, de mão-de-obra intensiva. Na verdade, suas exportações abrangem todo o espectro da complexidade tecnológica.

O Brasil figura em todos os gráficos, mas não tem um desempenho expressivo. Seu melhor resultado é nos produtos baseados em recursos natu- 
Figura 6: Principais exportadores de manufaturados baseados em recursos naturais (em milhões de dólares)

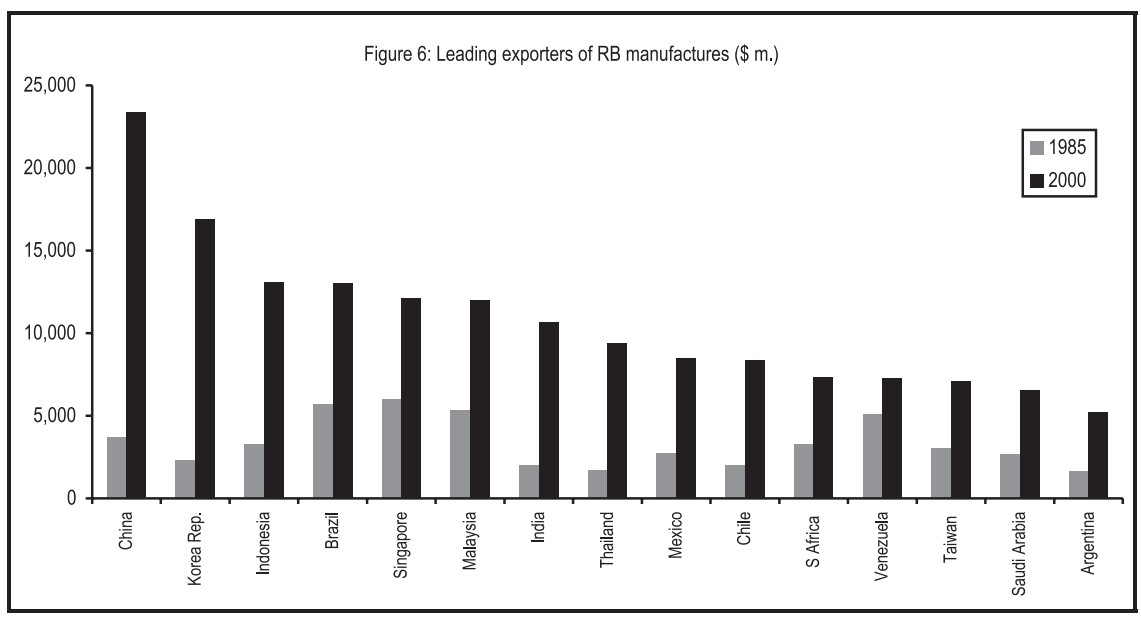

Figura 7: Principais exportadores de produtos manufaturados de baixa tecnologia (em milhões de dólares)

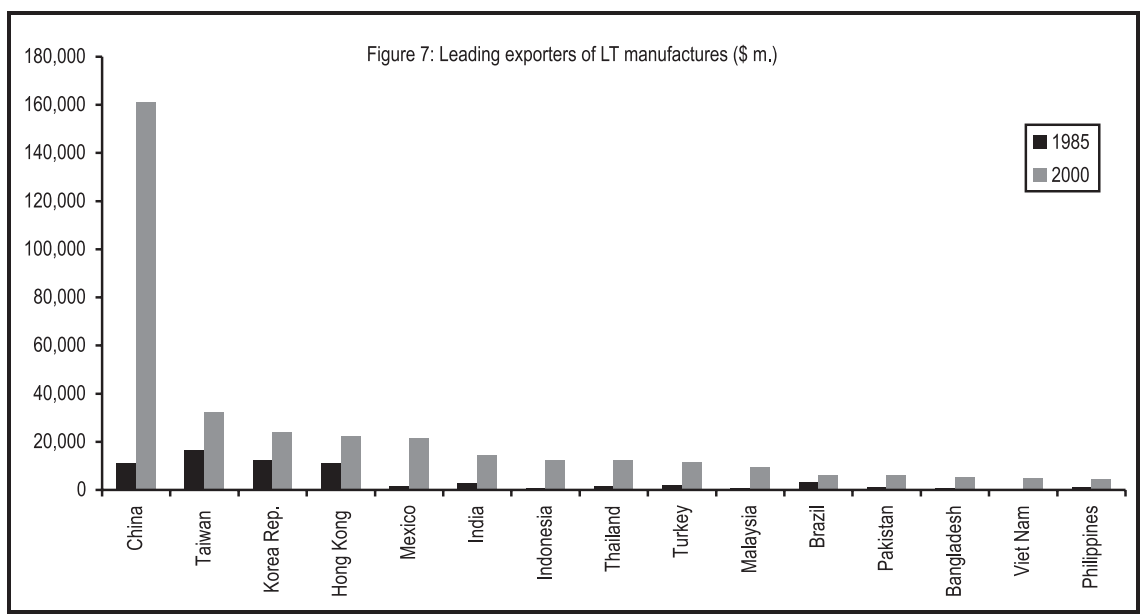


Figura 8: Principais exportadores de produtos manufaturados de média tecnologia (em milhões de dólares)

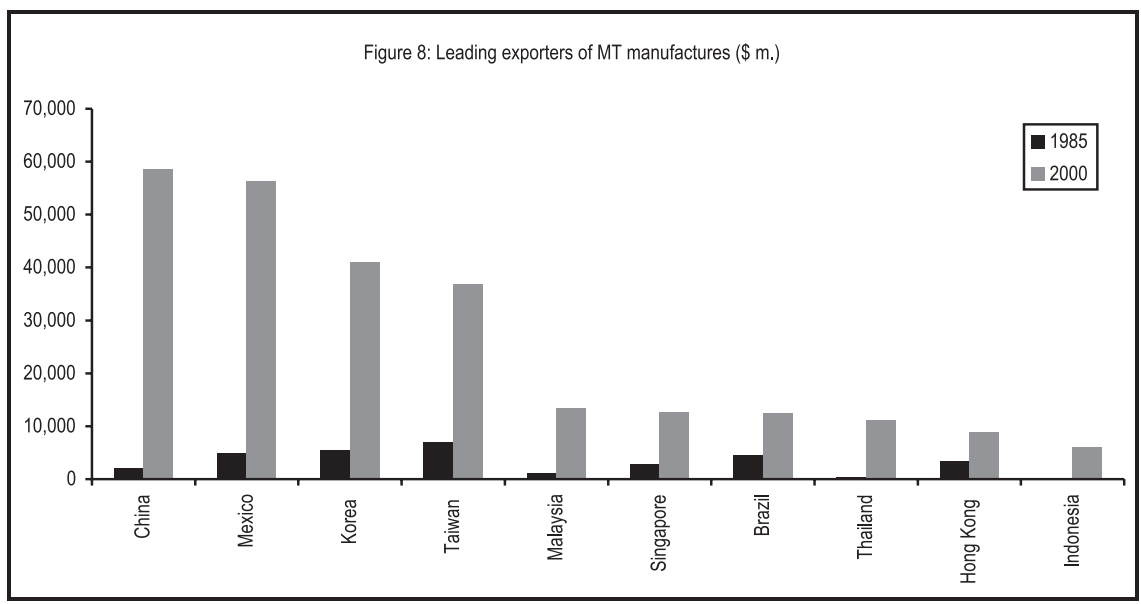

Figura 9: Principais exportadores de produtos manufaturados de alta tecnologia (em milhões de dólares)

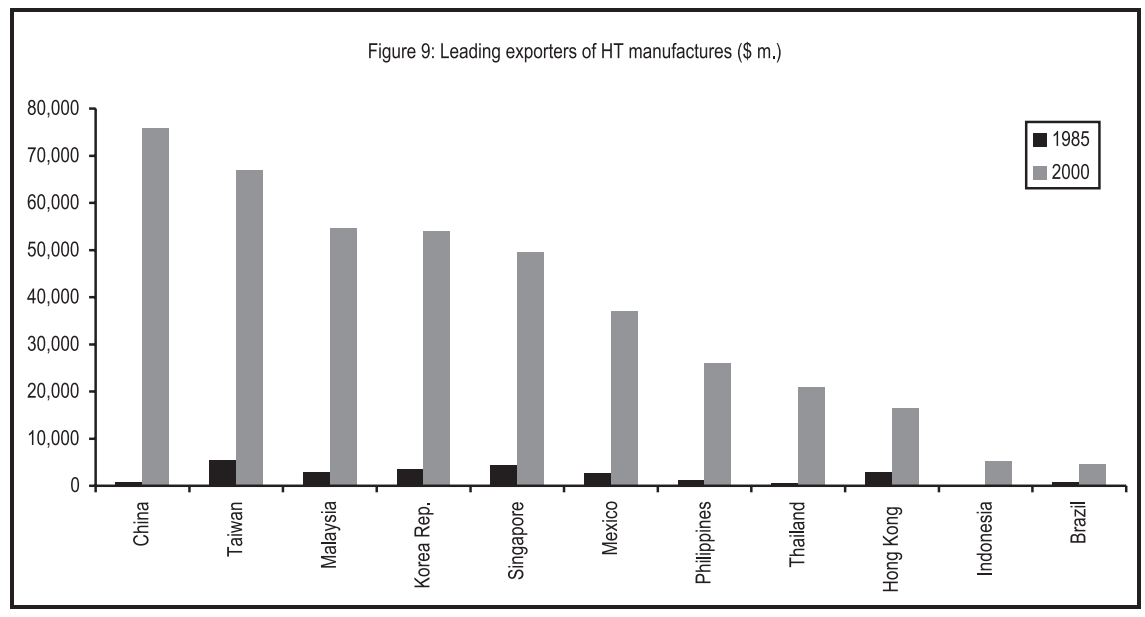


rais e nos de média tecnologia, porém, nestes últimos (área em que o país é um ator importante, graças a sua indústria automobilística), seu desempenho empalidece em comparação com o México e os líderes do Leste Asiático. Nos produtos de alta tecnologia, seu desempenho é realmente muito decepcionante (e seria ainda pior, não fossem as exportações de aeronaves da Embraer). Sua especialização em produtos baseados em recursos naturais, apesar de cada vez mais característica da América Latina após a liberalização, não é um bom presságio para o dinamismo competitivo a longo prazo.

\section{Impulsionadores estruturais da competitividade}

Examinemos agora alguns dados sobre os impulsionadores estruturais da competitividade. A título de pontos de referência, no relatório da UNIDO eles foram considerados como sendo: IED, qualificações, P\&D nacionais, sistema de licenciamento e de patentes, e infra-estrutura física. Obviamente, essa não é uma "explicação" completa do desempenho industrial, uma vez que deixa de fora a accountability, as instituições, a governance e outros fatores difíceis de quantificar num grande número de países. Não obstante, ela fornece um quadro plausível dos fatores estruturais que entram no sucesso industrial, e os "impulsionadores" correlacionam-se muito bem com o desempenho tal como medido acima.

O primeiro impulsionador é o investimento externo direto (IED). A Figura 10 o apresenta como uma percentagem do investimento interno

Figura 10: Investimento externo direto como $\%$ do investimento interno bruto, 1997

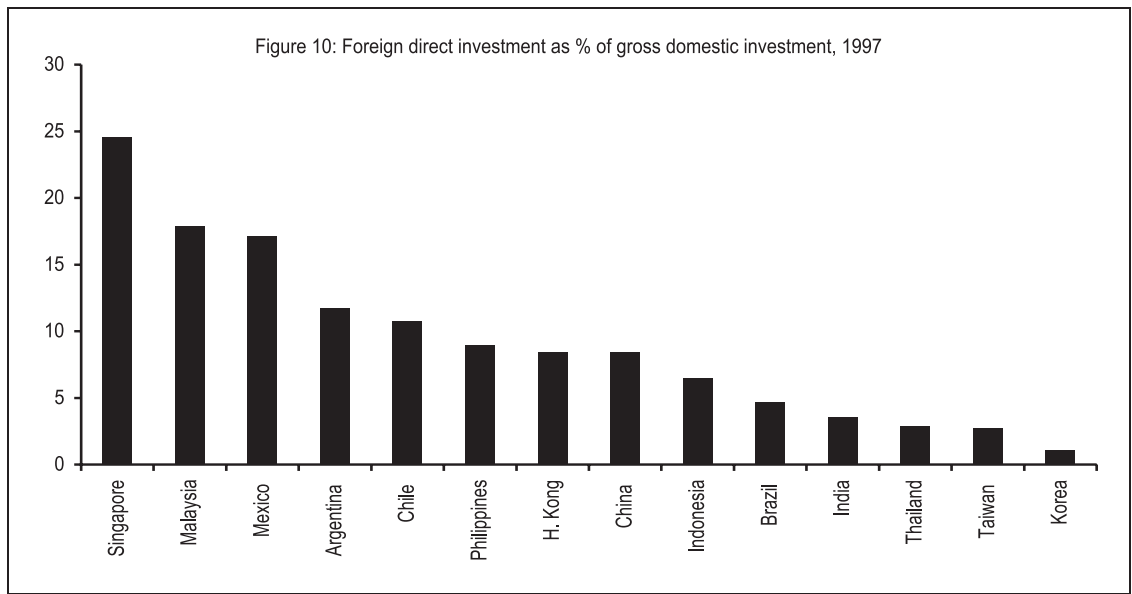


bruto em 1997 (porém o quadro é mais ou menos o mesmo a prazo mais longo). A confiança no IED varia marcantemente entre as novas economias industrializadas, como foi observado, havendo uma dependência muito alta na Malásia e Cingapura, no Leste Asiático, e na maior parte da América Latina. Há uma baixa dependência dele na Coréia do Sul e em Taipei, na China, que restringiram deliberadamente a entrada de IED a fim de aprimorar sua capacidade de inovação. Isso sugere um trade-off entre o aprofundamento das potencialidades tecnológicas e a dependência da tecnologia já pronta das corporações transnacionais (CTNs).

Que dizer do papel do IED no desempenho nas exportações? Os dados são escassos, mas a Figura 11 mostra algumas estimativas da parcela recente das corporações multinacionais nas exportações nacionais. A Figura 12 mostra o papel das multinacionais nas atividades locais de pesquisa e desenvolvimento.

Figura 11: Parcela das empresas multinacionais nas exportações mais recentes

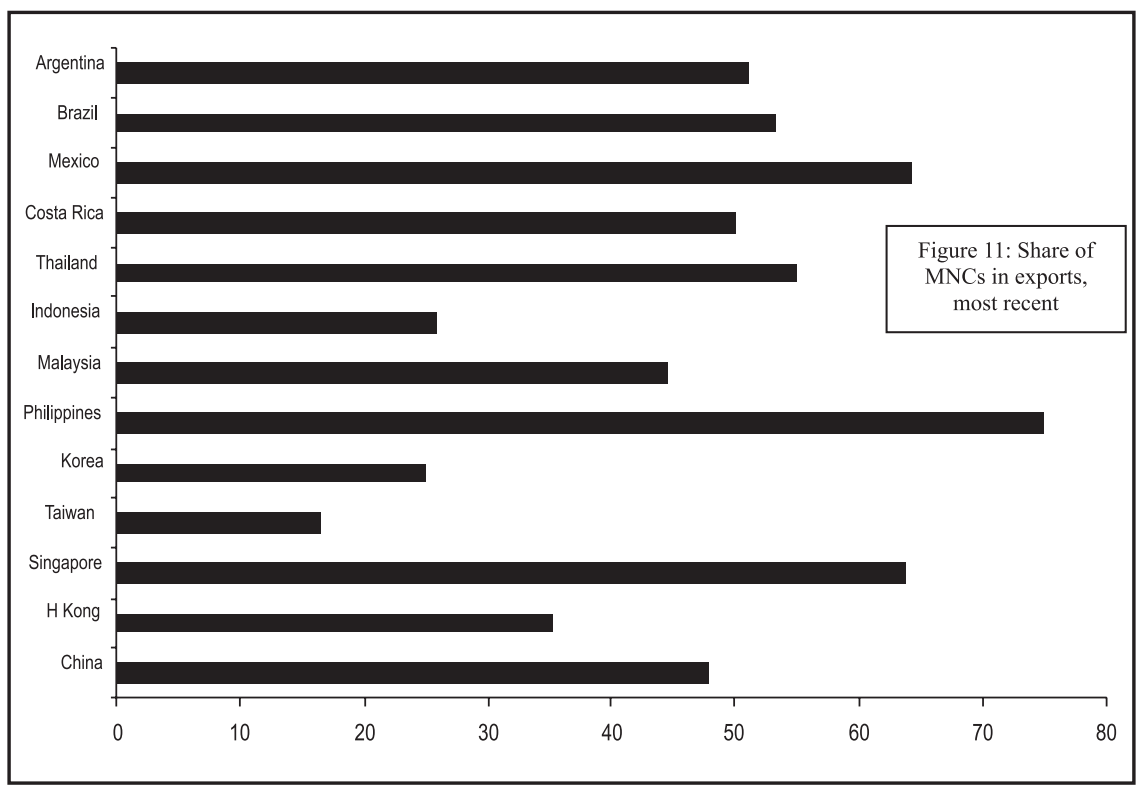


Figura 12: Parcela das filiais estrangeiras na pesquisa e desenvolvimento (c. 1996-1998)

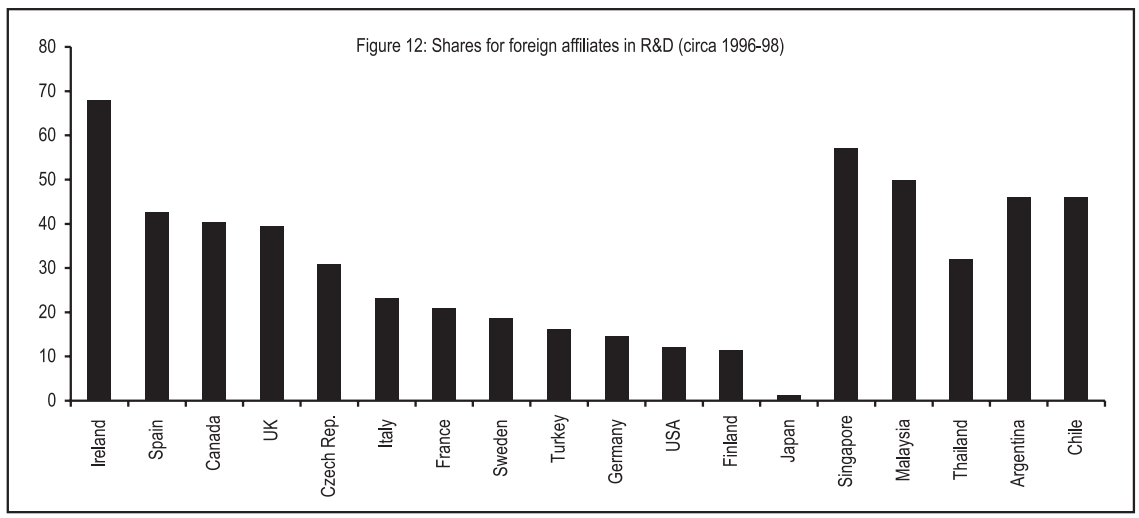

Um fator vital a ser assinalado com respeito à América Latina é que boa parte do IED recente, com a grande exceção do México e da Costa Rica, não foi para a fabricação voltada para as exportações, mas para atividades e serviços baseados em recursos naturais. Isso significa que a região não se integrou em cadeias de valor dinâmicas, e seu atraso na eletrônica é particularmente notável. Como as firmas locais não conseguem empreender um esforço independente para se tornarem competitivas nas atividades de alta tecnologia, isso deu à região uma estrutura de exportação de baixo crescimento, com menores benefícios de "transbordamento" (spillovers) e de aprendizagem, comparada ao Leste Asiático. Um grande trampolim para a estratégia futura para lidar com a globalização tem que consistir em destinar o IED voltado para as exportações a atividades intensivas em tecnologia. Contudo, dados os salários relativamente elevados, isso requer um capital humano melhor, para o qual nos voltamos agora.

Consideremos o capital humano. Há grandes disparidades na base de qualificações em que os países têm que competir nos mercados globais baseados na tecnologia. Os números constituem apenas uma indicação grosseira da formação dessas qualificações, já que se referem apenas à matrícula formal em escolas e universidades, ignorando a qualidade e outras diferenças da educação fornecida. Mas esses são os únicos dados comparativos disponíveis e servem para mostrar a forma geral da formação de qualificações. O foco aqui recai nas qualificações 
técnicas de alto nível, tais como medidas pelas matrículas de nível superior em disciplinas técnicas essenciais (ciência pura, matemática e engenharia e informática) como percentagem da população. A análise estatística mostra que essa medida é a melhor variável do capital humano para explicar o dinamismo nas exportações (Figura 13).

Figura 13: Matrícula de nível superior em disciplinas técnicas como \% da população, 1995

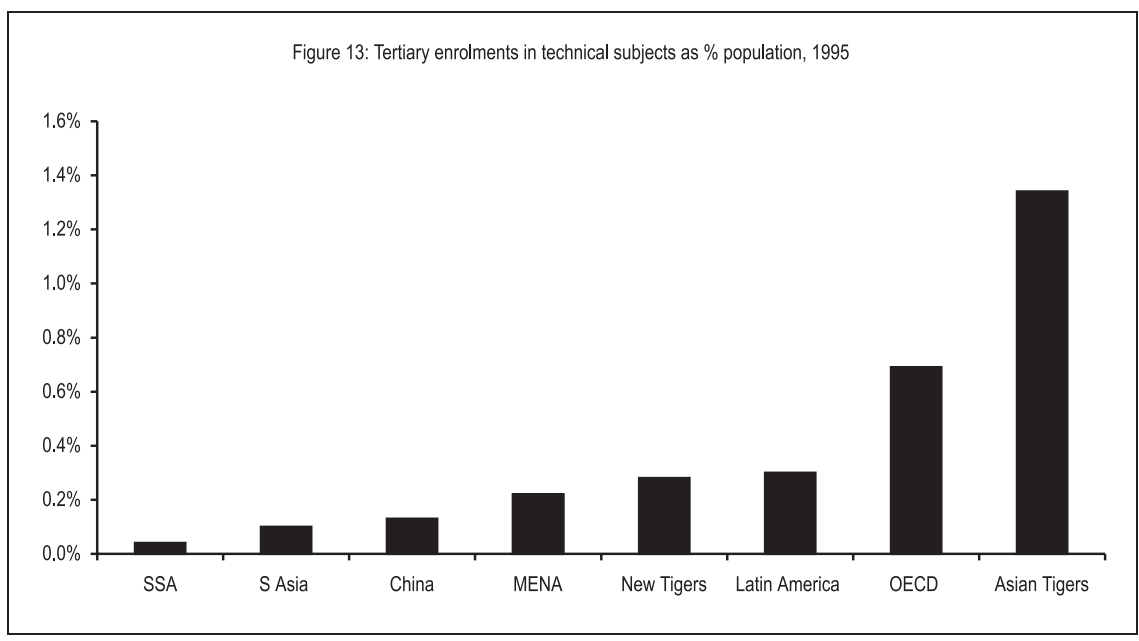

Notas: Tigres Asiáticos = Hong Kong, China, Cingapura, Coréia, Formosa;

Novos Tigres = Malásia, Filipinas, Tailândia, Indonésia;

OCDE = Organização de Cooperação e Desenvolvimento Econômico (países industrializados); AfSS = África subsaariana.

O dado mais impressionante nesse gráfico é a enorme liderança assumida pelos quatro Tigres Asiáticos maduros (Hong Kong, Coréia do Sul, Formosa e Cingapura), ultrapassando até mesmo os países industrializados. Eles estão à frente dos "Novos Tigres" (Malásia, Filipinas, Tailândia e Indonésia) e das principais potências industriais da América Latina (Argentina, Brasil e México) com margem ainda maior. A África sub-saariana é a mais atrasada na criação de qualificações, o que reforça o quadro de marginalização indicado pelos dados já mencionados sobre as exportações.

Examinemos agora os gastos com pesquisa e desenvolvimento, não tomando o total do valor gasto em P\&D (que pode ser enganoso na análise da atividade industrial tecnológica), mas o que é financiado por empresas produtivas (Figuras 14 e 15). Os líderes mundiais nessa ati- 
Figura 14: P\&D por empresas produtivas

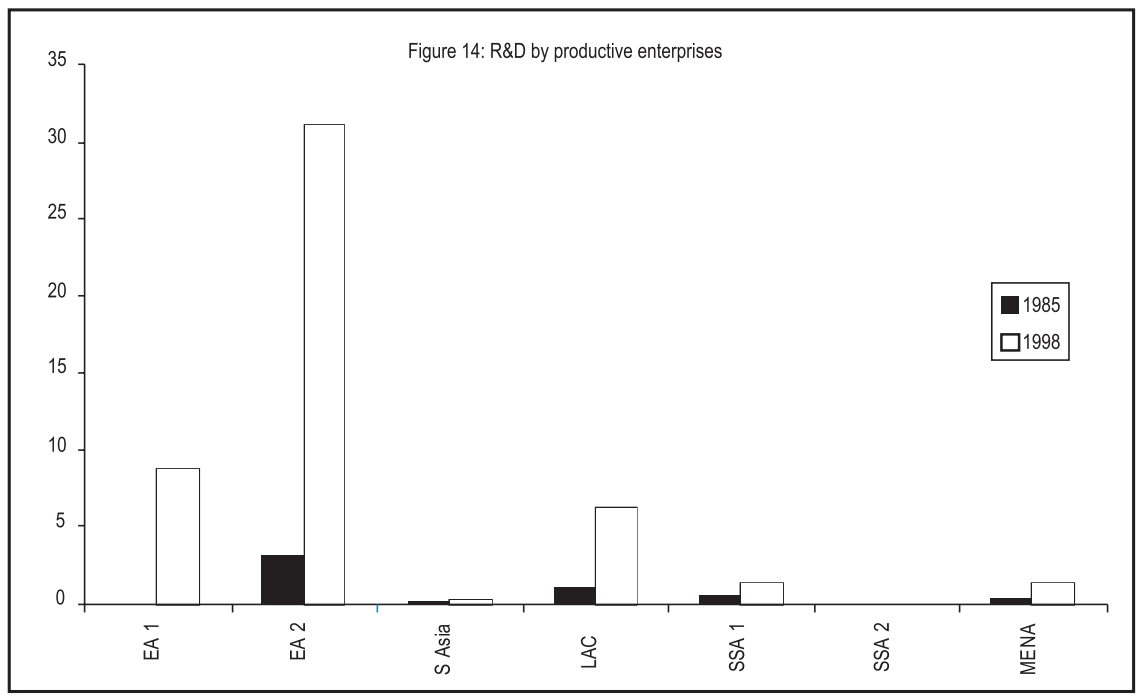

Figura 15: P\&D por empresas produtivas como \% do PIB, dados recentes

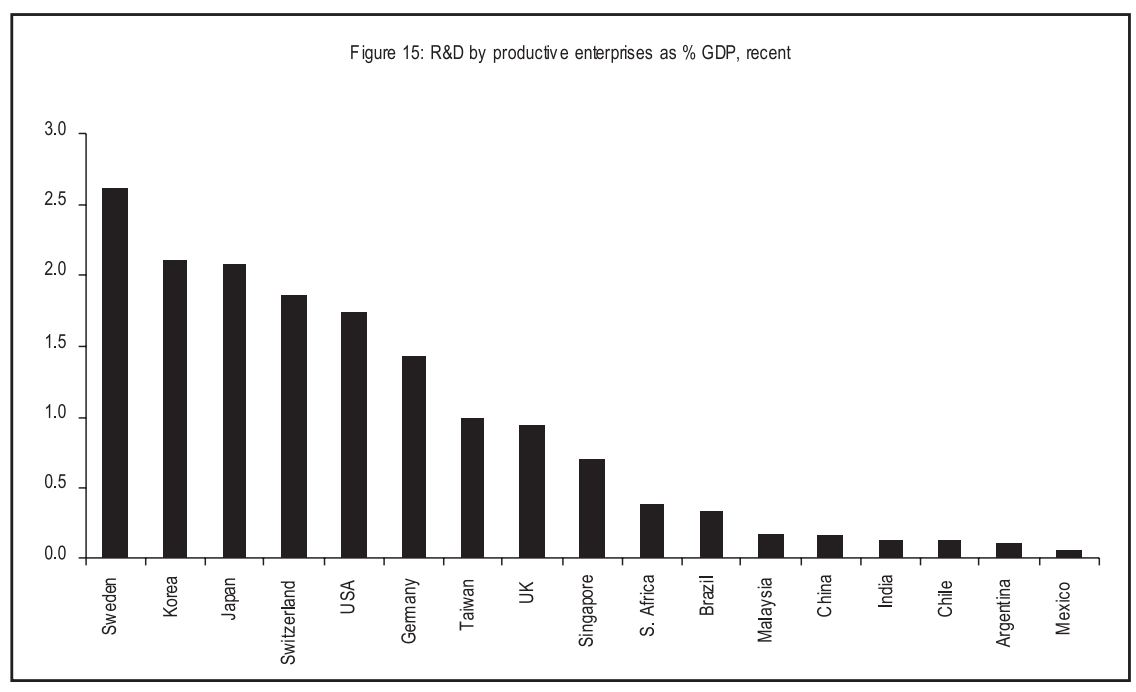


vidade, como percentagem do PIB, são o Japão e a Coréia do Sul. No entanto, há apenas vinte anos, a Coréia do Sul era um típico país em desenvolvimento, com $0,2 \%$ do PIB sendo destinados à pesquisa e desenvolvimento, sendo que $80 \%$ dessa parcela vinham do setor público. Atualmente, o gasto total com P\&D está acima de 3\% do PIB e mais de $80 \%$ dele vêm do setor privado. Cingapura e Taipei, na China, aparecem em seguida no mundo em desenvolvimento, com os outros países bem atrás.

Mais uma vez, esses dados mostram a resposta sumamente diferenciada à globalização e à mudança técnica entre os países em desenvolvimento. Os três Tigres Asiáticos maduros lideram o grupo restante, vindo bem atrás os outros países em processo de industrialização na América Latina e na Ásia. Embora os Novos Tigres, como Malásia, Filipinas ou Tailândia, tenham um bom desempenho nas exportações intensivas em tecnologia, sua base de capacitação continua fraca e superficial. A discrepância acentuada entre a intensidade tecnológica de suas exportações e suas qualificações e potencialidades tecnológicas nacionais, compostas por atividades de montagem de empresas multinacionais, precisa ser retificada, se tais países quiserem manter seu desempenho anterior. Caso contrário, a mudança tecnológica e a entrada de rivais com bases de qualificação mais sólidas farão com que as futuras atividades dinâmicas se localizem noutros lugares.

A China encontra-se numa situação intermediária, com uma combinação de potencialidades e estratégias de cada um dos três Tigres principais. Seu tamanho e sua capacitação já estabelecida sugerem que ela continuará a alcançar os outros líderes e, possivelmente, fará melhor do que eles.

Os países latino-americanos encontram-se bem abaixo na escala de P\&D, comparados ao Leste Asiático, mas saem-se muito melhor do que outras regiões em desenvolvimento. No plano nacional, o Brasil é o líder da América Latina e aparece em quarto lugar no mundo em desenvolvimento, atrás da Coréia, Formosa e Cingapura.

Não há necessidade de reproduzir os dados sobre os outros impulsionadores (que estão disponíveis no relatório da UNIDO). O quadro referente às concessões de licenças é muito parecido, com o Leste Asiático liderando as várias regiões por larga margem. Na infra-estrutura de ICT, entretanto, a América Latina tem uma boa comparação com o Leste Asiático.

Em geral, o atraso do desempenho competitivo latino-americano deve-se ao fraco desempenho tecnológico e do IED voltado para as exportações; com exceção do México, a região não conseguiu avançar no 
caminho autônomo ou dependente do IED para chegar ao dinamismo nas exportações. E o México não está seguro, já que sua base de P\&D é muito reduzida.

\section{Conclusão}

Esta visão geral das tendências tecnológicas das exportações de produtos manufaturados e de seus impulsionadores fornece um prisma útil para se examinar o crescimento. Não se está sugerindo que o crescimento seja o único fator a aliviar a pobreza, mas ele é claramente um fator importante. Sem promover o crescimento, é difícil reduzir a pobreza em bases sustentáveis. Num mundo liberalizado e com um inexorável progresso técnico, é ainda mais difícil, para a maioria dos países, crescer sem construir uma competitividade industrial.

Esse panorama tem um lado otimista e um lado pessimista. O otimista consiste em que se mostra ser possível os países em desenvolvimento crescerem e competirem com eficiência no contexto emergente, entrando em mercados competitivos de produtos manufaturados e subindo rapidamente na escala tecnológica. O pessimista é que há uma tendência para uma divergência cada vez maior, e não para uma convergência. O processo de globalização tem distanciado os que estão "dentro" e os que estão "fora" do dinamismo tecnológico. Alguns países "de dentro" têm participado de sistemas internacionais e integrados de produção. Dentre estes, os realmente dinâmicos são os que desenvolveram uma sólida capacitação tecnológica local; os demais países "de dentro" precisam seguir seu exemplo, investindo em capital humano e tecnológico. Os demais países em desenvolvimento encontram-se "do lado de fora" em graus variáveis, desde os que estão prestes a se juntar aos que já entraram, num dos extremos, até os que correm o risco de marginalização a longo prazo, no outro.

A globalização movimenta os recursos produtivos e o conhecimento pelo mundo afora, em ritmo acelerado. Todavia, não reduz a necessidade de capacitação e instituições locais; muito pelo contrário, a força do sistema local de aprendizagem torna-se cada vez mais importante para atrair e "enraizar" os recursos móveis que se acham disponíveis no exterior. Pelo simples fato de o capital e as tecnologias estarem mais acessíveis (e mais livres para se movimentar), os países têm que oferecer qualificações, potencialidades, redes de abastecimento, instituições e 
infra-estrutura melhores para atrair recursos de alta qualidade. A simples abertura das economias para as forças do mercado global, sem aprimorar as qualificações e as potencialidades, pode servir para explorar a capacidade já existente, mas, a prazo mais longo, pode ser a receita da estagnação na base da escala tecnológica e de renda.

\section{Referências bibliográficas}

DICKEN, P., Global Shift: Transforming the World Economy, Londres: Paul Chapman, 1998, $3^{a}$ edição.

LALL, S., Learning from the Asian Tigers, Londres: Macmillan, 1996.

LALL, S., Competitiveness, Technology and Skills, Cheltenham: Edward Elgar, 2001.

NOLAN, P., China and the Global Business Revolution, Basingstoke: Palgrave, 2001.

NSF, Science and Engineering Indicators, Washington, DC: National Science Foundation, Senado dos EUA, 1999.

STIGLITZ, J. E., 'Some Lessons from the East Asian Miracle', The World Bank Research Observer, 11(2), 1996, p. 151-177.

STIGLITZ, J. E. , Globalization and Its Discontents, Londres: Allen Lane, 2002.

UNIDO, Industrial Development Report 2002/2003: Competing through innovation and learning, Viena, 2002: UN Industrial Development Organization. Ver: www.unido.org/idr. 
DEBATEDORES

\section{A Nova Agenda Mundial: REVOLUÇÃO TECNOLÓGICA E INTEGRAÇÃO GLOBAL}


Desenvolvimento em Debate -132 
Helio Jaguaribe*

Antes de começar a breve exposição de comentários sobre as excelentes apresentações que tivemos a oportunidade de ouvir, queria registrar a satisfação com que participo da celebração dos cinqüenta anos de existência do BNDES, talvez a mais importante agência do Brasil, desde a sua fundação, na promoção do desenvolvimento nacional, que está continuando sob a atual direção, na sua importantíssima tarefa. Creio que muito do que o Brasil é se deve ao BNDES, mas acho que o BNDES tem agora, diante das terríveis conjunturas com que nos defrontamos, nesse dificílimo século vinte e um, uma tarefa ainda mais importante do que aquela que ele realizou no meio século que acaba de terminar.

Tivemos oportunidade de ouvir três excelentes exposições. Creio que, sintetizando os aspectos fundamentais de cada uma delas, diria que o professor Fishlow que é um dos mais eminentes conhecedores, não apenas fora do Brasil mas dentro do próprio Brasil, do nosso Brasil, apresentou três principais reivindicações, duas expostas e uma que consta no texto que ele não leu. $\mathrm{Na}$ parte que ele expôs, salientou a absoluta necessidade de maximizar exportações. Não há saída para o subdesenvolvimento brasileiro, a não ser através de um significativo, diria mesmo gigantesco, incremento de nossa participação no comercio internacional. Isso significa uma grande maximização das exportações, a qual, entretanto, não é possível sem contrapartidas de apoio de importações adequadas. O exemplo de EMBRAER foi citado como ilustração de que, importações adequadas permitiram capacitar essa empresa para ser uma empresa líder nessa difícil atividade de ponta que é a indústria aeronáutica. A segunda grande recomendação do professor Fishlow é no sentido de que temos que incentivar, energicamente a nossa taxa de poupança, que tem se mantido no curso dos últimos vinte anos, praticamente es-

* Decano do Instituto de Estudos Políticos e Sociais. 
tagnada em torno de menos de $20 \%$, quando o mínimo necessário para o país seria de $25 \%$, e os países Asiáticos de maior êxito, tem poupanças na ordem de $30 \%$. Há, portanto, um enorme intervalo entre a poupança atual e a poupança que devemos atingir. Finalmente, na parte do texto de Fishlow não lida, ele faz algumas referências à ALCA, que ele apresenta como algo de mais favorável, do que desfavorável, se o Brasil negociar adequadamente seu ingresso nessa projetada instituição.

O professor Dosi nos apresenta um texto que é, sobretudo, um texto de crítica. Crítica a respeito dos resultados da globalização, que se supunham fossem a universalização do bem-estar mundial mas, na verdade, resultaram num forte incremento da assimetria entre nações e dentro das nações. Crítica da atividade, do sistema financeiro internacional, que na verdade tem contribuído muito modestamente para o desenvolvimento. Finalmente, a necessidade de que os países adotem medidas adequadas, através do Estado Nacional, para se proteger dos aspectos negativos da globalização e do sistema financeiro internacional.

O professor Sanjaya Lall nos dá uma excelente exposição demonstrativa da medida em que o desenvolvimento tecnológico é a chave do progresso. Constante inovação tecnológica é o segredo da manutenção da sua liderança pelos países que já tinham esse desenvolvimento, em meados do século e para os Estados Unidos, que conseguiram atingir um alto nível de desenvolvimento tecnológico, um pouco depois dos europeus. Assim também é o caso dos países Asiáticos, que lograram uma importante participação no mercado internacional através de um forte incremento da tecnologia. Tecnologia, tecnologia e mais tecnologia, é recomendação do Professor Lall.

Estas recomendações vem ao encontro de um país como o Brasil que está, no momento, caracterizado por uma situação de "longa" estagnação. O Brasil nesses últimos 20 anos, a despeito de que diversos governos não tiveram a ideologia neoliberal, na verdade adotou, de uma maneira bastante sistemática, o "Consenso de Washington", tanto no sentido de tentar melhorar as linhas de governabilidade e de responsabilidade na administração financeira do país, como também no sentido da abertura do mercado, da privatização, da abertura indiscriminada ao capital estrangeiro, etc.

O que resultou desta longa política em que, em lugar de se imprimir um esforço pelo Estado Nacional, de orientação de uma política industrial de desenvolvimento, se confiou na capacidade de otimização que o mercado livre teoricamente deveria apresentar? $\mathrm{Na}$ verdade, foram vinte anos de estagnação, no curso do qual o crescimento do PIB, mal tem compensado o 
crescimento da população, gerando não apenas desemprego como forte subemprego um incremento das "diversificações" regionais, etc...É interessante observar que, isso não obstante, como já foi dito em algumas ocasiões pelo nosso Presidente, o nível de consumo da sociedade brasileira melhorou! $\mathrm{Ou}$ seja, os pobres brasileiros, em termos de capacidade de consumo, estão menos pobres do que antes. Mas o intervalo entre os pobres e os não pobres aumentou extraordinariamente, e as expectativas dos pobres, de superar sua condição, se tornou extremamente precária. Existe hoje um profundo desânimo, por parte de amplos setores majoritários do país, da possibilidade de que, nas condições atuais, eles logrem aumentos significativos da sua renda e da sua participação nos bens da civilização brasileira.

O que está ocorrendo para asfixiar atualmente o Brasil? Uma das coisas que me parecem mais interessantes, na constatação da situação atual, é o contraste entre a excelência do Presidente e as dificuldades com que o país se encontra. Nunca o Brasil teve um Presidente mais qualificado do que Fernando Henrique Cardoso, que não hesito em qualificar como um dos mais qualificados Presidentes do mundo. Simplesmente isso. E no entanto, a despeito desta excelência do Presidente, e de alguns Ministros admiráveis, um dos quais eu não posso deixar de salientar que é o que está aqui ao meu lado e que fez um extraordinário esforço de melhoria do desenvolvimento cientifico e tecnológico brasileiro, acontece que nós estamos numa situação de extraordinária dificuldade.

O que está ocasionando esta dificuldade brasileira e como, em face desta dificuldade, poderíamos utilizar as recomendações que nos vem de Fishlow, e dos dois outros expositores? O problema é que o país está sofrendo um duplo constrangimento estrutural. Por um lado, em virtude de circunstâncias diversas, temos um déficit anual das transações correntes que se aproxima da ordem de 20 bilhões de dólares. Por outro lado, estamos tendo a necessidade de rolar anualmente a nossa dívida externa, envolvendo a necessidade de renovação de créditos da ordem de mais de 30 bilhões de dólares. Ou seja, cerca de 20 bilhões de capital novo, cerca de 30 ou mais bilhões de capital antigo renovado, que significam um montante anual de mais de 50 bilhões de dólares, que quase se aproxima do total das nossas exportações.

Esse duplo estrangulamento, a demanda de capital novo para tapar buracos das transações correntes, e a renovação da dívida, estão imobilizando completamente o país. Desde logo porque, para atrair capitais estrangeiros que atendam à necessidade de evitar um "default", o Brasil tem adotado uma política de juros altos, os quais tem efetivamente exercido atração de capital estrangeiro. O capital estrangeiro especulativo calcula 
que a probabilidade de desvalorização da moeda nacional apresenta uma taxa significativamente inferior à extraordinária rentabilidade que as aplicações financeiras têm no Brasil. Daí o fato de terem vindo até agora grandes inversões, muito embora, no momento, as condições se estejam tornando menos favoráveis. Importantes influxos de capital estrangeiro, mas a decorrente necessidade de juros elevados, levaram a um gigantesco endividamento interno, muito mais grave do que o nosso endividamento externo. A União está atualmente arrecadando cerca de 16\% do PIB, o que é uma coisa extremamente importante. Entretanto algo como 35\% da receita federal está imobilizada pelo pagamento dos juros, algo como 3\% do PIB nacional é imobilizado pelos déficits da previdência. O que acontece é que a despeito da União ter uma arrecadação extremamente considerável, ela está completamente manietada. A União não tem um centavo disponível para projetos prioritários. No momento em que se nos recomenda aumento da tecnologia, aumento da exportação e uma série de outras recomendações, que são obviamente corretas, nos defrontamos com a absoluta incapacidade por parte da União, em virtude dos estrangulamentos domésticos gerados pelos juros do próprio mercado interno e da iniciativa privada de responder dinamicamente às necessidades que estes desafios estão nos impondo. E ai surge a pergunta, o que fazer?

Não vou evidentemente, nestes breves comentários que me cabem, pretender apresentar uma solução, para esses terríveis problemas brasileiros. Desejo apenas mencionar duas coisas. Para que o Brasil supere o seu subdesenvolvimento renitente, que já vem desde as nossas origens, e consiga um espaço adequado, entre as nações desenvolvidas, tem de fazer um extraordinário esforço de desenvolvimento. É importante levar em conta um fato, que não está sendo suficientemente observado pelos analistas da situação contemporânea em geral e do Brasil em particular, o fato de que o processo de globalização, a hegemonia semimundial americana, e vários outros fatores, estão restringindo dramaticamente, de forma extremamente acelerada, o espaço de permissibilidade de que ainda dispõem os países emergentes. Quando Stephen Weig dizia "o Brasil é um país de futuro" tinha razão nos anos 40. Hoje, o futuro brasileiro é problemático. Se o Brasil não conseguir superar o seu subdesenvolvimento, crônico, e atingir um patamar de desenvolvimento social não inferir ao atual da Espanha, e um patamar econômicotecnológico não inferior ao atual da Itália, o que, para isso, ele não dispõe de mais de duas décadas, o Brasil está condenado, como tantos ouros países já o estão, a se converter num segmento anônimo do mercado 
internacional. Terá hino, soberania de fachada, exército de parada, etc...Será totalmente controlado, endogenamente por multinacionais, e exogeneamente pelas potências imperiais.

O Brasil dispõe de um prazo extremamente curto, em termos históricos, com a margem de que ainda detém de autonomia nacional, para superar a condição lamentável de ser parte do lixo histórico, a que estão condenados os países que não tiverem capacidade de preservar a sua autonomia. E daí? Como é possível, num prazo historicamente tão curto, que são 20 anos, conseguir essa coisa extraordinária que é nos equiparar ao nível social da Espanha, e ao nível econômico-tecnológico da Itália? É evidente que nenhum projeto de grande vulto, que certamente os excelentes economistas e técnicos do BNDES seriam capazes de elaborar, teria possibilidade de vigorar no curso de cinco quadriênios presidenciais, cada um deles com suas próprias características, com suas próprias demandas. É evidente que não é possível fazer num país democrático, felizmente democrático, mantendo este debate que parece indispensável, um projeto de longo prazo como por exemplo, os chineses, em condições institucionais completamente diferentes, estão pretendendo fazer. E então, é possível fazer alguma coisa? Eu creio que há uma única resposta. Se nós conseguirmos um consenso nacional, no nível da classe política e da opinião pública, a respeito das grandes metas que o Brasil precisa atingir, para precisamente alcançar o nível social semelhante ao espanhol, e o nível econômico-tecnológico semelhante ao da Itália, a Itália de hoje, não a Itália daqui há vinte anos, é necessário um consenso a respeito das grandes metas nacionais. Não um consenso de métodos de atingí-las, isso cada partido, cada governo, cada Presidente de turno terá de dar sua resposta. Mas se houver consenso a respeito das metas, das condições fundamentais para se as atingir, a possibilidade do país chegar a esse resultado é razoável.

É com satisfação, estimados senhores, que lhes digo que um Comitê de Consenso que se organizou em fins do ano passado, e que trabalhou intensamente durante a primeira metade deste ano, chegou a um resultado de metas muito interessante.

Essas metas, que representam um consenso de representantes de todos os partidos políticos, que se reuniram em Brasília durante todos os meses do primeiro semestre, e que foi finalmente coordenado por uma Comissão Relatorial, coordenada pelo Deputado Aloísio Mercadante, integrada pelas Deputadas Rita Camata e Yeda Crusius e Senadores Jefferson Peres e Roberto Saturnino, logrou um documento de consenso dentro desse Comitê de Consenso. Esse documento foi entregue ao Presi- 
dente da República, aos vários candidatos, e será objeto, depois das eleições, de um amplo debate nacional, para que, em função desse debate, se tente chegar a um consenso final. Se o Brasil lograr, o que parece já um bom encaminhamento inicial, se aproximar de um consenso nacional a respeito de macrometas e de condições mínimas, deixando a cada partido e a cada governo de turno como atingir essas metas - por que seria insensato prever e prescrever para esses governos o que eles vão fazer - eles obviamente terão decisões próprias, mas se esse governos, se essa classe dirigente, se a opinião pública, tiver coincidência, a respeito das grandes metas, a possibilidade de as atingir é muito grande.

Terminaria, senhores, dizendo que um dos problemas, o alcance de macro metas no horizonte de 2020, apresente como sair da estagnação atual para esse crescimento acelerado, que foi calculado pelo Comitê de Consenso, como exigindo, a partir de um certo momento, uma taxa igual à que o Brasil teve nas décadas de $50 \mathrm{a} 70$, de $7 \%$ ao ano. Esse é o grande problema, e é o problema com o qual se vai defrontar o governo que vier a ser eleito para o quadriênio de 2003/2006. Nunca, um quadriênio vai ser tão estratégico como esse porque, na medida em que o governo que surgir das novas eleições tiver capacidade de sair da estagnação atual, e encaminhar o Brasil em condições que permitam se aproximar dessas metas, o Brasil terá um grande destino histórico. Na medida em que não o fizer, o Brasil não terá destino histórico.

Eu terminaria dizendo que uma das questões fundamentais, que vão ser a curtíssimo prazo enfrentadas pelo novo governo, será a questão da ALCA. Entrar ou não entrar em ALCA, essa é a questão. Quando se diz que ALCA é uma questão de negociação, eu estou de acordo. Evidente, tudo é questão de negociação. Mas que negociação e negociação com quem? Ai entra uma ilusão. Não se trata de que ALCA, tal como ela se nos é apresentada pelo governo americano, dependa de negociações entre representantes do executivo brasileiro e do executivo americano. Não se trata disso. Trata-se de que é preciso uma negociação entre o Presidente Bush e o Congresso Americano para que o Presidente Bush logre suprimir a legislação protecionista, no âmbito da qual entrar em ALCA é um suicídio nacional. É essa a questão com que o futuro governo se defrontará. Sr. Presidente Bush, a bola está consigo. Opte pela eliminação das medidas protecionistas para que o Brasil considere a possibilidade de entrar na ALCA. Senão, nem conversar, muito obrigado. 
Rubens Ricupero*

Gostaria de propor que fizéssemos uma breve reflexão, em termos do que os anglo-saxões chamam de "reality-check", quer dizer, uma tentativa de ver qual é a realidade em torno de nós. Estamos aqui iniciando um seminário de altíssimo nível, com gente de grande qualidade e já ouvimos hoje apresentações de muito valor. No entanto, nesta mesma cidade em que nos encontramos, vivia-se poucas horas atrás, episódio de um dramatismo extraordinário e que por um triz não redunda numa tragédia da dimensão que teve em São Paulo a rebelião do presídio do Carandiru. Trata-se de episódio que evidentemente é perturbador, por não ser único, porque vem se repetindo com freqüência e indica alguma coisa de muito grave na falência do Estado brasileiro. Há tempos que nos preocupamos com episódios semelhantes em nações vizinhas e hoje começamos a sentir, cada vez mais perto de nós, esse problema de uma cidade em parte até governada pelo narcotráfico, na qual um poder paralelo pode dar-se ao luxo de mandar fechar o comércio, as escolas, as universidades, na qual o Estado já não tem mais o monopólio da coação, nem dispõe de condições para impor um mínimo de segurança.

Pode parecer que este comentário é um pouco extemporâneo, mas como não vivemos num mundo abstrato, temos de encontrar as ligações que existem entre o tema da retomada do desenvolvimento e o problema grave da falência do Estado. Essa é questão que tem ligação com muita coisa que foi dita aqui durante o seminário, inclusive sobre problemas como o da necessidade de que o Estado brasileiro produza superávits fiscais cada vez maiores nos próximos anos. Sei que nada disso é simples, que é preciso guardar espírito de equilíbrio, sentido de medida, mas permito-me sugerir que há uma ligação entre esses fenômenos.

* UNCTAD. 
Para mim, é também uma grande satisfação ver que estamos comemorando meio século de uma grande instituição do passado brasileiro. Houve um momento, não faz muito tempo, que uma personalidade que todos admiramos teve uma frase pouco feliz, quando afirmou que esperava superar totalmente o legado da Era Vargas. É claro que se compreende que a intenção não foi essa, ele queria provavelmente se referir ao lado negativo da "Era Vargas". Não podemos esquecer que uma das heranças da Era Vargas é justamente o BNDES. Encontra-se entre nós o professor Hélio Jaguaribe, e é com sentimento de grande respeito que me honro de estar ao seu lado, por ser ele um dos símbolos mais marcantes dessa época, dos que trabalharam diretamente com o Presidente Getulio Vargas, na luta pelo desenvolvimento do Brasil. É pena que não esteja conosco também o professor Celso Furtado, e outros que já partiram, Creanto de Paiva Leite, Inácio Rangel, tantos outros que deram contribuição valiosa. Desse modo, em compensação por esse horror que vivemos com o narcotráfico, o Comando Vermelho, a situação dos presídios brasileiros, é importante destacar que nesses cinqüenta anos fizemos algumas coisas positivas e para isso muito contribuiu o BNDES.

Li com atenção os três trabalhos e gostaria de ter tempo de comentálos com mais vagar. Não sendo esse o caso, quero dizer que me impressionou sobretudo o alto grau de convergência entre eles, especialmente na questão da importância central da ciência e tecnologia. Esse é um dos consensos a que se referia o professor Helio Jaguaribe. Num livro recente, publicado pelo IPEA e pelo escritório da CEPAL no Brasil, intitulado "Políticas para a retomada do crescimento", com entrevistas a trinta e seis economistas brasileiros, afirma-se a certa altura, que talvez a única área onde se registra consenso quase completo, até por parte dos economistas mais críticos da intervenção do Estado, é em relação à necessidade de uma ação estatal em três áreas: pobreza, educação primária e ciência e tecnologia. A obra contém muitas outras referências a esse consenso sobre ciência e tecnologia.

Caberia aqui um comentário sobre essa questão de consenso. Concordo plenamente com o que diz o professor Jaguaribe sobre a necessidade de um esforço urgente nesse sentido. Infelizmente, quando se parte de uma sociedade profundamente dividida em linhas tanto sociais quanto raciais, aspectos de que esquecemos com freqüência, não é fácil conseguir construir um consenso, pois o que existe de comum entre as pessoas é muito pouco. Não há dúvida, contudo, de que esse esforço em prol do consenso tem de ser buscado, um consenso genuíno e 
significativo, que vá além do consenso sobre os fins e vise a edificar um consenso sobre os meios. O primeiro tipo nunca foi difícil. Sabemos, por exemplo, que durante a monarquia, havia no Brasil quase unanimidade em relação à necessidade de pôr fim à escravidão, principiando pelo próprio Imperador D. Pedro II. Ninguém defendia a escravidão no Brasil como se fazia no sul dos Estados Unidos, com argumentos até teológicos, de valor perene. Aqui, todo o mundo considerava a escravidão como um mal a ser abolido; mas esse consenso limitava-se aos fins, não chegando aos meios. Quando o Imperador consultou o Conselho de Estado, em 1867, sobre diversos quesitos relativos à escravidão, um dos quais a data em que se poderia abolir o chamado "estado servil", nenhum dos conselheiros, salvo um, teve coragem de arriscar uma opinião sobre a questão do prazo. A exceção foi o Visconde de Muritiba, o qual sugeriu que talvez se pudesse abolir a escravidão em 1930, quando os cativos remanescentes seriam remidos pela metade do preço .... Essa é que é a verdade, nossos consensos são raros, superficiais, não abrangem os meios, como chegar lá, como resolver, por exemplo, o problema da pobreza e outros consensos do tipo.

Nos poucos minutos que me restam, tenciono apresentar algumas observações sobre a contribuição do professor Fishlow, que se refere à área que venho acompanhando mais de perto no meu trabalho, a questão do comércio internacional, primeiro como diplomata, e agora, na UNCTAD, o braço das Nações Unidas que se ocupa da promoção do desenvolvimento por meio do comercio. Concordo de início com o que ele diz: de fato, durante muito tempo, não demos a importância necessária ao comércio. Fico satisfeito em ver que essa é uma das áreas em que agora temos um consenso generalizado. Não é exagero afirmar que hoje no Brasil todos estamos de acordo em que a saída para o Brasil diminuir gradualmente seu índice de vulnerabilidade, é aumentar as exportações. Isso significa, é claro, também aumentar as importações e adquirir maior eficiência no domínio do comércio exterior. No trabalho escrito, o professor Fishlow discute as várias opções, em termos de negociações, na OMC, na ALCA, no Mercosul, sempre com coisas sensatas e equilibradas. Por exemplo, ele declara que o ideal seria que essa inserção no sistema comercial se fizesse através da Organização Mundial de Comércio, porque não haveria assim discriminações, nem de caráter regional, postura que endosso por completo. Em seguida, faz considerações sobre a ALCA, à qual o professor Jaguaribe também se referiu. Em relação a esse debate, desejaria chamar a atenção para aspecto 
que talvez não tenha recebido, pelo menos explicitamente, a atenção que merece.

É verdade que estamos começando a despertar para o problema do comércio mundial, mas estamos fazendo isso com certa distorção, com fixação excessiva no valor das negociações comerciais. Não quero com isso dizer que elas não tenham valor, mas as negociações comerciais são apenas uma resposta parcial ao problema do comércio. O máximo que uma negociação comercial pode lograr, quando tem êxito, é criar uma oportunidade de exportação. Essa oportunidade só será aproveitada se houver oferta em termos competitivos. Todo país tem esses dois tipos de problemas, o de barreiras de acesso aos mercados, e problemas de oferta, mas alguns tem mais o segundo do que o primeiro tipo. A meu ver, esse é o caso do Brasil. Isso não significa que o Brasil não tenha problemas sérios de acesso ao mercado, é óbvio que tem e alguns foram citados pelo professor Jaguaribe. Infelizmente, a competitividade indiscutível do Brasil se concentra muito em alguns dos produtos mais complicados do comercio mundial, aço, por exemplo, ferros ligas, produtos agrícolas sensíveis, suco de laranja, mas também tabaco, açúcar, - o Brasil é país quase imbatível em açúcar, mas não antevejo, nem em vinte anos, um mercado totalmente livre para o açúcar por ser esse um dos produtos mais protegidos no mundo - etanol, óleo de soja, etc. Devido a essa oferta complicada, o país tem muita dificuldade para poder realmente expandir suas exportações a curto prazo. No fundo, esse é o problema que explica o medo brasileiro de negociar. Em certo trecho do seu trabalho, o professor Fishlow diz que a postura brasileira não é irracional; de fato, não é, bastando lembrar a esse propósito, a frase do nosso Millor: "O fato de eu ser paranóico não quer dizer que eu não esteja sendo perseguido". Quer dizer, efetivamente temos medo de negociar porque sabemos que somos frágeis, sabemos que a nossa competitividade, fora esses poucos produtos, é muito discutível. É isso que nos inibe, seja na ALCA, seja na OMC, seja lá onde for. Temos de superar esse medo, e a única forma de superar esse tipo de temor é justamente resolvendo o problema da oferta, o que não é simples por que não existem soluções a curto prazo. Lamentavelmente, somos até hoje dependentes de produtos intermediários, muito ligados a recursos naturais e oriundos do último grande ciclo de investimento que o país conheceu nos anos 70 e começos dos anos 80. Quase todos os ítens que citei e mais, o minério de ferro de Carajás, da Vale do Rio Doce, o complexo soja, o papel e a celulose, tudo veio daquela época, com muito 
pouca exceção após. Por que estamos nessa situação? Porque o Brasil depois não investiu, não cresceu. Um fato invariável que se observa na história do comércio brasileiro é que o Brasil sempre aumentou mais suas exportações, inclusive de manufaturados de valor tecnológico, nas fases em que acelerou seu crescimento, por razão que é perfeitamente óbvia: porque a aceleração do crescimento aumenta a oferta, tanto doméstica quanto internacional. Até hoje, temos oferta muito estreita em quantidade e qualidade e é suficiente que o mercado doméstico se reative para que o setor siderúrgico, por exemplo, se desinteresse de exportar, por não ter mais excedentes. Assinalo, portanto, que o problema da oferta merece maior atenção por ser essa missão crucial para o BNDES.

Meus comentários conduzem, assim, a essa conclusão: o BNDES cumpriu um papel muito importante na expansão da oferta, por exemplo, na implantação da indústria de bens de capital e seria agora indispensável que essa ação se direcionasse a superar os problemas de estreiteza de oferta. À luz das apresentações que foram feitas aqui, vimos com clareza que há para isso uma diversidade de caminhos, pois a globalização, longe de impor um só caminho, possibilita muitas abordagens diferentes, quase tantas quanto são os países existentes no mundo. Cada um tem de encontrar o seu próprio caminho para inserir-se qualitativamente na globalização. No caso brasileiro, há evidentemente certas características que não são as mesmas do México, para escolher um termo de comparação. Embora o México tenha tido sucesso extraordinário em aumentar suas exportações, mesmo antes do NAFTA, ele já tinha nos Estados Unidos uma concentração extraordinária do seu comércio exterior, tanto em exportações quanto nas importações, da ordem de mais de $80 \%$, que hoje está perto, às vezes, de 90\%. Já para o Brasil, ainda nos melhores momentos, o mercado americano chega a $25 \%$, nos piores a $19 \%, 18 \%$, nunca mais voltou a ser o que era na época do Barão do Rio Branco, quando representou $36 \%$ das exportações totais do país. Por conseguinte, essa já é diferença muito grande. Outra diferença bem conhecida é o peso dos fatores políticos, e uma adicional é a vantagem da contigüidade geográfica. Uma curiosidade pouco divulgada é que $80 \%$ das mercadorias transacionadas dentro do NAFTA são transportadas por caminhão. Só isso basta para mostrar a vantagem imensa de que dispõe um país com contigüidade territorial. Desse modo, a solução brasileira não pode ser idêntica à do México.

Mudando um pouco de registro, a solução para nós não é apenas a exportação de produtos de alta tecnologia. É certo que os produtos mais 
dinâmicos do comércio mundial, aqueles cujo comércio cresce a taxas duas ou três vezes superiores à média geral, são esses produtos de alta tecnologia. Recentemente, em maio, a UNCTAD publicou o seu relatório sobre comércio e desenvolvimento, no qual mostra quais são os 20 produtos mais dinâmicos do comércio mundial. É preocupante que, nessa lista, a América do Sul só aparece em duas categorias e, mesmo assim, as menos importantes, bebidas não alcoólicas e roupa de baixo de malha, com porcentagens baixas até nessas exportações. Temos, portanto, que cuidar da diversificação da oferta, não podendo desprezar as oportunidades que possam existir no campo de tecnologia avançada, como dos aviões da Embraer. Ao mesmo tempo, é preciso não esquecer que o Brasil tem uma diversidade muito grande de recursos naturais, o que abre outras possibilidades. Não se deve esquecer que para a Austrália, país de grande êxito no comércio mundial, $60 \%$ das exportações são commodities. Nem por isso, a Austrália está em situação difícil, ao contrário, é nação cuja presença aumenta constantemente no comércio mundial. É verdade que, das commodities australianas, as de maior peso são as minerais ou industriais, entre as quais o carvão siderúrgico, uma das raras commodities cujo preço tem crescido sempre ao longo dos anos, já que a oferta é controlada por poucos fornecedores. Contudo, a Austrália exporta também $70 \%$ da carne bovina que produz, enquanto o Brasil exporta apenas 5\% da sua produção. Tecnologia e valor agregado não estão necessariamente limitados aos setores de alta tecnologia em telecomunicações, em eletrônica, ou outras áreas tecnológicas de ponta onde é indispensável ter laboratórios sofisticados e recursos vultosos. $\mathrm{O}$ professor Lall perguntou, em sua intervenção, por que os países industrializados estão aumentando sua participação na exportação de produtos primários, inclusive naqueles só produzidos nos trópicos. A resposta é simples, é por causa da re-elaboração da matéria prima e do valor agregado. Pouca gente está consciente de que Alemanha hoje é o segundo maior exportador de café, resultado de um processo pelo qual os alemães importam café de várias precedências, fazem o "blending", isto é, a mescla, processam a mistura e exportam o café industrializado (solúvel com diversos sabores, torrado, etc). Conforme se vê nesse exemplo, a tecnologia também se aplica ao produto primário, o que abre uma enorme gama de possibilidades que o Brasil deveria explorar, tanto em termos da variedade de produtos agro-pecuários ou minerais possibilitada pelas dimensões continentais do território, quanto em relação à diversidade de mercados em termos geográficos Nesse sentido, penso que deveríamos procurar sintonizar e sincronizar as negociações 
da ALCA com as negociações comerciais globais na Organização Mundial do Comércio. É sabido, com efeito, que, dentro da ALCA, os americanos dizem claramente que a agricultura e o antidumping são temas sistêmicos que só poderão ser resolvidos de forma significativa na negociação global. Também é certo que em outros temas igualmente sistêmicos, os negociadores americanos querem avançar na ALCA mais do que na OMC, como é o caso de serviços, propriedade intelectual, compras governamentais, investimentos, concorrência, sem ver nisso nenhuma contradição. Talvez a única explicação dessa incoerência é o famoso adágio: "o que é meu é meu, o que é seu, é negociável". Cabenos evidentemente resistir à tal postura e a melhor maneira de fazê-lo é sintonizando esses dois processos de negociações, um regional, outro global, levando em conta, ao mesmo tempo, a pré-condição de que necessitamos de crescimento, a fim de ampliar a oferta.

Concluo minha intervenção precisamente com uma reflexão sobre a questão da poupança doméstica. Sei que é questão de extrema complexidade e não sou macroeconomista, nem mesmo economista para discutir a matéria com competência profissional. Não ignoro que, mesmo entre os economistas, existem nomes respeitáveis em favor da tese de que a poupança aumenta como resultado do crescimento. O próprio BID, anos atrás, defendeu essa posição num relatório. A Coréia do Sul, por outro lado, quando iniciou seu processo de desenvolvimento, não tinha um índice de poupança nem de longe tão elevado como tem hoje. Seja como for, sabemos que precisamos aumentar a poupança doméstica, havendo diversos caminhos para isso, não se reduzindo a questão apenas ao superávit fiscal. Concordo que o superávit fiscal é problema que deve merecer exame ponderado e cuidadoso, dado o alto nível de endividamento a que chegamos. Por outro lado, não se pode negar que, se o país tiver de produzir saldos primários crescentes por três ou quatro anos seguidos, tal esforço afetará profundamente a capacidade de o Estado atuar em áreas prioritárias inadiáveis como a da segurança e até mesmo em setores diretamente ligados à produção. Neste mesmo momento, a Embrapa não tem recursos nem para pagar a forragem dos animais, o que, cedo ou tarde, vai incidir diretamente sobre a própria capacidade de exportação. Até que ponto é possível produzir superávits primários crescentes numa economia combalida, quase estagnada, se não em recessão, utilizando medidas pró-cíclicas, exatamente o oposto do que fazem os Estados Unidos, que passou de posição de superávit para déficit orçamentário. Do mesmo modo, na Europa, quatro economias, dentre 
as quais, três das maiores, a Alemanha, a França e a Itália, não conseguem nem viver dentro do déficit de 3\% do PIB. Se isso ocorre com economias muito mais sólidas e prósperas, será possível produzir saldos primários da magnitude de 3,7\% por três, quatro ou cinco anos seguidos em país como o nosso, com as fragilidades dramáticas conhecidas, com as deficiências agudas do Estado e já com uma carga tributária que se aproxima, se é que não chegou, aos 35\% do PIB? Tenho realmente sérias dúvidas de que tais metas sejam factíveis. Discutir a questão em abstrato leva a generalizações perigosas. Se pudéssemos crescer via exportações, talvez esse esforço fosse viável, mas será isso possível com a economia mundial como está? O comercio mundial, dizia o professor Fishlow, cresceu no período de após guerra duas vezes mais do que o crescimento do produto, mas infelizmente não é o que está acontecendo agora. No ano 2000, o comércio cresceu $12 \%$ em volume, mas no ano 2001, teve uma queda de menos um por cento em volume e menos quatro por cento em valor. Para este ano de 2002, a Organização Mundial de Comércio está estimando um crescimento modesto de um, um e meio por cento, mas qual será o crescimento o ano que vem? Alguém sabe? Alguém sabe o que vai acontecer com a economia americana? Nas condições prováveis do futuro próximo, será possível crescer via exportações? E qual será, nesse cenário adverso, o comportamento da nossa economia? Dispomos acaso de um setor privado capaz de substituir o Estado, e voltar imediatamente a investir, tendo de trabalhar com taxa de juros reais de 10,4\%, (na realidade muito mais), quando a taxa de crescimento da economia é quase zero? São questões difíceis que não devem ser simplificadas. Confesso não ter respostas para essas perguntas, que requerem realismo, senso de equilíbrio e de medida. Acredito, porém, que esses fatos apontam para uma conclusão: temos de procurar o nosso próprio caminho, dentro da diversidade de caminhos possíveis, levando em conta os constrangimentos brasileiros, que são numerosos. Como estamos longe de atuar num mundo ideal, tampouco as políticas ideais poderiam ser aplicadas de imediato. O processo para definir uma estratégia para o Brasil é o que muito bem assinalou o professor Jaguaribe, a edificação de um consenso que não seja apenas sobre os fins, mas igualmente sobre os meios, sobre os instrumentos efetivos de lograr a retomada do crescimento em bases menos precárias das que até agora tivemos. 
PALESTRAS

\section{Agenda Social e Combate À Pobreza: SOCIEDADE, CULTURA, DEMOCRACIA}

E LIBERDADES INDIVIDUAIS 


\title{
POR UMA NOVA VISÃO DA POLÍTICA SOCIAL NA AMÉRICA LATINA: DESFAZENDO MITOS
}

\author{
Bernardo Kliksberg*
}

\section{A América Latina em comoção}

O New York Times fez soar o alarme, em recente nota especial de primeira página, sobre a situação delicada da América Latina (Forum, 13 de julho de 2002). Assinalou haver uma insatisfação generalizada, dizendo que "os sonhos econômicos transformaram-se em demissões e recessão". Ressaltou que "milhões de pessoas vêm fazendo ouvir sua $\operatorname{voz}(. .$.$) contra o experimento econômico da última década. (...) Muitos$ acreditam que as reformas enriqueceram funcionários corruptos e multinacionais de rosto desconhecido, sem introduzir melhoras em suas vidas". Num sentido similar, Birdsall y De La Torre (2001) assinalaram: "As pesquisas de opinião pública do final dos anos noventa demonstraram que os latino-americanos sentiam que suas economias não iam bem, que sua qualidade de vida estava pior que a das gerações anteriores e que a pobreza vinha atingindo índices sem precedentes." A CEPAL (2002) afirmou que "a situação existente em 2002 evidencia claramente a defasagem surgida entre as expectativas do novo modelo econômico aplicado à região durante a década de 1990 e as perspectivas atuais de crescimento". Essa organização estimou, em 2002, uma queda de $0,8 \%$ do produto interno bruto, uma redução de $1,5 \%$ nas exportações e novas reduções nos investimentos externos. Mathews e Hakim (2001) descreveram nos seguintes termos a situação geral: "no final dos anos noventa, o futuro da América Latina parecia sombrio, em razão de quatro grandes problemas: crescimento lento e irregular, pobreza persistente, injustiça social e insegurança pessoal." Indicaram ainda que, ao longo

* Assessor internacional: BID, Nações Unidas, OEA, OIT, entre outras. 
de dez anos, os países "procuraram aplicar com vigor considerável as dez medidas econômicas sobre as quais dispõe o Consenso de Washington (...), mas os resultados ficaram abaixo das expectativas e um novo enfoque se fez necessário".

As análises das mais diversas fontes apontam para uma América Latina em profunda comoção. A evolução dos acontecimentos gerou fortes protestos sociais em numerosos países da região, os quais assumem formas diferentes, de acordo com os contextos históricos. Todavia, existem ao mesmo tempo alguns dados esperançosos. Segundo as pesquisas, apesar dos graves problemas econômicos, a grande maioria dos latino-americanos respalda firmemente o processo de democratização empreendido pela região. Num mundo em que, dentre mais de 190 países, apenas 82 são democracias, a América Latina aparece como uma das áreas do planeta com maiores avanços nesse campo. Os dados econômicos críticos destruíram boa parte da "ilusão econômica", mas não fizeram arrefecer a ilusão da democracia. O LatinBarómetro (2002) assinalou que, longe de cair em tentações autoritárias, em quatorze países da região o apoio à democracia cresceu, apesar da crise. Um caso muito significativo é o da Argentina. A despeito dos dramáticos prejuízos econômicos e sociais, o respaldo à democracia aumentou no último ano. Uma mensagem muito concreta parece surgir dessas tendências. Os latino-americanos, em ampla proporção, não estão pensando em deixar de lado a democracia, não estão pedindo menos democracia, e sim mais. Uma sociedade civil cada vez mais articulada e ativa vem exigindo uma participação real dos cidadãos no planejamento e na implementação das políticas públicas, transparência, controle social, aprofundamento da descentralização do Estado e outras metas similares.

Essa combinação de uma situação delicadíssima com a intensa busca de soluções através da democracia abre possibilidades de ação muito importantes para as políticas renovadoras. Urge que se pense em novas idéias em alguns aspectos cruciais, dentre eles: como planejar políticas econômicas com feições humanas, como articular estreitamente as medidas econômicas e as sociais, como melhorar a eqüidade no continente mais desigual de todo o planeta, e como levar adiante alianças construtivas entre o Estado, as empresas e a sociedade civil, em todas as suas manifestações, a fim de enfrentar a pobreza. Uma pergunta de fundo é como recuperar uma reflexão que vincule a ética à economia, iluminando com valores éticos o caminho a seguir e resgatando a ética como um motor do projeto de desenvolvimento. 
A política social é um agente estratégico do futuro em sociedades tão atingidas pela pobreza. Quando a sociedade em seu conjunto tem uma visão apropriada de seu papel, adotando-se as medidas apropriadas e sendo estas supervisionadas com eficiência, sua contribuição pode ser fundamental. Quando, ao contrário, a visão é equivocada e dá lugar a medidas débeis e isoladas, a deterioração social continua a aumentar, com graves riscos de implosão.

Este trabalho tem por finalidade concentrar-se na situação social e em algumas visões da política social de ampla circulação e forte influência, que é imprescindível rever para que se possa avançar. Considera que muitas dessas visões representam mitos, os quais entravam com extremo vigor a adoção da "política social necessária", e aspira a colocálos em foco e a pensar em propostas superadoras. Para isso, o trabalho recorre à soma de três etapas sucessivas. Em primeiro lugar, constrói um quadro básico dos delicados problemas sociais enfrentados pela região. A seguir, apresenta oito mitos largamente difundidos, procurando mostrar alguns de seus impactos regressivos na política social. Por último, extrai algumas conclusões para o futuro.

\section{Algumas tendências preocupantes no campo social}

O protesto social que hoje se expande na América Latina tem bases muito concretas. As tendências observáveis suscitam profunda inquietação e implicam sérias dificuldades em aspectos essenciais da vida cotidiana, para grandes setores da população. Entre elas destacam-se as que são resumidamente apresentadas a seguir:

\section{A. Aumenta a pobreza}

Segundo o Panorama Social da CEPAL (2001), a população situada abaixo da linha de pobreza representava $41 \%$ da população total da região em 1980, o que é uma cifra muito elevada em relação às médias do mundo desenvolvido e dos países de desenvolvimento médio. Portugal, o país com maior índice de pobreza na União Européia, tem $22 \%$ de sua população entre os pobres. $\mathrm{O}$ índice piorou nas duas últimas décadas, e a percentagem de pobreza latino-americana passou a representar, no ano $2000,44 \%$ de uma população muito maior. 
As estimativas nacionais indicam que a pobreza tem presença elevada em toda a região, com pouquíssimas exceções. Na América Central, são pobres $75 \%$ dos guatemaltecos, $73 \%$ dos hondurenhos, $68 \%$ dos nicaragüenses e $55 \%$ dos salvadorenhos. Também pobres são $54 \%$ da população peruana, mais de $60 \%$ da equatoriana, $63 \%$ da boliviana e, segundo se estima, acima de $70 \%$ da venezuelana. No México, o índice não é inferior a $40 \%$. Na Argentina, que tinha nos anos sessenta a menor percentagem, equivalente a $10 \%$, o quadro atual é de extrema gravidade, como se pode aquilatar pelos seguintes números, gerados por seu sistema oficial de estatísticas sociais:

\section{Tabela 1}

\begin{tabular}{|l|c|c|}
\hline \multicolumn{3}{|c|}{ ARGENTINA: Pobreza e indigência } \\
Anos de 1998 e 2002 \\
\hline $\begin{array}{c}\text { Outubro de } \\
\mathbf{1 9 9 8}\end{array}$ & $\begin{array}{c}\text { Maio de } \\
\mathbf{2 0 0 2}\end{array}$ \\
\hline Incidência da pobreza & $32,6 \%$ & $51,4 \%$ \\
\hline População pobre & 11.219 .000 & 18.219 .000 \\
\hline População indigente & 3.242 .000 & 7.777 .000 \\
\hline $\begin{array}{l}\text { Incidência da pobreza em } \\
\text { menores de 18 anos }\end{array}$ & $46,8 \%$ & $66,6 \%$ \\
\hline $\begin{array}{l}\text { Incidência da indigência em } \\
\text { menores de 18 anos }\end{array}$ & $15,4 \%$ & $33,1 \%$ \\
\hline Menores de 18 anos pobres & 5.771 .000 & 8.319 .000 \\
\hline $\begin{array}{l}\text { Número de pessoas que ingressam } \\
\text { na pobreza por dia }\end{array}$ & 1.898 .000 & 4.138 .000 \\
\hline Menores de 18 anos indigentes & 2.404 & 20.577 \\
\hline
\end{tabular}

Fonte: Presidência da Nação, Conselho Nacional de Coordenação de Políticas Sociais, Sistema de Informação, Avaliação e Monitoração de Programas Sociais, SIEMPRO (www.siempro.gov.ar/default2./htm), 2002.

Como se pode observar, mais da metade do país já é pobre, e a qualidade da pobreza deteriorou-se acentuadamente. Os extremamente pobres representam uma proporção crescente da pobreza total. As cifras relativas aos jovens são ainda muito piores. 


\section{B. Falta trabalho}

A pesquisa LatinBarómetro 2001 perguntou aos latino-americanos como estavam eles em matéria de trabalho. Um total de $17 \%$ respondeu não ter trabalho algum, enquanto $58 \%$ disseram-se inseguros quanto à possibilidade de conservar o emprego. Três em cada quatro tinham dificuldades significativas para trabalhar. Os dados estatísticos atestam a fragilidade do mercado de trabalho. Segundo os dados da CEPAL, o total de desempregados subiu de 6 milhões em 1980 para 17 milhões em 2000. Estima-se que a taxa atual de desemprego da região supere os $9 \%$. A isso vem somar-se uma tendência alarmante: houve um crescimento muito acentuado da população empregada na economia informal, em ocupações precárias, em sua grande maioria. Em 1980, isso representava 40\% da mão-de-obra agrícola inativa, cifra que se elevou para $60 \%$ no ano 2000 .

É particularmente aguda a situação dos setores mais jovens da força de trabalho. As taxas de desemprego, em numerosos países, correspondem ao dobro das taxas de desemprego gerais, como se pode verificar na tabela seguinte:

Tabela 2

\begin{tabular}{|c|c|c|c|c|c|}
\hline \multicolumn{4}{|c|}{ Taxa de desemprego } & \multicolumn{2}{|c|}{ Jovens } \\
\hline \multicolumn{4}{|c|}{ totais por sexo } & \multicolumn{2}{|c|}{ (14 a 25 anos) } \\
\hline País & Sexo & 1990 & 1999 & 1990 & 1999 \\
\hline Argentina & Total & 6 & 15 & 13 & 24 \\
\hline (Grande Buenos & Homens & 6 & 13 & 12 & 23 \\
\hline Aires) & Mulheres & 6 & 17 & 16 & 26 \\
\hline \multirow[t]{3}{*}{ Bolívia } & Total & 9 & 7 & 17 & 15 \\
\hline & Homens & 10 & 6 & 18 & 13 \\
\hline & Mulheres & 9 & 9 & 17 & 19 \\
\hline \multirow[t]{3}{*}{ Brasil } & Total & 5 & 11 & 8 & 22 \\
\hline & Homens & 5 & 9 & 9 & 18 \\
\hline & Mulheres & 4 & 14 & 8 & 26 \\
\hline \multirow[t]{3}{*}{ Chile } & Total & 9 & 10 & 18 & 22 \\
\hline & Homens & 8 & 9 & 17 & 20 \\
\hline & Mulheres & 10 & 11 & 19 & 24 \\
\hline \multirow[t]{3}{*}{ Colômbia } & Total & 9 & 19 & 20 & 37 \\
\hline & Homens & 7 & 16 & 15 & 32 \\
\hline & Mulheres & 13 & 23 & 25 & 42 \\
\hline \multirow[t]{3}{*}{ Costa Rica } & Total & 5 & 6 & 11 & 15 \\
\hline & Homens & 5 & 5 & 10 & 15 \\
\hline & Mulheres & 6 & 7 & 12 & 15 \\
\hline \multirow[t]{3}{*}{ Equador } & Total & 6 & 14 & 14 & 26 \\
\hline & Homens & 4 & 11 & 11 & 20 \\
\hline & Mulheres & 9 & 20 & 17 & 34 \\
\hline \multirow[t]{3}{*}{ El Salvador } & Total & 10 & 7 & 19 & 14 \\
\hline & Homens & 10 & 9 & 18 & 16 \\
\hline & Mulheres & 10 & 5 & 21 & 11 \\
\hline
\end{tabular}




\begin{tabular}{|c|c|c|c|c|c|}
\hline \multirow{3}{*}{ Guatemala } & Total & 4 & 3 & 7 & 5 \\
\hline & Homens & 3 & 4 & 7 & 6 \\
\hline & Mulheres & 4 & 2 & 7 & 3 \\
\hline \multirow[t]{3}{*}{ Honduras } & Total & 7 & 5 & 11 & 9 \\
\hline & Homens & 8 & 6 & 12 & 10 \\
\hline & Mulheres & 6 & 4 & 11 & 7 \\
\hline \multirow[t]{3}{*}{ México } & Total & 3 & 3 & 8 & 7 \\
\hline & Homens & 3 & 4 & 8 & 8 \\
\hline & Mulheres & 3 & 3 & 8 & 6 \\
\hline \multirow[t]{3}{*}{ Nicarágua } & Total & $\ldots$ & 14 & $\ldots$ & 21 \\
\hline & Homens & $\ldots$ & 14 & $\ldots$ & 18 \\
\hline & Mulheres & $\ldots$ & 14 & $\ldots$ & 26 \\
\hline \multirow[t]{3}{*}{ Panamá } & Total & 19 & 13 & 35 & 27 \\
\hline & Homens & 16 & 11 & 32 & 23 \\
\hline & Mulheres & 23 & 17 & 40 & 34 \\
\hline Paraguai & Total & 6 & 10 & 16 & 20 \\
\hline \multirow[t]{2}{*}{ (Assunção) } & Homens & 6 & 10 & 15 & 22 \\
\hline & Mulheres & 7 & 10 & 17 & 17 \\
\hline República & Total & 20 & $\ldots$ & 34 & $\ldots$ \\
\hline \multirow[t]{2}{*}{ Dominicana } & Homens & 11 & $\ldots$ & 22 & $\ldots$ \\
\hline & Mulheres & 32 & $\ldots$ & 47 & $\ldots$ \\
\hline \multirow[t]{3}{*}{ Uruguai } & Total & 9 & 11 & 24 & 26 \\
\hline & Homens & 7 & 9 & 22 & 21 \\
\hline & Mulheres & 11 & 15 & 28 & 32 \\
\hline \multirow[t]{3}{*}{ Venezuela } & Total & 10 & 15 & 19 & 26 \\
\hline & Homens & 11 & 14 & 20 & 22 \\
\hline & Mulheres & 8 & 16 & 18 & 33 \\
\hline
\end{tabular}

Fonte: CEPAL. Panorama Social da América Latina 2000-2001

Mais de $20 \%$ da população jovem encontram-se inativos, o que significa uma grave exclusão social logo no início da vida produtiva. Isso terá toda sorte de impactos regressivos e incide sobre os índices de delinqüência juvenil. Na tabela apresentada, pode-se observar o quadro de persistência de uma discriminação sexual significativa, apesar dos avanços obtidos. Os índices de desemprego das mulheres jovens são acentuadamente maiores que os dos homens.

\section{A situação crítica da infância}

O discurso generalizado da América Latina diz que as crianças devem ser a prioridade máxima, que a sociedade deve fazer todos os esforços para protegê-las. Mas elas não são protegidas. As cifras elevadas de pobreza são ainda muito mais altas entre as crianças. Enquanto a média da pobreza é calculada em $44 \%$, a pobreza afeta $58 \%$ das crianças com menos de cinco anos e $57 \%$ das que estão entre seis e doze anos. As expressões dessa situação são muito cruas. Segundo as esti- 
mativas da OIT (2002), 22 milhões de crianças com menos de 14 anos são obrigadas pela pobreza a trabalhar - em muitos casos, em condições que afetam gravemente sua saúde, e em prejuízo de sua educação. Por outro lado, uma em cada três crianças da região vem experimentando a mais severa das carências: a desnutrição. Acham-se na situação do "alto risco alimentar". Como expressão suprema do desamparo da infância, aumenta em toda a região o número de crianças que vivem nas ruas, na mais extrema desproteção e sujeitas aos mais graves perigos, entre eles o assassinato por grupos de extermínio, com alto grau de impunidade para policiais cuja ideologia, segundo se evidencia, só é equiparável ao nazismo. Investigações recentes do BID em Honduras indicaram que, tal como noutras realidades, o número de meninos de rua vem aumentando. Eles são atualmente estimados em $20.000,60 \%$ dos quais sofrem de depressão e, numa proporção de 6 em cada 100, optam por se suicidar. Nos últimos quatro anos, foram assassinados 1.300 crianças e jovens. Cesare de la Rocca (BID, 2002), diretor de um projeto inovador - o Axé de Salvador - que pretende oferecer alternativas para essas crianças, declarou, esclarecendo a situação, que na verdade não se deveria chamá-las de "meninos de rua", pois o problema não está nelas. De la Rocca salientou que "não existem meninos de rua, mas meninos fora da escola, da família e da comunidade": é a sociedade inteira que está falhando.

\section{O direito à saúde}

O teste mais elementar do progresso social consiste em assegurar ao conjunto da população o acesso ao direito humano primário - a saúde. Apesar de grandes esforços, as cifras latino-americanas indicam defasagens acentuadas entre regiões, setores da população, grupos étnicos e faixas etárias, além de carências significativas. Alguns problemas básicos, que os avanços da medicina permitiriam minimizar, continuam a ter alta freqüência nos setores pobres da região. Assim, segundo os dados da Organização Pan-americana de Saúde (2002), uma em cada 130 mães morre durante a gravidez ou no parto na América Latina, o que corresponde a 28 vezes mais do que nos Estados Unidos. Somam 18\% as mães que dão à luz sem nenhum tipo de assistência médica. À parte alguns progressos, as distâncias entre os países e as camadas sociais, no tocante à mortalidade infantil, são muito grandes. Na Bolívia, 83 em cada 1.000 crianças morrem antes de completar um ano de idade. No Canadá esse número é de apenas 5,7. A OPS calcula que morram 190.000 crianças anualmente na região latinoamericana, em decorrência de doenças que poderiam ser prevenidas ou controladas, como enfermidades diarreicas e infecções respiratórias. 
Esses dados estão ligados à baixa cobertura fornecida: 218 milhões de pessoas carecem de proteção de saúde; 100 milhões não têm acesso a serviços básicos de saúde; 82 milhões de crianças não recebem as vacinas necessárias; um elemento vital - a água - está fora do alcance de amplos setores da população pobre, havendo 160 milhões de pessoas que não dispõem de água potável.

E. Educação, as perguntas inquietantes

Alguns esforços denodados têm sido feitos para melhorar os níveis educacionais da região. Se alguém tiver alguma dúvida sobre o que significa viver num regime ditatorial ou numa democracia, poderá encontrar diferenças fundamentais, à parte o campo das liberdades, no investimento muito superior que as democracias latino-americanas fizeram na educação. Os gastos nessa área subiram significativamente como percentagem do produto interno bruto. Esses esforços permitiram quase universalizar a matrícula na escola primária e reduzir consideravelmente os níveis de analfabetismo. Todavia, restam perguntas inquietantes sobre alguns temas essenciais, como a evasão escolar, a repetência e a qualidade diferenciada da educação conforme as camadas sociais.

Os dados abaixo (Preal, Diálogo Interamericano, 2001) são ilustrativos a esse respeito e indicam grandes distâncias entre a região e outras zonas do planeta. 


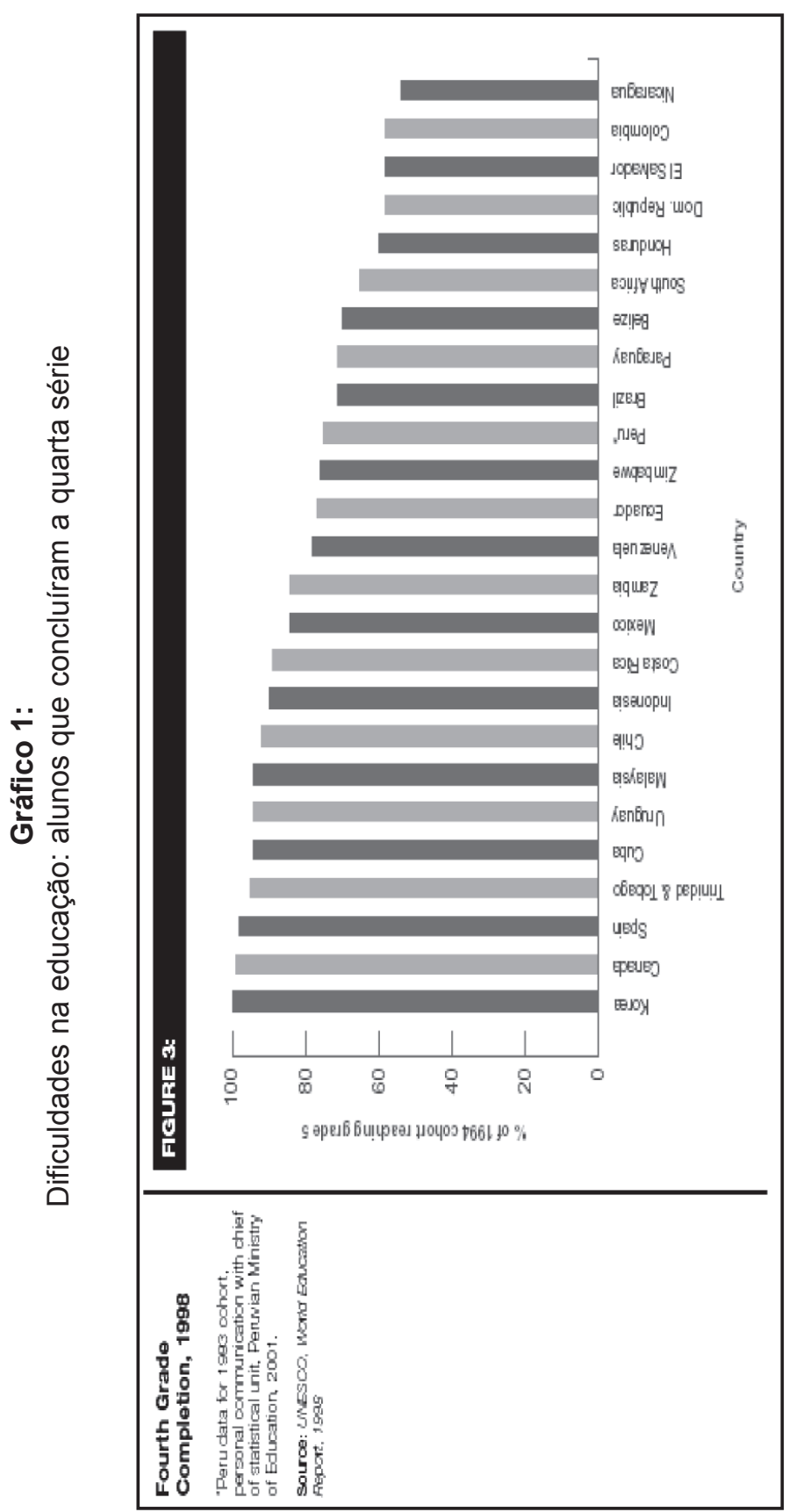

Agenda Social e Combate à Pobreza -157 
Enquanto, na Coréia, $100 \%$ das crianças concluem a quarta série, na América Latina esse resultado só é obtido por $25 \%$ a $50 \%$ delas, conforme o país. Isso se reflete na baixa escolaridade média da região, estimada em 5,2 anos.

A situação é também muito desfavorável na escola secundária, como se pode avaliar:

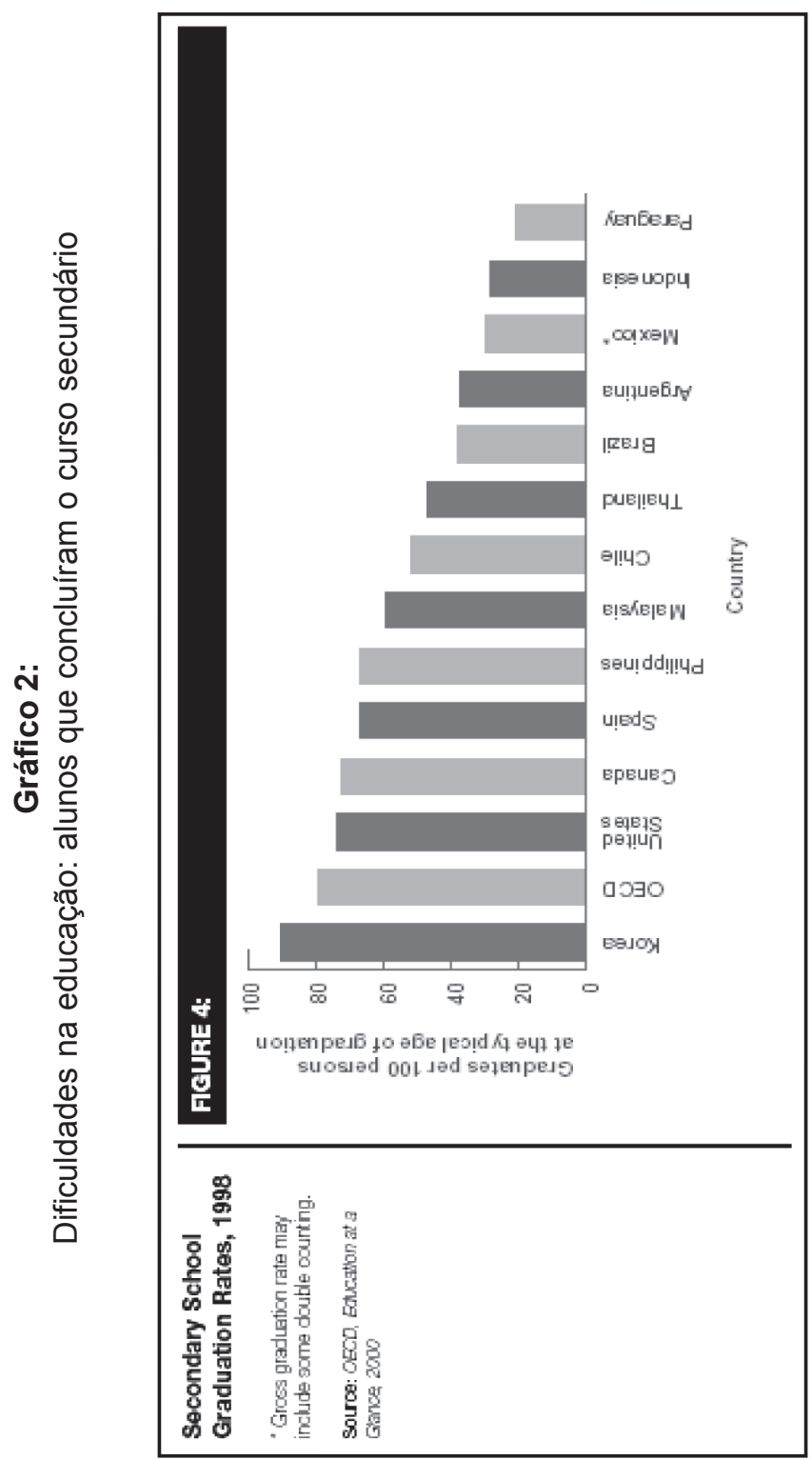

Desenvolvimento em Debate -158 
Na Coréia, 9 em cada 10 jovens terminam o secundário; no Sudeste Asiático em geral, 4 em cada 5. Nos três maiores países da América Latina, Brasil, México e Argentina, a proporção é de aproximadamente 1 em cada 3.

A escolaridade latino-americana tem um perfil fortemente enviesado. $\mathrm{Na}$ verdade, há uma intensa discriminação conforme o grupo étnico e a cor, como se pode observar pelo Gráfico 3.

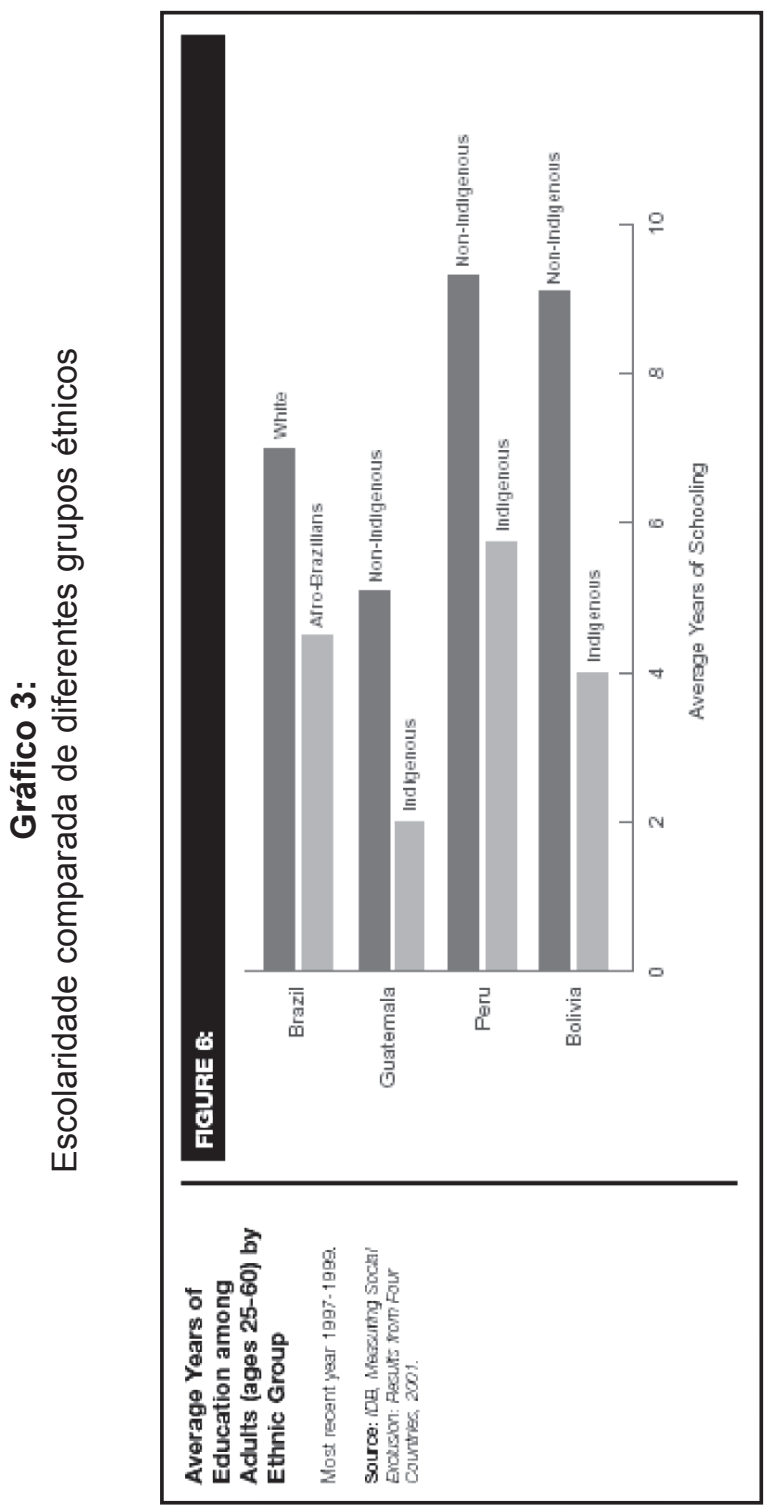


Os níveis de escolaridade, como se percebe, variam enormemente, conforme se trate da população branca ou afro-americana, indígena ou não indígena.

Embora tenha aumentado o investimento no ensino, medido em termos dos gastos com a educação em relação ao produto interno bruto, o que é um dado de alta positividade, as distâncias entre a região e as referências internacionais ampliaram-se no gasto público por aluno, o que constitui um indicador de valor estratégico. É o que mostra o Gráfico 4.

Enquanto o Canadá investe 6.000 dólares anuais por aluno, no Peru esse investimento é de 200 dólares anuais, e o Chile democrático, país da América Latina que mais gasta com a educação, investe a quarta parte do valor canadense, 1.500 dólares anuais.

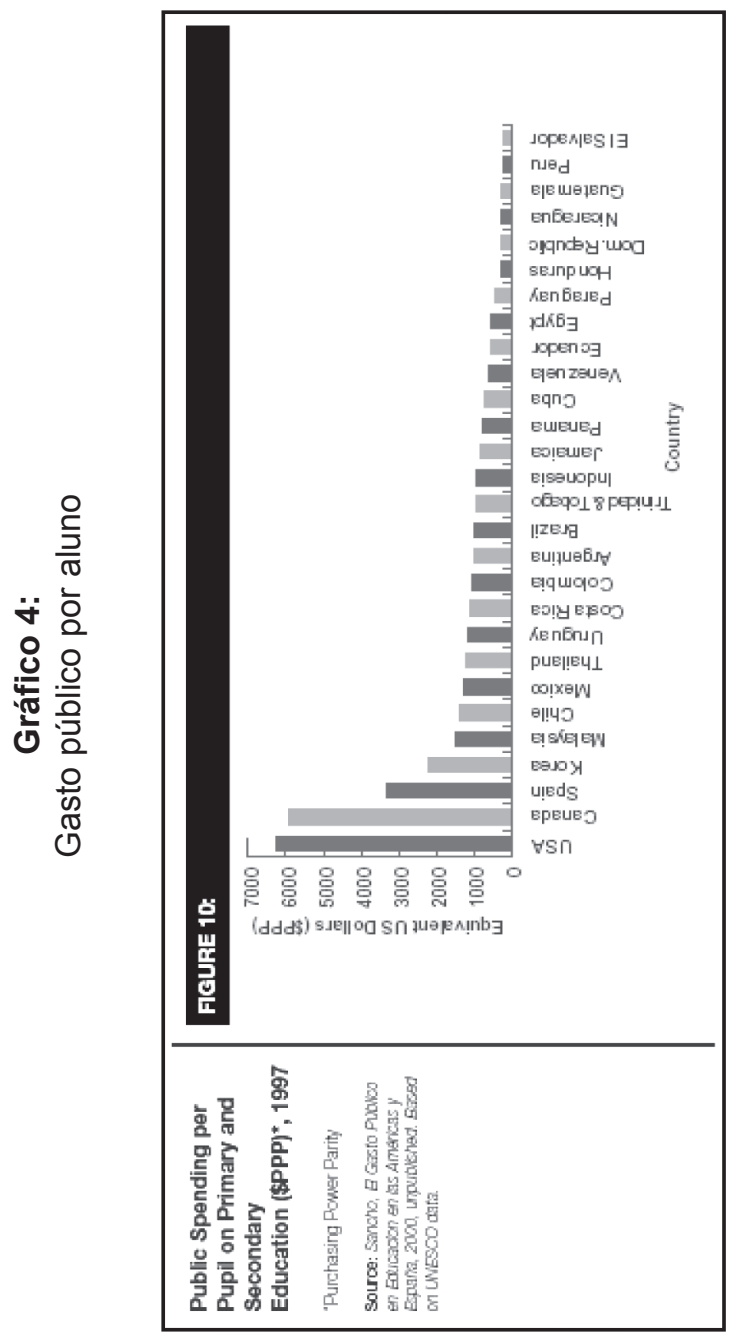




\section{F. A promessa da mobilidade social}

Um dos pilares da democracia é a visão de que é possível, através do esforço, melhorar a situação pessoal e familiar na sociedade. Essa aspiração legítima vem-se chocando, em muitos países da região latinoamericana, com duras realidades contrárias. As classes médias, em vez de se ampliar, tendem a se reduzir, e para muitos setores é dificílimo permanecer nelas. O caso mais dramático é o da Argentina, onde, em curto espaço de tempo, produziu-se uma destruição maciça de amplos setores das camadas médias. Mas ela não é a única: com menores graus de intensidade, essa deterioração também é registrada noutros países. As classes médias, poderoso motor de desenvolvimento, progresso tecnológico e criação de cultura, ávidas de educação, encontram-se historicamente encurraladas por políticas que lhes têm sido desfavoráveis, limitando suas possibilidades de desempenho na micro e na média empresas, o acesso ao crédito ou à tecnologia e algumas proteções elementares. Na Argentina, esses processos levaram a que um país que tinha $53 \%$ da população na classe média, em 1960, experimentasse, nos anos noventa, num prazo de apenas dez anos, a transformação de 7 milhões de pessoas $-20 \%$ de sua população da classe média - em "novos pobres". As camadas médias representam, atualmente, menos de $25 \%$ da população do país. Na busca da sobrevivência, vastos setores da classe média empobrecida geraram a economia do escambo. Outros vasculham diariamente as latas de lixo, à procura de restos de alimentos e de materiais recicláveis. A emigração, que implica o desarraigamento, a perda de laços familiares vitais e a destruição do capital social da pessoa, tem sido outro caminho preferido para escapar da falta de oportunidades. A pobreza e a nova pobreza têm alimentado uma onda de emigração sem precedentes.

\section{G. A família em risco}

Há uma vítima silenciosa do aumento da pobreza na região latinoamericana, uma instituição unanimemente reconhecida como esteio da sociedade, base do desenvolvimento pessoal, e que é também um refúgio afetivo e formadora dos valores básicos: a família. Muitas famílias não conseguem resistir à carência permanente dos recursos mais elementares, ao desemprego prolongado e às incertezas econômicas ameaçadoras e cotidianas, e se desfazem. Hoje, mais de 1/5 dos lares humildes da região ficaram apenas com a mãe à testa. Por outro lado, houve 
um expressivo aumento do índice de recusa dos casais jovens a constituir família, diante dos pontos de interrogação referentes ao trabalho, à renda e à moradia. As graves dificuldades econômicas causam extrema tensão não só nas famílias humildes, mas também nas das camadas médias. Criam-se condições que favorecem, entre outras coisas, uma canalização extremamente perversa, que é a violência doméstica. Estudos feitos pelo BID indicam um aumento acentuado dos indicadores correspondentes na região. Segundo eles, entre $30 \%$ e 50\% das mulheres latino-americanas, conforme o país em que vivem, sofrem violência psicológica no lar, enquanto $10 \%$ a $35 \%$ ficam expostas à violência física. São múltiplas as causas que influem nesse resultado, mas, claramente, a feroz tensão socioeconômica em que hoje vivem muitas famílias tem uma incidência significativa nessa situação.

Até em sociedades desenvolvidas, a pobreza deteriora severamente as famílias. Um estudo recente, de ampla cobertura nacional, com 11.000 entrevistas feitas nos Estados Unidos (Rumbelow, 2002), concluiu que as mulheres negras mais afetadas pela pobreza são as que têm as menores taxas de constituição familiar, os maiores índices de divórcio e as menores taxas de reconstituição da família. Dizem os investigadores que "as pressões impostas pela pobreza na relação familiar são as responsáveis por esse efeito”. E assinalam que os mesmos índices afetam as mulheres brancas que vivem em áreas pobres.

A desagregação de numerosas famílias na região latino-americana, sob o impacto da pobreza, significa, por sua vez, danos graves para as crianças em todos os planos fundamentais. Ela repercute no rendimento escolar, incide nos índices de evasão e repetência e afeta inclusive aspectos físicos básicos. Katzman (1997) assinalou, apoiado em diversos estudos realizados no Uruguai, que as crianças nascidas de uniões extraconjugais têm uma taxa de mortalidade infantil muito maior, e que as crianças que não vivem com os dois genitores sofrem danos maiores em diferentes aspectos do desenvolvimento psicomotor. No caso dos lares em que há violência doméstica, os efeitos são gravíssimos. Um estudo do BID feito na Nicarágua (1997) mostrou que os filhos de lares com violência intrafamiliar são três vezes mais propensos a buscar consultas médicas e são hospitalizados com maior freqüência. E 63\% deles repetem as séries escolares e abandonam a escola, em média, aos 9 anos de idade. 


\section{H. Uma sociedade cada vez mais insegura}

Os latino-americanos estão pagando muito caro pela deterioração social. Um dos custos mais visíveis e duros é o aumento incessante dos índices de criminalidade.

O número de homicídios teve um aumento de $40 \%$ na década de 1990. Há 30 homicídios anuais por cada 100.000 habitantes, taxa esta que multiplica por seis a dos países de criminalidade moderada, como os da Europa Ocidental. Esse aumento contínuo dos índices converteu a América Latina na segunda área geográfica com maior criminalidade do planeta, depois da zona mais pobre da Terra, o Saara africano. Na pesquisa LatinBarómetro 2001, dois em cada cinco entrevistados disseram que eles ou um membro de suas famílias tinham sido alvo de algum crime nos últimos doze meses.

Os custos econômicos dessa situação são altíssimos. Segundo os estudos do BID, o Brasil gasta com a segurança, em verbas públicas e privadas, $10,3 \%$ de seu PIB, o que significa uma cifra maior do que o PIB anual do Chile. A Colômbia gasta com a segurança $24,7 \%$ de seu PIB, e o Peru, 5,3\%.

A região é continuamente tentada a cair num raciocínio simplista a esse respeito: a criminalidade seria solucionada com o aumento cada vez mais intenso da repressão. Especialistas proeminentes nessa matéria, como Louis Vacquant (2000), advertem sobre a ineficácia e os riscos desse caminho. Analisando os dados comparativos internacionais, não se observam correlações significativas entre o aumento da população carcerária e a redução dos índices de criminalidade a médio e longo prazos. A simples punição não toca nas causas fundamentais que vêm gerando esse problema. Em contrapartida, adverte Vacquant, pode acabar levando a "criminalizar a pobreza", a uma opinião pública que comece a ver os pobres como criminosos em potencial e que, em vez de tentar ajudá-los a sair de sua situação, passe a isolá-los. Esse pode ser um cenário muito perverso em termos do perfil da sociedade, e um cenário sem saída.

O outro caminho consiste em buscar as causas profundas. É possível encontrar correlações sólidas entre a criminalidade latino-americana e pelo menos três variáveis. Em primeiro lugar, ela parece estar estreitamente ligada às altas taxas de inatividade juvenil já mencionadas. A criminalidade da região é praticada por pessoas muito jovens. Um aumento real das oportunidades de integração no merca- 
do de trabalho teria uma clara influência sobre ela. Por outro lado, há uma forte correlação entre a criminalidade e as famílias desfeitas. Um amplo estudo realizado nos Estados Unidos (Whitehead, 1993) comprovou que $70 \%$ dos jovens dos centros de detenção juvenil vinham de famílias em que o pai estava ausente. No Uruguai, investigando os menores internados no Instituto Nacional do Menor, Katzman (1997) constatou que apenas um em cada três fizera parte de uma família bem constituída na época em que se produziram os fatos que levaram a sua detenção. Esses dados correspondem a uma realidade: a família é uma instituição fundamental para a internalização de valores morais que afastam das condutas delituosas. Seu bom funcionamento, por conseguinte, incide de maneira relevante na prevenção de tais condutas.

Em terceiro lugar, observa-se uma alta correlação entre a criminalidade e os níveis de instrução. O aumento da escolaridade atua como um poderoso fator de prevenção da criminalidade.

A análise das causas conduz o enfoque simplista a uma direção muito diferente. A chave para atacar estruturalmente esse problema gravíssimo está ligada à implementação de medidas políticas que abram oportunidades para os jovens, protejam a estrutura familiar e elevem os níveis educacionais.

\section{A maior desigualdade do planeta}

Nos órgãos internacionais, há uma unanimidade quanto ao fato de que a América Latina é a região mais desigual do planeta. Os dados disponíveis atestam essa situação. A estrutura de distribuição da renda é a mais regressiva no plano internacional, como se pode observar pelos gráficos a seguir: 
Gráfico 5:

Renda recebida pelos $5 \%$ mais ricos

(Percentagem da renda total)

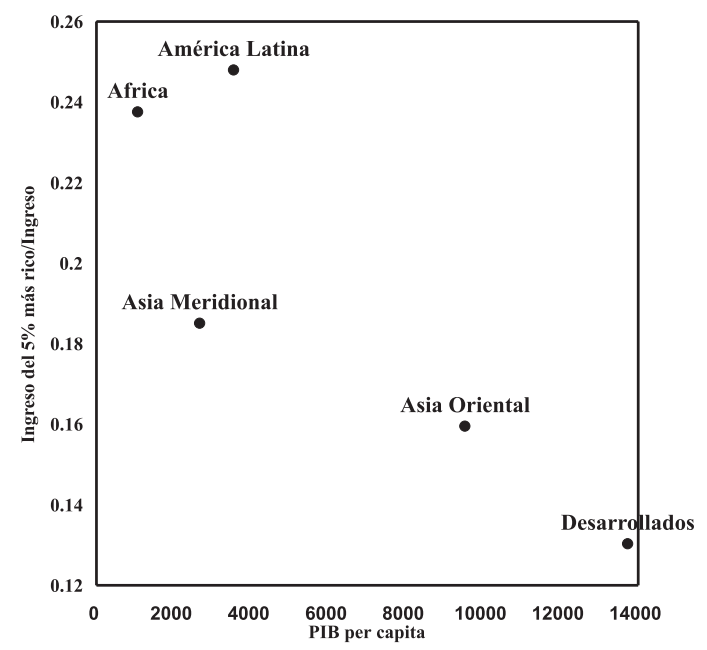

Gráfico 6:

Renda recebida pelos $30 \%$ mais pobres

(Percentagem da renda total)

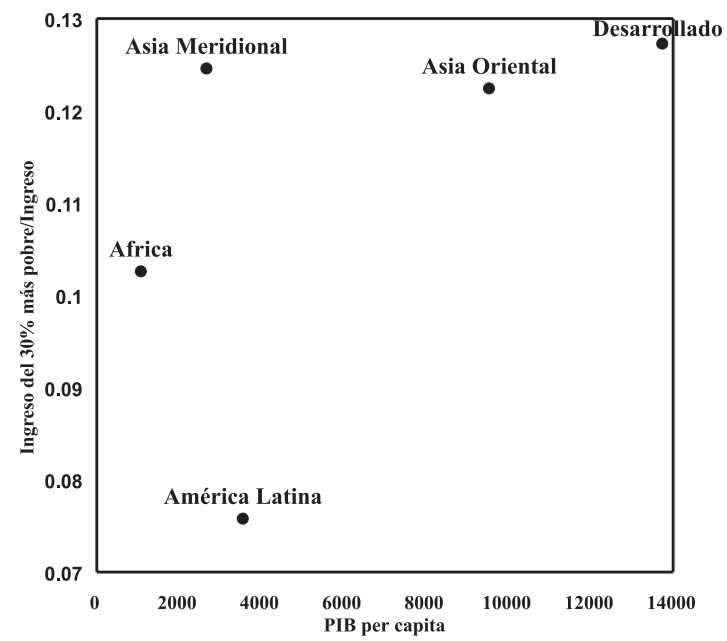

Fonte: BID (1998), Relatório sobre o Progresso Econômico e Social, Washington, 1998. 
A América Latina é a região em que a receita dos $5 \%$ mais ricos é superior à que eles percebem em qualquer outra área $-25 \%$ da renda nacional -, bem como o lugar em que os $30 \%$ mais pobres têm a menor renda: $7,5 \%$. Nela se encontra a maior defasagem de todas as regiões entre as classes sociais.

Os 10\% mais ricos da população latino-americana têm uma renda 84 vezes maior que a dos $10 \%$ mais pobres.

Essa elevada desigualdade determina que $2 / 3$ a 3/4 da população, conforme o país, tenham uma renda per capita inferior à renda per capita nacional. Isso confirma o acerto do paradigma de desenvolvimento humano da ONU e outras aproximações, quando ele questiona a utilidade da renda per capita nacional como medidor do progresso das nações. Como se observa nas sociedades muito desiguais, como as latino-americanas, esse dado não informa sobre a situação real da grande maioria da população.

A desigualdade da América Latina não se apresenta apenas no plano da distribuição da renda. Afeta outras áreas essenciais da vida, como o acesso a ativos produtivos, o acesso ao crédito, as possibilidades de educação, a saúde e, atualmente, a integração no mundo da informática. ${ }^{1}$ A crescente desigualdade no acesso à informática vem criando o risco de uma nova forma de analfabetismo, o analfabetismo cibernético, que exclui vastos setores populacionais do circuito fundamental da informação e das comunicações avançadas.

A desigualdade da região não é um problema a mais no rol de problemas sociais enunciados. Tudo indica que seja uma causa-chave do descumprimento da "promessa latino-americana". Quando se pergunta como é que, com freqüência, um continente com recursos naturais de riqueza excepcional, uma abundância de matérias-primas estratégicas, fontes de energia baratas, campos férteis e uma boa localização geográfica tem indicadores sociais tão deprimentes, uma das razões principais parece encontrar-se nos impactos regressivos implicados pelas desigualdades extremas. Uma abundante literatura recente dá conta delas, demonstrando que, entre outros impactos, elas reduzem a formação da poupança nacional, estreitam os mercados, impedindo a produção em escala e o aproveitamento das externalidades, permitem a formação de recursos humanos que geram fortes desigualdades em seu interior (por

\footnotetext{
${ }^{1} \mathrm{O}$ autor analisa detalhadamente as diferentes desigualdades latino-americanas e sua dinâmica in Bernardo Kliksberg, Desigualdade na América Latina. O debate adiado, UNESCO, Cortez Editora, Brasil, 2000.
} 
exemplo, os chefes de família dos $10 \%$ com a maior renda da região têm 12 anos de escolaridade, enquanto os dos $30 \%$ mais pobres têm apenas 5), reduzem os níveis de governabilidade e destroem o clima de confiança interna e o capital social. Os dados comparativos mundiais demonstram que a desigualdade é um entrave portentoso ao desenvolvimento sustentado. A "promessa latino-americana" espatifou-se contra esse obstáculo. Entre outros efeitos, o aumento da desigualdade aparece como uma causa importante do aumento da pobreza na região. As análises de Birdsall e Londoño (1997) demonstram que ele contribuiu para praticamente duplicar a pobreza. Berry (1997) deu a esse quadro o nome de situação de "pobreza desnecessária", porque ela seria muito menor se os decis inferiores da distribuição da renda não tivessem dela uma fração tão limitada.

\section{III. É hora de encarar os mitos sobre a política social}

Como atacar problemas tão graves como os que aqui foram sucintamente apresentados, que significam a subutilização de boa parte dos recursos humanos da região, solapam a governabilidade e entram em colisão direta com os valores éticos em que a América Latina acredita, como a proteção às crianças e à família, a oportunidade para os jovens e as possibilidades de uma vida digna para todos os cidadãos? A política social aparece como um instrumento central para enfrentá-los. Se os países da região contassem com políticas sociais integradas, coesas, descentralizadas, implementadas em co-gestão com a sociedade civil, participativas, transparentes e com um alto padrão de gerenciamento social, tais medidas poderiam transformar-se em meios efetivos de mobilização produtiva, resgate da dignidade e integração social. Mas esse caminho é dificultado, entre outras coisas, por percepções errôneas sobre o papel das potencialidades da política social. Abordaremos sucintamente vários desses mitos.

\section{Primeiro mito: a superfluidade da política social}

Uma aura de ilegitimidade costuma cercar a política social na região latino-americana. Setores influentes costumam expor, implícita ou explicitamente, a visão de que ela é uma espécie de "concessão forçada" à política. A mensagem transmitida é que os esforços deveriam concen- 
trar-se no único caminho real, que seria o crescimento econômico. A política social seria uma espécie de "custo forçado", que amiúde desviaria recursos desse esforço central. Essa visão foi sinteticamente verbalizada, em algumas ocasiões, com a afirmação de que "a única política social é a política econômica".

Colocada nessa difícil situação de deslegitimação contínua, a política social fica com suas possibilidades limitadas. Antes de mais nada, tem que argumentar permanentemente sobre seu direito de existir. É natural que, nessas condições de debilidade institucional, ela seja uma vítima fácil de cortes e ajustes, seja situada em lugares secundários nos organogramas e tenha seus representantes excluídos da participação nos espaços em que são tomadas as grandes decisões macroeconômicas. Uma experiente ministra latino-americana do Desenvolvimento Social resumiu sua vivência a esse respeito, num foro internacional, ao relatar que, após longos esforços, conseguira ser admitida no gabinete econômico do ministro coordenador das questões sociais, só que, é claro, “com voz, mas sem voto".

Os fatos indicam que é um grave erro considerar quase supérflua a política social. Em primeiro lugar, a suposta concessão política não o é. Constitui a própria essência do funcionamento da democracia. Segundo as pesquisas, a ação contra a pobreza é a reivindicação prioritária da cidadania latino-americana, cidadania esta que, numa democracia, é a real depositária do poder. A cidadania quer políticas sociais agressivas, bem articuladas, bem gerenciadas e eficazes. Ouvi-la não é fazer-lhe uma concessão, mas respeitar o sistema democrático.

Por outro lado, as experiências mundiais das últimas décadas demonstraram que, além de uma resposta a demandas legítimas, a política social é um aspecto fundamental da ação em prol de um desenvolvimento sustentável. O crescimento econômico é imprescindível e nele devem ser envidados os maiores esforços possíveis. Um país deve ter todo o empenho em crescer e dispor de estabilidade, progresso tecnológico e competitividade, mas os fatos indicam que, por si só, o crescimento não resolve o problema da pobreza. Um dos mitos que ficaram no caminho das idéias freqüentemente convertidas em dogmas, nas últimas décadas, é o do "gotejamento". O pressuposto da visão econômica convencional é que, produzido o crescimento, ele se derramará aos poucos por entre os desfavorecidos e os tirará da pobreza. As realidades têm tomado outra direção. Quando uma sociedade é muito desigual, como as latino-americanas, e quando suas políticas sociais são débeis, 
mesmo havendo crescimento, este quase nunca permeia os setores pobres. O Instituto de Pesquisas do Banco Mundial pergunta-se, em seu sugestivo texto "A qualidade do crescimento" (2000), como se explica que países que tiveram índices de crescimento similares apresentem, ainda assim, resultados muito distintos quanto às conquistas na melhoria de vida da população e quanto à sustentabilidade desse crescimento. Há uma grande questão ligada à qualidade do crescimento. Há uma grande diferença entre um crescimento que beneficia principalmente uns poucos setores, concentra ainda mais as oportunidades e a renda, só se verifica em alguns centros urbanos e dificulta o desenvolvimento das pequenas e médias empresas, bem como de outras iniciativas econômicas de base, e um crescimento que gera pólos de desenvolvimento em todo o país, potencializa o campo, melhora a eqüidade, impulsiona a pequena e média indústria e difunde a tecnologia. É característica do primeiro tipo de crescimento, "um crescimento distorcido", a relegação da política social, que existe apenas para apagar grandes incêndios. O segundo, o "crescimento compartilhado", tem como eixo uma política social que potencializa a população e aumenta suas possibilidades de integração no modelo de crescimento. A política social é uma base estratégica para se obter a qualidade de crescimento desejável.

\section{Segundo mito: a política social é um gasto}

Essa é uma terminologia totalmente difundida e avalizada. Quando falamos do social, estamos falando de um "gasto", de recursos que são consumidos. Isso transmite uma visão que reforça a anterior: a política social é supérflua e constitui uma despesa. E não se trata de uma linguagem insignificante, mas de algo que, com freqüência, expressa concepções subjacentes muito arraigadas.

A esta altura da experiência comparativa sobre a política social, cabe nos perguntarmos: será que ela é realmente um gasto?

A Organização Mundial de Saúde aceitou o desafio no campo da saúde. Convocou uma comissão, formada por economistas e especialistas ilustres, para analisar as relações entre saúde e economia. O relatório produzido, "Macroeconomia e saúde" (2002), jogou por terra algumas suposições generalizadas e demonstrou que destinar recursos à saúde não é gastar, mas investir, e com altíssimos níveis de retorno sobre o investimento. A comissão indicou que o mito diz que o crescimento econômico, por si só, melhoraria os níveis de saúde. Por conseguinte, 
os esforços deveriam concentrar-se nele. Mas a análise da história recente mostra realidades diferentes. Examinando as economias mais bemsucedidas dos últimos cem anos, verifica-se que os fatos funcionaram no sentido inverso. Grandes melhorias na saúde pública e na nutrição estiveram por trás de impressionantes arrancadas econômicas, como a do sul dos Estados Unidos, o rápido crescimento do Japão no início do século XX e o progresso do Sudeste Asiático nas décadas de 1950 e 1960. Fogel mostrou estatisticamente que o aumento das calorias disponíveis para os trabalhadores nos últimos 200 anos, em países como a França e a Inglaterra, fez uma contribuição importante para o crescimento do produto bruto per capita. Diamond (2002) assinalou que as histórias recentes de sucesso econômico, como as de Hong Kong, Mauritânia, Malásia, Cingapura e Taiwan, tiveram algo em comum: investiram maciçamente na saúde pública e tiveram um aumento de seu produto interno bruto com a queda da mortalidade infantil e a ampliação da expectativa de vida. Os bons níveis de saúde pública, portanto, não são uma conseqüência, mas um pré-requisito para que a economia possa crescer. Com uma população com problemas de saúde, o rendimento escolar cai, perdem-se muitos anos de vida ativa possível e os níveis de produtividade se reduzem. A comissão fez uma medição econométrica dos custos da não implantação de políticas de saúde enérgicas. Concluiu que o produto bruto da África estaria hoje aumentado em 100 bilhões de dólares, se, anos atrás, tivessem sido feitos todos os esforços para agir contra a malária. $\mathrm{O}$ índice elevado de malária está associado a uma redução do crescimento econômico de $1 \%$ ou mais a cada ano.

Os dados informam que a alocação de recursos na saúde, forma típica do chamado gasto social, não constitui um gasto, mas um investimento líquido. Por outro lado, a comissão estimou que a taxa de retorno sobre esse investimento é de 6 para 1.

Múltiplas análises indicam que a mesma situação é observada noutra expressão básica do chamado gasto social, a educação. A educação é um fim em si nas sociedades democráticas. Por outro lado, é um recurso econômico decisivo no atual panorama econômico mundial. A qualidade das qualificações da população de um país determina aspectos fundamentais de sua possibilidade de desenvolvimento e de absorção de novas tecnologias, bem como seus níveis de competitividade. Como assinalou Thurow (1996), passamos para economias "intensivas em conhecimento". As indústrias de ponta não se baseiam em recursos na- 
turais nem no capital, mas principalmente no conhecimento, como acontece com as telecomunicações, a biotecnologia, a microeletrônica e a informática. Nessas condições, como destacou esse autor, "o conhecimento é a única fonte de vantagens relativas". A educação é a via mestra para que se possa gerar e utilizar o conhecimento. O índice de retorno sobre o investimento, nas indústrias que investem em conhecimento e capacitação, é o dobro do obtido pelas indústrias que concentram seus investimentos no ativo imobilizado e em equipamentos. O mesmo ocorre noutros campos. Segundo os cálculos do UNICEF, um ano a mais de escolaridade entre as meninas da América Latina poderia reduzir as taxas de mortalidade infantil em 9 a cada 1.000. O incremento do capital educativo reduziria a gravidez na adolescência, melhoraria a capacidade de acompanhamento da mulher na gestação e no período pós-parto e ampliaria sua cultura para um desempenho nutricional adequado.

Novamente, não constitui gasto o conceito que descreve o valor, para a economia e a sociedade, da aplicação de recursos em programas educacionais eficientes. Como assinalou Delors (1999), "há muito mais coisas em jogo: da educação depende, em larga medida, o progresso da humanidade. (...) Hoje, está cada vez mais arraigada a convicção de que a educação constitui uma das armas mais poderosas de que dispomos para forjar o futuro".

A visão estreita da política social como um gasto deve dar lugar a seu verdadeiro papel: destinar recursos a uma política social gerida com eficiência significa investir no desenvolvimento das potencialidades e capacidades da população de um país. Esse é um fim em si e, ao mesmo tempo, é a mais poderosa ferramenta de desenvolvimento que se conhece.

\section{Terceiro mito: é possível prescindir do Estado}

Às características de superfluidade e mera despesa com que a política social tende a ser associada vem somar-se, com freqüência, uma terceira: essa política seria, quase por natureza, sumamente ineficaz. Com isso se fecha um círculo que cria as condições para se considerar como única alternativa a substituição das políticas sociais públicas pelo mercado, em forma total ou considerável. Na América Latina, esse raciocínio tem assumido, com freqüência, o caráter de uma "profecia autorealizadora". O fato de se postular como ponto de partida a inutilidade do Estado gerou medidas que debilitaram fortemente suas capacidades institucionais, desarticularam órgãos vitais, propiciaram, quase agressi- 
vamente, a retirada das pessoas mais capazes do setor público, e deshierarquizaram a função pública no campo social, assim como noutras áreas. Em diversas realidades, um Estado minado em suas bases organizacionais cumpriu essa profecia. Sua capacidade real de operação sofreu uma redução significativa.

Mas as exigências da realidade tomaram outro rumo. Stiglitz (2002) retratou do seguinte modo sua experiência pessoal com esse tema, numa visão que é provavelmente representativa de muitos outros especialistas: "Eu havia estudado as falhas tanto do mercado quanto do Estado, e não era tão ingênuo a ponto de fantasiar que o Estado pudesse resolver todas as falhas do mercado, nem tão tolo que acreditasse que os mercados resolviam sozinhos todos os problemas sociais. A desigualdade, o desemprego e a corrupção, estes eram pontos em que o Estado deveria assumir um papel importante." Na região mais desigual do planeta, e com altos índices de desemprego, o papel social da política pública é estratégico. Assim, enfrentar as desigualdades significa pôr ativamente em marcha, e bem administradas, políticas públicas que convertam em realidade os lemas consensuais da região: educação para todos, saúde para todos e trabalho - aos quais se poderiam acrescentar outros, como a democratização do crédito, o impulsionamento das pequenas e médias empresas e o acesso universalizado à informática e à Internet.

Como indica a experiência, o mercado - que tem amplo potencial produtivo, mas traz, ao mesmo tempo, o risco de falhas graves, como a substituição da concorrência por monopólios e oligopólios - não está em condições de responder a essas necessidades peremptórias. Destacando suas limitações no campo da saúde, por exemplo, o relatório da OMS sobre "Macroeconomia e Saúde" (2001) afirma que as doenças típicas dos pobres não interessam aos grandes laboratórios, porque não são atraentes em termos de mercado. Assim, havendo dois bilhões de pessoas com tuberculose latente e 16 milhões com a doença já em atividade, o último medicamento contra ela foi lançado no mercado em 1967. Um estudo da Associação Norte-americana de Medicina concluiu, a propósito das doenças tropicais que afetam majoritariamente os setores humildes, que, entre 1975 e 1997, surgiram apenas 13 novos medicamentos, metade deles fruto de pesquisas veterinárias.

No campo da educação, problemas muito delicados, como a alta desigualdade - que significa que menos de $20 \%$ das crianças da região freqüentam a pré-escola, requisito obrigatório de formação atual no mundo desenvolvido -, não encontram solução por parte do mercado, 
porque, em sua grande maioria, trata-se de crianças de famílias sem recursos. Os não freqüentadores não terão nenhuma possibilidade, se esta não surgir da política pública.

Os cidadãos captam claramente essas realidades. Na pesquisa LatinBarómetro de 2001, quando se perguntou aos entrevistados se o Estado não podia resolver nenhum dos problemas identificados por eles, apenas $6,6 \%$ responderam pensar assim; 53,2\% consideraram que o Estado poderia resolver todos, a maioria, ou um número considerável dos problemas existentes. Há uma expectativa, ampliada pelas frustrações com a inexistência de políticas públicas ativas, particularmente no campo social, de que tais políticas sejam administradas com eficiência e transparência.

Serão elas possíveis? Um eminente pensador administrativo, Henry Mintzberg, assinalou na Harvard Business Review (1996) que não vê por que não, frisando que a ineficiência não é exclusiva de nenhum setor da economia e afirmando, em tom irônico, que a idéia de que o melhor governo é o não-governo "é o grande experimento de economistas que nunca tiveram que administrar nada".

Quarto mito: a contribuição da sociedade civil é marginal

Assim como se desqualifica a política social pública, o raciocínio circulante tende a relativizar as possibilidades de contribuição da sociedade civil para a ação social. Ele transmite a mensagem de que essa contribuição é simbolicamente meritória, mas equivale à caridade. Não resolve nenhum problema de peso e, portanto, não mereceria um apoio especial. Assim, pouquíssimos países da região latino-americana tentaram explorar a sério a possibilidade de incentivos fiscais sistemáticos para promover essa contribuição. Em geral, respondendo a essa visão subestimadora, são débeis as medidas que almejam potencializar as possibilidades de participação da sociedade civil na política social.

Uma visão de peso cada vez maior nas análises sobre o desenvolvimento em nossos dias, a do capital social, denuncia com clareza o caráter regressivo desse mito. O capital social implica instalar no foco do desenvolvimento fatores pouco considerados, como a confiança interpessoal, a capacidade de associação, a consciência cívica e os valores éticos (Kliksberg, 2001). As medições indicam que esses fatores têm um peso direto nos desempenhos macroeconômicos, produtivos, políticos e sociais dos países. A capacidade de associação vincula-se sobretudo à capacidade de a sociedade gerar toda sorte de formas de cooperação. Quando ela é vigorosa, constrói-se um tecido social rico, 
que dá margem a múltiplas formas de contribuição para o projeto global de desenvolvimento. O nível de consciência cívica e o tipo de valores predominantes, por sua vez, têm alta influência nas decisões individuais de participar ativamente da resolução de problemas coletivos. Entre outras expressões do capital social encontram-se o voluntariado e a responsabilidade social das empresas privadas.

Segundo as estatísticas, o voluntariado constitui, atualmente, a sétima economia do mundo em produto bruto. Em diversos países desenvolvidos, gera mais de 5\% do PIB em bens e serviços, principalmente sociais. Em países como a Noruega, a Suécia, a Holanda, Israel, o Canadá, os Estados Unidos e outros, uma gigantesca rede de organizações baseadas no trabalho voluntário presta uma gama vastíssima de serviços aos setores mais fragilizados da população, como os sem-teto, as crianças, a família, os imigrantes, os deficientes e os idosos. A responsabilidade social empresarial começa a ser avaliada nas medições da qualidade das empresas, e surgiram os primeiros fundos de investimento que pedem aos investidores que só comprem ações das empresas com melhores índices de responsabilidade em termos de cidadania.

Existe na América Latina um imenso potencial nesse campo, o qual, se estimulado e canalizado, poderá converter-se num poderoso instrumento da política social. A atitude positiva para com o trabalho voluntário é ampla. Na Argentina, uma pesquisa do Instituto Gallup verificou que $20 \%$ das pessoas realizavam trabalhos voluntários e outros $30 \%$ se dispunham a fazê-lo, ou seja, um em cada dois argentinos. No Brasil, a GIFE integra um grupo crescente de fundações empresariais e organizações da sociedade civil que levam à frente um esforço de alta relevância, com instrumentos cada vez mais avançados. A riqueza do voluntariado na Argentina mostrou-se um elemento-chave diante dos dramáticos problemas sociais atuais. Agindo em coordenação com a enérgica política pública social que foi deslanchada, diversas organizações da sociedade civil multiplicaram seus esforços frente à emergência. Assim, entre elas, a Caritas, um grande projeto de apoio social da igreja católica, vem dando cobertura a 600.000 pobres, com base em 20.000 voluntários. A comunidade judaica, fortemente atingida pela destruição das pequenas classes médias em que se concentrava, organizou um amplo programa social, o Aliança Solidária, que vem dando proteção a quase 1/3 dela, apoiando-se em 9.000 voluntários. Iniciativas semelhantes surgiram em outras religiões e, na base social, em associações de bairro, clubes desportivos e associações culturais, nos quais elas se multiplicam diariamente. O Brasil 
teve uma grande riqueza de experiências desse tipo, entre elas a campanha contra a fome, encabeçada, anos atrás, por Herbert de Souza (Betinho), que atraiu milhões de pessoas.

Esse formidável capital latente numa sociedade, que ao mesmo tempo a impregna de solidariedade, foi marginalizado pelo mito e deve ser resgatado, valorizado e impulsionado.

\section{Quinto mito: a desqualificação dos pobres}

O Banco Mundial realizou uma pesquisa em larga escala com os pobres do mundo. Perguntou-se a 40.000 pobres de 50 países, entre eles vários da América Latina, quais eram suas percepções da pobreza (Banco Mundial, 2000). Eles explicaram que a pobreza não é apenas a carência de recursos básicos, mas destrói ou desgasta as famílias, além de causar danos psicológicos e afetivos. Enfatizaram que, acima de tudo, ela atenta contra sua dignidade como seres humanos. Uma de suas vivências centrais é o "olhar desvalorizador" que converge para eles dos diferentes setores da sociedade. Eles são vistos como pessoas inferiores, quase subumanas, em função de sua pobreza material. E isso afeta sua auto-estima e sua dignidade.

Ao serem interrogados sobre as organizações em que confiavam, eles puseram em primeiro lugar em sua escala as organizações dos próprios pobres. Um dos elementos fundantes disso é que, nestas, os pobres realmente participam, recuperando a confiança em si mesmos e em suas comunidades. As recomendações dos pesquisadores foram as de superar os moldes tradicionais da política social e investir no fortalecimento da capacidade de organização dos pobres, mediante a capacitação de seus líderes, a oferta de infra-estruturas para atividades societárias, a desregulamentação jurídica e outros meios.

As visões que circulam na região latino-americana costumam ver o pobre encerrado no olhar desvalorizador, sem incluir essas realidades. O pobre aparece como alvo de projetos que procuram atenuar impactos, e não como um sujeito capaz de dar contribuições importantes e, através delas, por sua vez, recobrar sua dignidade.

Diversos levantamentos latino-americanos indicam que, quando a capacidade de organização dos pobres é incentivada, ou, pelo menos, não é obstruída, os resultados produtivos são muito relevantes. Assim, num estudo econométrico da mobilização do capital social de campone- 
ses pobres através dos comitês de camponeses do Paraguai, José R. Molinas (2002) concluiu: "A ação coletiva entre os camponeses é central em qualquer tentativa eficaz de redução da pobreza rural. Pode contribuir significativamente para reduzir a pobreza rural através da oferta de bens públicos, como a melhoria do ensino público, melhores estradas, melhores postos de saúde, ajuda na disseminação de novas tecnologias e solução das falhas do mercado na oferta de crédito aos pobres. (...) O capital social facilita a ação coletiva entre os camponeses."

No Peru, uma pesquisa da Universidade do Pacífico (Portocarrero e Millán, 2001) constatou que os pobres têm uma atitude muito positiva em relação ao trabalho voluntário. Díaz Albertini (2001) assinalou: “eles não têm acesso ao mercado e ao Estado e, assim, recorrem a eles mesmos para garantir toda uma série de bens, serviços e respaldos sociais." Os pobres contribuem com mais de $80 \%$ do trabalho voluntários nas principais cidades do Peru, como indica a tabela abaixo:

\section{Tabela 3:}

Comparação de diferentes dimensões do trabalho voluntário nas cinco principais cidades do Peru, conforme o nível socioeconômico - 1997 (em percentagens)

\begin{tabular}{|l|c|c|cc|cc|}
\hline \multicolumn{1}{|c|}{ Dimensões do trabalho voluntário } & $\begin{array}{c}\text { Nível } \\
\text { Alto }\end{array}$ & $\begin{array}{c}\text { Nível } \\
\text { Baixo }\end{array}$ & $\begin{array}{r}\text { Nível } \\
\text { Baixo } \\
\text { Superior }\end{array}$ & $\begin{array}{c}\text { Nível } \\
\text { Baixo } \\
\text { Inferior }\end{array}$ & $\begin{array}{l}\text { Nível Muito Nível Muito } \\
\text { Baixo Sup. Baixo Inf. }\end{array}$ \\
\hline $\begin{array}{l}\text { \% que fez trab. voluntário em 1997 em } \\
\text { cada nível socioeconômico }\end{array}$ & 25,0 & 33,0 & 37,4 & 34,1 & 26,2 & 23,9 \\
\hline $\begin{array}{l}\text { Com respeito ao total do trab. } \\
\text { voluntário de 1997 }\end{array}$ & 2,8 & 16,9 & 16,9 & 28,5 & 31,0 & 4,0 \\
\hline Trabalho voluntário na área religiosa & 27,3 & 25,4 & 31,3 & 22,1 & 13,0 & 12,5 \\
\hline $\begin{array}{l}\text { Trabalho voluntário na área do } \\
\text { desenvolvimento e da moradia }\end{array}$ & 9,1 & 16,4 & 17,9 & 22,1 & 34,4 & 31,3 \\
\hline $\begin{array}{l}\text { Tipo de trabalho realizado: ensino e } \\
\text { capacitação }\end{array}$ & 54,5 & 53,7 & 37,3 & 20,4 & 21,1 & 25,0 \\
\hline $\begin{array}{l}\text { Tipo de trabalho realizado: mão-de- } \\
\text { obra }\end{array}$ & 27,3 & 29,9 & 32,8 & 33,6 & 50,4 & 50,0 \\
\hline
\end{tabular}

Fonte: Portocarrero e Millán (2001) 
Como se observa, os pobres são a grande maioria entre os voluntários. Enquanto as camadas altas e médias fazem suas contribuições fundamentalmente no ensino e na capacitação, os pobres as fazem através de sua mão-de-obra.

Ante o mito que desvaloriza os pobres e que se auto-realiza, ao aprofundar dessa maneira a exclusão deles, surge a possibilidade de uma política ativa de conferir poder a suas comunidades e organizações. Como destacou Brown (2002), administrador geral do Programa das Nações Unidas para o Desenvolvimento, "uma fonte central da pobreza é a falta de poder dos pobres". Conferir-lhes esse poder permitirá que eles recuperem sua "voz" abafada pelo mito.

\section{Sexto mito: 0 ceticismo quanto à participação e à cooperação interorganizacionais}

Dois instrumentos essenciais da política social necessária para enfrentar a pobreza, que são a participação e a cooperação interorganizacionais, encontram forte resistência na região.

O discurso latino-americano é cada vez mais unânime a respeito da participação. Tem uma "centimetragem" altíssima nas declarações públicas de líderes de toda sorte de organizações, públicas e privadas. Mas os avanços reais são limitados. Os indicadores mostram progressos escassos quanto ao estabelecimento de políticas concretas pró-participação, ao apoio substantivo às experiências participativas já em andamento e à busca de novos instrumentos jurídicos, institucionais e financeiros para apoiá-las. Que está ocorrendo, na realidade? Por um lado, tão forte parece ser a demanda pública de participação, que se torna quase inviável voltar-lhe as costas. Por outro, como sói acontecer, as resistências profundas contra ela refugiam-se no nível da gestão, que é o que dá forma às políticas reais. E nele, a participação tende a ser bloqueada.

Isso acontece a despeito das confirmações esmagadoras da superioridade administrativa da participação. Em todas as suas formas, a participação sempre teve legitimidade política. É uma via que fortalece o sistema democrático. Agora, porém, tem também a respaldá-la alguns argumentos gerenciais de peso. No centro da gestão do século XXI encontram-se modelos participativos. A possibilidade de alcançar, nos campos privado ou público, modelos organizacionais considerados ótimos, como as "organizações que aprendem", as "organizações inteli- 
gentes", as "organizações capazes de gerir conhecimentos", está fortemente ligada ao envolvimento dos membros na organização. Um guru da administração, Peter Drucker (1993), postulou: "O líder do passado era uma pessoa que sabia dar ordens. $\mathrm{O}$ do futuro tem que saber perguntar." Necessita, imprescindivelmente, da ajuda dos outros.

No campo social, sucedem-se as experiências que demonstram a superioridade produtiva dos modelos organizacionais que recorrem à participação ativa e autêntica da comunidade, comparados aos modelos verticais ou paternalistas. É o que ilustram os seguintes resultados, obtidos pelo Banco Mundial, ao analisar 121 projetos de abastecimento de água potável para camponeses pobres em 49 países da Ásia, da África e da América Latina:

Tabela 4:

Como construir o capital social?

O papel da participação

Efetividade segundo os níveis de participação da comunidade em projetos rurais de abastecimento de água

\begin{tabular}{|l|l|c|c|c|c|}
\hline \multirow{2}{*}{ Variação } & \multicolumn{4}{|c|}{ GRAU DE PARTICIPAÇÃO DOS BENEFICIÁRIOS } \\
\cline { 2 - 6 } & & Baixo & Médio & Alto & $\begin{array}{l}\text { TOTAL de } \\
\text { Projetos }\end{array}$ \\
\hline \multirow{2}{*}{$\begin{array}{l}\text { Grau de } \\
\text { efetividade } \\
\text { dos projetos }\end{array}$} & Maixo & 21 & 6 & 0 & $\begin{array}{c}27 \\
(22 \%)\end{array}$ \\
\cline { 2 - 6 } & Alto & 15 & 34 & 5 & $\begin{array}{c}54 \\
(45 \%)\end{array}$ \\
\hline $\begin{array}{l}\text { TOTAL DE } \\
\text { PROJETOS }\end{array}$ & & $\begin{array}{c}\mathbf{3 7} \\
\mathbf{3 1 \%}\end{array}$ & $\begin{array}{c}\mathbf{5 8} \\
\mathbf{( 4 8 \% )}\end{array}$ & $\begin{array}{c}\mathbf{2 6} \\
\mathbf{( 2 1 \% )}\end{array}$ & $\begin{array}{c}\mathbf{1 2 1} \\
\mathbf{( 1 0 0 \% )}\end{array}$ \\
\hline
\end{tabular}

Fonte: "Deepa Narayan. "The contribution of People's Participation: 121 Rural Water Supply Projects”, Banco Mundial, 1994.

Como se observa em 37 projetos realizados segundo um modelo de baixa participação, apenas um teve alta efetividade (a efetividade foi medida por 140 parâmetros). Em contrapartida, dos 26 executados segundo um modelo de alta participação, 21 foram muito eficazes. As explicações dessa distância acentuadíssima da eficiência são concretas. A participação comunitária vai acrescentando "pontos positivos" gerenciais a cada passo. Ajuda a fazer uma identificação correta das 
necessidades reais, gera idéias contínuas sobre como melhorar a administração do projeto, introduz na execução um controle social em tempo real, proporciona um feedback permanente e convoca a comunidade a "tornar seu" o projeto.

Diante dessas evidências, alguns argumentos do mito mostram-se inconsistentes. A velha alegação de que a participação toma tempo e é mais cara não é sustentável, frente aos resultados econômicos muito superiores gerados, desde o prazo imediato até o longo prazo. A atribuição das dificuldades da participação às próprias comunidades pobres, a pretexto de que elas não têm nível de instrução suficiente, não resiste ao cotejo com experiências como as do Grameen Bank, ou as do Educo, em El Salvador, nas quais setores muito pobres da população conseguiram levar adiante vigorosos processos participativos e crescer com eles. A realidade tem sido diferente, muitas vezes. As resistências à participação determinam que os encarregados de executar os projetos adotem desde o início normas e atitudes contraditórias com seu desenvolvimento. Depois, na busca de culpados pelos fracassos, é costumeiro adjudicálos ao desinteresse dos pobres, quando se fez todo o necessário para que esse interesse não surgisse, ou se frustrasse.

As causas reais do ceticismo antiparticipativo são variadas e complexas. Têm a ver, entre outras coisas, com o apego cultural à organização vertical como única forma possível de organização, apego este que caracteriza o meio organizacional latino-americano, com o predomínio de um pendor para o curto prazo e uma visão economicista estreita, que nega outros fatores que não sejam as variáveis econômicas clássicas.

Subjacente a isso, em muitas ocasiões, há outra visão ainda mais poderosa. A participação autêntica significa, decididamente, compartilhar o poder. Isso é próprio da democracia, mas não das estratégias concentradoras de poder.

O bloqueio da participação tira da política social uma via mestra para melhorar os desempenhos. Quando ele é enfrentado e superado, os resultados são surpreendentes. A participação comunitária vigorosa foi a característica da maioria dos projetos sociais bem-sucedidos da região latino-americana.

Outro recurso de peso, freqüentemente dificultado pelos mitos, é o da cooperação interorganizacional. Uma política social eficaz é aquela que ataca efetivamente as causas, e não apenas os sintomas da pobreza. Visto que tais causas são múltiplas, requer-se, necessariamente, a ação integrada de diversas organizações de diferentes campos. É preciso so- 
mar o governo federal, as regiões, os municípios, a sociedade civil e as organizações dos próprios pobres, e integrar as ações nos campos do trabalho, da educação, da saúde, da família e outros. Impõem-se alianças estratégicas entre as diferentes organizações.

De diversas maneiras, o mito postula falsas oposições. Uma de suas expressões mais freqüentes é o suposto confronto entre o Estado e a sociedade civil no campo social. Eles são apresentados como opções excludentes. No entanto, o que se requer é a soma. Ninguém pode realizar a tarefa sozinho. Uma política social pública agressiva é uma responsabilidade a que não se pode renunciar, numa América Latina que apresenta as tendências alarmantes vistas na primeira parte deste traba1ho. Ao mesmo tempo, a sociedade civil tem que ser um agente atuante da política social e se responsabilizar pelo problema. A soma das duas coisas, através de toda sorte de alianças, reforça-as mutuamente, amplia os recursos reais e maximiza as possibilidades de eficácia. O que podem fazer as políticas públicas ativas, combinadas com o voluntariado, a responsabilidade social empresarial, a ação das associações de bairro, o respaldo das comunidades religiosas e a contribuição das universidades, é muito mais do que os esforços isolados dos agentes.

A "criação de pontes organizacionais" na política social responde por sua eficiência. Assim, a experiência comparada indica que, para realmente potencializar as organizações dos pobres, é preciso criar laços entre elas e organizações maiores da realidade, que tenham acesso aos recursos econômicos e ao poder. Do contrário, os êxitos possíveis das organizações dos desfavorecidos serão limitados. Esse papel de facilitação de tais ligações pode ser desempenhado por organizações da sociedade civil e pelas próprias políticas públicas.

Diante do mito que institui como antagônicos o Estado, a sociedade civil e as organizações dos pobres, surge a possibilidade de "alianças virtuosas" entre políticas públicas que mobilizem e aproveitem o apoio da sociedade civil e que, em combinação com ela, potencialize o capital social dos pobres.

Será difícil abrir caminho para uma nova geração de políticas sociais renovadas, na América Latina, sem encarar de frente as resistências profundas à participação e às alianças interorganizacionais, sem desfazer mitos e preconceitos, enfrentar interesses e avançar para uma cultura organizacional que os supere a todos. 


\section{A ética da urgência}

Na América Latina, urge recuperar a política social em sua plenitude, para dar combate aos níveis agudos de pobreza que oprimem grande parte da população, num continente com uma pletora de riquezas potenciais.

Para isso, será necessário superar mitos como os aqui examinados e outros similares, muito ligados a uma visão estreitamente economicista e reducionista do desenvolvimento, a qual tem poucos resultados e conduziu a graves erros, em diversos casos.

Essa visão é hoje ativamente questionada no plano internacional. Desde o paradigma do desenvolvimento humano da ONU, que propõe um desenvolvimento cujos avanços se meçam por indicadores que evidenciem a melhora de aspectos substanciais da vida diária das maiorias, o ajuste com feições humanas da UNICEF e as críticas de diversos setores ao Consenso de Washington, até a concepção do desenvolvimento como crescimento da liberdade, formulada por Amartya Sen, múltiplas aproximações expressam a necessidade de articular um desenvolvimento integral com eqüidade.

Todas elas atribuem um lugar estratégico, nesse desenvolvimento, a uma política social ativa e hierarquizada. É o que sucede também com a nova geração de ilustres economistas jovens que se preocupam com o desenvolvimento, para a qual um recente artigo do New York Times (Altman, 2002) chamou a atenção. Eles trabalham em algumas das universidades de melhor reputação, como Harvard, o MIT e a London School of Economics, e têm várias queixas de peso contra a economia convencional. Dizem que ela se concentra apenas no "panorama geral" e não leva em conta o que acontece na realidade. Por outro lado, oferece receitas universais, enquanto, como assinala Besley (da London School), "os problemas são diferentes de um país para outro e até de uma região para outra dentro de um mesmo país". Assim, as receitas que ajudaram alguns em certos momentos não funcionaram para outros, como se observou na África, na antiga União Soviética, em diferentes partes do Sudeste Asiático e na América Latina. Esses jovens economistas “estão insatisfeitos com as supostas panacéias, tais como orçamentos equilibrados, nova infraestrutura e estabilidade financeira, e investigam em campo o que acontece com fatores como a motivação das pessoas e os fluxos de informação que norteiam as medidas políticas, país por país". Um de seus mais destacados expoentes, Ester Duffo, do MIT, diz que "o desenvolvimento é uma série de perguntas e, na verdade, não se define por técnicas". 
Frente a seus detratores, a necessidade de uma política social vigorosa pode exibir, ao lado de seu caráter fundamental para um desenvolvimento sustentável, uma legitimidade ética fundante. Até os textos bíblicos, pilares de nossa civilização, não apenas indicam que a pobreza é uma ofensa à dignidade do ser humano, criado por Deus, e que as grandes desigualdades atentam contra a moral básica, como também prescrevem normas detalhadas de política social. O Velho Testamento contém desde um sistema fiscal completo para financiar a ajuda aos mais fracos - o dízimo - até normas sobre a propriedade e a proteção do trabalhador, orientações sobre a ajuda ao semelhante, preceitos para assegurar o respeito à dignidade dos pobres e uma multiplicidade de normas similares. Na Bíblia, a voz dos profetas levanta-se para dizer que "Não haverá pobres entre vós" (Deuteronômio, 15:4). Não se trata da voz de um oráculo, mas de uma exigência moral. Ela assinala que depende de nós, da comunidade organizada e de cada pessoa, eliminar a pobreza. E a conclamação do Novo Testamento é a mesma.

Construir um modelo de desenvolvimento integral, produtivo e equitativo, norteado pelos valores éticos básicos; mobilizar como um de seus eixos uma política social de novo cunho, fundamentada em alianças entre as políticas públicas, a sociedade civil e as organizações dos desfavorecidos, instrumentada de modo descentralizado e que seja transparente e bem gerenciada; e postular a superação da pobreza e da desigualdade como prioridades fundamentais, tudo isso parece constituir o grande desafio que tem pela frente o continente latino-americano.

Por outro lado, há mais uma consideração ética que deve acompanharnos. Não é possível esperar mais. Existe uma "ética da urgência" a ser aplicada. Muitos dos danos causados pela pobreza são irreversíveis. Dia após dia, há vítimas irrecuperáveis, mães que perecem ao dar à luz, crianças desnutridas cuja capacidade neurológica fica permanentemente prejudicada pela fome, jovens sem oportunidade, à beira do delito, famílias destruídas pela pobreza. O campo social não admite postergações, diversamente de outros. Como assinalou o papa João Paulo II (1999), “o problema da pobreza é uma coisa urgente, que não pode ser deixada para amanhã”.

A América Latina pode avançar por esse caminho ou por um outro, muito arriscado, que também se insinua no horizonte. Trata-se do último mito que este trabalho quer enfocar. Existem setores de nossas sociedades que, mesmo sem intenção, começam a perder a sensibilidade para os males da pobreza. Vão-se acostumando, sem nenhuma revolta, com o espetáculo das crianças vivendo nas ruas, dos velhos abandona- 
dos, dos jovens sem saída, e passam a encarar tudo isso como uma espécie de fenômeno da natureza, "como se estivesse chovendo". Eles vêm perdendo a capacidade de indignação diante da injustiça, que é um dos dons centrais do ser humano. Recuperar essa capacidade será a base para se lutar por um desenvolvimento que inclua a todos.

\section{Referências bibliográficas}

ALTMAN, Daniel, "Small picture approach to a big problem, poverty", The New York Times, 20 de agosto de 2000.

BANCO INTERAMERICANO DE DESENVOLVIMENTO ( BID), IDB Bulletins, Washington, 21 de maio de 2002 ..

BANCO INTERAMERICANO DE DESENVOLVIMENTO (BID), "Informativo especial. Violência Doméstica", Washington, 1997.

BANCO INTERAMERICANO DE DESENVOLVIMENTO (BID), Relatório sobre o progresso econômico e social, Washington, 1998. BERRY, Albert, "The income distribution threat in Latin America", Latin American Research Review, Vol. 32, 1997, № 2.

BIRDSALL, Nancy e DE LA TORRE, Augusto, com Rachel Menezes, El disenso de Washington, Fundo Carnegie para a Paz Internacional e Diálogo Interamericano, Washington, 2001.

BIRDSALL, Nancy e LONDOÑO, Juan Luis "Assets inequality matters. An assessment of the World Bank's approach to poverty reduction", American Economic Review, maio de 1997.

BROWN, Mark, Apresentação mundial do Relatório sobre Desenvolvimento Humano 2002, do PNUD, Manila, 24 de julho de 2002.

CEPAL, Conferência de imprensa do Diretor Geral, José Antonio Ocampo, Santiago do Chile, $1^{\circ}$ de agosto de 2002.

CEPAL, Panorama Social da América Latina, Santiago do Chile, 2001.

DELORS, Jacques, Relatório da Comissão Internacional sobre educação para o século XXI, Paris, UNESCO, 1999.

DIAMOND, Jared, "Why we must feed the hands that could bite us", The Washington Post, 13 de janeiro de 2002.

DIAZ ALBERTINI, Javier, "Capital social, organizaciones de base y el Estado”, CEPAL, Conferência Regional, setembro de 2001. 
FORERO, Juan, "Still poor, Latin Americans protest push for open markets", The New York Times, 19 de julho de 2002.

JOÃO PAULO II, Discurso em Elk, na Polônia, 8 de junho de 1999.

KAZTMAN, Ruben, "Marginalidad e integración social en Uruguay", Revista de la CEPAL, agosto de 1997.

KLIKSBERG, Bernardo, Falácias e mitos do desenvolvimento social, UNESCO, Cortez Editora, Brasil, 2002. Ver também, sobre o tema do capital social, B. Kliksberg, Hacia una economía con rostro humano, Buenos Aires, Fondo de Cultura Económica, 2002.

LATINBARÓMETRO, Encuesta 2002, Santiago do Chile, 2002.

MATHEWS, Jessica T. e HAKIM, Peter, Prólogo ao dissenso de Washington, 2002.

MINTZBERG, Henry, "Managing government, governing management", Harvard Business Review, maio-junho de 1996.

MOLINAS, José R., ¿Es posible generar círculos virtuosos de acumulación de capital social y de reducción de pobreza rural?, Universidad Católica del Paraguay, 2002.

OIT, Relatório Anual, Genebra, 2002.

PARTNERSHIP FOR EDUCATIONAL REVITALIZATION IN THE AMERICAS (PREAL), "Lagging behind”, Diálogo Interamericano, Washington, 2001.

PORTOCARRERO, Felipe e MILLAN, Armando ¿Perú, país solidario?, Centro de Investigación de la Universidad del Pacífico, Lima, 2001.

RUMBELOW, Helen, "Study looks at women, marriage and divorce", The Washington Post, 25 de julho de 2002.

STIGLITZ, Joseph, El malestar en la globalización, Buenos Aires, Taurus, 2002. THUROW, Lester C., "Preparing students for the coming century", The Washington Post, 7 de abril de 1996.

VACQUANT, Louis, Las cárceles de la miséria, Buenos Aires, Editorial Manantial, 2000.

WHITEHEAD, Dafoe e B. Whitehead, "Don Quayle was right”, The Atlantic Monthly, Nova York, abril de 1993.

WORLD BANK, The quality of growth, Washington, 2000.

WORLD BANK, Deepa Narayan and others. Voices of the poor, Washington, 2000.

WORLD HEALTH ORGANIZATION, Macroeconomics and health, Genebra, 2002. 


\title{
RUMO A UMA GUERRA SOCIAL PLANETÁRIA?
}

\author{
Ignacio Ramonet*
}

Um ano após os atentados de 11 de setembro de 2001 e o começo da guerra contra a rede Al-Qaeda, quais são as principais características do planeta neste início do século XXI?

Os Estados Unidos dominam o mundo como nenhum império jamais o dominou. Exercem uma supremacia esmagadora nos cinco campos tradicionais do poder: político, econômico, militar, tecnológico e cultural. "Os Estados Unidos são como que o primeiro Estado protomundial", avalia um analista norte-americano: "Têm a capacidade de assumir a liderança de uma versão moderna do império universal, um império espontâneo cujos membros se submetem voluntariamente à sua autoridade."

Pela primeira vez na história da humanidade, portanto, o mundo é dominado por uma hiperpotência. Que exibiu de três maneiras, no Afeganistão, a sua hegemonia imperial: arrasando sob suas bombas, em poucas semanas, o regime Talibã e as redes armadas do Al-Qaeda que o sustentavam; montando uma enorme coalizão diplomática de apoio a sua ação de represália (com o respaldo, em particular, da Rússia e da China), ao mesmo tempo que restringia ao mínimo a referência à Organização das Nações Unidas; e, por fim, recrutando como simples forças suplementares as outrora orgulhosas forças armadas britânicas, e mantendo à distância aliados solícitos porém considerados incômodos, como a França, a Alemanha, a Itália ou o Japão.

Nesta nova era, entretanto, tal demonstração de poderio militar e diplomático é enganosa. Por quê? Porque a supremacia militar já não se

\footnotetext{
* Diretor de Le Monde diplomatique, Paris. Fundador e presidente de honra da ONG internacional ATTAC.

${ }^{1}$ International Herald Tribune, 7 de janeiro de 2002.
} 
traduz, como no século XIX e na primeira metade do século XX, por conquistas territoriais. Estas se tornaram, a longo prazo, politicamente impossíveis de gerir, financeiramente onerosas e midiaticamente desastrosas. Os meios de comunicação confirmam-se como um ator estratégico de primeira grandeza. ${ }^{2}$

\section{A dinâmica da globalização}

Eis outro fenômeno central: todas as nações vêm sendo arrastadas para a dinâmica da globalização. Trata-se, de certo modo, de uma segunda revolução capitalista. A globalização econômica atinge os mais ínfimos recônditos do planeta, ignorando tanto a independência dos povos quanto a diversidade dos regimes políticos.

Assim, a Terra passa por uma nova era de conquistas, como nos tempos da colonização. Mas, enquanto os atores principais da expansão conquistadora anterior eram os Estados, desta vez eles são as empresas e conglomerados, os grupos industriais e financeiros privados que pretendem dominar o mundo. Os senhores da Terra nunca foram tão reduzidos em termos numéricos nem tão poderosos. Esses grupos situam-se, essencialmente, na tríade Estados Unidos-Europa-Japão. Metade deles tem sua sede nos Estados Unidos.

Essa concentração do capital e do poder acelerou-se de maneira espantosa nos últimos vinte anos, sob o efeito das revoluções na tecnologia da informática.

A partir deste começo de milênio, dar-se-á um novo salto à frente, com as novas técnicas genéticas de manipulação da vida. A privatização do genoma humano e o patenteamento generalizado do ser vivo abrem novas perspectivas de expansão para o capitalismo. Uma grande privatização de tudo o que concerne à vida e à natureza está em fase de preparação, favorecendo o aparecimento de um poder provavelmente mais absoluto do que tudo o que já se conheceu na história.

A globalização visa menos a conquistar países do que a conquistar mercados. A preocupação desse poder moderno, com efeito, não é a

\footnotetext{
${ }^{2}$ A ex-secretária de Estado do presidente Clinton, Sra. Madeleine Albright, chegou mesmo a afirmar que "a rede CNN é o décimo sexto membro do Conselho de Segurança da ONU".
} 
conquista de territórios, como nas grandes invasões ou nos períodos coloniais, mas a apropriação das riquezas.

Essa conquista é acompanhada por estragos impressionantes. Indústrias inteiras são brutalmente arruinadas em todas as regiões. E com o sofrimento social daí resultante: desemprego maciço, subemprego, precariedade, exclusão. Há 50 milhões de desempregados no seio da União Européia, um bilhão de desempregados e subempregados no mundo... Há uma superexploração de homens, mulheres e - o que é ainda mais escandaloso - crianças: 300 milhões delas são exploradas, em condições de grande brutalidade.

A globalização é também a pilhagem planetária, como mais uma vez acaba de denunciar a Conferência de Joanesburgo sobre desenvolvimento sustentável. Os grandes conglomerados devastam o meio ambiente através de expedientes absurdos; tiram proveito de riquezas naturais que são patrimônio comum da humanidade, e o fazem sem escrúpulos e de maneira irrefreada. Isso é igualmente acompanhado pela criminalidade financeira ligada ao mundo dos negócios e aos grandes bancos, que reciclam somas superiores a um trilhão de euros por ano, ou seja, mais do que o produto interno bruto de um terço da humanidade.

\section{A pilhagem planetária}

A mercantilização generalizada traduz-se num assombroso agravamento das desigualdades. Enquanto a produção planetária de gêneros alimentícios básicos representa mais de $110 \%$ das necessidades mundiais, 30 milhões de pessoas continuam a morrer de fome a cada ano e mais de 800 milhões estão subalimentadas.

Em 1960, os 20\% mais ricos da população mundial dispunham de uma renda 30 vezes maior que a dos $20 \%$ mais pobres. Isso já era escandaloso. Mas, em vez de melhorar, a situação agravou-se ainda mais. Porque hoje, a renda dos mais ricos em relação aos mais pobres não é 30 , porém 82 vezes mais elevada! Dos seis bilhões de habitantes do planeta, apenas 500 milhões vivem na fartura, enquanto 5,5 bilhões continuam a passar necessidade. $\mathrm{O}$ mundo anda de cabeça para baixo.

As estruturas estatais, assim como as estruturas sociais tradicionais, têm sido desbaratadas de maneira desastrosa. Mais ou menos em toda parte, nos países do Sul ou do Leste, o Estado está desmoronando. As autoridades se retiram ou são expulsas dos territórios periféricos, que se 
transformam em terras de ninguém em que o direito não vigora. Mais ou menos em toda parte, no Paquistão, na Argélia, na Somália, no Congo, na Colômbia, nas Filipinas ou no Sri Lanka, desenvolvem-se entidades caóticas ingovernáveis, que escapam a toda e qualquer legalidade e tornam a mergulhar num estado de barbárie. A força suplanta o direito e somente os grupos de saqueadores ficam em condições de impor sua lei, transformando a população em refém.

Surgem perigos de um tipo novo: hiperterrorismo, fanatismos religiosos ou étnicos, proliferação nuclear, crime organizado, redes mafiosas, especulação financeira, grande corrupção, ampliação de novas pandemias (AIDS, o vírus Ebola, a doença de Creutzfeldt-Jakob etc.), poluição de extrema intensidade, efeito estufa, desertificação e outros mais.

Embora a democracia e a liberdade pareçam triunfar, num planeta livre dos piores regimes autoritários, as censuras e manipulações fazem um retorno paradoxal e vigoroso, sob diversas fachadas. Novos e sedutores "ópios do povo" propõem uma espécie de "melhor dos mundos", distraem os cidadãos e tentam desviá-los da ação cívica e reivindicatória. Nesta nova era da alienação, na era da Internet, da world culture, da "cultura global" e da comunicação planetária, as tecnologias da informação desempenham, mais do que nunca, um papel ideológico central de amordaçar o pensamento.

\section{O estilhaçamento do mundo}

Todas essas mudanças estruturais e conceituais, que atuam há uma dezena de anos, produziram um autêntico estilhaçamento do mundo. Conceitos geopolíticos como Estado, poder, soberania, democracia ou fronteira já não têm a mesma significação. A tal ponto que, se observarmos o funcionamento real da vida internacional, constataremos que seus atores mudaram.

$\mathrm{Na}$ escala planetária, os três protagonistas principais, que, no Antigo Regime, eram a nobreza, o clero e o terceiro estado, são agora: (1) as associações de Estados - NAFTA (Estados Unidos, Canadá e México), União Européia, MERCOSUL, ANSA etc.; (2) as empresas globais e os grandes grupos midiáticos ou financeiros; (3) as organizações não governamentais (ONGs) de envergadura mundial (Greenpeace, Anistia Internacional, Attac, Human Rights Watch, World Wild Life etc.) 
Esses três novos atores agem num quadro planetário que, num sinal dos tempos, é menos fixado pela Organização das Nações Unidas do que pela Organização Mundial do Comércio (OMC), novo árbitro global.

$\mathrm{O}$ voto democrático tem pouquíssima influência no funcionamento interno desses três novos atores. Essa grande mutação mundial, que esvazia o sentido da democracia, instaurou-se sem que nos apercebêssemos e sem que os próprios responsáveis políticos tenham consciência dela.

\section{Agir contra a globalização}

Todas essas mudanças, rápidas e violentas, efetivamente desestabilizam os dirigentes políticos. Em sua maioria, eles se sentem oprimidos por uma globalização que modifica as regras do jogo e os deixa parcialmente impotentes. É que os verdadeiros donos do mundo não são os que detêm as aparências do poder político.

Por isso é que os cidadãos vêm multiplicando as ações e mobilizações contra os novos poderes, como temos visto desde dezembro de 1999, por ocasião da conferência de cúpula da Organização Mundial do Comércio em Seattle, depois em Praga, em Davos, em Nice, em Quebec e em Gênova. Eles estão convencidos de que, no fundo, o objetivo da globalização liberal, neste começo de milênio, é a destruição do coletivo, a apropriação das esferas pública e social pelo mercado e pelo setor privado. E estão decididos a se opor a isso.

Outra constatação: a supremacia geopolítica e o exercício da hiperpotência, na era do neoliberalismo, de modo algum garantem a todos os cidadãos um nível de desenvolvimento humano satisfatório. Por exemplo, entre os habitantes de um país rico como os Estados Unidos, há 32 milhões de pessoas cuja expectativa de vida é inferior a 60 anos, 40 milhões sem assistência médica, 45 milhões vivendo abaixo da linha de pobreza e 52 milhões de analfabetos... Do mesmo modo, no seio da opulenta União Européia, na era do nascimento do euro, há 50 milhões de pobres e 18 milhões de desempregados...

Em escala mundial, a pobreza continua a ser a regra, enquanto a fartura é a exceção. As desigualdades tornaram-se uma das características estruturais de nossa época. E estão-se agravando, afastando cada vez mais os ricos dos pobres. As 225 maiores fortunas do mundo representam um total de mais de um trilhão de euros, ou seja, o equivalente à renda de $47 \%$ das pessoas mais pobres da população mundial $(2,5$ bi- 
lhões de pessoas!). Simples indivíduos são hoje mais ricos do que Estados: o patrimônio das 15 pessoas mais ricas do planeta ultrapassa o produto interno bruto total do conjunto dos países da África sub-saariana...

\section{Dominadores e dominados}

Desde o início do século XX, o número de nações do mundo não parou de aumentar, passando de cerca de quarenta para quase duzentas. No plano geopolítico, entretanto, o mundo continua a ser dominado pelo pequeno número de Estados (Reino Unido, França, Alemanha, Japão, Estados Unidos, Rússia) que já o dirigia no fim do século XIX. Dentre as dezenas de países nascidos do desmantelamento dos grandes impérios coloniais - britânico, francês, espanhol, holandês, português ou belga -, apenas três (Coréia do Sul, Cingapura e Taiwan) atingiram níveis de progresso que lhes permitem aceder à condição de países desenvolvidos. Os demais continuam atolados num subdesenvolvimento crônico e numa pobreza endêmica.

Ser-lhes-á ainda mais difícil sair desse atoleiro, na medida em que as matérias-primas (inclusive os hidrocarbonetos) em cuja venda se apóia essencialmente a sua economia têm visto seus preços despencarem de forma inelutável. Numerosos produtos de base (metais, fibras, gêneros alimentícios) são agora menos utilizados pelos grandes países desenvolvidos, ou foram substituídos por produtos sintéticos. Assim, no Japão, em relação a 1973, cada unidade de produção industrial reduziu o consumo de matérias-primas em aproximadamente $40 \%$ !

A nova riqueza das nações repousará cada vez mais, no curso deste século XXI, na massa cinzenta - no saber, na pesquisa, na capacidade de inovar -, e não mais na produção de matérias-primas. A propósito disso, pode-se até afirmar que os três componentes tradicionais do poder - tamanho do território, importância demográfica e riqueza em matérias-primas - não mais constituem trunfos invejáveis e, paradoxalmente, até se tornaram desvantagens onerosas na era pós-industrial.

As nações muito extensas, muito populosas e muito ricas em matérias-primas - Rússia, Índia, China, Brasil, Nigéria, Indonésia, Paquistão, México - figuram entre as de maior desigualdade do planeta, com a maioria da população ainda mergulhada na pobreza. A exceção dos Estados Unidos mascara a norma. 
Em contrapartida, na era da globalização financeira, micro-Estados quase desprovidos de território, sem grande população e sem matériaprima alguma - Mônaco, Liechtenstein, ilhas Cayman, Cingapura possuem rendas per capita situadas entre as mais altas do mundo...

\section{O caos generalizado}

A área do caos generalizado não pára de se ampliar, englobando e absorvendo cada vez mais Estados na economia definitivamente estagnada e um número maior de países na violência endêmica. Desde 1989, data do término da Guerra Fria, houve mais de sessenta conflitos armados, que fizeram centenas de milhares de mortos e mais de dezessete milhões de refugiados! Em muitos lugares da Terra, a vida cotidiana tornou-se simplesmente infernal, a ponto de cada vez mais pessoas, em particular as mais jovens, procurarem fugir do caos e da violência e quererem emigrar a qualquer preço para as regiões desenvolvidas e pacíficas.

Chegamos até mesmo a ver habitantes de alguns países renegarem a luta dos mais velhos pela independência e pleitearem o retorno da potência colonial (na República de Comores), ou mesmo a absorção pura e simples pela metrópole dominante (em Porto Rico). O Terceiro Mundo deixou de existir como entidade política.

Tudo isso atesta a crise do Estado nacional e da política, no momento em que a segunda revolução capitalista, a globalização da economia e as mudanças tecnológicas estão transformando o meio geopolítico. E também no momento em que se multiplica, em razão das fusões e das concentrações, o número de empresas gigantescas cujo peso às vezes supera o dos Estados. O volume de negócios de algumas grandes empresas é superior ao PIB de inúmeros países. Cada uma das cem principais empresas globais vende mais do que é exportado pelos 120 países mais pobres. Essas firmas gigantescas e globais controlam $70 \%$ do comércio mundial...

Os dirigentes dessas empresas, bem como os dos grandes grupos financeiros e midiáticos, detêm a realidade do poder e, através de seus lobbies poderosos, influem com todo o seu peso nas decisões políticas dos governos legítimos e eleitos. Com isso, confiscam a democracia em benefício próprio. 


\section{Os contrapoderes necessários}

Mais necessários do que nunca, os contrapoderes tradicionais (partidos, sindicatos, imprensa livre) parecem pouco atuantes. E os cidadãos se perguntam que iniciativas audaciosas poderiam restabelecer o contrato social contra o contrato privado no século XXI. Perguntam-se se o mundo terá que passar por um novo ciclo de revoluções violentas como as que se sucederam ao longo dos séculos XIX e XX - para deter de maneira duradoura o rolo compressor do capitalismo.

\section{Informática e globalização}

Conhecemos o dito de Karl Marx: "Dêem-me o moinho movido a vento e eu lhes darei a Idade Média." Poderíamos acrescentar, parafraseando-o: "Dêem-me a máquina a vapor e eu lhes darei a era industrial." Ou ainda, aplicando seu dito à era contemporânea: "Dêem-me o computador e eu lhes darei a globalização."

Ainda que esses determinismos sejam forçosamente exagerados, eles resumem bastante bem esta idéia central: em momentos cruciais da história, uma invenção capital - que nunca resulta do acaso - subverte a ordem das coisas, desvia a trajetória de uma sociedade e desencadeia um novo movimento de longa duração. Imperceptivelmente, há uns bons dez anos, entramos num movimento desse tipo.

No fim do século XVIII, a máquina a vapor, ao provocar a revolução industrial, modificou a face do mundo: foi o deslanchar do capitalismo, o aparecimento da classe trabalhadora, o nascimento do socialismo, a expansão do colonialismo etc. Pois bem, essa máquina, decididamente, substituía apenas os músculos.

Com sua vocação para substituir o cérebro, o computador vem provocando, bem diante de nossos olhos, mudanças ainda mais assombrosas e inéditas. Com efeito, todos podem constatar que tudo já está modificado a seu redor: o ambiente geopolítico, o contexto econômico, os dados políticos, os parâmetros ecológicos, os valores sociais, os critérios culturais e as atitudes individuais.

As tecnologias da informação e da comunicação, assim como a revolução digital, fizeram-nos entrar, nolens volens, numa nova era. Uma era cujas características centrais são a transmissão instantânea de dados virtuais e a proliferação de ligações e redes eletrônicas. A Internet cons- 
titui o cerne, a encruzilhada e a síntese da grande mudança que está em andamento. As vias expressas da comunicação representam, na era atual, o que foram as estradas de ferro na era industrial: fatores vigorosos de impulsionamento e intensificação das trocas.

\section{A nova economia}

Tendo em mente essa comparação, muitos especuladores lembraram-se de que "as vantagens econômicas de um sistema de transporte aumentam em linha poligonal, com saltos repentinos, quando se realizam certas ligações". E recordaram que, "na década de 1840, a construção das estradas de ferro constituiu, por si só, a mola mais importante do crescimento industrial na Europa Ocidental". ${ }^{3}$ A partir de meados dos anos noventa, portanto, os neocapitalistas apostaram no crescimento exponencial, durante essa fase de decolagem, de todas as atividades ligadas às vias expressas da comunicação, às tecnologias das redes virtuais e à Internet. Chamou-se a essa febre especulativa, em 1999 e 2000, a "nova economia".

Muitos investidores estavam convencidos de que, no momento de uma das mudanças mais rápidas que o mundo já havia conhecido, as empresas de toda parte seriam obrigadas, para se adaptar, a fazer grandes gastos com equipamentos de informática, telefonia digital, telecomunicações por satélite, redes etc. As perspectivas de crescimento pareciam ilimitadas.

Na França, de 1997 a 2000, por exemplo, o índice de instalação de computadores em escritórios e residências duplicou. Por outro lado, no decorrer desses três aos, mais de dez milhões de pessoas compraram telefones celulares. Em 31 de dezembro de 2001, o índice de penetração da telefonia móvel havia atingido $61,6 \%$ e havia 37 milhões de franceses equipados com telefones celulares. Além disso, consideravase que o número de usuários mundiais da Internet, estimado em 142 milhões em 1998, deveria ultrapassar 500 milhões em 2003...

A grande batalha econômica do futuro veria enfrentarem-se as empresas norte-americanas, européias e japonesas na batalha pelo controle das redes, assim como pela dominação do mercado de imagens, bancos

\footnotetext{
${ }^{3}$ David S. Landes, L'Europe technicienne, Paris, Gallimard, 1975, p. 214.
} 
de dados, atividades de lazer, som, jogos - em suma, dos conteúdos. Mas elas se enfrentariam também, talvez acima de tudo, para se imporem no setor do comércio eletrônico, em expansão exponencial. A Internet deveria ser transformada num vasto shopping center. ${ }^{4}$ Embrionário em 1998, com cerca de 8 bilhões de euros em compras, o comércio eletrônico havia atingido 40 bilhões em 2000 e deveria ultrapassar 80 bilhões em 2005.

Tomados por uma febre ardente de opulência, sonhando com uma fonte de riqueza fácil e estimulados pela maioria dos meios de comunicação, enxames de investidores (antigos e novos) atiraram-se às bolsas de valores de quase toda parte, no correr dos dois anos da "explosão tecnológica" de 1999-2000, como outrora tinham feito os exploradores em busca de ouro no Eldorado ou no rio Klondike. As cotações de alguns títulos ligados à galáxia da Internet explodiram. Em 1999, uma dezena de companhias viu o valor de suas ações multiplicar-se por cem. Outras, como a America On Line (AOL), fizeram melhor: o valor de suas ações na bolsa, a partir de 1992, multiplicou-se por 800 !

\section{$O$ craque da Nasdaq}

Um poupador que houvesse investido apenas 1.000 euros em ações de cada uma das cinco grandes da Internet (AOL, Yahoo!, Amazon, AtHome e eBay), no dia de sua introdução na bolsa de valores, teria ganho, já em 9 de abril de 1999, um milhão de euros... O índice da NASDAQ (a bolsa em que é negociada a maioria das ações de alta tecnologia em Nova York) estampou um lucro de $+85,6 \%$ em 1999 !

Mas enriquecer depressa, sem esforço e sem trabalho, muitas vezes é algo da ordem da miragem. E, a partir de março de 2001, o índice NASDAQ despencou, arrastando em sua queda, pelo mundo afora, a maioria das ações de empresas de tecnologia e telecomunicações...

As recentes falências fraudulentas gigantescas da Enron, da WorldCom, da Qwest, da Tyco, da Lucent etc., que arruinaram dezenas de milhares de acionistas assalariados, confirmam que a década de expansão econômica - de março de 1991 a março de 2001 - baseada nas novas tecnologias já terminou.

\footnotetext{
${ }^{4}$ Ver Ignacio Ramonet, La Tyrannie de la communication, Paris, Galilée, 1998.
} 
Mesmo durante os anos do boom tecnológico, as desigualdades nos Estados Unidos, paradoxalmente, continuaram a se aprofundar. No começo do craque da NASDAQ, em março de 2001, portanto, atingiram níveis nunca vistos desde a Grande Depressão. A prosperidade da "nova economia" revelou-se tão frágil que fez pensar na explosão de crescimento econômico dos anos vinte, quando, a exemplo do que aconteceu em 1999 e 2000, a inflação era pequena e a produtividade, elevada - a ponto de alguns analistas, ao verem o índice NASDAQ levantar vôo, não hesitarem em prever um "craque tecnológico" e anunciarem um "risco de falência", fazendo pairar o espectro de 1929. ${ }^{5}$

Hoje em dia, calcula-se que apenas $25 \%$ das empresas da economia da Net deverão sobreviver a médio prazo. As altas autoridades financeiras foram rápidas em alertar os poupadores. "Tomem cuidado com os papéis das empresas da Internet", afirmou em março de 2000, por exemplo, o Sr. Arnout Wellink, presidente do Banco Central dos Países Baixos, que comparou os operadores a "cavalos enlouquecidos, todos correndo, uns atrás dos outros, à procura de uma mina de ouro". ${ }^{6}$

Dizem, às vezes, que as revoluções políticas devoram seus filhos. As revoluções econômicas fazem a mesma coisa...

\section{A Argentina, um exemplo típico}

Assim, o ciclone econômico que se abateu sobre a Argentina, por exemplo, no fim de dezembro de 2001, não somente provocou tumultos sangrentos (30 mortos) e mergulhou esse país latino-americano no caos, como também derrubou seu governo e cinco presidentes em menos de duas semanas... Essa crise mostra-se exemplar, por diversas razões. Desde 1989, a Argentina vinha seguindo ao pé da letra todas as recomendações do Fundo Monetário Internacional (FMI) e de todos os órgãos financeiros internacionais. O conjunto do patrimônio do Estado fora privatizado (petróleo, minas, eletricidade, água, telefones, rodovias, estradas de ferro, metrô, empresas aéreas e até o correio!), o comércio exterior fora inteiramente liberalizado, o controle cambial fora eliminado, e dezenas de milhares de funcionários públicos estavam licenciados

\footnotetext{
${ }^{5}$ Business Week, 14 de fevereiro de 2000.

${ }^{6}$ Le Monde, 12 de março de 2000.
} 
ou tinham visto seus salários e pensões de aposentadoria serem diminuídos, a fim de reduzir o déficit público. A própria moeda fora posta em paridade com o dólar (decisão registrada na Constituição!), a fim de não mais permitir que um futuro governo a desvalorizasse.

Mas o montante da venda de todo o patrimônio do Estado, que se elevava a dezenas de bilhões de dólares, simplesmente se evaporou, em decorrência de uma corrupção fenomenal. E não serviu sequer para pagar a dívida externa do país! E o mais insólito é que essa dívida, que era de 8 bilhões de dólares antes das privatizações, atingiu, após a venda dos bens estatais, um montante 16 vezes maior, ou seja, 132 bilhões de dólares!

Ainda assim, a Argentina continuava a ser considerada a "melhor aluna" do FMI, e seu ministro da Economia, Sr. Domingo Cavallo, artífice das privatizações e da dolarização, recebeu do New York Times, em março de 2001, o título de "herói liberal do ano". Com isso, a Argentina era um exemplo citado por todos os incensadores do ultraliberalismo, que não paravam de enaltecer o "modelo argentino". Foi esse modelo que, após quatro anos de recessão econômica, desmoronou tragicamente em dezembro de 2001.

Eleito na noite de $1^{\circ}$ de janeiro de 2002, o peronista Eduardo Duhalde desancou de imediato, em seu discurso de posse, esse "modelo liberal". Acrescentou: "Meu compromisso, a partir de hoje, é acabar com esse modelo esgotado, que fez mergulhar no desespero a grande maioria de nosso povo." Esse modelo, esclareceu ainda, "gerou a pobreza de dois milhões de compatriotas, destruiu a classe média, arruinou nossas indústrias e reduziu a zero o trabalho dos argentinos". ${ }^{7}$ Raras vezes os aspectos nocivos do ultraliberalismo foram denunciados com tanta severidade e clareza.

Esse desastre que se abateu brutalmente sobre a Argentina, como fizera em 1997 com vários países do Sudeste Asiático, ameaça outras nações pelo mundo afora, em particular a Turquia, a Rússia, o Brasil, o Uruguai, a África do Sul e as Filipinas. Mesmo que a falência argentina tivesse sido prevista pelos mercados, a diminuição do ritmo da atividade econômica no mundo reforça a aversão dos investidores aos riscos e inaugura um período de maior incerteza econômica.

${ }^{7}$ Le Monde, 3 de janeiro de 2002. 


\section{Firmas gigantescas, Estados nanicos}

O caso argentino demonstra, mais uma vez, como a globalização do capital financeiro vem colocando os povos num estado de insegurança generalizada. Essa globalização contorna e rebaixa as nações e seus Estados como lugares pertinentes do exercício da democracia e avalistas do bem comum.

A globalização financeira, aliás, criou seu próprio Estado. Um Estado supranacional, que dispõe de seus próprios aparelhos, redes de influência e modos de ação. Trata-se da constelação formada pelo Fundo Monetário Internacional (FMI), pelo Banco Mundial, pela Organização para a Cooperação e Desenvolvimento Econômicos (OCDE) e pela Organização Mundial do Comércio (OMC). Essas quatro instituições falam a uma só voz - que ressoa na quase totalidade dos grandes meios de comunicação - para exaltar as "virtudes do mercado".

Esse "Estado mundial" é um poder sem sociedade, sendo o papel desta exercido pelos mercados financeiros e pelas empresas gigantescas de que ele é mandatário, com a conseqüência de que as sociedades que existem de verdade, por sua vez, são sociedades sem poder. ${ }^{8} \mathrm{E}$ isso não pára de se agravar.

Sucedendo ao GATT, a OMC tornou-se, a partir de 1995, uma instituição dotada de poderes supranacionais e situada fora de qualquer controle da democracia parlamentar. Uma vez convocada a se manifestar, ela pode declarar que as legislações nacionais, seja em matéria de direito do trabalho, direito ambiental ou de saúde pública, são "contrárias à liberdade do comércio" e, por conseguinte, exigir sua revogação. ${ }^{9}$

Antes da crise atual, não se passava uma semana sem que a mídia anunciasse novas fusões e aquisições, um novo casamento entre grandes empresas, uma união colossal, uma megaconcentração que dava origem a uma firma gigantesca. Lembremos, por exemplo, a aquisição da fabricante de automóveis Chrysler pela Daimler-Benz (por um montante de 43 bilhões de euros), do banco Citicorp pelo Travelers (82,9 bilhões), da companhia telefônica Ameritech pela SBC Communications (60 bilhões), da empresa farmacêutica Ciba pela Sandoz (36,3 bilhões),

\footnotetext{
${ }^{8}$ Ver André Gorz, Misères du présent, richesse de l'avenir, Paris, Galilée, 1997.

${ }^{9}$ Cf. François Chesnais, La Mondialisation du capital, Paris, Syros, 1997 (nova edição ampliada).
} 
o que deu origem à Novartis, da operadora MCI Communications pela WorldCom (30 bilhões), do Banco de Tóquio pelo Banco Mitsubishi (33,8 bilhões) e da Sociedade de Bancos Suíços pela União dos Bancos Suíços (24,3 bilhões). E recordemos ainda a decisão de fundir os dois gigantes históricos da siderurgia alemã, a Thyssen e a Krupp, cujo volume de negócios, segundo seus diretores, se elevará a 63 bilhões de euros... Mas a maior operação do mundo foi a compra, feita em 2001 pelo grupo norte-americano de telecomunicações Comcast, da operadora de cabos AT\&T Broadband, pelo montante de 73 bilhões de euros...

Só no ano de 1997, por exemplo, as operações mundiais de aquisição e fusão de empresas atingiram um montante superior a 1,6 trilhões de euros! E, em 2001, apesar da retração econômica geral e da queda das ações das empresas de tecnologia nas bolsas de valores, o montante das operações mundiais de fusão e aquisição elevou-se a 1,958 trilhões de euros! Os setores mais sensíveis a essa corrida para o gigantismo são os bancos, a indústria farmacêutica, a indústria química, os meios de comunicação, as telecomunicações, a agroindústria e a indústria automobilística.

Por que essa efervescência? No contexto da globalização, os grandes grupos da Tríade (Estados Unidos-União Européia-Japão), aproveitando a desregulamentação da economia, querem ter uma presença planetária. Procuram tornar-se atores importantes em todos os grandes países e neles deter parcelas significativas do mercado. Por outro lado, a queda das taxas de juros (que acarreta uma transferência das obrigações para as ações), as massas de capital que fogem das bolsas asiáticas ou latino-americanas (depois da crise asiática de 1997 e da crise argentina do fim de 2001), a colossal capacidade financeira dos principais fundos de pensão norte-americanos e britânicos e a melhor rentabilidade das empresas (na Europa e nos Estados Unidos), tudo isso dopou as bolsas ocidentais em 1999 e 2000 e provocou a embriaguez das fusões.

Estas deparam com um número cada vez menor de tabus. Por exemplo, a indústria automobilística, tal como a siderurgia ou as telecomunicações, antigamente era considerada um setor estratégico pela maioria dos governos. Isso já não acontece há uns vinte anos no Reino Unido e, a partir da compra da norte-americana Chrysler pela Daimler-Benz, também já não ocorre nos Estados Unidos.

Outro testemunho disso, na Alemanha, a maior potência econômica da zona do euro, foi a decisão do governo do Sr. Gerhard Schröder de eliminar o imposto sobre os lucros auferidos pelas empresas em caso de cessão. Havendo entrado em vigor em $1^{\circ}$ de janeiro de 2002, essa medi- 
da tem como efeito acelerar a transferência do capital renano para o capitalismo anglo-saxão e favorecer as fusões de empresas que atuam nos mesmos setores estratégicos - como, aliás, já foi demonstrado, no verão de 2001, pela assunção do controle do Dresdner Bank pela seguradora Allianz, numa aquisição cujo montante elevou-se a 19,7 bilhões de euros...

"Agora, os patrões estão inteiramente desinibidos", declarou um especialista do Boston Consulting Group. "As fechaduras do capitalismo tradicional estão sendo arrombadas e os pactos mútuos de não-agressão já não vigoram. Não é mais proibido sacudir violentamente a porta de um grupo, mesmo quando a diretoria rejeita a idéia de uma aproximação."10 Tivemos um exemplo eloqüente disso na França, em março de 1998, quando da fusão-absorção da Havas pela Compagnie Générale des Eaux, então presidida pelo Sr. Jean-Marie Messier, que deu origem ao grupo Vivendi; este foi transformado em Vivendi-Universal, depois da aquisição da empresa norte-americana Universal, e, como sabemos, foi vítima do delírio de grandeza de seu presidente - demitido em julho de 2002 -, que multiplicou as aquisições e fusões e, já no verão de 2002, em graves dificuldades, viu-se obrigado a vender ativos para sobreviver, depois de haver despencado o valor das ações da empresa na bolsa.

\section{Dimensões titânicas}

Aos olhos dos predadores, as fusões apresentam inúmeras vantagens. Permitem reduzir a concorrência através de sua compra, pois a maioria desses acordos une empresas rivais, desejosas de dominar seu setor de maneira quase monopolista. ${ }^{11}$ Dão uma oportunidade de recuperar o atraso em matéria de pesquisa e desenvolvimento, mediante a absorção de empresas que possuem um verdadeiro avanço tecnológico; e, por último, permitem proceder a demissões em massa, a pretexto de reduzir os custos (a fusão das empresas farmacêuticas britânicas Glaxo e Wellcome, por exemplo, traduziu-se, logo no primeiro ano, na eliminação de 7.500 postos de trabalho, ou seja, 10\% do efetivo).

\footnotetext{
${ }^{10}$ Libération, 15 de outubro de 1997.

${ }^{11}$ Foi para não ser acusado de favorecer a reconstituição de "monopólios naturais" que o governo dos Estados Unidos, em 18 de maio de 1998, instaurou um processo contra a firma Microsoft, do Sr. Bill Gates, por violação da legislação antitruste.

${ }^{12}$ François Chesnais, La Mondialisation du capital, Paris, Syros, 1997, p. 251.
} 
Algumas firmas atingiram dimensões titânicas. Por vezes, seu volume de negócios é superior ao produto interno bruto de numerosos países desenvolvidos; assim, o da General Motors é maior que o PIB da Dinamarca, o da Exxon é superior ao PIB da Noruega e o da Toyota suplanta o PIB de Portugal. ${ }^{12} \mathrm{O}$ montante dos recursos financeiros de que dispõem essas empresas é amiúde superior à receita orçamentária dos Estados, inclusive dos mais desenvolvidos. E é superior, acima de tudo, às reservas cambiais guardadas pelos bancos centrais da maioria dos grandes Estados. ${ }^{13}$

Como nos vasos comunicantes, à medida que, através das fusões, as empresas transformam-se em gigantes, pelo abandono do patrimônio econômico representado pelas privatizações, os Estados tornam-se cada vez mais nanicos.

Desde que, no começo dos anos oitenta, a Sra. Margaret Thatcher lançou as primeiras privatizações, tudo (ou quase tudo) está à venda. Em toda parte. A maioria dos governos, tanto de direita quanto de esquerda, do Norte e do Sul, desmonta a machadadas os patrimônios do Estado e dos serviços públicos.

Durante a década de 1990, em escala mundial e em prol de empresas privadas, os Estados se desfizeram de uma parte de seu patrimônio estimada em mais de 513 bilhões de euros (215 bilhões unicamente na União Européia)! As empresas privatizadas são particularmente valorizadas pelos investidores, pois se beneficiam de antemão de uma reestruturação financiada pelo Estado e, ainda por cima, suas dívidas são canceladas. Elas representam aplicações extremamente atraentes, em particular as dos setores de primeira necessidade (energia, gás, água, transportes, telecomunicações, saúde), que garantem uma receita regular muito lucrativa, isenta de riscos, e nas quais os investimentos anteriores, que podem ter durado décadas, foram realizados pelo Estado.

Assistimos, assim, a um espetáculo insólito: a ascensão poderosa de firmas planetárias, diante das quais os contrapoderes tradicionais (Estados, partidos, sindicatos, meios de comunicação) parecem cada vez mais impotentes. O fenômeno principal de nossa época, a globalização liberal, não é pilotado pelos Estados. Frente às empresas gigantescas, estes perdem mais e mais as suas prerrogativas. Os cidadãos assistem, impotentes, a uma espécie de golpe de Estado planetário de um novo tipo. E

${ }^{13}$ Idem, p. 253. 
constatam simultaneamente que, tanto no Norte quanto no Sul, flagelos sociais que se acreditava haverem desaparecido, como a exploração de crianças, encontram-se em pleno recrudescimento.

\section{Infâncias destroçadas}

Alguns sinais, com efeito, não deixam margem para enganos. Ao ressurgimento da mendicância, do desemprego, dos sopões populares e das "classes perigosas", nos "bairros" e "municípios" das periferias, veio somar-se - como prova suplementar da desumanização provocada pela globalização econômica no fim do século $\mathrm{XX}$ - a figura social do trabalhador infantil.

Já no século XIX, o agravamento das desigualdades refletia-se particularmente na exploração das crianças, cujo emprego se havia generalizado. Descrevendo, em 1840, num relatório célebre, ${ }^{14}$ a situação das crianças trabalhadoras na França, onde a jornada de trabalho era de 14 horas, Louis Villermé evocou "a multidão de crianças fracas e macilentas, cobertas de andrajos, algumas com apenas sete anos de idade, que chegam descalças às fábricas, atravessando a chuva e a lama, pálidas, irritadas, oferecendo uma aparência de miséria, sofrimento e desânimo".

Longe de se horrorizarem com essa situação - que romancistas como Charles Dickens, Victor Hugo, Émile Zola e Edmondo de Amicis também haviam denunciado -, alguns "liberais" consideravam-na um "mal necessário": "Essa miséria", escreveu um deles, "proporciona um espetáculo salutar a toda uma parcela das classes menos afortunadas, que permaneceu sadia; serve para enchê-las de medo; exorta-as às difíceis virtudes de que elas necessitam para chegar a uma situação melhor." 15

Diante de tamanho cinismo, como não compreender, por exemplo, a revolta de Karl Marx, que, em seu Manifesto do Partido Comunista, em 1848, denunciou "a grande indústria, que destrói todos os laços de família do proletário e transforma as crianças em simples artigos de comércio, em simples instrumentos de trabalho", e reivindicou - já se vai

\footnotetext{
${ }^{14}$ Louis Villermé, Tableau de l'état physique et moral des ouvriers..., Paris, 1840 (reeditado pela UGE, col. 10-18, Paris, 1971).

${ }^{15}$ Citado por Jacques Droz in Histoire générale du socialisme, Paris, Quadrige-PUF, 1997, vol. I, p. 369.
} 
um século e meio! - a "abolição do trabalho infantil nas fábricas, tal como é hoje praticado"? ${ }^{16}$

A história mostrou que a abolição progressiva do trabalho infantil e a instituição do ensino obrigatório foram, na Europa Ocidental, na América do Norte e no Japão, as condições indispensáveis do desenvolvimento. No entanto, foi preciso esperar pelo ano de 1990 para que, ratificada no âmbito da ONU - com a exceção dos Estados Unidos -, a convenção sobre os direitos da criança entrasse em vigor e, como desejava a Organização Internacional do Trabalho (OIT) desde 1973, fixasse uma idade mínima para o ingresso no mundo do trabalho.

Apesar disso, estima-se que cerca de 250 milhões de crianças trabalhem, as menores delas não chegando a ter cinco anos... Se sua maioria encontra-se nos países pobres do Sul, muitas são exploradas nos Estados do Norte. No conjunto da União Européia, seu número ultrapassa dois milhões... em particular nas zonas atingidas pelas reestruturações ultraliberais, como o Reino Unido. Contudo, mesmo em países considerados "socialmente avançados" - Dinamarca, Holanda etc. -, o fenômeno do trabalho infantil reapareceu. "Também na França", afirma uma especialista do Fundo das Nações Unidas para a Infância (UNICEF), "várias dezenas de milhares de crianças exercem empregos assalariados sob a capa da aprendizagem, e 59\% dos aprendizes trabalham mais de quarenta horas por semana, às vezes chegando a sessenta." 17

\section{Escravos e servos}

Na escala planetária, o número de trabalhadores infantis não pára de crescer. Em alguns países, como o Paquistão, trata-se de um flagelo de massa: às dezenas de milhões, crianças com menos de seis anos são exploradas no país. ${ }^{18} \mathrm{Na}$ América Latina, uma em cada cinco crianças trabalha; na África, uma em cada três; na Ásia, uma em cada duas! O primeiro setor a empregar crianças é a agricultura. Nela se pratica a

\footnotetext{
${ }^{16}$ Karl Marx, Manifeste du parti communiste, Paris, UGE, col. 10-18, 1962, p. 42 e 46 [ver in Vários autores, O Manifesto comunista 150 anos depois, Rio de Janeiro, Contraponto/Ed. Fundação Perseu Abramo, 1998].

${ }^{17}$ Cf. Claire Brisset, Un monde qui dévore ses enfants, Paris, Liana Lévi, 1997.

${ }^{18}$ Ver Bernard Schlemmer, L'Enfant exploité, Paris, Khartala, 1996; ver também o relatório “L'Enfant exploité", p. 2, n 2, Lausanne, junho de 1996.
} 
servidão por endividamento: as crianças têm que pagar com seu trabalho as dívidas contraídas por seus pais ou avós. Escravas de fato, tais crianças jamais sairão dessa situação, passarão a vida inteira na lavoura, ali se casarão e darão à luz novos escravos...

Numerosas crianças empregam-se na economia informal, no artesanato, no pequeno comércio e na mendicância. $O$ trabalho doméstico (Magrebe, Oriente Próximo, África ocidental, América Latina) é dos mais perniciosos, ficando a criança exposta a toda sorte de humilhações e atos de violência, sobretudo sexuais. A causa primordial desse quadro desolador é a pobreza, uma pobreza que a globalização econômica tem generalizado e agravado.

Dos seis bilhões de habitantes existentes no planeta, cinco bilhões são pobres. Partindo dessa constatação, um número cada vez maior de organizações vem-se mobilizando em torno da OIT e do UNICEF, para pôr fim a um dos escândalos mais revoltantes de nossa época e para reivindicar o direito sagrado de toda criança a uma vida decente. Elas se dirigem, em primeiríssimo lugar, aos chefes de Estado e de governo de todos os países do mundo. E constatem que, até no nível mais alto, muitos desses dirigentes políticos, nestes tempos de globalização, deixam-se dominar pela febre do dinheiro fácil, da especulação, e sucumbem à corrupção.

\section{Presidentes acossados}

De fato, mais ou menos por toda parte e desta ou daquela maneira, presidentes, às vezes em exercício e democraticamente eleitos, são acusados, perseguidos e acossados, sem que haja o menor respeito por sua função - que até recentemente era considerada quase sagrada e fazia deles uma espécie de intocáveis. Tudo isso acabou. Os que falam em "fim derradeiro do Antigo Regime" não estão inteiramente errados, pois é a "majestade" da função presidencial, por assim dizer, que está sendo rigorosamente decapitada diante de nossos olhos.

Já nem mesmo os "donos do mundo" escapam ao assédio. Os presidentes reunidos em Gênova entre 20 e 22 de julho de 2001, por ocasião da conferência de cúpula dos sete países mais ricos do planeta (mais a Rússia, o G8), também se confrontaram com manifestações de cólera de enorme amplitude. Manifestações que não visavam pessoalmente a eles, mas à globalização que eles encarnam e a qual, por sua vez, não 
tem rosto. Esses chefes de Estado e de governo apresentaram à opinião pública, nessa ocasião, a imagem detestável de um clube de ricaços arrogantes, entrincheirados a bordo de um luxuoso navio de cruzeiro, cercados por muralhas militarizadas, isolados do povo enfurecido e protegidos por uma polícia em estado de guerra, que não hesitou em matar um jovem manifestante, Carlo Giuliani, de 23 anos...

Cercados por cerca de 200 mil manifestantes, os presidentes do G8, visivelmente desconcertados, limitaram-se a repetir um único argumento, à guisa de defesa: "Fomos eleitos democraticamente!" Como se houvesse nisso alguma virtude mágica. Como se isso não fosse, hoje em dia, o que existe de mais insignificante!

Pois o terem sido eleitos democraticamente não autoriza os presidentes, de modo algum, a traírem suas promessas eleitorais e o interesse geral, ou a quererem privatizar e liberalizar a torto e a direito. E a satisfazer a qualquer preço as exigências das empresas que financiaram suas campanhas eleitorais. Dois desses sete, pelo menos - os Srs. George W. Bush e Silvio Berlusconi -, são mais representantes do mundo dos negócios de seus países que de seus concidadãos.

O questionamento atual dos governos tem por alvo, acima de tudo, os chefes de Estado ou de governo acusados de haver cometido crimes de guerra ou crimes contra a humanidade. Como o general Augusto Pinochet, ex-ditador do Chile, detido em Londres em 1998, mediante uma queixa do juiz espanhol Baltasar Garzón, e devolvido a seu país em março de 2000, onde foi novamente acusado pelo juiz Guzmán, até finalmente ver suspensos os processos movidos contra ele, em 9 de julho de 2001, a pretexto de uma "degradação do estado de saúde mental do ex-ditador".

\section{Exigência moral}

O caso Pinochet modificou profundamente as regras do jogo na luta contra a impunidade dos dirigentes políticos, em escala internacional. Desde então, mais ou menos por toda parte, vimos antigos responsáveis serem convocados por juízes, a exemplo do ex-secretário de Estado norte-americano Henry Kissinger, intimado por um juiz de instrução de Paris por sua suposta participação no golpe de Estado contra o presidente socialista Salvador Allende, ocorrido no Chile em 1973. Ou o primeiro-ministro israelense Ariel Sharon, forçado a evitar pôr os pés na Bélgica, 
onde se apresentaram queixas contra ele por cumplicidade em crimes cometidos durante os massacres de Sabra e Chatila, em Beirute, em 1982.

Em 3 de fevereiro de 2000, no Senegal, onde ele se havia refugiado, vimos também o ex-presidente do Chade, Hissène Habré, ser acusado de "cumplicidade em atos de tortura" e submetido à prisão domiciliar. Mais recentemente, em 10 de julho de 2001, o general argentino Jorge Videla, autor do golpe de Estado de 1976, foi acusado e teve a prisão preventiva decretada por sua suposta participação no Plano Condor, o pacto de morte aprovado na década de 1970 entre as ditaduras militares latino-americanas, para fazer seus adversários "desaparecerem" sistematicamente. E houve ainda, em 29 de junho de 2001, a controvertida entrega do ex-presidente iugoslavo Slobodan Milosevic ao Tribunal Penal Internacional da Antiga Iugoslávia, em Haia, sob a acusação de "crimes contra a humanidade".

Mas não são apenas os autores de crimes sangrentos que vêm sendo perseguidos hoje em dia; presidentes democraticamente eleitos são também acossados pela justiça, sobretudo em decorrência de sua corrupção. Uma exigência moral manifesta-se a esse respeito em escala internacional. Assim, em junho de 2001, antes de ser finalmente inocentado, o expresidente argentino Carlos Menen foi detido e mantido em prisão domiciliar, sob a acusação de venda ilegal de armas e de haver recebido comissões ocultas que montavam a várias dezenas de milhões de dólares.

Também eleito democraticamente, Alberto Fujimori, ex-presidente do Peru, refugiou-se no Japão em novembro de 2000, para fugir da justiça, que o acusa de corrupção e assassinato. Seu antigo braço direito e homem forte do regime, Vladimiro Montesinos, também foi detido e encarcerado em junho de 2001. Nas Filipinas, o presidente Joseph Estrada foi expulso do poder por pressão popular, em 20 de janeiro de 2001, após um escândalo de corrupção. Foi preso em 25 de abril de 2001, acusado de desvio de 80 milhões de euros dos recursos econômicos do país. Na Indonésia, o presidente Wahid foi deposto em 23 de julho de 2001, acusado de corrupção. Em 28 de dezembro de 2001, o ex-presidente da República do Congo, Pascal Lissouba, foi julgado à revelia e condenado a trinta anos de trabalhos forçados por "alta traição petro-financeira e desvio de dinheiro público". E poderíamos continuar citando outros exemplos.

A contestação dos dirigentes políticos não é característica dos países democráticos desenvolvidos do Norte. Vem-se estendendo, como vimos, a numerosos países do Sul, como se à globalização financeira 
viesse responder uma internacionalização da exigência moral - e numa velocidade quase tão grande quanto a que viu o movimento antiglobalização, em menos de dois anos, de Seattle até Gênova, passar de protesto folclórico à revolta de uma geração inteira, de contestação pontual a uma guerra social planetária.

\section{Desarmar os mercados}

Para esses que manifestam seu protesto, o desarmamento do poder financeiro tem que se transformar num grande celeiro cívico, se quisermos evitar que o mundo do século XXI se transforme numa selva em que os predadores ditarão a lei.

Cotidianamente, cerca de 1,6 trilhões de euros fazem múltiplas idas e vindas, especulando com as variações do valor das divisas. Essa instabilidade cambial é uma das causas da alta dos juros reais, que freia o consumo das famílias e os investimentos das empresas. Ela aprofunda os déficits públicos e, por outro lado, incita os fundos de pensão, que manipulam centenas de bilhões de euros, a exigir das empresas dividendos cada vez mais elevados. As primeiras vítimas dessa "perseguição" do lucro são os assalariados, cujas dispensas maciças - "dispensas de conveniência bolsista" - fazem o valor das ações de seus ex-empregadores dar saltos na bolsa.

Podem as sociedades democráticas tolerar o intolerável por muito tempo? É urgente jogar areia nessas movimentações de capital devastadoras. De três maneiras: pela eliminação dos "paraísos fiscais", pelo aumento da fiscalização dos lucros do capital, e pela taxação das transações financeiras.

Os paraísos fiscais são um punhado de regiões em que impera o sigilo bancário, que só serve para camuflar malversações e outras atividades mafiosas. Com isso, bilhões de dólares são subtraídos de qualquer fiscalização, em benefício dos poderosos e das instituições financeiras, pois todos os grandes bancos do planeta têm sucursais nos paraísos fiscais e deles extraem imensos lucros. Por que não decretar um boicote financeiro, por exemplo, contra Gibraltar, Aruba, as ilhas Cayman, Mônaco ou Liechtenstein, proibindo os bancos que trabalham com os poderes públicos de abrir filiais nesses lugares?

A taxação dos lucros financeiros é uma exigência democrática mínima. Esses lucros deveriam ser taxados exatamente pelos mesmos índi- 
ces aplicados à renda do trabalho. Isso não acontece em parte alguma, em especial no seio da União Européia.

A completa liberdade de circulação dos capitais desestabiliza a democracia. Por isso é que se faz importante instaurar mecanismos de dissuasão. Um deles é o imposto Tobin, baseado no sobrenome de James Tobin, norte-americano agraciado com o Prêmio Nobel de economia, que o propôs já em 1972. Trata-se de taxar em bases módicas todas as transações dos mercados cambiais, a fim de estabilizá-los e, ao mesmo tempo, proporcionar receitas à comunidade internacional. Com uma taxa de $0,1 \%$, o imposto Tobin proporcionaria cerca de 166 bilhões de euros por ano, ou duas vezes mais do que a soma anual necessária para erradicar a pobreza extrema em cinco anos. ${ }^{19}$

Numerosos especialistas mostraram que a implementação desse imposto não apresenta nenhuma dificuldade técnica. ${ }^{20}$ Sua aplicação destruiria o credo liberal de todos os que não param de invocar a inexistência de uma solução que substitua o sistema atual.

Foi por isso que se criou em Paris, em abril de 1998, com vocação para se estender a todo o planeta, a organização não-governamental Ação por uma Taxação das Transações Financeiras para Ajuda aos Cidadãos (ATTAC), ${ }^{\mathrm{T} 1}$ que já conta, na França, com mais de 40.000 adeptos, e tem representantes em mais de 50 países. Em ligação com os sindicatos e associações de finalidade cultural, social e ecológica, a ATTAC age como um portentoso grupo de pressão civil junto a parlamentares e governos do mundo, para levá-los a reivindicar, finalmente, a implementação efetiva desse imposto mundial de solidariedade.

Mas a ATTAC tem também uma vocação de educação popular. Ao lado de outras associações, esforça-se por montar em toda parte seminários de formação em análise crítica da economia financeira. Dentro desse espírito, a ATTAC esteve na origem de um dos mais audaciosos projetos de resposta intelectual e social à globalização: o Fórum Social Mundial de Porto Alegre, no Brasil.

\footnotetext{
19 "Rapport sur le développement humain 1997”, Economica, Paris, 1997.

${ }^{20}$ Cf. Mahbub Ul Haq, Inge Kaul e Isabelle Grunberg, The Tobin Tax: Coping with Financial Volatility, Oxford, Oxford University Press, 1996.

${ }^{\mathrm{T} 1}$ A denominação original da $\mathrm{ONG}$ é Action pour une taxation des transactions financières pour l'aide citoyens. (N. da T.)
} 


\section{Porto Alegre}

O século XXI começou em Porto Alegre. Com efeito, todos aqueles que, de um modo ou de outro, contestam ou criticam a globalização neoliberal reuniram-se, de 25 a 30 de janeiro de 2001 e de 31 de janeiro a 5 de fevereiro de 2002, nessa cidade do sul do Brasil, onde se realizaram os dois primeiros encontros do Fórum Social Mundial ${ }^{21}$ e onde se realizará, em janeiro-fevereiro de 2003, o terceiro FSM.

Não para protestar, como em Seattle, Quebec, Gênova, Monterrey, Joanesburgo e outros lugares, contra as injustiças, as desigualdades e os desastres provocados em diversos lugares do mundo pelos excessos do neoliberalismo, mas para tentar, desta vez com um espírito positivo e construtivo, propor um quadro teórico e prático que permita contemplar uma globalização de um novo tipo e afirmar que é possível um outro mundo, menos desumano e mais solidário.

Essa espécie de Internacional rebelde reuniu-se em Porto Alegre no exato momento em que se realizou, em Davos (Suíça), em 2001, e em Nova York, em 2002, o Fórum Econômico Mundial, que há décadas reúne os "novos donos do mundo", em particular todos os que pilotam concretamente a globalização. E que já não escondem sua inquietação. Eles levam muito a sério os protestos da cidadania que, de Seattle a Kananaskis, passaram a ocorrer sistematicamente a cada conferência de cúpula das grandes instituições que de fato governam o mundo: $\mathrm{OMC}$, FMI, Banco Mundial, OCDE, G7, ALCA e até a União Européia.

Já em 1999, os acontecimentos de Seattle ${ }^{22}$ haviam impressionado profundamente os tomadores de decisões reunidos em Davos. "A cada ano", observou um jornalista, por exemplo, "um tema ou uma personalidade é a vedete do Fórum Econômico Mundial. Em 2000, a vedete de Davos foi, indiscutivelmente, Seattle. Ali se falou principalmente de Seattle." ${ }^{23}$ Conscientes do déficit democrático que acompanha a globalização, outros defensores do modelo dominante não mais hesitam em pedir que "se reflita seriamente para modificar, num sentido mais democrático, as normas e processos de funcionamento da

\footnotetext{
${ }^{21}$ Para qualquer informação, consultar o site www.forumsocialmundial.org.br.

${ }^{22}$ Ver o relatório “Comment l'OMC fut vaincue”, Le Monde diplomatique, janeiro de 2000.

${ }^{23}$ International Herald Tribune, Paris, 2 de fevereiro de 2000.
} 
globalização". ${ }^{24}$ E o próprio Sr. Alan Greenspan, presidente do Federal Reserve dos Estados Unidos, passou a afirmar: "As sociedades não podem ter sucesso quando setores significativos percebem seu funcionamento como injusto." 25

Vindos dos quatro cantos do planeta, esses "setores significativos", que se opõem à atual barbárie econômica e rejeitam o neoliberalismo como "horizonte inultrapassável", tentaram, num impulso que cabe realmente qualificar de inovador, lançar as bases de um verdadeiro contrapoder ${ }^{26}$ em Porto Alegre.

\section{Sonhando com o absoluto}

E por quê exatamente lá? Porque faz alguns anos que Porto Alegre se tornou uma cidade emblemática. Como capital do estado do Rio Grande do Sul, o mais meridional do Brasil, na fronteira com a Argentina e o Uruguai, Porto Alegre é uma espécie de laboratório social que os observadores internacionais examinam com certo fascínio. ${ }^{27}$

Governada de maneira original, há quatorze anos, por uma coalizão de esquerda liderada pelo Partido dos Trabalhadores (PT), essa cidade experimentou, em inúmeros campos (habitação, transportes coletivos, rede viária pública, coleta de lixo, postos de saúde, hospitais, rede de esgotos, meio ambiente, sistema de habitações populares, alfabetização, escolas, cultura, segurança etc.), um desenvolvimento espetacular. Qual o segredo de tamanho sucesso? O "orçamento participativo", ou seja, a possibilidade de os habitantes dos diferentes bairros definirem, de maneira muito concreta e muito democrática, a destinação das verbas municipais. Isto é, de decidirem que tipo de infra-estrutura desejam criar ou melhorar, e de acompanharem passo a passo a evolução dos trabalhos e o trajeto dos compromissos financeiros. Com isso, nenhum desvio de verbas, nenhum abuso é possível, e os investimentos

\footnotetext{
${ }^{24}$ Joseph S. Nye Jr, “Take Globalization Protests Seriously”, International Herald Tribune, 25 de novembro de 2000.

${ }^{25}$ Citado por Jean-Paul Maréchal in Humaniser l'économie, Paris, Desclée de Brouwer, 2000, p. 22.

${ }^{26}$ Ver Miguel Benassayag e Diego Sztulwark, Du contre-pouvoir, Paris, La Découverte, 2000. ${ }^{27}$ Ver Bernard Cassen, "Démocratie participative à Porto Alegre”, Le Monde diplomatique, agosto de 1998.
} 
correspondem na exatidão aos desejos majoritários da população dos bairros.

Essa experiência política vem-se efetuando, convém sublinhar, num clima de total liberdade democrática, em confronto com uma vigorosa oposição política de direita. O PT não controla os grandes jornais locais, nem tampouco o rádio e muito menos a televisão, todos nas mãos de grandes grupos midiáticos ligados ao patronato local, hostil ao Partido dos Trabalhadores. Além disso, obrigado a respeitar a Constituição federal brasileira, o PT tem margens de autonomia política muito restritas e, sobretudo em matéria fiscal, não pode legislar a seu gosto. Ainda assim, a satisfação dos cidadãos é tamanha que, em outubro de 2000, o candidato do PT foi reeleito para a chefia da prefeitura com mais de $63 \%$ dos votos...

Nessa cidade singular, onde floresce uma democracia que não é como as outras, o Fórum Social Mundial tentou, em 2001 e 2002, montar uma outra globalização que não mais exclua os povos. O capital e o mercado repetem, já se vão dez anos, que, ao contrário do que afirmavam as utopias socialistas, são eles, e não o povo, que fazem a história e a felicidade dos homens.

Em Porto Alegre, neste século XXI que começa, alguns novos sonhadores que almejam o absoluto lembraram que não é apenas a economia que é mundial: a proteção do meio ambiente, a crise das desigualdades sociais e a preocupação com os direitos humanos também são questões internacionais. E cabe aos cidadãos do planeta finalmente as tomarem em suas mãos.

\section{Referências bibliográficas}

BENASSAYAG, Miguel e SZTULWARK, Diego, Du contre-pouvoir, Paris, La Découverte, 2000.

BRISSET, Claire, Un monde qui dévore ses enfants, Paris, Liana Lévi, 1997.

CASSEN, Bernard, "Démocratie participative à Porto Alegre”, Le Monde diplomatique, agosto de 1998.

CHESNAIS, François, La Mondialisation du capital, Paris, Syros, 1997 (nova edição ampliada).

DROZ, Jacques, in Histoire générale du socialisme, Paris, QuadrigePUF, 1997, vol. I, p. 369. 
ECONOMICA, “Rapport sur le développement humain 1997”, Paris, 1997.

GORZ, André, Misères du présent, richesse de l'avenir, Paris, Galilée, 1997.

INTERNATIONAL HERALD TRIBUNE, 7 de janeiro de 2002.

INTERNATIONAL HERALD TRIBUNE, Paris, 2 de fevereiro de 2000.

LANDES, David S., L'Europe technicienne, Paris, Gallimard, 1975, p. 214.

LE MONDE DIPLOMATIQUE, "Comment l'OMC fut vaincue”, janeiro de 2000.

LIBÉRATION, 15 de outubro de 1997.

MARÉCHAL, Jean-Paul, in Humaniser l'économie, Paris, Desclée de Brouwer, 2000, p. 22.

MARX, Karl, Manifeste du parti communiste, Paris, UGE, col. 10-18, 1962, p. 42 e 46 [ver in Vários autores, O Manifesto comunista 150 anos depois, Rio de Janeiro, Contraponto/Ed. Fundação Perseu Abramo, 1998].

NYE JR, Joseph S., "Take Globalization Protests Seriously", International Herald Tribune, 25 de novembro de 2000.

RAMONET, Ignacio, La Tyrannie de la communication, Paris, Galilée, 1998.

SCHLEMMER, Bernard, L'Enfant exploité, Paris, Khartala, 1996; ver também o relatório “L'Enfant exploité”, p. 2, n 2, Lausanne, junho de 1996.

UL HAQ, Mahbub, KAUL, Inge e GRUNBERG, Isabelle, The Tobin Tax: Coping with Financial Volatility, Oxford, Oxford University Press, 1996.

VILLERMÉ, Louis, Tableau de l'état physique et moral des ouvriers..., Paris, 1840 (reeditado pela UGE, col. 10-18, Paris, 1971). 


\section{DA POLÍTICA SOCIAL PARA UM \\ CONTRATO SOCIAL DE ECONOMIA ABERTA \\ NA AMÉRICA LATINA}

Nancy Birdsall*

\section{Introdução}

Após uma década de reformas econômicas que alteraram drasticamente a estrutura das economias da América Latina, tornando-as mais abertas e mais competitivas, e um decênio de aumentos substanciais nos gastos públicos com a educação, a saúde e outros programas sociais, em praticamente todos os países, a pobreza e a extrema desigualdade continuam profundamente enraizadas. Nos anos noventa, a maioria dos países da região adotou, sob alguma forma, a receita que pareceu produzir índices excepcionais de crescimento e de redução da pobreza no Leste Asiático: uma ênfase no crescimento baseado no mercado e o compromisso de um investimento substancial das verbas públicas nos recursos humanos. ${ }^{1}$ Mas a proporção dos pobres, correspondente a $40 \%$ ou mais na maioria dos países, teve um declínio reduzido ou nulo. O Chile, com uma redução da estimativa de $32 \%$ para $16 \%$ entre 1990 e 1998 , e o Uruguai, baixando do valor estimado de $23 \%$ para $13 \%$, foram as úni-

\footnotetext{
* Presidente, Center for Global Development, Washington, D.C. (nbirdsall@cgdev.org). Agradeço a Sônia Draibe (Universidade de Campinas) e Carlos Francisco Lessa (reitor da Universidade Federal do Rio de Janeiro) por seus comentários como debatedores, a Michael Clemens e William Easterly, assim como aos demais participantes do seminário do BNDES, e ainda a Maria Beatriz Orlando, Ceran Özer e Andrew Stober por sua ajuda no trabalho de pesquisa e documentação.

${ }^{1}$ É claro que, comparando a América Latina dos anos noventa com o Leste Asiático nas décadas de 1970 e 1980, houve muitas diferenças na política econômica e social. Alguns diriam que as economias latino-americanas foram até mais abertas, na década de 1990, do que os tigres asiáticos na época em que viveram um rápido crescimento baseado nas exportações Não há dúvida de que, nos anos noventa, os gastos com programas sociais, como percentagem do PIB, foram tão grandes na América Latina quanto tinham sido e continuaram a ser nos tigres do Leste Asiático, embora, é claro, tenham sido muito inferiores por habitante em termos absolutos. Ver Birdsall, Ross e Sabot (1997) para uma discussão das diferenças entre o Leste Asiático e a América Latina na política social.
} 
cas exceções. Como não é de admirar, a proporção dos pobres aumentou, na verdade, em países que tiveram baixas taxas de crescimento, como a Venezuela. Mas a proporção aumentou também em países como o México e o Peru, onde houve um crescimento de aproximadamente $2 \%$ per capita anualmente. Em nenhum país houve uma melhora evidente naquilo que constitui, de modo geral, taxas altíssimas de desigualdade de renda. ${ }^{2}$

Que há de errado e que é possível fazer para modificar esse quadro sombrio? É óbvio que taxas de crescimento mais altas ajudariam. Mas estas continuam a escapar à maioria dos países - até ao Chile, nos últimos anos - e, na última década, mesmo os pequenos efeitos positivos do crescimento na redução da pobreza foram solapados por ligeiros aumentos da desigualdade. ${ }^{3}$ Os ingredientes da boa política social - ênfase contínua nos investimentos no ensino fundamental e concentração dos programas de saúde, nutrição e treinamento nas famílias pobres têm melhorado a vida das pessoas e podem vir a aumentar a renda. Mas, sem crescimento, parece improvável que eles possam causar uma redução de fato dos altos índices de pobreza, agora ou mais adiante; nem mesmo nos anos de algum crescimento nos anos noventa ele parecem haver conseguido resolver as desigualdades profundas e estruturais que inibem a redução da pobreza. Além disso, não é fácil manter investimentos sociais adequados quando o crescimento é pequeno, a dívida pública é grande e não há expansão dos orçamentos governamentais.

Neste artigo, enfatizo a necessidade de ir além dos componentes tradicionais da boa política social na região, remontando à velha idéia de um contrato social mais amplo, porém numa forma atualizada: um contrato social explicitamente concebido para as economias competitivas, abertas, globalizadas e, portanto, vulneráveis. Tal contrato social pós-moderno ampliaria de duas maneiras a atual política social: primeiro, seria explicitamente calcado no crescimento baseado no emprego. Não dependeria unicamente do crescimento, mas seria projetado para ajudar a promovê-lo. Segundo, em termos políticos e econômicos, voltar-se-ia não apenas para os pobres, mas também para a camada de renda média, cada vez mais infeliz e insegura (e que, na verdade, corre o

\footnotetext{
${ }^{2}$ Os dados sobre pobreza e desigualdade a que nos referimos encontram-se em Behrman, Birdsall e Székely (2001a.) Eles provêm de levantamentos familiares feitos no fim da década de 1980 e na de 1990.

${ }^{3}$ Attanasio e Székely (2001). Ver Apêndice 1.
} 
risco constante de empobrecer). Ele partiria da observação de que a integração na economia global, atualmente, só vem ajudando uma pequena minoria de famílias, e de que a dependência maciça da poupança externa, bem como a conseqüente vulnerabilidade às crises financeiras e de outra ordem, tem criado uma instabilidade que prejudica particularmente não apenas os pobres, mas também uma faixa muito maior de famílias não ricas. ${ }^{4} \mathrm{O}$ contrato social de uma economia aberta se basearia em políticas e programas voltados para a criação de empregos para a grande maioria dos não ricos, inclusive muitos dos que concluíram o curso primário e até o secundário, porém não foram mais além, e o faria, necessariamente, de um modo que respaldasse o crescimento contínuo impulsionado pelo setor privado, necessário para a criação desses empregos e para financiar internamente os investimentos públicos requeridos para preparar de maneira adequada um número maior de pessoas para eles.

Na Parte 1, examino a evolução da política social na região durante o período pós-guerra, baseando-me sobretudo num artigo anterior, escrito em co-autoria com Miguel Székely. ${ }^{5} \mathrm{Na}$ Parte 2, discuto três pontos que pretendem respaldar minha defesa de um novo contrato social baseado no emprego e voltado para as necessidades da maioria de renda média. $\mathrm{Na}$ Parte 3, resumo as implicações desse contrato social reformulado para as políticas macroeconômicas e setoriais específicas. Enfatizo a lógica difícil mas inevitável de um contrato social esteado em alguns alicerces fundamentais do tenebroso Consenso de Washington.

\section{Parte 1. O contrato social na América Latina do pós-guerra}

Hoje em dia, a política social da região é uma combinação sadia de gastos razoáveis em investimentos básicos na saúde e na educação, uma ênfase em chegar até os pobres - a qual, apesar de estar longe de ser implementada à perfeição, constitui uma melhora substancial em relação a períodos anteriores - e um conjunto impressionante de reformas administrativas, inclusive a descentralização para governos locais mais responsáveis e inovações institucionais como subsídios em espécie para

\footnotetext{
${ }^{4} \mathrm{Na}$ América Latina, talvez a melhor maneira de traçar essa distinção entre a pequena minoria e a grande maioria de famílias seja situá-la entre os cerca de $10 \%$ que têm alguma instrução além do curso secundário e os $90 \%$ que não a têm - tema a que voltarei mais adiante.

${ }^{5}$ Birdsall e Székely, a ser publicado.
} 
as famílias pobres que mantiverem seus filhos na escola. Mas essa combinação sadia não representa, em nenhum sentido, um contrato social significativo que proteja a vasta maioria das pessoas da região e no qual a vasta maioria de eleitores das democracias latino-americanas esteja engajada.

A política social de hoje evoluiu ao longo do que poderíamos considerar quatro fases ou períodos. O primeiro abrange o intervalo entre a Segunda Guerra Mundial e o fim da década de 1970, os "anos dourados" da América Latina em termos de crescimento econômico. Na maioria dos países, o setor industrial cresceu vigorosamente, impulsionado pela estratégia desenvolvimentista de substituição de importações que prevaleceu nessas décadas. $\mathrm{O}$ grupo urbano de renda média estava em expansão. ${ }^{6}$ Durante esse período, a política social foi uma parte fundamental da estratégia global de desenvolvimento. A política social consistia principalmente na ampla oferta de subsídios aos bens e serviços, da qual quem mais se beneficiou foram os crescentes grupos urbanos de renda média. Alguns desses subsídios - como os destinados ao consumo de combustíveis - eram justificados como algo que sustentava salários reais mais altos no setor industrial. As áreas rurais desempenhavam o papel de fornecer produtos primários e recursos naturais a preços baixos para a produção industrial, assim como produtos de baixo custo para o consumo dos consumidores urbanos. Em muitos casos, isso implicou subsidiar a produção rural e, em alguns, implicou a redistribuição da terra, a fim de minimizar os recursos ociosos e a subutilização do solo. Na maioria dos países, contudo, as necessidades dos estruturalmente pobres foram negligenciadas, embora, é claro, muitas famílias que haviam iniciado essa fase na pobreza tenham-se beneficiado do crescimento geral da renda. Nessa época, aliás, houve um declínio saudável da pobreza e da desigualdade. ${ }^{7}$ Mas a estratégia de crescimento industrial e os subsídios dependiam maciçamente de empréstimos públicos e acabaram sendo insustentáveis. Isso terminou, no início dos anos oitenta, na crise da dívida. ${ }^{8}$

\footnotetext{
${ }^{6}$ Ver, por exemplo, Székely (1998), para uma descrição do caso do México.

${ }^{7}$ Ver Londoño and Székely (2000) para dados sobre as tendências da pobreza e da desigualdade na América Latina durante a década de 1970.

${ }^{8}$ Os subsídios públicos, inclusive os fornecidos à indústria através do protecionismo nas importações, dependiam maciçamente de empréstimos públicos internos e externos, e não da poupança pública interna, e não puderam ser mantidos quando o acesso aos empréstimos tornou-se mais difícil e seu custo se elevou.
} 
No segundo período, ante as novas restrições macroeconômicas do início dos anos oitenta, a política social efetivamente desmoronou. Com a escalada das taxas de inflação, a desvalorização e as quedas do PIB, a prioridade política passou a ser a estabilização da economia a qualquer preço. Os amplos subsídios e transferências sociais foram vistos como um obstáculo ao crescimento, e não como um motor potente do desenvolvimento, como no passado. As pressões fiscais e o ônus da dívida, combinados com o baixo índice de crescimento, restringiram severamente os novos investimentos na saúde e na educação. Na maioria dos países, os gastos não se reduziram proporcionalmente ao orçamento, uma vez que era considerável a pressão política para preservar os empregos e salários do funcionalismo público, que consumiam a maior parte do gasto social. Entretanto, em termos absolutos, por criança e por cliente dos serviços de saúde, o gasto reduziu-se, uma vez que houve um declínio dos gastos gerais do governo. Além disso, as incertezas e a falta de novos investimentos contribuíram para uma deterioração geral das instituições - os sistemas de saúde e de ensino -, já que os professores e os profissionais de saúde tiveram que enfrentar o acesso restrito a insumos complementares, como livros, medicamentos etc. Esses sistemas sem dúvida perderam parte de seu pessoal mais qualificado, passando a sofrer com as mudanças constantes na direção. $\mathrm{O}$ que restava do contrato social ofereceu uma garantia de emprego limitada, além de incerta, à parcela do grupo de renda média que tinha a sorte de trabalhar no serviço público ou numa empresa estatal, mas prestou pouco ou nenhum serviço aos pobres das regiões rurais e urbanas. No fim da década de 1980, havia indícios crescentes de uma desigualdade cada vez maior e, o que era mais preocupante, de um aumento substancial da pobreza. ${ }^{9}$

O terceiro período teve início na segunda metade dos anos oitenta, com o reconhecimento de que os programas de ajuste estrutural e reforma econômica não estavam atendendo às necessidades do grande número de pobres - 30\% a $40 \%$ da população da maioria dos países. ${ }^{10} \mathrm{~A}$ política social passou a se concentrar na proteção aos pobres, num meio macroeconômico desfavorável e diante da competição global cada vez maior. Reconheceu-se que, de modo geral, os pobres têm menos meios de proteger sua renda de choques inesperados e do desgaste dos ativos

\footnotetext{
${ }^{9}$ Ver Morley (1995). A tese de que os programas de ajuste solaparam a política social foi defendida de maneira convincente em Cornia, Jolly and Stewart (1987).

${ }^{10}$ Usando como referência o valor de 2 dólares/dia em termos de paridade do poder aquisitivo.
} 
líquidos trazido pela inflação elevada. Os pobres também foram vistos como os mais desfavorecidos, em termos de sua probabilidade de engajamento nos setores de alta produtividade, com melhores chances de sobreviver à concorrência externa. A solução política foi a introdução de medidas compensatórias, através da implementação de programas que compunham uma rede de segurança, inclusive fundos de emergência social e de investimentos sociais (que se tornaram os programas preferencialmente apoiados pelos bancos multilaterais). Diante das pressões fiscais contínuas, passou-se a usar a abordagem de direcionar os recursos para os pobres, ou seja, de alocar os recursos orçamentários limitados de modo a obter a maior redução possível da pobreza por cada centavo gasto. Levantaram-se mapas e perfis da pobreza, a fim de identificar a população com os mais altos índices de pobreza. Os programas resultantes foram concebidos como programas pequenos, específicos e rigorosamente direcionados. ${ }^{11}$ Nesse sentido, a política social abandonou por completo a idéia de um contrato social maior entre o Estado e a sociedade como um todo. A política social e as estratégias globais de desenvolvimento e crescimento dos países da região ficaram inteiramente desvinculadas. Tal como no segundo período, a ênfase continuou a recair no equilíbrio fiscal entre as políticas macroeconômicas e os programas sociais, sendo estes vistos como uma ameaça potencial ao déficit público e à estabilidade macroeconômica.

Em meados da década de 1990, com a recuperação do crescimento econômico positivo na maioria dos países latino-americanos, emergiu uma quarta fase da política social. Embora o crescimento regional ainda fosse modesto, com exceção do Chile e talvez do Uruguai, ele foi suficiente para estimular os governos e a comunidade política a implementarem aumentos reais dos gastos públicos em amplos programas sociais - de um modo visto como tributariamente responsável. Os gastos públicos com a educação e a saúde, na maioria dos países da região, tiveram um aumento de no mínimo $20 \%$ entre 1990 e $1996 .{ }^{12} \mathrm{~A}$ abertura das economias da América Latina para os mercados mundiais, que se iniciara em meados dos anos oitenta na maioria dos países, criou um interesse maior em garantir que as economias pudessem competir

\footnotetext{
${ }^{11}$ A política social passou a se concentrar no problema de encontrar o ponto de equilíbrio entre os custos administrativos (e políticos) de identificar os pobres e evitar o escoamento dos benefícios para os não-pobres, por um lado, e o atendimento insuficiente dos pobres, por outro.

${ }^{12}$ Birdsall e Londoño (1997).
} 
com eficiência na economia global e, portanto, em garantir que uma parcela maior da força de trabalho pudesse ser mais produtiva. Dispor de um exército de trabalhadores não qualificados e de baixos salários deixou de ser visto como uma base para a competitividade global. A ênfase em atender às necessidades dos pobres continuou, porém com uma atenção muito maior para o aumento de sua capacidade produtiva, compatível com a visão de que a competitividade nas economias abertas exigia um investimento muito maior no capital humano. Em muitos países, o aumento dos gastos com a saúde e a educação favoreceu o ensino primário e secundário, comparado aos gastos com a universidade (a exemplo do Brasil e do México; no Chile, essa mudança e outras reformas começaram na década de 1980 e foram reforçadas na de 1990). ${ }^{13}$ Alguns novos projetos, como o Progresa mexicano, que recentemente teve seu nome trocado por Oportunidades, o Bolsa Escola, em Brasília, capital do Brasil, e o Chile Joven, no Chile, ${ }^{14}$ apesar de voltados para os pobres, foram concebidos não só como redes de segurança para proteger a capacidade de consumo, mas também como investimentos no ca-

\footnotetext{
${ }^{13}$ É provável que esses esforços tenham levado, nos anos noventa, a uma redução da defasagem na escolarização das crianças de famílias ricas e pobres, tomando por base, na maioria dos países, a menor defasagem entre os jovens de 15 anos do que entre os de 21 anos - embora as provas disso ainda não sejam claras nem convincentes, uma vez que há uma tendência natural para o aumento da defasagem conforme a idade (dados de Filmer e Pritchett, 1999). Em muitos países, todavia, a defasagem continuou dramaticamente alta - o que se harmoniza com outros indícios de que, na maioria dos casos, as diferenças no nível de instrução dos pais conforme o grupo de renda, na América Latina, reproduzem-se nas diferenças de escolarização dos filhos na geração seguinte (Behrman, Birdsall e Székely, 2000; e Birdsall, 2001).

${ }^{14}$ Progresa é a sigla em espanhol de Programa de Educación, Salud y Alimentación. Esse programa oferece subsídios em dinheiro e um complemento alimentar às famílias em situação de extrema pobreza nas áreas rurais. O auxílio em dinheiro é condicionado a índices de pelo menos $85 \%$ de freqüência escolar dos filhos e ao comparecimento regular a clínicas de saúde para exames de rotina e acompanhamento médico. O auxílio em dinheiro é entregue à mãe, que também tem de assistir a uma série de palestras e cursos sobre práticas sanitárias. O Bolsa Escola é um programa similar, que oferece bolsas de estudo a crianças desfavorecidas. Parte do pagamento em dinheiro é mantida numa conta especial, à qual o beneficiário poderá ter acesso ao concluir um ciclo escolar. O Chile Joven também é um programa de ajuda em dinheiro, mas, nesse caso, este é oferecido a adultos jovens para incentivar sua formação. É possível obter uma descrição e avaliação detalhadas do programa Progresa no endereço www.ifpri.org/country/mexico.htm. A descrição do programa Bolsa Escola pode ser obtida em http://www.mec.gov.br/home/ bolsaesc/default.shtm. Ver De Janvry e Sadoulet (2002) para uma discussão sobre os alvos do Progresa.
}

Agenda Social e Combate à Pobreza -219 
pital humano dos pobres. Os aumentos dos gastos sociais foram acompanhados, em alguns países, por novos grandes esforços de lidar com reformas estruturais nos sistemas de saúde e educação, particularmente através da ênfase na descentralização e num controle maior das escolas por parte dos pais e da comunidade (por exemplo, em Minas Gerais, no Brasil, e em El Salvador e na Bolívia).

Essa quarta geração da política social (e, para todos os fins práticos, ainda em vigor), portanto, concentra-se essencialmente em programas voltados para atender às necessidades e aumentar o capital humano dos pobres de hoje. Isso faz sentido numa região em que pelo menos $30 \%$ da população encontram-se na pobreza e em que a redução desta e o crescimento futuro dependem maciçamente da captação do potencial de aumento do engajamento produtivo dos pobres na economia. Além disso, com sua ênfase na melhoria do capital humano dos pobres, essa abordagem da política social faz parte, de um modo mais visível, de uma estratégia global de desenvolvimento.

Mas ela tem seus inconvenientes. Primeiro, é sumamente vulnerável no plano político; os programas sociais têm que entrar numa competição feroz pelos recursos públicos e, até hoje, ainda não foram institucionalizados em nenhum país. São primordialmente vistos como investimentos de longo prazo num crescimento futuro incerto, dadas as demandas do mercado global. Mas, à medida que o crescimento vacila e a sensação de extrema vulnerabilidade aos mercados externos aumenta, essa abordagem da política social, por mais sensata que seja, corre o risco de se desfazer - ameaçada por mais uma rodada necessária de austeridade fiscal, ou por um retorno a programas e subsídios amplos e tributariamente irresponsáveis, de estilo populista.

Em termos mais fundamentais, essa abordagem da política social não lida com eficácia com as causas subjacentes da pobreza contínua e elevada e da obstinada desigualdade. Por exemplo, o aumento dos gastos com a educação fez subir o nível de escolaridade entre as crianças pobres, mas (como mostrarei mais adiante) não elevou muito suas expectativas de renda futura, porque o baixo crescimento e as altas taxas reais de juros continuam a restringir a criação de empregos, porque o retorno médio do ensino primário e secundário continua baixo, e porque, em alguns países, a persistente discriminação étnica, racial e sexual, assim como seus efeitos históricos, mantêm baixo o nível salarial de alguns pobres. Os investimentos sociais tampouco elevarão a renda, se os pobres não puderem acumular capital físico e financeiro, ou se as 
fases recorrentes de declínio da economia obrigarem a uma desacumulação periódica de seus recursos limitados. A política social por si só, tal como atualmente concebida, não consegue modificar o meio econômico nem os elementos subjacentes da estrutura da economia que contribuem para a pobreza e tornam lento o crescimento global.

\section{Parte 2. Três fatos destacados}

1. O aumento do emprego na região foi ainda menor nos anos noventa do que o crescimento econômico; os salários elevaram-se muito mais depressa para as pessoas com instrução acima do secundário do que para a maioria dos menos instruídos.

O índice de aumento do emprego na região durante a década de 1990 foi menor que a taxa de crescimento (elasticidade estimada de 0,79 , segundo informações da CEPAL). Examinando os vários setores, o emprego aumentou num índice maior do que o crescimento global no setor do "comércio", que tem baixos salários, e subiu com uma taxa próxima à do crescimento nos "serviços básicos", porém teve um aumento muito inferior à taxa de crescimento na "indústria" (elasticidade de aproximadamente 0,3 ; ver Tabela $1 \mathrm{~A}) .{ }^{15}$ Os dados por tipo de trabalho contam uma história similar; a taxa média de crescimento do emprego na região foi maior nos serviços domésticos, de baixa remuneração, e nas categorias de trabalhadores autônomos do que na dos assalariados (Tabela 1B). ${ }^{16}$ Esses dados agregados sobre o crescimento do emprego nos vários setores e tipos de atividade são compatíveis com ganhos de produtividade em alguns setores, mas com um aumento limitado de empregos nesses setores para os trabalhadores sem instrução universitária. Graham e Sukhantar (2000) mostraram que, em toda a região, os trabalhadores com instrução secundária e nada mais têm maior probabilidade de ficar desempregados do que os que contam apenas com a instrução primária, e uma probabilidade muito maior de ficar desempregados do que aqueles que têm pelo menos alguma instrução superior. ${ }^{17}$ Tais dados também são compatíveis

\footnotetext{
${ }^{15}$ Tabelas da CEPAL baseadas em Stallings e Weller (CEPAL, 2001).

${ }^{16}$ Esse resultado predomina no sul; no México e em boa parte da América Central, o crescimento do emprego entre os assalariados foi relativamente mais rápido.

${ }^{17}$ Eles informam que a diferença da proporção de graduados do secundário na população geral $(22,3 \%)$ e entre os desempregados $(24,7 \%)$ é maior do que em outros grupos e é estatisticamente significativa.
} 
com outros indícios de que muitos dos ganhos de produtividade do setor manufatureiro durante a década de 1990 tanto se deveram aos cortes de pessoal praticados pelas firmas (bem como pelo setor público e por antigas empresas estatais) quanto aos aumentos de produtividade por insumo. ${ }^{18}$

Tabela 1A: Crescimento do emprego por setor na América Latina durante a década de 1990 (média nos vários países)

\begin{tabular}{|cc|}
\hline Setor & $\%$ \\
\hline Agricultura & $-0,1$ \\
Indústria & 1,6 \\
Construção Civil & 2,8 \\
Comércio & $\mathbf{5 , 8}$ \\
Serviços Básicos & $\mathbf{4 , 1}$ \\
Serviços Financeiros & 6,6 \\
Serviços Sociais & 3,0 \\
Outros & $-1,1$ \\
\hline Total & $\mathbf{3 , 5}$ \\
\hline
\end{tabular}

Fonte: CEPAL (2001).

Os dados provenientes dos levantamentos domiciliares também sugerem aumentos limitados de salário para quem tinha no máximo instrução secundária. Behrman, Birdsall e Székely (2001b), usando dados sobre salários e instrução provenientes de dezoito países latino-americanos ao longo da década de 1990, mostraram que o retorno marginal para o ensino primário e secundário caiu durante os anos noventa, ao passo que aumentou para o ensino superior (Figura 1A). Esses dados são compatíveis com os drásticos aumentos salariais dos detentores de instrução superior, comparados aos de escolaridade primária e secundária, o que resulta de uma mudança tecnológica favorecedora das qualificações que é conhecida no mundo inteiro, mas que é incomumente dramática na América Latina (Figura 1B). Mais preocupante foi o declínio dos salários relativos dos que têm instrução secundária, comparados aos que concluíram o curso primário. Uma vez que os índices de conclusão do secundário ainda são relativamente baixos, esse resultado é surpreendente e preocupante, pois sugere que a demanda de mão-de-

\footnotetext{
${ }^{18}$ Stallings e Peres (2000).
} 
obra de diplomados no segundo grau é limitada, dada a posição da América Latina na economia global. ${ }^{19} \mathrm{O}$ declínio relativo dos formados no secundário sugere que apenas um número restrito de integrantes da força de trabalho - os que tinham instrução pós-secundária - se beneficiou (especialmente em termos relativos) do crescimento apresentado pela maioria dos países nos anos noventa.

Tabela 1B: Crescimento do emprego por tipo de trabalho na América Latina durante a década de 1990 (média nos vários países)

\begin{tabular}{|cc|}
\hline Assalariados & 2,7 \\
Autônomos & $\mathbf{4 , 0}$ \\
Serviços Domésticos & $\mathbf{3 , 2}$ \\
Membros não-remunerados & $-1,9$ \\
da família & \\
Outros Trabalhadores & 0,2 \\
\hline Total & $\mathbf{3 , 4}$ \\
\hline
\end{tabular}

Fonte: CEPAL (2001).

2. As famílias de renda média não têm nada de "classe média"; na verdade, são bem pobres.

Isso se deve a que a desigualdade na região é não apenas grande, como favorece inusitadamente os que estão no topo, pois o decil superior das famílias em matéria de renda percebe $50 \%$ ou mais da renda total. Os altos níveis de desigualdade da América Latina refletem, primordialmente, a tremenda concentração da renda na camada superior. Se ignorarmos o decil superior, o coeficiente de Gini (e outras medidas de desigualdade da renda) será praticamente idêntico nos Estados Unidos e na maioria dos países da América Latina. ${ }^{20}$ Há dois corolários dessa distribuição de renda concentrada no topo. O primeiro é a renda extraordinariamente baixa em relação à renda "média" das famílias situadas na faixa intermediária da distribuição. A Figura 2 mostra a dife-

\footnotetext{
${ }^{19}$ Tendler (2002) oferece alguns esclarecimentos sobre esse problema, com base em pesquisas feitas com empregadores no nordeste do Brasil.

${ }^{20}$ Inter-American Development Bank (1999), p. 16.
} 
rença entre uma estimativa da renda da família mediana ${ }^{21}$ (medida em termos de renda familiar per capita) e a renda média ou mediana calculada a partir do mesmo levantamento domiciliar em vários países da região, durante os anos noventa. No Brasil, a mediana equivale a cerca de 1/3 dos ganhos médios. Em Honduras, equivale a cerca de metade da renda média. Nos Estados Unidos, por outro lado, a renda nacional mediana equivale a cerca de $90 \%$ da renda nacional média. ${ }^{22}$

Em Birdsall, Graham e Pettinato (2000), definimos uma "camada intermediária" de famílias como sendo aquelas cuja renda per capita fica dentro da faixa de $25 \%$ da família de renda média. Isso nos permitiu avaliar o "tamanho" da camada intermediária e sua parcela da renda total. Essa parcela, na América Latina, situa-se na faixa de 9\% (Brasil, 1996) a $18 \%$ (Costa Rica, 1997), comparada a cerca de 35\% nas economias em transição e a uma faixa de 18\% (EUA, 1999) a 42\% (Bélgica e Dinamarca, 1992) nas economias avançadas. ${ }^{23}$ No Brasil, a renda per capita das famílias mais ricas da camada intermediária ficou em cerca de 2.200 dólares (em 1996, pela conversão da paridade do poder aquisitivo); isso equivaleu a menos da metade da renda familiar média per capita de 4.500 dólares.

O outro corolário é que, em termos absolutos, as famílias de renda média na América Latina, mesmo nas economias de renda média, encontram-se no limiar da linha de pobreza, usando o padrão de dois dólares/dia (ou 730 dólares/ano) adotado pelo Banco Mundial. Nossa estimativa (Apêndice II) da renda familiar mediana per capita no México, em 1992, ficou em 1.148 dólares. A renda da camada intermediária no México situa-se entre 1.000 e 1.700 dólares per capita; nos Estados Unidos, nação parceira dos mexicanos no NAFTA, ela varia de 13.000 a 21.000 dólares. A Figura 2 mostra, no caso do Brasil, que a renda mediana ficou abaixo da linha de pobreza (60 dólares por mês em PPP) entre 1986 e 1989, mantendo-se próxima dos níveis da pobreza entre 1989 e 1996. Em Honduras, a renda mediana per capita ficou abaixo da

\footnotetext{
${ }^{21}$ Nossa estimativa foi derivada usando as estimativas disponíveis dos coeficientes de Gini e presumindo uma distribuição logarítmica normal da renda global, a fim de chegar a uma média estimativa. Ver Apêndice II.

${ }^{22}$ A renda mediana dos Estados Unidos foi calculada usando dados dos Indicadores do Desenvolvimento Mundial (Banco Mundial, 2002).

${ }^{23}$ Tabela 1 de Birdsall, Graham e Pettinato (2000). Os dados ali apresentados abrangem apenas seis países da América Latina.
} 
linha de pobreza entre 1989 e 1996 . Na Venezuela, vem decrescendo quase continuamente, aproximando-se dos níveis da linha de pobreza.

A quase-pobreza das famílias de renda média reflete-se em seus baixos níveis de saúde e instrução. A Figura 3 mostra os indicadores de saúde de vários países latino-americanos nos quintis superior, médio e inferior da distribuição estimativa da riqueza. ${ }^{24}$ Os indicadores do quintil intermediário ilustram a que ponto esse grupo está mais perto de ser pobre, pela maioria dos padrões, do que de pertencer à "classe média". Na Bolívia, o índice médio de mortalidade infantil é de 99,1 por 1.000. A mortalidade infantil nas famílias de renda intermediária ultrapassa 146 por 1.000 (ver Figura 3). Isso é mais do que a taxa média de mortalidade infantil registrada em Gana (132,8 por 1.000) e na Tanzânia (139,4 por 1.000). No Peru, durante 1990, quase $20 \%$ das crianças abaixo de cinco anos nas famílias de renda média tiveram prejuízos no crescimento. Na Guatemala, as crianças da camada intermediária tinham mais probabilidade de ser subnutridas do que os filhos do quintil mais pobre das famílias ganenses. No Peru e na Bolívia, as crianças do quintil mais pobre tinham mais probabilidade de ser subnutridas que as das famílias ganenses do quintil mais pobre.

O nível de instrução dos adultos da camada intermediária também fica bem abaixo do que se esperaria da "classe média" no sentido ocidental. Entre os adultos brasileiros em idade de trabalhar, a média da escolaridade fica em cerca de 4,5 anos; na Costa Rica, que tem uma longa história de investimentos na educação, ela ainda está em apenas cerca de seis anos. Nos Estados Unidos, equivale a treze anos. ${ }^{25} \mathrm{~A}$ instrução média dos adultos em idade de trabalhar, na maioria dos países da América Latina, subiu de aproximadamente três para cerca de cinco anos a partir de 1960. Essa cifra baixa é citada com freqüência em comparações pesarosas com o aumento havido, no mesmo período, nas economias em rápido crescimento no Leste Asiático, onde houve uma elevação de quatro para nove anos de escolaridade, aproximadamente. Ainda assim, apesar de baixas, essas médias são enganosas como medida do grau de instrução das famílias de nossa camada intermediária. A Figura 4 mostra que o nível médio de instrução entre os adultos da Bo-

\footnotetext{
${ }^{24}$ Esses quintis baseiam-se em estimativas da riqueza familiar per capita, derivadas de um conjunto de indicadores que incluem informações como tipo de piso, posse de rádio, bicicleta, automóvel etc. Ver as fontes indicadas na figura.

${ }^{25}$ Cálculos da autora, baseados em dados de Barro e Lee (Estatísticas do Banco Mundial, 2002).
} 
lívia e do Brasil ainda é inferior a dois anos; na Argentina, ultrapassa em pouco os cinco anos - ou seja, primeiro grau incompleto. ${ }^{26}$

Essas estimativas do nível médio de escolaridade dos adultos tornam particularmente inquietantes as indicações de que, durante a década de 1990, houve um aumento da defasagem salarial entre os que têm maior ou menor instrução posterior ao curso secundário. A grande maioria das famílias da região continua muito aquém da instrução necessária para desfrutar de qualquer ganho salarial "médio" (por mais limitado que este tenha sido).

Há duas implicações do fato de a camada intermediária estar, na verdade, muito próxima da definição de "pobre", usando-se os indicadores de educação e saúde e a linha de pobreza de dois dólares/dia adotada no âmbito internacional. A primeira é que o próprio processo de crescimento é restringido pelos bens limitados (instrução e outros ativos sólidos) de uma grande proporção das famílias. ${ }^{27} \mathrm{~A}$ ênfase da atual política social em desenvolver os ativos produtivos dos pobres, inclusive através da educação, também tende a ser benéfica para a camada intermediária. Isso fica muito claro num país como o Brasil, onde o número de matrículas no ensino secundário aumentou rapidamente na última década, graças a um esforço político concertado, principalmente por parte do governo central. Mas esse não é um processo rápido. Na conclusão, voltarei a falar brevemente do desafio de melhorar a distribuição dos ativos, em grande parte porque esse desafio já vem sendo enfrentado.

A segunda implicação é que até os períodos curtos de declínio da economia podem facilmente empurrar as famílias de renda média para a pobreza. ${ }^{28}$ Essas famílias são sumamente vulneráveis ao empobrecimento

\footnotetext{
${ }^{26}$ É claro que esses números são melhores entre os integrantes mais jovens do grupo em idade de trabalho, o que reflete o progresso das duas últimas décadas. Mas entre as famílias da camada intermediária incluem-se aquelas em que muitos adultos têm mais de 40 anos.

${ }^{27}$ Aghion et al. (1999) oferecem um modelo em que o retorno médio sobre os investimentos é mais baixo nas economias em que um número limitado de integrantes tem possibilidade de investir (só os que têm bens a oferecer como garantia, dadas as implicações do mercado de crédito).

${ }^{28}$ Cline (2001) examinou o impacto que exercem sobre a pobreza as crises financeiras nos mercados emergentes, havendo concluído que pelo menos 40 milhões de pessoas foram levadas à pobreza durante as crises ocorridas no México (1995), na Tailândia e na Indonésia (1997), na Coréia e na Rússia (1998), no Brasil (1999) e na Argentina e na Turquia (2001). A pobreza teve um aumento significativamente maior nos países que administraram as crises com extremo insucesso (Indonésia, Rússia e Argentina).
} 
através da perda temporária de renda e, o que é pior, da perda de seus ativos limitados, em decorrência da instabilidade econômica. Dado que inúmeras famílias da camada intermediária estão próximas da linha de pobreza, as fases de declínio da atividade econômica que elevam os preços e reduzem o emprego, ainda que por períodos relativamente curtos, são particularmente dolorosas para elas. Durante a década de 1980, a percentagem de pobres duplicou na Grande Buenos Aires (de 10\% para mais de $20 \%$ ) e subiu de aproximadamente $32 \%$ para $50 \%$ nas regiões urbanas do Peru (Lustig, 2000). A situação atual da Argentina é reconhecidamente extrema, porém o aumento registrado do número de pobres, que chega a atingir 53\% nas áreas urbanas (INDEC, 2002) deixa muito clara essa questão. ${ }^{29}$

Mesmo nos casos em que o aumento da percentagem de pobres é pequeno, é provável que as famílias de renda mediana reduzam sua renda permanente, desfazendo-se de parte de seus ativos financeiros e de outros ativos fixos para manter o nível de consumo. $\mathrm{O}$ valor dos ativos financeiros, inclusive de pequenas empresas e contas bancárias, pode ser rapidamente corroído nas fases de declínio da atividade econômica, ou, no caso das contas bancárias, pela inflação, o que implica uma mobilidade social descendente para as famílias de recursos limitados, mesmo que não signifique um mergulho na pobreza. Comparando dados sobre a mobilidade da renda de famílias do Peru e dos Estados Unidos (em relação a outros quintis), Birdsall et al. (2000) constataram uma probabilidade muito maior de mobilidade descendente nos quintis médios das famílias peruanas (48\% desceram) do que nos das norte-americanas (34\% desceram), ao longo de um prazo mais curto ( 6 anos versus 10 anos). É provável que o agudo sentimento de insegurança daí resultante, para inúmeras famílias de renda média, esteja por trás do ceticismo crescente a respeito dos benefícios

\footnotetext{
${ }^{29}$ Em termos mais gerais, ocorre que muito mais famílias são "pobres" na maioria dos países, numa ou noutra época, do que implicam os índices do número de pobres. Pritchett et al. (2000) constataram que, na Indonésia, presumindo-se que $20 \%$ das famílias sejam pobres, é provável que outros $30 \%$ tenham sido ou venham a ser pobres num prazo de três anos. Por exemplo, Baulch e Hoddinott (2000) informam que a proporção de pobres na China foi de 0,2\% no período de $1985-1990$, mas que até $48 \%$ da população estiveram na pobreza em algum momento desse período. Os números correspondentes foram $3 \%$ e $55,3 \%$ com respeito ao Paquistão e 10,6\% e 59,6\% em relação ao Zimbábue entre 1993 e 1996.
} 
das reformas econômicas dos últimos 10-15 anos (as reformas do chamado Consenso de Washington). ${ }^{30}$

3. As reformas econômicas da década de 1990 (as chamadas reformas do Consenso de Washington) não prejudicaram os pobres. Mas também não os ajudaram, nem foram benéficas para a camada intermediária. Seus benefícios foram basicamente colhidos pelos ricos.

Para começar, o copo está pela metade. A análise econométrica, usando dados de levantamentos domiciliares sobre a maioria dos países da região em vários anos das três últimas décadas, combinados com índices de reformas econômicas nos diferentes países, sugere que a liberalização do comércio e, como grupo, outras reformas econômicas estruturais, como a privatização, as reformas trabalhistas e as reformas fiscais, não prejudicaram os pobres (e a redução drástica da inflação os ajudou). A única exceção foi a liberalização do setor financeiro, que prejudicou os pobres pelo menos em termos relativos. ${ }^{31}$

Por outro lado, as reformas tampouco ajudaram os pobres (na maioria dos países, os 30\% das famílias do patamar econômico inferior) e, com base na análise de seus efeitos sobre a desigualdade, é improvável que tenham ajudado a camada intermediária. Behrman, Birdsall e Székely (2001b) mostraram que, de modo geral, as reformas (liberalização do comércio, privatização, reforma fiscal e reforma do mercado de traba-

\footnotetext{
${ }^{30}$ Ver Graham (2002) para indícios de que as atitudes frente às reformas econômicas dos anos noventa são cada vez mais negativas, conforme dados de pesquisa do Latinobarometro. Birdsall, Graham e Pettinato (2000) usaram dados anteriores de levantamentos do Latinobarometro sobre as atitudes relativas às reformas, a fim de avaliar até que ponto elas diferem entre os pobres, os da camada intermediária e os ricos. Os resultados de análises de regressão apresentados indicam que os respondentes de renda média dão mais apoio às reformas nos países que se encontram no início do processo e lhes dão menos respaldo naqueles em que o processo está mais avançado - ou seja, exibem uma atitude geral cada vez mais negativa. Ver a Tabela 8 deste último livro citado.

${ }^{31}$ Behrman, Birdsall e Székely (2001a) usaram dados de levantamentos domiciliares cobrindo a maioria dos países da região ao longo de vários anos, nas décadas de $1980 \mathrm{e}$ 1990, combinados com índices de seis reformas econômicas por país e por ano, desenvolvidos por Morley e atualizados por Lora. As estimativas são reproduzidas no Apêndice III. A Tabela 2 do Apêndice III sugere que a liberalização do setor financeiro aumentou a defasagem entre o grupo intermediário e os pobres e aumentou a defasagem da pobreza, isto é, a diferença total de renda entre todos os que são considerados pobres e a linha de pobreza. Sobre essa mesma abordagem para avaliar os efeitos das reformas sobre a desigualdade salarial, ver Behrman, Birdsall e Székely (2001b).
} 
1ho, liberalização do setor financeiro e abertura da conta de capitais) ampliaram a desigualdade salarial, levando efetivamente, em média, a um declínio dos salários reais dos que não tinham pelo menos alguma instrução além do segundo grau, bem como a um declínio relativo dos salários dos que tinham alguma instrução acima desse nível. Isso implica que nossa camada intermediária, a maioria de cujos membros adultos não chega a ter o curso secundário completo, obteve pouco ou nenhum benefício das reformas, em termos absolutos, e com certeza saiu perdendo em relação aos ricos (e mais instruídos). As "vilãs" das reformas não foram a liberação do comércio nem as privatizações, mas a reforma do setor financeiro e a abertura da conta de capitais. ${ }^{32}$

Behrman et al. (2001a) também mostraram que os pobres e a camada intermediária quase pobre foram auxiliados pela redução da inflação e da volatilidade macroeconômica (Apêndice III, Tabela 2). Os declínios nos termos de comércio não tiveram muita importância e, em si mesma, a valorização da taxa de câmbio pareceu ajudar. Examinando os efeitos que as reformas econômicas e as mudanças do meio macroeconômico ocorridas nesse período exerceram sobre a renda dos $10 \%$ de famílias mais ricas, comparados aos 30\% mais pobres, constata-se que, em termos relativos, os mais pobres saíram perdendo com a inflação, com a volatilidade macroeconômica e com a liberalização do setor financeiro. No caso da liberalização do setor financeiro, é possível que o menor custo do capital ou o melhor acesso a empréstimos privilegie o trabalho qualificado em relação ao não qualificado, possivelmente porque o investimento maior de capital (em tecnologias mais novas, por exemplo) requer um uso maior de mão-de-obra especializada. Os mais pobres saíram ganhando com a valorização da taxa de câmbio e (embora esse resultado seja estatisticamente menos significativo) com a melhoria nos termos de comércio.

Qual é o panorama global que emerge dessas análises? Os pobres e a camada de renda intermediária não estão em condições particularmente piores em decorrência das reformas econômicas, e certamente não o estão por causa da abertura da economia, estritamente definida

\footnotetext{
${ }^{32}$ Behrman et al. (2001b) afirmaram que o efeito das reformas no aumento da defasagem salarial não persiste ao longo do tempo, mas vai desaparecendo, em consonância com a probabilidade de ajustes do mercado. Assim, as reformas não necessariamente prejudicaram os pobres nem a camada intermediária em caráter permanente, mas também não ajudaram esses grupos.
} 
em termos de liberalização do comércio. Mas estão pior em decorrência da instabilidade contínua; aliás, talvez não seja por acaso que a reforma que pode ter surtido efeitos claramente negativos nos pobres - a liberalização do setor financeiro - e as duas reformas que aumentaram a desigualdade salarial - a liberalização do setor financeiro e a abertura da conta de capitais - tenderam a desempenhar um papel central na instabilidade econômica a curto prazo. ${ }^{33}$

\section{Parte 3. Os ingredientes de um contrato social baseado no emprego e no crescimento}

Quais são as implicações, em termos de medidas políticas, que constituiriam um contrato social mais amplo numa economia aberta? Considero quatro delas. Três têm a ver com a política tributária interna e uma com as políticas das economias avançadas. ${ }^{34}$

Primeiro, uma política tributária brilhante é o ingrediente central do contrato social numa economia aberta. É difícil evitar essa conclusão, a despeito de sua aparente banalidade. Emprego a palavra "brilhante" porque, ironicamente, o padrão das economias de mercado emergentes na América Latina é mais alto que o dos Estados Unidos e das economias européias. É que essas economias latino-americanas emergentes têm dois problemas: mercados financeiros internos menos sólidos e menos resistentes aos revezes econômicos e um histórico ruim. Os mercados financeiros de pouco lastro dificultam a administração da instabilidade por parte do governo. ${ }^{35} \mathrm{O}$ histórico ruim (de tomada de empréstimos mal administrada, com as crises resultantes de inflação e monetárias) significa que os credores internos e externos continuam céticos quanto à capacidade política de os governos administrarem seus orçamentos, sem recorrerem, nas situações de crise, à emissão de moeda ou a novas rodadas de empréstimos excessivos e dispendiosos.

\footnotetext{
${ }^{33}$ Gavin e Hausmann (1996) documentaram as fontes da volatilidade na América Latina. Kose, Prasad e Terrones (2002) mostraram o impacto da liberalização financeira na volatilidade do consumo em alguns países de baixa renda.

${ }^{34}$ Esta seção baseia-se, em parte, nas idéias políticas expostas em Birdsall e de la Torre (2001), onde a ênfase recai sobre as medidas que abordam diretamente a equidade, sem sacrificar o crescimento. Ver também de la Torre (2002).

${ }^{35}$ Banco de Desenvolvimento Interamericano (1995).
} 
A brilhante administração fiscal implica, entre outras coisas, a disposição e a capacidade política de reduzir a dívida pública. A menos que ela já esteja em declínio, os déficits fiscais têm que ser vistos como má política social, violadora do contrato social, a não ser que o governo que já tenha apresentado superávits durante vários anos seguidos e que o gasto com a dívida seja claramente contracíclico e temporário. Com a única exceção do Chile, todos os países latino-americanos tiveram um déficit fiscal global em todos os anos, desde $1993 .{ }^{36}$ Quando o déficit global é negativo em relação à perspectiva de crescimento, nem mesmo o superávit primário é sustentável (nos bons tempos) com um déficit global. É tentador contrair empréstimos para bons investimentos (inclusive saúde e educação) nas épocas de fartura. Mas só os países que já conseguiram evitar a instabilidade na última década (o Chile, talvez El Salvador e a Costa Rica) podem escapar ao ônus de manter o superávit durante os anos de crescimento, ainda por muitos anos.

Para a maioria dos países latino-americanos, os superávits são cruciais para o contrato social, pelo menos por duas razões. Primeiro, são a chave para manter as taxas reais de juros num patamar baixo. As taxas reais de juros foram muito altas na América Latina durante os anos noventa, atingindo, em média, mais de $10 \%$ na maioria dos países, enquanto, de modo geral, ficaram abaixo de $10 \%$ nos outros países em desenvolvimento e em cerca de 5,6\% nos Estados Unidos (ver Tabela 2). Reduzir as taxas de juros é fundamental para a geração de empregos para a vasta maioria da força de trabalho, com seu nível de instrução limitado. ${ }^{37}$

\footnotetext{
${ }^{36}$ Fundo Monetário Internacional (2001).

${ }^{37} \mathrm{Na}$ OCDE, verificou-se que as taxas reais de juros mais altas contribuíram para o aumento do desemprego (Blanchard e Wolfers, 1999). As estimativas dessa relação não mostram um efeito estatisticamente robusto na América Latina; todavia, os dados são muito mais "ruidosos" quanto à taxa real de juros (em vista da própria volatilidade não captada da inflação), os mercados de crédito são muito mais segmentados e os dados sobre o emprego e o desemprego são menos fidedignos.
} 
Tabela 2: Comparação das Taxas Médias Reais de Juros (década de 1990): América Latina, outros países em desenvolvimento e Estados Unidos

\begin{tabular}{|c|c|c|c|}
\hline \multicolumn{4}{|c|}{ Taxas médias reais de Juros } \\
\hline \multicolumn{2}{|l|}{ América Latina } & \multicolumn{2}{|c|}{ Outros países em desenvolvimento } \\
\hline Argentina $(1990-2000)$ & 11,02 & Argélia (1994-2000) & $-1,62$ \\
\hline Belize (1990-2000) & 12,61 & Angola (1995-2000) & $-55,68$ \\
\hline Bolívia (1990-2000) & 33,49 & Bangladesh (1990-2000) & 10,27 \\
\hline Brasil (1997-2000) & 65,01 & China $(1990-2000)$ & 2,61 \\
\hline Chile (1990-2000) & 11,82 & Croácia (1992-2000) & 11,11 \\
\hline Colômbia (1990-2000) & 13,46 & Egito $(1990-2000)$ & 6,45 \\
\hline Costa Rica (1990-2000) & 9,01 & Índia (1990-2000) & 6,52 \\
\hline Rep.Dominicana (1991-2000) & 14,65 & Indonésia (1990-2000) & 7,66 \\
\hline Equador (1990-2000) & 1,36 & Rep.Coréia (1990-2000) & 4,51 \\
\hline El Salvador (1990-2000) & 8,33 & Malásia (1990-2000) & 4,43 \\
\hline Guatemala (1990-2000) & 7,80 & I.Maurício (1990-2000) & 12,40 \\
\hline Honduras $(1990-2000)$ & 6,77 & Marrocos (1990-2000) & 8,59 \\
\hline México (1993-2000) & 9,49 & Filipinas (1990-2000) & 6,73 \\
\hline Nicarágua (1990-2000) & $-12,19$ & Cingapura (1990-2000) & 4,72 \\
\hline Panamá (1990-2000) & 8,85 & Sri Lanka (1990-2000) & 6,58 \\
\hline Paraguai $(1990-2000)$ & 14,45 & & \\
\hline Peru $(1990-2000)$ & 25,91 & \multirow{2}{*}{\multicolumn{2}{|c|}{ Países desenvolvidos }} \\
\hline Uruguai (1990-2000) & 40,06 & & \\
\hline Venezuela (1990-2000) & 0,47 & Estados Unidos (1990-2000) & 5,64 \\
\hline
\end{tabular}

Segundo, a poupança pública (isto é, o superávit fiscal) é fundamental para a capacidade governamental de usar a política fiscal e monetária contracíclica para proteger a grande camada intermediária, assim como os pobres, nas fases de declínio da atividade econômica. Durante as recessões dos países desenvolvidos, os governos podem contrair dívidas para financiar o seguro-desemprego, aumentar os gatos com cupons de alimentos, com a merenda escolar e com a saúde pública, e para tomar outras providências que constituam uma rede de segurança social para seus cidadãos. Seus mercados financeiros internos e a confiança em suas moedas lhes permite financiar os déficits contracíclicos nas fases de declínio econômico. Para todos os fins práticos, num futuro previsível, poucos governos latino-americanos - com a possível exceção do Chile - têm setores financeiros locais capazes de absorver mais dívidas, a não ser a um custo elevado, e poucos despertam confiança suficiente nos mercados externos para tomar empréstimos nas fases ruins. Ironicamente, o fato de eles serem mercados "emergentes", e não emersos, com sua história de inflação e má administração da dívida, exige uma disciplina fiscal mais contínua e rigorosa do que os credores internos e externos esperam dos governos dos países desenvolvidos. 
Não há como evitar essa assimetria, se esses países quiserem participar dos benefícios da integração global.

Em suma, a capacidade de reduzir as taxas reais de juros e implementar uma política contracíclica está no cerne do contrato social de uma economia aberta. Essa capacidade depende de uma política tributária brilhante.

Os eleitores da América Latina demonstraram, durante a última década, sua desconfiança do populismo e seu apoio a candidatos vistos como capazes de garantir a estabilidade macroeconômica; isso não é de admirar, dada a comprovação de que os custos da instabilidade são altos para a maioria das famílias. Mas a lembrança coletiva da hiperinflação, como um ônus imposto pelo Estado aos cidadãos, pode estar desaparecendo, e a instabilidade vem-se associando mais às crises financeiras desencadeadas no exterior. Com os indícios crescentes de desânimo em relação às reformas, ${ }^{38}$ mais uma vez parece haver uma permuta entre a boa política social e a boa política fiscal. Esse efeito nocivo só pode ser evitado se for estabelecido um vínculo entre a boa administração fiscal e um contrato social baseado no emprego.

Segundo, uma política tributária brilhante implica reformas difíceis pelo lado dos gastos e dos impostos. Na questão dos gastos, a maioria dos países consegue fazer deles uma distribuição muito mais progressiva do que é a distribuição da renda, especialmente no tocante aos investimentos sociais. ${ }^{39}$ Mas em certos países, como o Brasil, por exemplo, algumas áreas importantes de gastos, como a das pensões e aposentadorias dos servidores públicos e dos militares, são ineficientes e injustas. (Por outro lado, no Brasil, a eliminação do déficit fiscal e quase fiscal dos gastos no nível estatal foi um enorme passo na direção certa - um passo que não foi dado na Argentina. ${ }^{40}$ ) Os credores continuarão desconfiados da capacidade a longo prazo de administração do orçamento,

\footnotetext{
${ }^{38}$ Ver em Graham (2002) os indícios de mudança da postura política em relação às reformas econômicas da década de 1990, bem como do sentimento crescente de insegurança econômica na região. A autora afirma (com base em pesquisas do Latinobarometro) que, na América Latina, apenas $16 \%$ dos respondentes das pesquisas acreditam estar vivendo melhor do que seus pais, em comparação com $64 \%$ nos Estados Unidos. Ela informa também que o nível de riqueza das pessoas tem uma correlação positiva com o apoio à "produtividade" versus a "redistribuição" na região.

${ }^{39}$ Birdsall e de la Torre (2000).

${ }^{40}$ No Brasil, as pensões dos servidores públicos e dos militares consomem pelo menos $25 \%$ da receita pública anual. Os aposentados recebem $100 \%$ de seu salário mais alto, acrescido do ajuste pleno da inflação e de ajustes calculados com base nos aumentos do salário mínimo.
} 
enquanto não forem eliminadas essas barreiras estruturais contra a redução dos gastos. A melhor das providências "emergenciais" para reduzir os gastos tributários, mesmo quando é convincente, ${ }^{41}$ fica demasiadamente sujeita à liderança individual, a qual, para os credores, por sua vez, é por demais incerta em termos políticos (como indica a reação do mercado à candidatura Lula no Brasil). Dado o efeito que a desconfiança dos credores exerce sobre as taxas de juros na tomada de empréstimos públicos, a reforma dos gastos é fundamental para reduzir a taxa de juros para o setor privado, bem como para o crescimento do emprego e, portanto, para o contrato social de uma economia aberta.

Pelo lado dos impostos, há pelo menos dois problemas. Um deles é que, na maioria dos países, os 10\% mais ricos pagam poucos impostos. O uso de brechas para fugir da tributação e a sonegação fiscal constituem a norma. ${ }^{42} \mathrm{Na}$ Argentina, as famílias mais ricas arcam com uma taxa média de impostos de $8 \%{ }^{43}$ São evidentes os limites da obtenção global de receita, quando as famílias que controlam mais de $50 \%$ da renda pagam poucos impostos. ${ }^{44}$ Segundo, a região depende maciçamente do imposto sobre o valor adicionado, o qual, junto com outros impostos diretos, gera $90 \%$ do total da receita, comparados aos $60 \%$ gerados na Europa. Como imposto que incide no consumo, o imposto sobre o valor adicionado não é progressivo em si mesmo (embora possa ser e seja administrado no sentido de limitar seu impacto regressivo). Além disso, à semelhança dos impostos que incidem na folha de pagamentos (dada a maneira como costumam ser administrados), ele é um imposto invisível; os cidadãos não têm conhecimento do ônus que representa. Para estes, ele não tem como encarnar o reverso do contrato social entre o Estado e os cidadãos, que consiste em que os cidadãos assumem a res-

\footnotetext{
${ }^{41}$ Refiro-me aos benefícios de melhor gestão emergencial que são irreverentemente chamados "benefícios Pedro Malan", aludindo ao ministro da Fazenda brasileiro do período de 1995-2002. Mas até esses benefícios são limitados.

${ }^{42}$ Birdsall e de la Torre (2001) citam algumas provas disso.

${ }^{43}$ O Banco Interamericano de Desenvolvimento (1999) mostra a incidência da taxação por decil em vários países latino-americanos. Com referência à incidência de impostos na Argentina, a fonte é o Centro de Estudios Bonaerense (1997).

${ }^{44}$ Nos anos de crescimento explosivo nos Estados Unidos, no fim da década de 1990, estima-se que $60 \%$ do total da receita do imposto de renda tenham vindo das famílias situadas nos 5\% superiores (verificar) da renda per capita. (V) Ana: continuou a indicação "check" entre parênteses no original; que fazer?
} 
ponsabilidade por financiar o Estado e esperam que os representantes estatais respondam por um governo receptivo e responsável. ${ }^{45}$

Para encarnar melhor o contrato social, a reforma dos sistemas tributários da região precisaria implementar uma política tributária mais visível e mais progressiva. Isso não precisa implicar a elevação das taxas de impostos marginais. Em alguns países, implicaria aumentar a receita global através da eliminação das brechas para a evasão e mediante a redução da sonegação (e o aumento da receita permitiria gastos maiores, os quais, como já foi assinalado, têm uma distribuição mais progressiva do que a renda). Poderia implicar um aumento do imposto sobre as vendas de artigos de luxo ou o restabelecimento de um imposto modesto sobre as importações incidindo sobre todas elas, para fins de obtenção de receita, e não de protecionismo -, que se elevaria nas fases de crescimento e cairia nos períodos de recessão. Na maioria dos países, essas reformas reduziriam a dependência maciça do consumo invisível e dos impostos sobre a folha de pagamentos, que impõem um ônus pesado à camada intermediária.

Terceiro, um contrato social implica uma nova ênfase numa questão tradicional: a proteção aos direitos dos trabalhadores. Um contrato social baseado no emprego não pode ignorar a insegurança e o desamparo da vasta maioria dos trabalhadores da região nas fases de declínio da economia. Como ilustra a Figura 5, a reforma do mercado de trabalho é a menos avançada da América Latina, comparada a outras reformas econômicas ligadas ao Consenso de Washington, presumivelmente porque a ênfase na "flexibilidade" do mercado de trabalho tem sido muito ameaçadora, em termos políticos, para os remanescentes do contrato social anterior aos anos oitenta, baseado na proteção do emprego no setor industrial. Um contrato social baseado no emprego, numa economia aberta, implica valorizar maciçamente a proteção da renda dos trabalhadores. Esse objetivo pode ser alcançado de duas maneiras: garantindo os direitos de negociação coletiva, paralelamente a programas de regulamentação que assegurem a democracia dos sindicatos, e garantindo uma mobilidade muito maior e mais fácil no emprego, em contraste com a garantia da estabilidade individual em determinados empregos.

A proteção à mobilidade no emprego não precisa depender de um seguro-desemprego do tipo que é comum nas economias mais ricas, que

\footnotetext{
${ }^{45}$ Essa questão é discutida em Birdsall e de la Torre (2001) e convincentemente elaborada em de la Torre (2002).
} 
requer uma capacidade maior de financiamento contra-cíclico do que tem atualmente a maioria dos governos latino-americanos. Ela pode basear-se num programa parcialmente autofinanciado de contribuições obrigatórias de empregadores e empregados para contas individuais, que podem ser transferidas para fundos de aposentadoria. O Chile criou um sistema financiado e portátil desse tipo, com contas individualizadas dos trabalhadores, as quais podem ser usadas para o seguro-desemprego e das quais o trabalhador também pode fazer um conjunto restrito de outras retiradas, como para a compra da casa própria. ${ }^{46}$

Por último, o acesso aos mercados dos países ricos deve ser visto como central para o contrato social da economia aberta. O contrato social baseado no emprego e no crescimento, numa economia aberta, não depende apenas da abertura das economias da América Latina, mas de seus mercados externos. Pelo menos parte da instabilidade que tanto tem custado à camada intermediária e aos pobres se reduziria na região, se houvesse uma melhora em seu acesso ao mercado norte-americano e aos europeus; o maior crescimento das exportações e a diminuição da necessidade de empréstimos externos afastariam mais as economias da instabilidade financeira. Além disso, é provável que os empregos criados em setores como a agricultura (no Brasil, a soja), a indústria de calçados e a indústria têxtil ampliasse a demanda de mão-de-obra menos qualificada. Nesse caso, os benefícios da ligação com a economia global aumentariam para a vasta maioria de famílias em que os adultos ainda têm níveis relativamente baixos de instrução. Sem esse acesso, pode não ser impossível, mas com certeza será difícil imaginar que a região possa implantar o tipo de contrato social que esbocei.

\section{Observações finais}

Aludi apenas indiretamente ao problema subjacente da má distribuição dos ativos produtivos na região, que se reflete na distribuição sumamente desigual da renda e que a reforça. A razão disso é que alguns esboços gerais da política social já vêm abordando esse problema, através da maior atenção dedicada à educação (o ativo do povo ${ }^{47}$ ), dos esforços crescentes para ampliar os projetos de microfinanciamento (a

\footnotetext{
${ }^{46}$ Marquez (2000) e Cortazar (1995).

${ }^{47}$ Enfatizo essa questão em Birdsall (2000). Ver também Birdsall e Londoño (1997).
} 
fim de oferecer crédito e aumentar a acumulação de bens dos pobres) e da reforma agrária (especialmente no Brasil e na Colômbia, onde inovações sensatas têm provado que a reforma agrária baseada no mercado é sumamente viável). Tudo isso é não apenas central para a boa política social, mas é também crucial para ampliar o nível sustentável de crescimento a longo prazo da região, através do aumento da produtividade da vasta maioria de seus cidadãos. Há bons indícios de que, nas economias em que o mercado de capitais e outros são relativamente fracos, nas quais as próprias medidas reguladoras para compensar as imperfeições intrínsecas dos mercados nem sempre são satisfatórias, a própria desigualdade de acesso solapa o crescimento. ${ }^{48}$ (O exemplo clássico é a impossibilidade de os pobres contraírem empréstimos, o que não só limita sua renda como restringe o crescimento econômico global.) O contrato social de qualquer dos países latino-americanos também não pode desconhecer o custo permanente da discriminação étnica e racial.

Optei, ao contrário, por enfatizar um problema que tem recebido menos atenção, qual seja, o de que não apenas os pobres, mas a vasta maioria dos trabalhadores e famílias da região, ainda não se estão beneficiando - ou, certamente, não se estão beneficiando muito - da abertura das economias e das outras reformas da última década, comparados a seus vizinhos altamente instruídos. Na verdade, é possível que a ênfase tradicional e sensata no atendimento às necessidades dos pobres tenha criado alguns pontos cegos (especialmente na comunidade internacional voltada para o desenvolvimento) na percepção da realidade de que as famílias situadas na faixa intermediária da distribuição da renda na América Latina estão longe dos níveis de renda e segurança associados à "classe média" nas economias avançadas. Elas podem não ser consideradas pobres hoje, mas talvez tenham sido pobres há pouco tempo e é bem possível que venham a empobrecer amanhã. Em termos de sua

\footnotetext{
${ }^{48}$ A literatura sobre os efeitos da desigualdade no crescimento é muito mais clara a esse respeito do que se costuma pensar. A melhor avaliação isolada (Barro, 2000) é aquela que faz uma distinção criteriosa entre as economias desenvolvidas e as que estão em desenvolvimento. Nas primeiras, a desigualdade anterior pode, na verdade, fomentar o crescimento; nas últimas, tem um efeito negativo. Birdsall e Londoño (1997) mostraram que a desigualdade na instrução e na terra, medida no nível amplo da economia, reduz o aumento da renda do quintil mais pobre duas vezes mais do que reduz o aumento da renda da família média, e que, levando em conta a desigualdade desses dois tipos de ativos, a América Latina nada tem de "especial"; é sua desigualdade nos ativos que responde por seu distanciamento das economias avançadas na distribuição da renda.
} 
capacidade de acumular bens e da probabilidade de receberem um retorno adequado sobre esses bens, mais vale considerá-las como quase pobres do que como a "classe média" que constitui o baluarte do sistema democrático nas economias abertas. É provável que, ironicamente, a ênfase num contrato social que atenda às necessidades dessa maioria oculta das populações, e não apenas dos atualmente pobres, também beneficie mais os pobres, pois é sabido que estes retiram um enorme proveito do crescimento em si, e sobretudo do crescimento estável, baseado no emprego. ${ }^{49}$

A América Latina implementou um conjunto de mudanças em direção às economias de mercado mais abertas e competitivas. Agora, é preciso complementar e reforçar os benefícios de crescimento desse primeiro grande passo com um segundo passo: um contrato social que se concentre maciçamente no emprego e no crescimento e, por conseguinte, numa administração tributária brilhante, na proteção aos direitos dos trabalhadores e na pressão sobre os Estados Unidos e as demais economias avançadas para que eles ampliem o acesso a seus mercados.

\footnotetext{
${ }^{49}$ Nelson (2000) discute a política desse tipo de aliança. Ravallion (2002) mostra que, na Argentina, assim como em Bangladesh e na Índia, o desempenho concentrado dos programas de redes de segurança se deteriora quando os programas se contraem. Isso sugere "uma tendência subjacente da economia política a proteger os gastos dos nãopobres" (p. 18). Ironicamente, o corolário é que ampliar os gastos, a fim de que eles atinjam um número maior de pessoas, tende a ajudar imensamente os pobres.
} 


\section{Figura 1A:}

Taxa marginal de retorno sobre a educação na América Latina na década de 1990, conforme a conclusão dos ciclos de estudos

Figure 1

\section{Marginal Returns to Education in} Latin America in the 1990 s

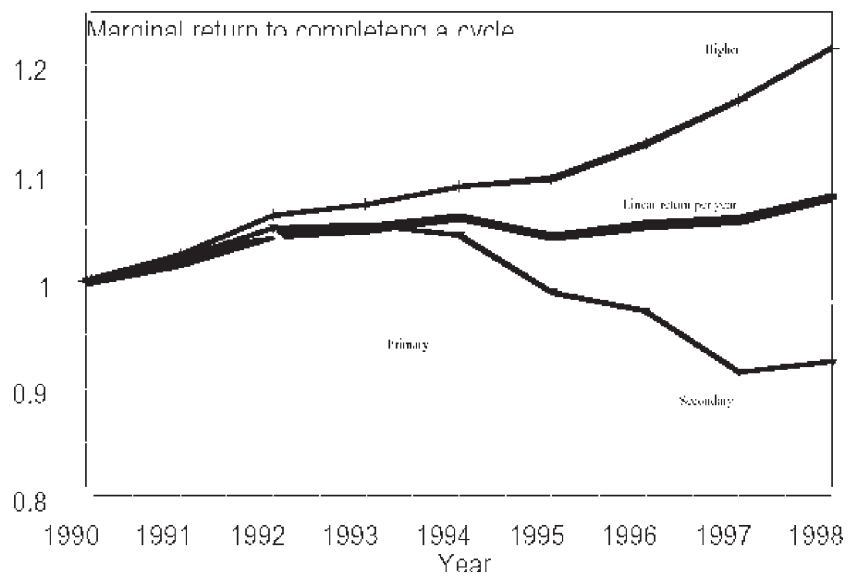

Fonte: Birdsall, Behrman e Székely (2001).

Figura 1B:

Diferenciais de salário na América Latina

Figure 1(b): Wage Differentials in Latin America

Figure 2

Wage Differentials in

Latin America in the 1990 s

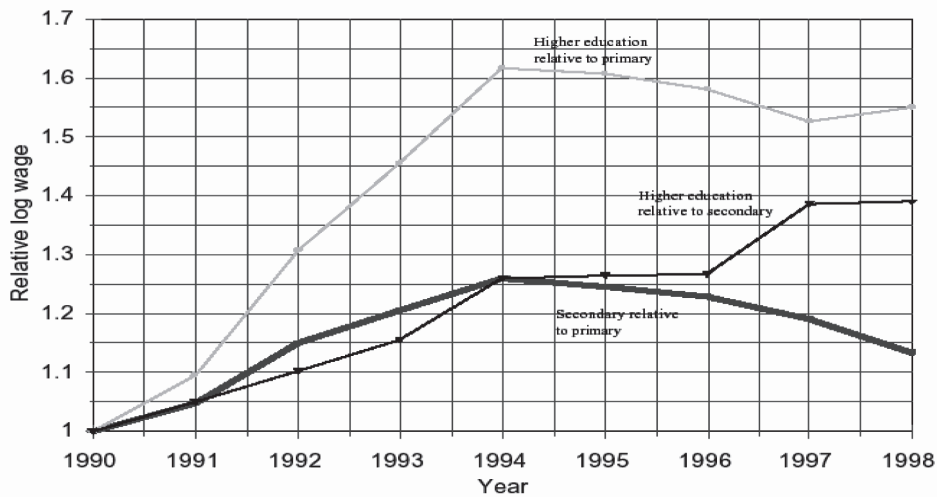

Source: Birdsall, Behrman, and Szekely (2001)

Fonte: Birdsall, Behrman e Székely (2001). 
Figura 2:

Grupos de renda média na América Latina.

Renda familiar média e renda familiar mediana, década de 1990

Figure 2: Middle Income Groups in Latin America. Average Household Income and Median Household Income. 1990's .
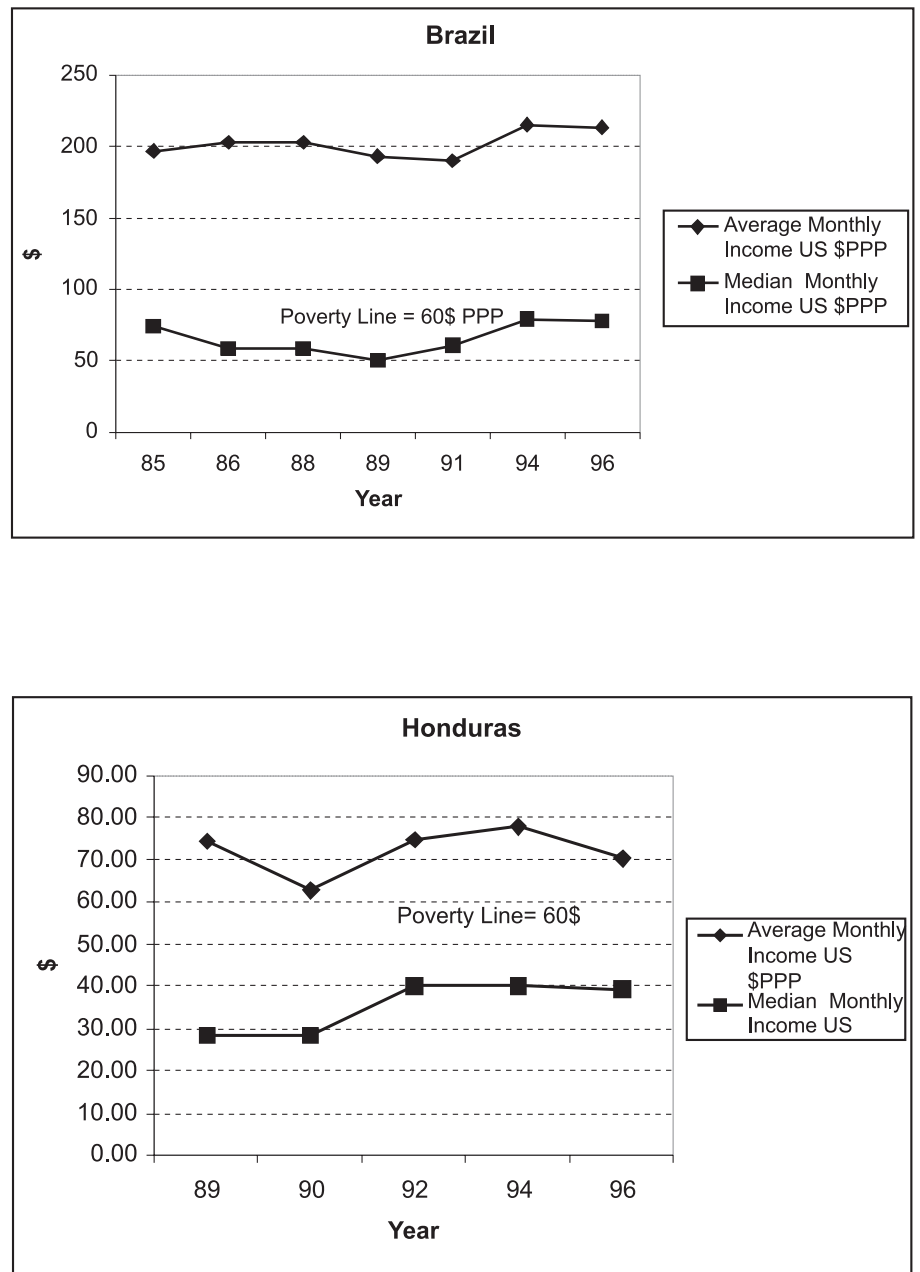

Source : Own Estimations from World Bank Data Sets (2002)

Fonte: Estimativas da autora a partir de estatísticas do Banco Mundial (2002). 

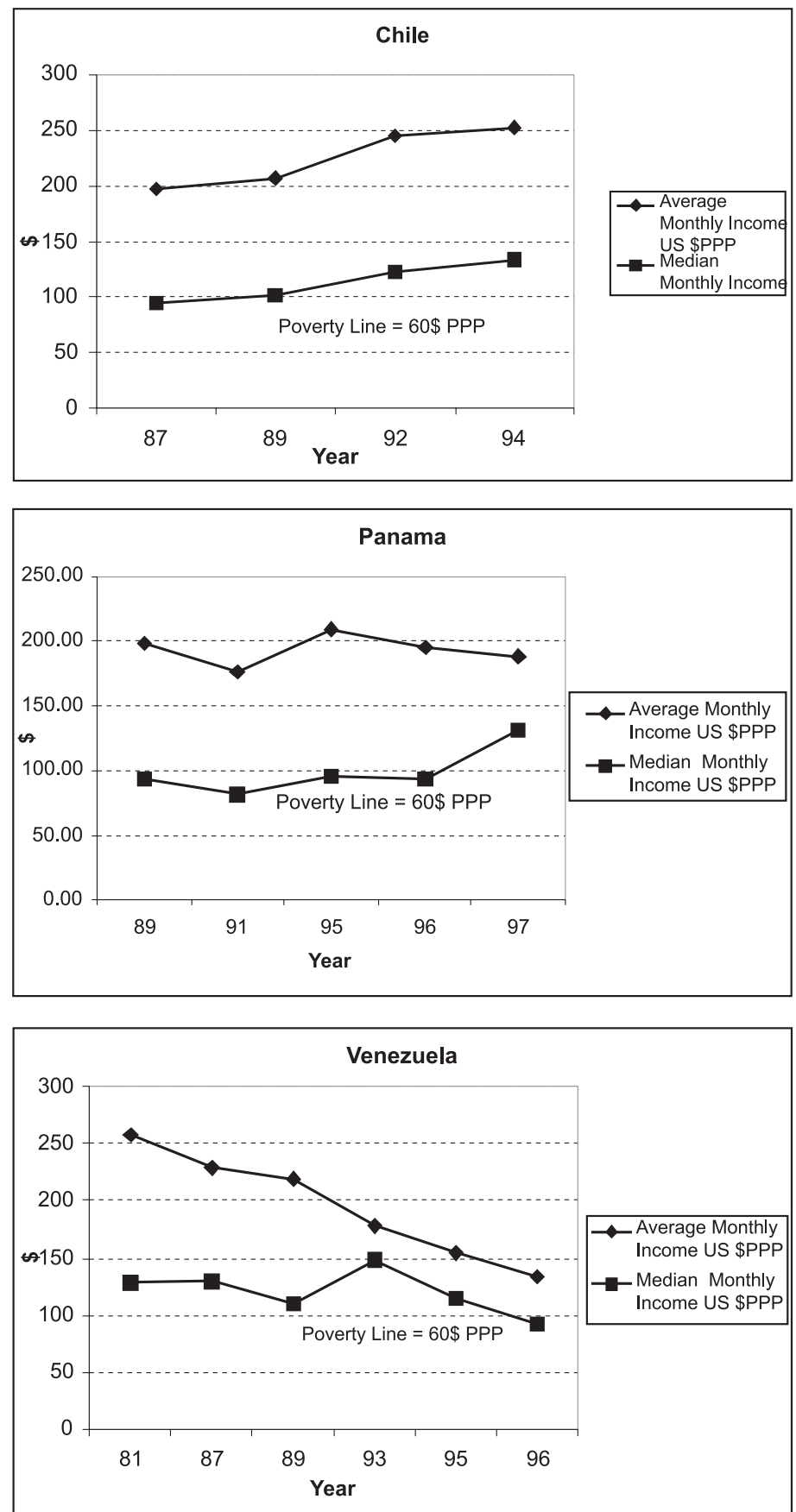

Source : Own Estimations from World Bank Data Sets (2002)

Fonte: Estimativas da autora a partir de estatísticas do Banco Mundial (2002). 
Figura 3:

Indicadores de saúde de vários países latino-americanos conforme o grupo de renda, década de 1990

Figure 3: Health Indicators for Several Latin American Countries by Income Group. 1990's.
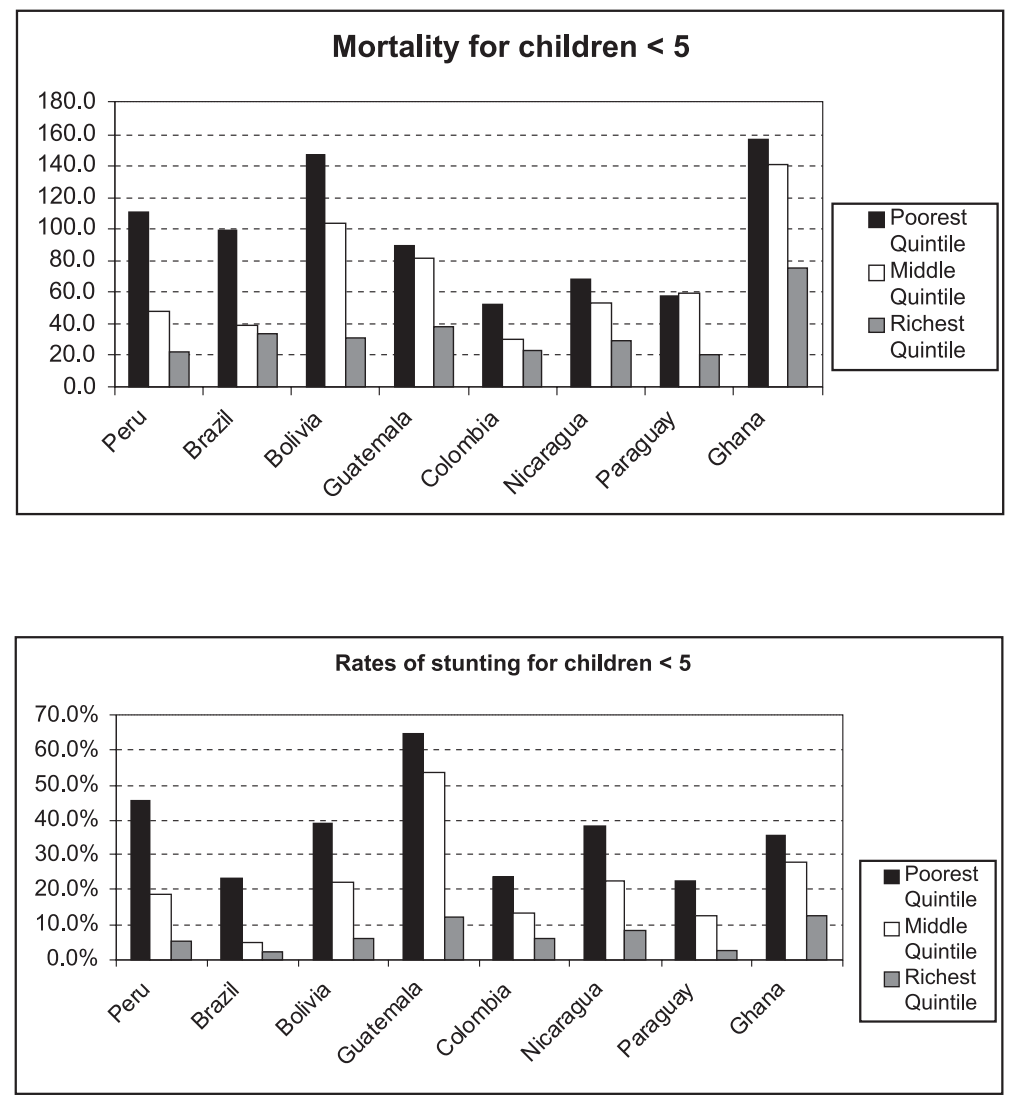

Source: World Bank's Health and Population Advisory Service. Demographic and Health Surveys: Peru (1996), Brazil (1996), Bolivia (1998), Guatemala(1995), Colombia (1995), Nicaragua (1997), Paraguay (1990), Ghana (1993).

http://www.worldbank.org/poverty/health/data/index.htm

Fontes: Serviço de Assessoria sobre Saúde e População, Banco Mundial. Levantamentos demográficos e de saúde: Peru (1996), Brasil (1996), Bolívia (1998), Guatemala (1995), Colômbia (1995), Nicarágua (1997),

Paraguai (1990), Gana (1993).

http://www.worldbank.org/poverty/health/data/index.htm 
Figura 4:

Níveis médios de instrução e níveis medianos de instrução na América Latina

Figure 4: Average Levels of Education and Median Levels of Education in Latin America BRAZIL

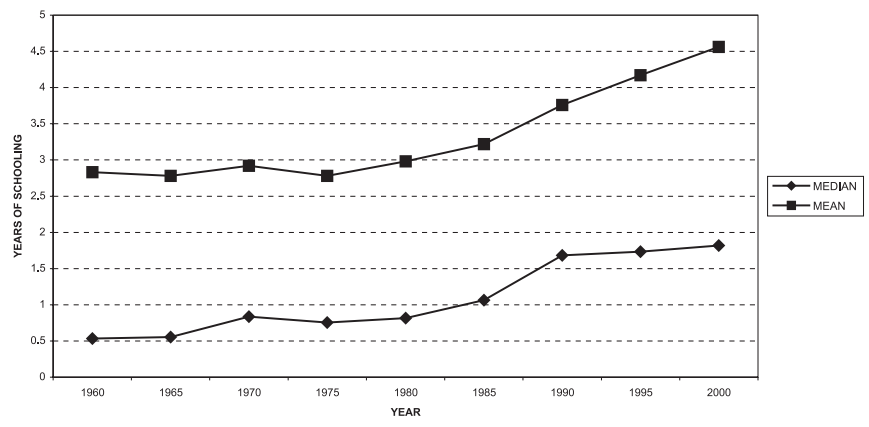

BOLIVIA

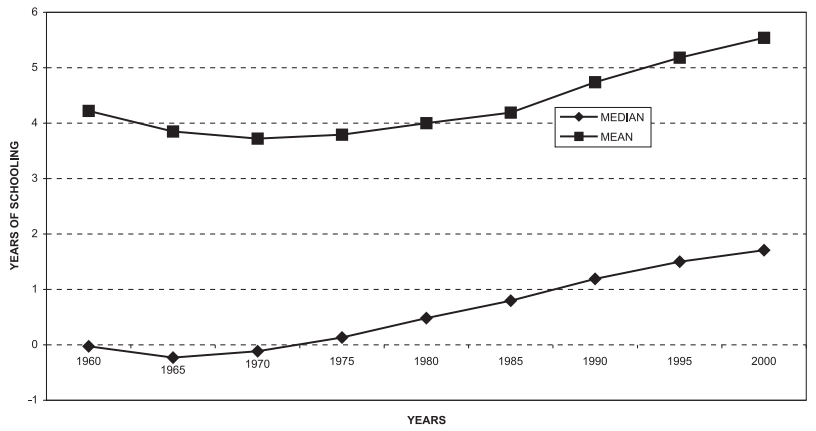

ARGENTINA

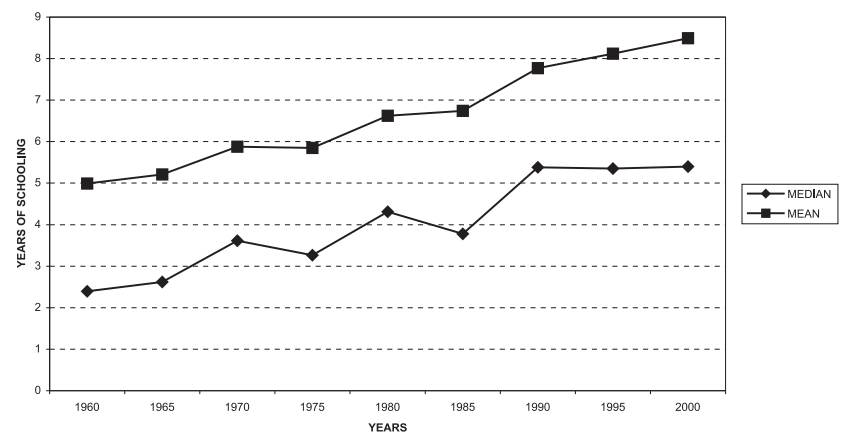

Source: Own Estimations, based on Barro and Lee Data Set (World Bank Data Sets, 2002).

Fonte: Estimativas da autora com base nos dados de Barro e Lee (estatísticas do Banco Mundial, 2002). 


\section{Figura 5:}

Evolução das reformas na América Latina.

Indicadores médios da política adotada, período de 1970-1995

Figure 5: Evolution of Reforms in Latin America . Average Policy Indexes

Figure 3a

Average Policies

Latin America, 1970-1995

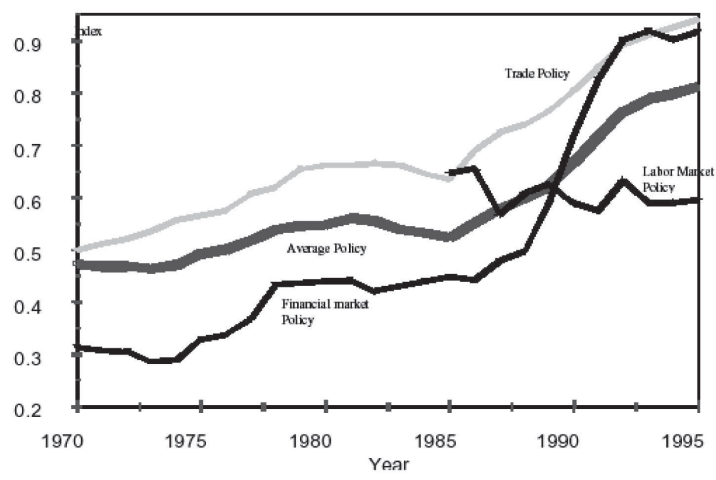

Source: Birdsall, Behrman, and Szekely (2001)

Fonte: Birdsall, Behrman e Székely (2001).

\section{Apêndice I:}

Efeitos do crescimento e da desigualdade sobre a pobreza na América Latina

Appendix I: Effects of Growth and Inequality on Poverty in Latin America

Changes in Poverty and Decomposition

of the Change into Growth and Redistribution Effects

\begin{tabular}{|c|c|c|c|c|c|c|c|}
\hline Country & Period & $\begin{array}{c}\text { Poverty } \\
\text { Line }\end{array}$ & $\begin{array}{c}\text { Initial } \\
\text { Poverty } \\
\text { Rate }\end{array}$ & $\begin{array}{l}\text { Change } \\
\text { (Points) }\end{array}$ & $\begin{array}{c}\% \text { Change } \\
\text { due to } \\
\text { Growth }\end{array}$ & $\begin{array}{c}\% \text { Change } \\
\text { due to } \\
\text { Redisrtibution }\end{array}$ & $\begin{array}{c}\% \text { Change } \\
\text { due to } \\
\text { Residual }\end{array}$ \\
\hline \multirow[t]{2}{*}{ Brazil } & $(1985-95)$ & Extreme & 10.03 & 1.02 & -0.40 & 1.45 & -0.05 \\
\hline & $(1985-95)$ & Moderate & 30.42 & -2.4 & -0.40 & -0.70 & 0.10 \\
\hline Bolivia & (1990-95) & Moderate & 52.4 & -5.3 & -1.47 & 0.44 & 0.03 \\
\hline Chile & $(1987-96)$ & Moderate & 45.1 & -21.9 & -0.85 & -0.07 & -0.08 \\
\hline Colombia & (1991-95) & Moderate & 58.5 & -0.04 & -1.03 & 0.06 & -0.03 \\
\hline Costa Rica & $(1986-95)$ & Moderate & 29.4 & -3.8 & -1.17 & 0.17 & -0.02 \\
\hline Peru & $(1985-96)$ & Moderate & 43.1 & 7.4 & 0.99 & -0.27 & 0.28 \\
\hline
\end{tabular}

Source: Calculated from country studies in this volume.

Fonte: Attanasio e Székely (2001). 


\section{Apêndice II: Estimativa da renda mediana}

A estimativa seguiu Cline (2002) e Bourguignon (2002). A mediana é o valor $m$ de uma variável $\mathrm{X}$ tal que:

$$
\begin{aligned}
& \operatorname{Pr} o b(X \leq m) \geq \frac{1}{2} \quad \text { and } \\
& \operatorname{Pr} o b(X \geq m) \leq \frac{1}{2}
\end{aligned}
$$

onde Prob = função probabilística.

Assim, a renda mediana é o valor da renda do indivíduo ou família que se situa bem no meio de todas as faixas da distribuição de renda. Quase todos os dados sobre a renda por país incluem uma renda média e algum índice da desigualdade (dispersão), mas não a mediana. Para calcular a mediana, tal como definida na equação (1), usando a média e a dispersão, é necessário usar uma função probabilística. Presumindo-se que a renda (y) tenha uma distribuição probabilística logarítmica normal, sua distribuição probabilística pode expressar-se da seguinte maneira:

$$
f(y)=\frac{1}{\sqrt{2 \pi} \sigma y} e^{\frac{(\ln y-\delta)^{2}}{2 \sigma^{2}}}
$$

onde $\delta=$ média de $\ln$ y

$$
\sigma=\text { desvio padrão de } \ln \text { y }
$$

A distribuição logarítmica normal pode expressar-se como uma distribuição padrão normal, depois de se normalizar y:

$$
f(x)=\frac{1}{\sigma x} \psi\left(\frac{1}{\sigma} \ln x+\frac{\sigma}{2}\right)
$$

onde $\psi$ é a Distribuição Normal Padrão e $\mathrm{X}=$ y normalizado.

A função de distribuição cumulativa de $\mathrm{X}$ é: 


$$
F(x)=\Pi\left(\frac{1}{\sigma} \ln x+\frac{\sigma}{2}\right)
$$

onde II = Distribuição Normal Cumulativa Padrão.

Numa distribuição logarítmica normal, o parâmetro ó pode ser obtido a partir do coeficiente de Gini:

$$
\boldsymbol{\sigma}=2\left\{\Pi^{-1}\left(\frac{G+1}{2}\right)\right\}^{2}
$$

onde $\mathrm{II}^{-1}$ é a função inversa da distribuição normal cumulativa padrão e G é o coeficiente de Gini.

Usamos um banco de dados do Banco Mundial (2002), montado a partir de levantamentos domiciliares. Os dados incluem a renda média e os coeficientes de Gini nos países da América Latina durante a década de 1990. Inicialmente, calculamos $o$ usando os coeficientes de Gini, e depois usamos a função indicada em (4) para calcular a mediana. 
Apêndice III:

Liberalização do comércio, contexto macroeconômico, desigualdade e pobreza na América Latina

Tabela 1:

Liberalização do comércio, contexto macroeconômico

e desigualdade na América Latina

Appendix III: Trade Liberalization, Macroeconomic Context, Inequality, and Po in Latin America

Table 1: Trade Liberalization, Macroeconomic Context and Inequality in Latin America.

\begin{tabular}{|c|c|c|c|}
\hline \multirow{3}{*}{$\begin{array}{l}\text { Variable } \\
\text { Independiente }\end{array}$} & \multicolumn{3}{|c|}{ Variable Dependiente } \\
\hline & \multirow{2}{*}{$\begin{array}{c}\text { Estimación Preferida } \\
\text { LogR-LogP } \\
(\mathrm{P}=30 \% \text { más pobre })\end{array}$} & \multicolumn{2}{|c|}{ Otras Estimaciones } \\
\hline & & $\begin{array}{c}\text { LogR-Log } \mathrm{P} \\
(\mathrm{P}=10 \% \text { más pobre })\end{array}$ & $\begin{array}{c}\text { Indice de } \\
\text { Gini }\end{array}$ \\
\hline \multirow[t]{2}{*}{ Liberalización Comercial } & -0.39 & -0.60 & -0.43 \\
\hline & -1.32 & -0.91 & -2.40 \\
\hline \multirow[t]{2}{*}{ Liberalización Financiera } & 0.16 & 0.18 & 0.06 \\
\hline & 2.33 & 1.60 & 2.91 \\
\hline \multirow[t]{2}{*}{ Otras Reformas } & -0.09 & -0.12 & 0.40 \\
\hline & -0.41 & -0.41 & 2.06 \\
\hline \multirow[t]{2}{*}{ Volatilidad Macro Económica } & 0.13 & 0.14 & 0.04 \\
\hline & 2.65 & 1.66 & 3.47 \\
\hline \multirow[t]{2}{*}{ Inflación } & 0.09 & 0.12 & 0.02 \\
\hline & 2.43 & 1.52 & 3.24 \\
\hline \multirow[t]{2}{*}{ Términos de Intercambio } & -0.35 & -0.31 & -0.14 \\
\hline & -1.47 & -0.86 & -2.38 \\
\hline \multirow[t]{2}{*}{ Tipo de Cambio Real } & -0.30 & -0.40 & -0.10 \\
\hline & -6.17 & -4.27 & -7.58 \\
\hline \multirow[t]{2}{*}{ Constante } & 2.16 & 2.57 & 1.34 \\
\hline & 6.95 & 4.25 & 15.01 \\
\hline Número de Observaciones & 75 & 75 & 75 \\
\hline$F(7,46)=$ & 15.22 & 8.53 & 20.31 \\
\hline Prob $>F=$ & 0.000 & 0.000 & 0.000 \\
\hline R-cuadrada & 0.297 & 0.141 & 0.485 \\
\hline
\end{tabular}

Fuente: Cálculos de los autores en base a encuestas de hogares.

*Prueba 't' en paréntesis.

Source: Behrman,Birdsall and Szekely, 2001a

Fonte: Behrman, Birdsall e Székely (2001a). 
Tabela 2:

Liberalização do comércio, contexto macroeconômico

e pobreza na América Latina

Table 2 : Trade Liberalization, Macroeconomic Context and Poverty in Latin America.

Liberalización, Contexto Macro Económico y Pobreza

\begin{tabular}{|c|c|c|c|c|c|}
\hline \multirow{3}{*}{$\begin{array}{l}\text { Variable } \\
\text { Independiente }\end{array}$} & \multicolumn{5}{|c|}{ Variable Dependiente } \\
\hline & \multirow{2}{*}{$\begin{array}{c}\text { Estimación Preferida } \\
\text { LogM-LogP } \\
(\mathrm{P}=2 \text { dólares diarios })\end{array}$} & \multicolumn{4}{|c|}{ Otras Estimaciones } \\
\hline & & $\begin{array}{c}\log \mathrm{R}-\mathrm{Log} \mathrm{P} \\
(\mathrm{P}=2 \text { dólares diarios })\end{array}$ & $\begin{array}{c}\text { Proporción } \\
\text { de Pobres }\end{array}$ & $\begin{array}{l}\text { Brecha de } \\
\text { Pobreza }\end{array}$ & $\begin{array}{l}\text { Indice } \\
\mathrm{FGT}(2) \\
\end{array}$ \\
\hline \multirow[t]{2}{*}{ Liberalización Comercial } & -0.03 & -0.12 & -0.38 & -0.43 & -0.60 \\
\hline & -1.21 & -1.68 & -1.18 & -1.53 & -1.66 \\
\hline \multirow[t]{2}{*}{ Liberalización Financiera } & 0.27 & 0.21 & 0.26 & 0.26 & 0.34 \\
\hline & 2.54 & 2.02 & 1.25 & 1.70 & 1.75 \\
\hline \multirow[t]{2}{*}{ Otras Reformas } & -0.03 & -0.04 & 0.46 & 0.33 & 0.38 \\
\hline & -1.64 & -0.73 & 1.21 & 1.03 & 0.92 \\
\hline \multirow[t]{2}{*}{ Volatilidad Macro Económica } & 0.18 & 0.23 & 0.26 & 0.42 & 0.51 \\
\hline & 2.10 & 1.79 & 3.62 & 5.42 & 4.83 \\
\hline \multirow[t]{2}{*}{ Inflación } & 0.21 & 1.16 & 0.05 & 0.08 & 0.09 \\
\hline & 2.99 & 3.88 & 0.91 & 1.83 & 1.71 \\
\hline \multirow[t]{2}{*}{ Términos de Intercambio } & -0.22 & -0.38 & -0.60 & -0.83 & -1.05 \\
\hline & -0.10 & -0.19 & -1.98 & -2.22 & -2.32 \\
\hline \multirow[t]{2}{*}{ Tipo de Cambio Real } & -0.37 & -0.35 & -0.20 & -0.25 & -0.32 \\
\hline & -2.23 & -4.38 & -2.13 & -3.53 & -3.57 \\
\hline \multirow[t]{2}{*}{ Constante } & 1.09 & 1.25 & 1.39 & 1.83 & 2.17 \\
\hline & 29.90 & 12.77 & 3.06 & 3.45 & 3.30 \\
\hline Número de Observaciones & 75 & 75 & 75 & 75 & 75 \\
\hline $\mathrm{F}(7,46)=$ & 4.82 & 7.65 & 10.51 & 13.01 & 11.49 \\
\hline Prob $>\mathrm{F} \quad=$ & 0.000 & 0.000 & 0.000 & 0.000 & 0.000 \\
\hline R-cuadrada & 0.321 & 0.395 & 0.363 & 0.459 & 0.437 \\
\hline
\end{tabular}

Source: Behrman, Birdsall and Szekely, 2001a

Fonte: Behrman, Birdsall e Székely (2001a). 


\section{Referências bibliográficas}

AGHION, Phillippe, CAROLI. Eve e GARCIA-PENALOSA, Cecilia "Inequality and Economic Growth: The Perspective of the New Growth Theories", Journal of Economic Literature 37:4, dezembro de 1999.

ATTANASIO, Orazio e SZÉKELY, Miguel "Going Beyond Income: Redefining Poverty in Latin America," in Orazio Attanasio e Miguel Székely (orgs.), A Portrait of the Poor: An Asset-Based Approach, Baltimore: Johns Hopkins University Press, 2001.

BARRO, Robert, "Inequality, Growth, and Investment", NBER Working Papers, No.W7038, Boston, Harvard University, 1999.

BAULCH, Bob e HODDINOTT, John "Economic Mobility and Poverty Dynamics in Developing Countries", Journal of Development Studies, agosto de 2000.

BEHRMAN, Jere, BIRDSALL, Nancy e SZÉKELY, Miguel, "Pobreza, Desigualdad y Liberalización Comercial y Financiera en América Latina”, in GANUZA, Eduardo, PAES DE BARROS, Ricardo Taylor, Lance e Vos, Rob (orgs.), Liberalización, Desigualdad y Pobreza: América Latina y el Caribe en los 90s, United Nations Development Program, Buenos Aires, Editorial Universitaria de Buenos Aires (EUDEBA), 2001a.

BEHRMAN, Jere, BIRDSALL, Nancy e SZÉKELY, Miguel "Economic Policy and Wage Differentials in Latin America", Penn Institute for Economic Research Working Papers, Working Paper 01-048, 2001 b.

BIRDSALL, Nancy, "Education: The People's Asset”, Center on Social and Economic Dynamics Working Papers, No. 5, Washington, DC, Brookings Institution, 1999.

BIRDSALL, Nancy e DE LA TORRE, Augusto, Washington Contentious: Economic Policies for Social Equity in Latin America, Carnegie Endowment for International Peace and the Inter-American Dialogue, Washington D.C., 2001.

BIRDSALL, Nancy, GRAHAM, Carol e PETTINATO, Stefano, "Stuck in the Tunnel: Have New Markets Muddled the Middle Class?", Center on Social and Economic Dynamics. Working Paper No. 14, Washington D.C., Carnegie Endowment for International Peace, 2000.

BIRDSALL, Nancy e LONDOÑO, Juan Luis, “Asset Inequality Matters: An Assessment of the World Bank's Approach to Poverty Reduction", American Economic Review Papers and Proceedings, maio de 1997. 
BIRDSALL, Nancy e SZÉKELY, Miguel, "Bootstraps Not Bandaids: Poverty, Equity and Social Policy in Latin America", in Pedro Kucynski e John Williamson, Institute for International Economics, a ser publicado.

BIRDSALL, Nancy, ROSS, David e SABOT, Richard, "Education, Growth, and Inequality", in BIRDSALL, N. e JASPERSEN, F. (orgs.) Pathways to Growth: Comparing East Asia and Latin America, Washington, DC, Inter-American Development Bank, 1997.

BLANCHARD, Olivier e WOLFERS, Justine, "The Role of Shocks and Institutions in the Rise of European Unemployment: The Aggregate Evidence," Working Paper, Massachusetts Institute of Technology, 1999.

BOURGUIGNON, François, "The Growth Elasticity of Poverty Reduction: Explaining Heterogeneity Across Countries and Time Periods", World Bank Working Paper, 2002, disponível em http:// faculty.washington.edu.

CENTRO DE ESTUDIOS BONAERENSE, Informe de Coyuntura, No. 7, Argentina, 1997.

CLINE, William, "Financial Crises and Poverty in Emerging Market Economies", Center for Global Development, Working Paper No. 8, Washington, DC, 2002.

CORNIA, Giovanni, JOLLY, Richard e STEWART, France (orgs.), Adjustment with a Human Face: Protecting the Vulnerable and Promoting Growth, UNICEF, Nova York, Oxford University Press, 1987.

CORTAZAR, Ricardo et al., "Hacia un Nuevo Diseño del Sistema de Protección de Cesantes”, Colección Estudios CIEPLAN, No. 40, 1995.

DE JANVRY, Alain e SADOULET, Elisabeth, "Targeting and Calibrating Educational Grants: Focus on Poverty or on Risk?", Working Paper, University of California at Berkeley, 2002.

DE LA TORRE, Augusto, "La Reforma Económica y la Nueva Legitimidad”, Economía Exterior, No. 22, outono de 2002.

FILMER, Deon e PRITCHETT, Lant, "The Effect of Household Wealth on Educational Attainment: Evidence from 35 Countries", Population and Development Review, 25 (1), 1999.

GAVIN, Michael e HAUSMANN, Ricardo, "Sources of Macroeconomic Volatility in Developing Economies", Research Department Working Papers Series, Inter-American Development Bank, 1996. 
GRAHAM, Caroline, "Crafting Sustainable Social Contracts in Latin America: Political Economy, Public Attitudes, and Social Policy", Center on Social and Economic Dynamics Working Paper Series, No. 29, Brookins Institution, julho 2002.

GRAHAM, Caroline e SUKHANDAR, Sandip, "Is Economic Crisis Reducing Support for Markets and Democracy in Latin America? Some Evidence from the Economics of Happiness", Center on Social and Economic Dynamics Working Paper Series, No. 30, Brookings Institution, novembro de 2002.

INSTITUTO NACIONAL DE ESTADISTICA Y CENSOS, "Indicadores de Pobreza", obtenível na página da Internet http:// www.indec.mecon.gov.ar, Argentina, outubro de 2002.

INTER-AMERICAN DEVELOPMENT BANK, "Competitiveness. The Business of Growth", Economic and Social Progress in Latin America: 2001 Report. Washington, DC. (2001).

INTER-AMERICAN DEVELOPMENT BANK, "Facing up to Inequality in Latin America", Economic and Social Progress in Latin America: 1999 Report, Washington, DC, 1999.

INTER-AMERICAN DEVELOPMENT BANK, "Overcoming Volatility in Latin America", Economic and Social Progress in Latin America: 1995 Report, Washington, DC. (1995).

.KOSE, Ayhan, PRASAD, Esware TERRONES, Marco, "Financial Integration and Macroeconomic Volatility," International Monetary Fund Third Annual Research Conference Papers http://www.imf.org, novembro de 2002.

LONDOÑO, Juan Luis e SZÉKELY, Miguel "Persistent Poverty and Excess Inequality", Journal of Applied Economics, 3:1, 2000.

LUSTIG, Nora, "Crises and the Poor", Social Equity Forum, Poverty and Inequality Advisory Unit, Inter-American Development Bank, 2000.

MARQUEZ, Gustavo, "Labor Markets and Income Support: What Did We Learn from the Crises?", Research Department Working Papers, No. 425, Inter-American Development Bank, 2000.

MORLEY, Samuel, Poverty and Inequality in Latin America. The Impact of Adjustment and Recovery in the 1980s, Baltimore, The Johns Hopkins University Press, 1995.

NELSON, Jon, "Grounds for Alliance? Overlapping Interests of Poor and Not so Poor", in Peter Houtzager, Mick Moore e James Putzel (orgs.), Changing Paths: International Development and the New Politics Inclusion, University of Michigan Press, 2000. 
PRITCHETT, Lant, SURYAHADI, Asep e SUMARTO, Sudarno "Quantifying Vulnerability to Poverty: A Proposed Measure with Application to Indonesia”, World Bank, Washington D.C., 2000.

RAVALLION, Martin, "Who is Protected? On the Incidence of Fiscal Adjustment," World Bank Working Paper, 2002.

SHOME, Peter, "Taxation in Latin America - Structural Trends and Impact of Administration", Working Paper WP/99/19, International Monetary Fund, Washington, DC, 1999.

STALLINGS, Barbara e WELLER, Jurgen "Job Creation in Latin America in the 1990s: The Foundation for Social Policy," Development Macroeconomic Papers Series No. 5, CEPAL, 2001.

STALLINGS, Barbara e WILLIAM, Peres, Growth, Employment, and Equity: The Impact of the Economic Reforms in Latin America and the Caribbean, Comissão Econômica para a América Latina e o Caribe (CEPAL) e Brookings Institution Press, Washington, DC, 2000.

SZÉKELY, Miguel, The Economics of Poverty, Inequality and Wealth Accumulation in Mexico, Londres, MacMillan, 1998.

TENDLER, Judith, "The Fear of Education", artigo de fundo para Inequality and the State in Latin America and the Caribbean, World Bank, outono de 2002.

WORLD BANK, WORLD BANK DATA SETS, http://devdata.worldbank.org/, outubro de 2002. 


\section{DEBATEDORES}

\section{Agenda Social e Combate à Pobreza: SOCIEDADE, CULTURA, DEMOCRACIA \\ E LIBERDADES INDIVIDUAIS}




\section{Carlos Francisco Lessa*}

Quero começar agradecendo o convite, e ao mesmo tempo pedir desculpas pelo atraso. Perdi por conseguinte a exposição da professora Nancy. Tive a felicidade de ouvir o Bernardo e o Inácio, e ouvi as palavras da Sônia. Vou tentar socializar uma dúvida, tomando um caminho um pouco diferente. Com respeito ao Bernardo, eu participei na semana passada de um encontro em Buenos Aires, e tive oportunidade de acessar uma excelente resenha organizada por ele a respeito de um conceito que é proposto, a discussão de capital social. Devorei o livro no final de semana, achei muito estimulante. O Dr. Inácio nos brindou com um diagnóstico quase que impecável - eu teria uma ou outra discordância dentro do conjunto, porém o diagnóstico impecável tem um grave problema de juízo: não há nenhuma perspectiva. E a Sônia, minha colega de Unicamp, co-fundadora da Unicamp, creio que avançou algumas observações de imensa pertinência.

Mas vou ganhar um caminho que pode parecer um pouco gratuito, embora espere que não o seja: vou começar com o enigma Argentina. É que tenho procurado me debruçar para interpretar a Argentina, uma experiência histórica singular que, como num macrolaboratório, oferece, no limite, questões que tocam a fronteira da nossa perplexidade e nos lançam a um território de profunda dúvida. E não é porque eu acho que a Argentina oferece um caso absolutamente excepcional de reflexão para nós, vizinhos, parceiros e co-protagonistas neste continente, e obviamente uma experiência a ser acompanhada com a maior atenção; acho que, em nível mundial, o que Botsuana não consegue inspirar, certamente a Argentina inspira, ou seja, uma imensa perplexidade.

\footnotetext{
* Reitor da Universidade Federal do Rio de Janeiro.
} 
Contudo, não vou visitar as mazelas da Argentina, porque elas são por demais conhecidas. Não preciso visitar o processo de desenvolvimento com sinal contrário que a Argentina atravessa, que já vem de muitas décadas, e que apresentou, de certa maneira, nos últimos dez anos, uma aceleração de movimento. Quer dizer, não percebo na trajetória argentina nenhum movimento ascendente que ciclicamente se desconstruiu. Percebo um movimento que é muito mais de esfinge, de uma sociedade nacional que vai batendo em uma série de portas que vão se fechando, e perdas vão se acumulando ao longo dessa trajetória, até que chega o momento em que elas se expressam com absoluta dramaticidade, que é o cenário atual. Entretanto, não vou sustentar esta tese, vou apenas afirmá-la, e quem estiver interessado leia um pouco sobre a Argentina que perceberá o que estou falando.

O que, sim, quero colocar, vai além do diagnóstico corrente, do diagnóstico que está na boca dos argentinos. Passei esta semana lá, e tive oportunidade de conversar desde com professores distinguidos, alguns velhos companheiros meus dos sonhos de juventude, que são professores eméritos na sociedade argentina, a um par de políticos com os quais tive contato, e uma vasta quantidade de estudantes, garçons, arrumador de quarto, porteiro do hotel. Na verdade, ouvi de todos, até mesmo de mendigo, e nem precisava perguntar, que os culpados são "os políticos". A categoria "os políticos" é absolutamente compreensiva, incorpora todas as lideranças da história argentina, gregos e troianos, magros e gordos, competentes e incompetentes, radicais e transigentes, militares ou não, que administraram o país durante meio século. É um pouco como se na percepção do homem comum - e não tão comum assim, porque os professores universitários, afinal de contas, não são exatamente pessoas comuns - há uma espécie de acerto de conta com aqueles que dirigiram o curso da história argentina nas últimas décadas. Todos são culpados, e isso se refere desde a prática de erros históricos até à imputação genérica de que todos são praticantes de corrupção.

Tirando o caráter de bode expiatório de que obviamente em toda e qualquer situação patológica inspira a busca, há alguma coisa a mais em relação a esse diagnóstico. Tive oportunidade de pelo menos duas vezes assistir a uma manifestação - aliás, em quatro dias vi três manifestações semi-espontâneas, em que as pessoas se levantaram no restaurante para bater palmas para um conjunto de carros que iam buzinando. Aí, perguntei: O que é? "Protestan contra los políticos". Quais? "Todos". É realmente uma coisa fantástica assistir a isso. Bem, como contraponto 
quero apontar dois fenômenos que são perceptíveis em embrião, nos seus primeiros movimentos. A um deles Bernardo já fez referência, que é o fato de que as instituições de solidariedade social na Argentina cresceram exponencialmente. O voluntariado se multiplicou, e, hoje, existem milhares e milhares e milhares de argentinos que estão - deixemme usar a expressão da forma mais singela - "se dedicando ao próximo". É um aspecto belíssimo. Esse fenômeno acontece por debaixo deste diagnóstico que estou classificando de vulgar.

Outro processo igualmente interessante, e que eu tive oportunidade de checar, conversando com pessoas de livrarias e de lojas de discos, é um exponencial crescimento de busca de obras sobre a história argentina, de ensaios sobre a Argentina. Estão sendo reeditados os clássicos. Encontrei uma série de autores que estavam sendo reeditados. Nas lojas de discos, o que se vende agora é música argentina. Caiu a venda da música globalizada. É um pouco como se os argentinos estivessem começando a fazer um exercício introspectivo, começando a procurar as suas manifestações de ser, mediante uma revalorização dos seus traços de identidade, em busca talvez de uma identidade que fica, no nível global e nacional, danificada de forma quase que dramática por aquele diagnóstico vulgar, que é uma rejeição total e completa dos políticos. Quero dizer que esse tipo de rejeição sempre me lembra uma recomendação de uma professora de catecismo, que eu tive quando era jovenzinho - toda a vez que nós fazíamos barulho ou bagunça, ela dizia: "Vocês estão cuspindo para cima". Com isso ela queria dizer que, com a lei da gravidade, o cuspe cairia sobre nós.

É evidente que este diagnóstico "dos políticos" suscita a seguinte questão: há um povo chamado argentino, "vocacionado" para escolher maus políticos durante décadas e décadas. Isso passa a constituir uma terrível especialidade argentina, se o diagnóstico é correto, não é?. Pois bem, isso lembra a lição da minha professora de catecismo. Mas o ponto para o qual quero chamar a atenção é que, no cruzamento do que eu estou chamando de "redescoberta da argentinidade", com o aumento de solidariedade, de forma inovadora - porque acho que a experiência argentina é até certo ponto um laboratório para o futuro -, está se resgatando o "eu", e se resgatando, de certa maneira e ainda não totalmente consciente, a idéia da "nação" argentina. E é um pouco como se esse movimento estivesse levando ao umbral de uma série de descobertas, algumas das quais são, absolutamente, visíveis para o forasteiro. 
Olhar a Argentina hoje é olhar um país que tem uma excepcional agricultura - fantástica agricultura, aliás, pois a própria construção da Argentina se deu em cima da carne e do pão; uma competência industrial bastante atrofiada, bastante desmontada, porém, com uma excepcional competência técnica de uma população extremamente educada e culta. Na América Latina só o Uruguai tem indicadores melhores do que a Argentina em matéria de educação - e o Uruguai, infelizmente, está caminhando para ser uma Argentina em escala reduzida. O padrão educacional e cultural da Argentina é absolutamente deslumbrante, em termos de América Latina; o padrão dos centros de excelência de pesquisa da Argentina, apesar de muito afetado, ainda é de qualidade. A Argentina exportou talento para o mundo inteiro, mas ainda tem nas suas entranhas uma quantidade imensa de quadros extremamente talentosos, é uma população muito culta, o momento editorial argentino é de fazer nós, brasileiros, ficarmos encabulados.

Apesar de toda a pobreza argentina, Buenos Aires, que é muito menor do que as nossas megacidades, tem mais livrarias do que nós temos [não mais as que eu conheci na minha mocidade, que chegavam ao requinte de uma livraria especializada em humor, pois isso já se perdeu; mas se perderam apenas os anéis, os dedos foram retidos]. É uma sociedade que tem um povo extremamente bem preparado, em termos latino-americanos, com uma infra-estrutura levemente envelhecida, aqui e acolá enferrujada, mas tem uma ótima rede de transportes, andou arrebentando seus campos de petróleo, mas ainda tem petróleo, tem energia elétrica - vejam só, a Argentina tem os elementos básicos para poder viver bem, tem, ao nível da economia real, o que é necessário, pelo menos para um retomar excepcional. Não faria o mesmo discurso em relação ao Equador, e deveria ser internado se o fizesse para a Guatemala, mas para a Argentina o meu discurso é solidamente apoiado.

Onde a Argentina tem, hoje, uma vantagem gigantesca em relação a qualquer outro país prisioneiro da malha da globalização? A Argentina privatizou o setor público, abriu mão de todo o aparelho público, abriu mão também de praticamente seus equipamentos produtivos, porque as empresas argentinas foram todas vendidas para o exterior. Os dólares que a Argentina tinha desapareceram. Então, de certa maneira, a Argentina resolveu a questão cambial. Ela não pode pagar, ponto. Ela não precisa decretar a moratória, ela não precisa se preocupar em recuperar reservas, porque pura e simplesmente ela não tem como pagar, os ativos argentinos que permaneceram dentro da Argentina ficaram perfeitamente 
ilíquidos em matéria do equivalente internacional. O investidor Soros perdeu uma brutalidade ao comprar cento e tantos mil hectares na Argentina, deve valer hoje um décimo do que valia quando os comprou, então não adianta oferecer para o Sr. Soros mais terras, porque ele não vai comprar.

Digamos o seguinte: a Argentina dispõe, "no limite", a liberdade. Não estou explorando nenhum paradoxo. Não foi conquistada como possibilidade pelos méritos dos argentinos, e até pelos seus desastres políticos e econômicos, a Argentina já resolveu seus problemas. Só que não descobriu que os resolveu. A comunidade internacional, em relação à Argentina, teve um gesto de Pôncio Pilatos: pura e simplesmente lavou as mãos. É mais ou menos uma espécie da declaração seguinte: "Os teus ativos não nos interessam, e eu não estou disposto a te refinanciar, porque o teu refinanciamento não me leva a nada adicional, a nada mais". Por isso é que está resolvido. Ela saiu da esfera de interesse. Interpreto, pois, dessa maneira: a Argentina pode construir um projeto nacional argentino. Por que não o constrói? Porque essas coisas que eu estou colocando aqui - perdoem uma certa irreverência, a idade já me permite um pouco isso - a Argentina ainda não descobriu, embora seja o óbvio ululante.

Se ela construir um projeto nacional, se ela centralizar o câmbio, e se ela fortalecer a moeda nacional, se ela romper os paradigmas fiscais a que fazia referência a Sônia, e se perder o medo de um determinado déficit com gastos responsáveis, ela é capaz, rigorosamente, pelo menos, de garantir que nenhum argentino morrerá de fome. Ao contrário, todos poderão comer um bom pão e uma boa carne - excedentes inexportáveis, porque não há mercado nem para o excesso de trigo nem para o excesso de carne. Então os argentinos têm mais que comer comer bem, diga-se de passagem, é uma das melhores coisas do mundo, é só ter fome para descobrir o que isso significa. Pois bem, a pergunta que eu faço é a seguinte: por que essas coisas que eu estou colocando para vocês não estão claras na discussão da Argentina? Por que não surgiu nenhuma proposta que de alguma maneira implique alguma coisa do tipo? Uma reforma monetária que restaure a soberania argentina, uma certa capacidade de manejar as suas contas fiscais, um novo pacto social que dê sustentação a um Estado Nacional Argentino - e eu não tenho medo de ser jurássico - reconstruído? Por que isso não surgiu?

$\mathrm{Eu}$ acho que não surge porque o argentino médio está vivendo dentro da sua cabeça uma visão que o paralisa, ele pensa por um lado que é 
proprietário, real ou potencial, de equivalente internacional, ele acredita que tem um patrimônio que pode ser dólar, patrimônio que pode ser tão pequeno como sua casa. Diga-se de passagem que um terço das lojas de Buenos Aires está à venda. O pequeno comerciante acredita que a sua riqueza tem uma equivalência em dólar, certamente o seu depósito bancário, o seu depósito em caderneta, o corralito - este não é grave porque aprisionou peso, o corralito é grave porque não lhe deixa ter acesso a pesos conversíveis em dólar, só que os dólares não existem nem existirão -, mas na cabeça dele a defesa do seu patrimônio está associada a sua equivalência em conversibilidade com o dólar. Ao mesmo tempo ele tem um filho desempregado, ao mesmo tempo ele tem medo de perder o emprego, ou ele tem um pequeno negócio que está ameaçando fechar porque ele não consegue vender. Entretanto, entre a defesa da riqueza e a retomada da atividade, a mesma pessoa se vê dividida entre duas lealdades.

Entretanto, se nós temos de procurar alguma coisa, nós temos de procurar em desdobramentos dos conceitos de capital social, só que eu acho que o conceito de capital social, tal como está sendo trabalhado por Bernardo e todo o seu conjunto de talentos que foi mobilizado, tem alguns defeitos. Primeiro, uma certa analogia com a idéia de capital humano, que é uma idéia, a meu juízo, extremamente precária do ponto de vista teórico. Mas há um outro problema, é que conceito de capital humano está sendo formulado ainda de maneira muito comportamental, e eu acho que o conceito de capital social é um conceito que passa por dimensões do tipo: auto-estima, clara consciência de identidade e a capacidade de, por cooperação, construir um projeto nacional. Eu suspeito que quando nós formos investigar os exemplos históricos de sociedades respondendo a crises, encontraremos essas dimensões se movendo juntas.

E me permitam terminar dizendo: se tudo isso é verdade, a verdade está com o poeta, não é? Que diz o seguinte: "Nada vale a pena se a alma é pequena". Não há nenhum medidor, nenhum indicador para alma, mas se a alma nacional fenecer, ela pode pura e simplesmente caminhar para a pura entropia. A ameaça que nós estamos percebendo é uma ameaça de entropia. Isso repõe a necessidade de reconstruir, sim, um discurso sobre a nação. A nação não pertence ao jurássico. O discurso da globalização supôs cancelá-la, mas, na hora da aflição, a última instância, a última barreira, está exatamente na idéia da nação. Esta idéia é que tem de ser reconstruída, como barreira, como linha de defesa, como 
a possibilidade de construir as respostas, quando se está isolado e levado à situação de passar a ser uma peça não mais desejada pelo processo de globalização. Penso que se a África subsaariana pudesse construir um movimento desse tipo, escaparia das maldições trágicas a que ela está submetida. Acho que a Argentina vai dar para a América Latina o exemplo histórico da reconstrução por esse caminho. Vou prognosticar, ou pelo menos eu vou fazer uma espécie de aposta na reconstrução de um discurso nacional argentino. Espero que ele seja nacional, democrático e preocupado com o social. E acho que necessariamente assistiremos a uma retomada da idéia de nação.

Quando uma sociedade gasta, educando sua nova geração, ela está se repondo no futuro. Quanto é que isso vale? Eu acho que o exercício de custo/beneficio para avaliar isso é um exercício de mediocridade, de aprisionamento dos direitos. No limite, o custo/benefício pode justificar coisas absurdas. Por exemplo: eu tenho uma previsão orçamentária para política de saúde, eu tenho enfermidades degenerativas de alta incidência nos cidadãos de idade mais avançada, e eu tenho enfermidades infecciosas de alta incidência na população mais jovem. Como planificador eu vou decidir o seguinte: o que é conveniente para a economia? Ampliar alguns anos de vida dos cidadãos já experimentados e testados, ou ampliar a disponibilidade de mão-de-obra não-qualificada e jovem. Em função disso, eu boto orçamento degenerativo ou orçamento infeccioso. Vocês dirão: "Mas que horror!" Mas isto é uma aplicação de custo/beneficio.

Aliás, custo/beneficio é a pior maneira de se pensar a partir do paradigma medíocre do mercado. O mais engraçado é que os economistas que aplicam isso se esquecem de que o mercado só é virtuoso por leilão, seqüencialmente, no tempo. O mercado pode produzir horrores. Um bom exemplo disso é o seguinte: companhias aéreas competindo umas com as outras, para reduzir a tarifa; além de apertar os passageiros, e passar a servir só frango dentro do avião, que é uma agressão ao bom humor do passageiro, começam a reduzir os gastos de manutenção. Aí os aviões começam a cair. Então as pessoas aprendem que tarifas baixas implicam um maior risco de morrer na viagem aérea. Aí passam a comprar tarifas mais altas, e se estabelece o ponto de equilíbrio. Só que ninguém consulta os que morreram para chegar a esse ponto de equilíbrio.

Por favor, afastem das políticas sociais raciocínios economicistas. Espero que essa moda seja jogada para o fundo das estantes. São direitos, ponto. Tão simples quanto isso. Do contrário, fica a seguinte per- 
gunta: se eu tenho mão-de-obra excedente, miserável, condenada a uma vida triste, por que lhe dar um prato de comida? Deixa morrer de fome. Aliás, esse foi o argumento do Pastor Malthus numa discussão clássica de economia política: não havia melhor solução do que deixar as pessoas morrerem, porque, não morrendo, sobreviveriam e aí vinham as pestes, as guerras, os Cavaleiros do Apocalipse. Aliás, a incapacidade de ler os clássicos na discussão do presente produz muitas besteiras. Malthus de repente reaparece travestido de custo/benefício. Voltando ao ponto: educação é um absoluto, pronto. Como proteção, seguro universal é outro absoluto, que não compete discutir.

Aliás, para mim, quando se fala de contrato social, ou contrato ético, em última instância estamos falando de uma pactuação pela qual cada um assume em relação a determinados direitos e determinadas obrigações. Quer dizer, quando uma sociedade diz que dará pensão a todos os portadores de deficiência, ela não está fazendo caridade para os portadores de deficiência, mas, sim, construindo uma regra para que, quem sabe, meu filho possa ser protegido, se caso vier a ser um deficiente. A regra é dada de "um a n menos um". Mas uma sociedade pode pactuar de forma contrária, dizendo: deficientes, morram. Aliás, o regime hitlerista produziu genocídio nos seus pacientes mentais, no século vinte. Ou não?

Gosto muito de distinguir globalização em que você participa passivamente, daquela em que você assume o cenário e toma as suas decisões a partir dos graus de liberdade que você tem. Ninguém é compelido a praticar superávits fiscais, que no limite nos condenam à estagnação. Nenhuma sociedade é compelida a elevar as taxas de juros a ponto de que, como hoje no Brasil, quem ganha até cinco salários mínimos, na cidade do Rio de Janeiro, gasta com juros e prestações de dívidas mais do que com alimentação das famílias. Ninguém tem que necessariamente cair nessas esparrelas. Elas podem e devem ser flexibilizadas, elas podem e devem ser negociadas.

Agora, quando você aceita a globalização porque assim definiu o profeta, e os caminhos estão prescritos, rigorosamente você se entrega ao pensamento único. Aliás, tenho também uma certa implicância com a palavra globalização. Não é semântico, não. Falou-se nas ONGS, no passado elas eram conhecidas como entidades filantrópicas, cooperativas, sociedades esportivas, etc. Quando você as define como organização não-governamental, você está colocando em tela de juízo a legitimidade do Estado. No fundo, você está admitindo a possibilidade de atrofiar e reduzir o Estado a sua expressão mínima. Vejam, a maior ONG 
do mundo chama-se Igreja Católica. Mas ninguém a batizou nem registrou como ONG. Aliás, as constituições religiosas, todas elas, têm o seu lado ONG. Mas elas não se definem como ONG. De modo que eu acho isso muito engraçado em termos de neologismo.

Globalização é uma dessas palavras: o que é globalização? É a construção de redes que vão se integrando... mas as redes, a partir da perspectiva européia, começaram quando as naus portuguesas da Escola de Sagres começaram a desvelar o périplo africano. E desde então não pararam. Na verdade, redes mundiais de comércio, de intercâmbio, de trocas, de informações, de protagonistas, de populações, cresceram, cresceram, cresceram. Dirão vocês, no momento elas ganham características tais que parecem ser instantâneas. Mas não é por esse lado que elas são inovadoras. São inovadoras porque deram origem a novos agentes, novos protagonistas no cenário mundial, houve uma reordenação no tecido do mundo. Aí é uma questão de poder. Aliás, acho que a geopolítica que havia sido retirada do raciocínio das pessoas reapareceu de maneira absolutamente inequívoca nos últimos anos. Os Estados nacionais são protagonistas, sim! E uns são mais Estados do que os outros. Alguns chegam até a ser não Estados.

Então, voltando à questão do mercado: o mercado não é necessariamente mundial - aliás, existem muitas coisas que são não-comercializáveis fora do marco nacional, sendo algumas das mais importantes de que nós estivemos falando aqui, tais como segurança, justiça, até certo ponto saúde, em grande parte educação (porque não acredito nos méritos da educação à distância). Não são mercadorias, nem são objetos de comercialização, e exigem e empregam quantidades imensas de mãode-obra. Aliás, políticas que privilegiem essas frentes de expansão têm o duplo mérito de gerar empregos, objetivamente criando sistemas universais de serviços. Agora, é preciso desatar a armadilha financeira. Se você aceitar que o paradigma correto é realizar superávits primários a qualquer preço, e gestão cambial por diferenciais de taxa de juros, se você fizer isso, rigorosamente, você é prisioneiro do discurso externo e no limite você vira Argentina, se liberta...

Mas estou pensando dialeticamente. Ou vocês acham que uma dívida pode crescer para sempre com mais velocidade do que o PIB mundial? Aliás, é uma coisa engraçada, porque os cálculos contábeis mais elementares demonstram que a matemática financeira do mundo está com os pés meio bambos, mas isso é outra questão. Então, vejam bem: é claro que é possível criar mercado. Aí vem a pergunta: enfrentar as 
questões da desigualdade e formar uma política de inclusão é compatível com uma ampliação de mercado e com uma expansão na economia? Eu creio que é perfeitamente compatível. Agora, não é fazendo um compósito de políticas sociais contra a pobreza. É operando uma dimensão social como prioritária num projeto global de desenvolvimento, que é uma coisa muito diferente. Isso é uma nova maneira, é uma outra maneira de falar num pacto ético social diferente. 


\title{
POR UM NOVO CONTRATO SOCIAL COMO BASE PARA O ENFRENTAMENTO DA POBREZA
}

\author{
Sônia M. Draibe*
}

O convite para participar deste ciclo de seminários me honra duplamente: pela oportunidade de ouvir e debater com especialistas internacionais da mais alta excelência, como os que aqui me antecederam, e também pela oportunidade de prestar uma modesta mas muito grata homenagem ao BNDES, no seu cinqüentenário.

Atendendo à convocatória deste Painel Agenda Social e Combate à Pobreza e aos temas tratados pelos conferencistas, minha reflexão toma a perspectiva da política pública e tem como quadro de fundo o contraponto entre a experiência nacional e a experiência internacional no combate à pobreza.

Organizei meus comentários em 3 sessões, cada uma delas referida a uma pergunta central. Em primeiro lugar, tomo por referência a experiência brasileira recente em programas e políticas de enfrentamento da pobreza e redução das desigualdades, perguntando o quê e o quanto aprendemos, a respeito, e a quais resultados chegamos. Em seguida, trato de, rapidamente, confrontar a experiência brasileira com a experiência internacional de combate à pobreza, perguntando-me até que ponto somos diferentes, nos avanços e nos resultados. Finalmente, na última sessão, teço considerações acerca dos requisitos e características do cenário mais amplo de proteção social, o qual penso ser necessário para a redefinição das políticas voltadas para a superação da pobreza.

\footnotetext{
* UNICAMP.
} 


\section{O que se pode dizer da experiência brasileira recente em matéria de enfrentamento da pobreza e redução das desigualdades}

Não tenho dúvida de que este campo dos programas de assistência social e de enfrentamento da pobreza foi e tem sido, em toda a área social, um dos que, além de rica e variada experiência, registra também, no plano institucional, uma das mais radicais mudanças, dos anos 80 para cá, equiparando-se talvez tão somente à política de saúde e, bem mais recentemente, à política educacional.

O Brasil, à diferença de alguns países latino-americanos - como é o caso da Argentina e, em menor medida, o Chile - vem de uma forte e antiga tradição de política assistencial.

No passado do nosso limitado welfare state, estavam aqui presentes todos os mitos apontados por Kliksberg, infelizmente não como mitos, mas como infeliz realidade: a superfluidez dos programas; o reino da arbitrariedae e do clientelismo; o assistencialismo e a desqualificação dos pobres; a fragmentação organizacional; a forma autoritária de fazer política, etc.

Dois movimentos ou ondas de reforma alteram substancialmente este campo de intervenção pública:

- nos anos 80, a formulação da Política Nacional de Assistência Social, definida na Constituição de 1988, com tonalidade bastante universalista e pretendendo uma forte e complexa institucionalidade, semelhante à do SUS - Sistema Único de Saúde. É de se chamar a atenção para o fato de que, entre suas tantas características, está o de não se definir nem se tratar de uma políitica para o enfrentamento da pobreza;

- O segundo movimento se dá nos anos 1990, tendo como ponto central a temática da pobreza, pela primeira vez presente na agenda pública brasileira com todos seus créditos.

O balanço de quase duas décadas de transformações na política de assistência social e de enfrentamento da pobreza revela terem sido muitas e significativas as mudanças ocorridas. Por economia de tempo, aponto no quadro a seguir apenas os principais eixos e conteúdos das referidas alterações. 


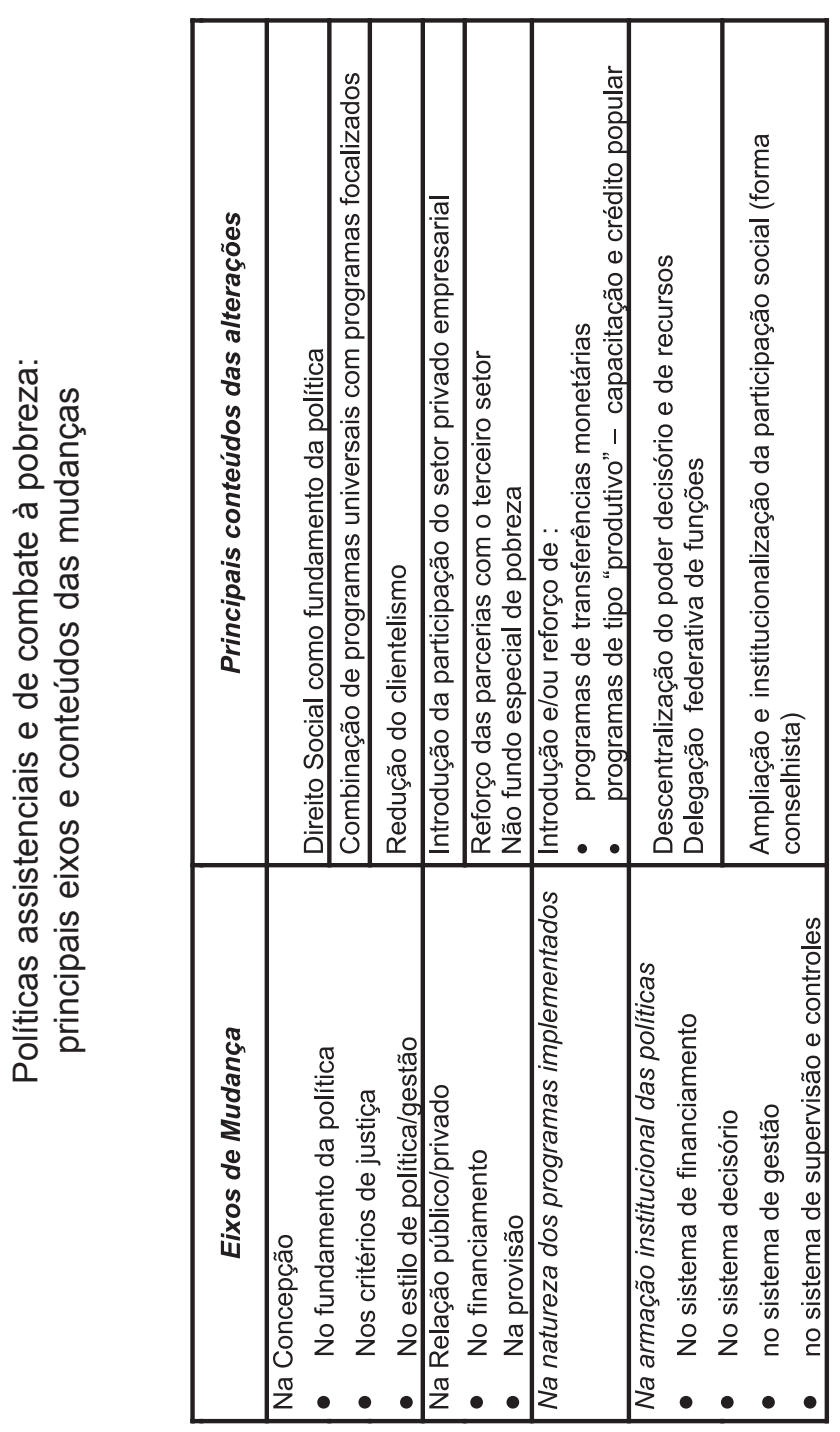


Na minha opinião, o avanço alcançado se deu sobretudo no plano institucional. Mas também no plano conceitual, refletindo a forte aprendizagem institucional acumulada nestes quase quinze anos de inovações e mudanças, os ganhos parecem-me decisivos. Pode-se dizer que a experiência brasileira assenta-se hoje em uma nova concepção de pobreza, apoiada tanto nos conhecimentos sobre a realidade das situações de pobreza quanto na eficácia de certos tipos de programas e ações.

Entre as lições aprendidas, destacam-se, quando confrontadas com a tradição anterior, pelo menos os seguintes novos entendimentos das situações de pobreza, com óbvios desdobramentos para os programas que pretendem enfrentá-las:

- a pobreza é muldimensional e muito heterogênea; ao mesmo tempo envolve aspectos materiais e imateriais;

- a superação da pobreza passa necessariamente pelas pessoas e pelo seu meio. Envolve portanto dimensões tais como o desenvolvimento pessoal, o reforço da auto-estima, o desenvolvimento das capacidades próprias e do seu entorno, o acesso a ativos diferenciados, etc;

- a pobreza é um problema societal e de relações sociais; sua superação passa necessariamente por mudanças nas relações entre pobres e não-pobres, entre o meio social pobre e o meio social não-pobre.

Não são desprezíveis os resultados alcançados, ao longo do período referido, ainda que sejam modestos e que muito tenhamos a fazer, todavia. Os anos 1990 registraram razoável redução da incidência de pobreza, resultado devido também e principalmente à estabilidade econômica, como se sabe. Mas esse resultado foi também amparado por melhoras significativas nos níveis de bem-estar das populações mais pobres, principalmente referidos à redução da mortalidade infantil, aos níveis nutricionais das crianças menores de cinco anos, à praticamente universalização do acesso à educação fundamental e à melhora dos níveis de aprovação e terminalidade dos alunos, ao significativo aumento do acesso ao ensino médio, etc.

Não são tão positivos os resultados em termos de habitação e saneamento. Menos ainda os referidos aos ainda escandalosos níveis de desigualdade social com que convivemos. Como se sabe, nossos indicadores de desigualdade mantêm-se relativamente estáveis há mais de quarenta anos, registrando quase nula redução, salvo no tocante à desigualde de gênero, em termos educacionais. 
No plano institucional, apesar dos avanços já referidos, é importante ressaltar a ainda forte fragmentação dessa área de política social. Só no plano federal, convivem três conjuntos complexos de programas de enfrentamento da pobreza: o Comunidade Ativa, o Projeto Alvorada e o Comunidade Solidária. O reconhecido êxito do Programa Comunidade Solidária, na sua dimensão não-governamental, nem de longe compensa as perdas e ineficiências de tal fragmentação, absolutamente desprovida de sentido e lógica.

Mais que examinar êxitos e fracassos, meu objetivo maior é refletir sobre a experiência brasileira recente à luz da experiência internacional e no campo mais amplo dos novos padrões de política social que parecem estar emergindo no mundo, após quase vinte anos de reformas e mudanças nos velhos modelos de welfare state. É o que farei, na próxima sessão.

\section{O Brasil e a experiência internacional de superação da pobreza e da desigualdade}

No plano de políticas, programas e resultados, por específica que seja, a experiência brasileira não difere muito da experiência internacional de programas de enfrentamento da pobreza.

Muito brevemente, registro que, em termos de avanços institucionais e de lições aprendidas, nossa experiência aproxima-se muito das vividas por muitos países latino-americanos desde os anos 1980.

Mas também em termos dos modestos resultados e da nula incidência dos programas na redução da desigualdade social, a experiência nacional longe está de ser ímpar. Sendo mais explícita, perguntaria a respeito: qual o programa de maior sucesso de enfretamento da pobreza, na experiência internacional dos últimos 50 anos? O que mostra a literatura sobre políticas e programas de combate à pobreza?

Seguramente, é o Programa de Guerra à Pobreza, da administração Lindon Johnson, o mais complexo dos programas de enfrentamento da pobreza, dos anos sessenta em diante. Elaborado através da mobilização dos mais competentes técnicos e intelectuais americanos e implementado num período de grande folga financeira dos Estados Unidos, se é verdade que o programa registrou sucessos parciais e programáticos, não é menos verdadeiro o seu insucesso, no geral, a crer na literatura dedicada ao seu estudo e avaliação. No plano mais estrutural, a permanência dos indicadores de pobreza e de níveis insuficientes de bem-estar, entre de- 
terminados grupos populacionais e em determinadas áreas e territórios, tende a confirmar isso. O estudo de longa duração que faz a Universidade de Michigan através de um panel com um universo de cinco mil famílias pobres concluiu, após trinta anos de seguimento, que, embora importantes, não são os programas para os pobres os que os tiram das situações de pobreza. Antes de mais nada, os níveis de incidência da pobreza oscilaram segundo os ciclos de expansão e de retraimento da economia americana, e principalmente com o comportamento das taxas de emprego e desemprego.

Estamos longe de uma conclusão deste teor? Creio que não. A experiência recente da maioria dos países latino-americanos, nestes tempos de globalização e ajustamentos fiscais, mostrou já ao cansaço que, aqui, a oscilação das altas taxas de incidência da pobreza teve e tem a ver com dois fenômenos: a inflação e o crescimento da economia. Altas taxas de pobreza tenderam a acompanhar as situações de alta inflação, caindo nos períodos imediatamente posteriores à estabilização. E tendem a crescer e a manterem-se altas nos períodos de baixo crescimento e altas taxas de desemprego. É possivel esperar que sejam os programas de enfrentamento da pobreza os que resolvam equações como estas, que se desenham em outros planos da economia?

$\mathrm{Na}$ verdade, o que estamos sugerindo é que as mudanças estruturais que, entre outros resultados, fizeram aumentar a instabilidade dos empregos obrigam-nos a repensar o locus no qual deva estar centrada a política social e, em especial, os programas de superação da pobreza.

Em outras palavras, é no plano maior dos fundamentos de um novo contrato social que, creio, deve ser equacionada a questão da proteção social. Esse é o tema da última sessão destes comentários.

\section{Concepções e escopo da Política Social: bases para um novo contrato social}

A concepção de um novo contrato social apóia-se na plena democracia, em uma regulação mais efetiva da economia, uma mais eqüitativa distribuição da riqueza, no trabalho decente e em um adequado sistema de proteção social para todos.

Um novo contrato social supõe pelo menos dois níveis ou tipos de requisitos: novas relações entre a política econômica e a política social e novas instituições da política social. 
Repensar as relações entre a política econômica e a política social ultrapassa em muito a questão, importante sem dúvida, da maior centralidade e mesmo de defesa de um patamar de gasto social. De fato, o que parece estar em jogo, dadas as novas condições socioeconômicas, é o conceito de "segurança socioeconômica" - ou seja, a proteção econômica do social. Ou, ainda, o enraizamento da economia na sociedade através de estruturas, de sistemas de regulação, de proteção e de distribuição que limitam a insegurança social e econômica, reduzem as desigualdades e produzem padrões mais amplos de oportunidades.

É sabido que o crescimento econômico não necessariamente gera emprego nem tão pouco redistribui automaticamente a riqueza produzida. Ainda mais, é preciso que sejam criados tipos adequados de emprego às necessidades e especificidades nacionais e regionais. Entretanto, sem desenvolvimento econômico, todo o esforço institucional e financeiro feito em matéria de política social se revela sistematicamente insuficiente, insatisfatório, ineficaz.

Por sua natureza, o gasto público social tende a gerar relações virtuosas entre a dinâmica econômica sustentada e a proteção social ampliada. Isto porque dinamiza a economia e o processo de geração de renda, cria emprego e sustenta a ampliação dos serviços sociais públicos. Tal virtuosidade merece melhor aproveitamento, de modo que políticas sociais e proteção social constituam partes indissolúveis da nova economia.

Em outras palavras, parece haver espaço em nossas sociedades para um novo "new deal", principalmente se concertado global e regionalmente entre as nações e apoiado pelas instituições internacionais.

Para que isto se cumpra, duas condições se impõem. De um lado, é necessário buscar e sustentar formas não-inflacionárias de financiamento do gasto público social, compatíveis com o equilíbrio fiscal. De outro, é necessária uma política tributária que seja simultaneamente redistributiva e compatível com a busca de competitividade dos nossos países, em sua integração regional e global. Tal como se revelaram no passado recente, os ajustes fiscais experimentados na região são sistematicamente vulnerabilizados pelos custos financeiros das dívidas públicas, estreitando a margem de sustentabilidade do gasto social.

Uma nova política tributária cumprirá melhor tais requisitos sempre e quando desenvolvida em uma ampla esfera pública, apoiada em processos vigorosos de informação, em procedimentos fundados na transparência das ações e na accoutability do trato dos recursos públicos. 
Um novo sistema de proteção social requer compreensibilidade e flexibilidade; políticas ativas, cidadania, assim como o reforço das organizações sociais. Envolve o público e o privado; exige a incorporação às formas clássicas de intervenção social dos novos riscos coletivos; deve mover-se de seus formatos tradicionais a formas mais universais de proteção. Supõe enfim e também políticas sociais muito ativas, capazes de reduzir o mais rapidamente possível o stock de problemas sociais acumulados no tempo.

Desde logo, as instituições da política social serão tão mais fortes quanto logrem tomar seriamente em conta a diversidade e a heterogeneidade de nossas sociedades, desde os pontos de vista de raça, de gênero e principalmente o cultural. Ou seja, que se apoiem e dêem sustentação a um contrato social centrado nos direitos humanos e nos direitos da diversidade humana. E serão tanto mais capazes e efetivas quanto consigam conferir voice aos pobres e excluídos.

Por isso mesmo, um novo sistema de proteção social requer um significativo reforço da capacidade institucional do Estado e, em especial, das instituições da política social, objetivando:

- elevar a capacidade estatal de regulação das ações da proteção social, internamente nos organismos públicos e entre instituições públicas e privadas;

- aumentar as capacidades das instituições públicas de articular os múltiplos interesses, de enraizar as ações sociais na sociedade civil e de promover alianças de apoio e sustentação política;

- melhorar as capacidades administrativas e gerenciais dos organismos da proteção social, em especial aumentando as qualificações de suas burocracias e corpos técnicos.

Uma compreensiva proteção social supõe também a armação de uma efetiva rede de segurança humana, que capacite os grupos mais desprovidos com os recursos, instrumentos e mecanismos de enfrentamento das adversidades.

Além das esferas tradicionais da intervenção social, um contemporâneo e adequado sistema de proteção social deverá ter reforçadas suas capacidades institucionais de erradicação da violência de nossas sociedades.

Por sua capacidade de criar solidariedades e ao mesmo tempo de desenvolver capital humano - pilares do novo contrato social - o novo sistema de proteção social tem na educação e na política de saúde suas áreas estratégicas de intervenção. 
Para que assim se comportem, é indispensável conceber educação e saúde como direito dos cidadãos, a serem exercidos de maneira a mais ampla possível.

Finalmente, um efetivo sistema de proteção social deve e pode abrigar desde formas de renda mínima, salário - cidadania até a forte afirmação do direito ao trabalho, não substituível pelos programas anteriormente referidos. Em outros termos, por novo que seja, há uma dimensão de conservação no novo sistema de proteção social aqui delineado, dado que se insiste também e sempre no papel fundamental de trabalho, do direito ao trabalho e da proteção ao emprego como suas formas centrais.

Entre os requisitos de uma tal nova agenda, estão alguns que, sabemos todos, são desafiantes:

- geração de emprego, em quantidade e qualidade maiores, proporcionando salários dignos, melhores condições de trabalho, além de seguro-desemprego e outros benefícios previdenciários;

- apoios para melhorar a qualidade de vida (melhor educação, saúde, habitação, aposentadorias);

- mecanismos que proporcionem renda aos que não podem trabalhar;

- financiamento adequado, público e privado, que sustente tal sistema de proteção;

- forte comprometimento político que dê bases, sustentação e factibilidade à nova agenda.

Finalmente, um novo sistema de proteção social será tão mais efetivo quanto fundado em um contrato social que conte também com uma dimensão internacional, em especial com o firme comprometimento das instituções de Bretton Woods com o desenvolvimento humano e a redução dos riscos sociais e da necessidade. 
Desenvolvimento em Debate -274 
PALESTRAS

Desenvolvimento e GlobalizaÇão:

PERSPECTIVAS PARA AS NAÇÕES 


\title{
DEPOIS DO NEOLIBERALISMO, O QUÊ?'
}

\author{
Dani Rodrik*
}

Após mais de duas décadas de aplicação de uma política econômica neoliberal no mundo em desenvolvimento, estamos em condições de formar um juízo inequívoco sobre seu histórico. O quadro não é bonito.

Consideremos o crescimento econômico, para começar. Na América Latina, apenas três países cresceram mais depressa durante os anos noventa do que no período de 1950-1980. Um deles foi a Argentina, país cujas esperanças de salvação econômica através da integração financeira na economia mundial estão agora destroçadas. O segundo foi o Uruguai, que também enfrenta graves problemas. Apenas o Chile parece ser um sucesso a longo prazo. Entre as antigas economias socialistas, a produção real ainda está abaixo dos níveis de 1990 em todos os países, com exceção de quatro. E os índices de pobreza continuam mais altos do que em 1990 até mesmo na Polônia, que é, sem sombra de dúvida, o mais bem-sucedido dentre os países do Leste Europeu. $\mathrm{Na}$ África sub-saariana, os resultados continuam a ser decepcionantes e muito piores do que os obtidos antes do fim da década de 1970.

Ademais, esse histórico de crescimento tem sido acompanhado por um agravamento das desigualdades de renda e por uma profunda insegurança econômica, na maioria dos países que adotaram a agenda do Consenso de Washington. Crises financeiras freqüentes e dolorosas devastaram o México, o Leste Asiático, o Brasil, a Rússia, a Argentina e a Turquia. O Brasil sofre hoje as conseqüências devastadoras de mais uma reviravolta nos sentimentos do mercado - uma reviravolta para a qual é muito difícil identificar razões fundamentais sólidas.

\footnotetext{
* Universidade de Harvard.

${ }^{1}$ Estas notas foram preparadas para apresentação no seminário do BNDES sobre os "Novos Rumos do Desenvolvimento no Mundo", Rio de Janeiro, 12-13 de setembro de 2002. Basearam-se em comentários feitos numa conferência sobre Alternativas ao Neoliberalismo, realizada em Washington, D.C., em 23 de maio de 2002.
} 
Os poucos exemplos de sucesso ocorreram em países que dançaram conforme sua própria música e dificilmente serviriam de cartazes de propaganda para o neoliberalismo. É o caso da China, do Vietnã e da Índia - três nações importantes, que violaram praticamente todas as regras do manual neoliberal, mesmo tomando um rumo mais orientado para o mercado.

Uma vez que o fracasso é patente para todos, uma das conseqüências foi a transformação do programa original de reformas políticas num "Consenso Ampliado de Washington", que implica reformas institucionais pesadas (ver Tabela 1). Seus proponentes afirmam agora que o Consenso de Washington precisa ser complementado por reformas na "governança" e pela apropriação dessas idéias pelos países. Nessa visão de mundo, o fracasso do consenso original deveu-se a uma aplicação inadequada de um conjunto de princípios que seria essencialmente sensato.

O Consenso Ampliado de Washington está fadado a ser uma decepção, tal como foi seu predecessor. Há muitas coisas erradas nele. Trata-se de um programa absurdamente amplo e indiferenciado de reformas institucionais. É demasiadamente insensível ao contexto e às necessidades locais. Não corresponde à realidade empírica de como efetivamente se dá o desenvolvimento. Descreve o que são as economias "avançadas", em vez de prescrever um caminho prático e viável para se chegar lá. Em suma, o Consenso Ampliado de Washington é inviável, impróprio e irrelevante.

Para os críticos do Consenso de Washington, o desafio é este: eles precisam oferecer um conjunto alternativo de diretrizes políticas para promover o desenvolvimento, sem cair na armadilha de terem que propor mais uma receita inviável, que supostamente seria boa para todos os países, em todas as épocas.

\section{O que não rejeitar}

Como primeiro passo na elaboração desse programa, temos que compreender com clareza, logo de saída, para que é que isso não constitui uma alternativa: 


\section{Princípios econômicos dominantes}

Os críticos do neoliberalismo não devem opor-se aos princípios econômicos dominantes - apenas à sua má utilização. A análise econômica expõe muitos princípios sólidos e que são universais, no sentido de que qualquer programa de desenvolvimento sensato tem que levá-los em conta. O que tenho em mente são coisas como:

- assegurar os direitos de propriedade e a vigência da lei (para que os investidores, atuais e potenciais, possam ter a expectativa de conservar a renda de seus investimentos);

- reconhecer a importância dos incentivos privados e alinhá-los com os custos e benefícios sociais (para que se possa chegar à eficiência produtiva).

- administrar a política financeira e macroeconômica com a devida consideração para com a sustentabilidade da dívida, os princípios de prudência e a moeda sólida (para que a inflação, a volatilidade macroeconômica, as crises financeiras e outras patologias possam ser evitadas).

Esses são princípios universais da boa gestão econômica, mas - e este é o ponto fundamental - não constituem um mapa de arranjos institucionais ou receitas políticas únicos. O princípio de que o direito de propriedade deve ser protegido implica muito pouco quanto à melhor maneira de fazê-lo, dentro das precondições institucionais existentes numa sociedade. Certamente não implica que um sistema de direitos de propriedade privada e gestão empresarial anglo-americana seja a abordagem certa para todos os países, em todas as épocas. Vejam o enorme volume de investimentos e iniciativa empresarial que a China conseguiu arrebanhar, através de um sistema híbrido de direitos de propriedade e de um regime jurídico que está tão distante quanto se possa imaginar do sistema anglo-americano. As inovações institucionais chinesas - o sistema de responsabilidade familiar, as empresas distritais e municipais e o sistema dual de preços - obviamente lograram proporcionar direitos eficazes de propriedade, a despeito da própria ausência do direito de propriedade privada.

Similarmente, o princípio de que os incentivos privados devem alinhar-se com os custos e benefícios sociais está longe de resultar num apoio incondicional às medidas de liberalização do comércio, desregulamentação e privatização, que são as pedras angulares do Con- 
senso de Washington. Como sabe qualquer economista bem formado, nas condições de informações incompletas, externalidades e economias de escala que prevalecem na vida real (para não falar nas restrições administrativas e de economia política), os modelos econômicos geram uma orientação política extremamente específica de cada contexto e, muitas vezes, heterodoxa (pelos padrões do Consenso de Washington). O exercício mais fácil do mundo, para um pós-graduando em economia, é escrever um modelo em que as restrições ao comércio ou controles de capital sejam ampliadores do bem-estar.

Por último, a sustentabilidade da dívida, a prudência fiscal e a moeda sólida também são, obviamente, compatíveis com diversos arranjos institucionais. A atual obsessão com bancos centrais independentes, taxas de câmbio flexíveis e metas de inflação nada mais é do que um modismo.

Tudo isso equivale a dizer que a economia da sala de seminários é muito diferente da economia tal como praticada pelo Banco Mundial ou pelo FMI. Ou então, para enunciá-lo em minha formulação favorita: $\mathrm{O}$ neoliberalismo está para a economia neoclássica assim como a astrologia para a astronomia. Em ambos os casos, é preciso um bocado de confiança cega para passar de um para outro.

\section{Crescimento econômico}

A alternativa não deve ir contra o crescimento econômico. Na verdade, deve ser inflexivelmente favorável a ele. O crescimento nem sempre precisa gerar uma redução satisfatória da pobreza e pode ter efeitos adversos sobre a preservação ambiental. Mas os problemas da pobreza e do meio ambiente são muito mais fáceis de enfrentar no contexto de uma atividade econômica robusta do que em meio à estagnação.

A principal crítica ao neoliberalismo não é que ele tenha gerado crescimento à custa de uma pobreza maior, do aumento da desigualdade e da degradação ambiental, mas que, na verdade, ele não conseguiu gerar o desenvolvimento econômico de que o mundo necessita, a fim de estar mais preparado para lidar com esses outros desafios. 


\section{Globalização}

Por último, acho que não nos devemos opor à globalização em si. Os países pobres precisam de mercados e de tecnologia, aos quais só podem ter acesso através do contato estreito com a economia mundial. O problema não está na globalização, mas na agenda distorcida que a dirige atualmente.

Quando falo em "agenda distorcida", penso em coisas que vão além da reclamação tradicional a respeito das assimetrias no acesso ao mercado. O que temos hoje em dia é uma orientação que privilegia em excesso a liberalização do comércio e dos mercados financeiros, enquanto desconsidera por completo os benefícios muito maiores que se podem extrair da liberalização do comércio da mão-de-obra. É uma agenda que desconhece a necessidade legítima dos países em desenvolvimento de dispor de "espaço" e autonomia políticos em que possam elaborar suas próprias estratégias. E é uma orientação que equipara quase por completo a chamada "rodada de desenvolvimento" com a liberalização da agricultura, embora os beneficiários primordiais desse processo sejam os próprios países avançados, enquanto muitos países pobres, importadores de alimentos, tendem a sair perdendo. Não devemos rejeitar a globalização; devemos corrigir seu protocolo.

\section{Que mostra o registro empírico?}

O segundo passo na construção de uma agenda alternativa é conhecer com clareza o registro empírico. A alternativa tem que se fundamentar na realidade, e não na confiança ou em mitos. Resumo o histórico do crescimento e seus determinantes sob a forma de quatro proposições.

1. As transições para o alto crescimento econômico são desencadeadas, tipicamente, por uma gama relativamente estreita de mudanças políticas e reformas institucionais. Eis alguns dos exemplos principais: a Coréia do Sul e Taiwan, a partir do início da década de 1960; as Ilhas Maurício, desde o começo da década de 1970; o Brasil, o México, a Turquia e outros, antes de 1980; a China, a partir de 1978; a Índia, desde o início dos anos oitenta; e o Chile, desde meados da década de 1980. Em nenhum desses casos vemos as reformas ambiciosas recomendadas pelo Consenso Ampliado de Washington desempenharem um papel importante logo de saída, ou como pré-requisito. 


\section{As mudanças políticas que dão início a essas transições para o}

crescimento combinam, tipicamente, componentes ortodoxos e inovações institucionais pouco convencionais. O Leste Asiático combinou uma extensa orientação industrial com uma "orientação para fora". A China combinou o sistema de responsabilidade familiar e de empresas distritais e municipais com a liberalização (parcial). As Ilhas Maurício criaram uma ZPE (Zona de Livre Comércio) para suas atividades voltadas para a exportação, em vez de fazer uma liberalização geral. O Chile combinou os controles sobre o capital com outros arranjos econômicos bastante ortodoxos.

\section{As inovações institucionais não se transferem com facilidade de} um lugar para outro. $\mathrm{O}$ que funciona num contexto amiúde não funciona bem em outro. A reforma em duas vias funcionou extremamente bem no setor rural da China, mas foi um fracasso lamentável quando Gorbatchóv tentou implantá-la na União Soviética. A substituição das importações funcionou bem no Brasil e no México, mas não na Argentina. A ZPE (Zona de Livre Comércio) funcionou nas Ilhas Maurício, mas não produziu nada que se aproximasse de resultados semelhantes na maioria dos outros países que o criaram. $\mathrm{O}$ gradualismo funcionou bem na Índia, mas não na Ucrânia.

4. Sustentar o crescimento econômico é um desafio em si, e não se pode presumi-lo como um resultado certeiro. Historicamente, poucos países mantêm o crescimento elevado ao embarcarem nele. A China, a Coréia do Sul e alguns outros, nestas últimas décadas, são mais a exceção do que a regra. A maioria dos países que registraram um crescimento elevado no regime de substituição de importações acabou estagnando. Antes de 1973, havia nada menos de quinze países na África sub-saariana crescendo a taxas superiores a 2,5\% ao ano. A maioria dessas economias acabou entrando em colapso, por não conseguir lidar com os choques que as atingiram no fim dos anos setenta. Isso aponta para a importância crucial de fortalecer e renovar as instituições durante as fases de crescimento acelerado da economia, a fim de poder lidar com choques e outras fontes de adversidade.

\section{Dois componentes cruciais de um programa de crescimento}

Esta breve resenha do histórico empírico sugere um programa de crescimento com dois componentes: (i) uma estratégia de investimento 
a curto prazo para deslanchar o crescimento, e (ii) uma estratégia de criação de instituições a médio e longo prazos, para dar resistência à economia frente à volatilidade e aos choques adversos.

\section{Uma estratégia de investimento}

Aqui, a chave é levar o empresariado nacional a se animar a investir na economia interna. Estimular os investimentos externos ou liberalizar tudo, e depois esperar que as coisas aconteçam, simplesmente não funciona. Uma estratégia eficiente de investimento exige que se façam duas coisas: ${ }^{2}$

- estimular investimentos em áreas não tradicionais (a promessa de recompensa);

- eliminar os projetos/investimentos que fracassarem (a ameaça de punição).

Para entender por que a intervenção pública é necessária e por que precisa ter essas duas ramificações, consideremos o problema de transformação econômica enfrentado por todos os países pobres. Saber na produção de quê um país é (ou pode ser) bom constitui um grande desafio do desenvolvimento econômico. Nem a teoria econômica nem a ciência administrativa são muito úteis para ajudar os empresários (ou o Estado) a escolher os investimentos apropriados no amplo leque de atividades dos setores modernos, dentre as quais pode haver dezenas de milhares, quando se vai além de categorias genéricas como "produtos intensivos em mão-de-obra" ou "produtos baseados em recursos naturais". No entanto, tomar as decisões certas de investimento é a chave do crescimento futuro, uma vez que determina o padrão de especialização. Nessa situação, há um grande valor social em descobrir, por exemplo, quais são as flores, bolas de futebol ou programas de computador que podem ser produzidos por um custo baixo, pois esse conhecimento pode orientar os investimentos de outros empresários. Mas o empresário inicial que faz a "descoberta" só consegue apreender uma pequena parte do valor social gerado por esse conhecimento, quando os outros empresários conseguem imitar rapidamente essas descobertas. Tipicamente, portanto,

\footnotetext{
${ }^{2}$ Esta exposição baseia-se maciçamente em Ricardo Hausmann e Dani Rodrik, "Economic Development as Self-Discovery,” NBER Working Paper No. 8952, maio de 2002.
} 
há uma oferta reduzida desse tipo de iniciativa empresarial - saber o que é possível produzir - e a transformação econômica é retardada.

Esta visão difere do ponto de vista padrão num aspecto importante. No modelo neoclássico, presume-se que as funções de produção de todos os produtos existentes sejam de conhecimento comum. Esse não é um bom pressuposto, quando se trata de países em desenvolvimento. Boa parte da tecnologia é "tácita", o que significa que não é fácil codificála em receitas que permitam uma aplicação simples. Além disso, mesmo quando as técnicas de produção usadas nos países avançados são transparentes para as pessoas de fora, é comum sua transferência para novos meios econômicos e institucionais exigir adaptações com um grau incerto de sucesso.

O regime de propriedade intelectual dos países avançados protege os inovadores através da emissão de monopólios temporários, ou seja, patentes. Mas o investidor do país em desenvolvimento que descobre que uma mercadoria existente pode ser lucrativamente produzida em casa, e cria um modelo a ser imitado por outros, não costuma receber essa proteção, muito embora os benefícios sociais possam ser muito altos. Nessas circunstâncias, o laissez-faire não pode ser a solução ótima, tal como não o é no caso da $\mathrm{P} \& \mathrm{D}$ de novos produtos. A política ótima de governo consiste, ao contrário, numa estratégia dupla: (i) estimular de antemão o investimento e a iniciativa no setor moderno, mas, o que é igualmente importante, (ii) racionalizar a posteriori a produção e eliminar as empresas de mau desempenho. A política industrial tem que combinar a recompensa e o castigo.

A maneira específica de chegar a esse resultado tende a diferir consideravelmente de um país para outro, dependendo da capacidade administrativa, do sistema vigente de incentivos, da flexibilidade do sistema tributário, do grau de sofisticação do setor financeiro e da economia política subjacente. Os sistemas de subsídios por prazo limitado, as verbas para novos empreendimentos públicos e o subsídio às exportações são algumas das maneiras de implementar essa abordagem, mas existem muitas outras. Nenhum instrumento isolado funciona em todos os lugares. Mesmo no Leste Asiático, houve diferenças importantes na maneira como a promoção foi posta em prática. (A Coréia calcou-se maciçamente nos subsídios ao crédito, enquanto Taiwan recorreu principalmente aos incentivos fiscais). Os governos sem capacidade suficiente para exercer liderança nos setores privados tendem mais a confundir as coisas do que a melhorá-las. Mas há exemplos sugestivos de que a tarefa é exeqüível. 
Este modo de ver as coisas ajuda-nos a entender por que, por exemplo, a garantia de rendas pelos governos (mediante a proteção ao comércio, os monopólios temporários, o subsídio ao crédito e os incentivos fiscais) costuma caminhar de mãos dadas com o crescimento e a diversificação industriais. Essas receitas são necessárias para estimular o processo custoso de descoberta. Sem essa compreensão, certos relatos detalhados que documentam essas receitas na Coréia do Sul e em Taiwan (ver, por exemplo, o trabalho de Alice Amsden, Robert Wade e Peter Evans) ficam impossíveis de compatibilizar com o entendimento convencional do que constitui uma política econômica desejável. Ao mesmo tempo, essa estrutura destaca como as receitas podem ter resultados nefastos, quando os governos não as complementam com medidas de racionalização das indústrias e disciplinamento das empresas que venham a ficar com custos elevados. O que se destaca em muitas discussões sobre o Leste Asiático é o modo como os governos da região foram inusitadamente eficazes na imposição da disciplina necessária. Os governos coreano e taiwanês eram rápidos em suspender seus programas de apoio a determinadas firmas ou indústrias, quando novas informações sugeriam que haveria uma queda da produtividade. O Japão usou uma combinação similar de promoção/proteção estatal, seguida pela racionalização em diversas indústrias.

Consideremos, por outro lado, a América Latina durante seu período de industrialização pela substituição de importações (ISI). A ISI latino-americana produziu muitas firmas de sucesso, mas também uma estrutura industrial diversificada demais - um excesso de empresas de baixa produtividade, ao lado de outras de alto desempenho. A disciplina chegaria à América Latina na década de 1990, sob a forma da abertura comercial, e muitas empresas de baixa produtividade acabaram sendo eliminadas. Países como a Argentina, o Brasil e o Chile aprofundaram sua especialização em indústrias intensivas em capital, baseadas em recursos naturais, enquanto outros, como o México e os países menores da América Central, aumentaram sua concentração nas indústrias montadoras que servem ao mercado norte-americano. Mas a abertura e a reforma institucional não foram suficientes para desencadear uma nova onda significativa de iniciativas empresariais e investimentos em atividades não tradicionais.

Uma caracterização tosca mas útil dos ambientes de implementação de medidas políticas no Leste Asiático e na América Latina, vistos pela perspectiva do quadro referencial aqui exposto, seria a seguinte: os go- 
vernos do Leste Asiático deram a suas empresas, durante as décadas de 1960 e 1970, tanto proteção (o incentivo) quanto disciplina (o castigo). Cotejado com esse marco, o desempenho industrial latino-americano ficou aquém das expectativas, em função de várias deficiências. No período de ISI, a América Latina distinguiu-se por grandes incentivos, mas por uma disciplina insuficiente. Na década de 1990, teve uma disciplina considerável (trazida pelos mercados competitivos e pela abertura comercial), mas muito poucos incentivos.

\section{Uma estratégia de construção institucional}

Os mercados não são autocriadores, auto-reguladores, autoestabilizadores nem autolegitimadores. O crescimento econômico requer mais do que um aumento temporário dos investimentos e da iniciativa empresarial. Exige o esforço de construir quatro tipos de instituição, necessários para manter o impulso de crescimento e criar resistência aos choques:

- instituições criadoras de mercados (direitos de propriedade e cumprimento de contratos);

- instituições reguladoras do mercado (para lidar com externalidades, economias de escala e informações incompletas);

- instituições estabilizadoras do mercado (para a gestão monetária e fiscal);

- instituições legitimadoras do mercado (proteção e seguridade sociais; política redistributiva; instituições de administração de conflitos; parcerias sociais).

Construir e consolidar essas instituições leva tempo. Usar um período inicial de crescimento para experimentar e inovar nessas frentes pode trazer grandes dividendos mais adiante. Os estudos transnacionais mostram que as instituições são o mais importante determinante isolado do desenvolvimento econômico a longo prazo. Uma vez levada em conta a qualidade institucional, nem a geografia nem o comércio desempenham qualquer papel na explicação das diferenças de níveis de renda entre os países (ver Figura 1).

Como já foi sugerido, as "funções" exercidas por instituições de alta qualidade (conceder direitos de propriedade, regular os incentivos e assim por diante) configuram múltiplas formas institucionais, como mos- 
tram esquematicamente as Figuras 2 a 4. A primeira coluna de cada figura refere-se aos objetivos a serem alcançados: eficiência produtiva, estabilidade macroeconômica e financeira, justiça distributiva e alívio da pobreza. A coluna seguinte lista os conceitos relevantes, a partir da análise econômica. Por exemplo, os direitos de propriedade e a estrita observância da norma legal são necessários para se chegar à eficiência produtiva; a sustentabilidade da dívida e a solidez da moeda são necessárias à estabilidade macroeconômica, e assim por diante. A terceira coluna ilustra algumas das escolhas institucionais que precisam ser feitas. Essas escolhas não são fixadas pela análise econômica (embora a análise econômica possa ser de enorme utilidade para esclarecer as contrapartidas a obter). Que tipo de sistema jurídico deve o país adotar: o direito consuetudinário, o direito romano, ou um híbrido dos dois? Qual é o equilíbrio exato entre a competição descentralizada no mercado e a intervenção pública? Quais os tipos de instituições financeiras/de gestão empresarial mais apropriados para mobilizar a poupança interna? Deve a política tributária ser pautada por normas legais e, nesse caso, quais são as normas apropriadas? Qual é o tamanho apropriado da economia pública? Qual é o aparelho regulador apropriado para o sistema financeiro? Quão progressivo deve ser o sistema tributário? Como devem organizar-se os mercados de trabalho?

Os arranjos institucionais têm um grande componente de especificidade. Descobrir o que "funciona" no plano local requer experimentação. As reformas que têm sucesso num contexto podem exibir um rendimento precário ou fracassar por completo em outros. Como afirmei antes, essa especificidade ajuda a explicar por que os países bem-sucedidos - China, Índia, Coréia do Sul e Taiwan, entre outros quase sempre combinaram elementos heterodoxos com medidas ortodoxas. Explicaria também por que persistem importantes diferenças institucionais entre os países avançados da América do Norte, da Europa Ocidental e o Japão, em áreas como o papel do setor público, a natureza dos sistemas jurídicos, a gestão empresarial, os mercados financeiros, os mercados de trabalho e os mecanismos de seguridade social.

Além disso, como os planejadores políticos sempre operam em ambientes que ficam aquém da perfeição, é impossível conceber trajetórias ótimas de reforma - mesmo em casos aparentemente simples, como uma reforma de preços - sem a devida consideração para com as condições vigentes e sem que se pesem as conseqüências da reforma para múltiplas margens de distorção. 
Vejamos um experimento hipotético, para elucidar esse ponto. Imaginemos que uma economista ocidental fosse convidada, em 1978, para orientar os governantes chineses a respeito de uma estratégia de reforma. Como formularia sua orientação, à luz do que hoje "sabemos"? Sendo uma economista sensata, é presumível que ela soubesse que o ponto de partida deveria ser a agricultura, já que a vasta maioria da população chinesa vive na zona rural. A liberalização dos preços agrícolas seria o item número um da agenda. Ciente de que os incentivos aos preços fazem pouca diferença quando a renda agrícola é destinada a comunas, ela acrescentaria, imediatamente, que a privatização da terra deveria acompanhar a liberalização dos preços. Lembrada de que o fornecimento obrigatório da safra ao Estado era uma importante fonte implícita de tributação, ela acrescentaria que também haveria necessidade de uma reforma tributária, para compensar a perda de receita fiscal. Mas então surgiria outro problema: se o Estado não pudesse fornecer alimentos às áreas urbanas a preços inferiores aos do mercado, não iriam os trabalhadores urbanos exigir salários mais altos? Sim, isso também requereria algumas reformas. As empresas estatais precisariam ser transformadas em corporações, a fim de poderem fixar os salários e tomar livremente as decisões de contratação e demissão. (A privatização seria ainda melhor, é claro.) Mas, se as empresas estatais passassem a ter autonomia, não viriam a agir como monopólios? Bem, a legislação antitruste, ou a liberalização do comércio, usada como um atalho, cuidariam desse problema. Quem financiaria as empresas estatais enquanto elas estivessem procurando reestruturar-se? É óbvio que também haveria necessidade de uma reforma do mercado financeiro. E quanto aos trabalhadores que fossem demitidos das empresas estatais? Sim, é por isso que as redes de segurança são um componente necessário de qualquer programa de ajuste estrutural. E assim por diante.

Essas recomendações reproduzem a lista padrão de itens do Consenso de Washington, e sua lógica é impecável. Mas poderíamos desculpar os destinatários desses conselhos se, porventura, eles chegassem à conclusão de que essa história de reforma é difícil demais de realizar durante a vida de um sujeito. Felizmente, a experiência real das reformas bem-sucedidas oferece uma lição diferente: não é necessário um programa ambicioso de reformas institucionais complementares para dar o pontapé inicial no crescimento. Como sabemos ao olhar para trás, os reformadores chineses puderam usar atalhos criativos, que contornaram as complementaridades que, de outro modo, teriam estragado uma 
abordagem parcial e gradativa. A reforma de preços por um sistema dual e a introdução do sistema de responsabilidade familiar aumentaram os incentivos à produção agrícola na margem, sem exigir uma reforma da propriedade, cortes na receita tributária e a perturbação do equilíbrio social nas áreas urbanas. Talvez não tenha sido uma reforma ideal, pelos padrões indicados nos manuais, mas funcionou.

Embora a análise econômica possa contribuir para as escolhas institucionais, há também um enorme papel a ser desempenhado pela deliberação pública e pela opção coletiva. Na verdade, podemos pensar na democracia participativa como uma meta-instituição que faz escolhas no "cardápio" de arranjos institucionais possíveis em cada uma dessas áreas.

\section{Resumindo}

Como demonstra o caso chinês, as transições para o crescimento econômico de vulto raramente são desencadeadas por receitas importadas do exterior. Abrir a economia ao comércio e aos fluxos de capital e adotar as instituições "de melhor prática" quase nunca são fatores fundamentais logo de saída. Ao contrário, as reformas iniciais tendem a ser uma combinação de inovações institucionais não convencionais e elementos extraídos do receituário ortodoxo. Os recursos humanos adequados, a infraestrutura pública, a estabilidade macroeconômica e a paz social, tudo isso são elementos-chave que viabilizam uma estratégia de crescimento. Mas a estratégia tem que ir mais além e atiçar a vitalidade dos investidores internos. Essas combinações tendem a ser específicas de cada país, exigindo conhecimento e experimentação locais para ser implementadas com sucesso. Elas visam os investidores internos e são talhadas de acordo com as realidades institucionais internas.

Conceber uma estratégia de crescimento desse tipo é mais difícil e mais fácil do que implementar políticas típicas de integração. Mais difícil, porque as restrições ao crescimento costumam ser específicas de cada país e não reagem bem às receitas padronizadas. Porém mais fácil, porque, uma vez tomando por alvo essas restrições, algumas mudanças políticas relativamente simples podem gerar enormes benefícios econômicos e dar início a um círculo virtuoso de crescimento e reformas adicionais. 


\section{Implicação para as instituições globais}

Nesta visão alternativa, um regime econômico internacional favorecedor do desenvolvimento é aquele que faz muito mais do que promover o acesso dos países pobres aos mercados dos países industrializados avançados e promulgar códigos, padrões e "práticas ótimas". É aquele que permite aos países pobres experimentarem arranjos institucionais e lhes dá espaço para conceberem suas próprias soluções, possivelmente divergentes, para os gargalos de desenvolvimento que têm de enfrentar. É aquele que avalia as demandas de reforma institucional não pela perspectiva da integração ("de que precisam os países para se integrar?”), mas pela perspectiva do desenvolvimento ("de que precisam os países para chegar a um crescimento econômico amplo e eqüitativo?"). Segundo esta visão, os arranjos econômicos internacionais não mais serviriam de instrumentos de harmonização de políticas e práticas econômicas entre os vários países, visando à maximização do comércio e dos fluxos de investimento, mas de arranjos capazes de intermediar as diferentes práticas e instituições nacionais.

Na verdade, precisamos voltar a um modelo "leve" de globalização - com menos concentração na disciplina e na harmonização internacionais - e desistir de adotar uma versão "pesada", que sufoca os países em desenvolvimento. A abordagem de "integração superficial" do GATT mostrou-se muito mais acolhedora para os projetos de desenvolvimento do que o modelo de "integração profunda" da OMC.

E, num modelo "leve" de globalização, é preciso deslocar a atenção para o relaxamento das restrições à mobilidade da mão-de-obra. Essa é uma área em que os benefícios são maiores para a eficiência global $e$ os países pobres do que todas as outras coisas constantes da agenda atual de negociações. ${ }^{3}$

\footnotetext{
${ }^{3}$ Para maiores discussões, ver Dani Rodrik, "Feasible Globalizations," maio de 2002 (http://ksghome.harvard.edu/ .drodrik.academic.ksg/Feasible.pdf).
} 


\section{Comentários finais}

O novo Consenso de Washington, em sua versão reformulada, não constitui um guia útil para a promoção do desenvolvimento nos países pobres. Sua mensagem de que "instituições 'de prática ótima' + abertura comercial e fluxos de capital = crescimento econômico" tem toda a probabilidade de levar a mais uma decepção. Ofereci aqui uma abordagem alternativa, que se concentra na experimentação - tanto na esfera institucional quanto na produtiva - como um motor importante do desenvolvimento econômico. A chave está em reconhecer que não se pode obter tecnologia nem boas instituições sem adaptações internas significativas. Essas adaptações, por sua vez, requerem um papel proativo do Estado e da sociedade civil, bem como estratégias de colaboração que estimulem a iniciativa empresarial e a construção de instituições. O que o mundo precisa, hoje em dia, é de menos consenso e mais experimentação. O papel dos organismos externos, por sua vez, deve ser o de promover a capacidade de as democracias nacionais implementarem essas inovações, e não o de cerceá-las. Atende-se melhor às necessidades do mundo em desenvolvimento com um conjunto "leve" de regras de gestão econômica global (em contraste com um "pesado" conjunto de regras voltadas para a maximização do comércio e dos fluxos de investimento).

Voltando a meu título, depois do neoliberalismo, o quê? Certamente, não um novo lema ou receita. A abordagem que esbocei aqui fundamenta-se em princípios econômicos sólidos e está impregnada do histórico empírico, mas deixa espaço para que a imaginação institucional e a política participativa concebam estratégias de desenvolvimento que atendam às necessidades locais e lhes sejam apropriadas. Talvez não tenha os atrativos das soluções prontas, mas tem, pelo menos, uma probabilidade de funcionar. 


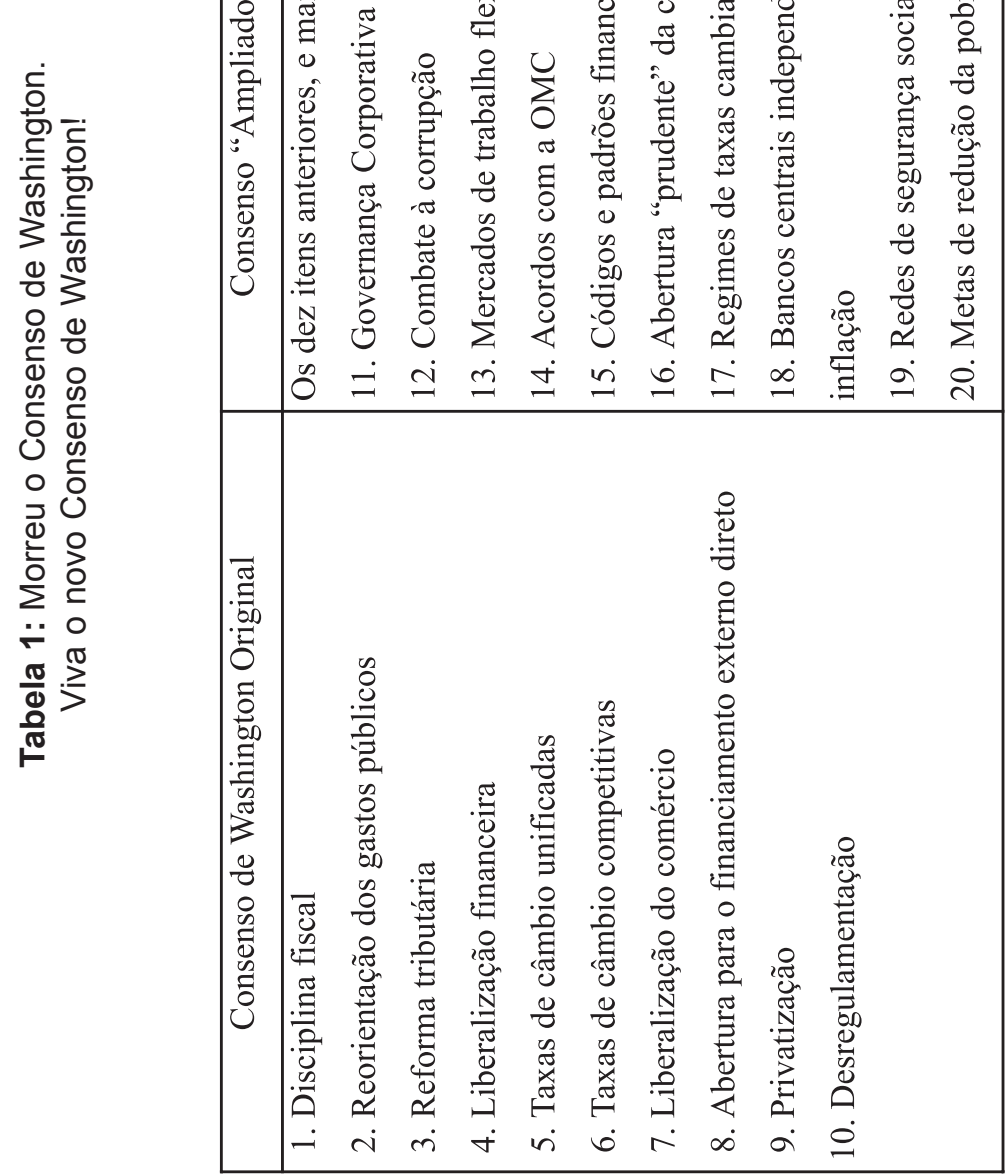



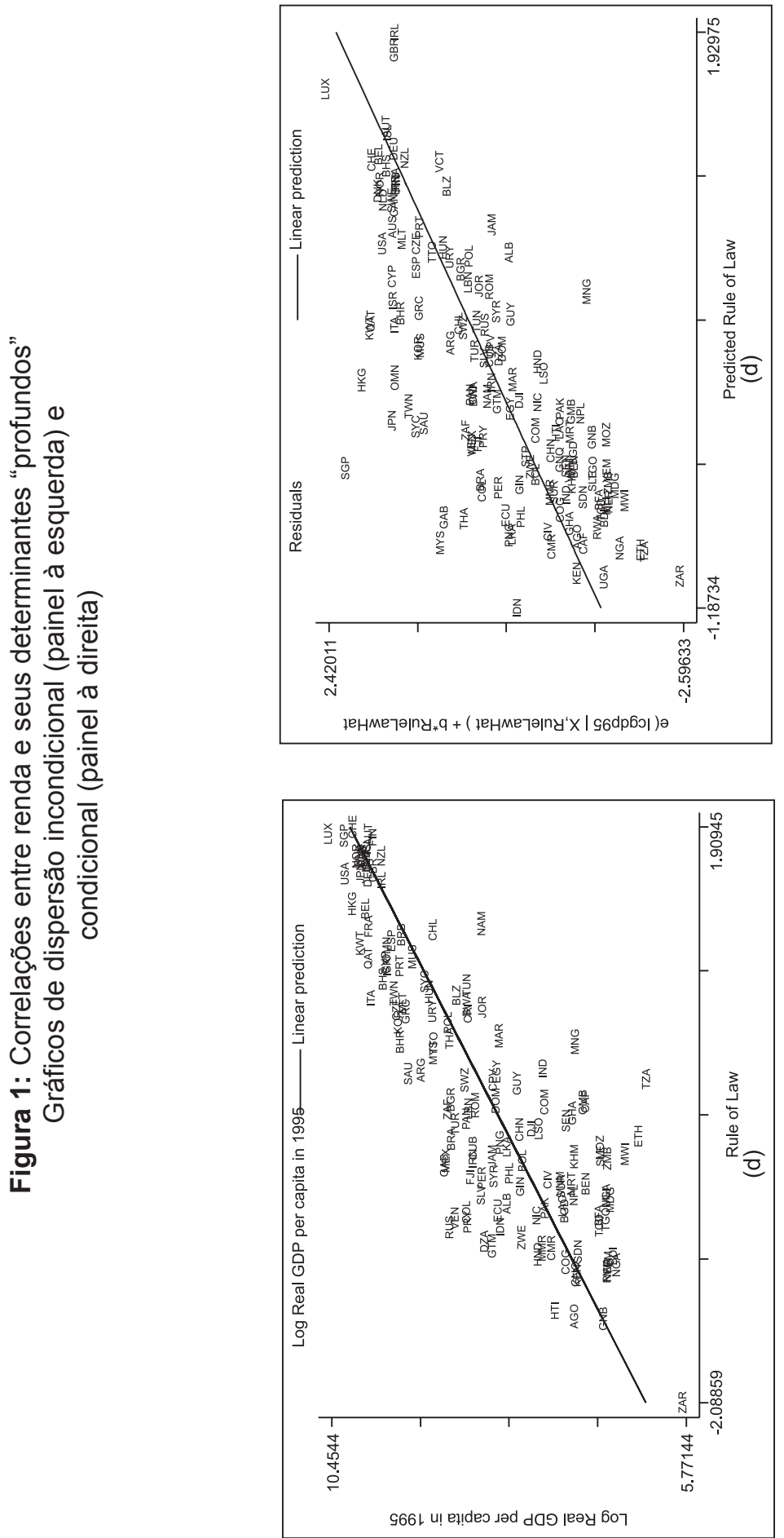

Desenvolvimento e Globalização — 293 

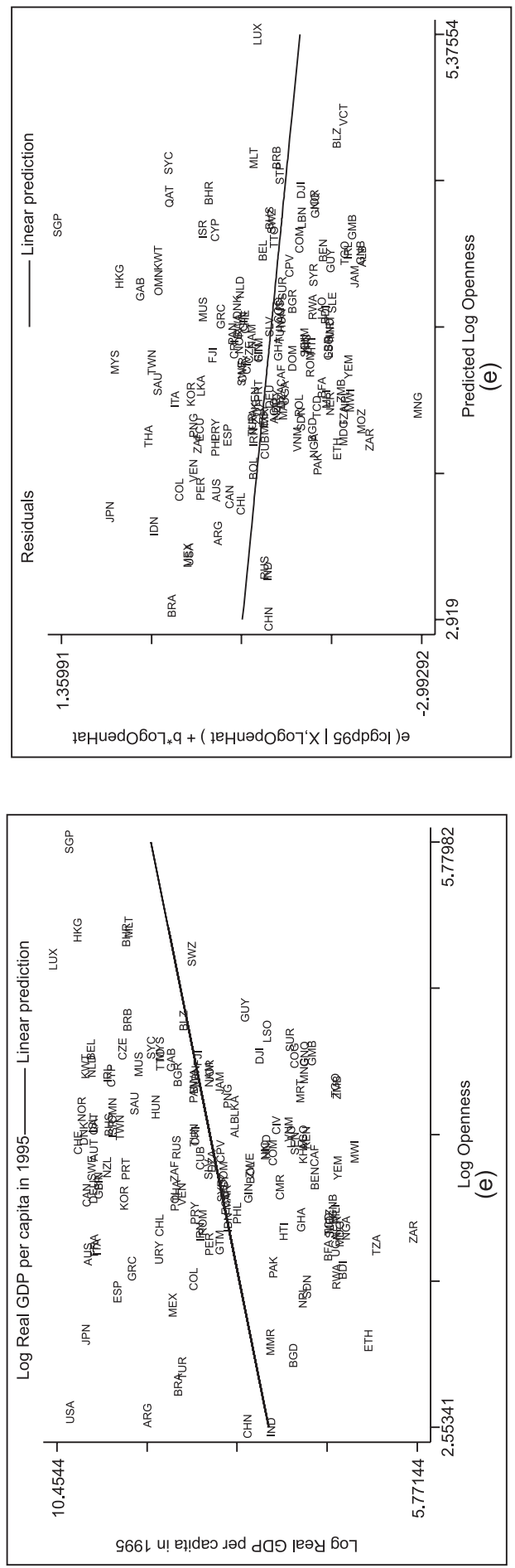

Desenvolvimento em Debate -294 


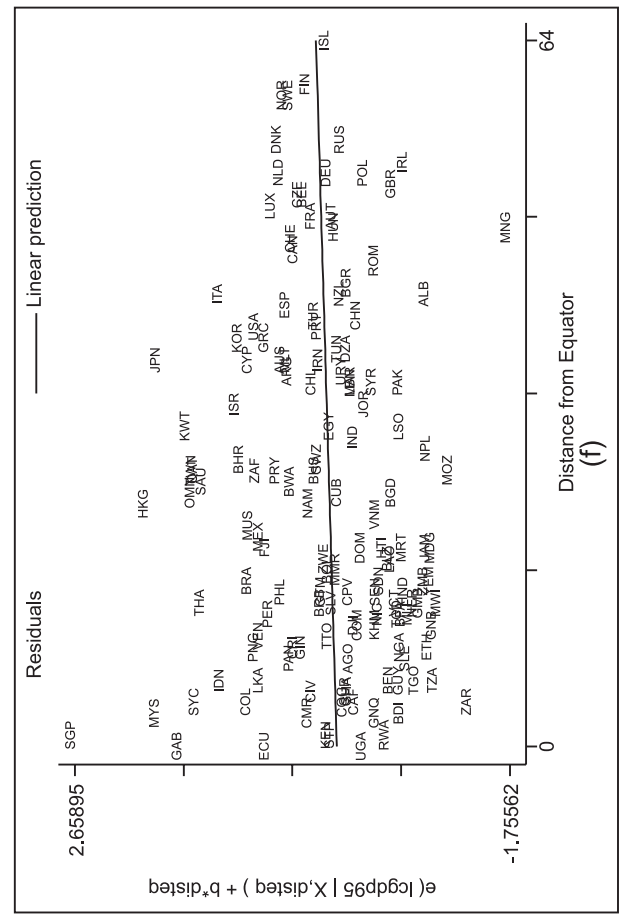

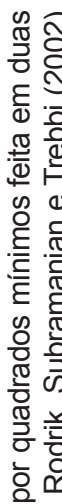

ㄷำ $\frac{E}{10}$

कू ए

띤

응 응

๑)

흐

ते

है ญे

()

잉

产

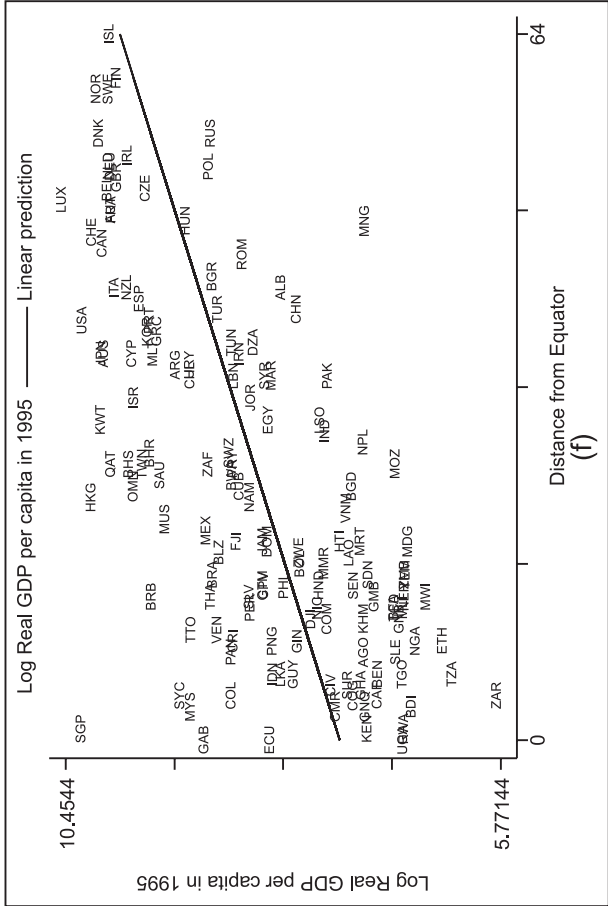

응

๓

त्ర

항

뜨를

पํำ

ब

증

응 종

잔

흠

-

趂

$\Phi$

응

응 음

क तั

은

ธัँ

๑ 0

i 


\section{Figura 2}

\begin{tabular}{|c|c|c|}
\hline OBJETIVOS & PRINCÍPIOS UNIVERSAIS & ARRANJOS INSTITUCIONAIS \\
\hline $\begin{array}{l}\text { Estabilidade macroeconômica e } \\
\text { financeira }\end{array}$ & $\begin{array}{l}\text { Solidez da moeda: Não gerar } \\
\text { liquidez além do aumento da } \\
\text { demanda nominal de moeda, com } \\
\text { uma inflação razoável. } \\
\text { Sustentabilidade fiscal: Garantir } \\
\text { que a dívida pública se mantenha } \\
\text { "razoável" e estável em relação } \\
\text { aos agregados nacionais. } \\
\text { Regulamentação prudencial: } \\
\text { Impedir que o sistema financeiro } \\
\text { assuma riscos excessivos. }\end{array}$ & $\begin{array}{l}\text { Quão independente deve ser o } \\
\text { Banco Central? } \\
\text { Qual é o regime cambial } \\
\text { apropriado (dolarização, regime dł } \\
\text { conversibilidade, câmbio fixo } \\
\text { ajustável, câmbio flutuante } \\
\text { controlado, câmbio flutuante) } \\
\text { Deve a política fiscal ser limitada } \\
\text { por regras e, nesse caso, quais são } \\
\text { as regras apropriadas? } \\
\text { Tamanho da economia pública. } \\
\text { Qual é o aparelho regulador } \\
\text { apropriado para o sistema } \\
\text { financeiro? }\end{array}$ \\
\hline
\end{tabular}




\section{Figura 3}

\begin{tabular}{|c|c|c|}
\hline OBJETIVOS & PRINCÍPIOS UNIVERSAIS & ARRANJOS INSTITUCIONAIS \\
\hline $\begin{array}{l}\text { Justiça distributiva e alívio da } \\
\text { pobreza }\end{array}$ & $\begin{array}{l}\text { Estabelecimento de metas: Os } \\
\text { programas redistributivos devem } \\
\text { visar ao máximo os beneficiários } \\
\text { pretendidos. } \\
\text { Compatibilidade dos incentivos: } \\
\text { Os programas redistributivos } \\
\text { devem minimizar as distorções } \\
\text { dos incentivos. }\end{array}$ & $\begin{array}{l}\text { Progressividade do sistema } \\
\text { tributário. } \\
\text { Pontos apropriados de } \\
\text { intervenção: Sistema de ensino? } \\
\text { Acesso à saúde? Acesso ao } \\
\text { crédito? Mercados de trabalho? } \\
\text { Sistema tributário? } \\
\text { Fundos sociais. } \\
\text { Redistribuição das dotações } \\
\text { (reforma agrária, doações no } \\
\text { nascimento)? } \\
\text { Organização dos mercados de } \\
\text { trabalho: decentralizados ou } \\
\text { institucionalizados? } \\
\text { Formas de prestação de serviços: } \\
\text { ONGs, arranjos participativos etc. }\end{array}$ \\
\hline
\end{tabular}




\section{Figura 4}

\begin{tabular}{|c|c|c|}
\hline OBJETIVOS & PRINCÍPIOS UNIVERSAIS & ARRANJOS INSTITUCIONAIS \\
\hline $\begin{array}{l}\text { Eficiência produtiva } \\
\text { (estática e dinâmica) }\end{array}$ & $\begin{array}{l}\text { Direitos de propriedade: Garantir } \\
\text { que os investidores atuais e } \\
\text { potenciais possam conservar o } \\
\text { retorno de seus investimentos. } \\
\text { Incentivos: Alinhar os incentivos } \\
\text { concedidos aos produtores com os } \\
\text { custos e benefícios sociais. } \\
\text { Estado de direito: Fornecer um } \\
\text { conjunto transparente, estável e } \\
\text { previsível de regras. }\end{array}$ & $\begin{array}{l}\text { Que tipo de direitos de } \\
\text { propriedade: privados, públicos, } \\
\text { cooperativos? } \\
\text { Que tipo de regime legal: direito } \\
\text { consuetudinário ou direito } \\
\text { romano? Adotar ou inovar? } \\
\text { Qual é o equilíbrio exato entre a } \\
\text { competição descentralizada de } \\
\text { mercado e intervenção pública? } \\
\text { Que tipos de instituições } \\
\text { financeiras/governança } \\
\text { corporativa são mais apropriados } \\
\text { para mobilizar as poupanças } \\
\text { internas? }\end{array}$ \\
\hline
\end{tabular}

\section{Referências bibliográficas}

HAUSMANN, Ricardo e RODRIK, Dani, "Economic Development as Self-Discovery," NBER Working Paper No. 8952, maio de 2002. RODRIK, Dani, "Feasible Globalizations," maio de 2002 (http:// ksghome.harvard.edu/ .drodrik.academic.ksg/Feasible.pdf). 


\title{
GLOBALIZAÇÃO E DESENVOLVIMENTO*
}

\author{
José Antonio Ocampo**
}

A ordem econômica neoliberal tem sido alardeada, nos últimos vinte e cinco anos, como a porta de entrada para uma era de prosperidade sem precedentes. Seu principal instrumento para o mundo em desenvolvimento - a liberalização econômica - foi apresentado como uma saída das estratégias ineficazes associadas ao protecionismo comercial e aos altos níveis de intervenção do Estado, bem ao comportamento rentista que era estimulado por tais estratégias. O Consenso de Washington forneceu o resumo mais conhecido desse projeto de reforma, embora certamente não reflita suas versões mais radicais, que advogam um Estado minimalista (Wiliamson, 1997).

Nos últimos anos, a sabedoria dessa visão tem sido contestada. $\mathrm{O}$ comércio e o investimento externo direto tiveram um grande surto de crescimento, mas a "Terra Prometida" das altas taxas de crescimento é tida cada vez mais como uma miragem. A defasagem internacional dos níveis de renda acelerou-se e as tensões distributivas aumentaram, tanto no mundo desenvolvido quanto nos países em desenvolvimento. A alta volatilidade financeira e o déficit geral de regulamentação são agora evidentes, até mesmo no mundo industrializado.

A reivindicação de "civilizar" a economia global (Helleiner, 2000), a fim de gerar uma forma de globalização mais inclusiva, ou, nas palavras da Declaração do Milênio da Organização das Nações Unidas, "para assegurar que a globalização se torne uma força positiva para todos os povos do mundo" (ONU, 2000), tornou-se a norma. Essa tem sido a opinião insistente da sociedade civil internacional desde Seattle. O de-

\footnotetext{
* Este artigo baseou-se largamente no recente relatório da CEPAL, "Globalização e Desenvolvimento" (CEPAL, 2002a), dirigido pelo autor.

** Secretário Executivo, Comissão Econômica para a América Latina e o Caribe (CEPAL).
} 
sencanto com a liberalização no mundo desenvolvido e o pluralismo no debate econômico (ver, por exemplo, Rodrik, 1999, e Stiglitz, 2002a) também estão em ascensão. Até o presente, no entanto, todos esses processos positivos levaram a uma ação muito limitada. Em diversos aspectos, a ordem neoliberal globalizada continua a se aprofundar, enquanto os processos que se opõem a ela avançam em ritmo lento.

Aliás, à medida que prossegue a controvérsia em torno da liberalização, a terminologia empregada no debate vai-se tornando cada vez mais obscura. Fala-se muito da necessidade de consolidar a "primeira geração" de reformas e de complementá-las com uma "segunda geração", visando a fortalecer as instituições ${ }^{1}$ e as redes sociais de segurança. Nesse aspecto, há um substrato básico de concordância (embora também aí existam dissensões): fala-se da necessidade de estruturas macroeconômicas fortes, de acesso às oportunidades oferecidas pela economia internacional, de maior participação do setor privado no processo de desenvolvimento, de um Estado mais eficiente e, sem dúvida, de instituições mais sólidas e uma política social atuante. Todavia, afora essa dimensão de concordância, existem profundas diferenças de opinião quanto aos significados exatos de todos esses termos.

$\mathrm{Na}$ verdade, o "fetichismo da reforma" implícito na idéia da "geração de reformas" é uma parte essencial do problema. Seu grande pressuposto básico é que os processos de desenvolvimento são de natureza linear e universal. Assim, de acordo com essa visão, os passos tomados nos estágios iniciais do processo constituem a fundação sobre a qual se podem erigir as partes adicionais da construção. Sem dúvida, essa é uma estrutura imprópria, quando a precariedade de parte dessas fundações conduz a problemas que têm de ser solucionados nos estágios subseqüentes. Nesses casos, fazse necessário "reformar as reformas". É o que acontece, por exemplo, nas situações em que os sistemas administrativos macroeconômicos levaram a práticas pro-cíclicas de administração que aumentam os riscos enfrentados por todos os agentes econômicos, nas quais a liberalização tem fortes efeitos distributivos adversos, ou nas quais as reformas da política social deixam de defender o princípio da solidariedade.

\footnotetext{
${ }^{1}$ Neste artigo, o conceito de "instituições" é usado num sentido mais tradicional e mais amplo do que o empregado na literatura mais recente, incluindo tanto organizações (p. ex., empresas comerciais, associações de produtores e órgãos de governo) quanto medidas políticas, dispositivos constitucionais, legais e regulatórios, e ainda alguns fatores intangíveis, como as tradições e as convenções.
} 
Contrariando o segundo pressuposto implícito, o da universalidade, pode-se argumentar que não existe um modelo único de gestão econômica que garanta a estabilidade macroeconômica, nem tampouco existe uma forma única de integração na economia internacional ou de concepção das instituições econômicas e sociais. Na terminologia de Albert (1991) e Rodrik (1999), existem diferentes "variedades de capitalismo", como indica a experiência dos países desenvolvidos e em desenvolvimento. É bom que seja assim, pois isso implica que a democracia tem um papel a desempenhar e que a "posse" das políticas de desenvolvimento tem um sentido positivo, não constituindo uma simples concordância "voluntária" com o paradigma dominante (ou, o que dá na mesma, uma aceitação cega das "restrições" impostas pela globalização).

Este artigo oferece uma visão alternativa do projeto de desenvolvimento e das reformas correspondentes que se fazem necessárias nos arranjos globais. Ele se divide em quatro partes. As duas primeiras examinam fatos globais e latino-americanos. A terceira expõe em linhas gerais uma agenda global que atribui um papel crucial às instituições regionais. A quarta examina as estratégias nacionais de desenvolvimento.

\section{Disparidades históricas globais}

A história demonstra que a "convergência" internacional dos níveis de renda, previsão típica de muitos modelos ortodoxos do crescimento econômico, mais se tem mostrado a exceção do que a regra. $\mathrm{O}$ único exemplo significativo de convergência dos níveis da renda per capita ocorreu entre os países desenvolvidos, durante os "anos dourados" do período do pós-guerra, 1950-1973 (Maddison, 1991). Esse processo continuou a avançar até 1990, embora em ritmo mais lento, e estancou na última década do século XX. O’Rourke e Williamson (1999) demonstraram que, durante esse período, os Estados Unidos e a Europa assistiram a uma convergência dos níveis salariais, basicamente em resultado da migração maciça da mão-de-obra européia para o Novo Mundo. Dentro da Europa Ocidental também ocorreu um processo de equiparação salarial, embora não tenha abrangido os países da periferia européia ou outras regiões do mundo. Assim, mesmo no grupo dos países hoje industrializados, houve uma ligeira divergência nas tendências do PIB per capita, divergência esta que é ainda maior quando se inclui um grupo mais amplo de nações. 
Esse tema foi minuciosamente examinado na bibliografia sobre o crescimento econômico no último quarto de século. Em geral, essas análises confirmam que houve uma divergência a longo prazo nos níveis de renda per capita nos dois últimos séculos, que ela foi particularmente acelerada no século XIX e na primeira metade do século XX, que diminuiu um pouco o ritmo em 1950-1973 e que foi retomada desde então. Assim, usando os níveis do PIB per capita dos 141 países incluídos na série histórica de Angus Maddison (Maddison, 2001), o desvio logarítmico médio aumentou de 0,56 em 1973 para 0,65 em 1998 (Figura 1, painel A). Todavia, diversos estudos também indicam ter havido alguns indícios, ainda que não sistemáticos, de uma "convergência condicional", quando se levam em consideração outros fatores que influenciam o crescimento dos países, entre eles o nível educacional da população, a infra-estrutura, a estabilidade macroeconômica e as instituições políticas, sociais e econômicas. Tomados em conjunto, esses dois grupos de dados indicam que tais determinantes do crescimento econômico distribuem-se com a mesma desigualdade que o PIB per capita, ou mais até. $\mathrm{E}$ isso, convém acrescentar, lança sérias dúvidas sobre a validade do conceito de "convergência condicional".

\begin{tabular}{|l|r|r|r|r|}
\cline { 2 - 5 } \multicolumn{1}{c|}{} & 1950 & 1973 & 1990 & 1998 \\
\hline 141 países & 0,54 & 0,56 & 0,58 & 0,65 \\
\hline América Latina & 0,14 & 0,14 & 0,16 & 0,21 \\
\hline
\end{tabular}

\begin{tabular}{|l|r|r|r|}
\cline { 2 - 4 } \multicolumn{1}{c|}{} & $1950-1973$ & $1973-1990$ & $1990-1998$ \\
\hline 141 países & 1,73 & 2,35 & 2,95 \\
\hline América Latina & 1,5 & 1,43 & 2,15 \\
\hline
\end{tabular}


Figura 1:

Tendências da desigualdade internacional

A. Average log deviation of GDP per capita

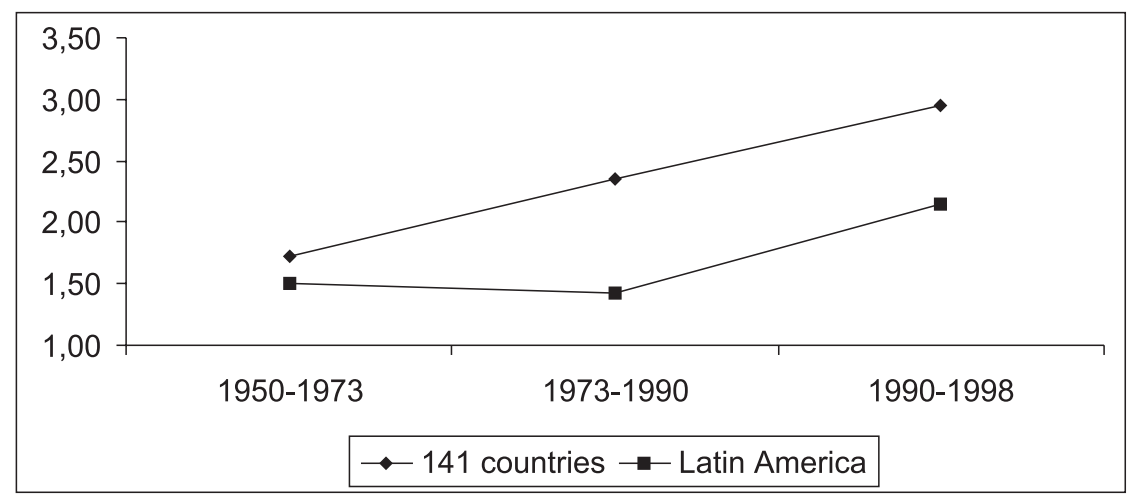

B. Standard deviation of GDP per capita growth

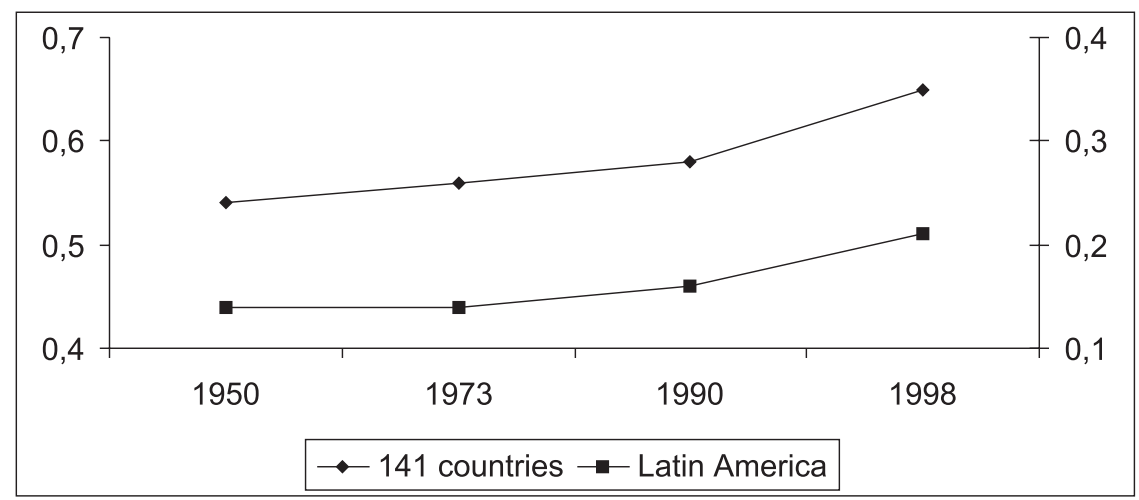

Source: ECLAC, based on Maddison (2001) 
Uma análise da mesma fonte de dados revela outro fenômeno: a dispersão acentuada e crescente dos índices de crescimento entre os países em desenvolvimento durante os últimos 25 anos do século XX - em outras palavras, a coexistência dos "bem-sucedidos" e dos "fracassados". Na verdade, o desvio padrão do crescimento do PIB per capita elevou-se, na mesma amostra de 141 países, de 1,73 em 1950-1973 para 2,5 em 1973-1990, e para 3,09 na década de 1990 (Figura 1, painel B). É importante enfatizar que essa tendência foi muito mais difundida do que a tendência para maiores disparidades internacionais de renda, pois afetou todas as regiões e os países de baixa e média renda.

Tais tendências fazem parte de um processo mais amplo de piora da distribuição de renda no nível mundial, como indica uma série de artigos recentes. O mais abrangente deles, preparado por Bourgignon e Morrison (2002) sobre as tendências da distribuição da renda mundial entre 1820 e 1992, concluiu que as desigualdades internacionais tiveram um aumento significativo entre 1820 e 1910, mantiveram-se estáveis de 1910 a 1960 e tornaram a crescer de 1960 a 1992. Até 1910, o aspecto dominante desse processo foi o aprofundamento das disparidades internacionais nos níveis do PIB per capita. Durante o período marcado por uma inversão do processo de globalização (1914-1950), a divergência internacional contínua da renda per capita foi contrabalançada por uma melhora da distribuição da renda dentro dos países, ligada ao surgimento dos Estados de bem-estar social na Europa Ocidental e nos Estados Unidos e às revoluções socialistas na Europa Central e Oriental.

A tendência para a ampliação das desigualdades internacionais nas décadas recentes pode ser atribuída não apenas a um novo aumento das disparidades internacionais nos níveis do PIB per capita, mas também a um aumento bastante disseminado das desigualdades no interior dos países. A título de ilustração, no período de 1975-1995, 57\% da população de uma amostra de 77 nações estavam vivendo em países em que a distribuição da renda vinha piorando (Cornia, 1999). Apenas 16\% viviam em nações em que ela estava melhorando. Os demais habitavam países com níveis estáveis de desigualdade, ou outros em que não se pôde discernir nenhuma tendência clara.

Vistas em conjunto, as considerações anteriores não deixam dúvida quanto à existência de fatores de peso que determinam uma distribuição desigual da renda mundial. Nos casos em que houve convergência, ela se deu apenas entre os países desenvolvidos e somente em estágios específicos da evolução da economia mundial. A tendência geral para a 
divergência nos níveis de desenvolvimento mesclou-se com a estagnação dos níveis relativos de renda, experiência média da América Latina entre 1870 e 1973 (ver adiante), ou com diversas experiências de "convergência truncada", como a da Argentina, após seu período de crescimento rápido entre 1880 e 1913, ou as do Brasil e do México, após sua fase bem-sucedida de industrialização conduzida pelo Estado, que prosseguiu por várias décadas, até ser interrompida pela crise da dívida nos anos oitenta.

O ressurgimento vigoroso da tendência para a divergência da renda, nestas últimas décadas, também contraria as expectativas de que a liberalização econômica viesse a acelerar a convergência, por fornecer amplas oportunidades aos países em desenvolvimento. Portanto, a tentativa de estabelecer vínculos simplistas entre a liberalização econômica e o crescimento foi equivocada. A verdade mais bem caracterizada nesse aspecto é que, embora a política de comércio, a liberalização do mercado de capitais e os incentivos conferidos ao mercado sejam de fato importantes, não existem regras únicas que se possam aplicar a todos os países e em qualquer época, nem a nenhum país isolado em diferentes épocas. Essa conclusão nos chega com força das análises comparativas de diversas experiências de desenvolvimento (ver, por exemplo, Helleiner, 1994). Assim, o protecionismo mostrou-se uma fonte de crescimento em certos períodos e em países específicos, mas serviu para bloqueá-lo em outros. O mesmo se pode dizer do comércio mais livre. As estratégias mistas revelaram-se as melhores em muitas situações. Assim, como têm observado Chenery e muitos outros há pelo menos duas décadas, as experiências exitosas de aumento da exportação de produtos manufaturados no mundo em desenvolvimento, a partir de meados dos anos sessenta, em geral foram precedidas por períodos de industrialização voltada para a substituição de importações, e a integração muito bem-sucedida dos países recém-industrializados [NICs] asiáticos na economia mundial emparelhou-se com uma forte intervenção do Estado (ver, por exemplo, Chenery et al., 1986). Curiosamente, Bairoch (1993) chegou a opiniões semelhantes acerca das relações entre o protecionismo e o crescimento econômico no período que antecedeu a Primeira Guerra Mundial e, aliás, enunciou a conclusão paradoxal de que os períodos de crescimento mais rápido do comércio mundial antes da guerra não foram os caracterizados pelos regimes de comércio mais liberais e, portanto, de que o crescimento econômico levou à expansão do comércio mundial, e não o inverso. 
$\mathrm{O}$ aumento e a persistência de grandes desigualdades na economia mundial tornam proveitoso pensar nela como um sistema em que as oportunidades se distribuem sem equanimidade entre o centro da economia mundial e sua periferia, idéia esta frisada por pensadores estruturalistas latino-americanos há meio século (ver, por exemplo, as contribuições clássicas de Prebisch, 1951). Na verdade, a melhor manifestação simples dessa realidade é que, a despeito de algumas mudanças, a hierarquia mundial dos níveis do PIB per capita manteve-se extraordinariamente estável ao longo dos últimos cem anos, como é demonstrado pelo fato de que cerca de $60 \%$ das atuais disparidades mundiais de renda podem ser explicados, simplesmente, pelas mesmas disparidades, tais como existiam em 1913. Isso também se reflete em outros aspectos cruciais da ordem econômica mundial: a altíssima concentração da geração de tecnologia de ponta num punhado de países, bem como a concentração igualmente elevada das finanças mundiais e das sedes de empresas multinacionais nessas mesmas nações.

As implicações principais desse fato são que, embora os fatores econômicos, sociais e institucionais nacionais obviamente tenham importância, as oportunidades econômicas são predominantemente determinadas pela posição ocupada na hierarquia mundial, o que implica que subir os degraus da escada internacional é tarefa das mais difíceis. Algumas assimetrias internacionais essenciais ajudam a explicar por que a economia internacional, na verdade, é um "campo de jogo não nivelado" (ver Parte III, adiante), o que implica que, a menos que tais assimetrias sejam sistemicamente abordadas, as desigualdades mundiais se manterão ou poderão aprofundar-se no correr do tempo.

Por sua vez, isso implica que o desenvolvimento econômico não é uma questão de atravessar "etapas" de um padrão uniforme, associado à elevação da renda per capita: ele tem a ver com lograr êxito nas transformações estruturais necessárias e nas estratégias macroeconômicas e financeiras adequadas, dentro das restrições impostas pela posição ocupada na hierarquia mundial e pelas estruturas econômicas e sociopolíticas internas, que em parte são uma função dessa posição e, em parte, são determinadas por seu próprio desenvolvimento histórico. Essa é a percepção essencial da escola estruturalista latino-americana, bem como da bibliografia sobre a "industrialização tardia” a partir de Gerschenkron (para uma reafirmação recente, ver Amsden, 2001). 


\section{Frustrações latino-americanas recentes ${ }^{2}$}

Nas últimas décadas, a América Latina foi uma grande vitrine - talvez a maior delas - da liberalização econômica. A região empreendeu com entusiasmo (com um sentido de "posse") a liberalização econômica, a partir de meados da década de 1980 (ou desde antes, em alguns países), e levou-a mais longe do que outras regiões do mundo em desenvolvimento. Portanto, as frustrações com os resultados devem ser tomadas como uma demonstração séria das fragilidades sobre as quais se erigiu o programa de liberalização.

Do lado positivo, fez-se um progresso substancial no controle da inflação. Em média (e contrariando algumas percepções muito difundidas), os déficits orçamentários também foram controlados na segunda metade da década de 1980 e, desde então, mantiveram-se moderados na maioria dos países, ainda que com uma ligeira piora desde a crise asiática. Mais importante, a região teve um claro sucesso em fomentar a exportação e se tornar um ímã para o investimento externo direto [IED]. Entre 1990 e 2002, o aumento médio anual das exportações de mercadorias correspondeu a 8,6\% em termos de volume e 9,1\% em termos de valor, índices estes que só foram suplantados pela China e pelas economias asiáticas mais animadas. Enquanto isso, o fluxo dos investimentos externos diretos para a região aumentou numa taxa sem precedentes, subindo mais de cinco vezes, se compararmos o nível recorde de 1999 com a média do período de 1990-1994; entretanto, esse fluxo experimentou um declínio significativo a partir de 2000.

A integração na economia mundial seguiu três padrões básicos. No primeiro, exibido primordialmente pelo México, mas também por algumas nações da América Central e do Caribe, os países ingressaram nos fluxos verticais de comércio de produtos manufaturados que são característicos dos sistemas de produção internacionalmente integrados, concentrando suas exportações no mercado norte-americano. No segundo, típico da América do Sul, os países integraram-se na produção e nas redes de comercialização globais horizontais, sobretudo de matériasprimas e produtos baseados em recursos naturais. Esse grupo também se caracterizou por um comércio intra-regional sumamente diversifica-

\footnotetext{
${ }^{2}$ Para uma análise extensa dessas questões, ver CEPAL (2000, 2001a, 2001b, 2002a e 2002b). Para uma análise similar com respeito aos países em desenvolvimento como um todo, ver UNCTAD (1997, 1999 and 2002).
} 
do e por uma concentração menor nos mercados-alvo. O terceiro padrão baseou-se na exportação de serviços, especialmente para o turismo, mas também em serviços financeiros e de transporte, e constitui o padrão predominante em alguns países do Caribe e no Panamá.

Entretanto, o sucesso da região no aumento de sua fatia dos mercados mundiais e na atração do IED não se refletiu num crescimento rápido do PIB. Na verdade, a taxa média de crescimento anual de 19902002 , equivalente a $2,6 \%$, correspondeu a menos da metade da taxa recorde do período de $1945-1980$, caracterizado pela industrialização impulsionada pelo Estado ${ }^{3}$ (5,5\% ao ano). Embora haja muitas razões em particular, as grandes mudanças havidas na economia mundial pelas quais seria um grave erro retomar as políticas típicas desse período histórico anterior, fica claro que o ônus da prova recai agora sobre aqueles que o caracterizaram como um grande fracasso histórico, e que caracterizam a liberalização como a chave do crescimento rápido. Tomando por pano de fundo a década perdida de 1980, isso significa que a América Latina completou quase um quarto de século em que seus níveis de renda distanciaram-se dos medidos nos países industrializados. Segundo as estimativas de Maddison, os níveis de renda latino-americanos oscilaram em torno de $28 \%$ da renda per capita dos Estados Unidos no período de 1870 a 1973, caíram para 22\% em 1998 e, com o declínio adicional ocorrido desde então, situam-se agora em $20 \%$.

Um grande concomitante desse resultado é a deterioração estrutural da contrapartida entre crescimento e balança comercial, ou, o que é equivalente, o enfraquecimento do elo entre o aumento do PIB e as transferências de recursos para o exterior. A Figura 2 indica que esse elo já estava enfraquecido na década de 1970, comparada às de 1950 e 1960 (o crescimento dinâmico só continuou com base num déficit mais alto na balança comercial e num aumento das transferências de recursos). Ele se deteriorou ainda mais no período de 1990-1997, em relação à década de 1970 (obteve-se um crescimento muito menor, com déficits comerciais e transferências de recursos similares), e tornou a piorar no período de 1998-2002. Isso reflete uma série de tendências adversas na estrutura produtiva: (a) a diminuição das indústrias de substituição de importações, não contrabalançada por uma aceleração do crescimento

\footnotetext{
${ }^{3}$ Essa expressão é preferível ao conceito usual de industrialização pela substituição de importações, pelas razões explicadas em Cárdenas, Ocampo e Thorp (2000).
} 
das exportações; (b) a demanda elevada de capital importado e produtos intermediários (um dos traços dos sistemas de produção internacionalmente integrados) que caracteriza as atividades dinâmicas, o que, ao lado do fator precedente, reduziu os vínculos da produção; e (c) o enfraquecimento dos sistemas de inovação nacionais herdados do estágio anterior de desenvolvimento, uma vez que as funções de engenharia e a pesquisa e desenvolvimento (P\&D), que costumavam ser realizadas por firmas locais, estão sendo transferidas para fora da região. Uma tendência inversa foi o rápido crescimento da conectividade, embora sua contrapartida tenham sido os crescentes "divisores digitais internos", que refletem o acesso muito desigual das diferentes empresas e setores sociais às novas tecnologias.

Figura 2:

Transferências líquidas de recursos, déficit na balança comercial e crescimento do PIB

Figure 2

NET RESOURCE TRANSFERS, TRADE DEFICIT AND GDP GROWTH

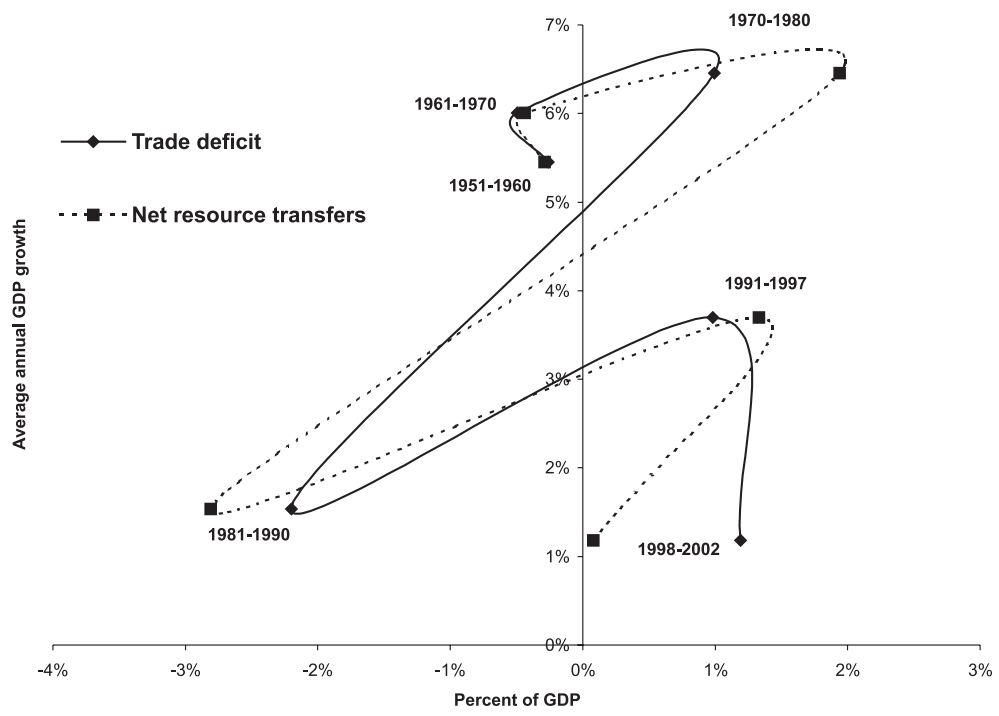


Como resultado desses fatores, o efeito multiplicador e as externalidades tecnológicas geradas pelas atividades em rápido crescimento, associadas às exportações e ao IED, mostraram-se fracos. Além disso, o dualismo (ou heterogeneidade estrutural) característico das estruturas produtivas da América Latina tornou-se ainda mais acentuado: existem hoje muito mais empresas "de categoria internacional", a maioria das quais compõe-se de filiais de empresas transnacionais, porém, ao mesmo tempo, uma parcela crescente do emprego vem-se concentrado nas atividades de baixa produtividade do setor informal, que responde por sete em cada dez novos empregos criados nas áreas urbanas latino-americanas na última década. Num sentido muito importante, as novas atividades dinâmicas são "enclaves" de redes de produção globalizada, incapazes de induzir a um rápido crescimento geral da economia.

A deterioração estrutural da permuta crescimento/balança comercial gerou uma intensa sensibilidade ao financiamento estrangeiro, que foi favorecido pela abertura financeira, pelos sistemas financeiros internos pró-cíclicos e por políticas macroeconômicas igualmente pró-cíclicas. Nos termos de Stiglitz (2002b), o processo de reforma substituiu os estabilizadores automáticos por desestabilizadores automáticos. Como resultado, o crescimento econômico tornou-se cada vez mais sensível à volatilidade da conta de capitais. A recuperação do crescimento econômico do início da década de 1990 associou-se à renovação das transferências líquidas de recursos, mas foi interrompida em três ocasiões, em menos de uma década $(1995,1998$ 1999 e 2001-2002). Grosso modo, um período de crescimento econômico razoável em 1990-1997 - 3,7\% ao ano (significativamente abaixo do recorde de 1945-1980, de qualquer modo) - foi seguido pela "meia década perdida" de 1998-2002, em decorrência da contração significativa dos fluxos de capital desde a crise asiática. A partir de 1998, o PIB per capita contraiu-se na América Latina em geral e em metade dos países da região. Além disso, todos os casos de crescimento rápido foram interrompidos, inclusive os do Chile e da República Dominicana, as duas economias mais dinâmicas da América Latina na década de 1990.

$\mathrm{O}$ crescimento econômico lento e volátil e os padrões estruturais adversos refletiram-se em mercados de trabalho precários. A geração de empregos foi particularmente minguada na América do Sul, refletindo seus padrões de especialização intensivos em recursos naturais. 
A informalidade crescente, que amplia as defasagens de renda entre o trabalho qualificado e o não qualificado, e o dualismo crescente das estruturas produtivas, como já indicamos, são tendências mais gerais da região. Um grande reflexo disso é que o elo entre pobreza e desenvolvimento econômico sofreu uma deterioração estrutural na década de 1990, como indica a Figura 3. Com isso, os níveis de pobreza continuaram significativamente mais altos em 1997 do que em 1980, apesar de já ter sido revertido o declínio do PIB per capita que caracterizou os anos oitenta. Com o declínio adicional da renda média per capita na recente "meia década perdida", os índices de pobreza estagnaram ou aumentaram. Por sua vez, essa deterioração do elo entre pobreza e crescimento reflete o fato de que cerca de metade dos países da região experimentou uma deterioração da distribuição de renda durante os anos noventa, com um único caso (o do Uruguai) em que se observou o padrão inverso (CEPAL, 2001b).

\begin{tabular}{|l|r|r|r|r|r|r|}
\hline PIB & $\mathbf{5 , 4 5 \%}$ & $\mathbf{6 , 0 1} \%$ & $\mathbf{6 , 4 6 \%}$ & $\mathbf{1 , 5 4 \%}$ & $\mathbf{3 , 7 0 \%}$ & $\mathbf{1 , 1 8 \%}$ \\
\hline BC & $-0,26 \%$ & $-0,49 \%$ & $0,99 \%$ & $-2,20 \%$ & $0,98 \%$ & $1,19 \%$ \\
\hline TNR & $-0,29 \%$ & $-0,44 \%$ & $1,94 \%$ & $-2,81 \%$ & $1,33 \%$ & $0,08 \%$ \\
\hline
\end{tabular}

\begin{tabular}{|l|r|r|r|r|r|r|}
\cline { 2 - 7 } \multicolumn{1}{c|}{} & 1980 & 1990 & 1994 & 1997 & 1999 & 2001 \\
\hline PIB per capita & 3564,932 & 3287,7 & 3593,8 & 3770,7 & 3740,5 & 3784,2 \\
\hline Pobreza & 40,5 & 48,3 & 45,7 & 43,5 & 43,8 & 43 \\
\hline
\end{tabular}


Figura 3:

Pobreza e PIB per capita

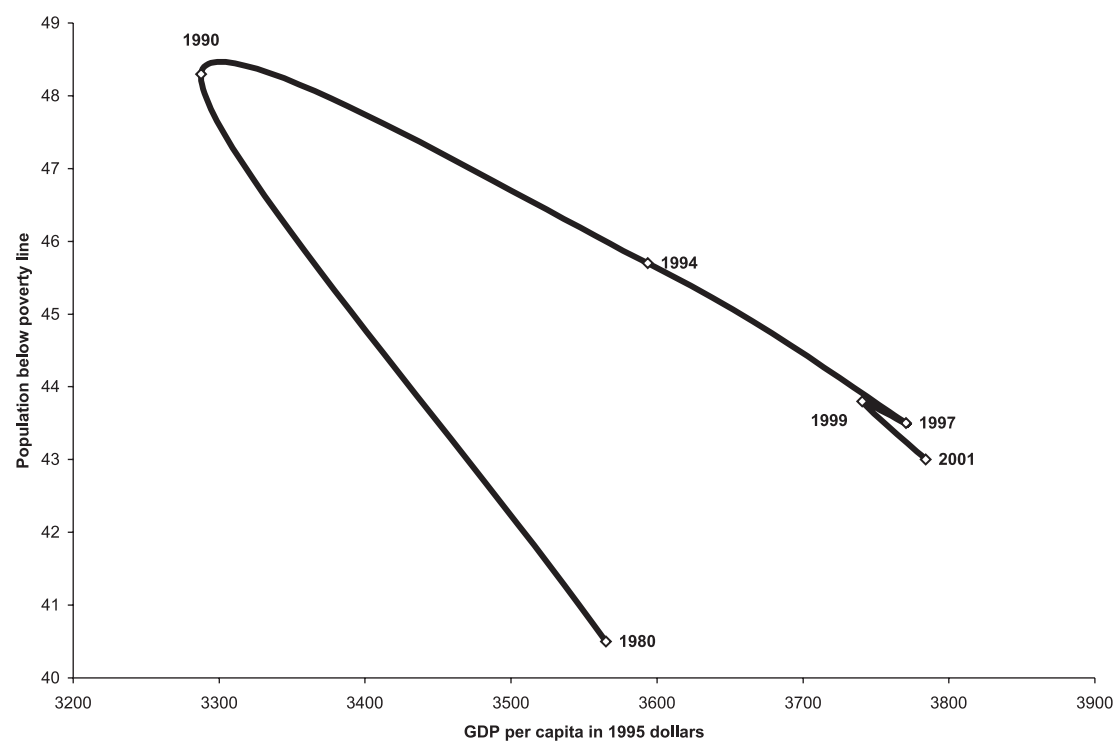

Essas tendências adversas, estreitamente associadas aos padrões de transformação estrutural, destruíram os efeitos positivos do aumento dos gastos sociais, que subiram de uma média de $10,4 \%$ para $13,1 \%$ do PIB ao longo da década de 1990 - sem dúvida, uma grande recompensa pelo retorno generalizado da região à democracia. Elas também destruíram algumas inovações de grande porte na política social, particularmente a melhora na escolha dos objetivos. O progresso contínuo para o ensino primário universal foi acompanhado por um alcance maior do ensino secundário (atingindo uma média de 70\% nos últimos anos). A despeito desse progresso, no entanto, ampliou-se a defasagem educacional - em termos da abrangência do ensino secundário e superior e das realizações educacionais - que separa a América Latina das economias desenvolvidas e das economias emergentes da Ásia. Numa tendência igualmente inquietante, a defasagem no alcance do ensino secundário e superior que separa os grupos de alta renda dos de baixa renda tendeu a se ampliar em muitos países. 
Os sistemas de seguridade social e as redes de segurança social da região tiveram que se haver com os problemas criados pela cobertura segmentada e insuficiente dos sistemas desenvolvidos no passado, bem como com a demanda gerada pelo envelhecimento da população e pela instabilidade salarial e empregatícia associada aos padrões de desenvolvimento recentes. Assim, os níveis aumentados de riscos macro e microeconômicos traduziram-se em riscos sociais maiores e em mais demandas de proteção por parte de sistemas subdesenvolvidos de proteção social. Em diversos casos, além disso, os princípios de universalidade e solidariedade que devem caracterizar os sistemas de proteção social foram postos de lado nas reformas da seguridade social. Aliado às tendências adversas do mercado de trabalho, isso se refletiu na frustração do avanço no custeio desses sistemas.

\section{Uma ordem global melhor}

\section{Três objetivos essenciais da cooperação internacional}

Uma lição essencial da história é que a resistência a qualquer processo tão poderoso quanto a atual globalização acaba fracassando. Mas isso não significa que as tendências atuais possam ser entendidas como realidades imutáveis. Embora haja imperiosos processos tecnológicos e econômicos subjacentes a ela, a globalização pode ser moldada e, a rigor, a forma que vem assumindo foi predominantemente moldada por decisões políticas explícitas.

As deficiências exibidas pelo atual processo de globalização demonstram a necessidade de trabalharmos em direção a três objetivos fundamentais (CEPAL, 2002a):

- garantir uma oferta satisfatória de bens públicos globais;

- construir um sistema mundial baseado nos direitos humanos, isto é, uma cidadania global; e

- superar gradualmente as assimetrias que caracterizam o sistema econômico mundial.

O primeiro desses objetivos enfatiza a administração da interdependência entre as nações. Os dois seguintes concentram-se na eqüidade em suas duas dimensões: cidadãos melhores e relação entre as nações. Depois de alguns comentários sobre os dois primeiros, discorreremos mais detidamente sobre o terceiro, que desempenha o papel essencial de garantir um desenvolvimento econômico equânime no nível mundial. 
$\mathrm{Na}$ literatura recente, o conceito de bens públicos globais tem sido entendido num sentido lato, que vai além da definição tradicional da economia do bem-estar - bens que não podem ser excluídos e não são rivais no consumo, ou "bens públicos puros" - e passa a incluir bens e serviços com grandes externalidades, mas cujos benefícios podem ser apropriados em caráter privado, e bens comuns globais (que são rivais no consumo). Nesse sentido lato, o conceito inclui, entre outras coisas, a paz e a justiça internacionais, o conhecimento humano, a diversidade cultural, a luta contra as pandemias internacionais, a sustentabilidade do meio ambiente, a regulamentação do uso dos bens comuns globais, normas para regular as transações econômicas internacionais e a estabilidade macroeconômica e financeira mundial. O que é preciso enfatizar nesse aspecto é a imensa defasagem entre o reconhecimento da importância crescente da interdependência, e portanto, dos bens públicos globais, e a precariedade das estruturas internacionais existentes - tomada de decisões, financiamento e administração - que garantem que eles sejam adequadamente fornecidos (Kaul, Grunberg e Stern, 1999; Kaul et al., 2002).

Por outro lado, construir a cidadania global numa comunidade internacional heterogênea implica o respeito pelos direitos humanos básicos e pela diversidade cultural, assim conciliando o princípio da igualdade com o "direito de ser diferente". Nessa visão, os poderes civis e políticos foram um todo indivisível e interdependente com os direitos econômicos, sociais e culturais. Reconhece-se, no entanto, que o exercício dos direitos econômicos e sociais não é automático e que, por conseguinte, sua implementação progressiva exigirá um esforço resoluto. Isso acarreta, necessariamente, um processo político que leve à formação de pactos sociais e fiscais nacionais - embora cada vez mais globais -, nos quais o acesso aos bens e serviços que garantem os direitos econômicos e sociais resulte de uma decisão política concernente à alocação dos recursos.

Mas a defesa desses direitos continua a ser uma responsabilidade essencialmente nacional. Por conseguinte, a imposição de direitos econômicos, sociais e culturais precisa deslocar-se aos poucos das avaliações nacionais para uma implementação política definida com muito mais clareza no âmbito dos foros internacionais e, o que é de suprema importância, para foros nacionais representativos, nos quais o cumprimento dos compromissos por parte dos países seja discutido. Essa imposição política poderá, em certas condições, levar gradativamente a uma imposição jurídica, no contexto das cortes nacionais e internacio- 
nais correspondentes - passo que, até agora, só foi dado pela União Européia. Os compromissos assumidos e sua possibilidade de implementação devem ser proporcionais, em todas as situações, ao nível de desenvolvimento de cada país, a fim de prevenir o surgimento do voluntarismo e do populismo. Dadas as gritantes desigualdades que caracterizam a ordem global, um componente central da expressão material desses direitos é o cumprimento dos compromissos de assistência oficial ao desenvolvimento (AOD) assumidos no contexto da ONU. A longo prazo, isso deverá levar à criação de um verdadeiro "fundo global de coesão social" que facilite o exercício dos direitos econômicos e sociais dos membros mais pobres da comunidade internacional.

O terceiro objetivo implica que, assim como a ação redistributiva do Estado é indispensável no nível nacional, para assegurar a igualdade de oportunidades, os esforços nacionais só podem ter pleno sucesso no nível global se forem complementados por uma cooperação internacional projetada para superar, gradativamente, as assimetrias básicas da ordem global, que estão na raiz das profundas desigualdades internacionais na distribuição de renda.

Essas assimetrias enquadram-se em três categorias básicas. A primeira está associada à maior vulnerabilidade macroeconômica dos países em desenvolvimento aos choques externos, o que também pressiona os limitadíssimos recursos desses países para lidar com tais impactos. $\mathrm{O}$ efeito final dessa situação é que, enquanto os países industrializados têm maior espaço de manobra para adotar políticas anticíclicas e provocar uma resposta estabilizadora dos mercados financeiros, as economias em desenvolvimento quase não têm essa margem de manobra, já que os mercados financeiros tendem a acentuar as variações cíclicas e os agentes do mercado esperam que as autoridades nacionais também se comportem pró-ciclicamente.

O segundo tipo de assimetria é a concentração extrema do progresso técnico nos países desenvolvidos. A disseminação do progresso técnico dos países de origem para o resto do mundo continua a ser "lenta e irregular", seguindo o veredicto qüinquagenário de Prebisch (Prebisch, 1951). Isso reflete os custos proibitivos do ingresso em atividades tecnológicas dinâmicas e até as restrições enfrentadas pelos países em desenvolvimento para entrar em setores maduros, nos quais as oportunidades para tais países restringem-se, predominantemente, a atrair empresas multinacionais que já estejam estabelecidas nesses setores. Por sua vez, a transferência de tecnologia fica sujeita ao pagamento de 
royalties pelas inovações, as quais têm recebido uma proteção cada vez maior da difusão dos direitos de propriedade intelectual. O efeito conjunto de todos esses fatores explica por que, no nível mundial, a estrutura produtiva continua a exibir um alto grau de concentração do progresso técnico nos países industrializados, que com isso mantêm sua posição predominante nos ramos do comércio internacional que crescem com mais rapidez, bem como sua hegemonia na formação de grandes empresas transnacionais.

Uma terceira assimetria está associada ao contraste entre o alto grau da mobilidade do capital e a mobilidade internacional limitada da mãode-obra, especialmente entre os trabalhadores pouco qualificados. Essa assimetria é um aspecto característico do estágio atual da globalização, uma vez que não era observada no século XIX e no início do século XX (quando todos os fatores de produção eram altamente móveis), nem tampouco no primeiro quarto de século posterior à Segunda Guerra Mundial (quando todos tinham uma mobilidade restrita). Esse componente é essencial, visto que a assimetria na mobilidade dos fatores de produção tem um impacto regressivo, pois funciona beneficiando os fatores de produção com maior mobilidade - o capital e a mão-de-obra especializada -, em detrimento de outros menos móveis, como o trabalho não qualificado (Rodrik, 1997).

Em virtude da marcante tendência para a desigualdade gerada pelas assimetrias internacionais, "nivelar o campo de jogo" através de dispositivos regulatórios é uma diretriz imprópria para a reforma internacional. As tentativas de aplicar medidas idênticas a situações diversas só podem servir para acentuar as desigualdades já existentes. Assim, o princípio das "responsabilidades comuns, mas diferenciadas", consagrado na Declaração do Rio sobre Meio Ambiente e Desenvolvimento, assim como o princípio do "tratamento especial e diferenciado", incorporado na agenda comercial, são normas mais apropriadas para construir uma ordem global mais equitativa do que o "nivelamento do campo de jogo", que tem norteado os esforços de reforma da ordem econômica internacional nos últimos anos.

Esta análise estabelece alguns fatores essenciais da reforma internacional no tocante aos países em desenvolvimento. Corrigir a primeira dessas assimetrias implica que se deve adotar uma abordagem abrangente para reduzir a segmentação e a volatilidade do acesso dos países em desenvolvimento aos mercados financeiros internacionais, bem como para lhes proporcionar mais espaço de manobra para a adoção de políti- 
cas macroeconômicas anticíclicas. Corrigir a segunda implica que o sistema de comércio deve facilitar a transferência tranqüila da produção de matérias-primas, de indústrias tecnológicas maduras e de serviços padronizados para os países em desenvolvimento. Essa correção deve também acelerar o acesso dos países em desenvolvimento à tecnologia (assim evitando, através da proteção exagerada dos direitos de propriedade intelectual, a elevação de seu custo ou a limitação excessiva das modalidades pelas quais a transferência se realiza), bem como garantir a participação crescente dos países em desenvolvimento na geração de tecnologia e nos ramos da produção com tecnologia mais alta. Para facilitar esses processos, o sistema de comércio deve dar espaço suficiente para a adoção de estratégias produtivas nacionais atuantes nos países em desenvolvimento (ver adiante). Por último, superar a terceira assimetria implica que a migração da mão-de-obra deve ser plenamente incluída na agenda internacional, através de um acordo global sobre a política de migração e de acordos regionais e sub-regionais, devendo-se adotar também um mecanismo complementar que facilite a migração (como o reconhecimento das realizações educacionais e a possibilidade de transferência de pensões e outros benefícios da seguridade social).

\section{Melhores estruturas de governabilidade}

$\mathrm{Na}$ falta de instituições adequadas que garantam a capacidade de a ordem internacional assegurar esses três objetivos, a globalização temse revelado uma força sumamente desintegradora no nível internacional, bem como um fator conducente ao desgaste da coesão social no plano nacional. Isso impõe enormes exigências à governança, em todos os seus níveis. Há hoje um amplo consenso quanto ao papel decisivo desempenhado pelas estratégias e pela governança nacionais na determinação do sucesso obtenível por um país no estabelecimento de vínculos sólidos com a comunidade internacional. Entretanto, sem uma estrutura internacional adequada, a oferta insuficiente de bens públicos globais e as forças geradoras de desigualdade produzidas pelas assimetrias internacionais prejudicarão o desenvolvimento nacional.

Isso implica que o esforço de construir instituições fortes para uma ordem global melhor deve basear-se numa rede de instituições mundiais, regionais e nacionais, em vez de se limitar a uma ou algumas instituições internacionais. A ação nos níveis regional e sub-regional desempenha um papel de peso como intermediária entre as ordens global 
e nacional, por quatro grandes razões: a complementaridade entre as instituições globais e regionais numa comunidade internacional heterogênea; o tamanho desigual dos atores envolvidos nos processos globais, que significa que a voz dos países se fará ouvir melhor se for expressa como uma voz regional; o maior sentimento de posse das instituições regionais e sub-regionais; e o fato de que, em algumas áreas (como na política macroeconômica e regulatória), o alcance da autonomia eficaz da política econômica deslocou-se da arena nacional para os níveis subregional ou regional. Portanto, um sistema que se baseie em redes de instituições globais e regionais será não apenas mais eficiente, como também mais equilibrado em termos das relações de poder.

O papel crucial desempenhado pelas instituições regionais tem um significado importante na América Latina, que progrediu mais em termos da integração regional do que as outras regiões do mundo em desenvolvimento. Não obstante, essa integração esteve sujeita a fortes tensões nos últimos anos, as quais só podem ser solucionadas por uma renovação do compromisso político com a integração e um aprofundamento dos atuais processos integradores. Isso significa que, além da liberalização do comércio e da criação de regras comuns para ele, há uma demanda acentuada de cooperação macroeconômica e financeira, harmonização dos regimes regulatórios, complementação da infra-estrutura física, defesa dos bens comuns da região e um avanço gradativo na integração social e política.

Em última instância, todavia, as instituições internacionais continuariam a depender das responsabilidades e políticas nacionais, o que é uma característica essencial de um sistema internacional em que os processos políticos continuam a se alicerçar em Estados nacionais. Um corolário fundamental disso é que as instituições globais devem ser firmemente respeitadoras da diversidade. Ademais, esse é o único sistema compatível com a promoção da democracia no nível mundial. Aliás, promover a democracia como valor universal implica assegurar que os processos nacionais que proporcionam representação e participação possam influir na definição das estratégias de desenvolvimento econômico e social, bem como intermediar as tensões inerentes ao processo de globalização. Esse princípio está incorporado no pensamento mais recente sobre a cooperação para o desenvolvimento, que enfatiza que sua eficácia dependerá de uma vigorosa política nacional de "posse" dos compromissos assumidos pelos países em desenvolvimento. 
Convém recordar, nesse aspecto, que o multilateralismo que obteve êxito nos termos de Bretton Woods baseou-se, precisamente, numa mescla criteriosa de regras e de cooperação internacionais, que proporcionou graus suficientes de liberdade às autoridades nacionais para que elas perseguissem suas metas de crescimento e desenvolvimento. Essa política baseou-se em autoridades nacionais fortes e eficientes, e não nas fracas. Vista por esse prisma, a mescla atual de acordos internacionais incompletos e enfraquecimento da eficiência da política nacional afigura-se a mais imprópria de todas as misturas possíveis.

Por fim, as medidas adotadas para reestruturar a ordem internacional também devem assegurar a participação dos países em desenvolvimento em bases eqüitativas, assim como a adoção de regras de governança adequadas. A consecução desse objetivo exigirá uma discriminação positiva, por parte da comunidade internacional, para respaldar os países pequenos e pobres, além de exigir um esforço desses países no sentido de se organizarem no âmbito de instituições regionais e sub-regionais. Outra implicação desse princípio é que se deve dar preferência aos arranjos institucionais que tenham o maior número possível de participantes ativos. Por último, a adoção de regras apropriadas de governança é outro componente essencial para garantir os direitos básicos dos países em desenvolvimento - sobretudo os menores - na ordem institucional, institucionalizando a responsabilidade e fortalecendo as funções de auditoria exercidas por instituições que desfrutem de credibilidade junto a todos os atores pertinentes. Essa abordagem envolve a imposição de limites aos países de maior influência nas instituições internacionais, o que não funciona necessariamente em detrimento deles, já que também levará a um maior compromisso dos países em desenvolvimento com a ordem institucional global.

\section{Estratégias nacionais para lidar com a globalização}

Qualquer estratégia nacional de desenvolvimento, na era global, deve alicerçar-se em sólidos pactos sociais que assegurem a estabilidade política, em sistemas e práticas legais não arbitrários, que garantam a segurança dos contratos, e numa burocracia de Estado imparcial e relativamente eficiente. Esses requisitos institucionais genéricos, que têm sido corretamente enfatizados na bibliografia recente, são componentes essenciais de um ambiente adequado de investimento e, como tais, podem ser vistos como condições necessárias do crescimento. Todavia, nenhum 
deles responde pelas forças específicas que impulsionam o crescimento econômico, nem fornece meios para lidar com as velhas e novas formas de vulnerabilidade. Assim, as estratégias adotadas pelos países em desenvolvimento devem incorporar pelo menos quatro componentes adicionais: políticas macroeconômicas destinadas a reduzir a vulnerabilidade externa e facilitar o investimento produtivo; estratégias de desenvolvimento produtivo atuantes, que visem a criar uma competitividade sistêmica; uma política social sumamente atuante, em especial nos campos da educação, emprego e proteção social; e instituições específicas que gerem um equilíbrio apropriado entre os interesses públicos e privados. Não há modelos universalmente válidos em nenhuma dessas áreas e, por conseguinte, há muito espaço para a aprendizagem institucional e, o que é mais importante, para o exercício da democracia.

\section{Visão geral da estabilidade macroeconômica e do papel das políticas anticíclicas}

A coerência que deve caracterizar as medidas políticas macroeconômicas precisa basear-se numa definição ampla da estabilidade, que reconheça a inexistência de uma correlação isolada entre suas dimensões alternativas e, portanto, reconheça que pode haver concessões compensatórias significativas. Duas lições são particularmente importantes nesse aspecto. A primeira é que a instabilidade real custa caro. As recessões acarretam perdas significativas de recursos, as quais podem ter efeitos duradouros: as empresas podem sofrer prejuízos irreparáveis em bens tangíveis e intangíveis, enquanto o capital humano dos desempregados ou subempregados pode perder-se em caráter permanente. Por sua vez, a incerteza associada à variabilidade das taxas de crescimento incentiva as estratégias microeconômicas "defensivas", em vez das estratégias "ofensivas" que levam a altas taxas de investimento e a rápidas mudanças tecnológicas. $\mathrm{O}$ crescimento volátil conduz a um alto índice médio de subutilização da capacidade produtiva, reduzindo a produtividade e o lucro e afetando adversamente o investimento, o que afeta o crescimento a longo prazo (French-Davis, 2000).

A segunda lição é que os déficits privados são tão dispendiosos quanto os do setor público e que os balanços arriscados podem ser tão nocivos quanto os desequilíbrios de fluxo. Quando as crises levam a colapsos financeiros, os custos associados são extremamente altos. As perdas de ativos podem destruir anos de acumulação de capital. A socialização dos prejuízos pode ser a 
única maneira de evitar uma crise sistêmica, mas afeta o futuro desempenho fiscal (ou quase fiscal). Restabelecer a confiança no sistema financeiro leva tempo, e o próprio setor financeiro torna-se avesso ao risco, o que solapa sua capacidade de exercer suas funções econômicas primárias.

Essas duas lições acham-se basicamente interligadas, já que os ciclos de crescimento e declínio financeiros tornaram-se a fonte predominante dos ciclos comerciais do mundo em desenvolvimento, sobretudo nas economias emergentes. A tarefa essencial da política macroeconômica, portanto, é administrá-los com instrumentos anticíclicos apropriados. Em particular, gerir a volatilidade exige uma combinação de três pacotes políticos cuja importância relativa varia de acordo com as características estruturais e a tradição de política macroeconômica de cada país. O primeiro deles compõe-se de medidas macroeconômicas coerentes e flexíveis, destinadas a impedir que os agentes públicos ou privados acumulem níveis excessivos de endividamento e a prevenir desequilíbrios nos preços macroeconômicos essenciais. O segundo é um sistema de regulamentação e supervisão prudenciais rigorosas, que devem acentuar-se nos períodos de euforia financeira, a fim de contrabalançar os riscos crescentes em que incorrem os intermediários financeiros. $\mathrm{O}$ terceiro compõe-se de políticas concernentes ao passivo, que visam assegurar a manutenção de perfis adequados de vencimento com respeito às obrigações públicas e privadas, nos âmbitos interno e externo (Ocampo, 2002).

Administrar medidas macroeconômicas anticíclicas não é tarefa simples, uma vez que os mercados financeiros geram grandes incentivos para que os países em desenvolvimento exagerem nos gastos durante os períodos de euforia financeira e façam ajustes excessivos durante as crises. Além disso, a globalização impõe limites objetivos à autonomia nacional e cobra um preço elevado por qualquer perda de credibilidade, quando os instrumentos da política nacional são mal administrados. Por essa razão, torna-se necessário confiar em instituições e instrumentos políticos que ajudem a dar credibilidade, inclusive fundos de estabilização fiscal e bancos centrais independentes. No entanto, a renúncia explícita à autonomia política (por exemplo, através da adoção direta de uma moeda estrangeira) não chega a constituir uma solução para esse dilema. Os acontecimentos recentes não deixam dúvida quanto ao fato de que a credibilidade das autoridades macroeconômicas pode ser fortalecida com mais eficácia pela flexibilidade, administrada com prudência, do que pela adoção de regras excessivamente rígidas. 
A longo prazo, o crescimento econômico depende de uma combinação de sistemas tributários sólidos, que proporcionem os recursos necessários para que o setor público cumpra sua tarefa, de uma taxa de câmbio competitiva e de taxas de juros reais moderadas e mercados financeiros fortes. A política macroeconômica deve concentrar-se em garantir os três primeiros elementos. $\mathrm{O}$ objetivo do fortalecimento financeiro é proporcionar o financiamento de investimentos com preço adequado e prazos de vencimento suficientemente longos. A liberalização dos sistemas financeiros na América Latina não fortaleceu os mercados financeiros nem reduziu tanto quanto se esperava os elevados custos regionais de intermediação. Conseqüentemente, o setor público continua a ter um papel importante a desempenhar no fornecimento de serviços financeiros e na promoção do surgimento de novos agentes e segmentos nos mercados de capital. Enquanto isso, os esforços para aumentar a poupança do setor público, a criação de incentivos à poupança empresarial e mecanismos especiais para estimular a poupança interna (em especial para a aposentadoria) podem ser meios úteis de elevar as taxas nacionais de poupança.

\section{As medidas políticas macroeconômicas não bastam: o papel das estratégias de desenvolvimento produtivo}

Até o momento, não se confirmou a idéia de que a combinação de economias abertas e macroeconomia estável - no sentido restrito em

que essa expressão passou a ser usada, isto é, designando equilíbrio fiscal e inflação baixa - seria suficiente para promover o rápido crescimento econômico. Isso desencadeou um debate ainda não resolvido acerca das razões que estão por trás desse resultado. A interpretação ortodoxa é que os mercados não foram suficientemente liberalizados. Tal visão é desmentida pelos episódios mais prolongados de crescimento rápido no mundo em desenvolvimento (isto é, os "milagres" do Leste Asiático ou, mais recentemente, da China e da Índia, ou ainda, no passado, os períodos de crescimento rápido do Brasil ou do México), todos os quais envolveram uma mistura de "heresias locais" com prescrições políticas mais ortodoxas (Rodrik, 1999; Amsden, 2001). As interpretações alternativas enfatizam o papel das falhas do mercado, particularmente no funcionamento dos mercados de capital e de tecnologia, como explicação do crescimento lento. Também essa linha de raciocínio precisa explicar por que, no passado, foi possível um crescimento rápido 
em muitos países em desenvolvimento que enfrentavam limitações dessa natureza.

Uma linha de raciocínio mais promissora recorre às diferentes variantes históricas do estruturalismo no pensamento econômico. Essa visão enfatiza que o crescimento econômico envolve uma transformação constante das estruturas de produção. Trata-se de um processo que não resulta automaticamente de um bom desempenho macroeconômico nem ocorre de maneira automática e harmoniosa, uma vez que a expansão de novos setores implica a acumulação de capacidade tecnológica e a criação de conjuntos complementares de atividades e redes comerciais, todos os quais envolvem um processo de aprendizagem e custos de coordenação (Chang, 1996; Ocampo, 2001). A transformação das estruturas produtivas, portanto, deve ser uma prioridade explícita de qualquer estratégia de desenvolvimento. Seu objetivo central, num meio aberto como o que caracteriza as economias latino-americanas de hoje, deve ser a criação de uma competitividade sistêmica, baseada em três pilares fundamentais: a criação de sistemas de inovação para acelerar a acumulação de capacidade tecnológica; o respaldo a novas atividades produtivas e à formação de vínculos na produção; e a oferta de serviços infraestruturais de alta qualidade. O papel dos mercados financeiros fortes já foi enfatizado como um complemento essencial a um ambiente macroeconômico apropriado.

Essa interpretação destaca um aspecto central das experiências de desenvolvimento bem-sucedidas no passado: o vigoroso impulso de industrialização baseado em sólidas parcerias entre o Estado e o setor empresarial. Do lado oposto, a experiência recente da América Latina e de outras regiões do mundo em desenvolvimento indica que a abertura dos mercados com incentivos "neutros", as relações distantes entre o governo e as empresas e as restrições multilaterais (Rodada do Uruguai) a instrumentos tradicionais do desenvolvimento não fornecem um substituto adequado para as estratégias ativas de desenvolvimento produtivo.

Dado o papel fundamental do conhecimento, qualquer dessas estratégias deve basear-se num maior investimento público e privado na educação, na formação profissionalizante e administrativa e na ciência e tecnologia. Essa estratégia deve ser implementada através de muitas formas diferentes de colaboração entre o Estado e o setor privado, todas as quais devem concentrar-se na criação de sistemas dinâmicos de inovação. Em vista da importância intrínseca e da natureza entrelaçada das novas tecnologias de informática e comunicação, os esforços para pro- 
mover sua utilização ativa são de importância vital nos sistemas contemporâneos de inovação.

Considerando-se as condições vigentes na América Latina, a estratégia para diversificar a produção tem três prioridades claras: (a) diversificação das exportações e de seus mercados de destino, o que requer uma diplomacia comercial muito atuante e o desenvolvimento de uma infra-estrutura de serviços competitiva e de alta qualidade, a fim de respaldar as atividades de exportação nas áreas de finanças, seguros, promoção e certificação; "políticas de vinculação" especificamente destinadas a ampliar os vínculos entre a produção interna e as atividades voltadas para o mercado internacional, ou nas quais o investimento externo direto seja um fator fundamental; e (c) apoio à formação de clusters, em resposta ao dinamismo crescente das esferas locais da atividade econômica e à necessidade de integrar pequenas e médias empresas na produção para o mercado internacional. Dados os processos acentuados de "destruição criativa" que caracterizam as economias modernas, essas medidas devem ser acompanhadas por uma política explícita que vise a reestruturar as atividades não competitivas.

O outro elemento nuclear da competitividade sistêmica é o oferecimento de serviços de infra-estrutura de alta qualidade. Em diversos países, várias parcerias entre o setor público e o privado lograram obter um progresso significativo nesse aspecto, particularmente nas telecomunicações, nos serviços portuários e no transporte marítimo, e - em menor grau e com diferenças maiores entre os países - nos serviços de energia (eletricidade e gás). Nessa área, as prioridades consistem em promover melhorias substanciais na infra-estrutura de transportes terrestres, preencher as lacunas de regulamentação na prestação dos serviços correspondentes, e aumentar a eficiência das empresas estatais nas áreas em que o Estado continua a fornecer esses serviços diretamente.

A incorporação eficaz do projeto de desenvolvimento sustentável impõe outras exigências às atuais estratégias de produção e, em particular, à mobilização do investimento em setores dinâmicos da produção, que utilizem métodos e tecnologias de produção limpos, nos quais se chega à competitividade através da acumulação de capital no sentido amplo do termo (isto é, capital humano, social, físico e natural). A criação de mercados para os serviços ligados ao meio ambiente é a idéia mais promissora nesse campo, uma vez que gera, simultaneamente, os incentivos econômicos e o financiamento necessários à adoção das novas tecnologias. 
Progredir em todas essas frentes requer parcerias inovadoras entre o setor público e o privado, com base numa visão estratégica comum. Um processo ativo de aprendizagem geraria, necessariamente, misturas variadas de envolvimento dos setores privado e público e de instrumentos horizontais e seletivos. Seja como for, esses instrumentos devem incluir uma vinculação clara entre os incentivos e os resultados.

\section{Melhora dos vínculos sociais}

Podemos pensar no progresso social como o resultado de três fatores fundamentais: uma política social de longo prazo, que almeje melhorar a eqüidade e garantir a inclusão; um crescimento econômico que gere um número adequado de empregos de alta qualidade; e uma redução das defasagens de produtividade (dualismo) entre as diferentes atividades e agentes econômicos. A globalização aumentou as tensões em todos esse campos, uma vez que ampliou a demanda de sistemas de ensino de qualidade, gerou novas tensões entre a competitividade e o emprego e aumentou o dualismo nas estruturas produtivas, além de criar novos riscos sociais. Assim, as estratégias sociais devem concentrarse em três áreas: (a) educação, (b) emprego e promoção de pequenas empresas, e (c) proteção social.

Os avanços nessas áreas complementam uns aos outros. A educação é o meio primário de sustar a reprodução intergeracional da pobreza e da desigualdade. Tornou-se ainda mais importante na medida em que a globalização aumentou a necessidade de recursos humanos capazes de se engajar em novos modos de produção, competição e convívio harmonioso. O emprego é um fator chave da integração social, em virtude de sua importância em termos da realização social e como determinante das oportunidades de consumo dos indivíduos. À medida que as pequenas empresas vão gerando mais empregos, o meio em que tais firmas operam tornou-se um grande determinante da qualidade do trabalho. Os riscos enfrentados pela população incluem os associados à volatilidade macroeconômica, à adaptação a novas tecnologias e maneiras de organizar o trabalho, e à deterioração da situação empregatícia em muitos setores.

$\mathrm{Na}$ área da educação, os esforços devem concentrar-se na conquista de uma abrangência universal, de preferência até a conclusão do curso secundário, e na redução das diferenças na qualidade do ensino oferecido aos diferentes grupos socioeconômicos. Também se fazem necessárias novas abordagens da aprendizagem, envolvendo o acesso ao co- 
nhecimento, a integração em redes de computadores e o uso das tecnologias de informática e comunicações. A modernização das ferramentas de ensino não é suficiente, entretanto. Ainda mais importante, em conjunto com essas novas ferramentas, é desenvolver as funções cognitivas superiores, orientando o processo de aprendizagem para a identificação e a resolução de problemas, a maior capacidade de reflexão, a criatividade, a capacidade de distinguir entre o que é o que não é importante, e as aptidões de planejamento e pesquisa, já que essas funções são vitais num mundo saturado de informações.

As iniciativas políticas referentes ao trabalho devem basear-se na conscientização de que a criação de empregos só é sustentável quando as atividades econômicas em questão são competitivas a longo prazo. A reorganização e modernização das atividades produtivas e a maior mobilidade da mão-de-obra tornam necessário implementar medidas agressivas de formação da mão-de-obra, que dêem aos trabalhadores a oportunidade de aprenderem a se adaptar às novas condições. Por outro lado, o papel central das pequenas empresas (inclusive as microempresas) e o dualismo crescente que caracteriza as estruturas produtivas enfatizam a necessidade de medidas especiais, que visem a garantir o acesso dessas firmas à tecnologia, ao capital e à capacidade administrativa, e ainda, como foi assinalado na seção anterior, a necessidade de agrupar suas atividades e estimular suas ligações com empresas maiores. Além disso, os ministérios do Trabalho devem adotar uma política que ajude a fomentar a auto-regulação pelos agentes sociais (o diálogo social) e dedique uma atenção especial aos trabalhadores que não obtiveram acesso aos setores modernos (os desempregados e os trabalhadores do setor informal). Com esses objetivos em mente, é preciso restaurar o papel desses ministérios como órgãos de criação e implementação de medidas políticas.

O desenvolvimento dos sistemas de proteção social deve ser norteado pelos princípios da universalidade, solidariedade, eficiência e integridade. Não se pode progredir em direção à universalidade se não forem corrigidas as desigualdades marcantes no acesso aos serviços e na qualidade destes. A solidariedade deve ser garantida por uma combinação de contribuições compulsórias, transferências públicas e subsídios cruzados entre as diferentes camadas de renda e grupos de risco. Os países latino-americanos têm enfrentado enormes exigências nessa área, já que a deficiência crônica na cobertura dos riscos tradicionais mistura-se agora ao ônus adicional gerado pelos novos riscos associados à vulnerabilidade em termos do emprego e da renda. Além disso, a extensão do desempre- 
go, e particularmente do emprego no setor informal, limita a viabilidade de se alcançar uma cobertura universal por meio das formas tradicionais de proteção social. Por conseguinte, a ênfase deve recair na implementação de mecanismos mistos e complementares de segurança, compatíveis com a vasta gama de arranjos empregatícios atualmente utilizados. Esses tipos de arranjos devem ser concebidos para promover a mobilidade da mão-de-obra e fornecer proteção contra os choques externos e internos.

As enormes disparidades da distribuição de renda que caracterizam os países latino-americanos geram demandas consideráveis para a política social. Os dados comparativos entre os vários países indicam que tais disparidades podem ter-se convertido num obstáculo essencial ao crescimento econômico, indicando que as políticas sociais atuantes transformaram-se, num sentido muito direto, num investimento produtivo. Por outro lado, essas exigências enfrentam, na América Latina, as restrições impostas pela baixa receita fiscal da maioria dos países e pela tradicional demanda elevada de gastos sociais por parte dos grupos de renda média. Assim, é preciso empreender um esforço político considerável para garantir um pacto fiscal que satisfaça às múltiplas exigências enfrentadas pela política social na região, mas é difícil pensar em qualquer solução que não envolva uma receita tributária elevada e com um componente progressivo.

\section{Um equilíbrio apropriado entre o interesse privado e o interesse público}

Dadas as tensões que caracterizam o mundo contemporâneo, um novo equilíbrio entre o mercado e o interesse público é um componente essencial da construção das instituições. Isso não deve ser visto como algo que vai de encontro ao funcionamento do mercado, uma vez que as medidas que asseguram uma oferta adequada de bens públicos e de qualidade, que exploram as externalidades positivas entre os agentes e evitam as negativas, e que garantem uma distribuição eqüitativa dos benefícios do desenvolvimento podem funcionar como promotoras do mercado.

O conceito de "política pública" deve ser entendido, num sentido amplo, como qualquer forma organizada de ação que vise alcançar objetivos de interesse coletivo, e não como sinônimo de medidas governamentais. Essa definição do "público" harmoniza-se com a conscientização da necessidade de criar oportunidades de participação 
da sociedade civil. É também compatível com a necessidade de superar uma crise do Estado que caracteriza muitos países, bem como de corrigir tanto as "falhas de mercado" quanto as "falhas de governo". Essa abordagem enfatiza a importância de se atingir uma "densidade institucional" elevada, da qual uma vasta gama de agentes sociais participe ativamente e tenha responsabilidades perante o conjunto dos cidadãos - ou seja, uma alta "densidade democrática".

A construção das instituições, nesse sentido, reconhece que o desenvolvimento abarca objetivos amplos, idéia esta que está implícita no conceito de desenvolvimento humano sustentável ou no conceito mais recente de "desenvolvimento como liberdade" (Sen, 1999). É óbvio que tais conceitos expressam elementos permanentes e profundamente arraigados da reflexão sobre o desenvolvimento. Sua principal implicação é que o sistema econômico deve estar subordinado a objetivos sociais mais amplos (Polanyi, 1957). Essa é a única maneira de enfrentar as violentas forças centrífugas que caracterizam os negócios privados de hoje. De fato, em muitas partes do mundo desenvolvido (e industrializado), as pessoas vêm perdendo o sentimento de pertencerem à sociedade, bem como sua identificação com as metas coletivas e sua consciência da necessidade de desenvolver laços de solidariedade. Esse fato deixa clara a importância de fomentar esses liames, a fim de "criar a sociedade". Significa, em outras palavras, que todos os setores da sociedade precisam participar mais ativamente de instituições políticas democráticas e que é necessário criar, na própria sociedade civil, uma vasta gama de mecanismos que fortaleçam as relações de solidariedade e responsabilidade sociais e, acima de tudo, consolidem uma cultura alicerçada no sentimento de identidade coletiva e de tolerância para com a diversidade.

\section{Referências bibliográficas}

ALBERT, Michel, Capitalisme contre capitalisme, Paris, Éditions du Seuil, 1991.

AMSDEN, Alice, The Rise of "The Rest": Challenges to the West from Late Industrializing Countries, Nova York, Oxford University Press, setembro de 2001.

BAIROCH, Paul, Economics and World History: Myths and Paradoxes, Chicago, University of Chicago Press, 1993. 
BOURGIGNON, François e MORRISON, C. (2002), "The size distribution of income among world citizens: 1820-1990", American Economic Review, a ser publicado.

CÁRDENAS, Enrique, OCAMPO, José Antonio e THORP, Rosemary, Industrialisation and the State in Latin America: the Post War Years. An Economic History of Twentieth Century Latin America, vol. 3, Nova York, Palgrave Press / Martins, 2000.

CHANG, Ha-Joon, The Political Economy of Industrial Policy, Londres, Macmillan, e Nova York, St. Martin's Press, 1994.

CHENERY, Hollis, ROBINSON, Sherman e SYRQUIN, Moshe, Industrialization and Growth: A Comparative Study, Nova York, World Bank, Oxford University Press, 1986.

CORNIA, Giovanni Andrea, "Liberalization, Globalization and Income Distribution", Working Papers, No. 157, Helsinki, United Nations University (UNU) / World Institute for Development Economics Research (WIDER), março de 1999.

CEPAL (Comissão Econômica para a América Latina e o Caribe), Globalization and Development, Santiago, Chile, 2002(a).

- Growth with Stability: Financing for Development in the New International Context, Libros de la CEPAL, No. 67, 2002(b).

- Una década de luces y sombras: América Latina y el Caribe en los años noventa, Bogotá, D.C., Comissão Econômica para a América Latina e o Caribe (CEPAL)/Alfaomega, 2001(a).

- Social Panorama of Latin America, 2000-2001, Santiago, Chile, 2001(b).

- Equity, Development and Citizenship, Santiago, Chile, 2000.

FRENCH-DAVIS, Ricardo, Reforming the Reforms in Latin America: Macroeconomics, Trade, Finance, Londres, Macmillan, e Nova York, St Martin's Press, 2000.

HELLEINER, Gerald K., "Markets, politics and globalization: can the global economy be civilized?", The Tenth Raúl Prebisch Lecture, Genebra, 11 de dezembro de 2000.

- (org.), Trade Policy and Industrialization in Turbulent Times, Nova York, United Nations University (UNU) / World Institute for Development Economics Research(WIDER), Nova York, Routledge, junho de 1994. 
KAUL, Inge, GRUNBERG, Isabelle e STERN, Marc A., (orgs.), Global Public Goods: International Cooperation in the $21^{\text {st. Century, }}$ Nova York, Oxford University Press, 1999.

KAUL, Inge, CONCEIÇÃO, Pedro, LE GOULVEN, Katell e MENDOZA, Ronald U. (orgs.) (2002), Providing Global Public Goods: Managing Globalization, a ser publicado.

MADDISON, Angus, The World Economy. A Millennial Perspective, Paris, Development Centre Studies, Organização para a Cooperação e Desenvolvimento Econômicos (OCDE), 2001.

-- Dynamic Forces in Capitalist Development: A Long-Run Comparative View, Nova York, Oxford University Press, 1991.

OCAMPO, José Antonio, "Structural Dynamics and Economic Development", Kurt Martin Lecture, Haia, Instituto de Estudos Sociais, 2001.

— "Developing Countries' Anti-Cyclical Policies in a Globalized World", in Amitava Dutt e Jaime Ros (orgs.) Development Economics and Structuralist Macroeconomics: Essays in Honour of Lance Taylor, Aldershot, UK, Edward Elgar, 2002.

ORGANIZAÇÃO DAS NAÇÕES UNIDAS, “United Nations Millennium Declaration" (A/RES/55/2), Nova York, Assembléia Geral (Reunião de Cúpula do Milênio, Nova York, 6-8 de setembro de 2000 .

O'ROURKE, Kevin H. e WILliAMSON, Davis Jeffrey G., Globalization and History. The Evolution of a Nineteenth-Century Atlantic Economy, Cambridge, Massachusetts, The MIT Press, 1999.

POLANYI, Karl, The Great Transformation: The Political and Economic Origins of Our Time, Boston, Beacon Press, 1957.

PREBISCH, Raúl, "Crecimiento, desequilibrio y disparidades: interpretación del proceso de desarrollo", Estudio Económico de América Latina 1949, Nova York, Organização das Nações Unidas, "Interpretación del proceso de desarrollo latinoamericano en 1949", Serie Conmemorativa del 25 aniversario de la CEPAL, Santiago, Chile, fevereiro de 1951.

RODRIK, Dani, Has Globalization Gone Too Far?, Washington, D.C., Institute for International Economics, 1997.

-- Making Openness Work: The New Global Economy and the 
Developing Countries, Washington, D.C., Overseas Development Council, 1999.

SEN, Amartya, Development as Freedom, Nova York, Alfred A. Knopf, 1999.

STIGLITZ, Joseph A., Globalization and its Discontents, Nova York, W. W. Norton, 2002(a).

— "Whither Reform? Toward a New Agenda for Latin America", Second Prebisch Lecture, CEPAL, Santiago, Chile, agosto de 2002(b).

UNCTAD (United Nations Conference on Trade and Development), Trade and Development Report, 2002, Genebra, 2002.

- Trade and Development Report, 1999 (UNCTAD/TDR/1999), Genebra, United Nations Publication, Sales No. E.99.II.D.1, 1999.

- Trade and Development Report, 1997 (UNCTAD/TDR/1997), Genebra, United Nations Publication, Sales No. E.97.II.D.8, 1997.

WILlIAMSON, John, "The Washington Consensus Revisited”, in L. Emmerij (org.), Economic and Social Development into the XXI Century, Washington, D.C., IDB, The Johns Hopkins University Press, 1997. 


\title{
POLÍTICAS DE DESENVOLVIMENTO NO MUNDO DA GLOBALIZAÇÃO
}

\author{
Joseph E. Stiglitz*
}

Atualmente, uma questão é debatida em toda a América Latina: falhou a globalização ou falhou a reforma? O que fica claro é que há uma decepção com as medidas políticas impostas nas duas últimas décadas aquelas que se concentraram na liberalização, na privatização e na estabilização, e que passaram a ser coletivamente conhecidas como normas do Consenso de Washington. Os dados relativos à década de 1990, verdadeiro teste inicial dessas medidas políticas, quando os países ficaram livres dos grilhões da dívida ameaçadora, ajudam a explicar o sentimento de desilusão. O crescimento dessa década correspondeu a pouco mais da metade do que fora nas décadas de 1950, 1960 e 1970, anteriores à reforma e à crise. Mesmo nos países que tiveram um crescimento significativo, uma parcela desproporcional dos lucros foi para os mais ricos, os $30 \%$ superiores, ou até para os $10 \%$ superiores, enquanto muitos dos pobres, na verdade, empobreceram ainda mais. Pouco ou nenhum progresso foi obtido na redução da desigualdade, que já era a maior de qualquer região do mundo, e as percentagens da população mergulhadas na pobreza, para não falar dos números, efetivamente aumentaram. O desemprego, já elevado, subiu três pontos percentuais. E o desempenho dos últimos cinco anos - que já começam a ser conhecidos como a meia década perdida - foi ainda mais desolador, para dizer o mínimo, com estagnação ou declínio da renda per capita. ${ }^{1}$

Em minha palestra em homenagem a Prebisch, proferida há um mês em Santiago, ${ }^{2}$ afirmei que havia uma clara ligação entre esses fracassos

\footnotetext{
* Universidade de Columbia, Prêmio Nobel.

${ }^{1}$ Ver CEPAL (2002).

${ }^{2}$ Ver Stiglitz (2002). Consultar esse artigo quanto às fontes dos dados citados na discussão anterior.
} 
e as medidas adotadas. Os resultados não devem ter sido surpresa. Eles refletem o que estava no programa e o que ficou de fora. $\mathrm{O}$ aparente sucesso dos primeiros $2 / 3$ da década não passou de uma miragem - em parte, um surto de crescimento causado por uma entrada insustentável de capital estrangeiro e, em parte, como tantas vezes acontece após um período de estagnação, uma "recuperação" da década perdida. Esse crescimento não se sustentou. E seria possível argumentar de maneira convincente que não era sustentável.

Um exame mais atento do único exemplo de sucesso freqüentemente repetido, o Chile, mostra que, nos anos de seu desempenho fenomenal, com um crescimento de $7 \%$, o país não fez simplesmente sucumbir, querendo ou não, aos ditames do Consenso de Washington. Como nos exemplos de sucesso do Leste Asiático, ele foi seletivo, fazendo acréscimos e subtrações nas receitas padronizadas, de um modo que lhe permitiu moldar a globalização de acordo com seus objetivos. Por exemplo, o Chile não liberalizou inteiramente seus mercados de capitais, conservando o que equivalia a um imposto sobre a entrada do capital de curto prazo, imposto este que impediu as entradas avassaladoras no país, o que, por sua vez, reduziu as fugas maciças depois da crise do Leste Asiático. Ele fez privatizações, mas de maneira seletiva, mesmo sob a pressão do FMI, que incluía estruturas contábeis que inclinavam a balança de maneira acentuada e injusta contra as empresas do governo; atualmente, cerca de $20 \%$ das exportações chilenas ainda provêm de uma empresa estatal, a CODELCO. Os governos social-democratas enfatizaram os gastos com a educação e a saúde, especialmente para os pobres; e esse é um mundo em que, muitas vezes, é preciso correr para ficar parado: embora tenha havido poucos avanços na redução da desigualdade, pelo menos ela não aumentou como em outros lugares. E, o que talvez seja mais importante, instaurou-se um círculo virtuoso: o crescimento permitiu que o governo bancasse esses gastos sociais vitais sem financiar a dívida, de modo que, hoje em dia, a proporção entre a dívida e o PIB chilenos está em torno de $15 \%$, o que torna o país menos vulnerável aos caprichos dos mercados internacionais, que tiveram efeitos devastadores em outros países latino-americanos. ${ }^{3}$

\footnotetext{
${ }^{3}$ A maior parte dessa dívida pode ser atribuída ao custo da recapitalização do sistema bancário depois da crise financeira do período de Pinochet. Para excelentes exposições sobre a liberalização imperfeita e a crise chilenas, ver Diaz-Alejandro (1985), Edwards e Edwards (1991) e de la Cuadra e Valdés (1992).
} 


\section{Globalização: oportunidades e desafios}

Os princípios básicos do Consenso de Washington têm sido crescentemente questionados.

- As medidas de estabilização não garantem o crescimento econômico. Países que seguiram as receitas do FMI, desde a Bolívia até a Mongólia, têm indagado: sentimos a dor, fizemos tudo o que vocês nos recomendaram; quando começaremos a colher os frutos? Enquanto isso, países que seguiram um curso independente, como a China, ou que foram seletivos, como o Chile, saíram-se muito melhor.

- As medidas de estabilização - definidas como rigor tributário e uma política monetária "sensata" - nem sequer garantem a estabilidade, uma vez que as mudanças repentinas nos sentimentos dos investidores, com mercados abertos de capitais, levam a evasões maciças, que deixam em sua esteira o caos econômico, mesmo em países com instituições moderadamente sólidas, mas especialmente naqueles em que a regulamentação do setor financeiro é fraca e não existem redes de segurança. As repetidas crises financeiras dos últimos seis anos dão amplas provas disso.

- A liberalização do mercado de capitais - feita na seqüência equivocada, ou prematuramente - não leva a um crescimento econômico mais rápido, porém expõe efetivamente os países a níveis de risco mais altos: trata-se de um risco sem recompensa.

- Os benefícios da liberalização do comércio são mais questionáveis do que sugeriria o mantra do livre comércio, particularmente quando a agenda do livre comércio é do tipo assimétrico, que tem caracterizado o mundo nos últimos anos, com os países desenvolvidos insistindo em que os países em desenvolvimento eliminem suas barreiras comerciais às mercadorias que eles produzem, porém mantendo suas próprias barreiras aos produtos provenientes do Sul. Os Estados Unidos, no governo Bush, têm estado na dianteira dessa hipocrisia, com subsídios agrícolas que atingem novos picos e com suas recentes tarifas impostas ao aço. Se os Estados Unidos - a nação mais rica do mundo, um país em que, mesmo numa recessão, menos de $6 \%$ dos trabalhadores enfrentam o desemprego, e onde os que perdem o emprego são protegidos por uma rede de segurança - afirmam que precisam recorrer a "salvaguardas", a medidas protecionistas, que não dizer dos países em 
desenvolvimento, onde não existem redes de segurança, o desemprego já é elevado, e onde os que perdem o emprego em decorrência da liberalização, juntamente com suas famílias, têm que enfrentar perspectivas realmente sombrias? Para piorar as coisas, diante da política de austeridade, os novos empregos prometidos não são criados: e como poderiam sê-lo, com as habituais taxas de juros elevadas da política do FMI, que se preocupa mais com a inflação e com o que ela poderia fazer com o valor dos papéis dos investidores do que com os desempregados? Como resultado, em vez de os trabalhadores passarem de empregos de baixa produtividade para empregos de alta produtividade, a "promessa" da liberalização, eles passam de empregos de baixa produtividade para o desemprego, ou para o trabalho mal remunerado no setor informal, que não favorece o crescimento mas aumenta a pobreza. Enquanto os Estados Unidos e outros países desenvolvidos recorrem cada vez mais a medidas protecionistas não tarifárias, ao mesmo tempo que continuam a usar a retórica do livre comércio e da globalização, uma pergunta natural começa a ser repetidamente formulada: por que existem dois pesos e duas medidas para o que é a prática comercial "lícita" ou "ilícita", uns para as mercadorias produzidas pelos fabricantes do próprio país, outros para os produtores de fora? Internamente, os Estados Unidos têm normas claramente definidas para o dumping, para a conduta predatória, nos termos da legislação antitruste. Por que não seriam elas aplicáveis em termos mais gerais?

- A última rodada de negociações comerciais, a rodada do Uruguai, demonstrou amplamente as desigualdades do regime global. $\mathrm{O}$ regime de propriedade intelectual foi ditado pelos interesses comerciais dos Estados Unidos e de outros lugares, prestando pouca atenção aos interesses dos países em desenvolvimento ou da comunidade de pesquisa no mundo inteiro. Foi desequilibrado. Alguns problemas, como os do acesso aos medicamentos, já vieram para o primeiro plano. Outros só despontarão de maneira mais gradativa. O mesmo se dá nas áreas de serviços: embora a extensão dos acordos de comércio aos serviços seja freqüentemente enaltecida como um grande feito, vale a pena ressaltar que foram os serviços financeiros, de interesse dos Estados Unidos, que entraram na agenda, e não os serviços de construção ou marítimos, que seriam de maior interesse para os países em desenvolvimento. 
- A privatização, feita da maneira errada - e é muito difícil realizá-la com acerto -, pode levar a preços mais altos dos serviços públicos, em vez de reduzi-los, com isso prejudicando ainda mais a competitividade dos países, e, através dos altos níveis de corrupção que comumente a acompanham, pode promover processos políticos corruptos e aumentar a desigualdade, como demonstrou amplamente a Rússia. Mas os problemas enfrentados pela GrãBretanha com o transporte ferroviário e a eletricidade mostram que até países com instituições altamente sofisticadas podem ter dificuldade de "acertar a medida", e os problemas da regulamentação da eletricidade nos Estados Unidos não apenas demonstram que, sem um controle adequado do governo, a manipulação maciça por parte das empresas privadas pode transtornar a economia e destruir as finanças públicas, como também que é extremamente difícil montar corretamente a estrutura reguladora.

- Desconhecer as dimensões sociais e políticas - como fizeram o FMI e o Consenso de Washington - é não apenas má política social, mas também má política econômica. A Indonésia levará anos para se recuperar dos tumultos para os quais contribuiu a política do FMI no país, assim como é possível argumentar que grande parte da América Latina tem sofrido com uma violência urbana e atividades guerrilheiras que resultam, em parte, das políticas equivocadas que foram impostas a esses países. Nos países com imensas desigualdades na posse da terra, nos quais a meação é uma forma comum de arrendamento, os 50\% da lavoura entregues ao dono da terra funcionam como um tributo pesado para os lavradores, com efeitos debilitantes sobre o crescimento.

\section{Mais alguns dados sobre a globalização das idéias e a hipocrisia global}

Um aspecto poderoso da globalização é que as pessoas dos países em desenvolvimento podem perceber a disparidade entre o que é dito e praticado no Norte, especialmente nos Estados Unidos, e as políticas que são recomendadas ou impostas a elas. Já mencionei a hipocrisia no comércio. Toquei brevemente nos problemas da privatização e da regulamentação no Norte, os quais têm levado a que se repense nessas questões naquele hemisfério, considerando inclusive iniciativas de re-nacionalização. As amplas discussões sobre as práticas contábeis, tanto no 
setor público quanto no privado, têm chamado a atenção não só para esses problemas, como também para as impropriedades das estruturas contábeis impostas pelo FMI aos países em desenvolvimento e para as diferenças entre elas e as que são convencionalmente usadas na Europa e noutras regiões.

Nos Estados Unidos, na recessão de 2001, democratas e republicanos concordaram quanto à necessidade de estímulos fiscais para recuperar a economia; no entanto, em todo o mundo em desenvolvimento, o FMI impõe uma política fiscal de contração a países que estão enfrentando fases de declínio - exatamente o inverso da missão para a qual ele foi criado.

Embora o FMI tenha imposto a privatização da seguridade social, a iniciativa de privatização nos Estados Unidos, mesmo parcial, teve uma acolhida fria (exceto na Wall Street). A eficiência do sistema público norte-americano - o fato de ele haver praticamente eliminado a pobreza no tocante aos idosos -, combinada com estudos que mostram que, no caso da Grã-Bretanha, os custos de transação no regime de privatização reduziram os benefícios em até $40 \%$, e também com o reconhecimento dos riscos impostos à segurança dos idosos pela volatilidade do mercado, contribuíram para fazer arrefecer o entusiasmo. ${ }^{4}$ (Naturalmente, aquilo a que se dá o nome de custos de transação, do ponto de vista da sociedade, afigura-se uma boa fonte de renda para outras pessoas e, como não é de admirar, as que têm a ganhar com esses custos continuam a ser defensoras ardorosas da idéia).

\section{Aprendendo com os erros dos outros}

A globalização tem outra vantagem: pessoas do mundo inteiro têm a oportunidade não só de aprender com os erros dos outros, mas de examinar os estudos analíticos que tentam interpretar essas experiências. Que a transição do comunismo para a economia de mercado, nos países que seguiram a política do Consenso de Washington, foi uma decepção, para dizer o mínimo, está mais do que claro. ${ }^{5} \mathrm{E}$ as pessoas podem acom-

\footnotetext{
${ }^{4}$ Murthi et al. (1999) calculam que, na Grã-Bretanha, esses custos de transação terão como resultado tornar os benefícios $40 \%$ menores do que eles seriam em outro regime (na parte privatizada de seu sistema de seguridade social).

${ }^{5}$ Stiglitz $(2000,2001)$.
} 
panhar o debate animado sobre o fracasso. Também podem ler o debate furioso sobre as conseqüências da inflação. Embora haja um consenso de que os altos níveis de inflação têm efeitos significativamente adversos sobre o crescimento, as pesquisas empíricas e teóricas (inclusive as de George Akerlof, que recebeu o Prêmio Nobel de economia junto comigo, no ano passado) sugerem que não só os benefícios de forçar a queda cada vez maior da inflação podem ser limitados, como, na verdade, é possível até que haja efeitos adversos de sua redução excessiva. ${ }^{6}$ Não era esse o problema enfrentado pela América Latina há um quarto de século. Mas é preciso ter cuidado com as camisas-de-força em que o passado nos coloca: atualmente, a Europa está enfrentando um enorme problema. Ao se confrontar com uma grande diminuição do ritmo de atividade, ela não consegue reagir com eficiência, por causa de uma autoridade monetária cujo único objetivo é a inflação (ao contrário da norte-americana, que também se preocupa com o desemprego e o crescimento), e por causa de um pacto de estabilidade que restringe as dimensões do financiamento da dívida. A França, a Alemanha, a Itália e Portugal reconhecem, todos eles, as conseqüências potenciais desastrosas, e estão buscando maneiras de reinterpretar esses compromissos.

\section{Os desafios propostos pela globalização}

Voltando-nos mais estritamente para a economia, a globalização tem três vantagens claras: a demanda dos produtos de um dado país já não fica restrita a seu próprio mercado; os investimentos do país não mais ficam restritos ao que ele próprio pode poupar; e os países podem ter acesso (mediante um preço) à mais avançada tecnologia. Mas, correspondendo a essas oportunidades, há alguns desafios de porte: os países desenvolvidos aprenderam a usar uma multiplicidade de barreiras não-tarifárias para manter do lado de fora os produtos do mundo em desenvolvimento; embora o investimento externo direto traga não só o acesso ao capital, mas também à tecnologia e aos mercados, isso não se aplica ao capital financeiro de curto prazo, que expõe os países a uma enorme instabilidade. A China, que foi quem melhor se saiu na obtenção de investimentos externos diretos, mostrou que a afirmação de que não se pode obtê-los sem fazer a abertura concomitante - tese dos de-

${ }^{6}$ Ver Akerlof et al. (1996). 
fensores da liberalização do mercado de capitais - está simplesmente errada. Os países também foram erroneamente levados a crer que as aquisições estrangeiras de bens de capital já existentes (por exemplo, associadas às privatizações) são investimentos externos diretos. Em alguns casos, pode ser, mas deve ficar claro o contraste entre os investimentos do tipo "greenfield", nos quais uma empresa estrangeira cria novos empregos, e essas outras formas de investimento externo. Em muitos casos, os estrangeiros podem realizar uma aquisição com o simples objetivo de fazer o desmonte do patrimônio, e não de gerar riqueza; e, a longo prazo, o país fica mais pobre, e não mais rico.

A globalização traz outros desafios: embora não haja uma movimentação livre da força de trabalho, a mão-de-obra altamente preparada é mais móvel, o que impõe um dilema aos países em desenvolvimento: ou eles pagam salários competitivos em termos internacionais, coisa com que mal podem arcar e que leva a uma desigualdade maciça, ou perdem esses trabalhadores qualificados. Em alguns países do Leste Europeu, a evasão da mão-de-obra qualificada tem sido maciça, deixando para trás os que estão velhos demais para se mudar e os que não têm qualificações, o que contribui para a espiral descendente desses países.

Similarmente, as assimetrias entre a mobilidade da mão-de-obra e a do capital impuseram reduções dos impostos incidentes sobre o capital, deixando o ônus maior sobre o trabalho, o que acrescenta mais uma força às que conduzem a uma desigualdade crescente no mundo inteiro.

Neste artigo, só disponho de tempo para abordar dois dos desafios criados pela globalização: os associados aos empréstimos tomados no exterior e, em particular, à falência soberana, e os associados à política industrial.

\section{A falência soberana}

O acesso ao capital, quando as coisas estão correndo bem, mostrouse irresistível para um número excessivo de países. Há um argumento econômico convincente a favor da tomada de empréstimos: o retorno sobre esses investimentos ultrapassa o custo do capital. E há um argumento político concomitante, também convincente: os benefícios dos empréstimos serão sentidos agora, enquanto os problemas da quitação ficarão a cargo de outras pessoas - como mostrou exemplarmente o caso da Argentina. 
O problema é que os bancos e os emprestadores em geral, para usar uma expressão norte-americana, são amigos das horas de bonança: enquanto se dispõem a lhe emprestar dinheiro quando você não precisa, querem recebê-lo de volta na hora em que você mais necessita dele. Essa é uma das razões por que, em todo o continente, os países têm adotado políticas contracíclicas. ${ }^{7}$ Não é que os economistas não tenham feito seu curso básico de macroeconomia, no qual devem ter estudado as políticas contracíclicas. Ocorre, antes, que esses empréstimos agem quase como um desestabilizador automático. (À medida que uma economia entra em declínio, os bancos ficam mais fracos; à medida que diminui a confiança nos bancos do país, as pessoas buscam portos mais seguros no exterior; à medida que elas retiram seu dinheiro do país e que há um aumento da inadimplência, a imposição de normas de adequação do capital e requisitos de reserva, para não falar de seu endurecimento, leva a uma contração do crédito, o que contribui ainda mais para o declínio econômico.)

Até países com uma relação moderada entre a dívida e o PIB podem ficar impossibilitados de arcar com o serviço dessa dívida, se, de repente, os mercados internacionais de capitais resolverem que o ágio cobrado sobre o risco da dívida dos mercados emergentes em geral, ou daquele país em particular, deve sofrer um aumento drástico. É fácil mostrar que pode haver múltiplas formas de equilíbrio. Se a taxa de juros fosse razoável, o país não teria problemas com o serviço da dívida, a probabilidade de moratória seria baixa e, por conseguinte, a taxa de juros continuaria moderada. Mas, quando a taxa de juros dispara, o país passa a ter dificuldades com o serviço da dívida, a probabilidade de calote aumenta e, por conseguinte, a alta taxa de juros parece perfeitamente racional. ${ }^{8}$

Esses problemas são exacerbados pelo desenho dos contratos de dívidas, que violam os princípios básicos dos mercados eficientes. Os países ricos têm mais capacidade de arcar com os riscos ligados à volatilidade das taxas de juros e de câmbio e os contratos de dívida deveriam ser concebidos em consonância com isso, ou assim o seriam, em mercados de capital eficientes. Mas não é isso que se vê na prática. Uma vez que cabe aos países pobres arcar com esse risco, quando as

\footnotetext{
${ }^{7}$ Ver Easterly et al. (2001) e as referências ali citadas.

${ }^{8}$ Ver Greenwald e Stiglitz (2003). (V) a ser lançado em 2003 ?
} 
coisas ficam ruins (ou são simplesmente percebidas como ruins), inicia-se um círculo vicioso: o medo da inadimplência leva à fuga de capitais, o que leva a taxas de câmbio mais baixas e de juros mais altas, com isso aumentando a dívida a ponto de tornar impossível o seu serviço.

Esses problemas são também agravados pelo fato de que o mundo não dispõe de nenhuma boa maneira de lidar com os calotes nacionais. Não existem meios rápidos e eqüitativos de resolver a questão do não pagamento, a exemplo da legislação sobre concordatas e falências, os quais atentem não só para os interesses dos credores, mas também para os das outras pessoas em risco, como os aposentados e pensionistas e aqueles que dependem do governo para obter serviços vitais, como saúde e educação. Não há dúvida de que obtivemos alguns avanços nos últimos cem anos.

Um século atrás, em 1902, o Dr. Luís Maria Drago, então ministro do Exterior da Argentina, anunciou a Doutrina Drago, em resposta ao bombardeio de partes da Venezuela por nações européias (com o consentimento expresso dos Estados Unidos), depois da moratória venezuelana de sua dívida internacional. Disse ele:

“... o que a República Argentina respalda é o princípio já aceito de que não pode haver expansão territorial européia na América, nem opressão dos povos deste continente, por causa de uma situação financeira adversa que leve um deles a adiar o pagamento de seus compromissos; o princípio de que a dívida pública não pode acarretar intervenções militares nem conferir mérito à ocupação material do solo das nações americanas por uma nação européia."

E disse ainda, o que é tão válido hoje quanto era há cem anos:

“... O credor sabe estar firmando um contrato com uma entidade soberana, e sabe que uma condição inerente a toda soberania é que não se pode mover processos contra ela nem recorrer a procedimentos de execução, visto que essa forma de cobrança comprometeria sua própria existência e faria desaparecerem a independência e a ação do respectivo governo. O reconhecimento da dívida e o pagamento de seu montante podem e devem ser feitos pela nação, sem que isso diminua seus direitos essenciais de entidade soberana, ao passo que a cobrança compulsória e imediata, em qualquer ocasião, por meio da força, não acarretaria nada senão a ruína das nações mais fracas e a absorção de seus governos, com todas as suas faculdades intrínsecas, pelas nações fortes da Terra." 
Cem anos atrás, a Argentina ergueu-se em defesa de um Estado conterrâneo latino-americano. Como declarou Drago,

“... não somos movidos por sentimentos egoístas, nem tampouco estamos buscando agir em proveito próprio, ao expressar nosso desejo de que a dívida pública dos Estados não sirva de motivo para a agressão militar, mas sim [movidos] pelo sentimento de fraternidade continental e pela força que sempre emana do apoio moral de uma nação inteira (...) de uma nação que confia em seu destino e no de todo este continente."

Essa não foi a primeira vez nem o primeiro lugar em que as potências militares e financeiras do mundo - o G-7 da época - valeram-se de meios militares para tentar impor o pagamento da dívida: em meados do século, elas ocuparam o México. Sua ocupação do Egito viria a durar décadas. E não seria a última.

A visão do calote, sob certos aspectos, alterou-se consideravelmente ao longo destes cem anos. No nível pessoal, já não temos presídios para devedores. Todos os grandes países do mundo aprovaram leis de falência que prevêem a reestruturação e o cancelamento da dívida. Nos Estados Unidos, nosso direito falencial prevê também a falência de governos estaduais e municipais, bem como de outras autoridades públicas (Capítulo 9 do Código).

Modificaram-se também as idéias sobre como reagir à impossibilidade ou à recusa de pagamento da dívida por parte de uma nação soberana. A Doutrina Drago é hoje universalmente aceita. Mas, no nível internacional, não há processos falimentares. E existe uma preocupação de que a pressão econômica exercida pelas nações grandes e poderosas, às vezes através das instituições econômicas internacionais, seja tão opressiva quanto as medidas militares do século XIX e, possivelmente, ainda mais destrutiva para a vida e para a liberdade política. Para muitas pessoas do mundo em desenvolvimento, a imagem de Suharto assinando a chamada Carta de Intenções afigurou-se uma abdicação tão grande da soberania econômica de seu país - e, em alguns aspectos, até maior - quanto as assinaturas que se seguiram à intervenção militar. (Aliás, no campo internacional, a distinção entre dívidas públicas e privadas às vezes se torna obscura, exercendo-se pressão pela nacionalização dos passivos privadas. Essa nacionalização ocorreu na crise latino-americana do início dos anos oitenta e na crise mais recente do Leste Asiático.) 
Muitos acreditam que as angústias por que a Argentina tem sido obrigada a passar são, pelo menos em parte, deliberadas: os devedores estão sendo avisados de que haverá graves conseqüências no caso de moratória. No entanto, teria sido possível conceber medidas para reativar a economia (e, a meu ver, isso deveria ter sido feito).

Foi o ultraje moral que pôs fim às intervenções militares, e foi o ultraje moral que acabou com as prisões para devedores. Talvez a nossa sensibilidade moral é que venha a introduzir uma nova era na maneira de lidar com as dívidas internacionais. A boa nova é que existem vislumbres de reconhecimento de que há algo errado nos arranjos correntes. Na crise do Leste Asiático (como tinham feito depois da crise latino-americana anterior), os críticos dos socorros financeiros do FMI afirmaram que era preciso confiar mais nas suspensões de pagamento e nas falências, e que era necessário aperfeiçoar os processos falimentares criar um super Capítulo 11, como o chamei. Mas o longo debate sobre a reforma da legislação falencial nos Estados Unidos deveria ter deixado claro que não existe um código de falências "ótimo" e único. O fato de todos os governos, nos países industrializados avançados, haverem adotado uma abordagem calcada na lei (em vez de confiarem em mecanismos de mercado, modificados, por exemplo, por cláusulas obrigatórias em ações coletivas) deveria ter deixado claro que a posição do Tesouro norte-americano não faz sentido, corroborando os resultados das pesquisas teóricas e empíricas sobre a falência e a negociação.

Portanto, é uma boa notícia saber que o FMI, após o fracasso de seis socorros prestados em igual número de anos, finalmente reconheceu que havia necessidade de uma abordagem alternativa e que era desejável um mecanismo de reestruturação da dívida soberana nacional. Ele também acertou em considerar que não se pode confiar em abordagens baseadas no mercado (fato que deixara de reconhecer no caso do Leste Asiático) e que era desejável alguma versão de uma abordagem jurídica. Deveria ser óbvio que, em qualquer processo falimentar tido como justo, um grande credor (como o FMI) não pode, simultaneamente, desempenhar o papel de juiz da falência e nem mesmo ter um papel central no processo, a não ser como um dos queixosos. Para muitos, a tentativa do FMI de conferir a si mesmo esse papel central diz muito sobre sua insensibilidade política.

Mas essas reformas, se vierem a ocorrer, levarão muito tempo. Em retrospectiva, fica claro que as discussões sobre a reforma da arquitetura financeira global tiveram mais a ver com acalmar nervos em franga- 
lhos do que com qualquer outra coisa. Pode-se suspeitar que, por parte do Tesouro norte-americano, a esperança era que o impulso de reforma passasse antes que fossem efetivamente abordadas as questões ligadas ao centros bancários no exterior ou aos fundos de hedge, ou até questões mais profundas, como a falência e a liberalização do mercado de capitais.

Assim, os países do mundo em desenvolvimento, hoje em dia, precisam enfrentar três duras realidades: primeiro, os mercados de capitais são sumamente voláteis; os países podem ser punidos não só pelos erros que cometem, mas por acontecimentos pelos quais não têm nenhuma responsabilidade; os países podem ser punidos não apenas por erros que tenham cometido, mas por erros que o mercado de capitais ache que poderiam cometer. A submissão à chamada disciplina dos mercados internacionais de capital não garante o crescimento nem a eficiência, mas expõe os países ao risco de serem forçados a abrir mão de componentes importantes de sua soberania. Isso é particularmente verdadeiro na medida em que o capital de curto prazo, como é natural, concentra-se no prazo curto.

Segundo, quando há uma crise, os custos são imensos, e, mesmo quando se evita a crise, os custos da dependência do capital estrangeiro são enormes, uma vez que, por exemplo, impõem uma política de contração, exatamente quando haveria necessidade de políticas de expansão. Esses custos mais do que anulam os benefícios auferidos anteriormente, quando o empréstimo foi tomado.

Terceiro, um mercado de capitais de funcionamento adequado faria com que os países ricos arcassem com os riscos das desvalorizações cambiais e dos aumentos da taxa de juros; uma arquitetura financeira global que funcionasse bem teria dispositivos que limitassem os custos da falência, quer de nações soberanas, quer de empresas engajadas na tomada de empréstimos transnacionais. Mas não temos mercados internacionais de capital que funcionem adequadamente, nem tampouco uma arquitetura financeira global que funcione bem (pelo menos nesse - e noutros - aspectos cruciais).

Sim, o custo de não tomar empréstimos é elevado - em termos de projetos de educação ou saúde não realizados, de estradas não construídas -, mas o custo de tomá-los é ainda maior. Os países que enfrentam essas realidades devem reduzir despesas e aumentar impostos. 


\section{Política industrial}

A globalização tem confrontado os países com o desafio de como competir no mercado global. Hoje se reconhece que o que separa os países desenvolvidos dos menos desenvolvidos não é apenas uma disparidade de capital e outros recursos, mas também uma defasagem no conhecimento. Os países se perguntam o que podem fazer para promover a tecnologia, melhorar sua competitividade e aumentar suas exportações e sua capacidade de competir com as importações estrangeiras.

Ultimamente, as formas de política industrial têm adquirido má reputação. Como disse meu antecessor no Conselho de Assessores Econômicos, não faz diferença se a economia produz batatas fritas ou chips de computador - ela deve produzir seja o que for que maximize o PIB, e o mercado é o melhor lugar para tomar essas decisões.

\section{Teoria econômica e política industrial}

A tese contrária às políticas industriais baseia-se numa interpretação ingênua da teoria econômica e numa leitura equivocada da história econômica. A teoria econômica padrão alardeia a eficiência dos mercados competitivos, mas o teorema da mão invisível, de Adam Smith, que afirma a eficiência do mercado, fundamenta-se em condições extremamente rigorosas. Presume, por exemplo, que a informação seja perfeita, que não haja assimetrias na informação e que os mercados sejam completos - que os mercados de capitais sejam perfeitos e que se possa obter garantias contra todos os riscos. É claro que esses pressupostos não se aplicam nem mesmo às economias de mercado que melhor funcionam. Os economistas perceberam, obviamente, que a informação era imperfeita e os mercados eram incompletos, mas havia uma esperança de que, se a informação não fosse ruim demais nem imperfeita demais, a economia poderia ser bem descrita pelos modelos de informação perfeita. Minhas pesquisas, assim como as de outros, mostraram que essa esperança era infundada: até pequenas quantidades de imperfeição nas informações podem ter efeitos acentuados. O trabalho com Bruce Greenwald ${ }^{9}$ mostrou que a razão de a mão invisível ser invisível era que ela simplesmente não existia, ou, se existia, era paralítica. Em princí-

\footnotetext{
${ }^{9}$ Greenwald e Stiglitz (1986).
} 
pio, havia um papel para o governo: em princípio, o governo poderia aumentar a eficiência dos mercados.

Esses argumentos são ainda mais convincentes quando se trata da inovação. Pode-se pensar no conhecimento como uma forma particular de informação e, como tal, os resultados da economia da informação seriam aplicáveis ao campo da economia da inovação. As teorias padronizadas presumiam uma tecnologia fixa, mas é claro que no cerne do crescimento e do desenvolvimento encontra-se a mudança tecnológica, a criação e adoção de novos modos de produção e novos produtos. Portanto, as teorias padronizadas sobre a eficiência dos mercados não têm nada a dizer sobre esse campo. Ao contrário, há boas razões para crer que, em geral, os mercados, por si mesmos, não produzem resultados eficientes. O conhecimento tem os atributos de um bem público (isto é, há um custo alto pela exclusão e um custo baixo ou zero pelo fato de um número adicional de indivíduos desfrutar das vantagens desse bem) e a inovação gera enormes externalidades. Além disso, há grandes incertezas associadas à inovação, de modo que as conseqüências da falta de mercados de seguros tendem a ser particularmente graves. Muito tempo atrás, Schumpeter enfatizou a importância das imperfeições do mercado de capitais, uma vez que, tipicamente, não há como garantir os investimentos feitos em pesquisa. Assim, a teoria econômica moderna criou um sólida presunção para o papel do governo.

\section{História econômica e política industrial}

Isso me traz à questão da história econômica. Os dois casos de desenvolvimento bem-sucedido que estudei mais de perto, o dos Estados Unidos e o do Leste Asiático, fornecem provas convincentes da importância da política industrial. A indústria de telecomunicações, em certo sentido, foi criada pelo governo. A primeira linha telegráfica norte-americana foi construída em 1842 pelo governo federal, ligando Baltimore a Washington, e a Internet moderna, que tanto contribuiu para criar a Nova Economia, foi criada, por sua vez, pelo governo estadunidense. A grande indústria do século XIX foi a agricultura, é claro, e o governo dos Estados Unidos, através de seus órgãos de pesquisa e extensão, transformou essa indústria, levando aos aumentos de produtividade que foram os precursores necessários do mundo moderno. Um ingrediente central das políticas de sucesso dos países do Leste Asiático foi a tentativa deliberada de reduzir a "defasagem do conhecimento". Esses paí- 
ses perceberam que o que os separava das nações mais desenvolvidas não era uma simples defasagem de capital, mas uma defasagem de conhecimento, e trabalharam com afinco e com êxito para introduzir a tecnologia moderna em suas sociedades. Hoje, em muitas áreas, eles se encontram na linha de frente.

\section{Fazendo a política industrial funcionar melhor: novos instrumentos e abordagens}

Os críticos da política industrial citam os fracassos e abusos, e é fato que houve fracassos e abusos. Em alguns casos, pressões políticas carrearam enormes subsídios para as indústrias preferidas. O governo, segundo se afirma, não tem um histórico confiável de "direção" da economia. O fato de o Japão haver pressionado a Honda a não produzir automóveis, sob a alegação de que já havia um número suficiente de fabricantes de carros, é repetidamente citado como uma tentativa equivocada (e felizmente malsucedida, para o Japão) de intervenção governamental. Mas os sucessos anteriormente assinalados sugerem que os benefícios sociais compensam os custos, e por larga margem. Aliás, mesmo com uma assunção ótima de riscos, é fatal que haja fracassos: se eles não existissem, seria, sem dúvida, pelo fato de o governo haver adotado uma estratégia excessivamente conservadora. As pesquisas feitas no Conselho de Assessores Econômicos, na época em que o presidi, mostraram de maneira convincente que, na verdade, o apoio governamental à pesquisa tem um retorno altíssimo, muito mais alto que o dos investimentos privados típicos. ${ }^{10}$

\section{Princípios}

Seja como for, aprendemos com os erros, e creio que estamos em condições de criar uma política industrial ainda mais eficaz. A política industrial moderna concentra-se em tentar identificar áreas em que as falhas de mercado tenham a máxima probabilidade de serem melhor sucedidas. Por exemplo, ela busca áreas em que avultem as falhas de coordenação, ou em que haja grandes desperdícios ou problemas significativos de apropriação. As pesquisas sobre a Internet ilustram todos

\footnotetext{
${ }^{10}$ Council of Economic Advisers, Executive Office of the President (1995).
} 
esses problemas. Seria difícil uma empresa privada apropriar-se de toda a gama de benefícios da Internet; o valor desta aumentou com o uso, mas, se um construtor potencial da rede tivesse que esperar que as empresas de aplicativos da Internet lhe pedissem para criá-la, ela nunca teria sido desenvolvida. A Internet teve enormes conseqüências para todas as empresas, e não apenas para as que estão diretamente envolvidas com o marketing em rede.

A economia da informação também nos ajuda a entender por que os mercados de capitais são amiúde imperfeitos e, por conseguinte, por que o governo pode ter que desempenhar um papel importante nesse campo. Nos Estados Unidos, num ano recente, 25\% de todos os financiamentos foram fornecidos pelo governo, ou com garantias do governo, ou através de empresas patrocinadas pelo governo. O governo ajudou a criar o mercado nacional de hipotecas, que baixou o custo do capital para os compradores da casa própria. Os empréstimos governamentais para as pequenas empresas (através da Small Business Administration [SBA]), nos últimos anos, tiveram um histórico notável. Toda grande empresa começa, é claro, como uma pequena empresa. Entre as grandes empresas que hoje desempenham um papel fundamental em nossa economia e que começaram com um empréstimo da SBA encontra-se a Federal Express.

Em certo sentido, o governo não tem como deixar de lidar com questões de política industrial. Ele desempenha um papel central em nossa economia. Além do grande papel que acabei de descrever nas finanças, ele é crucial também na pesquisa e na educação. A infra-estrutura é outra área em que o governo é dominante. As decisões que ele toma nessas esferas - que áreas de pesquisa apoiar, como conceber os currículos, onde construir estradas e aeroportos - ajudam a moldar a economia e sua competitividade. É melhor que essas decisões sejam tomadas com vistas ao rumo que se pretende dar à economia. Do mesmo modo, a política tributária ajuda a moldar a economia. O tratamento tributário especial concedido aos imóveis e à energia é uma forma de política industrial - direciona recursos para essas áreas. Mas, será que é para elas que o governo deve direcionar os recursos? Mais uma vez, pensar nessas questões a partir de uma perspectiva mais global pode favorecer o desempenho da economia.

A política industrial moderna não se envolve na microgestão econômica. Os críticos da política industrial dizem que o governo não está na melhor posição para "escolher os vencedores". E nem deve fazê-lo. Mas 
isso perde de vista o que se está discutindo, em dois aspectos. Quando o governo intervém no mercado, não é por não confiar na capacidade deste de escolher os predestinados ao sucesso (embora a alocação equivocada de recursos na bolha tecnológica norte-americana levante algumas dúvidas), mas por reconhecer que existem falhas de mercado, do tipo das que já assinalei. Os inventores do laser, da Internet e do transistor apropriaram-se apenas de uma pequena fração dos benefícios sociais associados a suas inovações. Assim, a política industrial de hoje baseiase em intervenções de caráter amplo, que tentam, em particular, lidar com essas falhas de mercado.

Ela começa por se concentrar na educação e na pesquisa. Países como a Costa Rica reconheceram que, para ter sucesso na era moderna, todos têm que dominar a utilização de computadores e a educação. A política industrial identifica outras áreas em que o governo desempenha naturalmente um papel importante, como a infra-estrutura, e indaga de que modo elas devem ser moldadas para favorecer o desenvolvimento da economia.

Da mesma forma, a moderna política industrial é, amiúde, de "bitola larga" e, na medida do possível, procura empregar mecanismos semelhantes aos de mercado a cada implementação. Assim, faz mais sentido o governo incentivar "tecnologias energéticas eficientes", facultando a concorrência entre abordagens alternativas, do que escolher de antemão uma tecnologia a ser promovida. Nessa competição, ele pode exigir que os que buscam apoio contribuam com somas substanciais de seus próprios recursos, para que seu capital corra tantos riscos quanto o do governo. Similarmente, nos empréstimos (como os feitos a pequenas e médias empresas), o governo pode usar bancos comerciais para ajudar na triagem dos candidatos, mas pode exigir que os bancos originários arrisquem um pouco de seu próprio capital. Nos projetos de ciência e tecnologia, deve-se usar a avaliação dos pares. (Algumas das experiências norte-americanas com esses aperfeiçoamentos trazem uma advertência: à medida que as receitas são eliminadas, também o apoio político a esses projetos desaparece!)

\section{Mercado de trabalho e educação}

Uma parte fundamental dessa política industrial de bitola larga consiste em trabalhar pela promoção da flexibilidade da economia, isto é, através de políticas ativas no mercado de trabalho, ensino permanente e educação voltada para o aprender a aprender. Haverá necessidade de mudanças nos currículos e de vínculos mais estreitos entre as universi- 
dades e a indústria. No século XIX, o ensino público era voltado para o desenvolvimento de uma força de trabalho treinada e disciplinada, necessária à industrialização. No século XXI, a educação precisa direcionarse para desenvolver a capacidade de iniciativa e a de lidar com um mundo em processo acelerado de mudança.

Alguns países enfrentarão um desafio para manter dentro de suas fronteiras as suas populações preparadas e instruídas. Isso se aplica particularmente às economias em transição, que têm assistido a uma enorme debandada. A menos que essa evasão seja contida, é difícil saber, por exemplo, como se poderá reconstruir uma nova economia moderna a partir das cinzas remanescentes da antiga economia comunista.

\section{Políticas industriais negativas}

A moderna política industrial tanto pode implicar medidas positivas quanto "negativas", reconhecendo que a especulação imobiliária pode contribuir menos para o emprego e o crescimento do que outros setores e expor a economia a uma instabilidade maior. Assim, talvez faça sentido restringir o volume de empréstimos bancários feitos ao setor imobiliário especulativo. Embora tais restrições normalmente não sejam vistas como parte da política industrial, estão integradas nela, num sentido muito realista.

\section{Pequenas empresas e capital de risco}

Conquanto haja casos de pequenas economias que desenvolvem grandes empresas (como a Nokia), é mais provável que as pequenas empresas continuem a predominar, e a política industrial precisa estar particularmente atenta a suas necessidades, através da criação de parques e incubadoras industriais e de pesquisa. Também é possível que haja necessidade de instituições financeiras especializadas, empresas de capital de risco que possam ir além das abordagens tradicionais de concessão de crédito a pequenas e médias empresas.

\section{Visão}

Embora a política industrial de bitola larga reduza a necessidade de o governo "escolher os vencedores", não há como o governo possa deixar de ter uma "visão" de para onde vai a economia. Aliás, há quem argumente que o estabelecimento dessa visão - em consulta com os 
integrantes do setor privado - foi um dos papéis importantes exercidos pelos governos do Leste Asiático. Eles não se empenharam no tipo de planejamento detalhado que costuma associar-se ao controle governamental, mas desempenharam um papel, talvez mais importante, de catalisadores. Na América Latina, tanto o setor público quanto o privado precisarão perguntar quais serão as vantagens comparativas no futuro, e de que modo eles podem e devem alterar essas vantagens comparativas através dos investimentos. Não posso fornecer nem mesmo uma resposta provisória a essa questão central, mas quero tocar em alguns aspectos relacionados com as questões da globalização.

Cada vez mais, as economias modernas são economias do setor de serviços e do conhecimento. A transformação da agricultura em indústria foi portentosa, e está claro que a transformação da manufatura na Nova Economia não será menos dramática. Não há respostas fáceis para perguntas sobre quais são as vantagens comparativas dinâmicas de um país. Mas ao menos isto deve ficar claro: na Nova Economia, é provável que essas vantagens sejam acentuadamente diferentes do que foram no passado. Isso exigirá que se repensem as estratégias de governo em cada uma das áreas em que ele se envolver.

A China, com seu imenso universo de mão-de-obra barata e cada vez mais instruída, representará um desafio para a indústria manufatureira em todos os lugares do mundo, especialmente se esse país der prosseguimento a políticas que resultem em baixas taxas de câmbio (em parte, através de reservas cada vez maiores, as quais, dada a instabilidade associada à globalização moderna, podem fazer um enorme sentido, sobretudo nos países que já tenham experimentado os riscos da instabilidade). Até os Estados Unidos, é claro, poderão encontrar nichos em que competir: a indústria computadorizada do vestuário fornece um produto feito sob encomenda que, na ponta superior, pode competir com as roupas produzidas na China. A globalização da tecnologia modificou a natureza da competição em aspectos fundamentais. Por mais que agrade à América dizer que foram os subsídios injustos de outros países que deixaram sua indústria siderúrgica em desvantagem competitiva, a verdade é que a Coréia, que há apenas vinte e cinco anos era um país menos desenvolvido, é capaz de produzir com maior eficiência técnica (mesmo numa empresa dirigida pelo Estado) do que os velhos gigantes do aço norte-americanos.

Existem nichos que um país como o Brasil pode descobrir, e alguns deles serão de alta tecnologia, como aviões que atendam a um mercado regional. Embora, em certas áreas, as novas tecnologias tenham reduzi- 
do consideravelmente as vantagens da proximidade do mercado, existem outras em que essas vantagens persistem. Elas terão que ser identificadas, explorando-se as oportunidades.

Houve avanços nos serviços comerciais e, considerando-se que, tipicamente, eles têm uma alta intensidade de mão-de-obra, países como o Brasil poderão descobrir oportunidades nesse campo. Ao mesmo tempo, muitos serviços continuarão altamente não comercializáveis e as melhoras na eficiência dessa parte da economia poderão trazer aumentos reais no padrão de vida.

Não devemos esquecer que, em diversos países em desenvolvimento, muitas das pessoas mais pobres permanecem no setor rural e nele tendem a continuar por várias décadas. Para reduzir a pobreza, é preciso fazer algo por esse setor. Mesmo que isso não traga uma grande contribuição direta para as exportações, é a coisa certa a fazer. As experiências dos países bemsucedidos demonstraram a importância da estabilidade social, e esta não pode ser mantida quando grandes parcelas da população ficam para trás. A educação das crianças dessas áreas não pode ser apenas uma saída, devendo ser também uma via de ascensão. Deve ser concebida de tal maneira que os que permanecerem no campo possam ver sua produtividade aumentar, ficando em sintonia com tecnologias de produção melhores e sendo sensibilizados para os produtos que o mercado mais valoriza. Mas isso não será o bastante, se, ao mesmo tempo, não lhes forem fornecidos recursos - capital e terra - para que eles ponham seus conhecimentos em prática. Em suma, a política industrial não pode ignorar a agricultura e o setor rural, em termos mais gerais. (Aliás, o sucesso inicial da China e de Taiwan alicerçouse numa estratégia de desenvolvimento de base rural.)

\section{Comentários finais}

Não há fórmulas fáceis de sucesso no mundo moderno. A Irlanda e Portugal, no entanto, mostram claramente que países que estavam na periferia da Europa, e cujos níveis de renda aproximavam-se da base da escala, podem progredir muito no caminho da equiparação. As políticas financeira, educacional e industrial foram centrais para seu sucesso. Os mercados - a iniciativa empresarial - são vitais, mas o governo tem a responsabilidade e a oportunidade de moldar o meio econômico. Há quem entoe o mantra simplista da redução de impostos e da desregulamentação, sugerindo que, se os impostos fossem reduzidos e a regulamentação fosse eliminada, o crescimento viria. Não há provas que 
corroborem essa visão. Sim, os impostos e regulamentos despóticos podem sufocar a economia e, para alguns, qualquer imposto ou regulamentação é despótico por definição. Mas uma postura mais equilibrada reconhece o papel vital que o governo pode e deve desempenhar, e que inclui tanto a regulamentação quanto o fornecimento de serviços públicos, como a educação. O problema que prejudicou o Leste Asiático foi a falta de regulamentação, e não seu excesso, e os problemas enfrentados pela economia norte-americana também provêm de uma regulamentação insuficiente, e não de seu exagero. As políticas industriais, quando bem construídas e bem elaboradas, podem ser uma parte importante de uma estratégia mais abrangente de gestão econômica, capaz de produzir crescimento e estabilidade econômicos com justiça social. Talvez precisemos inventar novos nomes - como "investimento favorecedor da produtividade" e "estratégias tecnológicas" - e é preciso estarmos cientes das armadilhas, mas essas políticas são essenciais para o crescimento a longo prazo.

Há pouco tempo, houve uma discussão na América Latina sobre as reformas de segunda geração: as da primeira geração, centradas na liberalização, na privatização e na estabilização, já estavam adiantadas e se presumia que teriam sucesso. Era hora de construir novas reformas, com base nesses sucessos passados. Hoje em dia, os aspectos insatisfatórios das reformas do Consenso de Washington são evidentes, embora alguns digam que é cedo demais para julgar e que as coisas estariam ainda piores sem as reformas. É claro que houve quem se beneficiasse delas, e é claro também que alguns reformadores têm interesse em que elas sejam consideradas um sucesso. Essas reformas também foram apoiadas pelo livre mercado, pelos ideólogos fundamentalistas do mercado, e estes continuarão a proclamar seu sucesso, sejam quais forem as provas com que se confrontem.

Muitas das antigas políticas tiveram que ser modificadas. Os governos não podiam continuar a acumular grandes déficits sem enfrentar as conseqüências. Os altos níveis de inflação eram prejudiciais. Muitas das empresas estatais eram ineficientes. O protecionismo desenfreado teve custos enormes. Não podemos retornar ao passado, mas também não devemos deixar de reconhecer as falhas do presente. A reforma precisa ser reformada. Em minha conferência em homenagem a Prebisch, enumerei vários componentes dessa estratégia de reforma reformada. Aqui, concentrei-me mais estritamente nas conseqüências da globalização.

A globalização ampliou as oportunidades de êxito, mas também criou 
novos riscos para os países em desenvolvimento. As regras do jogo foram concebidas, em sua maioria, pelos países industrializados avançados, ou, mais precisamente, por interesses especiais dentro desses países e em prol desses interesses egoístas, que amiúde não atendem aos interesses do mundo em desenvolvimento e, em especial, aos dos pobres. Países como o Brasil precisam adotar uma postura agressiva em defesa de um regime mais equilibrado, não só para seu próprio bem, mas em benefício do mundo inteiro.

Só que isso levará muito tempo. Até lá, os países têm que aprender a viver com as regras do jogo, por mais injustas que sejam. Mesmo dentro dessas regras, creio que países como o Brasil podem contribuir para moldar a globalização, para fazê-la funcionar não apenas para os ricos dentro do país, mas para todos. Para fazê-lo, porém, tais países precisam escolher seu próprio rumo, livres dos mantras simplistas que desempenharam um papel tão central no direcionamento da política econômica da América Latina na última década. Não será fácil, mas não existe alternativa.

\section{Referências bibliográficas}

AKERLOF, George A., DICKENS, William T. e L. PERRY, George "The macroeconomics of low inflation", Brookings Papers on Economic Activity 96(1), 1996, p. 1-76.

COUNCIL OF ECONOMIC ADVISERS, Executive Office of the President, Supporting Research and Development: the Federal Government's Role, 1995. Disponível no endereço www.whitehouse.gov/WH/EOP/CEA/econ/html/econ-rpt.html.

DELACUADRA, Sergio, eVALDES, Salvador, "Myths andFacts about Financial Liberalization in Chile: 1974-1983”, in P. Brock (org.) If Texas Were Chile: A Primer on Banking Reform, San Francisco: ICS Press, 1992, p. 11-101.

DIAZ-ALEJANDRO, Carlos, "Good-bye financial repression, hello financial crash", Journal of Development Economics 19(1-2), setembro-outubro de 1985, p. 1-24.

COMISSÃO ECONÔMICA PARA A AMÉRICA LATINA E O CARIBE (CEPAL), Social panorama of Latin America 2001-2002, Santiago, Chile: CEPAL, outubro de 2002. 
EDWARDS, Sebastian e COX EDWARDS, Alejandra, Monetarism and Liberalization. The Chilean Experiment, Chicago: University of Chicago Press, 1991.

EASTERLY, William, ISLAM, Roumeen e STIGLITZ, Joseph E., "Shaken and Stirred: Volatility and Macroeconomic Paradigms for Rich and Poor Countries," Annual Bank Conference on Development Economics 2000, Washington: World Bank, 2001, p. 191-212. Ver também Advances in Macroeconomic Theory, Jacques Drèze (org.), IEA Conference Volume, 133, Houndsmill: Palgrave, 2001, p. 352-372. (Discurso proferido na conferência em homenagem a Michael Bruno, XII Congresso Mundial of IEA, Buenos Aires, 27 de agosto de 1999.)

GREENWALD, Bruce, e STIGLITZ, Joseph E., "Externalities in Economies with Imperfect Information and Incomplete Markets", Quarterly Journal of Economics, maio de 1986, p. 229-264.

-, A New Paradigm for Monetary Economics, Londres: Cambridge University Press, 2003.

MURTHI, Mamta J., ORSZAG, Michael e ORSZAG, Peter R., "The Charge Ratio on Individual Accounts: Lessons from the U.K. Experience", Birbeck College Working Paper 99-2, University of London, março de 1999.

STIGLITZ, Joseph E., "Whither Reform? Ten Years of Transition", in Annual World Bank Conference on Economic Development, B. Pleskovic e J. E. Stiglitz (orgs.), Washington: World Bank, 2000, p. 27-56.

—, 2001 "Quis custodiet ipsos custodes? Corporate Governance Failures in the Transition", in Pierre-Alain Muet e J. E. Stiglitz (orgs.), Governance, Equity and Global Markets, Proceedings from the Annual Bank Conference on Development Economics in Europe, June 1999, Conseil d'Analyse économique, Paris, p. 51-84. (Originalmente apresentado como discurso sobre o tema central na Conferência Bancária Anual sobre Economia do Desenvolvimento na Europa, Paris, 23 de junho de 1999.) Versão francesa "Quis custodiet ipsos custodes? Les defaillances du gouvernement d'entreprise dans la transition", Revue d'Economie du Developpement, 0(1-2), junho de 2000, p. 33-70.

-, "Reforming Reform: Towards a New Agenda for Latin America", apresentado como a Conferência Raúl Prebisch de 2002 na CEPAL, Santiago, Chile, 26 de agosto de 2002. 
DEBATEDORES

\section{Desenvolvimento e Globalização: PERSPECTIVAS PARA AS NAÇÕES}




\title{
DO CONSENSO DE WASHINGTON AO DISSENSO DE CAMBRIDGE ${ }^{1}$
}

\author{
Edmar L. Bacha*
}

\section{Ciclos e modas}

À medida que os ciclos econômicos sobem e descem, o reinado do pensamento econômico nos EUA parece alternar-se entre os monetaristas e os keynesianos. Da mesma forma, à medida que o comércio e os fluxos de capital se expandem ou se contraem, a predominância do pensamento econômico na América Latina alterna-se entre a ortodoxia e a heterodoxia. Senão, vejamos.

- As dificuldades econômicas no pós 2a . guerra, com a 'escassez de dólares' na Europa e o estrangulamento externo' na América Latina, trouxeram para a linha de frente a estratégia de substituição de importações da Cepal.

- O crescimento do comércio na década de 60 e o auge dos mercados financeiros na década de 70 abriram o caminho para o monetarismo de economia aberta e a doutrina do FMI de equilíbrio orçamentário e alinhamento dos preços relativos.

- A crise da dívida da década de 80 levou às tentativas heterodoxas de estabilização.

\footnotetext{
* Consultor Senior, Banco BBA-Creditanstalt S.A.

${ }^{1}$ Versão revista de comentários aos artigos de Dani Rodrik, “After Neoliberalism, What?”, e de Joseph Stiglitz, "Development Policies in a World of Globalization", apresentados no Seminário do BNDES sobre Novos Rumos do Desenvolvimento no Mundo, no Rio de Janeiro, em 13 de setembro de 2002. Sem implicá-los nos resultados, agradeço os comentários de Marcelo de Paiva Abreu, Pérsio Arida, Regis Bonelli, Maria Laura Cavalcanti, Jose Antonio Ocampo, Dani Rodrik, João Moreira Salles, Joe Stiglitz, Flavio Versiani e John Williamson. Uma versão anterior deste texto foi publicada no jornal Valor/Revista EU\&, 27/9/2002.
} 
- A explosão do comércio e a globalização financeira da década de 90 produziram o Consenso de Washington e o neoliberalismo.

- A redução que ora se observa no comércio internacional, junto com a 'parada súbita' dos fluxos de capital, está fazendo florir uma nova heterodoxia, que vou tentativamente chamar de Dissenso de Cambridge - em homenagem à localização dos berços acadêmicos de seus dois principais expoentes, Dani Rodrik e Joseph Stiglitz.

\section{Progresso intelectual}

Na verdade, as alternâncias entre ortodoxia e heterodoxia não são só modismos ciclamente gerados, que vão e vêm. Atrás de uma retórica similar, há uma medida de progresso científico. As controvérsias na década de 90 entre os novos keynesianos e os novos clássicos estão certamente alguns degraus acima na escada do conhecimento do que as controvérsias entre keynesianos e monetaristas na década de 60 .

Da mesma forma, o debate atual entre os neoliberais e os dissidentes de Cambridge é mais sofisticado do que aquele entre a Cepal e o FMI na década de 50. Os dissidentes de Cambridge, por exemplo, situam-se firmemente dentro da tradição da economia neoclássica predominante. Tal era raramente o caso entre os economistas da Cepal ou daqueles que favoreceram os experimentos heterodoxos de estabilização.

Neste contexto, concordaria que o Consenso de Washington já foi embora, pelo menos até o próximo auge cíclico. Contudo, se o Dissenso de Cambridge quer manter-se vivo além do atual ciclo de baixa, ele precisa de um emblema mais forte do que o experimentalismo de Rodrik como sua característica distintiva. Paradigmas não sobrevivem bem sem um agente analítico unificador. Com este objetivo, gostaria de elaborar uma proposição crítica que não é suficientemente enfatizada nos textos de Rodrik e Stiglitz ${ }^{2}$.

${ }^{2}$ D. Rodrik, “After Neoliberalism, What?" e J. E. Stiglitz, "Development Policies in a World of Globalization", apresentados ao Seminário do BNDES sobre Novos Rumos do Desenvolvimento. Rio de Janeiro, 12-13 de setembro de 2002. 


\section{'Nova era' que não foi}

Meu ponto de partida é que, de uma perspectiva ampla, o erro básico do neoliberalismo foi presumir que uma 'nova era' de crescimento global havia sido lançada no início da década de 90, com o fím do comunismo, a emergência da 'nova economia' e a globalização financeira.

Nessa nova era, o pressuposto fundamental do crescimento neoclássico se afirmaria. Ou seja, haveria uma convergência da renda per capita entre os países emergentes e os países industrializados, baseada na expansão do comércio e na transferência de tecnologia destes para aqueles. Tal é de fato a predição do modelo neoclássico de crescimento para a economia mundial, com os distintos países tendendo a usar funções de produção similares, e o capital fluindo das economias em que é abundante para aquelas em que é escasso.

Com base nessa visão, o neoliberalismo interpretou equivocadamente o que era mais uma fase cíclica ascendente no nosso mundo imperfeito, como se fosse uma nova tendência em direção ao paraíso neoclássico. Agora que sabemos que a década de 90 foi de fato um ciclo e não uma nova tendência, gostaria de elaborar uma crítica específica ao modelo neoclássico de crescimento mundial. Quero crer que o obstáculo básico ignorado por esse modelo seja monetário em sua natureza.

\section{Restrição de divisas}

De forma abreviada, o maior problema para a convergência dos níveis de renda é que - exceto pelos exportadores de petróleo - o retorno ao capital estrangeiro se materializa na moeda doméstica do país importador de capital. E existe uma dificuldade, típica das estruturas econômicas e financeiras dos países emergentes, para transformar esses recursos em divisas fortes. Esta restrição de divisas limita o fluxo de capital (porque aumenta o risco do investimento) e tende a provocar crises periódicas de balanço de pagamentos.

Sob diferentes disfarces, este problema de transferência, ou restrição de divisas, tem uma longa história na literatura herética sobre comércio e desenvolvimento. Sua origem parece estar nas primeiras décadas do século XX na Europa, com o debate entre Keynes e Ohlin sobre as reparações alemãs. Reaparece na proposta de Keynes em Bretton Woods para a criação do Bancor, como forma de superar a "escassez de 
dólares" na Inglaterra e Europa. Na América Latina, ganha expressão no "estrangulamento externo" do manifesto da Cepal de 1949, cristaliza-se no modelo de dois hiatos de Chenery e suas extensões, e é agora revivido no problema da dolarização de passivos na $3^{\mathrm{a}}$. geração dos modelos de crises financeiras externas. Quer parecer-me que a restrição de divisas esteja no centro dos "desestabilizadores automáticos" das economias emergentes, mencionados no texto de Stiglitz ${ }^{3}$.

$\mathrm{Na}$ minha percepção, a forma como que, nas últimas décadas, os diversos países emergentes lidaram com essa restrição de divisas separa os casos de sucesso dos de fracasso de forma muito mais clara do que se seguiram ou não o Consenso de Washington.

Uma comprovação empírica dessa proposição ainda não está disponível. Mas se pensarmos em termos de pares de países razoavelmente similares, é possível construir uma sustentação inicial para ela. Por exemplo, a China parece ser mais bem-sucedida do que a Índia e resolveu melhor a questão da exportação. Taiwan parece ser mais bem-sucedida do que a Coréia e não se endividou em dólares. México parece ter mais sucesso que o Brasil e dinamizou suas exportações via Nafta. Venezuela parece ter menos insucesso do que a Argentina e é uma importante exportadora de petróleo. O Chile tem mais êxito do que o Peru e diversificou suas exportações além de desenvolver um mercado interno de capitais.

Se a restrição de divisas num mundo globalizado é de fato o principal obstáculo para o crescimento sustentado dos países emergentes, então o foco da solução parece estar na esfera financeira. No desenho de uma estratégia apropriada de desenvolvimento, questões de política industrial relacionadas à organização ou à estrutura da produção certamente devem intervir, mas através desse veio financeiro, como arguo em conclusão.

\section{Opções internacionais}

Para superar a restrição de dívisas, há, aparentemente, três opções, possivelmente complementares, para os países latino-americanos - uma no nível global, outra no nível regional, e uma terceira no nível nacional.

\footnotetext{
${ }^{3}$ Curiosamente, quase a mesma expressão - “desestabilizadores embutidos" - é usada por Triffin para criticar "o uso de moedas nacionais como reservas internacionais no sistema monetário mundial (baseado no dólar, da década de 1950)”. Cf. R. Triffin, Gold and the Dollar Crisis. New Haven: Yale University Press, 1961, pág. 87.
} 
A opção global seria o estabelecimento de um emprestador de última instância para as economias emergentes, no contexto de uma nova arquitetura financeira mundial. Esta entidade, que poderia ou não substituir o FMI, seria desenhada para atuar da mesma forma anticíclica como os bancos centrais dos países industriais o vêm fazendo desde a $2^{\mathrm{a}}$. Guerra.

O problema com esta alternativa é que o pensamento econômico dominante nos países industriais está perdido na trilha falsa do risco comportamental (moral hazard), segundo o qual a existência de um banco central incentivaria a exuberância irracional de banqueiros internacionais e países emergentes, nas fases ascedentes do ciclo econômico. Esta visão continua a ignorar que o problema real da década de 90 foi, ao contrário, na apta expressão de $\mathrm{Calvo}^{4}$, o risco da globalização, gerado pela internacionalização financeira sem um adequado emprestador de última instância.

A alternativa global parece, portanto, ainda estar muito longe de ser concretizada.

A opção regional seria o estabelecimento de uma área de livre comércio nas Américas, acompanhada de uma dolarização completa.

O problema econômico desta opção é a alta diversificação geográfica do comércio dos países sul-americanos ao sul do Equador - o que sugere que a área monetária ótima desses países é com o mundo como um todo e não só com a América do Norte. O problema político é que os maiores países da região dificilmente abdicariam de sua autonomia monetária em benefício dos EE.UU. Talvez se pudesse tentar convencer os políticos norte-americanos da criação de organismos de governança multinacional à semelhança daqueles existentes na Comunidade Européia, para facilitar a passagem política do conceito de integração monetária nas Américas. Mas, de novo, isso parece estar muito longe de acontecer.

Resta, pois, a alternativa nacional.

\section{A opção nacional}

A opção nacional seria ampliar e aprofundar os mercados financeiros domésticos, tornando assim o processo de investimento menos de${ }^{4}$ Cf. G. Calvo, "Globalization hazard and delayed reforms in emerging markets", Eco-
nomia/The Journal of LACEA, 2(2), Spring 2002: 1-30. 
pendente do financiamento externo. Como esta é a única alternativa inteiramente em mãos dos executores das políticas domésticas, vale a pena explorá-la um pouco mais.

Em primeiro lugar, alavancar as finanças locais não significa apenas aprofundar e ampliar os mercados financeiros domésticos. Com o perdão da palavra, a "exportabilidade" da produção é igualmente importante. $\mathrm{O}$ que está em causa é uma redução da vulnerabilidade financeira externa, conforme expressa, por exemplo, pela razão entre a dívida externa e a parcela exportável do PIB - que é uma primeira aproximação, em forma de fluxo, do volume de ativos internacionamente colaterizáveis do país ${ }^{5}$. Em princípio, esta redução pode ser alcançada, seja pela ampliação das oportunidades de financimento num mercado interno de capitais de longo prazo, seja por um aumento do grau de "exportabilidade" da economia.

O termo "exportabilidade" foi pela primeira vez introduzido por Albert Hirschman em seu clássico Strategy of Economic Development. Ele procura transmitir uma idéia diferente das visões convencionais sobre comércio e desenvolvimento. O foco é uma estratégia de desenvolvimento que, exceto para economias pequenas, é amplamente orientada para o mercado doméstico. Assim, "exportabilidade" não deve ser confundida com "enclaves de exportação" ou mesmo com estratégias de crescimento lideradas pelas exportações.

Além disso, exportar é diferente de substituir importações, ainda que ambas gerem divisas, a primeira as produzindo, a segunda as economizando. De uma perspectiva de crescimento, entretanto, a substituição de importações é operacional somente se dela resultam exportações adicionais. Hirschman, melhor do que ninguém, explica porque a "exportabilidade" dos produtos de rápido crescimento é uma condição para o equilíbrio externo:

"A única maneira segura de um país poder financiar as importações de que necessita para explorar o potencial de crescimento de suas atividades [em rápida expansão] é que consiga vender para o exterior uma

\footnotetext{
${ }^{5}$ Refiro-me aqui à literatura americana sobre a "restrição de crédito", conforme estendida para países emergentes na $3^{\mathrm{a}}$. geração de modelos de crises financeiras internacionais. Sobre a primeira, veja-se B. Bernanke e M. Gertler, "Agency costs, net worth, and business fluctuations”, American Economic Review 79-1, Março 1989, págs. 14-31. Sobre a segunda, veja-se Ricardo J. Caballero e A. Krishnamurthy, "A dual liquidity model of emerging markets", American Economic Review, Papers and Proceedings, May 2002.
} 
parcela da produção dessas mesmas atividades: somente assim, os saltos de importação gerados pelo padrão de crescimento nas atividades [em rápida expansão] poderão ser sistematicamente compensados por saltos nas exportações. Qualquer compensação por outras exportações será, de forma considerável, uma questão de sorte."’6

Note-se, ainda, que necessidade é de financiamento local de longa duração, que não é a mesma coisa que aumentar a taxa doméstica de poupança. Inicialmente, pelo menos, relações mais profundas de crédito e débito não se expressam necessariamente numa taxa de poupança doméstica mais alta, conforme seria sugerido por um esquema macroeconômico clássico, no qual o investimento é restrito pela poupança. Se a economia está em recessão, aumentar a poupança pode simplesmente aumentar o desemprego e sufocar ainda mais o incentivo para investir. O problema real é como mobilizar e canalizar as poupanças acumuladas e potenciais para empreendimentos de longo prazo.

Finalmente, também não se trata de substituir a poupança externa pela poupança interna, para "reduzir a vulnerabilidade do balanço de pagamentos do país", conforme tão frequentemente se lê na imprensa local. Ao contrário, a ampliação, pela exportabilidade, do volume de ativos internacionamente colaterizáveis permitirá ao país deter, com segurança, um maior volume de dívida externa por unidade de produto, e portanto ter acesso a uma maior poupança externa, de forma a acelerar o crescimento do PIB pelo aproveitamento das oportunidades existentes de investimento, que devem, em princípio, ser mais atrativas do que em países industrialmente avançados.

${ }^{6}$ Cf. A. O. Hirschman, The Strategy of Economic Development. New Haven: Yale University Press, 1958, págs. 171-2 (itálicos no original). 


\title{
DESENVOLVIMENTO E GLOBALIZAÇÃO: PERSPECTIVAS PARA AS NAÇÕES
}

\author{
Luciano Martins*
}

Duas palavras iniciais. A primeira para agradecer ao BNDES pelo convite que me proporcionou o privilégio de participar deste Seminário. Porque dos vários seminários de que tenho ultimamente participado este é seguramente um dos mais bem arquitetados e organizados. É particularmente gratificante para mim registrar, como estudioso que fui da criação do BNDES, que ele retoma a tarefa que lhe deu origem: a de ser não apenas uma agência de financiamento para projetos $a d$ hoc, mas a de um centro de reflexão sobre os rumos do desenvolvimento do país. E é isso que demonstra este Seminário.

A segunda palavra é para fazer a ressalva de praxe de que tudo o que aqui direi é de minha estrita responsabilidade pessoal e não envolve nenhuma instituição à qual eu esteja eventualmente vinculado.

$$
* * *
$$

Creio que se possa dizer que estamos discutindo, e desde a sessão de ontem, três temas principais, suscitados pelo processo de globalização. Estou certo que essa discussão, pela alta qualidade das exposições aqui apresentadas, contribuirá para melhor definir o novo contexto em que deve ser situada a problemática do desenvolvimento. Porque em última análise é disso que se trata e é essa, para nós, a questão estratégica.

Esses três temas são a seguir apontados.

a) A desconstrução das ideologias econômicas que prevaleceram nas duas últimas décadas, à luz dos resultados empíricos, tanto econô-

* Sociólogo. Atualmente Embaixador do Brasil em Cuba. 
micos quanto sociais, delas resultantes nos países que as adotaram; e também dos "fantasmas" que vinham se substituindo à crítica racional de tais ideologias, como notou ontem Helio Jaguaribe a propósito do "Consenso de Washington".

b) A necessidade de refazer visões de mundo e recriar instituições e centros decisórios. Nos planos nacionais, face à crise do estado-nação; e, no plano internacional, dada a falência ou insuficiência (ou "bad economic policies", como qualificou-as o Prof. Stiglitz) das instituições oriundas de Bretton Woods face às novas realidades e à complexidades criadas pelo próprio processo de globalização.

c) O imperativo político de criar novos parâmetros conceituais para repensar a questão do desenvolvimento num mundo marcado pela "interdependência assimétrica" gerada pela globalização. E permito-me insistir nessa expressão "interdependência assimétrica" porque ela delimita o alcance da globalização (e basta pensar na trágica exclusão africana), ao mesmo tempo que desmistifica logo muitos dos efeitos e implicações desse processo.

Esses três temas conduziriam na realidade a um quarto, no qual eu até me sentiria intelectualmente mais à vontade, e que é o da nova geometria mundial de poder nascida do fim da guerra-fria e hoje marcada pelo unilateralismo bushiano. Mas dele abdico para limitar-me ao meu papel de debatedor dos papers aqui apresentados e evitar um discurso paralelo. Vejamos.

\section{A desconstrução da ideologia dita "neoliberal"}

Creio que se pode dizer que os três expositores dessa sessão, e os da de ontem também, cada um à sua maneira e com argumentos diferentes, mas convergentes, demonstraram a parte que cabe ao receituário dito neoliberal no medíocre desempenho econômico dos países que foram levados a adotá-lo. O Prof. Stiglitz continuou sua implacável vivissecção (já que não se pode falar em autópsia porque ainda estão vivos) dos organismos criados em Bretton Woods e de sua degeneração, já tão bem exposta em seu livro The Globalization and its Discontents. José Antonio Ocampo fez uma excelente e matter-of-fact demonstração do recente desempenho econômico medíocre dos países latino-americanos, discutiu suas causas e apontou para soluções a partir da nova problemática 
do desenvolvimento. Não menos importante: demonstrou que historicamente não há convergência mas divergência em níveis de renda per capita entre países desenvolvidos e em desenvolvimento; e que a hipótese de uma "conditional convergence" depende da existência de fatores (educação, infra-estrutura, avanço científico e tecnológico, etc.) que só podem existir através da ação decidida do Estado.

O Prof. Rodrik foi mais longe ao afirmar que o "neoliberalismo está para a economia neoclássica assim como a astrologia está para a astronomia"; e ao afirmar que os três únicos países ultimamente mais bemsucedidos (China, Vietnam e Índia) foram justamente os que violaram a ortodoxia ideológica dos "fundamentalistas de mercado", sem que nem por isso deixassem de se dirigir para uma economia de mercado. Talvez se possa acrescentar que tal êxito também foi possível porque esses três países têm especificidades muito singulares. A China, por exemplo, já é um país capitalista, mas com uma estrutura de poder e uma burocracia ditas "comunistas", além de um peso político considerável em plano mundial. O Vietnam também dispõe de um sistema político centralizado e que lhe permite selecionar formas de inserção internacional. Já a Índia se, de um lado, encontrou por si mesma um nicho através da produção e exportação de medicamentos e de softwares, de outro, mantém indicadores sociais nada animadores. E também se poderia argumentar, em contraste com a performance dos dois primeiros países, e em apoio à afirmação do Prof. Rodrik, que as "privatizações selvagens" na Rússia, impulsionadas por Gaidar e pelo figurino do Banco Mundial, no início dos anos 90, tiveram por resultado uma fantástica "legitimação" da corrupção e a criação dos chamados "oligarcas" (o termo correto seria "plutocratas") que Putin procura agora desmontar. E tais exemplos já demonstram, por si sós, que não existe uma única fórmula ou receita de adaptação aos novos tempos que vivemos.

Nenhuma dessas qualificações, entretanto, invalida o que entendo ser o argumento central dos expositores, o qual vou resumir aqui em termos pessoais e que não envolvem a responsabilidade deles, mas que mostra minha concordância com eles: ou se repensam a teoria econômica e as políticas do desenvolvimento, sepultando tanto o lixo ideológico quanto os fantasmas que as contaminaram nas últimas duas décadas, ou não se chegará a nenhum lugar. Ou melhor, permaneceremos onde estamos: baixo ou nulo crescimento, desemprego, imobilização do Estado, vulnerabilidade externa estrutural e pobreza crescente. E isso nos conduz à segunda questão. 


\section{A crise do estado-nação}

Todo o pensamento latino-americano, a partir dos anos 30, tinha como referente o estado-nação, suas instituições e seus mecanismos de processos decisórios. Como se sabe, o nacionalismo, em suas vertentes populistas ou autoritárias, foi sua expressão. Parece-me inegável que o estado-nação está hoje em crise por toda parte e que, por isso mesmo, perderam sentido essas suas expressões ideológicas.

Em crise, porque ameaçado, "por baixo", pela diversificação de crescentes demandas sociais, movimentos separatistas, etc. E também, como mostra Ocampo em seu paper, no que se refere à América Latina, porque a "poverty/economic growth link" experimentou uma deterioração estrutural nos anos 90, a despeito de as despesas sociais terem aumentado, em média, nos mesmos anos 90, de 10,4\% para $13,1 \%$ do PIB. Ou seja: tais despesas não se substituem a uma política análoga à que gerou o welfare state. Como conciliar e atender essas demandas crescentes para refazer a base social em que se apoiavam a idéia e o princípio de legitimação política do estadonação? E é justamente essa questão que aponta para a necessidade da formulação de novas políticas de desenvolvimento.

Acrescente-se que o estado-nação também está em crise pelas ameaças "por cima". E essas vêm da globalização, ou seja, da vulnerabilidade por ela gerada no contexto da interdependência assimétrica por ela criada e agora agravada pela atual geometria mundial de poder. Essa vulnerabilidade talvez possa ser resumida em quatro fenômenos principais:

a) a "lógica" do sistema financeiro internacional (cujos movimentos estão gerando aquilo que o Prof. Stiglitz qualificou como "automatic destabilizers"), assim como a dos estranhos critérios adotados pelas agências de "rating", que oscilam, como escreveu em artigo recente Ocampo, da "exuberância irracional" ao "pânico irracional"-, mas que influenciam movimentos de capital;

b) as posições arbitrárias do FMI e, às vezes, do Banco Mundial. Vejam o caso interessante da crise energética de um país conhecido. Uma empresa estatal tinha US\$ 4 bilhões para investir para prevenir uma (previsível) crise energética. Mas foi impossibilitada de fazê-lo porque o FMI decreta que investimentos de empresas estatais devem ser contabilizados como gastos públicos. Curioso. Nos Estados Unidos, os novos "robber barons" da Enron e similares, graças a essa pérola semântica chamada "creative accountability" (leia-se fraudes contábeis), praticaram à vontade justamente o opos- 
to: contabilizaram como sendo investimentos o que na realidade eram gastos. E parece que os famosos mecanismos "auto-reguladores" do mercado foram incapazes de detectar tais procedimentos. Se é assim, pergunto que eficácia possuem;

c) Alberto Fishlow argumenta, a meu ver com razão ( e creio que há duas décadas que insiste nisso), que a forma de diminuir a vulnerabilidade decorrente da "ciclotimia" (para repetir a expressão do Presidente do Banco Central) dos fluxos de capital externo é aumentar a poupança doméstica. Mas isso supõe justamente a adoção de políticas públicas voltadas para criar condições de investimento e para restringir o deslocamento de capitais domésticos para o exterior. Segundo leio nos jornais, o Banco Central do Brasil estima que existam aplicados no estrangeiro cerca de US\$ 70 bilhões de dólares de empresas e pessoas físicas brasileiras; e só no mês passado saíram mais US\$1 bilhão e 700 milhões. Quer dizer: a questão de aumentar a poupança doméstica tanto tem a ver com políticas públicas que induzam ao investimento interno quanto com a própria "mentalidade" (vamos chamar assim, para sermos elegantes) das classes dominantes locais;

d) o Prof. Lall chamou a atenção em seu paper para o fato inegável de que a melhor inserção internacional dos países em desenvolvimento depende em grande parte do aumento da competitividade de suas exportações. Nada mais sensato. Mas como, atingido esse objetivo, lutar contra os subsídios e as barreiras de todo tipo através das quais os países desenvolvidos defendem seus mercados ao mesmo tempo que exigem a abertura dos nossos. Mais: num contexto internacional no qual a correlação de forças nos é totalmente desfavorável. Estão aí, no que se refere ao Brasil, os casos do aço, da soja, dos cítricos industrializados ou da Embraer, que exemplificam essas práticas abusivas, quando não cínicas.

Essa não é evidentemente uma listagem exaustiva do tipo de problemas que hoje enfrentam países como o Brasil. Haveria ampla matéria para discussão, por exemplo, sobre as razões do gap tecnológico aqui já mencionado e, sobretudo, sobre a centralização das decisões mundiais em arenas das quais os países de menor desenvolvimento relativo parecem praticamente excluídos.

Para concluir. O que quero sugerir, em síntese, é que não basta discutir apenas receituários econômicos, por mais importante que seja essa 
discussão, porque a verdadeira questão é política: é a da capacidade do Estado de definir políticas de desenvolvimento e de sua capacidade de enfrentar a atual correlação de forças em plano internacional. 
PALESTRAS

Desafios do Crescimento: INSTITUIÇÕES, INVESTIMENTOS, COMPETITIVIDADE E TECNOLOGIA 
Desenvolvimento em Debate -374 


\title{
O NOVO REGIME GLOBAL DE PROPRIEDADE INTELECTUAL E SUA DIMENSÃO IMPERIALISTA: IMPLICAÇÕES PARA AS RELAÇÕES "NORTE/SUL"
}

\author{
Benjamin Coriat*
}

Numa época em que a maioria das pessoas concorda em que as economias mundiais vêm-se tornando mais e mais "calcadas no conhecimento", a produção e a circulação mundial do saber transformou-se, mais do que nunca, numa questão estratégica. Além disso, o acesso ao conhecimento passou a ser um fator cada vez mais importante, sobretudo para os países em desenvolvimento, que, por enquanto, só podem dar uma contribuição limitada para a geração do saber.

No entanto, não há dúvida de que a dupla tendência que hoje caracteriza a economia mundial e que envolve, por um lado, um movimento de liberalização, e por outro, um uso cada vez mais intensivo do conhecimento, em todas as esferas da atividade humana, também tem sido acompanhada por um aumento antes desconhecido das "barreiras de ingresso" que impedem o acesso ao conhecimento. Na verdade, as mudanças em curso na legislação dos Direitos de Propriedade Intelectual (DPI), efetuadas por solicitação dos Estados Unidos, têm levado à criação de barreiras de natureza institucional (ou seja, novos direitos assegurados por lei e pelos tribunais de justiça), que reservam o uso exclusivo dos novos conhecimentos para o benefício das grandes empresas multinacionais dos países do Centro, ao mesmo tempo que esse direito exclusivo é imposto, através de acordos internacionais, aos mercados internos dos países em desenvolvimento, antes predominantemente protegidos dele.

O processo a que vimos assistindo no campo dos direitos de propriedade intelectual, nos últimos vinte anos, é tão importante e de tão amplas repercussões, que a reflexão sobre as forças que o impulsionam e

\footnotetext{
*Professor de Economia, Universidade de Paris XIII.
} 
sobre o papel desempenhado por esses direitos, como "arranjos institucionais" destinados a promover investimentos na pesquisa e na inovação (a fim de contrabalançar as diversas falhas do mercado nesses campos $^{1}$ ), tornou-se largamente difundida, preparando o terreno para inúmeros debates e controvérsias sumamente atuais.

Este artigo baseia-se numa análise dessas novas tendências no campo dos DPI e de seu impacto nos países em desenvolvimento. Após uma recapitulação sucinta dos principais componentes do novo regime de DPI estabelecido nos Estados Unidos desde a década de 1980, antes de se estender para o resto do mundo (seção 1), procuraremos demonstrar como esse novo regime concretizou mudanças no status das patentes, tendo por um de seus principais objetivos permitir que as autoridades governamentais concedam às grandes empresas vantagens competitivas institucionalizadas (seção 2). Examinaremos em seguida a dimensão imperialista desse novo regime e as vias e meios através dos quais ele se vem estendendo pelo mundo inteiro (seção 3), e usaremos os semicondutores como exemplo para ilustrar essa tese (seção 4). Concluiremos com algumas das implicações desta análise.

\section{Resumo do novo Regime dos Direitos de Propriedade Intelectual ${ }^{2}$}

O novo regime de DPI caracteriza-se, basicamente, pelo fato de duas áreas essenciais se haverem aberto para o registro de patentes: os produtos da pesquisa de entidades vivas, em particular os resultados de pesquisas relacionadas com o genoma, e os programas de computador

\footnotetext{
${ }^{1}$ Os textos que serviram de base para a reflexão posterior nesse campo, pelo menos até o início da década de 1980, foram sobretudo os de Nelson (1959) e Arrow (1962). Esses dois autores demonstraram que, dados alguns dos atributos peculiares da "informação", quando vista como uma mercadoria (a saber, sua indivisibilidade e a incerteza associada a sua produção), as economias de mercado ficam sob a ameaça constante de um subinvestimento nas áreas de pesquisa e desenvolvimento. Determinados arranjos institucionais (alocação de recursos públicos para a pesquisa básica, concessão do direito de propriedade intelectual para compensar investidores privados) tornam-se necessários, do ponto de vista do bemestar social, desde que tais arranjos não estimulem o desenvolvimento de práticas anticompetitivas por parte das empresas que deles se beneficiam.

${ }^{2}$ Esta seção é uma recapitulação muito abreviada de alguns dos argumentos expostos in Coriat e Orsi (2002). Sobre esse tema, o leitor também poderá consultar Jaffé (2000) e R. Eisenberg (2000).
} 
(software) (incluindo os algoritmos matemáticos empregados por eles), assim como, mais recentemente, os chamados "modelos de negócios".

Em ambas as áreas, nas quais se enraíza a atual revolução científica e tecnológica, o registro de patentes foi estabelecido com base em decisões de jurisprudência que "anularam" decisões e doutrinas anteriores, ao final de um processo longo e complexo, marcado por intensos conflitos jurídicos e econômicos, os quais, em última instância, só foram resolvidos mediante recurso às mais altas instâncias judiciais: a Suprema Corte dos Estados Unidos, ou, conforme o caso, os novos Tribunais de Apelação Federais (TAF), criados em 1984 e que, em diversos processos, começaram a desempenhar um papel decisivo na modificação da doutrina vigente sobre os DPI.

- Com respeito às rotinas e programas de computador, depois que uma lei inicial (o Computer Software and Amendment Act [Emenda Legislativa sobre Programas de Computador], de 1980) tentou oferecer uma solução, redefinindo a legislação dos direitos autorais [copyright] a fim de que ela pudesse abarcar tais rotinas e programas, os tribunais de justiça obrigaram todos os interessados a rumar numa outra direção, ao revogarem uma decisão prévia do Escritório de Patentes dos Estados Unidos (US PTO) que se recusara a conceder uma patente nos moldes legais da doutrina existente. Com isso, os tribunais catalisaram a nova ênfase na patenteabilidade. Agora, dentre todas as sentenças jurisprudenciais proferidas no esforço de reafirmar o novo rumo, duas se destacam, pelo impacto que têm exercido. ${ }^{3}$ A primeira (conhecida como Diamond vs. Diehr, 1981) declarou que era possível patentear algoritmos, o que escancarou as portas para a patenteabilidade do software. Ao fazê-lo, essa decisão revogou a jurisprudência anterior, que impedia explicitamente essa possibilidade. ${ }^{4}$ A segunda decisão (Street Bank Trust vs. Signature, 1988) abriu ainda mais a brecha, ao ampliar o alcance dos produtos patenteáveis pela inclusão de patentes de "modelos de negócios ou gerenciais", isto é, simples "métodos de trabalho" relacionados com vários tipos de

\footnotetext{
${ }^{3}$ A esse respeito, o leitor deve consultar um estudo muito preciso de I. Liotard (2002), que levantou a história da patenteabilidade nesse campo. Ver também P. Samuelson (1998) e Mergès (2001).

${ }^{4}$ Ver Besen e Raskind (1991), que forneceram uma documentação muito precisa sobre $\mathrm{o}$ assunto em seu levantamento sobre a propriedade intelectual.
} 
práticas comerciais tidas como automatizadas, na medida em que são exercidas numa plataforma da Internet e/ou de software. O que é digno de nota, nesse ponto, é que os registradores de patentes não são solicitados a revelar os métodos de computação exatos que utilizam. Não é o tratamento desses métodos que constitui a novidade, mas o fato de que os próprios "conceitos" tornam-se objeto de proteção. ${ }^{5}$ Note-se que essas novas práticas criaram enormes conflitos reais ou potenciais entre os detentores de patentes, pois cada editor usa em cada programa de computador centenas de algoritmos, muitos dos quais são hoje protegidos por elas. ${ }^{6}$

- Com respeito às entidades vivas, um primeiro momento-chave foi a decisão de 1980 tomada pela Suprema Corte dos Estados Unidos no caso Charkrabarty, que determinou a patenteabilidade de um organismo unicelular geneticamente modificado. Todavia, essa decisão, que foi um divisor de águas, não passou do ato inaugural de uma série de outras que culminaram, como demonstrou F. Orsi com grande minúcia, na patenteabilidade de seqüências genéticas parciais [SGPs] e também na de genes implicados em doenças (F. Orsi, 2002). Nesse processo, e à parte a decisão sobre Charkrabarty, pelo menos outra grande sentença (a "referente a Brana") desempenhou um papel crucial, já que também revogou a jurisprudência anterior que levara o Escritório de Patentes norte-americano a usar de grande circunspecção na concessão de patentes nesse campo. A decisão "referente a Brana" reconheceu o direito a descobertas ainda não feitas, ou seja, que não se materializaram ou sequer foram descritas até o presente. A criação de um novo direito de propriedade intelectual numa área hipersensível (por lidar, como veremos, com o status de produtos da pesquisa básica e por abranger e determinar as normas de acesso à assistência médica e à medicina) foi acompanhada por grandes controvérsias teóricas (Rai, 2001) e batalhas econômicas, ou, em alguns casos, levou a elas. Ao mesmo tempo, pôs em foco a necessidade de se repensar a dimensão ética de certas leis sobre a propriedade intelectual.

\footnotetext{
${ }^{5}$ Smets Solanes (2000) fornece diversos exemplos típicos de "modelos comerciais" que foram cobertos por patentes, sem que se tenha fornecido qualquer informação sobre os processos computacionais empregados.

${ }^{6}$ Ver maiores detalhes sobre as contradições e problemas criados por esse regime de patentes em Shapiro (2002).
} 
Essa evolução dupla (mas conjunta) dos direitos de propriedade intelectual, inicialmente ocorrida nos Estados Unidos, antes de se estender à maioria dos países desenvolvidos, ${ }^{7}$ requer pelo menos três séries de comentários.

1. Antes de mais nada, nas duas áreas que examinamos sucintamente, é essencial observar que as recentes mudanças (drásticas) na legislação sobre a propriedade intelectual inseriram-se solidamente nas características específicas de uma lei de patentes norte-americana que toma por base o direito comum, e na qual o critério fundamental de patenteabilidade é a pretensa "utilidade" da invenção em causa. A utilidade - propriedade que se refere a produtos das "artes úteis" - implica, basicamente, os avanços industriais e comerciais possibilitados por essa invenção. Nessas condições, a nosso ver, a mudança mencionada há pouco efetivamente consistiu em que, de repente, bastou afrouxar ou alterar o sentido do termo "utilidade" para que áreas não patenteáveis se tornassem patenteáveis. Por exemplo, na decisão referente a Brana, o tribunal considerou que, como o ato em si de destacar as seqüências parciais de genes [SPGs] ${ }^{8}$ era "útil" para futuros avanços do conhecimento, essas entidades haviam-se tornado patenteáveis, apesar de seu status de simples "instrumentos de pesquisa".

2. Outro desdobramento importante foi que se reconheceu aos que pleiteiam registros de patentes o direito de fazer amplas "reivindicações" concernentes a invenções ainda por fazer, e que são inteiramente virtuais (uma vez que é impossível prevê-las). Por exemplo, revogando uma sentença anterior da Suprema Corte, que havia alertado especificamente para esse perigo, as patentes foram trans-

\footnotetext{
${ }^{7}$ Na Europa, apesar da Diretriz da União Européia de 1998, esse processo de ampliação dos novos direitos concernentes a entidades vivas tem deparado com fortes objeções.

${ }^{8}$ Expressed Sequence Tags ou "seqüências parciais" de genes. A utilização desse processo constitui um avanço nos métodos que podem ser usados para identificar as seqüências completas de genes.

${ }^{9}$ Note-se que o modo como se desenvolveu a legislação norte-americana teria sido impossível, por si só, nos termos do direito seguido no continente europeu, no qual a distinção-chave é aquela que separa as "descobertas" (pertinentes ao conhecimento) das "invenções" (pertinentes às artes aplicadas), constituindo estas últimas a única área em que pode ocorrer a concessão de patentes. Entretanto, devemos ainda deixar claro que, mesmo na legislação norte-americana, as mudanças observadas não se calcaram em fatos objetivos ou sequer previsíveis. Quanto a isso, ver a discussão de F. Orsi (2002).
} 
formadas em verdadeiras "licenças de caça". ${ }^{10}$ Já não constituem um "prêmio" concedido ao inventor por sua revelação da invenção. Para a empresa que detém as patentes, elas se transformaram num direito de exploração concedido sob forma monopolista, antes mesmo de uma invenção ser feita e, por conseguinte, revelada.

3. Por último, obviamente não é à toa que as duas áreas em exame constituem campos novos e "emergentes" em que a pesquisa acadêmica norte-americana possuiu e ainda possui uma vantagem relativa considerável. É como se o novo regime de propriedade intelectual houvesse pretendido assegurar que essas vantagens da pesquisa pudessem ser imediatamente transformadas em vantagens competitivas, sendo o produto real da pesquisa diretamente coberto por patentes num nível muito "próximo da nascente", com isso garantindo o direito de excluir as empresas rivais. Como sugere este artigo, mais adiante, não há nada acidental na decisão das autoridades públicas de ajudar a "barrar" o acesso a uma descoberta, a fim de preservá-la sob forma patenteada. Também não é por acaso que essas patentes são concedidas através de licenças exclusivas. ${ }^{11}$

O resultado dessas mudanças é que o ambiente em que os atores operam fica completamente abalado. No cômputo final, essa é uma conseqüência importante das mudanças que descrevemos, nas quais o novo regime se caracteriza pelo fato de implicar um passo decisivo para a dissolução das normas tradicionais e vigentes da "ciência aberta" (Dasbugta \& David, 1994). Tanto na tecnologia de informação quanto em relação às entidades vivas, o novo regime abrange áreas que exibem uma dimensão predominantemente "transversal", para usarmos o significado específico que Arrow confere a esse termo, ao discutir os produtos do conhecimento que constituem "insumos" e "matérias-primas" para muitas outras áreas de inovação (Arrow, 1962). As descobertas doravante patenteáveis ficam freqüentemente "próximas da fonte", situadas num ponto muito alto da cadeia de inovações. Essa mudança deflagrou um debate generalizado na comunidade científica e também entre os economistas especializados em inovações.

\footnotetext{
${ }^{10}$ A despeito de a Suprema Corte haver advertido explicitamente que "uma patente não é uma licença de caça", em sua sentença no caso Brenner vs Manson (cf., a esse respeito, Orsi [2002] e R. Eisenberg [1995]).

${ }^{11}$ Nos termos da estipulação de uma "preferência pela indústria norte-americana", conforme a Lei de Bayh-Dole (ver adiante, seção 2).
} 
Por mais importantes que sejam essas mudanças, o fato é que elas respondem por apenas algumas das alterações introduzidas. Para apreender a totalidade dos efeitos dessa nova era da propriedade intelectual, da pesquisa e desenvolvimento e das inter-relações das inovações, convém examinarmos algumas das cláusulas da lei fundamental nesse campo, ou seja, a Lei de Bayh-Dole, aprovada pelo Congresso norte-americano em 1980.

\section{Das "licenças exclusivas" à "preferência norte-americana": mudanças no status e no papel dos incentivos}

Os estudos sobre os efeitos diretos da Lei de Bayh-Dole já constituem um corpo substancial de textos especializados (Mowery et al., 1999; Mazzeloni e Sampat, 2002). Resta-nos agora apenas fazer uma breve resenha dos pontos essenciais desse corpus, antes de partirmos para nosso objetivo primordial, que é levantar questões sobre o verdadeiro significado dessa lei, dado que as novas medidas por ela estabelecidas devem ser apreendidas à luz das outras mudanças que afetaram o sistema nacional norte-americano de inovações.

Atendo-nos à letra da Lei de Bayh-Dole, sua essência é apresentada por seus comentaristas como sendo a introdução de uma dupla mudança, composta: (1) do estabelecimento de um princípio (em contraste com uma isenção, como ocorria antes da aprovação dessa nova lei) que confere às instituições que recebem verbas públicas (universidades e órgãos públicos de pesquisa) o direito de registrar patentes de suas descobertas; (2) da possibilidade de tais instituições venderem a exploração das citadas patentes, como direitos exclusivos, a empresas particulares, e/ou fundarem com elas empresas de operação conjunta (ficando as universidades na condição de sócias).

Além dessas cláusulas, cuja importância tem sido destacada com freqüência, devemos ainda acrescentar mais uma (que, ao que saibamos, recebeu pouca ou nenhuma atenção na literatura especializada): o Artigo 204 da mesma Lei de Bayh-Dole. Ele afirma uma "preferência norte-americana" toda vez que se concederem licenças de exclusividade, estipulação esta a que retornaremos no final da presente seção.

Com respeito às duas primeiras séries de estipulações, e sem entrar, por enquanto, num debate quanto a tais medidas incentivarem ou não o desenvolvimento de inovações (ou tenderem a fazê-lo no 
futuro), ${ }^{12}$ gostaríamos simplesmente de reexaminar a importância do efeito de complementaridade que nasce da coexistência da criação do novo regime de direitos de propriedade intelectual com a implantação da Lei de Bayh-Dole. Nesse aspecto, tudo decorre do fato de que, na medida em que os principais centros de produção do conhecimento científico (universidades e laboratórios públicos) podem ceder seus produtos sob a forma de licenças exclusivas, estas passam a ser usadas como instrumentos de apropriação de conhecimentos básicos. Isso se dá através de uma série de "monopólios bilaterais" (cf. Dasbugta e David, 1994) que as universidades e laboratórios públicos compartilham com organizações particulares com fins lucrativos - atos estes que dão o toque final ao processo pelo qual os resultados da pesquisa fundamental são transformados em mercadorias privadas (cf. Eisenberg, 2000; Orsi, 2002).

Assim, devemos dar um passo adiante para afirmar que aquilo com que estamos lidando é uma mudança fundamental na maneira como se vem justificando a concessão de patentes. Em termos da teoria do incentivo, isso significa que a justificativa da "premiação" do inventor já não pode ser invocada, uma vez que, como observaram Mazzoleni e Nelson (2000), a pesquisa de que estamos falando é financiada por verbas públicas, ou seja, nesse caso específico, "o patenteamento [já foi] pago aos inventores". Não há nenhuma razão pela qual a sociedade deva "premiar" um inventor cujas pesquisas são feitas com dinheiro proveniente de impostos já pagos pelos cidadãos. Assim, cabe admitir que um efeito colateral sub-reptício das medidas introduzidas pelo Congresso norte-americano é um tipo inteiramente diferente (e radicalmente novo) de "incentivo" concedido a empresas que não participaram da pesquisa fundamental, no esforço de fazer com que elas se comprometam com produtos vendáveis no mercado. Mais ainda - e isso é essencial, em nossa opinião -, as empresas vêm sendo induzidas (pelo benefício das licenças de exclusividade) a se comprometerem antes que qualquer produto dessa natureza tenha efetivamente surgido. Esse tipo particular de incentivo, ao qual Mazzoleni e Nelson (2000) se referem como "teoria da comercialização induzida", talvez seja digno de atenção. No mínimo, ele suscita dois comentários. Primeiro, a recompensa já não é dada a posteriori (visto que o ineditismo, a não-obviedade e a utilidade já foram estabelecidos). Ao contrário, ocorre a priori, acarretando uma

\footnotetext{
${ }^{12}$ Pode-se encontrar uma discussão sobre esse tema em Mazzoleni e Sampat (2002).
} 
transformação no status da patente, que se transmuda de direito de exploração comercial em direito de investigação. Segundo, dado o caráter exclusivo das licenças cuja concessão o Congresso norte-americano vem autorizando, a empresa parece comprometer-se, em princípio, com uma via de inovação construída em torno de toda uma série de monopólios bilaterais concedidos a priori. Essa via é preferida à concorrência entre inovadores que se beneficiem igualmente do livre acesso aos produtos da pesquisa fundamental, como ocorria no sistema antes vigente e era, na verdade, o próprio cerne da política pública, até o início dos anos oitenta. A confusão que isso causa tem criado uma situação que está longe do "ótimo" contemplado na teoria dos incentivos. E suscita questões sobre a verdadeira finalidade da nova orientação.

Deparamos, neste ponto, com outra estipulação essencial da Lei de Bayh-Dole: o já citado Artigo 204, que adquire suprema importância. Intitulado "Preferência pela indústria dos Estados Unidos", o Artigo 204 afirma que os novos direitos concedidos às universidades e instituições financiadas por verbas públicas (e, em particular, o direito de patentear e vender as descobertas sob licenças exclusivas) só serão aplicáveis "se (...) qualquer produto que incorpore a invenção em causa ou seja produzido mediante o uso da invenção em causa for substancialmente fabricado nos Estados Unidos". ${ }^{13}$

Trata-se de uma estipulação crucial. Ela tende a indicar que, substituindo a preocupação anterior com o bem-estar, que havia fornecido a justificativa teórica para os arranjos institucionais que deveriam funcionar como impulsionadores da inovação (Arrow, 1962; Nelson, 1959), passou agora a haver uma outra preocupação, de caráter muito mais prosaico, que consolida uma perigosa proximidade entre o novo regime da propriedade intelectual e algumas teses da política estratégica industrial ${ }^{14}$ formuladas na mesma época. O Artigo 204 é uma

\footnotetext{
${ }^{13}$ Há uma isenção dessa obrigatoriedade no caso de "se haverem empreendido, sem sucesso, esforços para conceder licenças a licenciados potenciais cuja fabricação tenda substancialmente a ocorrer nos EUA, ou nos casos em que, na situação em vigor, a fabricação nacional não seja comercialmente viável" (Artigo 204 da Lei de Bayh-Dole).

${ }^{14}$ Para um livro que faz uma defesa inflexível dessas teses da política estratégica industrial, ver a coletânea de artigos publicada por L. Tyson (1996), ex-Chefe do Conselho de Assessores Econômicos no governo do presidente Clinton. Para uma crítica desse livro, ver esp. Baghwati (1996) e Coriat (2000).
} 
medida sumamente específica - afinal, as vantagens institucionais relativas concedidas às empresas sob a forma de licenças de exclusividade só são oferecidas às companhias capazes de impulsionar a indústria norte-americana. $\mathrm{O}$ resultado é que se materializou uma série peculiaríssima de complementaridades institucionais ${ }^{15}$ no Sistema $\mathrm{Na}$ cional de Inovações [NIS] norte-americano, construindo-se uma cadeia entre patentes "próximas da fonte" (em especial as concernentes aos produtos da pesquisa básica), licenças de exclusividade e uma "preferência pela indústria norte-americana". Em outras palavras, um processo de licenciamento que confere aos detentores o direito de excluir os rivais não norte-americanos caminha de mãos dadas com essa "preferência". Ademais, convém notar que isso acontece já desde a fase de investigação da potencialidade da descoberta científica. E o que revela é uma intenção de "confiscar" o saber, criando formas e regras institucionais que erijam barreiras ao acesso. Ao agir dessa maneira, o governo norte-americano vem proporcionando a suas empresas nacionais a oportunidade de desenvolver todo um conjunto de rendas legalmente garantidas, antes mesmo, muitas vezes, de se haver investido um único centavo na pesquisa. Em outras palavras, o Congresso norte-americano está criando um mercado virtual de renda a preços de pechincha. ${ }^{16}$

Estas considerações assumem uma importância ainda maior, se analisadas juntamente com as medidas grupais sistemáticas simultaneamente tomadas num outro campo, a fim de assegurar a defesa e a promoção internacionais do novo regime de propriedade intelectual que foi concedido às firmas norte-americanas.

\footnotetext{
${ }^{15}$ Empregaremos aqui o conceito de "complementaridade institucional" na acepção mais forte do termo, isto é, no sentido utilizado sobretudo por Aoki (2000) ao definir a situação de "complementaridade institucional" como aquela que implica uma coexistência de regras institucionais de origens variáveis, na qual se abrem espaços de ação novos ou originais para os agentes, vindo essas regras a constituir novos recursos que os agentes podem mobilizar de modo a atender a estratégias que, em seguida, podem assumir dimensões ou objetivos originais. (A esse respeito, ver também Coriat e Weinstein, 2002).

${ }^{16}$ Os custos do ingresso no mercado se reduzem, uma vez que a descoberta é financiada por verbas públicas. Além disso, o direito de explorar a renda virtual quase sempre é remunerado, quando os royalties sobre ela são retransferidos para as universidades - o que pode ocorrer em qualquer época em que a descoberta passe a se autofinanciar.
} 


\section{Do "Artigo 301, Especial" ao \\ Acordo da OMC sobre Aspectos dos Direitos de Propriedade Intelectual Relacionados com o Comércio (TRIPS): a promoção internacional da norma norte-americana}

Ao mesmo tempo que um regime "interno" (à legislação norte-americana) era alterado, tal como mencionamos, o governo dos EUA comprometia-se com uma política ativa que envolvia a defesa e promoção internacionais do novo regime. Com a assinatura dos TRIPS, em 1994, esse processo levaria à criação de um regime mundial de direitos de propriedade intelectual cujos princípios reproduzem a orientação mestra do regime "interno" norte-americano.

O principal instrumento dessa medida foi a adoção, nos termos do “Artigo 301" da Lei de Comércio de 1984, de um conjunto de estipulações específicas, destinadas a promover e assegurar a obediência internacional ao direito de propriedade intelectual conferido a empresas norteamericanas por entidades nacionais dos EUA. Essas normas foram agrupadas num parágrafo específico do "Artigo 301", chamado "Artigo 301, Especial", totalmente dedicado ao direito de propriedade intelectual. E foram reforçadas pela Lei Global de Comércio e Competitividade de 1988, que continua a abranger a legislação norte-americana nessa área. ${ }^{17}$

Em virtude dessas estipulações, os Estados Unidos se conferem, unilateralmente, o direito de praticar represálias contra os países que, mesmo cumprindo acordos internacionais nessa área (como os codificados pelas convenções de Genebra e de Paris, que estão sob a égide da Agência Internacional de Propriedade Intelectual [WIPO]), sejam considerados transgressores das normas que visam proteger o direito de propriedade intelectual das empresas norte-americanas. Em particular, a lei afirma que a Representação Comercial dos Estados Unidos deve adotar medidas unilaterais quando identificar atos que possam ser considerados "injustificados". No entender de Bayard e Eliot, segundo o Artigo 301 (d) (3) (2), um ato é considerado "injustificado" quando se afigura "injusto e desleal, de um modo ou de outro, mesmo que não viole necessariamente os direitos interna-

\footnotetext{
${ }^{17}$ Uma análise mais detalhada da forma como figuram essas estipulações nas versões sucessivas da legislação norte-americana sobre o comércio exterior (até a Lei Global de Comércio e Competitividade de 1988, que continua em vigor) é fornecida num artigo nosso (Coriat, 2000). Ver também Zhang (1994).
} 
cionais dos Estados Unidos nem seja incompativel com eles" (Bayard e Eliot, 1994). Bhagwati, em particular, numa série de ensaios muito divulgados, enfatizou o caráter exorbitante dessas estipulações, que constituem, a seu ver, uma postura de "unilateralidade agressiva", capaz, em suas palavras, de pôr "em risco" o sistema de comércio mundial. ${ }^{18}$

Essa nova vinculação entre o novo regime do direito de propriedade intelectual e as estipulações da legislação norte-americana sobre o comércio exterior deu às autoridades estadunidenses uma margem de manobra que elas têm explorado ativamente. Na prática, o que elas têm feito é usar uma estratégia em duas etapas.

Antes de mais nada, as cláusulas do "Artigo 301, Especial", que têm sido abundantemente usadas, permitem ao governo norte-americano, na pessoa do Representante Comercial dos Estados Unidos, incluir o reconhecimento do direito de propriedade intelectual de empresas estadunidenses nos acordos bilaterais negociados com diversos países. Para esse fim, o Representante Comercial dispõe de uma vasta gama de instrumentos, que vão desde a ameaça de represálias até concessões noutros campos do comércio internacional. Daí a primeira medida tomada pelo Representante Comercial em nome do Artigo 301, nos idos de 1985, contra a Lei de Informática brasileira, seguida por uma segunda medida tomada contra a Coréia em 1986 (Bayard e Eliot, 1994). ${ }^{19}$ Dentro do mesmo espírito, embora por um caminho um pouco diferente, a "Lei de Recuperação Econômica da Bacia do Caribe" (um tratado comercial de 1983 entre os Estados Unidos e os países da região do Caribe) deixou a critério do presidente norte-americano avaliar se os países caribenhos signatários vinham cumprindo o tratado e praticando uma política satisfatória de direito de propriedade intelectual - definida como precondição obrigatória para que esses países pudessem gozar das preferências tarifárias oferecidas pelo acordo (Bayard e Eliot, idem). Nos mesmos moldes, as negociações do Acordo Norte-americano de Livre Comércio (NAFTA) deram ensejo ao acréscimo de um capítulo essencial, em cujos termos

\footnotetext{
${ }^{18}$ A esse respeito, ver seu ensaio de 1991, cujo título, significativamente, é "The World Trading System at Risk" ["O sistema de comércio mundial em perigo"].

${ }^{19}$ Esse livro, do qual extraímos os dados incluídos neste parágrafo, oferece uma análise muito pormenorizada das medidas que precederam a adoção do Artigo 301 Especial, além de estudos de casos relacionados com sua implementação.
} 
os países são solicitados a assinar sua concordância com uma legislação baseada no direito norte-americano (e isto, bem antes da assinatura dos TRIPS), a fim de poderem desfrutar dos cláusulas de livre comércio do tratado.

Tempos depois, haveria uma mudança fundamental na estratégia das autoridades norte-americanas, passando os Estados Unidos a insistir, durante a Rodada do Uruguai, na inclusão de um capítulo sobre a propriedade intelectual. Após negociações demoradas e complexas (que opuseram os países do Ocidente à maioria dos países meridionais), esse processo veio finalmente a culminar nos acordos de Marraquech de 1994, que ficaram conhecidos como TRIPS. Embora o texto final do acordo sobre os TRIPS contenha várias exceções e modificações (essencialmente relacionadas com o desejo da OMC de levar em conta algumas das cláusulas dos tratados supervisionados pela Agência Internacional de Propriedade Intelectual), ${ }^{20} \mathrm{O}$ que ele fez foi obrigar todos os países signatários a alterarem sua legislação nacional, com isso convergindo para a nova norma estabelecida pelos Estados Unidos na década de 1980. Como observaram Reichman e Lange, foi aí que o paradoxo atingiu seu auge, pois passamos de uma situação que refletia a máxima diversidade possível de regimes nacionais de patentes (reconhecida como uma necessidade, dadas as variações no nível de desenvolvimento dos diferentes países) para uma situação de regimes jurídicos os mais homogêneos e padronizados do mundo (Reichman e Lange, 1998).

O exemplo dos semicondutores, que apresentaremos agora, fornece uma ilustração particularmente clara dessa estratégia "de acionamento duplo" que impulsionou a transição de uma situação extremamente heterogênea para a dos TRIPS, sempre destacando a "vocação imperialista" do tipo de regime de propriedade intelectual inicialmente instaurado nos Estados Unidos.

\footnotetext{
${ }^{20}$ Por exemplo, no campo dos biofármacos, "no caso de uma emergência de saúde", o texto dos TRIPS autoriza o país a promover medidas políticas específicas. Como nos relembra R. Mfuka (2002), essa é uma cláusula que, em princípio, deveria ajudar certos países que enfrentam a pandemia da AIDS (em especial o Brasil e a África do Sul) a se libertarem de algumas das regras mais restritivas dos TRIPS. Entretanto, também vale a pena assinalar que tais estipulações não impediram o surgimento de vários conflitos graves.
} 


\section{Uma ilustração: o exemplo da Lei de Proteção dos Semicondutores [SCPA]}

Para apreender em sua plenitude a importância da $\mathrm{SCPA}^{21}$ (que criou um direito original de propriedade intelectual sobre os semicondutores, conhecido pelo nome de "direitos de máscara"), é preciso situarmos o contexto em que evoluíram as discussões pertinentes à nova legislação. Como nos lembra R. Hunt, no alvorecer da década de 1980, os Estados Unidos ficaram traumatizados com a saída de seus maiores fabricantes de semicondutores (liderados pela Intel e pela Motorola) do mercado internacional. Segundo esse autor, "na verdade, as tendências exibidas por essa indústria tornaram-se um catalisador de mudanças drásticas na maneira como os Estados Unidos protegem a propriedade intelectual" (Hunt, 1999). Após décadas de dominação irrestrita, os EUA ressentiram-se profundamente de sua perda de competitividade num campo que haviam criado e no qual se haviam sobressaído, pelo menos até o início dos anos oitenta. Confrontadas com a impressionante ascensão do poder das empresas de semicondutores do Japão (ou até da Coréia, já naquela época), as firmas norte-americanas, a princípio, disseram-se vítimas da utilização, por suas rivais asiáticas, de práticas de "engenharia invertida" - apesar de estas também serem comuns entre as empresas estadunidenses, por permitirem um progresso tecnológico rápido e contínuo. $\mathrm{Na}$ época, R. Hunt resumiu a situação nos seguintes termos: "Na indústria semicondutora dos EUA, a engenharia invertida era uma prática solidamente estabelecida. Mas, no final da década de 1970, as empresas norte-americanas objetaram a uma conduta semelhante por parte das firmas japonesas, quando estas começaram a ampliar sua fatia do mercado nos produtos mais padronizados, como chips de memória de computadores. O nível de competição acabou por se intensificar a tal ponto que, em meados dos anos oitenta, a maioria das empresas norteamericanas abandonou por completo esses segmentos. (...) Quando ficou claro que não mais poderiam dominar as firmas japonesas unicamente com base na tecnologia de produção, as empresas norte-america-

\footnotetext{
${ }^{21}$ A Lei de Proteção dos Semicondutores [Semiconductor Protection Act (SCPA)], aprovada pelo Congresso em 1984, criou um novo direito de propriedade intelectual no tocante às "máscaras", o que se refere basicamente ao modo de projetar microprocessadores. Para uma exposição detalhada da história da SCPA e de seu teor, ver Hunt (1999) e Radomski (2000).
} 
nas tentaram consolidar sua vantagem comparativa na pesquisa e desenvolvimento. Para tanto, precisariam encontrar meios de reduzir a capacidade dos competidores de praticar a engenharia reversa com seus produtos (...). Com vistas a esse objetivo, as firmas norte-americanas começaram a pressionar o Congresso para que ele ampliasse a proteção da propriedade intelectual de seus projetos de semicondutores" (R. Hunt, 1999).

No fim, num clima marcado por uma "síndrome dos gigantes diminuídos" (Baghwati, 1991), esse lobby culminou na adoção da SCPA, em 1984. Mas a história não terminou aí. Na verdade, esse foi seu começo. Isso porque a SCPA, ao lado de cláusulas que prevêem a criação de uma nova lei da "máscara", contém uma série de cláusulas destinadas a garantir a promoção dessa lei no plano internacional. Estas se encontram codificadas no Artigo 902 e sobretudo no Artigo 914 da lei.

Essa parte final da citada lei contém uma série de medidas que permitem ao Representante Comercial dos Estados Unidos estender a legislação norte-americana aos países que demonstrem "boa fé em seus esforços" de cumprir as estipulações da SCPA, ou que estejam introduzindo legislações nacionais semelhantes a essa lei. Mas a verdade é que esse dispositivo legal, que parece muito generoso, deparou com duras críticas, porque, na prática, essa extensão da legislação estadunidense não se dá sem o atendimento de certas condições. A propósito disso, Radomski nos lembra que, "na verdade, o governo dos Estados Unidos exige o acesso a documentos dos governos estrangeiros e se reserva o direito de criticar a legislação estrangeira. Isso pode ser visto por alguns governos estrangeiros como uma usurpação de sua soberania" (Radomski, 2000). O que diz esse autor é que, em certo sentido, essa legislação nacional foi concebida, desde o início, como se fosse uma lei imperialista, ou, para dizer o mínimo, como se tivesse uma vocação imperialista, com os EUA reivindicando unilateralmente o direito, em certas condições, de estender sua própria legislação nacional, numa complementação do direito que o país concedera a si mesmo, com igual unilateralidade, nos termos do "Artigo 301 Especial", de processar os supostos "infratores".

A essência desses estranhos dispositivos, como também observou Radomski, é que "o objetivo do artigo 914 foi estimular o rápido desenvolvimento de um novo regime mundial de proteção para os chips de semicondutores" (Radomski, op. cit.). 
Na verdade, através de desvios e protocolos que descreveremos mais adiante, a nova legislação nacional norte-americana, tal como incorporada na SCPA, transformou-se rapidamente numa lei internacional. Tudo transcorre segundo um processo em duas etapas: (1) primeiro a lei é inserida em acordos bilaterais, e (2) uma vez conseguido isso, tais acordos bilaterais são apresentados como provas aos organismos internacionais, que deverão promovê-los ao status de acordos multilaterais e transformá-los numa norma internacional. O mecanismo geral descrito no parágrafo citado (no qual os acordos bilaterais são pressionados nos moldes do Artigo 301, antes de se transformarem em acordos multilaterais) é particularmente bem ilustrado pelos semicondutores, campo em que os eventos se desdobraram da seguinte maneira:

\section{i) O processo de bilateralização}

Por um lado, os direitos previstos na SCPA já vinham sendo estendidos, em 1985, nos termos do Artigo 904, à Grã-Bretanha e à Austrália. ${ }^{22}$ Por outro lado, após as devidas negociações, os principais parceiros comerciais dos Estados Unidos nesse campo enquadraram-se na lei norte-americana e modificaram sua própria legislação nacional. Isso também ocorreu no Japão, em 1985, com a implementação da "Lei do Design de Semicondutores", e nos Estados Unidos, com sua Diretriz de 1987. Seguiu-se a Lei Coreana, embora esta contivesse uma cláusula de "licenciamento compulsório" que entraria em vigor em três situações (defesa nacional, proteção contra as práticas anticompetitivas dos detentores de patentes e abuso da posição de dominação no projeto de semicondutores).

No fim, depois de os dispositivos dos Artigos 902 e 914 perfazerem um longo caminho na consecução de seus objetivos, chegou a hora de passar dos acordos bilaterais para acordos multilaterais generalizados.

\footnotetext{
${ }^{22}$ Muito embora, como Radomski também assinala, "nenhum desses dois países tivesse feito um progresso significativo, na época, na aprovação de leis sui generis para a proteção dos chips de computador" (op. cit.). Além disso e na realidade, nessa ocasião, uma lei de direitos autorais que diferia expressivamente da SCPA protegia a Grã-Bretanha. A partir de 1989, contudo, a legislação britânica aproximou-se mais da norte-americana, através de uma emenda introduzida na Lei de Direitos Autorais, Projetos e Patentes [Copyright, Design and Patent Act].
} 
ii) A mudança para o multilateralismo: um processo mais complexo, em duas etapas

Os primeiros esforços feitos nesse sentido fracassaram. A partir de 1989, a pedido dos Estados Unidos, tiveram início as negociações sobre um suposto tratado, a ser chamado de WIPIC (Washington Intellectual Property in Respect of Integrated Circuits [Tratado de Propriedade Intelectual de Washington com Respeito aos Circuitos Integrados]). Os debates foram realizados sob os auspícios da WIPO, ${ }^{23}$ a única organização, na época, autorizada a lidar com a propriedade intelectual no nível internacional. Como observou Radomski, o clima em Washington era de "controvérsia", havendo nada menos de cinco propostas em debate. Todas se baseavam em cláusulas da SCPA, mas o Terceiro Mundo manifestou sua resistência em três áreas: a preservação da possibilidade do licenciamento compulsório, a salvaguarda do princípio de que a resolução de conflitos deveria ocorrer sob os auspícios da WIPO, e a inexistência de sanções no caso de "infrações inocentes" (enquanto o contingente norte-americano exigia o pagamento de royalties nessa eventualidade).

A segunda tentativa foi coroada de êxito, transformando-se no tratado dos TRIPS, assinado em 1994. Observem-se seus artigos 35 a 38, dedicados à "Proteção da Topografia dos Circuitos Integrados".

A razão principal do sucesso dos TRIPS proveio de que, no contexto mais amplo da OMC, os Estados Unidos puderam pôr na mesa um poder de barganha adicional, o que não conseguiriam no âmbito da WIPO, onde se presumia que as negociações cobrissem apenas as cláusulas relacionadas com o direito de propriedade intelectual. $\mathrm{O}$ acesso aos mercados internos, o aumento das quotas de exportação, a redução das barreiras tarifárias de diferentes tipos de produtos, tudo isso foi posto na mesa, em troca do compromisso dos países signatários de introduzirem uma legislação nacional baseada no modelo da SCPA. Por si só, a transferência do âmbito da negociação da WIPO para a

\footnotetext{
${ }^{23}$ A Agência Internacional de Propriedade Intelectual. Convém lembrar que, na época, a WIPO era a única instituição guardiã dos tratados internacionais sobre propriedade intelectual. Assim, era um ponto de passagem obrigatório para qualquer acordo multilateral sobre esses direitos de propriedade. Cabe também assinalar que qualquer novo acordo sob a égide da WIPO só podia ser aprovado pela maioria de dois terços dos paísesmembros, segundo o princípio de um voto por cada país.
} 
OMC já foi uma grande vitória para os Estados Unidos. À parte o fato de que os EUA puderam, dentro do contexto "global" da OMC, exercer plenamente o seu poder de barganha, incluindo na equação o acesso a seu mercado interno, há também o fato de que, na OMC, eles deixaram de ser a minoria de um que tinham sido na WIPO, onde prevalecia o princípio de "um voto por cada nação" (Zhang, 1994).

Esses dados explicam por que se chegou ao acordo final, com o Terceiro Mundo cedendo nos três pontos sensíveis que haviam obstruído o pretendido Tratado de Washington (inexistência de licenciamento compulsório, resolução de conflitos no âmbito da $\mathrm{OMC}$, pagamento de royalties mesmo no caso de "infrações inocentes"). No fim, como disse Radomski, a proteção conferida pelos TRIPS “foi ainda maior do que a proporcionada pela SCPA” (idem).

Noutras áreas altamente sensíveis, houve processos semelhantes ao que acabamos de descrever para chegar aos TRIPS. Um bom exemplo são os biofármacos, caso em que o regime de direito de propriedade intelectual vigente na maioria dos países desenvolvidos vem sendo estendido ao Terceiro Mundo. As propostas norte-americanas nesse campo obtiveram rapidamente a aprovação e o apoio das grandes empresas farmacêuticas multinacionais. Durante as negociações de Marraquech, uma verdadeira coalizão dos "poderes estabelecidos" conseguiu impor a mudança para um regime de direito de propriedade no campo da medicina, o que privará (e já priva, se considerarmos o caso da pandemia de AIDS) dezenas de milhões de pessoas, no mundo inteiro, do acesso à assistência médica.

Dado o seu estabelecimento nas circunstâncias que acabamos de citar, não surpreende descobrirmos que a aplicação do TRIPS tem causado grandes conflitos, em especial nas questões de saúde pública. Uma vez que seus efeitos no comércio Norte/Sul, tais como podemos começar a avaliá-los e medi-los (Aboites e Cimolli, 2002), parecem totalmente incapazes de eliminar as desigualdades ligadas ao comércio (ao contrário do que afirmam os proponentes dessa política), o que temos testemunhado, em muitas áreas, é um espetáculo de grandes conflitos.

Um exemplo notável, extraído do campo altamente sensível do acesso à assistência médica, é o da terapia anti-AIDS, na qual o tratamento se baseia em drogas anti-retrovirais protegidas por patentes. Desde o acordo dos TRIPS, a produção (ou a importação) de medicamentos genéri- 
cos nos países do hemisfério sul foi congelada. Os recentes conflitos entre empresas farmacêuticas e o governo da África do Sul, ou entre os Estados Unidos e o Brasil, ligados ao direito de recorrer ao licenciamento compulsório a fim de produzir medicamentos genéricos por um custo mais baixo (Orsi et al., 2002), fornecem uma ilustração clara do tipo de problemas econômicos e éticos das relações Norte/Sul que podem decorrer da aplicação da nova lei de propriedade intelectual. A situação fica ainda mais insustentável na medida em que, durante os ataques feitos com antraz depois de setembro de 2001, os Estados Unidos não hesitaram em acionar as cláusulas de licenciamento compulsório e fazer a suas empresas farmacêuticas encomendas de dezenas de milhões de unidades de um medicamento protegido por uma patente da Bayer Company, que foi obrigada a concordar com reduções drásticas em seus preços de venda. Nesse tipo de situação e ainda no contexto do mesmo tipo de problema, por quanto tempo se pode impedir os países do Terceiro Mundo de usarem mecanismos competitivos para garantir sua obtenção de drogas anti-retrovirais?

Por trás do mal-estar atual encontra-se o fato de que, na nova doutrina do direito de propriedade intelectual, a própria referência à teoria do bem-estar sofre uma violenta transformação. A utilidade "social" já não parece constituir o fundamento da obtenção de patentes e outros direitos de propriedade intelectual. Ao contrário, criou-se uma cadeia destinada a oferecer às empresas que se beneficiam da nova legislação da propriedade intelectual vantagens relativas criadas institucionalmente e a priori, ficando implícita a tese de que o que é bom para elas é necessariamente bom para a economia mundial. A "preferência pela indústria norte-americana", estipulada no Artigo 204 da Lei de Bayh-Dole, parece constituir parte de um projeto mais amplo, cujo propósito é assegurar a aplicabilidade internacional do novo regime legal instituído pelos Estados Unidos. Medidas análogas já foram tomadas com freqüência noutras nações ricas do mundo. Assim, no que concerne ao acesso ao conhecimento, uma verdadeira coalizão de "poderosos" vem governando a nova ordem mundial.

Se as economias mundiais de fato passaram a fazer um uso mais intensivo do conhecimento, barrar o acesso a ele (através da extensão de patentes, que não passam de puras barreiras institucionais) não é, com certeza, o modo mais adequado de ajudar os países em desenvolvimento a crescer, a fim de que possam firmar-se sobre os próprios pés e 
dar sua contribuição para o crescimento e para o bem-estar que deveríamos estar contemplando. ${ }^{24}$

Se a meta é passar de um sistema que leva constantemente ao confronto para um sistema que destaque a cooperação, é urgente que as normas relacionadas com o acordo dos TRIPS sejam revistas e redefinidas.

\section{Referências bibliográficas}

ABOITES, J. e CIMOLLI (2002) "Intellectual Property Rights and National System of Innovation. Some Lessons from the Mexican experience", a ser publicado na Revue d'Économie Industrielle.

AOKI, M., Information, Corporate Governance and Institutional Diversity, Oxford University Press, 2000.

ARROW, K., "Economic Welfare and Allocation of Resources for Inventions", in R. R. Nelson (org.), The Rate and Direction of Inventive Activity, Princeton, NJ : Princeton University Press, 1962.

BESEN, M. e RASKIND, "An introduction to the Law and Economics of Intellectual Property", in Journal of Economic Perspectives, vol. 5, nº 1, inverno de 1991, p. 3-27.

BHAGWATI, J., The World Trading System at Risk, Princeton University Press, 1991.

BAYARD, T. e ELIOTT, K., Reciprocity and Retaliation in US Trade Policy, Institute for International Economics, Washington DC, 1994.

CORIAT, B. e ORSI, F. (2002), "Establishing a New Regime of Intellectual Property Rights in the United States. Origins, Content, Problems", a ser publicado, Research Policy.

CORIAT, B., ORSI, F. e WEINSTEIN, O., "Science-Based Innovation Regimes and Institutional Arrangements: from Science-Based ' 1 ' to ScienceBased '2' Regimes', artigo apresentado na Druid Summer Conference, Copenhagen, 2002, entregue à revista Industry and Innovation .

\footnotetext{
${ }^{24}$ Para não falar nos problemas e contradições que isso cria nos sistemas de inovação dos próprios países desenvolvidos. Quando o conhecimento se transforma numa mercadoria passível de apropriação privada, o que acontece é que se apresenta aos inovadores uma série de obstáculos que eles têm de superar. Isso leva ao que Heller e Eisenberg (1998) chamam de "tragédia antiplebe". Para outras discussões sobre esse tema, ver Rai (2001), Coriat e Orsi (2002), Coriat, Orsi e Weinstein (2002).
} 
CORIAT, B. e WEINSTEIN, O., "Organizations, Firms and Institutions in the generation of innovations", Research Policy, fevereiro de 2002, no 31, p. 273-290.

CORIAT, B., "Entre politique de la concurrence et politique commerciale: quelle place pour la politique industrielle de l'Union Européenne", in Lorenzi e Cohen (orgs.) Les Politiques industrielles européennes, Cahiers du Conseil d'Analyse Economique, primeiroministro, La Documentation Française, Paris, 2000.

DASGUPTA, P. e DAVID, P., "Toward a New Economics of Science", Research Policy 23(5), 1994, p. 487-521.

EINSENBERG, R., "Corporate Strategies and Human genome", in Intellectual Property in the Realm of Living Forms and Materials, Ata do Colóquio da Academia de Ciências, outubro de 1995, org. Technique et Documentation, p. 85-90.

EINSENBERG, R., "Analyse This: A Law and Economics Agenda for the Patent System”, Vanderbilt Law Review, vol. 53, 2000, p. 6.

HELLER, M. A. e EINSENBERG, R., "Can Patent Deter Innovation? The Anticommons in Biomedical Research”, Science, vol. 280, 1998, p. 698-701.

HUNT, R. M., "Patent Reform: A Mixed Blessing for the US Economy", in Business Review, Federal Bank of Philadelphia, novembro-dezembro de 1999.

JAFFE, B. J., "The US Patent System in Transition: Policy Innovation and the Innovation Process", Research Policy, 29, 2000, p. 531-557.

LIOTARD, I. (2002), "La Brevetabilité des logiciels: les étapes clés de l'évolution jurisprudentielle aus États Unis", a ser publicado, Revue d'Économie Industrielle, Paris.

MAZZOLENI, R. e NELSON, R., "The Costs and Benefits of Strong Patent Protection. A Contribution to the Current Debate", Research Policy, 2000.

MERGES, R., "As Many as Six Impossible Patents Before Breakfast: Property Rights for Business Concepts and Patent System Reform", Berkeley Technology Law Journal, 2001

MFUKA, C., "Accords ADPIC et Brevets Pharmaceutiques: le difficile accès des pays en développement aux médicaments Anti-Sida", 2002.

MOWERY, D. C., NELSON, R. R., SAMPAT, B. N. e ZIEDONIES, A. A., "The Effects of the Bayh-Dole Act on US University Research and Technology Transfer", in L. Branscomb, F. Kodama e R. Florida (orgs.), ..., 1999. 
MOWERY, D. C. e ROSENBERG, N., "The US National Innovation System", in R. Nelson, National Innovation Systems. A Comparative Analysis, Oxford University Press, 1993.

NELSON, R., "The Simple Economics of Basic Scientific Research", Journal of Political Economy, 67, 1959, p. 297-306.

ORSI, F. (2002), "La constitution d'un nouveau droit de la propriété intellectuelle sur le vivant aux États Unis: Origine et signification d'un dépassement de frontières", a ser publicado na Revue d'Economie Industrielle.

ORSI, F., CORIAT, B. e WEINSTEIN, O., From Marrakech to Doha: Some Reflexions on the Foundations of Patent Regimes in the Pharmaceutical Industry, artigo apresentado no XIV Congresso Internacional sobre a AIDS, Barcelona, junho de 2002.

RADOMSKI, “The SCPA Sixteen Years After", Berkeley Law and Technology Journal, 2000.

RAI, A. K., "Fostering Cumulative Innovation in Biopharmaceutical Industry: The Role of Patents and Antitrust", Berkeley Technology Law Journal, vol. 16, 2001, $\mathrm{n}^{\circ} 2$.

REICHMAN, J. e LANGE, D., "Bargaining around the TRIPS Agreement: The Case for Ongoing Public-Private Initiatives to Facilitate Worldwide Property Transactions", Duke Journal of Comparative \& International Law, vol. 9, 1998, p. 11.

SAMUELSON, P. (1998) "Economic and Constitutional Influences on Copyright Law in the United States", disponível na página http:/ www.berkeley.edu.

SHAPIRO, C. (2001) Navigating the Patent Thicket: Cross Licenses, Patents Pools, and Standard-Setting, disponível na página http:/ haas.berkeley.edu/-shapiro/thocket.pdf.

SMETS-SOLANES, J.P., Stimuler la concurrence et l'innovation dans la société de l'information, Document de Travail, Version 1.0, beta 5, cópia, 2000.

TYSON, L., Who's Bashing Whom? Trade Conflicts in High Technologies Industries, Institute for International Economics, Washington DC, 1996.

ZHANG, S., De l'OMPI au GATT. La protection internationale des droits de propriété intellectuelle, Paris, ed. IITEC, 1994. 


\section{O NOVO PARADIGMA DO \\ DESENVOLVIMENTO E SUAS INSTITUIÇÕES: \\ CONHECIMENTO, TECNOLOGIA DA INFORMAÇÃO E \\ RECURSOS HUMANOS. PERSPECTIVA COMPARADA \\ COM REFERÊNCIA À AMÉRICA LATINA}

Manuel Castells*

\section{Introdução}

Alguns observadores afirmam que a década de 1990 na América Latina pode ter-se perdido em termos do desenvolvimento, como aconteceu com a de 1980. Trata-se de uma afirmação injustificada, ainda que os dados sobre a pobreza, a desigualdade, a exclusão social, a produtividade econômica e a competitividade econômica continuem a ser preocupantes no que concerne à maioria dos países da região. ${ }^{1}$ As reformas macroeconômicas destinadas a controlar a inflação, racionalizar os gastos públicos e fortalecer o sistema financeiro foram absolutamente necessárias para ligar a América Latina à economia global informatizada que caracteriza nosso mundo. Uma vez feita a opção, no final dos anos oitenta, para tirar proveito dos benefícios potenciais de articular a região com o novo sistema global, a começar pelos mercados financeiros e pelo comércio internacional, as políticas de ajuste tornaram-se um imperativo. Em sua maioria, foram tecnicamente bem-sucedidas, embora com um elevado custo social. Mas, do ponto de vista do início do século XXI, os resultados da política adotada na maioria dos países revelaram os limites de um modelo unilateral de reforma econômica. ${ }^{2} \mathrm{~A}$ estabilidade macroeconômica, com efeito, é a base do atual modelo de desenvolvimento na América Latina e noutros lugares, porque só em condições de estabilidade os investimentos de capital podem fluir livremente, o comércio pode basear-se num sistema comum de pagamentos,

\footnotetext{
* Professor de sociologia e professor de planejamento, Universidade da Califórnia em Berkeley.

${ }^{1}$ Ver os diversos Relatórios sobre Desenvolvimento Humano da região, preparados pelo Escritório do Projeto de Desenvolvimento da ORGANIZAÇÃO DAS NAÇÕES UNIDAS.

${ }^{2}$ Ver a análise e os dados de Bernardo Kliksberg, neste volume.
} 
a transferência de tecnologia pode avançar e o processo de trabalho pode funcionar em condições de desempenho similares. Mas, se a estabilidade é uma condição necessária para o desenvolvimento, ela não é uma condição suficiente para o desenvolvimento, nem econômico nem social. Como afirmaram analistas, críticos e líderes políticos em debates a respeito da região, o crescimento econômico, na nova economia aberta, deve ser complementado por uma política de redistribuição. Contudo, para poder redistribuir, primeiro os países precisam gerar riqueza. Isso significa que a ênfase precisa voltar, como nos bons tempos da economia desenvolvimentista, para o crescimento econômico fundamentado na produtividade e para a geração das condições dessa produtividade: o desenvolvimento das forças produtivas. O problema é que, hoje em dia, as forças produtivas não se medem em toneladas de aço nem em quilowatts, como diriam Henry Ford ou Lênin, mas na capacidade inovadora de gerar valor agregado através do conhecimento e da informação. Esse modelo de crescimento econômico baseado no conhecimento é o mesmo em toda parte, como foi a industrialização no paradigma de desenvolvimento anterior. Ele requer o uso de tecnologias de informação e comunicação baseadas na eletrônica, mas não é resultado da tecnologia: é produto de um conjunto de condições inter-relacionadas que pretendo explicitar neste artigo. A verdade é que, como no caso do modelo da economia industrial, a dinâmica do desenvolvimento tem que ser adaptada às condições específicas de cada sociedade e cada nível de desenvolvimento.

Assim, para discutir a transformação do modelo de desenvolvimento da América Latina em relação à economia baseada no conhecimento, no contexto global, primeiro definirei qual é esse paradigma de desenvolvimento, para em seguida me concentrar nos mecanismos específicos que relacionam o saber e a inovação com a produtividade e a competitividade. Uma vez que existem diferentes modelos alternativos dessa economia do conhecimento, apresentarei duas perspectivas analíticas, uma baseada na observação da nova economia da Califórnia no fim da década de 1990, outra baseada na dinâmica da Finlândia no mesmo período, uma vez que a Finlândia é considerada a Sociedade de Informação número um no mundo, e seu desempenho econômico é comparável ao dos Estados Unidos nos primeiros estágios da nova economia. Em seguida, examinarei a especificidade da América Latina no contexto dessa compreensão plural dos meios e modos da nova economia pautada pelo conhecimento. A esperança é que isso possa estimular 
o debate sobre o desenvolvimento em termos menos tradicionais do que aqueles a que nos acostumamos.

\section{O novo paradigma do desenvolvimento}

Há uma nova economia em expansão por todo o mundo, impulsionando a produtividade e criando prosperidade, porém num padrão muito desigual. Essa economia caracteriza-se por três aspectos inter-relacionados.

- Informacional: a produtividade e a competitividade baseiam-se nos conhecimentos e na informação, impulsionados pela tecnologia de informática. Isso se traduz, essencialmente, na necessidade de uma infra-estrutura tecnológica e no papel crucial de recursos humanos altamente qualificados.

- Formação de redes: a nova economia garante a produtividade e a flexibilidade com base em redes impulsionadas pela informática redes intra- e interempresariais, redes entre regiões e redes descentralizadas em torno de nodos. A nova arquitetura global constrói-se em torno de fluxos entre nodos dinâmicos. $\mathrm{O}$ aspecto negativo dessa dinâmica é que o sistema permite a conexão e o desligamento de regiões e até de países, de acordo com sua contribuição para a cadeia de valor estruturada em torno dessas redes globais.

- A nova economia é uma economia global. A economia global é um novo tipo de economia. É a economia cujas atividades nucleares têm a capacidade de funcionar como uma unidade em determinado momento, em escala planetária. Essa capacidade precisa ser entendida em termos tecnológicos, institucionais e organizacionais. No plano tecnológico, ela se baseia nas telecomunicações, no transporte veloz e nos sistemas informatizados. Institucionalmente, baseia-se na desregulamentação, na liberalização e na privatização. Em termos organizacionais, baseia-se na ligação das empresas em redes e em formas flexíveis de gestão e trabalho. A dimensão-chave da globalização é a globalização financeira - os mercados financeiros são hoje globalmente interdependentes e funcionam eletronicamente em tempo real, contornando os controles governamentais e determinando o destino das economias (por exemplo, em 2001, os mercados financeiros negociaram, em média, cerca de dois trilhões de dólares norte-americanos por dia). Mas também o núcleo da produção de bens e serviços é globalizado, organizado em 
torno de empresas multinacionais e suas redes de apoio, que respondem por cerca de $30 \%$ do PIB global. O comércio internacional também é uma dimensão importante da globalização, mas sua expansão é sobretudo uma função da internacionalização da produção, visto que as empresas multinacionais e suas redes respondem por cerca de $2 / 3$ do comércio internacional, incluindo os mais ou menos $40 \%$ do comércio que ocorre dentro de uma dada empresa e suas redes. A ciência e a tecnologia, assim como o trabalho altamente qualificado, também se organizam em escala global. E a migração do trabalho não qualificado vem aumentando em toda parte. A economia global é sumamente segmentada: nem todos são incluídos, mas todos são afetados.

Essa nova economia tem novas regras.

- É movida pela Internet e por outras redes de computadores - o equivalente da máquina elétrica da era industrial -, que possibilitam o funcionamento da empresa em rede, equivalente histórico da fábrica industrial. As tecnologias da informação e da comunicação, que incluem sistemas de transporte informatizados, estão na base da conectividade e da produção baseada no conhecimento.

- Novas regras do trabalho: a mão-de-obra altamente qualificada é crucial - flexível, adaptável, autoprogramável e capaz de inovar, trabalhando em empresas flexíveis.

- Novas regras do capital: os mercados financeiros são o cerne da realização de valor. $\mathrm{O}$ aumento do valor das ações substitui os lucros como determinante da nova economia, já que é o critério principal para atrair investimentos. A valorização no mercado é movida pela informação - da qual um dos elementos é o lucro, embora não o único. A longo prazo, sim, os lucros (expressando a produtividade) têm que estar presentes, para que o crescimento seja economicamente sustentável. Mas os lucros podem vir como resultado do investimento no trabalho e na produção, e esse investimento é atraído por mecanismos de valorização das ações que são movidos por turbulências da informação nos mercados financeiros. Como disse Paul Volcker, num livro que escrevemos em co-autoria, "Os fluxos de capital e sua valorização nos mercados financeiros livres são tão influenciados pelas percepções quanto pela realidade objetiva - ou, talvez em termos mais exatos, a percepção é a 
realidade". ${ }^{3}$ Isso não é especulação, uma vez que esse processo gera valor a partir do investimento - nos bens, nos serviços e, cada vez mais, na produção imaterial (programas de computador, entretenimento, consultoria, pesquisas etc.). Entramos numa fase de volatilidade financeira sistêmica. Em vez de esperar em vão que a bolha estoure, para podermos retornar a um estado de equilíbrio do mercado, temos de aprender a viver em águas efervescentes. $\mathrm{O}$ aumento do valor das ações é determinado pelas expectativas e pela confiança, bem como por sua combinação certa: nos mercados emergentes, há grandes expectativas mas pouca confiança, de modo que o capital está sempre pronto para entrar e sair - como acontece nas economias avançadas. Nesse bravo novo mundo financeiro, as ações converteram-se em moeda, uma vez que as empresas utilizam as suas para adquirir outras ações e para remunerar com opções de compra de suas ações os seus empregados e consultores mais valiosos. A economia imaterial é uma economia real. O desempenho das empresas nessa economia baseada na informação, movida pela informação e valorizada pela informação determina o destino de pessoas e países. ${ }^{4}$

\section{Conseqüências para o desenvolvimento}

- A lógica de formação de redes do novo sistema global permite integrar numa rede tudo o que é valioso e, ao mesmo tempo, desligar dela tudo o que não tem valor ou é desvalorizado, conforme os critérios dominantes nas redes globais de capital, informação e poder. Portanto, o mundo já não se divide entre Norte e Sul, mas entre áreas e pessoas que estão ligadas a essas redes ou desligadas delas. Essa tendência levanta a questão fundamental de como difundir o dinamismo dos nodos meridionais das redes globais para o Sul como um todo.

- A conectividade global e a infra-estrutura da tecnologia de informação são condições necessárias mas não suficientes de desenvolvimento. Contudo, num país subdesenvolvido e empobrecido, por que investir numa infra-estrutura dispendiosa, se não há serventia para ela? Isso se transforma num círculo vicioso que perpetua o subdesenvolvimento.

\footnotetext{
${ }^{3}$ VOLCKER, Paul, "A Sea of Global Finance”, in HUTTON, Will e GIDDENS, Anthony (orgs.). On the Edge: Living in Global Capitalism, Londres, Jonathan Cape, 2000, p. 78. ${ }^{4}$ CASTELLS, Manuel, "Information Technology and Global Capitalism", in Hutton e Giddens (orgs.), op. cit., 2000.
} 
- Os recursos humanos são cruciais; a rigor, essa é a infra-estrutura essencial, sem a qual a tecnologia não significa nada. A nova economia é uma economia baseada em pessoas. Isso quer dizer instrução. Mas instrução não é a institucionalização de crianças em escolas deficientes. As questões-chave são a formação de professores e a reforma do sistema de ensino, passando para uma nova pedagogia adaptada à Era da Informação. O sistema universitário desempenha um papel crucial na nova estratégia de desenvolvimento, tanto na formação quanto na pesquisa. Outrossim, além do sistema de ensino, há uma necessidade crescente de um processo multifacetado de aprendizagem social ao longo da vida inteira.

- Os mercados financeiros globais garantem acesso a fontes de capital de toda parte, mas também deixam os países vulneráveis às inversões repentinas dos fluxos financeiros. É preciso ir gerando confiança, juntamente com as expectativas.

- O comércio, por si só, não funcionará como um instrumento do desenvolvimento. Esse comércio é a expressão de um sistema de produção internacional, de modo que a questão crucial, para qualquer país ou região, é integrar-se nesse sistema de produção internacional. Desenvolvimento significa, na verdade, a capacidade de aumentar o valor produzido em cada nodo, aumentando a competitividade com base numa produtividade maior. Por exemplo, a percentagem do comércio internacional no PIB da África sub-saariana é menor que nos países da OCDE. Mas o que a África exporta é cada vez mais desvalorizado, no confronto com o valor dos serviços avançados e dos produtos de alta tecnologia. A espiral ascendente da competitividade passa pela produtividade maior. A espiral descendente passa pela redução de custos, particularmente os da mão-de-obra e os custos ambientais. Há um círculo virtuoso de expansão da demanda e da produtividade para todos, através do desenvolvimento informacional. E há um círculo vicioso no esforço de vender mais barato do que os outros concorrentes, de modo que a maioria dos países acaba ficando mais pobre, enquanto as economias dominantes tiram proveito desse padrão de competição internacional. Na nova economia, a produtividade requer uma sólida base tecnológica, da qual a Internet é a expressão mais direta. Portanto, os países não precisam produzir a Internet nem desenvolver uma indústria da Internet. Mas todos os países, para serem produtivos e competitivos, precisam produzir, vender e administrar usando a Internet. A tecnologia da informação é a eletricidade da Era da Informação e a Internet é o equivalente da máquina a 
motor, situada na base das formas organizacionais: a fábrica da era industrial, a rede da Era da Informação.

\section{A diversidade de modelos da nova economia}

Vivemos numa economia global e interdependente, caracterizada pelo surgimento de um novo modelo de crescimento econômico que se vem disseminando pelo planeta, em virtude de sua vantagem competitiva superior. Esse modelo é específico, como são todos os novos modelos econômicos de crescimento, em decorrência de sua função de produção característica, ou seja, da combinação específica de fatores de produção que levam ao aumento de produtividade. Se podemos falar de uma nova economia, não é por causa da formação de redes nem da Internet (que são apenas meios para aumentar a produtividade), mas por uma aceleração do aumento da produtividade, particularmente nos Estados Unidos, terra natal da nova economia, durante o período de 1996-2002, em comparação com o de 1975-1995, de baixo aumento da produtividade. $\mathrm{O}$ aumento da taxa de crescimento da produtividade é particularmente notável quando referido ao período decorrido entre o terceiro trimestre de 2000 e o quarto trimestre de 2002 , ou seja, durante a fase declinante da economia de alto crescimento. Quando a taxa de crescimento da produtividade continua a aumentar durante períodos de crescimento lento, ou até de declínio, isso quer dizer que ela não resulta do ciclo comercial, mas de uma transformação da função de produção.

Entretanto, as condições em que a produtividade e a competitividade aumentam, nos moldes do novo paradigma do crescimento econômico, variam conforme os contextos institucionais e sociais. Assim, para ilustrar o núcleo comum dessa nova economia baseada no conhecimento e, ao mesmo tempo, sua variação em contextos específicos, apresentarei uma análise sucinta de dois modelos da nova economia, um na Califórnia e outro na Finlândia, no período de 1996-2000. Embora o contexto da América Latina seja claramente diferente, as lições extraídas dessas análises podem ser úteis para o exame das condições de crescimento e redistribuição econômicos latino-americanos dentro do novo paradigma desenvolvimentista. A bem da simplicidade, os dois processos serão esquematicamente representados como gráficos. Devo advertir que, dentro dos limites deste artigo, não há espaço para expor e analisar os dados empíricos em que esses gráficos se baseiam. Remeterei o leitor aos textos que fornecem algumas informações de apoio sobre a análise aqui apresentada. 


\subsection{O modelo californiano da nova economia}

A nova economia emergiu nos Estados Unidos, com epicentro na Califórnia, em meados da década de 1990. Sua existência pode ser estabelecida com base no índice mais alto de aumento da produtividade e na maior competitividade das empresas, em decorrência das inovações. ${ }^{5}$ Essas inovações dizem respeito à tecnologia, aos processos e aos produtos. As novas tecnologias de informação e comunicação, e particularmente a Internet e outras redes de computadores, são cruciais na economia do conhecimento, uma economia que se alicerça no processamento da informação e na capacidade de comunicação. O processo é transformado pela criação de redes, como uma forma eficiente e flexível de gerenciamento e organização. É claro que a formação de redes é altamente dependente da tecnologia de comunicação baseada na microeletrônica. Essas transformações sociotécnicas abrem caminho para toda uma gama de produtos novos e, quando esses produtos atendem à demanda real da sociedade, eles criam imensos mercados novos, como no caso dos telefones celulares e, mais adiante, dos dispositivos móveis de acesso à Internet.

A própria inovação é função de três fatores principais: (a) a criação de novos conhecimentos na ciência, na tecnologia e na administração. Os novos conhecimentos dependem de um sistema de P\&D, tanto público quanto privado, capaz de suprir os elementos fundamentais da inovação; (b) a disponibilidade de mão-de-obra altamente instruída e autoprogramável, capaz de usar os novos conhecimentos para aumentar a produtividade. Esse tipo de mão-de-obra pode ser fornecido por sistemas de ensino de alta qualidade, pela imigração ou por ambos, como acontece na Califórnia; (c) a existência de empresários competentes e dispostos a assumir o risco de converter projetos comerciais inovadores em empresas. Isso está relacionado com a cultura empresarial, mas também se relaciona com a abertura das instituições e da sociedade em geral para a iniciativa empresarial. No Vale do Silício, por exemplo, cerca de 1/3 das empresas de alta tecnologia criadas nos anos noventa tinham presidentes chineses ou indianos. Em outras palavras, existem empresários em muitas regiões do mundo e eles gravitam para as áreas em que podem efetivamente implementar seus projetos.

\footnotetext{
${ }^{5}$ Para um resumo dos dados e uma análise mais ampla da nova economia californiana, ver CASTELLS, Manuel, The Internet Galaxy, Oxford, Oxford University Press, 2001, capítulo 3 .
} 
Para que a inovação ocorra, no entanto, os empresários e firmas empresariais precisam de financiamento. Assim, o financiamento da inovação está no cerne da nova economia, que requer a existência de um mercado desenvolvido, ágil e bem formado de capital de risco, bem como a capacidade de as empresas recorrerem ao mercado de ações para obter financiamento. Assim, conquanto a produtividade e a competitividade sejam os fatores subjacentes ao crescimento econômico elevado sem inflação, e embora a inovação seja o motor da nova economia, as finanças são a fonte de tudo. No caso da Califórnia durante a década de 1990, a alta valorização das inovações potenciais no mercado de ações e sua antecipação pelo capital de risco foram os mecanismos que mobilizaram capital de todas as fontes (especialmente de investidores institucionais) e o canalizaram para as inovações. A valorização das ações e o financiamento dos investimentos em inovações dependem de duas condições principais: as expectativas de um retorno elevado sobre o investimento e a confiança nos mercados financeiros e em suas instituições gestoras. Esses fatores foram essenciais para dar respaldo ao desenvolvimento da nova economia na década de 1990. Ao mesmo tempo, quando há uma mudança nessas condições, as fontes de financiamento secam, a inovação pára e a máquina do crescimento entra em marcha a ré. Visto que a valorização das ações é determinada não apenas por cálculos econômicos, mas por turbulências imprevisíveis na informação, amplificadas nos circuitos eletrônicos de comunicação, ela é sumamente volátil e os movimentos de alta são seguidos por quedas vertiginosas, no que chamo de ciclo comercial psicológico. Se e quando as empresas tentam manipular a valorização com "informações fraudulentas", a fim de inverter essas turbulências da informação a seu favor (a exemplo do padrão de conduta da Enron), a confiança nos mercados também sai prejudicada. Com a redução das expectativas e a confiança abalada, a nova economia, na Califórnia como noutros lugares, entrou em sua primeira crise no início do século XXI. Entretanto, a questão crucial é que a inovação não se deteve por completo e, nos Estados Unidos, a produtividade continuou a aumentar, numa demonstração da resistência das fontes de crescimento da nova economia. Todavia, as ameaças terroristas devastadoras, a preparação da guerra e a ênfase e a paranóia com a segurança nacional poderão vir a destruir a promessa da nova economia, já que os investidores ficam compreensivelmente preocupados com a estabilidade e o rendimento futuro de seu capital. O Gráfico 1 resume a estrutura e os fluxos do mecanismo subjacente ao processo de crescimento da nova economia, numa representação esquemática da experiência californiana durante a segunda metade dos anos noventa. 


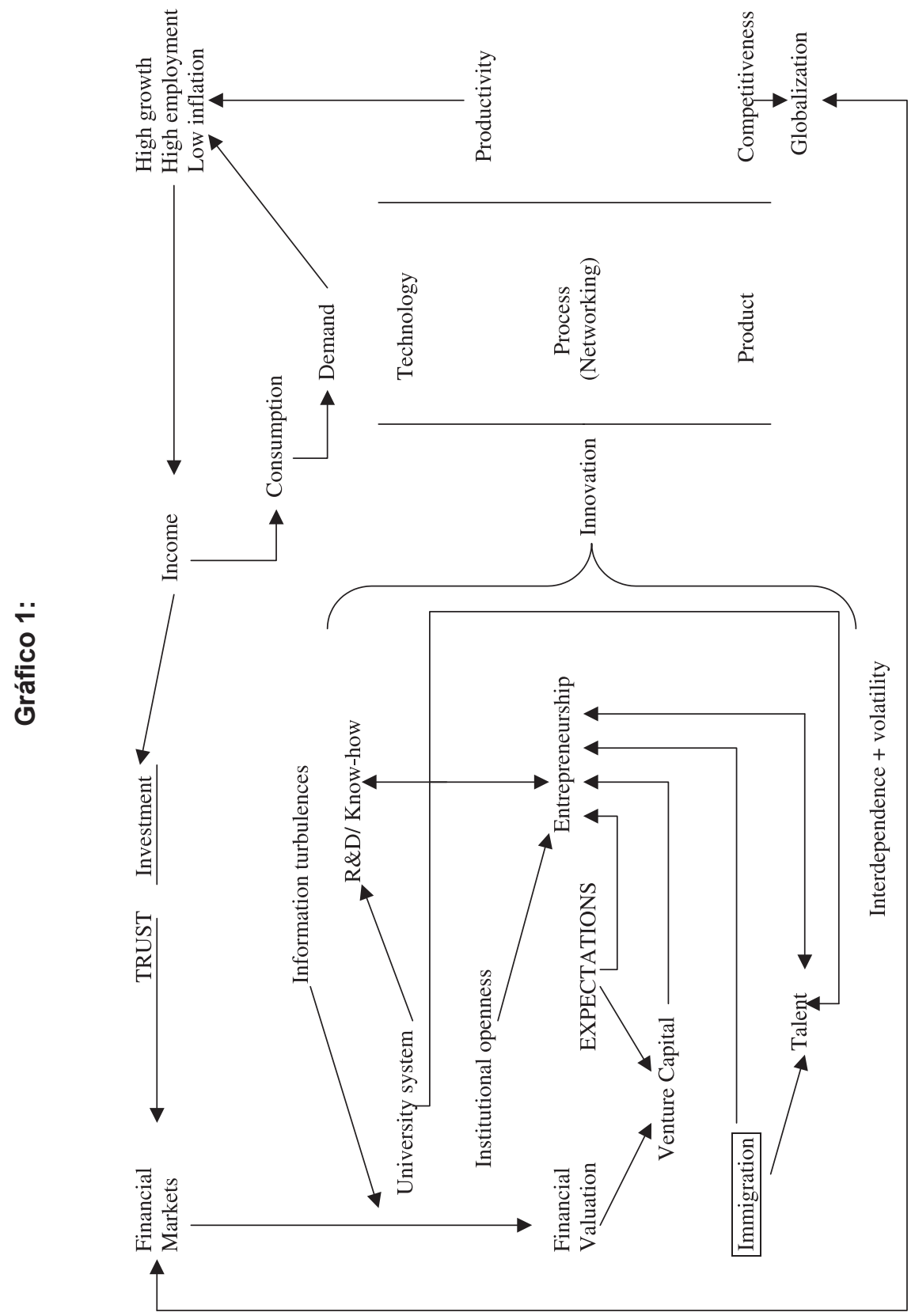

Desenvolvimento em Debate - 406 


\subsection{O modelo finlandês da nova economia}

A nova economia baseada no conhecimento, ou, se preferirmos, a sociedade da informação, não se desenvolve num formato cultural ou institucional uniforme. Seria um erro tão grave assemelhar a economia do conhecimento à Califórnia ou aos Estados Unidos quanto foi um erro assemelhar a economia industrial à reprodução do capitalismo inglês ou norte-americano. A mais avançada sociedade da informação no mundo, pela classificação da ONU em 2000, é a Finlândia. E a economia finlandesa também ficou em primeiro lugar no índice de competitividade do Fórum Econômico Mundial na mesma data - uma competitividade que se baseou num desempenho robusto da produtividade, cujo índice de crescimento suplantou o dos Estados Unidos no período de 1996-2000. E isso num país que há meio século ainda era pobre e cuja economia foi devastada, em 1991-1992, pelo colapso de seu principal mercado, a União Soviética. Como afirmamos Himanen e eu em nosso estudo sobre o modelo finlandês, ${ }^{6}$ o desempenho desse país foi muito além do fenômeno da Nokia. Aliás, a Nokia quase foi à falência em 1991 e sua recuperação decorreu do espírito de iniciativa interno da empresa e das políticas de desenvolvimento do Estado finlandês. O modelo de crescimento subjacente ao desempenho finlandês tem aspectos que são característicos da nova economia, mas também exibe diferenças institucionais muito significativas, que o aproximam mais, a despeito das inúmeras diferenças óbvias, dos problemas com que os países latino-americanos têm que lidar.

Como é crucial na nova economia, o modelo finlandês baseia-se na capacidade de inovação: inovação tecnológica, respaldada por um sólido sistema de $\mathrm{P} \& \mathrm{D}$, inovação empresarial (originalmente, dentro da Nokia, mas depois reproduzida e ampliada no setor de tecnologia de informação e comunicação [TIC), e inovação organizacional, já que a Nokia e o grupo de indústrias de TIC adotaram rapidamente o modelo empresarial em rede surgido na América no fim da década de 1980. O modelo baseou-se também na mão-de-obra altamente qualificada e numa sólida interação entre as empresas e o sistema universitário. No entanto, a diferença crucial em relação ao modelo californiano diz respeito ao papel do Estado. O Estado finlandês, de forte legitimidade como porta-

\footnotetext{
${ }^{6}$ Nossa análise da Finlândia é apresentada em CASTELLS, Manuel e HIMANEN, Pekka, The Information Society and the Welfare State. The Finnish Model, Oxford, Oxford University Press, 2002.
} 
dor-padrão da identidade e da independência finlandesas, ameaçadas durante séculos, tomou algumas iniciativas estratégicas essenciais no fim da década de 1960 e novamente na de 1990, para levar a Finlândia a ingressar na sociedade de informação e na nova economia, ao mesmo tempo preservando o Estado de bem-estar. Além disso, o Estado de bemestar é um componente essencial do novo modelo econômico finlandês. O Estado exerce um duplo papel, desenvolvimentista e social. No plano do desenvolvimento, ele construiu um extraordinário sistema universitário ao longo de trinta anos, com novas universidades localizadas em todo o país, investiu na $\mathrm{P} \& \mathrm{D}$, particularmente na engenharia e na tecnologia, e montou projetos conjuntos entre as universidades e as empresas. Adotou também uma política ativa de telecomunicações, baseada na privatização, na liberalização e na regulamentação flexível, ao mesmo tempo que abriu mercados públicos, sobretudo na telefonia móvel, primeiro mediante acordos com os países nórdicos e, mais tarde, com a União Européia. No plano social, a gratuidade do ensino e da saúde pública, o apoio às comunidades e aos serviços sociais e as políticas de desenvolvimento local e regional construíram uma base de recursos humanos, estabilidade social e relações industriais que assegurou um ambiente favorável aos negócios, ao mesmo tempo melhorando o padrão de vida e a qualidade de vida. Os impostos elevados, necessários para financiar esses projetos, parecem ser aceitos pela maioria da população, em virtude dos benefícios obtidos junto ao setor público. De fato, na década de 1990, o aumento da renda após a dedução de impostos expandiu-se mais depressa do que a receita tributária, sendo o segredo dessa fórmula a produtividade mais elevada, é claro. Por outro lado, a Finlândia continua a ser uma sociedade homogênea em termos étnicos e sociais, que beira a xenofobia, e isso restringe seus atrativos para os empresários e profissionais imigrantes, que são essenciais na Califórnia. Ademais, os mercados financeiros ainda são excessivamente rígidos e o capital de risco é limitado. O financiamento é compensado pelo uso do autofinanciamento pelas grandes empresas, em especial a Nokia, e pelo recurso aos mercados financeiros globais, sobretudo nos Estados Unidos. As novas empresas, contudo, foram favorecidas durante os anos noventa por instituições governamentais, particularmente a Sitra, fornecedora pública de capital de risco, e a Tekkes, uma empresa estatal voltada para o desenvolvimento da tecnologia. O Gráfico 2 resume os mecanismos subjacentes ao modelo finlandês da nova economia, com base no estudo empírico conduzido por Pekka Himanen e por mim. 


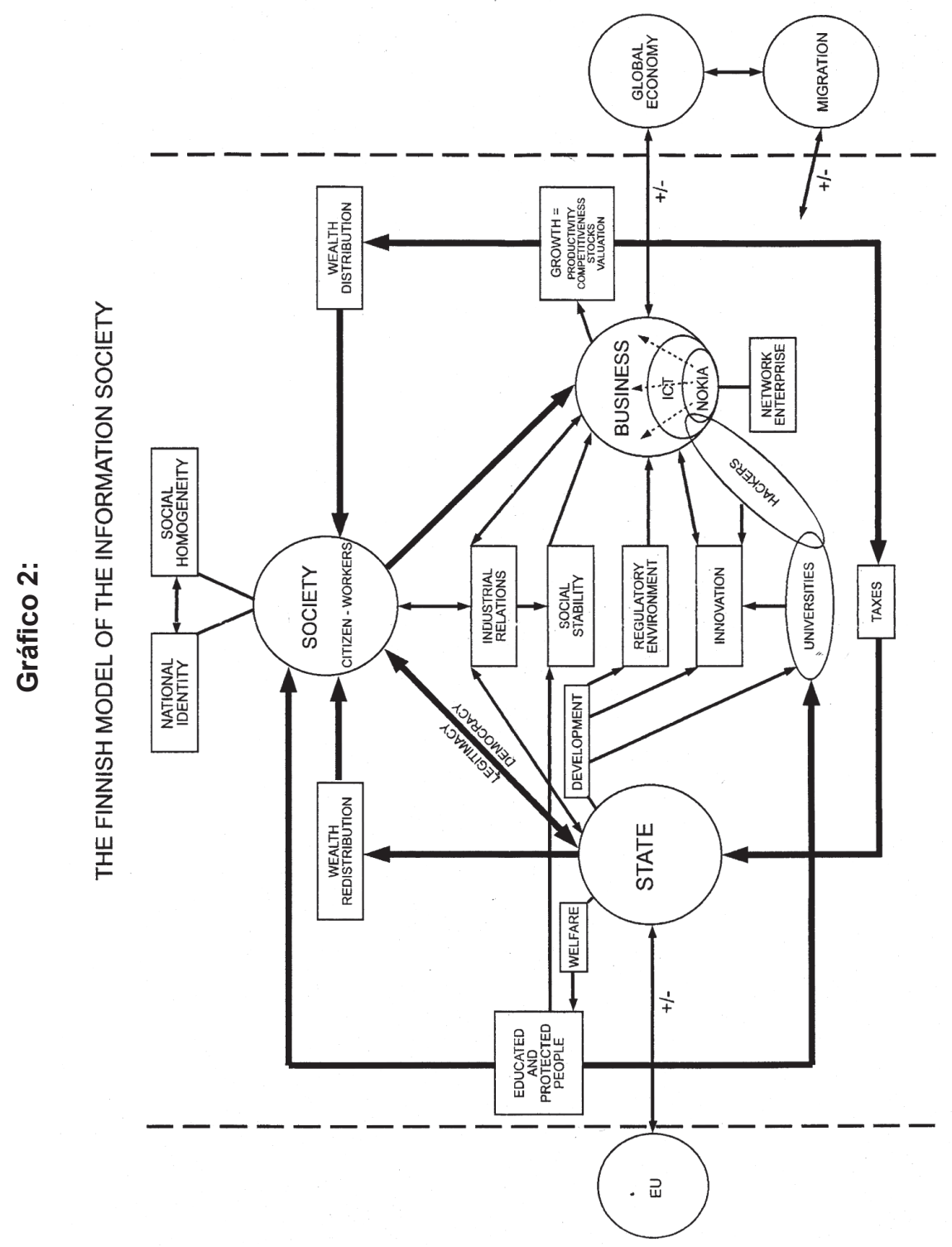


A lição que se extrai dessas análises é que as vias para o novo modelo de desenvolvimento são variadas e específicas das características institucionais e dos níveis de desenvolvimento de cada país. Isso se aplica ainda mais à América Latina. É muito fácil refutar a aplicabilidade desses modelos, dados o contexto da Califórnia, situada nos Estados Unidos, ou da Finlândia, membro da União Européia, bem como suas dimensões diferentes e suas condições culturais e educacionais. Mas, se há diversidade num desempenho tecno-econômico igualmente dinâmico entre os países desenvolvidos, uma via diferencial similar pode e deve ser encontrada em níveis mais baixos de desenvolvimento. O que importa, em termos analíticos, é a diversidade dos modelos e o caráter comum dos traços centrais que caracterizam o novo modelo de desenvolvimento socioeconômico, numa economia globalmente interdependente: a inovação (tecnológica e organizacional) como fonte da produtividade e da competitividade, e o financiamento flexível e o apoio institucional como bases da inovação empresarial.

Tendo em mente essas experiências, voltemo-nos agora para a situação específica da América Latina.

\section{A América Latina e o novo paradigma do desenvolvimento}

Serão aplicáveis à América Latina os processos característicos da economia baseada no conhecimento e na formação de redes? Se dissermos que não, as conseqüências dessa afirmação serão consideráveis, porque, dada a interdependência da economia global, isso condenaria a maior parte da região a ficar marginalizada no processo atual de geração e apropriação de valor. Seria o equivalente a renunciar ao desenvolvimento industrial no início do século XX. Mas dizer que sim, sem maiores ressalvas, seria não apenas ingênuo e voluntarista, como ficaria em contradição com os indicadores de desempenho da década de 1990. Portanto, a verdadeira questão é saber quais são os obstáculos a superar na América Latina para que ela desenvolva seu modelo específico de incorporação da economia em rede, baseada no conhecimento, e quais são as condições a satisfazer para eliminar os bloqueios atuais no caminho para o novo desenvolvimento.

O que revela a experiência da década de 1990 é que a simples abertura das fronteiras econômicas, sem uma transformação da capacidade produtiva das sociedades latino-americanas, simplesmente elimina os sistemas 
de produção ineficientes, sobretudo quando a liberalização do comércio é unilateral (o protecionismo continua a vigorar nos Estados Unidos e na União Européia, em especial no comércio agrícola). Além disso, a competição baseada nos custos só funciona até certo ponto, porque o componente do conhecimento e a qualidade dos produtos são os principais determinantes do valor e da competição. Em outras palavras, para que a América Latina exporte produtos manufaturados, é preciso que esses produtos estejam no mesmo nível tecnológico dos produzidos nas economias avançadas, e não importa que eles sejam mais baratos, se não atingirem esse nível de qualidade. O que mostram os estudos deste livro e de outras fontes recentes sobre a América Latina é que a homogeneização das condições macroeconômicas com as economias avançadas não foi acompanhada por uma modernização equivalente do sistema produtivo, o que leva a um regime comercial menos competitivo, não em termos de preços relativos, mas em termos de valor: uma nova forma de intercâmbio desigual entre produtos e serviços com um teor muito diferenciado de conhecimento. ${ }^{7}$ Graciela Moguillansky enfatizou a defasagem da produtividade nas economias latino-americanas e sua dificuldade de competir num sistema de economia global assimetricamente aberta. ${ }^{8}$ Por quê?

Uma dentre os melhores analistas da política tecnológica latino-americana, Judith Schutz, mostrou que, em muitas áreas e países, a América Latina tem um nível científico adequado e uma capacidade instalada de inovação tecnológica. ${ }^{9}$ Mas ela também demonstrou que, no conjunto, há uma falta substancial de ligação entre o sistema de P\&D e o mundo empresarial e que grandes problemas institucionais, no financiamento da pesquisa e nas pesquisas aplicadas baseadas nas universidades, têm prejudicado essa capacidade de inovação, na verdade descapitalizando as universidades e os sistemas de P\&D na maioria dos países, sobretudo na Argentina e no Uruguai. A difusão das tecnologias de informação tem um nível mais baixo e uma taxa de crescimento menor do que nas economias avançadas. As exportações de alta tecnologia vêm perdendo sua parcela do mercado. A política do Direito de Propriedade Industrial

\footnotetext{
${ }^{7}$ Para uma visão geral das crises sociais e econômicas da América Latina nos primeiros anos do século XXI, ver CALDERÓN, Fernando (org.), Es sostenible la globalización en America Latina?, a ser publicado.

${ }^{8}$ MOGUILLANSKY, Graciela, "La innovación: el talón de Aquiles de la inserción global de America Latina", in Calderón (org.), a ser publicado.

${ }^{9}$ SHUTZ, Judith, “Tecnologia y sociedade: miradas desde el Sur”, in Calderón (org.), a ser publicado.
} 
imposta pela Organização Mundial do Comércio, em benefício das empresas multinacionais, tem ampliado a defasagem tecnológica entre as economias de ponta e a América Latina. Somente o Brasil tem um certo potencial fabril de alta tecnologia, enquanto o Chile e a Costa Rica vêm tentando elevar o nível gerencial e tecnológico de sua base de exportação de produtos primários. Quase todas as indústrias de alta tecnologia do México são fábricas descentralizadas de multinacionais dos Estados Unidos, do Japão e da Europa, que visam a tirar proveito das possibilidades oferecidas pelo NAFTA, sem acrescentar muito valor tecnológico ou know-how.

Além disso, o fator crucial na economia do conhecimento é a existência de recursos humanos qualificados. Em última instância, isso significa a instrução em todos os níveis. Análises empíricas recentes, feitas por um dos mais ilustres economistas da educação, Martin Carnoy, mostram a insuficiência do desenvolvimento educacional na maioria dos países latino-americanos, onde o problema central ainda concerne à baixa remuneração e à formação insuficiente dos professores..$^{10}$ Assim, após anos de reformas, esforços e promessas, a educação latino-americana ainda está atrasada em relação ao mundo desenvolvido.

A forma de organização em rede na América Latina costuma ser mais eficiente na economia informal urbana do que nas grandes empresas - ainda sumamente burocráticas e organizadas em torno de princípios de integração vertical.

O uso da Internet é sobretudo uma questão de símbolo de status e se concentra na classe média alta. Uma boa notícia: a maioria das declarações de imposto de renda no Brasil é feita pela Internet. A má notícia é que é pequena a proporção das pessoas que entregam declarações do imposto de renda no Brasil.

Portanto, a defasagem tradicional entre os países industrializados e os países produtores de produtos primários, entre a empresa industrial de produção em massa e as formas semi-artesanais de produção, vem sendo predominantemente reproduzida. Carnoy também fala de maneira convincente sobre o do caráter socialmente regressivo do sistema latino-americano de universidades públicas, sobretudo no Brasil e no Chile: sua gratuidade é uma grande transferência de recursos do orça-

\footnotetext{
${ }^{10}$ CARNOY, Martin, "Is Latin American Education Preparing its Workforce for 21st Century Economies?", Stanford, Stanford University School of Education, trabalho de pesquisa para o Banco Mundial, setembro de 2002.
} 
mento governamental para a classe média, enquanto as classes populares ficam reduzidas à alternativa das universidades privadas, mais caras e de menor qualidade.

As experiências de desenvolvimento e as lições extraídas das economias de conhecimento avançadas indicam que o desafio dos países latino-americanos está em sua capacidade de agir sobre vários processos, de maneira simultânea e sinérgica.

- P\&D concentrada em áreas específicas, a fim de proporcionar às universidades e centros de pesquisa latino-americanos a oportunidade de entrar nas redes globais de ciência e tecnologia. Na verdade, a pesquisa de orientação tecnológica funciona hoje numa rede global, mas, para ingressar nessa rede de intercâmbio e cooperação, todo nodo tem que fazer alguma contribuição em termos de conhecimentos ou aplicações específicos. Portanto, não se trata de atingir o mais alto nível de excelência num determinado campo, mas simplesmente de atingir um nível científico suficiente para possibilitar a comunicação e a contribuição para essas redes de cooperação tecnológica.

- Desenvolvimento de aplicações específicas de novas tecnologias, ligadas às necessidades de desenvolvimento do país, com isso criando nichos de mercado para produtos e processos que não existam nas economias mais avançadas. Por exemplo, o uso de programas abertos do tipo Linux pode permitir que os usuários empresariais e governamentais se beneficiem do acesso gratuito a tipos de software avançados, vindo depois a contribuir com suas próprias elaborações para a rede, ao mesmo tempo que utilizam o software gratuito para criar suas aplicações.

- Os governos e as instituições financeiras precisam estimular o crescimento dos mercados profissionais de capital de risco e ajudar a financiar a criação de projetos empresariais, rompendo, ao mesmo tempo, com a postura conservadora e as estratégias especulativas das instituições financeiras latino-americanas, práticas conservadoras estas em que se inclui a maioria dos bancos estrangeiros que operam na América Latina.

- O desenvolvimento dos recursos humanos continua a ser uma prioridade, mas desde que haja um conjunto sustentado e direcionado de medidas políticas ao longo do tempo. Isso implica a educação e o treinamento para a população em geral. O gargalo dessa política 
é que a qualidade do ensino não poderá ser aprimorada, se não houver um número suficiente de professores qualificados. Isso requer, antes de mais nada, que os professores tenham salários e condições de trabalho decentes. Requer também a formação adequada dos professores - sua formação em número suficientemente grande e sua formação rápida -, pois é rigorosamente impossível que a América Latina espere duas décadas para criar as bases de uma economia do conhecimento, enquanto as economias avançadas aceleram o ritmo de seu novo paradigma do conhecimento. Além disso, uma política de recursos humanos exige também a reciclagem profissional da mão-de-obra já engajada no processo de trabalho. Só existe um modo de realizar essas duas promessas: um amplo projeto de educação à distância, baseado na Internet, que tenha boa qualidade e preço acessível e que seja administrado, direta ou indiretamente, pelo governo, com uma série de novas instituições de ensino diferentes das que já existem, para que não sejam sobrecarregadas por metodologias ultrapassadas nem sufocadas pelos interesses estabelecidos do corporativismo do sistema educacional.

Por último, uma vez instaurados esses componentes da economia do conhecimento, também será necessário instalar uma infra-estrutura desenvolvida de telecomunicações e sistemas de informação, incluindo-se aí o desenvolvimento da Internet em suas várias aplicações. De fato, a infra-estrutura da Internet é essencial para a educação à distância, para a educação em geral, para a pesquisa e para o gerenciamento em rede de empresas e governos.

Contudo, as questões mais prementes na América Latina são a pobreza, o subemprego e as necessidades básicas, como saúde, abastecimento de água, saneamento, habitação e serviços urbanos. Dir-se-ia que essas necessidades precisam ser atendidas antes que se avance para a pesquisa, a geração de conhecimento e a Internet. Mas, como lidar com a pobreza e com essas necessidades básicas usando sistemas de administração ultrapassados? Como gerar novos conhecimentos e capacidade de gestão sem entrar na Era da Informação? Obviamente, os investimentos públicos, juntamente com o apoio das iniciativas de base e das ONGs, são elementos-chave da política social. Mas essas medidas de redistribuição precisam de recursos públicos. De onde virão esses recursos? Portanto, essa abordagem supostamente "realista" do desenvolvimento leva, pura e simplesmente, a algumas perguntas fundamentais. 
a) Como gerar um excedente na economia com base na produtividade? A resposta é um novo modelo de geração da riqueza, o modelo que chamo de desenvolvimento informacional, baseado na geração de conhecimento e na aplicação de conhecimentos específicos do nível de desenvolvimento de cada sociedade.

b) Como fazer uma redistribuição inteligente? A resposta é oferecer serviços sociais de um modo que favoreça o desenvolvimento humano, portanto, enfatizar sobretudo a educação, a saúde e a saúde pública da população, que são fundamentais para a qualidade de vida e para o desenvolvimento baseado no ser humano. Isso requer o desenvolvimento tecnológico, baseado na informação e na participação pública.

A adoção e a implementação dessas medidas políticas dependem, em última instância, do Estado. Portanto, o Estado, e não o mercado, nas condições concretas da América Latina, é o ator principal e o componente essencial do processo de desenvolvimento. Especialmente porque, como no caso da Finlândia ou dos países asiáticos do Pacífico, é necessário um processo que avance aos saltos para que a América Latina se vincule aos segmentos dinâmicos da economia global baseada no conhecimento.

Mas, qual Estado? E Estado de quem? Isso porque o Estado não é uma entidade metafísica, mas uma instituição historicamente produzida e específica de cada sociedade, o que nos leva à discussão do Estado na América Latina em sua relação com o novo modelo de desenvolvimento.

\section{Estado, mas qual Estado? Estado de quem?}

Neste início do século XXI, o Estado, na América Latina - e não só na América Latina (vejam-se os Estados Unidos da Enron, ou o sistema bancário do Japão, ou a Itália de Berlusconi, entre muitos outros exemplos) -, é uma instituição que está atravessando uma crise fundamental. Crise de legitimidade política, uma vez que os cidadãos, em sua maioria, não confiam no Estado. Crise de governabilidade, uma vez que as instituições estatais são profundamente perpassadas pela corrupção sistêmica e apropriadas pelos interesses estabelecidos. Crise do sistema político, dominado por uma classe política profissional egoísta, cada vez mais distante da sociedade, manipuladora dos cidadãos, que pratica a política da mídia e se destrói coletivamente em lutas internas, que usam a política do escândalo como arma preferencial. 
Portanto, com uma crise de legitimidade política e com o Estado capturado por grupos empresariais, ou pelos representantes da minoria de trabalhadores organizados e protegidos e da classe média, a maioria da população fica fora do sistema político e à mercê do populismo manipulador - ou se arranjando com estratégias de sobrevivência.

Logo, a reforma da economia exige a reforma do Estado, e a reforma do Estado requer a regeneração da classe política. Por sua vez, isso só poderá ser conseguido com a cooperação da sociedade civil, com base em sua mobilização ativa.

\section{Observações finais}

Mais do que nunca, nessa economia global e em rede, baseada no conhecimento, faz-se necessário, na América Latina, um agente do interesse público capaz de promover o novo paradigma do desenvolvimento nas condições específicas de inserção de cada país na economia global, um agente que possa servir de interface entre o Estado e a sociedade civil, entre os fluxos globais de capital e as empresas nacionais, e entre as instituições existentes de produção do conhecimento e de recursos humanos (educação, pesquisa) e as novas necessidades desses fatores de produção, com isso estimulando o desenvolvimento dos recursos humanos e a geração de conhecimentos em projetos estabelecidos como metas.

Trata-se de uma estratégia de desenvolvimento concentrada num desenvolvimento econômico que seja sustentável, globalmente competitivo e alicerçado numa base endógena de recursos humanos, formada por pessoas sadias, instruídas e seguras.

Talvez os bancos de desenvolvimento tradicionais da América Latina, como o BNDES, que foram atores cruciais no período de industrialização e da modernização inicial da América Latina, possam ser regenerados para desempenhar esse papel. Somente se isso acontecer é que os bancos de desenvolvimento poderão deixar de se tornar remanescentes burocráticos de um modelo de desenvolvimento obsoleto. E somente se isso acontecer é que a América Latina poderá aceitar o desafio do novo modelo de desenvolvimento - um desafio que as políticas liberais de livre mercado que dominaram a última década não conseguiram enfrentar, com isso levando a América Latina a mergulhar numa situação dramática e, quem sabe, tornando a globalização socialmente insustentável na região. 


\title{
CRESCIMENTO ECONÔMICO NA AMÉRICA LATINA: DESAFIOS PARA UMA NOVA ERA ${ }^{1}$
}

\author{
Sebastian Edwards* \\ "O que nos salva é a eficiência- \\ a dedicação à eficiência..." \\ Joseph Conrad, \\ Heart of Darkness
}

\section{Introdução}

Durante a última década, o desempenho econômico da América Latina foi medíocre. Na região como um todo, o PIB teve um decepcionante crescimento anual de 3,3\% no período de 1990-2000. Essa cifra foi expressivamente inferior à meta do Banco Mundial para a região, correspondente a $6 \%$ ao ano, e ficou marcantemente abaixo da média do período de 1960-1982. Se essa taxa de crescimento se mantiver nos próximos anos, dificilmente a América Latina conseguirá progredir na melhoria das condições sociais e alcançar as nações mais avançadas. ${ }^{1}$ No centro do modesto desempenho da América Latina encontra-se uma baixa taxa geral de aumento da produtividade. Aliás, com exceção do Chile, o crescimento da produtividade total dos fatores (PTF) foi baixíssimo nas duas últimas décadas. No Brasil, por exemplo, o aumento da PTF alcançou meros 0,7\% ao ano durante a década de 1990 (ver

* Titular da Cátedra Henry Ford II, Universidade da Califórnia, Los Angeles, http://www.anderson.ucla.edu/faculty/sebastian.edwards/

${ }^{1}$ Esta é a versão revisada de um artigo apresentado no seminário comemorativo do $50^{\circ}$ aniversário do BNDES, Rio de Janeiro, 12-13 de setembro de 2002. Agradeço a meus debatedores, Winston Fritsch e Antonio Barros de Castro, pelos comentários proveitosos.

${ }^{2}$ Naturalmente, por trás dessas cifras médias esconde-se a diversidade complexa das experiências de cada país, que vão do sólido desempenho do Chile e da Costa Rica até a frustração e o retrocesso da Nicarágua e do Haiti. 
dados comparativos sobre a PTF na Tabela 1). Não há dúvida de que a aceleração do índice de crescimento econômico da região exigirá um impulsionamento significativo da produtividade.

O Chile e o México fornecem dois exemplos interessantes. Nesses dois países, até não muito tempo atrás, as autoridades de governo haviam estabelecido uma meta de $7 \%$ para o crescimento anual do PIB. Ainda que hoje essas metas se afigurem inalcançáveis, elas refletem o enorme abismo entre as expectativas e a realidade. Chegar perto desses índices ambiciosos de crescimento exigirá saltos de produtividade muito significativos. No Chile, significará ultrapassar o índice de $2 \%$ de aumento da PTF obtido no período de 1990-2000. E não será fácil, uma vez que as fontes de aumento mais rápido da produtividade, associadas à primeira onda de reformas voltadas para a modernização, já estão basicamente esgotadas. No caso do México, atingir a taxa de 7\% de aumento do PIB proposta pelo presidente Vicente Fox exigirá a transformação do índice negativo de aumento da produtividade da última década numa saudável taxa de 2,5\% anuais. Embora tenha havido uma melhora notável no crescimento da PTF no México durante o período de 1998-2000, atingindo uma média de $1,2 \%$, esse índice ainda está significativamente abaixo do necessário para atingir a meta do presidente Fox. ${ }^{3}$

Sem dúvida, à medida que se instala a decepção com as reformas do mercado e a globalização, a questão de como obter um crescimento rápido torna-se cada vez mais urgente. Neste artigo, abordo três problemas que são centrais para o desafio do crescimento nos próximos dez anos, aproximadamente. Abordo em primeiro lugar a estabilidade macroeconômica e o crescimento. Evitar a crise macroeconômica é um componente fundamental de qualquer estratégia sensata de promoção do crescimento; há uma ampla comprovação de que as crises cambiais tiveram efeitos devastadores no bem-estar econômico e atrasaram enormemente o crescimento. Pretendo concentrar-me em dois aspectos correlatos da estabilidade macroeconômica - a crise e o crescimento - e começarei por falar da abertura da Conta de Capitais. Embora alguns autores - inclusive representantes do FMI - afirmem que a maior mobilidade do capital terá um efeito positivo sobre o crescimento, outros adotam a visão de que essa mobilidade maior gera instabilidade. Houve

\footnotetext{
${ }^{3}$ É claro que há outros fatores que limitam o crescimento da PTF na América Latina. Entre eles se incluem o baixo grau de desenvolvimento do setor financeiro e a baixa qualidade dos serviços públicos.
} 
quem chegasse a ponto de afirmar que a abertura da Conta de Capitais esteve no centro de muitas das crises dos anos noventa. Em segundo lugar, falarei da poupança externa, dos déficits de Conta Corrente, da acumulação de capital e do crescimento. Defendo a tese de que a dependência excessiva da poupança externa - cuja contrapartida são os grandes déficits em Conta Corrente - é sumamente arriscada, uma vez que os fluxos de capital podem cessar abruptamente, obrigando o país a enfrentar uma grande e custosa inversão da Conta Corrente. Por fim, na última parte, pretendo afastar-me da macroeconomia e propor algumas reflexões sobre os determinantes do crescimento a longo prazo. Nela discutirei questões tão distintas quanto a cultura, a tecnologia e a nova economia.

\section{As críticas à globalização e a abertura da conta de capitais}

Muitos críticos da globalização, entre eles Joe Stiglitz e Paul Krugman, afirmaram que, para que a liberalização econômica tenha sucesso, é essencial que as reformas sejam implementadas na velocidade certa e na seqüência certa (ver, por exemplo, Stiglitz, 2002, p. 73-78). Esse é um princípio muito importante, que esses dois autores têm razão de enfatizar. Eles acertam particularmente o alvo ao afirmarem que a abertura demasiadamente precoce da Conta de Capitais tende a gerar graves perturbações e acaba contribuindo para a deflagração de grandes crises.

O interessante, porém, é que essa ênfase na velocidade e na ordenação da seqüência não é nova nas discussões de política. Na verdade, desde os primórdios da ciência econômica, ela tem sido repetidamente abordada. Adam Smith, por exemplo, em A riqueza das nações, afirmou que determinar a seqüência apropriada era um problema difícil, que envolvia primordialmente considerações de ordem política (ver a edição da Cannan, Livro IV, Capítulo VII, Parte III, p. 121). Além disso, Smith defendia o gradualismo - como fazem muitos críticos da globalização -, alegando que a liberalização abrupta resultaria num aumento significativo do desemprego. Consideremos o seguinte trecho, extraído de $A$ riqueza das nações:

“[A]brir de uma só vez o comércio colonial (...) poderia ocasionar não apenas inconvenientes transitórios, mas um grande prejuízo permanente (...). [A] simples perda repentina do emprego (...) poderia ser agudamente sentida" (Vol. II, cap. VII, Parte III, p. 120). 
Essa questão da velocidade e da seqüência também se tornou central nas análises de como planejar uma estratégia de reforma para os países do antigo bloco comunista. Ao discutir os problemas enfrentados pela Tchecoslováquia na fase inicial de sua transição, Vaclav Klaus assinalou que um dos grandes problemas consistiu em decidir sobre "a ordenação da seqüência no tocante às medidas institucionais e de preços no plano interno, por um lado, e no tocante à liberalização do comércio exterior e da taxa de câmbio, por outro" (The World Bank Economic Review, 1990, p. 18).

No começo da década de 1980, o Banco Mundial interessou-se particularmente pelo exame de questões relacionadas com a seqüência e a velocidade das reformas. Encomendaram-se artigos, organizaram-se conferências e exploraram-se as experiências variadas de diversos países. ${ }^{4}$ Como resultado dos debates que cercaram esse trabalho, chegouse a uma espécie de consenso sobre a seqüência e a velocidade das reformas. Entre os elementos mais importantes desse consenso incluíram-se: (1) a liberalização do comércio deveria ser gradativa e escorada numa ajuda externa substancial; (2) seria preciso envidar esforços para minimizar o desemprego decorrente das reformas; (3) nos países com inflação muito elevada, os desequilíbrios fiscais deveriam ser abordados logo no início do processo de reformas; (4) a reforma financeira exigiria a criação de agências modernas de supervisão e regulamentação; e (5) a conta de capitais deveria ser liberalizada no final do processo, e somente depois de a economia haver expandido com êxito seu setor de exportações. É claro que nem todos concordaram com a íntegra dessas recomendações, mas a maioria manifestou seu acordo. Em particular, os representantes do FMI não objetaram a esses princípios gerais. Por exemplo, num artigo de meados da década de 1980 nos IMF Staff Papers, Jacob Frenkel, que viria a se tornar assessor econômico do FMI, afirmou que a Conta de Capitais realmente deveria ser aberta no fim do processo de reformas. Parece-me lícito dizer que, no fim dos anos oitenta, a idéia do gradualismo e de uma seqüência com "a abertura da Conta de Capitais por último" havia-se tornado parte do saber aceito.

Em algum momento do início dos anos noventa, esse saber aceito sobre a ordenação da seqüência e a velocidade começou a ser questionado. Pessoas de Washington começaram a clamar cada vez mais por

\footnotetext{
${ }^{4}$ Boa parte dessa discussão encontra-se em Edwards (1984).
} 
reformas simultâneas e muito rápidas. Muitos argumentaram que, do ponto de vista político, essa era a única maneira de avançar. Caso contrário, prosseguia a argumentação, os adversários da reforma conseguiriam bloquear os esforços de liberalização. Foi mais ou menos nessa época que o governo dos Estados Unidos começou a pressionar as nações do Leste Asiático para que suspendessem suas restrições à liberalização financeira e permitissem o fluxo mais livre do capital. Os planejadores políticos e os acadêmicos da maior parte da região ficaram extremamente inquietos com essas recomendações. Tinham duas preocupações principais. Por um lado, diziam que - como havia acontecido em vários países latino-americanos no começo dos anos oitenta - a liberalização da Conta de Capitais resultaria numa elevação maciça da taxa de câmbio real. Isso, é claro, contrariava uma política de décadas, que consistia em manter uma taxa de câmbio real sumamente competitiva, como forma de incentivar as exportações. A preocupação principal baseava-se num argumento no estilo da histerese: se os fluxos de capital sofressem um declínio súbito, ou, pior ainda, se viessem a se inverter, o país ficaria com um setor de exportações diminuído em caráter permanente. A segunda preocupação era que essas entradas maciças de capital tenderiam a alimentar uma explosão e uma bolha de crescimento imobiliário que deixariam a economia particularmente vulnerável aos choques financeiros.

Em 1992, em resposta ao que foi percebido como uma pressão norte-americana para suspender os controles sobre o fluxo de capitais, Yung Chul Park, da Universidade da Coréia, organizou uma conferência sobre a liberalização da Conta de Capitais. Realizada em Seul, a conferência teve extremo sucesso e a maioria dos participantes concordou em que seguir uma seqüência apropriada era vital para o êxito da liberalização. Houve também um amplo apoio à idéia de que a abertura prematura da Conta de Capitais poderia acarretar graves perigos para o país em questão. ${ }^{5}$ Num artigo apresentado nessa conferência, Robert Mundell captou sucintamente a opinião da maioria dos participantes. A citação que se segue é ilustrativa:

"[I]nfelizmente, (...) há algumas externalidades negativas [numa liberalização prematura da conta de capitais]. Uma delas é que os empréstimos tomados vão para o consumo, e não para o investimen-

\footnotetext{
${ }^{5}$ Os artigos dessa conferência encontram-se em Edwards (1995).
} 
to, permitindo ao país importador de capital viver acima de seus recursos (...) sem nenhuma compensação na produção futura com que se possa pagar o serviço da dívida. Mesmo que o passivo fique inteiramente nas mãos de particulares, o governo pode sentir-se compelido a transformar a dívida não liquidável em dívida nacional, em vez de permitir a execução de hipotecas ou de outras garantias" (p. 20).

O que há de especialmente importante nessa citação é que Mundell reconhece como uma grave externalidade a probabilidade de que o governo venha a socorrer os tomadores particulares de empréstimos.

Na conferência de Seul sobre a liberalização de capitais, em 1992, uma das poucas vozes dissidentes foi a do falecido Manuel Guitian, na época alto funcionário do FMI, que defendeu uma transição rápida para a conversibilidade da conta de capitais. Todavia, em nítido contraste com a caracterização de Stiglitz (2002) sobre a liderança do FMI, não houve dogmatismo nem arrogância na postura de Guitian. Ele ouviu os argumentos de outros participantes, ofereceu contra-argumentos e ouviu atentamente as réplicas a estes. Creio que o artigo de Guitian - sugestivamente intitulado "Capital Account Liberalization: Bringing Policy in Line with Reality" ["Liberalização da Conta de Capitais: Alinhando a Política com a Realidade"] - foi um dos primeiros textos a documentar a mudança de postura do FMI com respeito à ordenação da seqüência e à conversibilidade da conta de capitais. Depois de discutir a evolução dos mercados financeiros internacionais e de expressar reservas sobre a recomendação da seqüência com "a abertura financeira por último", Guitian assim resumiu suas opiniões:

"Não parece haver uma razão a priori para que as duas contas [Corrente e de Capitais] não possam ser abertas simultaneamente (...). [P]ode-se fazer uma sólida defesa da liberalização rápida e decisiva das transações de capital" (p. 85-86).

Na segunda metade da década de 1990, a visão de que os países emergentes e em fase de transição deveriam suspender os controles sobre o capital e abrir suas contas de capitais tornou-se dominante no FMI e no Tesouro norte-americano. Em parte como resultado disso, a partir de 1995, mais países começaram a relaxar o controle sobre a mobilidade do capital. Ao fazê-lo, entretanto, tenderam a adotar diferentes estratégias e trajetórias. Enquanto alguns relaxaram apenas os empréstimos bancários, outros só permitiram os fluxos de capital de longo prazo, e outros ainda - como o Chile - usaram mecanismos baseados no merca- 
do para reduzir a velocidade com que o capital fluía para sua economia. Muitos países, contudo, não precisaram de nenhum incentivo do FMI ou dos Estados Unidos para adotar a liberalização financeira. A Indonésia e o México, para citar apenas dois casos importantes, tinham uma longa tradição de livre mobilidade do capital, anterior aos acontecimentos discutidos neste artigo, e nunca tencionaram adotar uma política diferente.

Todavia, concordar em que a seqüência é importante não é o mesmo que afirmar que os mecanismos de controle do capital nunca devem ser suspensos. Uma questão política difícil e importante - e que não é abordada por Stiglitz nem pela maioria dos críticos da globalização - é saber como e quando retirar os empecilhos à movimentação do capital. Um primeiro passo para responder a essa pergunta é determinar as conseqüências a longo prazo da mobilidade do capital para o desempenho econômico. Trata-se de um problema difícil e sobre o qual dispomos de indicações limitadas. Entretanto, pesquisas recentes, usando medidas novas e aperfeiçoadas do grau de abertura da mobilidade do capital, sugerem que a maior liberalização financeira exerce um efeito positivo no crescimento a longo prazo, nos países que ultrapassaram um certo estágio do processo de desenvolvimento e contam com instituições fortes e sólidos mercados internos de capital.

A questão de como chegar a uma mobilidade maior do capital é altamente complexa e requer pesquisas adicionais. Entretanto, alguns indícios sugerem que mecanismos transparentes e baseados nos preços, como o imposto flexível sobre os fluxos de curto prazo usado pelo Chile durante boa parte da década de 1990, funcionam relativamente bem como instrumentos transitórios. Permitem uma certa mobilidade do capital e desestimulam os investimentos especulativos de curto prazo; ao mesmo tempo, evitam decisões arbitrárias por parte dos burocratas. Entretanto, como afirmei em outro texto, até os mecanismos de controle de capital no estilo chileno têm seu custo, e não pouparam o Chile do contágio nem da instabilidade macroeconômica durante a segunda metade dos anos noventa.

A maioria dos críticos da globalização afirma que as experiências da China e da Índia, dois países que não passaram por uma crise monetária nos anos noventa, bem como as da Malásia - que não seguiu a orientação do FMI e se recuperou rapidamente -, corroboram a idéia de que os mecanismos de controle do capital são benéficos. Mas esse é um argumento pouco persuasivo. Qualquer pessoa medianamente informada sabe que há muitas razões pelas quais a Índia e a China não enfrentaram 
crises, e atribuir isso à presença de controles sobre o capital é excessivamente simplista, se não francamente equivocado. O caso da Malásia é um pouco mais complexo. Ela se recuperou com rapidez, embora não tão depressa quanto a Coréia do Sul, mas não se sabe ao certo se essa recuperação resultou da imposição de controles sobre o capital e da fixação da taxa de câmbio. Essa ainda é uma questão em aberto, que exigirá pesquisas adicionais. O que é verdade, no entanto, é que a Malásia surpreendeu muitos observadores, ao aumentar os controles apenas temporariamente; passado cerca de um ano e uma vez estabilizada a economia, os controles foram suspensos, exatamente como fora originalmente anunciado pelo Dr. Mahatir.

O que confere um interesse especial ao caso da Malásia é que, historicamente, o uso temporário de controles é bastante singular. A norma histórica aproxima-se mais do que aconteceu na América Latina durante a crise da dívida da década de 1980, quando o que se supunha ser uma acentuação temporária dos controles transformou-se numa característica permanente das economias regionais. Além disso, na América Latina, o controle mais rigoroso das saídas de capital não estimulou a reestruturação das economias nacionais nem resultou em reformas ordeiras. Na verdade, verificou-se o inverso. Num país após outro, os políticos fizeram experiências com medidas populistas que, no final das contas, aprofundaram a crise. O México nacionalizou o setor bancário e expropriou os depósitos em dólares. A Argentina e o Brasil criaram novas moedas - o austral e o cruzado -, ao mesmo tempo que impuseram controles de preços e ampliaram os gastos públicos. No Peru, os controles mais rígidos sobre a saída de capitais permitiram que o governo do presidente Alan Garcia desgastasse sistematicamente as bases de uma economia saudável e produtiva, enquanto o país foi sendo rapidamente consumido pelo que constituiu quase uma guerra civil. Como não é de admirar, o resultado dessas medidas políticas, nos três países, foi uma inflação galopante, acompanhada pelo colapso da atividade econômica. E, para piorar ainda mais as coisas, em nenhum deles os controles sobre a saída de capitais conseguiram refrear a fuga destes. 


\section{Investimentos, poupança externa e inversões na Conta Corrente}

Tradicionalmente, as economias da América Latina têm tido uma baixa taxa de poupança: de acordo com o Banco Mundial, a média desta ficou em $20 \%$ do PIB durante a década de 1990 . A poupança externa, por outro lado, tendeu a ser muito grande, ultrapassando 5\% do PIB no período de 1970-1999. Muitos economistas argumentam que essa dependência da poupança externa, bem como os grandes déficits de Conta Corrente daí resultantes, são benéficos, na verdade, porque os países relativamente pobres têm uma enorme produtividade marginal do capital (Corden, 1994; Sachs, 1981). O problema desse raciocínio, contudo, é que, historicamente, grandes déficits na Conta Corrente não são sustentáveis a longo prazo. Os grandes déficits costumam ser acompanhados por "inversões", amiúde geradas pela "cessação repentina" da entrada de capitais. Nesta seção, examinarei alguns dados relativos às reversões da Conta Corrente e seus custos.

São três as perguntas fundamentais a respeito dessas inversões da Conta Corrente. Primeiro, quão comuns são as grandes inversões do déficit de Conta Corrente? Segundo, do ponto de vista histórico, será que essas inversões estiveram associadas a colapsos monetários ou financeiros? E terceiro, qual foi o custo, em termos dos indicadores do desempenho econômico, dessas inversões? Com respeito a essa terceira pergunta, minha tese é que os efeitos mais graves das inversões da conta de capitais no desempenho econômico ocorrem de maneira indireta, através de seu impacto nos investimentos. A análise apresentada nesta seção complementa os resultados de um artigo recente e importante de Milesi-Ferreti e Razin (2000). ${ }^{6}$

Defino a "inversão da Conta Corrente" como uma redução do déficit de pelo menos três por cento do PIB em um ano. A primeira pergunta que formulo é quão comuns são essas inversões. Uma análise que utilizou dados de todos os países com informações disponíveis sobre o período de 1970-1998 indicou que a incidência das "inversões" correspondeu a $16,7 \%$ dos episódios anuais - o banco de dados incluiu 149 países, com um total de 2.949 dados (ver detalhes in Edwards, 2001). Essa ocorrência das inversões variou nas diversas regiões; como não é

\footnotetext{
${ }^{6}$ Meu banco de dados, entretanto, é maior que o de Milesi-Ferreti and Razin (2000).
} 
de admirar, considerada a definição das inversões, sua menor incidência ocorreu nos países industrializados (6\%). As duas regiões de maior incidência foram a África e o Oriente Médio, com $27 \%$ e $26 \%$ de inversões, respectivamente. Na América Latina, a incidência correspondeu a $19 \%$ das observações anuais.

Tanto do ponto de vista teórico quanto do político, é importante determinar se essas inversões são breves ou duradouras. As inversões de curto prazo podem resultar de uma facilitação do consumo, enquanto as mais permanentes tendem a ser uma conseqüência de ajustes externos relacionados com a política. Abordo essa questão indagando em quantos casos de "inversão" o déficit em Conta Corrente continuou menor, três anos depois de identificada a inversão. A resposta é que, no conjunto da amostra, 45\% das "inversões" traduziram-se numa melhora a médio prazo (três anos) da Conta Corrente. O grau de permanência dessas inversões, contudo, variou conforme a região. Nos países avançados, $75 \%$ das inversões se mantiveram depois de três anos; a menor percentagem correspondeu às nações da América Latina, nas quais apenas $37 \%$ das inversões se sustentaram após três anos.

Em seu influente artigo, Milesi-Ferreti e Razin (2000) analisaram os efeitos das inversões da Conta Corrente no desempenho econômico e, em particular, no crescimento do PIB. Basearam-se em dois métodos para examinar essa questão. Utilizaram, primeiramente, uma abordagem "antes e depois", chegando à conclusão provisória de que "as inversões nos déficits da Conta Corrente" não estão necessariamente associadas a uma compressão da produção interna" (p. 302). Uma vez que as análises do estilo "antes e depois" estão sujeitas a vários inconvenientes sérios, os autores também abordaram a questão fazendo uma estimativa de diversas regressões múltiplas em amostras diferentes. Sua variável dependente foi a taxa de aumento da produção per capita, enquanto as variáveis independentes incluíram uma medida da sobrevalorização da taxa de câmbio, um índice de abertura, o nível de endividamento, o PIB inicial e a relação entre investimento e PIB, entre outros. Depois de analisar os resultados obtidos dessa análise de regressão, os autores afirmaram que "as inversões (...) não estão sistematicamente associadas a uma diminuição do ritmo de crescimento" (MilesiFerreti e Razin, 2000, p. 303).

Milesi-Ferreti e Razin (2000) chegaram a essa conclusão depois de calcular equações de crescimento controladas pelo investimento (entre outras variáveis). É altamente provável, no entanto, que as inversões da 
Conta Corrente afetem o próprio investimento e que, por esse canal, causem um impacto no crescimento real do PIB. A razão desse efeito potencial das inversões é bem simples: o investimento é financiado pela soma da poupança nacional com a externa. Esta última, é claro, é exatamente igual ao déficit da Conta Corrente. Portanto, qualquer inversão da Conta Corrente implica uma redução na poupança externa. O que irá acontecer com a poupança agregada - e portanto, com o investimento dependerá da relação entre a poupança externa e a nacional. A evidência empírica existente nesse campo sugere fortemente que a poupança externa compete parcialmente, e apenas parcialmente, com a poupança interna. Edwards (1996), por exemplo, calculou várias equações da poupança privada de países em desenvolvimento e constatou que o coeficiente do déficit da Conta Corrente era significativo, situando-se em torno de -0,4. Loayza et al. (2000) usaram um novo banco de dados sobre a poupança privada nas economias emergentes, e estimaram que o coeficiente do déficit da Conta Corrente era de -0,33 e altamente significativo. Esses resultados, portanto, sugerem que o declínio da poupança externa isto é, um déficit menor na Conta Corrente - reduz a poupança agregada e, por conseguinte, o investimento agregado. Como há amplas provas corroboradoras da idéia de que o investimento surte um efeito positivo no crescimento, a argumentação anterior sugeriria que, contrariando a afirmação de Milesi-Ferreti e Razin (2000), as inversões da Conta Corrente têm um efeito negativo - embora indireto - no crescimento.

Para verificar se as inversões da Conta Corrente efetivamente afetaram o investimento agregado de um modo negativo, calculei diversas equações de investimento, usando dados sobre um grande número de países, relativos ao período de 1970-1997. A recente bibliografia empírica sobre o investimento, inclusive Attanasio et al. (2000), indica que o investimento exibe um grau marcante de persistência ao longo do tempo. Isso sugere equações estimativas do seguinte tipo: ${ }^{7}$

$$
\begin{aligned}
\text { INVPIB }_{\mathrm{t} j}= & \beta \text { INVPIB }_{\mathrm{t}-1 \mathrm{j}}+\delta \text { GOVCONS }_{\mathrm{tj}}+\phi \text { ABERTCOM }_{\mathrm{tj}} \\
& +\gamma \operatorname{INVERSÃO~}_{\mathrm{t} j}+\omega_{\mathrm{t} j}
\end{aligned}
$$

onde INVPIB é a relação entre investimento e PIB, GOVCONS é a relação entre os gastos governamentais e o PIB, ABERTCOM é um

\footnotetext{
${ }^{7}$ Sobre as recentes tentativas de calcular equações de investimento usando um corte transversal de vários países, ver, por exemplo, Barro e Sala-I-Marti (1995) e Attanasio et al. (2000).
} 
índice que capta o grau de abertura da economia e INVERSÃO é uma variável que assume o valor 1 quando o país em questão é submetido a uma inversão da Conta Corrente e assume o valor 0 em caso contrário. ${ }^{8}$ Por último, w é um termo de erro que assume a seguinte forma:

$$
\omega_{t j}=\varepsilon_{j}+\mu_{t j},
$$

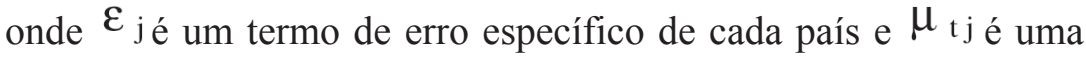
perturbação iid com as características usuais.

A estimativa da equação (1) apresenta dois problemas. Primeiro, a partir dos trabalhos iniciais de Nerlove (1971) sobre a estimativa agrupada dinâmica, sabe-se que, quando o erro contém um termo específico do país, o coeficiente da variável dependente defasada exibirá uma tendência para cima. Há várias maneiras de lidar com esse problema potencial. É possível que a abordagem mais elementar seja usar um modelo de efeito fixo, no qual um país simulado (esperemos) capta o efeito da perturbação específica do país. Uma segunda possibilidade é estimar o método de variáveis instrumentais recentemente proposto por Arellano e Bond (1991) para os dados agrupados dinâmicos. Esse método consiste em diferenciar a equação em pauta - a equação (1), no nosso caso - para eliminar perturbação específica do país, $\varepsilon_{j}$. Em seguida, calcula-se a equação diferenciada usando as variáveis instrumentais, com a variável dependente defasada (em níveis), as variáveis predeterminadas (também em níveis) e usando as primeiras diferenças das variáveis exógenas como instrumentos. Forneço neste artigo os resultados do cálculo da equação (1) usando o método do efeito fixo e o método de Arellano e Bond.

Um segundo problema no cálculo da equação (1) é que, como as inversões da Conta Corrente não são retiradas de um experimento aleatório, é possível que a simulação da INVERSÃO ${ }_{j t}$ se correlacione com o termo de erro. Nessas condições, os coeficientes estimados da equação (1) terão vieses e serão enganosos. Para lidar com esse problema, adotei o método sugerido recentemente por Heckman et al. $(1997,1998)$ para estimar os modelos de "intervenções de tratamento". Esse método

\footnotetext{
${ }^{8}$ Em princípio, o log do PIB inicial também pode ser incluído. Entretanto, dada a natureza agrupada dos dados e os processos de estimativa empregados, isso não é possível.
} 
consiste em calcular a equação em questão usando observações que tenham um respaldo comum para os paises que foram "tratados" e os que não foram "tratados". No caso em exame, os países que passam por uma inversão são considerados sujeitos à "intervenção de tratamento". Do ponto de vista prático, usa-se um processo em duas etapas: (1) primeiro, calcula-se a probabilidade condicional de que os países enfrentem uma inversão - o chamado escore de propensão -, usando uma regressão probit. (2) A equação dos interessados é calculada usando-se apenas observações cuja probabilidade estimada de inversão se enquadre no intervalo das probabilidades estimadas para os países em que há inversões reais. Adotei a correção amostral de Heckman et al. (1997, 1998) tanto no efeito fixo quanto no método de Arellano e Bond. Para calcular os escores de propensão, usei um método probit de dados agrupados e incluí como fatores de regressão o nível do déficit de Conta Corrente no período anterior, o nível do déficit fiscal, a criação de crédito interno e simulações temporais específicas. Os resultados obtidos nessa primeira etapa não são apresentados aqui, por considerações de espaço, mas podem ser obtidos mediante solicitação. A Tabela 2 contém os resultados do cálculo da equação de investimento (1) num grupo não equilibrado de 128 países, no período de 1971-1997. Na Tabela 1.A apresento os resultados da estimativa pelo método de variáveis instrumentais de Arellano e Bond. Na Tabela 1.B forneço os resultados da estimativa do efeito fixo. Em ambos os casos, introduzi o indicador de INVERSÕES em caráter contemporâneo e com uma defasagem de um período. Nas estimativas pelo método de Arellano-Bond, os erros padrões foram calculados usando o procedimento "robusto" de White, que corrige a heterocedasticidade. Os resultados obtidos são muito interessantes. Em ambos os grupos, o coeficiente da variável dependente defasada é relativamente alto, captando a presença da persistência. Convém notar, entretanto, que o coeficiente é significativamente menor quando se usa o método de Arellano-Bond. O coeficiente do GOVCON é positivo e não significativo. O coeficiente estimado de abertura comercial é significativo e positivo, indicando que, feito o controle de outros fatores, os países com um setor comercial mais aberto tenderão a apresentar uma relação mais alta de investimentos em relação ao PIB. O mais importante, para este artigo, é que os coeficientes dos indicadores de inversão contemporâneos e defasados são significativamente negativos, apresentando estimativas pontuais muito parecidas. Curiosamente, quando a variável da INVERSÃO foi somada a uma defasagem de dois anos, seu coeficiente estimado não foi significativo nos níveis convencionais. 
Uma indagação importante é se as inversões da Conta Corrente afetam o crescimento econômico por outros canais. Investiguei essa questão usando a base de dados grande para calcular algumas equações de crescimento básicas, do seguinte tipo:

$$
\begin{aligned}
& \text { CRESCIMENTO }_{\mathrm{tj}}=\beta \text { INVPIB }_{\mathrm{t} j}+\delta \text { GOVCONS }_{\mathrm{tj}} \\
& +\phi \text { ABERTCOM }_{\mathrm{t} j}+\theta \text { LOGPIB }_{\mathrm{j}}+\gamma \text { INVERSÃO }_{\mathrm{t} j}+\xi_{\mathrm{t} j},
\end{aligned}
$$

onde CRESCIMENTO ${ }_{\mathrm{t}}$ é o crescimento do PIB per capita num país j durante o ano t, e LOGPIB é o nível inicial do PIB (em 1970) do país j. Como assinalaram Barro e Sala-I-Martin (1995), espera-se que o coeficiente de GOVCONS seja negativo, enquanto há uma expectativa de que o da abertura seja positivo. Havendo uma equiparação no crescimento, é de se esperar que o coeficiente estimado do logaritmo do PIB per capita de 1970 seja negativo. O interesse principal desta análise está no coeficiente de INVERSÃO. Se as reduções abruptas e grandes no déficit de Conta Corrente surtem um efeito negativo no investimento, é de se esperar que o g negativo estimado seja significativamente negativo. Presume-se que o erro $\xi_{\mathrm{tj}}$, seja heterocedástico, com uma variância diferente em cada país (grupo).

A equação (2) foi calculada usando o método dos quadrados mínimos generalizados viáveis (FGLS), sugerido por Beck e Katz (1995) para grupos não balanceados. As amostras das diferentes estimativas foram determinadas pela disponibilidade de dados sobre os diferentes fatores de regressão. Os dados foram obtidos do Banco Mundial e do banco de dados de Summer e Heston. Nas estimativas básicas, usei a definição de inversões do balanço de pagamentos fornecida acima. Os resultados fundamentais do cálculo da equação (2) são apresentados na Tabela 3. Além dos fatores de regressão da equação (2), introduzi simulações de variáveis temporais específicas. Como se pode ver pela tabela, os resultados obtidos corroboram a hipótese de que as inversões da Conta Corrente têm um efeito negativo no crescimento do PIB per capita, mesmo depois de feito o controle do investimento. Além disso, os coeficientes das outras variáveis da regressão exibem os sinais esperados e são significativos nos níveis convencionais. Quando se utilizaram técnicas alternativas de estimativa, inclusive os efeitos fixos, os resultados obtidos foram muito semelhantes. ${ }^{9}$

\footnotetext{
${ }^{9}$ Naturalmente, quando se empregam efeitos fixos, não é possível incluir (o logaritmo do) PIB inicial como fator de regressão.
} 
Os resultados apresentados nesta seção sugerem que as inversões da Conta Corrente podem ser realmente muito custosas. Isso é de especial importância à luz do que Rudi Dornbusch chamou de "paradas repentinas", ou situações em que a suspensão abrupta do financiamento externo obriga um país a uma grande inversão da Conta Corrente. Por sua vez, as paradas repentinas estão relacionadas com a situação em que a comunidade financeira internacional percebe o fluxo vigente do capital internacional como insustentável. Uma pergunta importante, que ultrapassa o âmbito deste artigo, é se países como o Brasil e a Colômbia, no momento em que este texto está sendo redigido, encontram-se numa situação de insustentabilidade dos fluxos de capital.

\section{Considerações finais}

A discussão das duas seções precedentes versou sobre aspectos macroeconômicos do crescimento. Existe pouca dúvida de que a macroeconomia é importante e de que evitar as grandes crises macroeconômicas traz uma contribuição significativa para a consecução da meta do desenvolvimento e da prosperidade. Aliás, são amplos os indícios sugestivos de que as crises macroeconômicas e cambiais afetam desproporcionalmente os pobres.

Mas o nível macro não é tudo. Nesta última parte, ofereço algumas reflexões sobre outros aspectos do crescimento de longo prazo. Em particular, quero discorrer sobre a "cultura" e o papel potencial da nova economia.

Recentemente, o historiador econômico David Landes afirmou que, quando se trata de explicar as diferenças de crescimento e desempenho entre os países, "a cultura faz quase toda a diferença" (2000, p. 2).

A idéia de que a cultura afeta o desempenho econômico não é nova, obviamente. Max Weber deixou isso claro em sua análise das origens do capitalismo. Em época mais recente, a idéia de que a cultura e as instituições, em particular, desempenham um papel fundamental no desenvolvimento foi enfatizada por estudiosos como Douglas North, Francis Fukuyama e Robert Putnam. Douglas North, agraciado com o Prêmio Nobel, afirmou que os países capazes de desenvolver instituições fortes, que protejam os direitos de propriedade e ajudem a solucionar as disputas, têm "custos de transação" baixos e podem dedicar-se plenamente às atividades produtivas. Robert Putnam concentrou-se no 
papel do capital "social" e afirmou que as diversas culturas tratam essa importante forma de capital de maneiras diferentes. Francis Fukuyama enfatizou o papel da confiança. Baseando-se nessa idéia, Ronald Inglehart (2000) apresentou, recentemente, dados sugestivos de que algumas culturas têm um grau maior de confiança do que outras. As culturas "de alta confiança", por sua vez, têm-se saído melhor em termos do desempenho econômico. Os países da América Latina saem-se particularmente mal nessa dimensão da confiança, com a Argentina, o Brasil, o Chile e o México exibindo uma "confiabilidade" significativamente menor que a das nações européias e asiáticas.

Essa ênfase na cultura ajuda a situar a tecnologia numa perspectiva adequada. Em particular, frisa um aspecto recentemente salientado por alguns autores, no contexto da "nova" economia e do desempenho empresarial: ${ }^{10}$ a menos que seja acompanhada por mudanças "culturais" com o que me refiro a mudanças institucionais, mudanças de valores e profundas mudanças econômicas -, a tecnologia da informação terá pouco efeito no crescimento agregado e no desempenho. Em termos de clichês, poderíamos dizer que "a revolução da tecnologia da informação exige uma revolução cultural"!

$\mathrm{Na}$ vida real, as relações econômicas e sociais raramente são unidirecionais. Isso quer dizer que, embora uma adaptação eficaz da tecnologia da informação exija uma revolução cultural, essa tecnologia, por si só, pode ajudar a catalisar as mudanças culturais e institucionais. A tecnologia da informação pode contribuir para aumentar a transparência e reduzir a corrupção. Foi o que aconteceu, por exemplo, nos países em que as aquisições governamentais passaram a ser feitas on line. Além disso, ao reduzir o custo das comunicações, a tecnologia da informação pode reduzir a "distância econômica" entre os países. A "proximidade", por sua vez, aumenta o comércio internacional e contribui para tornar indistintas as diferenças culturais. Recentemente, Leamer e Storper (2001) afirmaram que, ainda que a Internet não venha a substituir os mecanismos básicos através dos quais se estabelecem relações comerciais "alicerçadas na confiança", ela reduzirá o custo de manutenção dessas relações. É provável que isso reduza os custos de transação e torne as relações econômicas mais eficazes e produtivas. E, na medida em que a tecnologia da informação ajudar a aprimorar a quali-

${ }^{10}$ Brynjolfsson, Renshaw e Van Alstyne (1997). 
dade do ensino - através do uso de computadores em salas de aula e da implementação de testes padronizados, do tipo do Third International Math and Sciences Survey (TIMSS), ${ }^{\mathrm{t} 1}$ a serem aplicados a alunos de curso médio -, ela também ajudará a introduzir mudanças culturais entre os jovens.

É importante assinalar que, quando se trata do uso da tecnologia da Internet, há custos envolvidos na utilização de "atalhos". Implementar grandes projetos tecnológicos em nível nacional, sem fazer mudanças nas áreas complementares identificadas neste artigo, pode ter efeitos indesejáveis e resultar em importantes custos sociais. Mais especificamente, as medidas de política pública que almejem subsidiar a adoção ou o uso da tecnologia de informação podem ser muito dispendiosas e gerar resultados escassos. Partir do esforço no nível educacional parece ser a estratégia correta. Se o esforço em prol da tecnologia da informação for efetivamente empreendido como parte de um "sistema" de mudanças que reforcem umas às outras, ele poderá de fato transformar-se num poderoso instrumento do empenho da América Latina em buscar o crescimento, o desenvolvimento e a prosperidade.

\section{Tabela 1:}

Crescimento da produtividade total dos fatores em países seletos da América Latina nas décadas de 1980 e 1990

\begin{tabular}{|c|c|c|}
\hline PAÍS & $\begin{array}{c}\text { CRESCIMENTO } \\
\text { ESTIMADO DA PTF (\%) } \\
\mathbf{1 9 8 0 - 9 0}\end{array}$ & $\begin{array}{c}\text { CRESCIMENTO } \\
\text { ESTIMADO DA PTF (\%) } \\
\mathbf{1 9 9 0 - 2 0 0 0}\end{array}$ \\
\hline Argentina & $-2,4$ & 1,1 \\
\hline Brasil & $-1,5$ & 0,7 \\
\hline Chile & 1,0 & 2,0 \\
\hline Colômbia & 0 & $-1,6$ \\
\hline Equador & $-1,3$ & $-0,6$ \\
\hline México & $-2,4$ & $-1,5$ \\
\hline Panamá & $-2,9$ & $-1,1$ \\
\hline Peru & $-3,3$ & 3,9 \\
\hline MÉDIA & $-1,6$ & 0,4 \\
\hline MEDIANA & $-2,0$ & 0,1 \\
\hline
\end{tabular}

Fonte: Goldman-Sachs, quanto ao período de 1980-1997; cálculos do autor quanto ao período de 1998-2000.

${ }^{\mathrm{T} 1}$ Terceiro Levantamento Internacional de Matemática e Ciências. (N. da T.) 
Tabela 2:

Investimento e inversões do balanço de pagamentos

\section{a. Variáveis Instrumentais de Arellano-Bond}

Dados do painel dinâmico de Arellano-Bond Variável grupal (i): cód. FMI

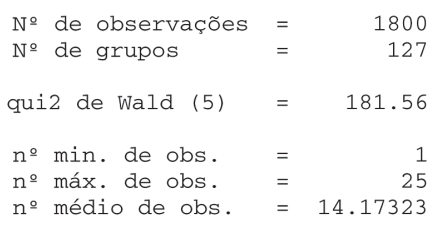

Variável temporal (t): ano

ํㅜ max. de obs.

14.17323

\begin{tabular}{|c|c|c|c|c|c|c|c|}
\hline \multicolumn{2}{|l|}{ invpib } & Coef. & $\begin{array}{l}\text { Erro pad. } \\
\text { Consist. }\end{array}$ & z & $\mathrm{P}>|\mathrm{z}|$ & \multicolumn{2}{|c|}{ [95\% Intervalo Conf.] } \\
\hline avpib & & & & & & & \\
\hline ovcon & LD & .6212481 & .0835012 & 7.44 & 0.000 & .4575887 & .7849075 \\
\hline & D1 & .0819257 & .1063111 & 0.77 & 0.441 & -.1264401 & .2902916 \\
\hline rev & D1 & -2.021207 & .2545002 & -7.94 & 0.000 & -2.520018 & -1.522396 \\
\hline comércio & D1 & -.8834781 & .2235849 & -3.95 & 0.000 & -1.321696 & -.4452596 \\
\hline cons & D1 & $\begin{array}{r}.0436178 \\
-.0480371\end{array}$ & $\begin{array}{l}.0127593 \\
.0169209\end{array}$ & $\begin{array}{r}3.42 \\
-2.84\end{array}$ & $\begin{array}{l}0.001 \\
0.005\end{array}$ & $\begin{array}{r}.0186101 \\
-.0812014\end{array}$ & $\begin{array}{r}.0686255 \\
-.0148727\end{array}$ \\
\hline
\end{tabular}

O teste de Arellano-Bond com autocovariância média em resíduos da ordem 1 é 0 : H0: sem autocorrelação $z=-4.46 \quad \operatorname{Pr}>z=0.0000$

o teste de Arellano-Bond com autocovariância média em resíduos da ordem 2 é 0 : H0: sem autocorrelação $z=-1.08 \quad \operatorname{Pr}>z=0.2809$

\section{b. Método dos Efeitos Fixos}

Efeitos fixos (dentro da) regressão $\quad$ № de obs. $\quad 1927$ Variável grupal (i) : cód. FMI

№ de grupos $\quad=128$

R-sq: $\begin{array}{ll}\text { dentro } & =0.6523 \\ \text { entre } & =0.9301\end{array}$

global $=0.8357$

Obs. por grupo: $\min .=1$

méd. $=\quad 15.1$

máx. = $\quad 26$

$\begin{array}{llll}\text { corr. }\left(u_{-} i, \mathrm{Xb}\right)=0.3082 & \text { F }(5,1794) & & 672.98 \\ & \text { Prob }>\mathrm{F} & & 0.0000\end{array}$

\begin{tabular}{|c|c|c|c|c|c|c|}
\hline invpib & Coef. & Erro Pad. & $t$ & $P>|t|$ & \multicolumn{2}{|c|}{ [95\% Intervalo Conf.] } \\
\hline invpib1 & .7655012 & .0139967 & 54.69 & 0.000 & .7380497 & .7929527 \\
\hline govcon & .0326171 & .0186247 & 1.75 & 0.080 & -.0039113 & .0691455 \\
\hline rev & -2.05903 & .1622943 & -12.69 & 0.000 & -2.377336 & -1.740724 \\
\hline revlag & -.8404217 & .1585791 & -5.30 & 0.000 & -1.151441 & -.5294026 \\
\hline comércio & .0324689 & .0051885 & 6.26 & 0.000 & .0222927 & .042645 \\
\hline _cons & 3.266194 & .4745214 & 6.88 & 0.000 & 2.335521 & 4.196867 \\
\hline sigma $u$ & 1.6838827 & & & & & \\
\hline sigma_e & 2.4746612 & & & & & \\
\hline rho & .31647855 & ção da & variân & 西 & $u$ i) & \\
\hline
\end{tabular}

$F$ teste de que todo $u_{-} i=0: F(127,1794)=2.61 \quad$ Prob $>F=0.0000$ 
Tabela 3:

\section{Crescimento do PIB e inversões do balanço de pagamentos}

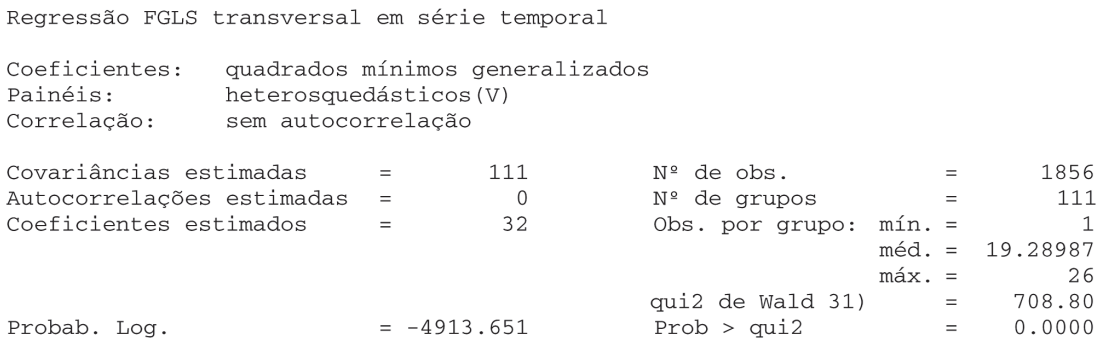

\begin{tabular}{|c|c|c|c|c|c|c|}
\hline crespib & Coef. & Erro Pad. & z & $\mathrm{P}>|\mathrm{z}|$ & \multicolumn{2}{|c|}{ [95\% Intervalo Conf.] } \\
\hline & & & & & & \\
\hline invpib & .1732786 & .0129535 & 13.38 & 0.000 & .1478901 & .198667 \\
\hline govcon & -.044147 & .0129061 & -3.42 & 0.001 & -.0694425 & -.0188514 \\
\hline comércio & .0066118 & .0021185 & 3.12 & 0.002 & .0024595 & .010764 \\
\hline loggpp 0 & -.7458834 & .0754805 & -9.88 & 0.000 & -.8938225 & -.5979443 \\
\hline rev & -.8387433 & .2063497 & -4.06 & 0.000 & -1.243181 & -.4343053 \\
\hline revlag & -.3106008 & .2014468 & -1.54 & 0.123 & -.7054293 & .0842277 \\
\hline $\mathrm{d} 73$ & 1.270318 & .759329 & 1.67 & 0.094 & -.2179398 & 2.758575 \\
\hline $\mathrm{d} 74$ & -1.342419 & .7482716 & -1.79 & 0.073 & -2.809004 & .1241666 \\
\hline d75 & -3.115973 & .7482444 & -4.16 & 0.000 & -4.582505 & -1.649441 \\
\hline $\mathrm{d} 76$ & .6267746 & .7248618 & 0.86 & 0.387 & -.7939283 & 2.047478 \\
\hline $\mathrm{d} 77$ & -.9757318 & .6522791 & -1.50 & 0.135 & -2.254175 & .3027116 \\
\hline $\mathrm{d} 78$ & .1379759 & .5050662 & 0.27 & 0.785 & -.8519357 & 1.127887 \\
\hline d79 & -1.096983 & .6317958 & -1.74 & 0.083 & -2.33528 & .1413142 \\
\hline d80 & -2.360201 & .6280218 & -3.76 & 0.000 & -3.591101 & -1.129301 \\
\hline d81 & -2.826354 & .6242467 & -4.53 & 0.000 & -4.049855 & -1.602853 \\
\hline $\mathrm{d} 82$ & -4.194326 & .6217559 & -6.75 & 0.000 & -5.412945 & -2.975707 \\
\hline d83 & -2.990355 & .6199746 & -4.82 & 0.000 & -4.205483 & -1.775227 \\
\hline $\mathrm{d} 84$ & -1.221758 & .6185186 & -1.98 & 0.048 & -2.434032 & -.0094836 \\
\hline d85 & -1.784731 & .6187208 & -2.88 & 0.004 & -2.997401 & -.5720605 \\
\hline $\mathrm{d} 86$ & -1.75282 & .617261 & -2.84 & 0.005 & -2.962629 & -.5430107 \\
\hline d87 & -1.596635 & .6173792 & -2.59 & 0.010 & -2.806676 & -.3865935 \\
\hline $\mathrm{d} 88$ & -.7132081 & .6150168 & -1.16 & 0.246 & -1.918619 & .4922027 \\
\hline d89 & -1.492796 & .6147887 & -2.43 & 0.015 & -2.69776 & -.2878324 \\
\hline d90 & -2.005303 & .6140373 & -3.27 & 0.001 & -3.208794 & -.8018121 \\
\hline d91 & -2.686583 & .6082038 & -4.42 & 0.000 & -3.878641 & -1.494526 \\
\hline d92 & -2.38132 & .6155925 & -3.87 & 0.000 & -3.587859 & -1.17478 \\
\hline d93 & -2.23038 & .6150288 & -3.63 & 0.000 & -3.435814 & -1.024945 \\
\hline d94 & -.8790476 & .6164939 & -1.43 & 0.154 & -2.087353 & .3292582 \\
\hline d95 & -.9938183 & .5940141 & -1.67 & 0.094 & -2.158065 & .170428 \\
\hline d96 & -1.480438 & .6129868 & -2.42 & 0.016 & -2.68187 & -.2790063 \\
\hline d97 & -1.263988 & .6449348 & -1.96 & 0.050 & -2.528037 & .0000611 \\
\hline _cons & 7.826786 & .8179467 & 9.57 & 0.000 & 6.22364 & 9.429932 \\
\hline
\end{tabular}




\section{Referências bibliográficas}

BERNDT, E. R., MORRISON, C. J. e RESENBLUM, L. S., "HighTech Capital, Economic Performance and Labor Compensation in U.S. Manufacturing Industries: An Exploratory Analysis", MIT Working Paper, 3414EFA, 1992.

BRYNJOLFSSON, Erik, "The Productivity Paradox of Information Technology", Communications of the ACM, 35(12), 1993.

BRYNJOLFSSON, Erik, A. Renshaw e M. Van Alstyne, "The Matrix of Change", Sloan Management Review, inverno de 1997.

BRYNJOLFSSON, Erik e HITT, Lorin M., "Beyond Computation: Information Technology, Organizational Transformation and Business Performance", The Journal of Economic Perspectives, 14(4), 2000.

CORDEN, M., "Does the Current Account Matter?” Documento de trabalho, 1994.

DE SOTO, Hernando, The Other Path, Harper and Row, 1989.

DJANKOV, S., LA PORTA, R., LOPEZ DE SILANES, F. e SHLEIFER, A., "The Regulation of Entry", National Bureau of Economic Research Working Paper 7892, 2000.

DOMS, Mark, DUNNE, Timothy e TROSKE, Kenneth R., "Workers, Wages and Technology", The Quarterly Journal of Economics, 112(1), 1997.

EDWARDS, S., The Order of Economic Liberalization, Princeton Essays in International Finance, 156, 1984.

EDWARDS, S., Capital Controls, Exchange Rates and Monetary Policy in the World Economy, Cambridge University Press, 1995.

EDWARDS, S., "Does the Current Account Matter? NBER Working Paper 8275, 2001.

EDWARDS, S. e FRANKEL, J. A., Preventing Currency Crises, University of Chicago Press, 2002.

GREENAN, Nathalie, LHORTHY, Yannick e MAIRESSE, Jacques, The Puzzling Relations Between Computer and the Economy. MIT Press, 2001.

GUITIAN, M., "Capital Account Liberalization: Bringing Policy in Line with Reality", in Edwards, S. (org.), Capital Controls, Exchange Rates and Monetary Policy in the World Economy, 1995.

INGLEHART, R., "Culture and Democracy”, in L. E. Harrisona e S. P. Huntington (orgs.), Culture Matters, Basic Books, 2000. 
LANDES, David, "Culture Makes Almost All of the Difference," in L. E. Harrisona e S. P. Huntington (orgs.), Culture Matters, Basic Books, 2000.

LEAMER, Edward e STORPER, Michael, "The Economic Geography of the Internet Age", Anderson Graduate School of Management, UCLA, abril de 2001.

MEADE, James E., The Balance of Payments, Londres, Oxford University Press, 1951.

MILESI-FERRETTI, Gian Maria e RAZIN, Assaf, "Sustainability of Persistent Current Account Deficits", National Bureau of Economic Research Working Paper No. 5467, 1996.

MILESI-FERRETTI, Gian M. e RAZIN, Assaf, "Sharp Reduction in Current Account Deficits: an Empirical Analysis." European Economic Review, 42, 1998.

MILESI-FERRETTI, Gian Maria e RAZIN, Assaf , "Current Account Reversals and Currency Crises: Empirical Regularities", in P. Krugman (org.), Currency Crises, University of Chicago Press, 1998.

MUNDELL, R., "Stabilization and Liberalization Policies in Semi-Open Economies", in Edwards, S. (org.) Capital Controls, Exchange Rates and Monetary Policy in the World Economy, Cambridge University Press, 1995.

NERLOVE, Mark, "Further Evidence on the Estimation of Dynamic Economic Relations from a Time Series of Cross-Sections", Econometrica 39, 1971.

NORDHAUS, William D., "New Data and Output Concepts for Understanding Productivity Trends", NBER Working Paper, 8097, 2001.

OBSTFELD, Maurice e ROGOFF, Kenneth, Foundations of International Macroeconomics, MIT Press, 1996.

SACHS, J., "The Current Account and Macroeconomic Adjustment in the 1970s", Brookings Papers, 1981.

STIGLITZ, J., Globalization and its Discontents, Norton, 2002.

WORLD ECONOMIC FORUM, The Global Competitiveness Report 2000, Oxford University Press, 2000. 
DEBATEDORES

\section{Desafios do Crescimento: INSTITUIÇÕES, INVESTIMENTOS, COMPETITIVIDADE E TECNOLOGIA}




\section{Antonio Barros de Castro*}

Quatro pequenas observações preliminares. Primeiramente este seminário se dá, ao que tudo indica, num momento muito, muito especial, não só no Brasil, como no mundo. Talvez se possa definir este momento como de reconhecimento, inequívoco, de que existe uma ampla crise do pensamento hegemônico acerca de como funcionam as economias de mercado. Luciano Martins chegou a fazer uma forte convocação, no sentido de se repensarem criticamente todas as crenças. O Bacha, também, na sua incisiva intervenção como debatedor, explorou, mais focalizadamente, esta questão. Eu vou prosseguir nessa linha.

Segunda observação: um ponto muito gratificante deste seminário é o retorno, desinibido, do tema da diversidade histórica; da biodiversidade econômico-nacional. Rodrik foi muito forte nesta direção; OCampo também. Do ponto de vista Brasil, duas observações neste mesmo tom. $\mathrm{O}$ Brasil deixou de ser visto pelas diferenças em relação a um modelo supostamente ideal de economia. Ou seja, até poucos anos, quando alguém pretendia caracterizar o Brasil apontava supostos atrasos, desvios, distâncias que faltava cobrir, para completar os "deveres de casa". Hoje, não: volta-se a buscar o que há de específico. Eu não acho coincidência que, neste exato momento, se faça uma homenagem do porte que vimos aqui a Celso Furtado, pensador da diversidade e, sobretudo, da especificidade do Brasil.

Terceira observação, rápida. Eu acompanho com fascínio a obra do professor Castells e gostaria que ele se posicionasse sobre um grande tema que está por trás de várias exposições neste seminário: o que, na nova economia, é ciclo, e o que é, efetivamente, nova economia?. O que

\footnotetext{
* Professor Titular, Instituto de Economia da Universidade Federal do Rio de Janeiro.
} 
é (ou foi) bolha, e o que é nova economia; o que é exuberância irracional, e o que é novo modo de funcionar. Só para provocar: uma das referências preferidas do professor Castells era a CISCO SYSTEM, representante máximo da empresa em rede, quase puramente virtual. Ora, o que mais representava o novo, literalmente desapareceu!

Quarta e última observação preliminar: quando me passarem a advertência tempo esgotado, pretendo parar na frase em que estiver. Estamos fortemente constrangidos pelo tempo, e sei que o Presidente da mesa gostaria de passar a palavra para a platéia.

Começo os meus comentários com uma frase, do Edwards, no documento que ele circulou e que não corresponde exatamente à exposição. Lá é dito: "a macroeconomia não é tudo". Dificilmente uma frase poderia representar melhor as mudanças em relação aos anos noventa. Estamos saindo de uma fase em que poucos questionavam a idéia de que o que interessa é, fundamentalmente, a microeconomia. Não havia que combater os ciclos, e não havia que promover, sobretudo via demanda, o crescimento. Faziam sentido duas coisas: estabelecer regras claras, límpidas e, em se tratando de um neo-institucionalista, ir mais além, aprimorando instituições destinadas a reduzir os custos de transação, assegurar os direitos de propriedade, e tudo o mais que deixe fluir as decisões dos agentes econômicos. Isto permitiria aumentar a eficiência e elevar a produtividade, chave da competição. O professor Edwards começa o artigo dizendo que no centro do problema latino-americano está a baixa produtividade. O problema, então, é essencialmente microeconômico!

Vamos passar agora para o Brasil, tendo como pano de fundo esta última questão. O Brasil em termos de estrutura produtiva, seja na indústria, seja na agropecuária, passou pelo teste da abertura, bastante bem e de forma muito peculiar. Enquanto as ex-economias soviéticas implodiram, enquanto o Chile descobriu novas especialidades ou reciclou especialidades antigas, enquanto a China e a Índia fizeram uma complexíssima transformação histórico-estrutural que não pode ser resumida numas poucas frases, o Brasil fez algo relativamente simples e único. Ele limitou-se a reciclar, e atualizar, a sua estrutura produtiva anterior. Com isso, no entanto, promoveu saltos de eficiência em diversas áreas: têxtil, automobilística, certos ramos de equipamentos, etc. Até mesmo nos campos mais tradicionais, verdadeiros saltos ocorreram e ou estão em curso, o que pode ser exemplificado pela soja, o algodão, e até mesmo o café. Os setores que não avançaram muito, tecnológica e 
organizacionalmente, são os que já eram avançados: siderurgia, celulose, petroquímica. Claro que, em alguns casos, houve perdas e defecções. Nos Estados Unidos também e na Europa também, como mostra abundantemente o professor Chandler em seu último livro (The Eletronic Century). Gostaria, a propósito, de introduzir um dado fundamental, ainda que, infelizmente, impreciso. Segundo a pesquisa industrial mensal do IBGE, PIM, a produtividade do trabalho cresceu $8,5 \%$ ao ano durante a década dos noventa, o que é uma média absolutamente extraordinária. O número equivalente nas Contas Nacionais é bem menor, 5,4 - ainda um alto nível (e os especialistas parecem, para este efeito, aceitar mais a PIM do que as contas nacionais). Enquanto isto as lavouras deram um salto. Em grãos passa-se de uma safra de 60, 70 milhões de toneladas para algo como 100 milhões de toneladas. E isto com a mesma superfície cultivada - e variando algo como $1 \%$ negativo a população diretamente aplicada em atividades agropecuárias. Mais uma vez os avanços são extraordinários. E quem diz isso quase necessariamente está dizendo que houve mudanças fortes de preços relativos, o que implica em forte aumento do poder aquisitivo dos salários em termos de manufaturas e de alimentos básicos. Quem vive no Brasil sabe, na prática, disso.

Então, o Brasil não foi para especialização alguma, ao contrário do que muitos previam, e cumpriu de uma forma também não prevista o objetivo forte aumento da produtividade. Em outras palavras, se a microeconomia decidisse, o Brasil teria começado um novo milagre. $\mathrm{Na}$ realidade o relatório Mc Kinsey, pioneiro na descoberta do grande salto da produtividade, tinha como subtítulo "produtividade, a chave para o desenvolvimento acelerado", e supunha que estávamos no limiar do crescimento rápido. Infelizmente, o diagnóstico microeconômico apontava na direção certa, mas a aposta se mostrou completamente equivocada. Antes de prosseguir e entrar no principal da minha análise, devo advertir que estes dados conflitam com os do professor Edwards. Um problema parece ser que ele está tentando medir uma produtividade conjunta, que combina trabalho e capital, e acontece que a produtividade do capital terá tido necessariamente (aritmeticamente) um resultado péssimo, já que a produtividade do trabalho aumentou drasticamente e a produção não cresceu. Repito: se a produção não cresceu, e a eficiência do trabalho aumentou muito, a produtividade do capital terá que ter tido um comportamento péssimo! 
Na realidade o Brasil, além de aumentar enormemente a eficiência do trabalho e a modernidade das empresas manufatureiras e agropecuárias, entrou num regime de oscilações violentíssimas. Entrou naquilo que nós poderíamos chamar de uma montanha russa do lado real da economia, especialmente na manufatura. Ignorando as mudanças do lado empresarial, poderia-se mesmo dizer que trocou a montanha russa nominal, de que falava Simonsen, por uma montanha russa real. A tendência ou resultante é muito medíocre, e nada revela das transformações ocorridas. O PIB cresceu algo como 2,4, enquanto a PEA, ou seja, a população economicamente ativa cresceu a 2 , o que significa que o produto por homem apto a trabalhar praticamente não cresceu: 2 versus 2,4 . Isto é bastante chocante, sobretudo quando se têm em conta os grandes avanços na esfera das empresas.

Para quem se debruça sobre este problema, a primeira questão a ser registrada é a seguinte: impulsão a partir das empresas é o que não faltou. Todas as vezes que a economia pode crescer, ela empinou com grande velocidade, liderada pela indústria. Quatro vezes a indústria arremeteu numa velocidade de $7 \%$ ao ano, e todas as vezes embicou, retraindo-se a algo como 4\% anual - o que só pode ser claramente visualizado em acompanhamentos trimestrais. Impulsão, portanto, não falta. Mas, também, não resolve. A microeconomia está longe de ser tudo.

A questão é que a demanda que anima a economia não vem de fora, não é exógena, ao contrário de outros países, que flutuam ao sabor da demanda externa. As restrições financeira e de confiança não permitem que a demanda (doméstica) cresça. É como se as relações com o exterior alternassem momentos em que o crescimento é permitido ou (alternativamente) é vetado. Sucessivos ajustes impostos à economia reiteradamente a derrubam - com as políticas públicas atuando como coadjuvante do movimento que vem de fora. Nada disto, diretamente, pelo menos, tem a ver com a base produtiva, com a microeconomia. E por trás disto está o fato de que o Brasil, lamentavelmente, fez uma combinação altamente nefasta de três elementos: juros elevados, dívida rapidamente crescente e crescimento médio baixo. Conjugar essas três variáveis, desta maneira, durante anos, é fatal. O Brasil havia sucumbido a esta atração fatal - à qual havia resistido, bravamente, em outros momentos de sua história. E diante deste regime suicida, o governo se tornou fortemente pró-cíclico, para impedir a consumação do suicídio. $\mathrm{E}$ os agentes privados também se tornaram pró-cíclicos, fazendo mais rápidas e eficazes as retrações. 
Mudando de ângulo, cabe perguntar por que o aumento da produtividade não se transformou em aumento das exportações. Deveria haver uma forte conexão entre aumento da produtividade e aumento das exportações. Mas acontece que o movimento que as empresas brasileiras percorreram as capacitou para disputar, preferencialmente, o mercado interno, como procurei mostrar em diferentes trabalhos. O que se fez no Brasil foi um catch up parcial, apenas produtivo. Através dele atingiuse excelência manufatureira, mas permaneceram relativamente atrofiadas as mais modernas armas da competição. E isto me leva a tocar a questão do conhecimento e a tangenciar problemas levantados por Coriat. Com este intuito farei uma breve referência a Prebish.

Prebish dizia que os preços dos produtos primários tendiam a cair em relação aos preços dos produtos industrializados. Ele tinha razão, num certo contexto histórico. Mas o mundo mudou e as multinacionais deslocaram para a periferia a fabricação de numerosas manufaturas. Com isto surge a tendência à queda dos preços relativos dos bens manufaturados! E aí surgem estudos, com copiosa base empírica, para mostrar que Prebish estava errado. Mas o que prejudica a periferia na visão de Prebish é, em última análise, a assimetria de poder. Enquanto as empresas do norte tiverem poder de mercado e sindicatos poderosos, elas retêm os ganhos de produtividade - enquanto no sul os ganhos de produtividade se esvaem para o mercado. Mutatis mutantis, Coriat, provocativamente, adiciona uma terceira etapa.

A terceira etapa da lei de Prebish qual seria? Os desenvolvidos agora tratam de impedir que os avanços da economia do conhecimento tenham o seu valor aviltado. Criar, prototipar, inovar está se tornando mais barato - e o conhecimento está se difundindo mais rapidamente. Aí vêm, a galope, pelo menos Coréia e China. Insisto, mais uma vez se recoloca a questão dos preços relativos. Trata-se, no instigante paper de Coriat, de impedir que os preços relativos dos produtos de fronteira caiam. E isto se tenta, criando uma série de dificuldades para a difusão do conhecimento. Diluem-se assim, mais uma vez, as possíveis "vantagens do atraso", na expressão de Gerschenkron. De fato, a grande possível vantagem do atraso é poder tomar o conhecimento a grandes goles. Mas desde List pelo menos se sabe que aqueles que sobem tendem a "chutar a escada pela qual subiram" (título do mais recente livro de Há Joon Chang). Nada há de surpreendente nisto. Nem sequer a renúncia à autodefesa, por parte de muitos, deve surpreender. 
Desenvolvimento em Debate - 446 


\section{Winston Fritsch*}

Muito obrigado, Embaixador Sergio Amaral. A primeira impressão que os Senhores devem ter tido, da apresentação dos trabalhos deste painel, é de como é hoje fragmentado o paradigma teórico de análise da relação entre crescimento econômico, produtividade e tecnologia. Num painel como este, há dez anos, certamente a maior parte das referências seria a modelagens neoclássicas na tradição de Harrod-Domar, que acabaram se esterilizando. Hoje o tema é tratado de uma maneira muito menos atrelada a este paradigma, após uma volta à tradição clássica original no tratamento da questão do crescimento econômico, onde não existe distinção entre curto e longo prazo, como é feita no arcabouço neoclássico, mas se analisa a relação entre crescimento e crescimento de produtividade como um processo. Esse processo, como foi apontado pelo professor Castels, é visto como um círculo vicioso, e há várias e ricas referências a aspectos que chamaríamos hoje de institucionais, como feito aqui pelos três expositores.

De fato, no tratamento do tema do desenvolvimento econômico, na obra-prima dos clássicos que é a riqueza das Nações, Adam Smith enfatiza a importância do investimento, em suas palavras, do aumento de estoque de capital, e sua relação com produtividade como motor do crescimento. Na visão de Smith, o crescimento do produto per capita é explicado dinamicamente como processo de causação circular (onde longo e curto prazo se fundem) entre o investimento e o aumento de produtividade. É o crescimento de estoque de capital, o aumento do capital produtivo, que aumenta o tamanho do mercado que, na visão de Smith, é o motor do aumento da divisão de trabalho - sinônimo de

\footnotetext{
* Dresden-Bank, Diretor.
} 
aumento da produtividade. Sobre essa dinâmica, nada foi dito que tenha aumentado muito nossa compreensão do processo nos últimos duzentos e cinqüenta anos desde a magistral intuição de Adam Smith.

Esse nexo de investimento, produtividade e crescimento é crucial. É intuitivo que é a tecnologia nova que explica o aumento de produtividade, e que ela se incorpora através do investimento. Que a invenção se torna inovação produtiva através do investimento. Portanto, se é o investimento produtivo que é propulsor não só do crescimento de produtividade como também desse circulo virtuoso entre produtividade e crescimento, a questão central da dinâmica do processo é a questão dos determinantes do investimento. Ou seja, crescimento econômico e crescimento de produtividade sem investimento é como Hamlet sem o príncipe.

Isso não quer dizer que o estudo da dinâmica da inovação, da capacidade empresarial de uma sociedade (que determina o conteúdo tecnológico do investimento num dado ponto do tempo) não seja relevante. E que sejam irrelevantes fatores como educação, propriedade intelectual, e outros mencionados pelos palestrantes. Mas do ponto de vista economicista, se quiserem, ou para um dado estado da tecnologia, o investimento é a mola propulsora do crescimento da produtividade.

A pergunta relevante é, então: quais os determinantes do investimento? Para discutir isso, eu preparei um slide bastante esquemático, que está sendo agora projetado para os senhores, e no qual chamo a atenção para dois elementos cruciais da dinâmica do investimento.

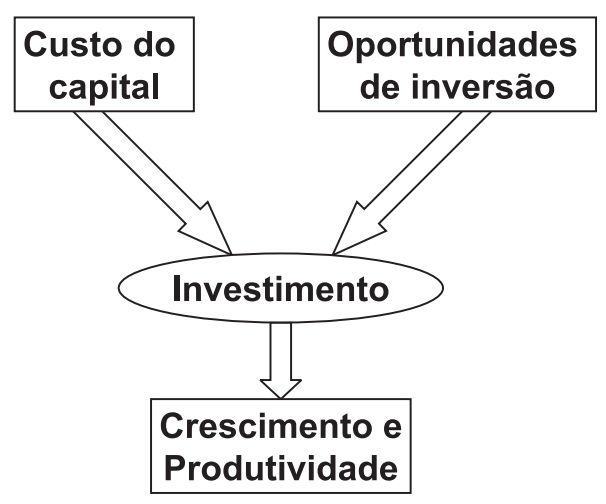


Primeiro: é o investimento que propele o crescimento e que, por esta forma virtuosa de se relacionar com a produtividade, gera o processo de crescimento. Segundo: a questão relevante do ponto de vista de política econômica no Brasil são os determinantes do investimento. Como se vê, no gráfico, existem dois determinantes fundamentais: o custo do capital por um lado, e as oportunidades de investimento, ou se você quiser, dado um conjunto de oportunidades de investimento, por outro. $\mathrm{Ou}$, colocando de um outro modo, dado um conjunto de oportunidades de investimento, é o custo de capital que vai determinar o nível de investimento. É claro que há fatores macroeconômicos e institucionais que influenciam o custo de capital. Há também um vastíssimo conjunto de fatores culturais, históricos, etc. que determinam o que está sendo chamado no meu diagrama de oportunidades de investimentos, influenciadas pelo que Keynes chamava de "o espírito animal dos empresários". Mas eu gostaria agora de me concentrar, por considerar extremamente relevante, no custo de capital como determinante de investimento. Vamos considerar que os outros determinantes das possibilidades de investimento são dados e olhar somente o custo de capital, pois estou convencido de que o maior problema, o maior desafio da política industrial no Brasil é o alto custo de capital, e não como normalmente se discute, a calibragem de incentivos tradicionais de política industrial que afetam preços relativos, como tarifas, subsídios, etc.

Na minha visão é o alto e especialmente volátil custo do capital do Brasil, pelo seu efeito sobre o investimento, o principal "handicap", o principal óbice, ao nosso crescimento e, portanto, à nossa competitividade. De fato o problema do capitalismo periférico é que falta capital, e, portanto, seu custo é alto. É interessante perguntar: qual é o custo do capital no Brasil? Qual o custo de capital de longo prazo, relevante para decisões de investimento no Brasil? Ora, como não existe mercado de dívida de longo prazo no Brasil, é o custo do BNDES, a velha TJLP, ou então o infinito. Mas, como o orçamento do BNDES é finito, o custo do capital no Brasil é infinito. E o mercado de ações? Como se sabe, é pequeno e, portanto, caro. Nem empresa triplo A no Brasil, consegue colocar mais do que vinte por cento, tipicamente, de um lançamento global de ações no mercado doméstico. Então o que se faz é ir ao mercado internacional, e é aí que está exatamente a importância do risco país e da volatilidade para o custo de capital: custo médio ponderado de capital (de dívida e de capital próprio) de quem vai ao mercado internacional de capital. Não há outra alternativa, como acabei de argumentar: 
o custo de empréstimos será contaminado pelo risco país. Se for um investimento totalmente alavancado, o custo em dólares depende não só do risco de crédito e cambial, mas do risco Brasil, que vai ser carregado ao longo do período do contrato.

Mas será isso relevante? Isto é, sim, extremamente relevante. Para dar uma idéia numérica, para uma empresa com spread de risco comercial típico, vamos dizer, duzentos, trezentos pontos base, e uma taxa de longo prazo do tesouro americano, em torno de quinhentos pontos, a longo prazo, estamos falando de uns oitocentos base points de risco comercial. E o risco Brasil? O risco Brasil em abril, quer dizer, antes de ser jogado para dois mil base points durante a campanha eleitoral, estava em oitocentos, e foi o melhor nível a que conseguimos chegar depois de descolarmos da crise Argentina. Ou seja, estamos falando de algo que pelo menos dobra o custo do capital de uma empresa de risco comercial equivalente nos Estados Unidos, se tomada por comparação a uma empresa dentro do Brasil! E além disso, o custo do capital é volátil. Como vimos, o risco Brasil, que estava em oitocentos em abril, em agosto chegou a dois mil.

É claro que isso tem um duplo efeito negativo sobre o crescimento, pelas razões que argumentamos há pouco, e, por essa via, sobre o crescimento da competitividade. $\mathrm{O}$ primeiro efeito negativo ocorre porque o alto custo do capital reduz o nível do investimento. E o segundo, porque ele carrega um potencial efeito de choque cambial que afeta a competitividade. De fato, empresas com passivo dolarizado perdem capacidade de investir, e vão crescer menos e fazer menos investimentos no futuro. Especialmente na produção de bens não-comercializáveis, o efeito é muito forte. Em resumo, crescer e ser competitivo, com esse custo de capital resultante da nossa baixa taxa de poupança, é como correr maratona de mochila.

Como se resolve isso? O que se pode fazer para baixar o custo do capital e aumentar a taxa de crescimento, que é a mãe do crescimento e de produtividade? A solução Band-Aid, que foi usada com muito sucesso na década de cinqüenta quando de fato não havia alternativa - nem mesmo essa alternativa perigosa do mercado internacional de capitais foi construir o BNDES, como foi feito. Uma solução genial na origem, porque o mercado de capital internacional só foi reconstruído no começo da década de sessenta e a criação do BNDES, em cinqüenta e dois, viabilizou a criação de nossa infra-estrutura, "desengargalou" a indústria. Sem o BNDES, nossa moderna infra-estrutura energética e de transporte não existiria. Sem o BNDES, a industrialização do Brasil teria de 
ser reescrita. Mas, um instrumento como o BNDES também tem alguns perigos: subsidiar o custo capital não é necessariamente ruim, se é um subsídio bem alocado, mas combinado a regimes comerciais restritivos, pode gerar um Frankenstein industrial. Isso aconteceu durante décadas, e o caráter concentrador desse modelo, de subsídio ao capital e proteção infinita da competição internacional, não pode ser minimizado. Graças a Deus, com a abertura da política comercial, nos anos noventa, o BNDES pode, de novo, financiar empresas que fazem sentido.

Mas qual alternativa, uma vez que o orçamento do BNDES não é infinito? A alternativa é simples, e é algo que o Sebastian Edwards sublinha nos seus trabalhos sobre estabilidade macroeconômica e produtividade: um compromisso inabalável em conduzir a economia ao nível de "Investment Grade", quer dizer, buscar reduzir o custo do País como um objetivo ferrenho de política econômica. Pode-se argumentar que isso é mais fácil falar do que fazer, que não dá para virar europeu por decreto, como tenho ouvido muitas vezes. Mas, a China e o Chile não são europeus. Há vários países em desenvolvimento que viraram "Investment Gra$d e$ ", e podem, com isso, sustentar crescimento mais alto e mais estável e, portanto, gerar a longo prazo um crescimento de produtividade mais alto. A receita é simples. Basta continuar fazendo o que se vem tentando fazer nos últimos oitos anos, no Brasil: aumentar a poupança do governo através de uma busca contínua de equilíbrio fiscal, reformar o mercado de capitais, manter uma estrutura legal regulatória estável e eficiente, etc. Isso leva tempo, mas é um processo cumulativo, de reformas e de construção de reputação. Não há saída, e o Brasil pode chegar lá.

Eu acho, e aqui termino Sr. Presidente, que o maior óbice ao crescimento e à competitividade brasileira é o alto risco País que nós enfrentamos por ainda não sermos "Investment Grade" e faço votos de que daqui a dez anos, quando o BNDES estiver fazendo sessenta anos, esse problema não mais exista, pois está ao nosso alcance resolver esse problema. Se isso ocorrer, eu acho que esse Banco não vai precisar continuar a ser o único emprestador de longo prazo, pois o mercado doméstico poderá fazê-lo. Ele certamente sempre poderá continuar seletivamente apoiando o setor financeiro privado como um banco de investimento parceiro do resto da comunidade financeira doméstica. Mas, no mundo que estou prevendo, o BNDES talvez possa também procurar novas vocações, como a de ser um Eximbank, como tantas vezes tenho dito deva ser seu principal foco, apoiando a internacionalização cada vez maior da economia brasileira. Muito obrigado. 
Este livro, produzido pela MAUAD Editora,

foi impresso em papel ofsete $70 \mathrm{~g}$,

na gráfica Lidador 